UNIVERSIDADE DE SÃO PAULO

FACULDADE DE EDUCAÇÃO

WIARA ROSA RIOS ALCÂNTARA

Por uma história econômica da escola:

a carteira escolar como vetor de relações (São Paulo, 1874-1914) 


\section{WIARA ROSA RIOS ALCÂNTARA}

Por uma história econômica da escola:

a carteira escolar como vetor de relações (São Paulo, 1874-1914)

Tese apresentada à Faculdade de Educação da

Universidade de São Paulo para obtenção do título de Doutora em Educação.

Área de Concentração: História da

Educação e Historiografia

Orientadora: Profa. Dra.

Diana Gonçalves Vidal 
Autorizo a reprodução e divulgação total ou parcial deste trabalho, por qualquer meio convencional ou eletrônico, para fins de estudo e pesquisa, desde que citada a fonte.

Catalogação da Publicação

Serviço de Biblioteca e Documentação

Faculdade de Educação da Universidade de São Paulo

ALCÂNTARA, Wiara Rosa Rios.

Por uma história econômica da escola: a carteira escolar como vetor de relações (São Paulo, 1874-1914). / Wiara Rosa Rios Alcântara; Orientadora Profa. Dra. Diana Gonçalves Vidal. São Paulo, 2014.

339f. : il

Tese (Doutorado - Programa de Pós-Graduação em Educação. Área de Concentração: História da Educação e Historiografia. Faculdade de Educação da Universidade de São Paulo, 2014).

1. Carteira escolar 2. História Econômica 3. Indústria escolar 


\section{FOLHA DE APROVAÇÃO}

ALCÂNTARA, Wiara Rosa Rios. Por uma história econômica da escola: a carteira escolar como vetor de relações (São Paulo, 1874-1914). Tese apresentada à Faculdade de Educação da Universidade de São Paulo para obtenção do título de Doutora em Educação.

Aprovado em:

\section{Banca Examinadora}

Prof. Dr. Instituição:

Julgamento: Assinatura:

Prof. Dr. Instituição:

Julgamento: Assinatura:

Prof. Dr. Instituição:

Julgamento: Assinatura:

Prof. Dr. Instituição:

Julgamento: Assinatura:

Prof. Dr. Instituição:

Julgamento: Assinatura: 
Ao Guilherme, por encher a minha vida de amor e alegria.

Com você, meus melhores momentos.

À Isabelle, por dar novo significado a tudo. 


\section{AGRADECIMENTOS}

À Deus, porque tudo recebemos de suas dadivosas mãos.

À minha família, pelo apoio e carinho.

À Igreja Presbiteriana do Brasil, incentivadora da leitura, do raciocínio, da argumentação, do questionamento, do cuidado de si e dos outros, elementos importantes em minha formação.

Aos meus queridos da Igreja Presbiteriana Peniel, pelo companheirismo e pela amizade, por sempre me ajudarem a lembrar de que a diversidade e mutualidade significam que não somos autossuficientes e completos em nós mesmos.

À Faculdade de Educação da USP, porque nos últimos 12 anos fez parte da minha vida e formação.

Ao pessoal da Secretaria de Pós-Graduação da FEUSP, sempre eficiente nos atendimentos.

Aos amigos e colegas do Núcleo Interdisciplinar de Estudo e Pesquisa em História da Educação (NIEPHE), pela leitura e crítica dos meus textos, pelo companheirismo nesta jornada acadêmica.

À Renata Duarte Simões, amiga querida que me ajudou nesta e em outras histórias.

Aos funcionários do Arquivo Público do Estado de São Paulo, pela eficiência e prontidão no atendimento.

Aos funcionários do Arquivo Nacional do Rio de Janeiro, pela cordialidade no atendimento.

À Anne Quillien, pela orientação e apoio durante a pesquisa no Centre National de Documentation Pédagogique e Musée National de l'Éducation (Rouen - França).

Ao Pedro do Instituto Histórico e Geográfico Brasileiro, pelas valiosas orientações durante a pesquisa.

Ao Centro de Memória da Faculdade de Educação da USP, pelo acesso aos modelos de carteira escolar.

Ao sr. João Simões e família, pela acolhida no Rio de Janeiro.

À Dra. Maurilane Biccas, professora querida que me introduziu nos estudos da História da Educação.

À Dra. Maria Angela Salvadori, pelo incentivo, carinho e pelas valiosas sugestões ao longo da pesquisa. 
À Dra. Wilma Peres Costa, pelas produções acadêmicas desafiantes, pelas importantes contribuições na Banca de Qualificação.

À Dra. Heloisa Barbuy, pelas aulas instigantes, pelas sugestões de leitura, pelas importantes contribuições na Banca da Qualificação.

Ao Dr. Hugo Segawa, pela gentileza em compartilhar comigo suas fontes de pesquisa.

À Diana Vidal, pela orientação e formação acadêmica proporcionada desde o mestrado. Sinto-me privilegiada por ter sido orientada por uma professora e intelectual competente e crítica. Por uma mulher forte, cujos ensinos ultrapassam as fronteiras da academia e cuja amizade faz quase lamentar o fim deste ciclo. As marcas de sua orientação estão e estarão em cada aula, texto e comunicação. À você, querida, minha gratidão, carinho e admiração.

À minha mãe, que com o braço sempre estendido tornou possível a conclusão deste trabalho. Reconheço seu esforço em cada etapa da minha formação, sua satisfação em cada conquista, seu amor em tudo.

À Isabelle, que nasceu dividindo comigo muitas madrugadas na fase final deste trabalho. À você minha pequena e doce menina, todo meu amor e dedicação.

Ao Guilherme, por compartilhar comigo as conquistas e durezas da vida. Juntos, o melhor de nós, Isabelle.

À Fundação de Amparo à Pesquisa do Estado de São Paulo (FAPESP), pela concessão da bolsa de doutorado e pelo apoio financeiro para o desenvolvimento desta pesquisa. 


\section{RESUMO}

ALCANTARA, Wiara Rosa Rios. Por uma história econômica da escola: a carteira escolar como vetor de relações (São Paulo, 1874-1914). 2014. 339 f. Tese (Doutorado) - Faculdade de Educação, Universidade de São Paulo, São Paulo, 2014.

O estudo da materialidade da escola, no caso, a carteira escolar, evidencia como questões de ordem econômica e administrativa estão relacionadas à estrutura e ao funcionamento das instituições de ensino. Por isso, neste trabalho, investiga-se a emergência da escola como mercado consumidor, do Estado como comprador e da indústria de mobiliário escolar, em São Paulo, entre o fim do século XIX e início do século XX. Para tanto, as fontes utilizadas foram inventários de bens, ofícios e correspondências de diretores e professores solicitando material escolar (documentos produzidos no interior da escola); notas fiscais de compra e/ou importação, catálogos de fábricas de móveis escolares, almanaques, recibos de fornecedores (fontes vinculadas ao comércio e à indústria escolar); manuais e revistas pedagógicas que discutem a relação entre a carteira escolar e a saúde dos alunos, os fundamentos higiênicos, pedagógicos, antropométricos e ergonômicos do mobiliário escolar (documentos produzidos por especialistas); relatórios, lista e livros de almoxarifado (documentos provenientes da administração pública). A opção metodológica consistiu em tomar a carteira como fio condutor da análise, seguindo os rastros deixados na cultura material escolar, como artefato escolar e industrial; na história econômica, como mercadoria; na história conectada, como objeto que circula entre países e culturas. Tal procedimento mostrou que a indústria teve uma contribuição significativa na expansão e criação das condições físicas da escola elementar, moderna e de massa. Elucida também os desafios econômicos e administrativos do Estado, como prestador de serviço público, para suprir materialmente a escola e permitir a implantação da obrigatoriedade escolar. Como resultado, evidenciou-se que as carteiras escolares são vetores de relações pedagógicas, higiênicas, culturais e comerciais. Portanto, além de um objeto escolar, ela é também um artefato industrial mostrando que a história e a configuração da escola não se definem somente no interior dela, mas na relação com o mundo externo, em dimensões econômicas, políticas e sociais. Isso implica em que as políticas públicas e práticas administrativas voltadas para a escola na sua formulação e introdução não podem levar em conta somente as questões internas à instituição. A compreensão da e a interferência na cultura escolar demandam atenção também às relações extraescolares.

Palavras-chave: Carteira escolar - História econômica - Indústria escolar 


\begin{abstract}
ALCANTARA, Wiara Rosa Rios. For an economic school history: the school desk as a vector of relations (São Paulo, 1874-1914). 2014. 339f. Doctorate Thesis. - Faculdade de Educação, Universidade de São Paulo, São Paulo, 2014.

The study of school materiality, in this case, the school desk, shows how economic and administrative matters are related to the structure and the operation of the teaching institutions. For such a reason, this reasearch studies the school as a consumer market, the Government as a buyer and the school furniture industry emergences, in São Paulo, between the end of the nineteenth and the beginning of the twentieth centuries. As a methodology, the sources used were inventories of goods, crafts and correspondences from the officials and the teachers requiring school material (files produced inside the school); buyings and/or importation invoices, school furniture industries' catalogues, almanacs, receipts from suplliers (linked to the market and to the school industry); manuals and pedagogical journals which approach the relation between the school desk and the students's health, the hygienic, pedagogical, anthropometric and anatomical elements of the school furniture (documents made by some specialists); reports, list and warehouse books (documents from the public administration). The methodological choice consisted on selecting the school desk as the main object of study, following the tracks left in the school material culture, as a school and industrial artifact; in the economic history, as goods; in the connected history, as an object which rounds countries and culture. This situation showed that the industry had a significative contribution to the expansion and creation of the physical conditions of the elementary, modern and mass school. It also elucidates the economic and the administrative challenges of the State, as a provider of public work, in order to physically supply the school and allow the implementation of the school obligatoriness. As a result, it pointed that the school desks are vectors of pedagogical, hygienic, cultural and commercial relations. Therefore, besides a school objetc, it is an industrial artifact as well, showing that the school history and configuration are not only defined inside it, but in the relation with the external world, in economic, political and social issues. It implies that public politics and administrative practices directed to school in its formulation and introduction may not only take into account the institutional internal issues. The understanding and the interference in the school culture demand attention to the extra school relations as well.
\end{abstract}

Keywords: School desk - Economic history - school industry 


\section{LISTA DE FIGURAS}

\begin{tabular}{|c|c|c|}
\hline Figura 1 & Modelo suíço de privada ou latrina escolar & 52 \\
\hline Figura 2 & Detalhe de uma privada & 53 \\
\hline Figura 3 & Iluminação da classe & 58 \\
\hline Figura 4 & Sala iluminada pelo lado esquerdo & 59 \\
\hline Figura 5 & Posição considerada nefasta, segundo Bagnaux & 66 \\
\hline Figura 6 & Diferentes tipos de distância entre mesa e carteira & 67 \\
\hline Figura 7 & Inclinações ideais de carteira & 68 \\
\hline Figura 8 & Má postura durante a escrita & 70 \\
\hline Figura 9 & Posição ideal ao assentar-se & 71 \\
\hline Figura 10 & Primeira carteira escolar de Cardot & 72 \\
\hline Figura 11 & Carteira Cardot com mesa móvel & 73 \\
\hline Figura 12 & Carteira sistema LHUILLIER & 76 \\
\hline Figura 13 & Carteira sistema Savary & 77 \\
\hline Figura 14 & Mesa-banco americano (Illinois) - 1867 & 87 \\
\hline Figura 15 & Carteira e banco de aluno em uma escola sueca - 1867 & 88 \\
\hline Figura 16 & Carteira Windsor, 1867 & 89 \\
\hline Figura 17 & Novo modelo das escolas de Paris & 91 \\
\hline Figura 18 & Sistema Cardot - mobiliário de pátio com encosto móvel & 92 \\
\hline Figura 19 & Sistema Cardot - banco em posição abaixada & 92 \\
\hline Figura 20 & Sistema Andrew e sistema Stevens & 93 \\
\hline Figura 21 & Carteira de Boston (Sistema Ross) & 94 \\
\hline Figura 22 & Carteira da "The National School Furniture C",", de Nova York. & 96 \\
\hline Figura 23 & The Peard Desk and Settee Combined & 97 \\
\hline Figura 24 & The Gem Desk & 100 \\
\hline Figura 25 & The Study Desk & 101 \\
\hline Figura 26 & High and Normal School Desks & 102 \\
\hline Figura 27 & Sistema Lenoir & 108 \\
\hline Figura 28 & Modelo da cidade de Paris & 122 \\
\hline Figura 29 & Carteira para Escola Normal & 123 \\
\hline Figura 30 & Tampo articulado & 123 \\
\hline Figura 31 & Modelo Cardot proposto em Paris & 129 \\
\hline Figura 32 & Modelo de mesa-banco Bapterosses & 130 \\
\hline Figura 33 & Carteira modelo André & 131 \\
\hline Figura 34 & Casa Paul Rousseau \& Cie & 154 \\
\hline Figura 35 & Syndicato de Mobilia e Material Escolares & 156 \\
\hline Figura 36 & Carteira Brazil & 165 \\
\hline Figura 37 & Carteira Paulista & 166 \\
\hline Figura 38 & Carteira Brazil & 172 \\
\hline Figura 39 & Fábrica de Móveis Escolares Eduardo Waller & 174 \\
\hline Figura 40 & Carteiras americanas & 181 \\
\hline Figura 41 & Fábrica de Móveis José Refinetti \& Irmão & 183 \\
\hline Figura 42 & Fábrica de Móveis de Luxo e Material Escolar & 184 \\
\hline Figura 43 & Carteira Chandler & 186 \\
\hline Figura 44 & Propaganda de 3 de dezembro de 1933 & 188 \\
\hline Figura 45 & Carteira Escolar Hygiênica I & 201 \\
\hline Figura 46 & Carteira Escolar Hygiênica II & 202 \\
\hline Figura 47 & Carteira Escolar Hygiênica III & 203 \\
\hline
\end{tabular}




\begin{tabular}{|l|l|l|}
\hline Figura 48 & Banco Carteira Paulistano & 206 \\
\hline Figura 49 & Organograma da administração pública I & 236 \\
\hline Figura 50 & Organograma da administração pública II & 239 \\
\hline Figura 51 & Organograma da administração pública III & 240 \\
\hline Figura 52 & Organograma da administração pública IV & 243 \\
\hline Figura 53 & Organograma da administração pública V & 245 \\
\hline
\end{tabular}




\section{SUMÁRIO}

INTRODUÇÃO - Entre o prego e o parafuso ………………………………………….......13

CAPÍTULO 1 - A CARTEIRA ESCOLAR: UM DIPOSITIVO HIGIÊNICO ............................41

1.1. Um local próprio para a escola: Higiene da escola e da sala de aula...............................43

1.2. "A carteira deve se adaptar ao aluno" - Higiene e mobiliário escolar ............................63

CAPÍTULO 2 - A INTERNACIONALIZAÇÃO DE OBJETOS DE DESEJO E OBJETOS DE NECESSIDADE ……………………………………………………….... 81

2.1. A carteira escolar nas Exposições Universais do século XIX ……………………………....85

2.2. Patentes e empresas norte-americanas e francesas de mobiliário escolar...........................109

2.3. Primeira Exposição Pedagógica do Rio de Janeiro (1883) ................................................117

CAPÍTULO 3 - MODERNIDADE A TODO VAPOR …………………………………….....135

3.1. Os caminhos da modernidade educativa - a proveniência da carteira escolar ..................139

3.1.1. Um viajante que traz a Modernidade Educativa ......................................... 143

3.1.2. Mediadores Culturais da Modernidade Educativa ……………………….... 146

3.1.3 Tradutores culturais da modernidade educativa........................................... 150

CAPÍTULO 4 - INDÚSTRIA ESCOLAR E ESCOLA DE MASSA …………………………....163

4.1. A "Terceirização" da fabricação da carteira escolar...........................................................163

4.2. Indústria, patentes, e contrafacção: a corrida pela proteção e garantia de mercado ..........191

4.2.1. Carteira Escholar Hygienica - Patente 2012 de 1896.................................. 200

4.2.2. Banco-Carteira Paulista - Patente 2077 de 1896 ........................................ 205

4.2.3. Outras patentes de carteira escolar ............................................................ 207

CAPÍTULO 5 - PRÁTICAS ADMINISTRATIVAS E OBRIGATORIEDADE DO

ENSINO: DESAFIOS DO INVESTIMENTO NA EDUCAÇÃO PÚBLICA...............................219

5.1. Fábrica de Ferro Ipanema: uma tentativa de produção estatal da carteira ..........................224

5.2. A centralização como prática administrativa ....................................................................2230

5.3. O investimento do governo na Instrução Pública ..............................................................25

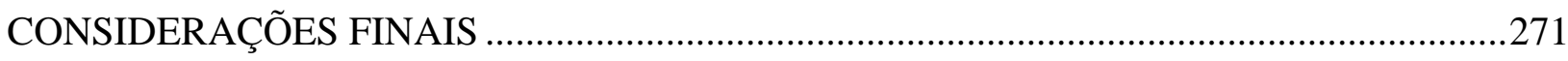

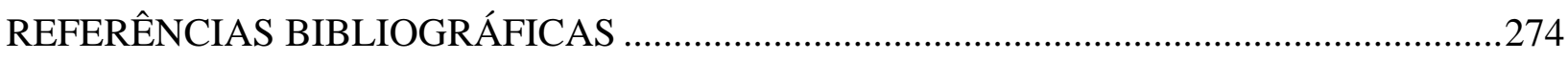

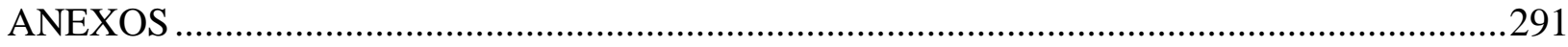




\section{INTRODUÇÃO Entre o prego e o parafuso}

For Want of a Nail

For want of a nail the shoe was lost. For want of a shoe the horse was lost. For want of a horse the rider was lost. For want of a rider the message was lost. For want of a message the battle was lost. For want of a battle the kingdom was lost. And all for the want of a horseshoe nail ${ }^{1}$.

A origem do provérbio acima é atribuída ao episódio da derrota e morte do Rei Richard III da Inglaterra na Batalha do Campo de Bosworth em 22 de agosto 1485. Tal derrota teria sido ocasionada pela perda da ferradura do cavalo que estava sem um prego. $\mathrm{O}$ cavalo ficou atolado, e o rei, à pé. $\mathrm{O}$ provérbio também é ilustrado no Ato $\mathrm{V}$, cena 4, da obra de Shakespeare Richard III, escrita por volta de 1592.

Ele é usado para ensinar que um "pequeno ato" (negligência em relação ao cuidado com a ferradura do cavalo) está diretamente associado a um grande acontecimento (perda do reino). No aspecto moral, significa que uma pequena negligência pode ter graves desdobramentos. Aqui, o provérbio é usado para fazer referência, de um lado, à opção teórico-metodológica adotada; e, de outro, à análise dos resultados.

No primeiro caso, diz respeito a opção de desenvolver o objeto de pesquisa a partir dos detalhes, da micro-análise, de um objeto escolar (a carteira) cuja biografia coloca em destaque a organização do sistema de ensino em São Paulo. No segundo, quanto à análise dos resultados, pode-se afirmar que a negligência quanto ao mobiliário, ao suprimento material e condições físicas da escola está diretamente associada às dificuldades de expansão do ensino e da escolarização obrigatória comandada pelo Estado.

A despeito do provérbio ser construído em cadeias de causalidades, de busca da condição inicial (ausência do prego na ferradura) que deu origem à derrota na batalha,

\footnotetext{
${ }^{1}$ Por falta de um prego

Por falta de um prego a ferradura se perdeu.

Por falta de uma ferradura o cavalo se perdeu.

Por falta de um cavalo o cavaleiro se perdeu.

Por falta de um cavaleiro a mensagem se perdeu.

Por falta de uma mensagem a batalha foi perdida.

Por falta de uma batalha, o reino foi perdido.

E tudo por falta de um prego de ferradura (Tradução Livre).
} 
não se pretende buscar aqui a origem do sistema de ensino ou estabelecer relações de causalidades entre a situação atual da escola e os primeiros momentos da consituição do sistema de ensino em São Paulo. No entanto, a opção pela perspectiva histórica justifica-se pelo entendimento de que "alguns pontos só podem ser ligados" quando se olha para o passado, o qual lança luz sobre problemas presentes.

"Entre o prego e o parafuso" é uma metáfora para evidenciar o processo de organização do sistema de ensino, a ampliação da escolarização obrigatória, "no tempo do prego e no tempo do parafuso". Chamo de "tempo do prego" o momento histórico em que havia uma predominância dos antigos bancos sem encosto, cuja produção era mais rudimentar e artesanal, com pregos batidos na madeira. O parafuso, usado nas carteiras de fabricação industrial, serve para fazer referência a paulatina expansão do ensino, sob os padrões higiênicos e pedagógicos da escola moderna.

Escola moderna, tomando a definição de um autor do período em estudo, Tavares Bastos, significa "a escola sem espírito de seita, a escola comum, a escola mista, a escola livre [...] obra original da democracia do Novo Mundo"2. No aspecto material, a escola moderna deveria ter "casas de escola próprias, que são essenciais para o desempenho dos métodos aperfeiçoados do ensino [...] mobílias, utensílios, modelos e livros escolares, acomodados aos métodos" $" 3$.

O objetivo não é expressar uma concepção evolutiva do tema, mas chamar a atenção para o processo de constituição do sistema de ensino e expansão da escolarização obrigatória em São Paulo, embora, durante muito tempo, bancos e carteiras estiveram simultaneamente presentes nas salas de aula das escolas paulistas.

Prego e parafuso incorporam conceitos diferentes de uso e movimento. O prego é introjetado na madeira por meio de golpes de martelo em um movimento reto para frente. Já o parafuso é um fixador cilíndrico rosqueado com emprego de chave, uma tecnologia mais elaborada do que a do prego. Aquele, admite com mais facilidade a desmontagem do móvel sendo incorporado ao objeto em movimento helicoidal ${ }^{4}$ para frente. Além de permitir a montagem e desmontagem do móvel, o parafuso compõe os mecanismos que tornam a altura da mesa ou carteira regulável. Já o prego, torna o móvel estático.

\footnotetext{
${ }^{2}$ BASTOS, Aurelino Cândido Tavares. A província: estudo sobre a descentralização no Brasil. $3^{\text {a }}$ Ed. São Paulo, Ed. Nacional; Brasília, INL, 1975, p.156. A primeira edição da obra é de 1870.

${ }^{33}$ Idem, p. 155

${ }^{4}$ Movimentos simultâneos de giro em torno de si mesmo e de avanço num eixo retilíneo perpendicular.
} 
Estes movimentos de alguma maneira também são metáforas do modo como pretendo operar nesta investigação. Não penso em um movimento evolutivo, reto para frente, mas opero montagens e desmontagens do objeto, girando em torno dele para observá-lo com diferentes lentes e a partir de diferentes ângulos.

De modo que a pesquisa tem por objetivo "seguir" a carteira escolar tomando-a como fio que permite investigar aspectos higiênicos, econômicos e administrativos da organização do sistema de ensino em São Paulo entre o fim do século XIX e início do século XX.

Acerca da delimitação temporal vale pontuar que o marco inicial, 1874, justificase pela primeira lei que estabeleceu a obrigatoriedade do ensino primário em São Paulo, a Lei n. 9 de 22 de março de 1874. Quanto ao marco final, 1914, considero que a Primeira Guerra Mundial põe fim ao "longo século XIX". Além disso, ela "levou a uma mudança de rumos, de relações internacionais e, em particular, do processo industrial paulista, com reflexos relevantes sobre as práticas comerciais" ${ }^{\text {. }}$.

O que é aqui compreendido como "carteira escolar"? Para tomar a definição de Maria Fátima Machado, diz respeito a "objeto composto por mesa e banco ou cadeira, unidos ou separados entre si e que faziam parte do mobiliário de uma sala de aula. As carteiras escolares tinham por função servir ao aluno quer na sua atitude de sentado em descanso, quer na sua atitude de trabalho",

A existência da carteira na escola, a partir da segunda metade do século XIX, está intimamente relacionada ao sentimento de infância e à superação das péssimas condições físicas e mobiliária da escola pública de primeiras letras no mesmo período. Por isso, abordo a seguir, ainda que de forma breve, esses dois aspectos, pois eles iluminam a compreensão da presença da carteira nas instituições de ensino no período em estudo.

\section{O sentimento de infância no século XIX}

\footnotetext{
${ }^{5}$ O longo século XIX, período que, segundo Eric J. Hobsbawm, vai da Revolução Francesa (1789), até a Primeira Guerra Mundial (1914), é apresentado como "um período de progresso material, intelectual e moral quase ininterrupto, quer dizer, de melhoria nas condições de vida civilizada" (Hobsbawm , 1995, p.22).

${ }^{6}$ BARBUY, Heloisa. A cidade-exposição: Comércio e Cosmopolitismo em São Paulo, 1860-1914. São Paulo: EdUSP, 2006, p.29

${ }^{7}$ MACHADO, Maria de Fátima Costa Monteiro de Sá. Maneiras de Sentar - Contributo para a História das carteiras escolares do ensino primário em Portugal (1835-1970). Lisboa: Faculdade de Psicologia e de Ciências da Educação, 2004 (Dissertação de Mestrado), p.187
} 
No século XIX, a criança assume um lugar importante ao seio da família e da escola (Estado). Para Rocha e Gouvêa, "a experiência histórica da(s) infância(s) brasileira(s) na segunda metade do século XIX [é] reveladora das profundas transformações históricas na vida social do país" $"$.

As autoras relembram que Ariès ${ }^{9}$ inaugurou um novo campo de investigação historiográfica: a história da infância. A despeito de os trabalhos de Ariès demonstrarem a emergência do sentimento de infância na modernidade, outros pesquisadores verificam uma "pluralidade de experiências históricas de infância"10. A "indiferença medieval pela criança é uma fábula", e, o interesse ou a indiferença "coexistem no seio de uma mesma sociedade, uma prevalecendo sobre a outra em determinado momento" $" 12$.

No entendimento de Heywood, é infrutífero falar da ausência ou presença do sentimento de infância em um ou outro momento histórico, bem como de uma única infância em cada momento. É mais operatório investigar as diversas concepções sobre a infância, em diferentes tempos e lugares ${ }^{13}$. A concepção de infância, a partir da segunda metade do século XIX, está intimamente relacionada a um lugar - a escola. Cada vez mais o tempo da criança é organizado em torno da escola, cada vez mais ser criança sugere ser aluno.

Esse sentimento de infância, a partir do século XIX, se traduz nos espaços reservados para as crianças; móveis e acessórios específicos são fabricados; a literatura infantil se desenvolve a partir da segunda metade do século XIX; publicidade de alimentação e moda a elas se dirigem. O desenvolvimento da psicologia infantil, no mesmo período, reconhecendo uma construção mental diferente do adulto, terá uma "grande influência sobre o ensino nas escolas e o desenvolvimento de métodos de aprendizagem específicos"14.

\footnotetext{
${ }^{8}$ ROCHA, Heloisa Helena Pimenta; GOUVÊA, Maria Cristina. Infâncias na História. Educação em Revista, Belo Horizonte, v.26, n.1, p.187, abr.2010.

${ }^{9}$ ARIÉS, Phillipe. História social da criança e da família. Rio de Janeiro: Zahar, 1979.

${ }^{10}$ ROCHA; GOUVÊA. 2010. op. cit., p. 188

${ }^{11}$ GÉLIS, Jacques. A individualização da criança. In: ARIÈS, P.; CHARTIER, R. História da vida privada, v.3. São Paulo: Companhia das Letras, 1992, p.328.

${ }^{12}$ Idem, ibidem.

${ }^{13}$ HEYWOOD, Colin. Uma história da infância: da Idade Média à época contemporânea no Ocidente. Porto Alegre: Artmed, 2004, 284p.

14 PEYRANNE, Josette. Le mobilier scolaire du XIX siècle a nos jours: contribution a l'etude des pratiques corporelles et de la pedagogie a travers l'evolution du mobilier scolaire. ANRT, 2001, p.73.
} 
Kuhlmann Jr. e Fernandes definem a infância como "a concepção ou a representação que os adultos fazem do período inicial de vida" ${ }^{15}$. Para eles "a infância

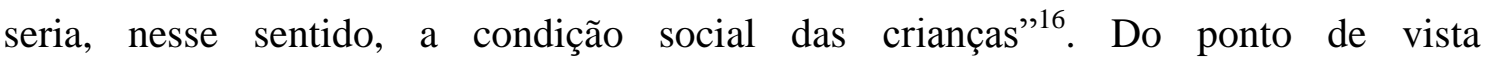
epistemológico, a infância "é entendida como categoria social, que informa a inserção de sujeitos concretos, ou seja, uma categoria que permite interrogar sobre a inserção de crianças na vida social, em diferentes tempos históricos e espaços sociais"17.

Nesta perspectiva, temos um conjunto de pesquisas que se debruçam sobre a "especificidade da infância como um tempo geracional; a definição da escola como espaço de formação da criança, no papel de aluno; a conformação de práticas sociais de intervenção sobre a criança"18

Dentre estas pesquisas, vale destacar a contribuição de Gondra quando afirma que "a ideia de infância não pode ser pensada no exterior das instituições que lhe são

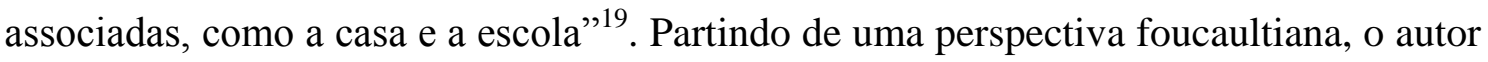
entende que o saber médico organizou uma representação da infância e "fomos capturados por essa ordem de saber, por seus jogos de poder, o que faz com que tenhamos condutas alinhadas às representações fabricadas no interior do campo médicohigiênico",20.

Além da preocupação médico-higiênica, Monarcha identifica, no caso paulista, uma preocupação sociológica e política, pois em uma "súbita valorização da criança" 21 , os republicanos "idealizam a instrução como condição prévia para o bom funcionamento das instituições republicanas" ${ }^{22}$. Essa instrução deveria ser encabeçada pelo Estado, a quem cabia “exercer o papel de preceptor dos novos, subtraindo-os do âmbito do privado, familiar e afetivo e conduzindo-os para o âmbito do público, social e político"23.

\footnotetext{
${ }^{15}$ FERNANDES, Rogério; KUHLMANN JR., Moisés. Sobre a infância. In: FARIA FILHO, Luciano (Org.). A infância e sua educação: materialidades, práticas e representações. Belo Horizonte: Autêntica, 2004, p. 15

${ }^{16}$ ROCHA; GOUVÊA, 2010. op. cit., p.189

${ }^{17}$ Ibidem., p.p. 190

${ }^{18}$ Ibidem., p.p. 191

${ }^{19}$ GONDRA, José Gonçalves. Educação em Revista, Belo Horizonte, v.26, n.1, p.195, abr.2010.

${ }^{20} \mathrm{Ib} .$, p. 196

${ }^{21}$ MONARCHA, Carlos. Arquitetura escolar republicana: a escola normal da praça e a construção de uma imagem de criança. In: FREITAS, Marcos Cesar (org.). História Social da Infância no Brasil. $3^{\mathrm{a}}$. Ed. São Paulo: Editora Cortez, 2001, p.101-140.

${ }^{22}$ Idem, p. 123

${ }^{23}$ Idem, ibidem.
} 
Assim, a escola, em expansão, sobretudo nos locais de maior industrialização e urbanização, torna-se uma das instituições "reguladoras da vida social" 24 . As casas de asilo e os jardins de infância são exemplos deste interesse pela criança. Acerca de tais instituições, o inspetor geral da Instrução Pública Souza Bandeira Filho afirma que

Nas grandes cidades europeias, e, sobretudo nos grandes centros industriais, têm-se efetivamente criado estabelecimentos especiais, destinados a receber os filhos dos operários e guardá-los durante o dia, enquanto os pais estão retidos na faina das oficinas. Alguns destes estabelecimentos aceitam as crianças desde os 2 ou 3 anos de idade até os 6 ou 7; é o caso dos asyles d'enfants em Paris, dos Kinderbewahranstalten em Viena e Berlim. Outros aceitam as crianças menores de 2 anos, mesmo as recém-nascidas: é o caso das crèches francesas, das krippen alemãs. Nenhum destes estabelecimentos, porém, corresponde ao jardim Froebel. Eles destinam-se a fins humanitários e caridosos, mas não envolvem rigorosamente uma ideia pedagógica ${ }^{25}$.

Dois elementos são importantes no excerto do relatório de viagem à Europa: a relação entre os centros industriais e o crescimento das instituições de guarda das crianças; e, o jardim de infância onde as preocupações pedagógicas e reguladoras se sobrepõem.

Nessa mesma direção, vão as palavras de Horace Lane, diretor da Escola Americana. Sobre o conteúdo da Revista do Jardim da Infância, em carta enviada a Gabriel Prestes, ele enaltece a iniciativa do diretor da Escola Normal da Praça:

A Revista tem ao meu ver, não sómente um valor intrínseco, na abundância de material criteriosamente escolhido que traz, como também um valor histórico, marcando época no desenvolvimento de S. Paulo [...].

O grande desenvolvimento da pedagogia moderna se prende a este estudo da criança na mais tenra edade, que sómente pôde ser feito no Jardim de Infancia. A ele se dedicam os educadores mais notáveis hoje como sejam - Rein [de Jena], Compayré, Harris, Stanley Hall, Parker, Payne e muitos outros. Recentemente do Verein pedagógico de Berlim, das Universidades Leland, Stanforde, Clark e Harvard, expediram circulares ao professorado convidando-o a estudar a individualidade da criança nos Jardins da Infancia, afim de determinar o conteúdo da intelligencia, a influencia sobre o desenvolvimento moral e intellectual do meio etc. A parte fundamental da psychologia e da pedagogia modernas é o produto destes estudos do homem, em pequeno, antes viciado no meio.

Trata-se de saber o conteúdo da mente da criança e de incitar-lhe as actividades proprias, de cultivar os sentidos [...] A litteratura

${ }^{24}$ KUHLMANN JR., Moysés. O jardim-de-infância e a educação das crianças pobres. Final do século XIX, iníci do século XX. In: MONARCHA, Carlos (org). Educação da infância brasileira (1875-1983). Campinas: Autores Associados, 2001, p.12-13.

${ }^{25}$ BANDEIRA FILHO, 1883, p.30 apud KUHLMANN JR., 2001, p.p.4 
froebeliana é já vasta: são a psychologia e a philosophia de Froebel e seus adeptos que têm revolucionado as escolas do mundo civilizado ${ }^{26}$.

As citações indicam que, também em São Paulo, houve um crescente interesse pela criança no século XIX, o que se torna visível pelas instituições (jardins da infância) e publicações para ela ou acerca dela.

Enfim, pode-se dizer que, no século XIX, em São Paulo, o sentimento de infância, ou o interesse pelas crianças, se caracteriza pela proliferação de instituições a elas destinadas, como a escola. Dentro da escola, a preocupação pedagógica e reguladora (médico-higiênica) do corpo infantil se torna visível por meio das prescrições quanto à postura que o aluno deveria manter ao sentar-se.

Citando um Manual Encyclopedico ${ }^{27}$, Boto nos conta do "sentimento de infância expresso no repertório do compêndio escolar". Nele, o sentimento de infância se expressa na "tentativa sistemática de retirar a criança de seu universo para construir o sujeito-aluno: regrado, normalizado; sob medida [...] O aluno é, por seu turno, o futuro adulto",28.

A produção de um conjunto de saberes sobre a criança e a infância, no fim do século XIX, se dá concomitantemente ao processo de difusão mundial da escola elementar. A carteira escolar faz parte deste caldo de preocupação com o corpo infantil, com a criança, o cidadão escolarizado.

\section{A escola pública de primeiras letras no século XIX}

Pergunta comum entre os meus colegas adolescentes, quando do término das férias escolares, era: quem inventou a escola? Por que somos obrigados a ir à escola todos os dias?

\footnotetext{
${ }^{26}$ MONARCHA, Carlos. Revista do Jardim da Infancia. Uma publicação exemplar. In: MONARCHA, Carlos (org). Educação da infância brasileira (1875-1983). Campinas: Autores Associados, 2001, p. 104105.

27 O Manual Encyclopedico, escrito para as escolas de instrução primária por Emílio Achilles Monteverde, em sua oitava edição, com data de 1865, é ilustrativo do caráter civilizador intrínseco à escolarização moderna (BOTO, 2011, p.68).

${ }^{28}$ BOTO, Carlota. A racionalidade escolar como processo civilizador: moral que captura almas. In: CARVALHO Maria Marta Chagas de; PINTASSILGO, Joaquim (orgs.). Modelos culturais, saberes pedagógicos, Instituições Educacionais: Portugal e Brasil, Histórias Conectadas. São Paulo: Editora da Universidade de São Paulo/FAPESP, 2011, p. 71.
} 
O fim das férias escolares estabelecia um imperativo sobre a vida dos adolescentes-alunos. Acordar cedo para o retorno às aulas. As duas perguntas acima, ao mesmo tempo, são carregadas de certa naturalização e questionamento. Naturalização, porque faz parecer que a escola sempre existiu para impor-se aos corpos dos sujeitos. Questionamento, porque interroga sobre quem teve a idéia de tornar a sua frequência obrigatória, mesmo por aqueles que, lá, não queriam estar.

Seguir o fio da carteira escolar faz perceber que, a despeito da perenidade do termo, a escola nem sempre teve a mesma forma de funcionamento, organização, contratação de pessoal, financiamento e frequência.

Giglio, ao se debruçar sobre a instrução pública na Província de São Paulo, entre 1836 e 1876, portanto, em período anterior ao estudado nesta pesquisa, afirma que a "escola elementar pública, como instituição destinada a instruir e educar, é inaugurada no século XIX, como uma necessidade do governo, um direito do cidadão e uma obrigação da família" 29 .

Para estabelecer essa genealogia da escola de massas, a autora lança mão de relatórios dos presidentes da província. Ela analisa as práticas de inspeção e "o processo de produção do escolar como conjunto de elementos que atuam na institucionalização tanto da escola quanto da instrução pública na província"30.

Giglio lembra que este é um momento de constituição do próprio governo e de um "contínuo movimento de legalização, de ordenação e de normatização da vida". Assim, "clivadas pelas demandas de controle social, a escola transforma-se num último reduto de institucionalização da própria sociedade [...] como obra de civilidade que deverá cobrir todo o corpo social, preparando os espíritos da infância e da mocidade para o ingresso na ordem da razão do Estado" 31 . Daí a proliferação dos regulamentos para a administração da província no século XIX. Eles "serviram de meios para a intervenção da autoridade no exercício de governar a instrução pública"32.

A aplicação dos regulamentos dá visibilidade a um elemento desse processo de institucionalização da instrução pública, a saber, a crise e os conflitos entre a administração da instrução pública e o governo da província, devido às "práticas de

\footnotetext{
${ }^{29}$ GIGLIO, Célia Maria Benedicto. Inspeção e produção de um modelo escolar. A instrução pública na província de São Paulo (Brasil, 1836-1876). In: CARVALHO Maria Marta Chagas de; PINTASSILGO, Joaquim (orgs.). Modelos culturais, saberes pedagógicos, Instituições Educacionais: Portugal e Brasil, Histórias Conectadas. São Paulo: Editora da Universidade de São Paulo/FAPESP, 2011. 472p, p.105

${ }^{30}$ Idem, ibidem.

${ }^{31}$ Idem, p. 106.

${ }^{32}$ Idem, p. 109.
} 
desrespeito às leis por parte do governo". 33 Isso porque as relações de fidelidade e arranjos casuais dificultavam, segundo a mesma autora, o movimento de uniformização das práticas decretadas.

Não se restringia à uniformização das práticas, mas também do suprimento material e mobiliário das escolas. O que coloca em evidência outro elemento já apontado por Giglio acerca da criação das escolas. Ela assevera que o "nascimento das escolas de primeiras letras não surge de um plano racionalmente traçado para cobrir o território da Província com as condições de realização do direito à instrução"34.

É denunciando a ausência de tais condições que a professora da Escola Publica Primaria do primeiro Districto desta Capital, Amelia de Oliveira Carvalho, em 30 de maio de 1881, escreve ao Inspetor Geral da Instrução Pública, Dr. Francisco Aurelio de Souza Carvalho:

Professora nomeada para reger aula do primeiro Districto, em 1868, "tive então que lutar com todas as dificuldades, como se tivesse de tomar conta de uma escola recentemente creada; sem alumnas, porque as primeiras acompanharão a minha antecessora para a sua nova cadeira, sem casa e sem moveis, porque esta escola funcionava no pavimento térreo do Thesouro Provincial, e d'ahi mudada por ordem do Governo, e os moveis ahi existentes ficarão em poder da minha antecessora. Foi então que em luta com esses embaraços encontrei o auxilio de alguns paes que desejando matricular suas filhas em minha aula, esforçarão-se por achar uma sala onde eu pudesse dar começo aos trabalhos escolasticos. Da mesma sorte encontrei promptidão da parte de V.Sa. em attender ao pedido que fiz de moveis e utensis e assim pude abrir a escola. Entretanto [...] a sala onde funcciona a escola é pequena, escura e com falta de todas as accomodações hygienicas, necessárias para um lugar em que diariamente há uma aglomeração de pessoas. E a este respeito é com pezar com menciono o facto de sermos obrigadas a tirar do nosso precário ordenado uma quota para o aluguel de um cubículo onde se bem que vexatoriamente possamos exercer o nosso magistério, enquanto que outras Professoras trabalhão em edifícios apropriados e fornecidos pelo Governo".

"[...] permita que desde já o scientifique de que não ella uma escola modelo, pois que falta-lhe um dos elementos efficientes para o progresso da instrução: a mobília apropriada; necessidade esta que se torna urgente ${ }^{35}$.

O ofício da professora denúncia uma situação que se prolongou após à Lei de Obrigatoriedade de 1874. Outra professora, Isabel Maria da Glória Vieira, cuja escola foi criada em 1882, relata:

\footnotetext{
${ }^{33}$ Idem, p. 113.

${ }^{34}$ GIGLIO, op. cit., p.115

${ }^{35}$ Arquivo Público do Estado de São Paulo. Instrução Pública - Relatório das localidades - Capital, anos: 1852-1888; Caixa 12; Ordem 4930.
} 
A minha escola [...] foi creada o ano passado e até hoje ainda não foi provida de moveis e utensis apenas recebi da substituta alguns exemplares e na Repartição da Instrução Pública outros de que existe recebi nessa Repartição, quanto aos moveis e utensis, não só por ser a minha eschola nova, matricula e frequência de alumnas como também para a boa marcha do ensino é necessário que V. Sa. mande fornecer os mesmos, e além disto nada mais tenho a relatar a V. Sa.

A Profa. Pública Normalista - Isabel Maria da Glória Vieira ${ }^{36}$.

De um lado, há uma desvinculação entre a obrigatoriedade da educação e as condições físicas da escola (espaço adequado, mobília). Por isso, também, Giglio vai afirmar que a "criação da escola, como instituição à qual corresponde um espaço com determinada arquitetura, um mobiliário específico, instrumentos próprios do ofício, não é o modelo de nascimento das escolas de primeiras letras na província”37.

De outro, destaca uma vinculação da escola à professora:

[...] são criadas não escolas mas "cadeiras" do magistério por meio de leis da Assembleia Provincial [...] O que se cria é uma "cadeira", um lugar, um posto de trabalho que vincula um professor a uma localidade. O professor, por sua vez, vincula-se ao espaço físico onde a escola deve se instalar para ocupar sua cadeira. Arranjo sempre móvel, que supõe o mestre como escola: ele é a escola; seu deslocamento implica o deslocamento espacial da escola, dos alunos que a freqüentam, da mobília, das obrigações dele com os custos de manutenção do prédio que aluga. Os mestres são responsáveis pela arregimentação dos alunos e pelo estabelecimento físico do espaço a seu encargo, em locais geralmente coincidentes com suas moradias; as chamadas escolas públicas de primeiras letras eram classes isoladas, funcionando em vários pontos da província [...] Esse período poderia denominar-se como o de "gênese das instituições escolares públicas" $" 38$.

Tratando do processo de institucionalização da escola primária no Brasil, Faria Filho e Vidal identificam três momentos da história da escola primária no Brasil: 1) casas-escolas; escolas-monumentos; escolas funcionais. Acerca do primeiro momento, afirmam os autores que

os diagnósticos dos mais diferentes profissionais que atuavam na escola ou na administração dos serviços da instrução, ou ainda políticos e demais interessados na educação do povo (médicos, engenheiros...), eram unânimes em afirmar que o estado de precariedade dos espaços ocupados pelas escolas, sobretudo as públicas, mas não somente essas, e advogavam a urgência de se

\footnotetext{
${ }^{36}$ Arquivo Público do Estado de São Paulo. Instrução Pública - Relatório das localidades - Capital, anos: 1852-1888; Caixa 12; Ordem 4930 - Relatório escolares - 1883; Pasta 23, maço 3 - Papeis fechados 23; M. D. Lorena. Relatório do estado da eschola pública do sexo feminino do Bairro do Lavapés, Distrito do Sul da Freguesia da Sé, nesta Capital. Ao Inspetor Geral da Instrução Pública.

${ }^{37}$ GIGLIO, op. cit., p.115.

${ }^{38}$ Idem, ibidem.
} 
constuírem espaços específicos para a realização da educação primária $^{39}$.

Por meio do suprimento mobiliário das escolas pretendo dar visibilidade a como ao criar estruturas, hierarquias e burocracias foi-se complexificando e racionalizando a criação e o funcionamento das escolas públicas, ampliando-se, paulatinamente, o controle e a padronização do mobiliário distribuído, fatores importantes para a expansão da escola de massas.

Ainda sobre o "nascimento das escolas", um roteiro modelar é apresentado por Giglio, a partir de uma descrição feita pelo inspetor-geral, em 1860, mas que segundo ela, "poderia ser mantido até 1880, sem alterações significativas".

A Lei cria uma cadeira, confia-a a um homem que sujeita apenas a exame sobre seus conhecimentos e... está tudo feito. Depois aluga a casa, em que tem de residir e aí instala a cadeira. Mas, seus ordenados são mesquinhos, e impossível lhe é pagar casa suficientemente espaçosa para receber todo o pessoal que a escola matricula, e demais os próprios móveis e utensílios lhe faltam, porque a quota anual de dois contos de réis que as Leis do orçamento consignam, é nimiamente escassa para o fornecimento de tais objetos a toda Província $^{40}$.

No relatório de 1864 é descrita a mesma situação:

Comumente os professores não moram nas povoações onde são chamados a servir. Chegados alugam uma casa, e compram ou pedem emprestados alguns trastes, é nessa casa e com esses trastes que a cadeira vai se instalar. Afora a capital, a província não os fornece; o professor vence ordenados diminutos. Não importa; a ele incumbe dar local e móveis e utensis. A casa é necessariamente pequena e a sala destinada ao ensino imprópria por seu aspecto e dimensões. Uma mesa pequena e um ou dois bancos velhos, eis a mobília, feliz ainda quem as obtém [...] Coisas indispensáveis são dispensadas ${ }^{41}$.

Outra contribuição importante do trabalho de Giglio acerca da "invenção da escola pública elementar paulista destinada às massas" é elucidar que a ausência de espaços específicos e próprios não era uma peculiaridade das escolas, mas das instituições públicas. Nesse período de gênese "era comum alugarem-se casas de

\footnotetext{
${ }^{39}$ FARIA FILHO, Luciano; VIDAL, Diana. As lentes da história: estudos de história e historiografia da educação no Brasil. São Paulo: Autores. Associados, 2005, (Coleção Memória da Educação), p.49.

${ }^{40}$ Relatório da Instrução Pública. Documentos com que o Ilustríssimo e Excelentíssimo Senhor Senador José Joaquim Fernandes Torres, Presidente da Província de S. Paulo, instruiu o Relatório que abriu a Assembleia Legislativa Provincial, em 2 de fevereiro de 1860 apud GIGLIO, 2011, p.118.

${ }^{41}$ Relatório sobre a Instrução Pública de S. Paulo, em 1864, apud GIGLIO, 2011, p.121-122.
} 
particulares para funcionarem os serviços [...] cadeias públicas, os lazaretos, os hospitais" ${ }^{\prime 42}$.

Uma pequena ressalva deve ser feita. Apesar de Giglio $^{43}$ datar em 1880 o fim da prática de instalação de escolas nas casas dos professores, em pesquisa de Mestrado ${ }^{44}$, acerca da trajetória da professora primária Botyra Camorim, encontrei informação diversa. Em suas narrativas acerca do trabalho em escolas isoladas rurais, na década de 1930, Botyra relata que a própria professora ou o fazendeiro local assumia a responsabilidade de providenciar o local para o funcionamento da escola. A mesma situação é narrada por Almeida Junior no Anuário do Ensino de 1935 e por Zeila Demartini $^{45}$. Assim, se na zona urbana a vinculação da moradia da professora ao espaço físico da escola vai rareando desde as últimas décadas do século XIX, na zona rural, tal situação adentrou e se estendeu às primeiras décadas do século XX.

De todo modo, se esta situação foi-se tornando exceção, no período estudado por Giglio, ela era a regra. Ou seja, a instalação física da escola era "responsabilidade quase exclusiva do mestre. Além da casa para a escola, os professores de primeiras letras necessitavam de mobília adequada à acomodação dos alunos - em geral bancos e mesas" $" 46$.

De forma análoga, Machado apresenta a escola elementar em Portugal. Até a passagem da primeira para a segunda metade do século XIX,

o ensino era ministrado ou em casas particulares onde o mobiliário era secundário ou em escolas públicas que funcionavam geralmente em casas impróprias para a função e sem grandes preocupações com o mobiliário escolar [...] as questões de higiene escolar começaram a pôr em questão a forma como os alunos se sentavam na escola e as implicações físicas e orgânicas que advinham das más posturas ${ }^{47}$.

Gondra se interroga sobre o "momento de estabelecimento da maquinaria escolar no Brasil" e sobre os "discursos que procuraram definir e construir a rede escolar oficial brasileira conformando, então, um discurso pedagógico"48.

\footnotetext{
${ }^{42}$ GIGLIO, 2011, p.120.

${ }^{43}$ Giglio, 2011, p.118 e 121.

${ }^{44}$ ALCÂNTARA, Wiara Rosa. Uma vida no magistério: fios e meadas da história de uma professora paulista. São Paulo: Faculdade de Educação da USP, 2008 (Dissertação de Mestrado).

${ }^{45}$ DEMARTINI, Zeila de Brito (Coord.). Velhos mestres das novas escolas: um estudo das memórias de professores da Primeira República em São Paulo. Sao Paulo: Centro de Estudos Rurais e Urbanos, 1984.

${ }^{46}$ GIGLIO, 2011, p.121.

${ }^{47}$ MACHADO, op. cit. p.195

${ }^{48}$ GONDRA, José Gonçalves. Conformando o discurso pedagógico: a contribuição da Medicina. In: FARIA FILHO, Luciano (org.). Educação, modernidade e civilização: fontes e perspectivas de análises para a história da educação oitocentista. Belo Horizonte: Autêntica, 1998, p.39.
} 
A hipótese desse historiador da educação é que "a construção do 'edifício escolar' brasileiro ocorreu no século XIX, mais precisamente, durante o período do Império, tendo o Segundo Reinado como um tempo em que esta preocupação ganhou maior visibilidade" 49 .

O século XIX é o

Século da Instrução Primária, pelo fato de ter sistematizado e generalizado o ensino inicial [...] e atribuído ao Estado a função de difundir entre o povo as primeiras letras, desencadeando um amplo movimento em prol da difusão da educação popular, que culminou com a intervenção do Estado na criação da escola primária de ensino obrigatório, laica e gratuita e na consequente organização dos Sistemas Nacionais de Ensino, em diversos países ${ }^{50}$.

A construção do "edifício escolar" não pode ser apartada da carteira, enquanto objeto que foi se tornando símbolo de um espaço fundamental na escola, a sala de aula. Assim, falar da carteira é pensar, não só o momento, mas os modos de estabelecimento da "maquinaria" e do "edifício" escolares. A escola, "sobretudo ao final do século XIX, foi sendo invadida por todo um arsenal inovador de materiais didático-pedagógicos" ${ }^{\text {51 }} \mathrm{e}$ também mobiliário.

Pelo estudo do mobiliário, especialmente das carteiras, é possível trazer outras nuances sobre como, nesse período, "a Medicina impôs um determinado projeto para a educação que, resumidamente, atendia dois princípios: o da localização das 'casas de educação' e o da sua organização interna" ${ }^{, 52}$.

Isso porque "o domínio da Medicina estendeu-se para tudo que se relacionava ao ambiente urbano e ao bom funcionamento da ordem burguesa"53. Procurava-se "forjar um novo homem, uma nova cidade; ambos, higienicamente produzidos" ${ }^{\text {, }}$.

No interesse dos médicos, a educação das massas foi tomada como ferramenta importante para "produzir um homem e uma sociedade regenerados" sociais e educacionais deveriam estar submetidos à ordem médica que, assumindo um

\footnotetext{
${ }^{49}$ Idem, p.39.

50 SCHELBAUER, Analete Regina. O método intuitivo e lições de coisas no Brasil do século XIX. In: STEPHANOU, Maria; BASTOS, Maria Helena C. (orgs). Histórias e memórias da educação no Brasil, Vol II: século XIX. Petrópolis, RJ: Vozes, 2005, p.133.

${ }^{51}$ FARIA FILHO; VIDAL, op. cit, p.51.

52 GONDRA, 1998, p.40.

${ }^{53}$ Idem, p.47

${ }^{54}$ Idem, ibidem.

${ }^{55}$ Idem, p.49
} 
papel de regeneradora, estrutura "a sociedade em 'corpo social' sobre o qual a Medicina deve agir diagnosticando, reconhecendo os focos dos males, prescrevendo e curando" ${ }^{„ 56}$.

No “corpo social”, um dos lugares responsáveis pela produção de vícios e deformidades física e morais nos sujeitos era a escola, um dos focos dos males produzidos, a carteira. A prescrição - a educação, "alçada à condição do melhor e, às vezes, o único 'remédio' para os problemas e crises da ordem urbana, fabril e capitalista" ${ }^{, 57}$.

O primeiro elemento a ser considerado na análise da carteira é a higiene pública e escolar. A atenção recai sobre os saberes e discursos produzidos por médicos e educadores, sobre os enunciados científicos que, no período, pretendiam higienizar a sociedade e, como parte dela, a escola, ou, por meio da escola, a sociedade.

\section{A carteira escolar: estado da arte}

As medidas administrativas e econômicas do Estado de São Paulo e da indústria para suprir materialmente as escolas permitem entender as carteiras como elementos que intervém em uma racionalidade, em uma organização.

A carteira é, portanto, um fio condutor que "ajuda a nos orientarmos no labirinto da realidade" 58 , tecendo uma rede que permite apreender a "dimensão material da vida escolar" ${ }^{\text {,9 }}$, um momento da constituição histórica da escola elementar, de massa e obrigatória, assumida pelo Estado. Neste ponto, micro-história e história econômica se complementam. Nas palavras de João Fragoso, "a micro-história italiana tem muito a dizer para os pesquisadores da economia [...] ela propõe uma maior atenção para o cotidiano das pessoas que viveram os fenômenos ditos econômicos",60.

\footnotetext{
${ }^{56}$ GONDRA, 1998, p.59.

${ }^{57}$ Idem, p.66

${ }^{58}$ GINZBURG, Carlo. O fio e os rastros: verdadeiro, falso, fictício. Trad. de Rosa Freire d'Aguiar e Eduardo Brandão. São Paulo: Companhia das Letras, 2007, p.7.

${ }^{59}$ VIDAL, Diana Gonçalves ; GASPAR, V. Por uma história sensorial da escola e da escolarização. In: Cesar Augusto de Castro. (Org.). Cultura material escolar: a escola e seus artefatos (MA, SP, PR, SC e RS, 1870-1925). São Luis - MA: Café \& Lápis, 2011, v. 1, p.20

${ }^{60}$ FRAGOSO, João. Para que serve a história econômica? Notas sobre a história da exclusão no Brasil. Estudos Históricos. Rio de Janeiro, n ${ }^{\circ} 29,2002$, p. 3-28.
} 
Uma das contribuições desta pesquisa reside no fato de que "são quase inexistentes as interpretações que privilegiam a materialidade da escola como núcleo de análise $^{61}$ ou que se interrogam sobre a implementação de artefatos no espaço escolar"62.

Diana Vidal e Vera Gaspar afirmam: "carecemos de mais estudos que revelem com mais precisão conexões entre a idealização dos artefatos, as defesas de seus usos e sua fabricação e comercialização; ou seja, o mapa das rotas entre idealização, fabricação, comercialização e usos"63.

Sobre as carteiras escolares, pelo menos três estudos merecem destaque: um brasileiro, um português e outro francês. Em sua dissertação de mestrado intitulada $D a$ cadeira às carteiras escolares individuais: entre mudanças e permanências na materialidade da escola primária catarinense (1836- 1914), Raquel Castro trata da relação da carteira escolar, "principal apoio para possibilitar a escrita", com métodos de ensino (individual, mútuo e simultâneo). Ela discorre também sobre disciplina, higienização e regulação dos corpos por meio do mobiliário escolar. Essas preocupações não estão presentes em minha pesquisa. As temáticas da higiene da escola e do mobiliário nas Exposições Universais, porém, estão presentes tanto na dissertação de Raquel Castro, quanto nesta tese. No entanto, enquanto Castro organiza o seu trabalho "de acordo com as funções que as carteiras escolares foram assumindo no período estudado - do imperial ao republicano (1836 a 1914)"64, este trabalho toma a carteira como um fio que permite investigar o nascimento da indústria escolar e da escola como mercado consumidor.

A pergunta de pesquisa de Maria de Fátima Machado, em sua dissertação intitulada Maneiras de Sentar: Contributo para a História das carteiras escolares do ensino primário em Portugal (1835-1970), é: “em que medida, os discursos institucionais, médicos e pedagógicos determinaram as alterações formais, operadas nas carteiras escolares durante o período considerado - 1835/1970?"65. Minha questão é: como se deu a relação entre Estado, comércio e a Indústria do mobiliário escolar tendo em vista a expansão da escola de massa? As duas pesquisas se aproximam nas discussões que empreendem acerca do contexto médico-pedagógico e da organização

\footnotetext{
${ }^{61}$ Vale destacar os estudos de Valdeniza Barra sobre a lousa (2001) e de Márcia Razzini sobre a história da produção do lápis.

${ }^{62}$ VIDAL; GASPAR, 2011, p.20.

63 Idem, p. 28

${ }^{64}$ CASTRO, Raquel Xavier de Souza. Da cadeira às carteiras escolares individuais: entre mudanças e permanências na materialidade da escola primária catarinense (1836- 1914). Florianopolis: UDESC, Dissertação de Mestrado, 2009, p.17

${ }^{65}$ MACHADO, op. cit., p. 12
} 
material da escola. Todavia, distanciam-se, em alguns aspectos. Para dar conta de sua interrogação, Machado concentra-se nos estudos antropométricos e ergonômicos; na influência das carteiras na saúde dos alunos; na arquitetura da carteira escolar. Sem deixar de considerar alguns desses pontos, dou atenção ao levantamento de dados sobre empresas, comércios e industriais que se tornaram fornecedores de mobiliário e material para o Estado, tendo a escola como importante mercado consumidor.

A tese da francesa Josette Peyranne ${ }^{66}$, defendida na Université Paris V, é formulada a partir de três hipóteses e um objetivo. A primeira hipótese é a de que a visão do homem e de sua saúde modificaram o mobiliário escolar, e este, é resultado de diversos conceitos de saúde; a segunda, diz que os métodos de aprendizagem, as escolhas de práticas educativas geram a criação de novos mobiliários; e a terceira sublinha que o mobiliário escolar do século XIX foi mais adaptado à altura dos alunos e às características morfotipológicas que o mobiliário atual. Ela objetiva mostrar as disfunções dos mobiliários antigos e atuais para fazer algumas proposições sobre as características do mobiliário da escola do futuro. Começando pelo mobiliário da Grécia e Roma antiga, passando pelo mobiliário escolar da Idade Média e Renascença, Peyranne analisa o mobiliário e o espaço escolar dos séculos XIX e XX para ao fim se perguntar: Qual o mobiliário escolar para o século XXI? Somente quando aborda a problemática do século XIX, há pontos em comum entre a tese de Peyranne e esta.

Nas três pesquisas citadas, e também nesta, observam-se algumas discussões em comum: a higiene pública e escolar como mola propulsora para fabricação/produção de um novo mobiliário e as Exposições Universais como espaço de fomento à adoção das novas carteiras. Nenhuma delas, entretanto, se aproxima do tratamento das questões econômicas e administrativas dos Estados que passam a adquirir estes materiais. Como as carteiras expostas nas grandes exposições chegam à sala de aula das escolas paulistas? Como se deu o acesso aos catálogos de material e mobiliário escolar pelos administradores públicos e escolares? Qual o trâmite para aquisição de material e mobiliário estrangeiro? Quem foram os comerciantes e empresários que forneciam para o governo paulista? As reflexões empreendidas a partir dessas interrogações são as contribuições desta tese, não contempladas nas demais produções acadêmicas sobre carteira escolar.

\footnotetext{
${ }^{66}$ PEYRANNE, Josette. Le mobilier scolaire du XIXe siècle a nos jours: contribution a l'étude des pratiques corporelles et de la pédagogie à travers l'évolution du mobilier scolaire. Lille: ANRT, 2001.
} 
Uma das grandes dificuldades destes estudos, no entanto, é seguir os rastros dos utensílios e objetos escolares, pois eles se apagam. Isto é, muitas vezes não é possível localizar os objetos para perceber neles as marcas dos usos, por exemplo. Daí a importância de um conjunto de outras fontes por meio das quais se busca esquadrinhar os rastros da materialidade da escola. A esse respeito, Vidal e Gaspar entendem que "a dificuldade em localizar os elementos dessa cultura material escolar tem levado pesquisadores a buscar indícios da materialidade da escola e da escolarização em um leque alargado de fontes" ${ }^{\prime 67}$.

Acerca da importância de se debruçar sobre a materialidade da escola, Agustín Escolano Benito afirma que os objetos e materiais são registros da cultura empírica das instituições educativas e, nesse sentido, sinalizam orientações pedagógicas subjacentes à formação e ao trabalho docente; o legado material é uma fonte essencial para o conhecimento do passado da escola em suas dimensões prática e discursiva; a história material da escola se constrói a partir dos objetos, os quais portam significados que devem ser decifrados pelos indícios que sugerem ao pesquisador ${ }^{68}$.

Nesta pesquisa, um conjunto diverso de fontes tem permitido compreender a carteira escolar como um elemento de formação de identidades corporais discentes, mas também como um elemento que elucida os modos como o Estado de São Paulo foi se organizando para atender a escolaridade obrigatória. E, como, impulsionada pelo fenômeno da escolarização obrigatória, emerge a indústria escolar.

\section{Fontes e discussão teórico-metodológica}

Para investigar as opções, possibilidades e desafios à expansão da escola pública, obrigatória e de massa, foram selecionadas fontes segundo cinco critérios: 1) documentos produzidos no interior da escola: inventários de bens, ofícios e correspondências de diretores e professores solicitando material escolar. 2) Fontes vinculadas ao comércio e à indústria escolar: notas fiscais de compra e/ou importação, catálogos de fábricas de móveis escolares, almanaques, recibos de fornecedores ou prestadores de serviço, móveis escolares. 3) Documentos produzidos por especialista da

\footnotetext{
${ }^{67}$ VIDAL; GASPAR, 2011, p.31

${ }^{68}$ ESCOLANO, A. La cultura material de la escola. En el centenário de la Junta para La Ampliación de Estudios, 1907-2007. Berlanga de Duero- Soria, 2007.
} 
educação, medicina, dentre outros: manuais e revistas pedagógicas que discutem a relação entre a carteira escolar e a saúde dos alunos, os fundamentos higiênicos, pedagógicos, antropométricos e ergonômicos do mobiliário escolar, textos que tratam do mobiliário escolar nas Exposições Universais do fim do século XIX; 4) documentos provenientes da administração pública: relatórios, lista de almoxarifado, ofícios e correspondências. 5) Objetos fotografados: digitalização da imagem por registro fotográfico de carteiras no Centro de Memória da Faculdade de Educação da USP e no Centre national de documentation pédagogique (CNDP - Rouen, França).

Tais fontes permitem não somente descrever o mobiliário escolar, identificar os modelos de carteiras, ou ainda, a proveniência das mesmas. Elas ajudam a problematizar a internacionalização ${ }^{69}$ de um mobiliário escolar considerado indispensável à modernidade pedagógica ${ }^{70}$ do final do século XIX.

Longe de exprimir uma homogeneização de modelos, o interesse reside em estabelecer conexões e comparações que vão além da constatação de interações e influências recíprocas entre os países estudados nesta pesquisa (Brasil, Estados Unidos e França $)^{71}$. Analisar a cultura material escolar sob a perspectiva da internacionalização dos objetos educativos faz emergir novos problemas, novos modelos, novas abordagens $^{72}$. Isso porque é importante perceber as redes ativas heterogêneas nas quais pessoas, objetos e rotinas estão conectados, nos modos de trabalho escolar ${ }^{73}$.

Ulpiano Menezes levanta questões teórico-metodologicas que são instigadoras quando se lança mão de artefatos materiais como documento: "qual a natureza do objeto material como documento, em que reside sua capacidade documental, como pode ele ser

\footnotetext{
${ }^{69}$ SCHRIEWER, Jürgen. L'internationalisation des discours sur l'éducation : adoption d'une " idéologie mondiale » ou persistence du style de « réflexion systémique » spécifiquement nationale ? Revue Française de Pédagogie, $\mathrm{n}^{\circ}$ 146, janvier-février-mars 2004, 7-26.

${ }^{70}$ Segundo Diana Vidal (2009), "a invenção da modernidade educativa" se fez sentir na circulação internacional de modelos pedagógicos, sujeitos e objetos. Essa "modernidade educativa" carregava a idéia de progresso que associava, segundo a autora, desenvolvimento científico e educativo à ampliação material escolar.

${ }^{71}$ OSSENBACH, Gabriela. Por una Historia Comparada de la Educación en España, Portugal Y América Latina. In: ESCOLANO, A. \& FERNANDES, R. (Eds.). Los caminos hacia la modernidad educativa en España y Portugal (1800-1975). Zamora: SEHE, 1997, p. 227-251

${ }^{72}$ NÒVOA, Antonio. Modeles d'analyse en education comparée: le champ et la carte. In: Education comparée. Montreal/Paris: l'Harmattan, 1998, p.9-61.

${ }^{73}$ LAWN, Martin \& GROSVENOR, Ian (éd.). Materialities of Schooling: design,Technology,Objects,Routines. Oxford: Symposium Books, 2005. - 217 p. (Comparative Histories of Education)
} 
suporte da informação? [...] que tipo de informação podem os artefatos conter, especialmente de conteúdo histórico?"74.

Para ele, os traços materialmente inscritos nos artefatos orientam leituras que permitem inferências, pois a matéria-prima, as técnicas de fabricação, a morfologia do artefato, os sinais de uso, os indícios de diversas durações, selam no objeto, informações materialmente observáveis sobre a natureza e propriedades dos materiais, bem como da organização econômica, social e simbólica da existência social e histórica do objeto.

Nesse caso, os "objetos materiais têm uma trajetória, uma biografia"75 que é preciso considerar. Não para recompor o cenário material, mas para "entender os artefatos na interação social". Portanto, são fontes "excepcionais para se entender a sociedade que os produziu ou reproduziu enquanto, precisamente objetos históricos" ${ }^{, 76}$.

Investigar a biografia dos objetos (no caso, a carteira escolar) é um procedimento fértil que pode ser usado para perceber como "em torno dos materiais escolares foram instituídas práticas discursivas, modos de organização pedagógica da escola, consolidação de métodos de ensino, constituição de sujeitos e práticas, aspirações de modernização educacional e significados simbólicos"77.

Laerthe de Moraes Abreu Junior oferece diretrizes para estudar essa produção da escola por meio da cultura material da escola. Segundo ele,

Há uma cultura material na escola que se manifesta vivamente pela concretude não só dos objetos, mas também das práticas empreendidas com esses (e através desses) objetos, que precisam ser investigados a partir desse suporte material, sem se deixar cair na tentação da interpretação objetiva, neutra, do que seria pretensamente a verdadeira natureza das atividades escolares ${ }^{78}$.

Para que essa interpretação seja mais rica, o autor sugere que ela deve ser interdisciplinar, já que "O campo da cultura material tem uma natureza complexa e interdisciplinar, pois abrange a história da educação, assim como a antropologia, a sociologia e a pedagogia" ${ }^{, 79}$.

\footnotetext{
${ }^{74}$ MENEZES, Ulpiano. Memória e cultura material: documentos pessoais no espaço público. Seminário Internacional sobre Arquivos Pessoais, Rio/São Paul, CPDOC/FGV/USP, 1997, p.90.

${ }^{75}$ Idem, p.92

${ }^{76}$ Idem, p.95

77 SOUZA, Rosa Fátima de. Vestígios da Cultura Material Escolar. Campinas: Editora Autores Associados. Revista Brasileira de História da Educação, n.14, mai/ago. 2007, p. 11-12.

${ }^{78}$ ABREU JUNIOR, Laerthe de Moraes. Apontamentos para uma metodologia em cultura material escolar. Campinas, Universidade Estadual de Campinas, Faculdade de Educação. Revista Pro-Posições, v.16, n.1 (46), jan./abr. 2005, p.146

${ }^{79}$ Idem, p. 145
} 
Além disso, o autor propõe três dimensões analíticas que podem ser importantes aqui: a materialidade, a tecnologia e a intencionalidade dos objetos. "A materialidade diz respeito à sua constituição enquanto suporte que ocupa determinado espaço em determinado tempo, contribuindo para contextualizar as práticas em seus constituintes materiais" $" 80$. A segunda dimensão, a da tecnologia, "está ligada aos conhecimentos, habilidades e procedimentos envolvidos na aplicação e utilização dos materiais e permite análises de amplitudes diversas, a começar por uma de natureza didáticopedagógica"81. Quanto à intencionalidade é preciso

Investigar as condições sociais e históricas que produzem o esteio da evolução da cultura material escolar. Os materiais não se explicam pelos materiais [...] Os materiais e seu uso na escolarização são a prioridade, mas eles têm que estar compreendidos em seu contexto, tanto espacial, quanto histórico. Não há materiais soltos, sem gênese e, consequentemente, sem valor social e político ${ }^{82}$.

Abordar estas três dimensões significa que esta pesquisa será desenvolvida no cruzamento de diversas áreas - Cultura Material, História Conectada, História Econômica - associando diversas dimensões do cotidiano escolar.

No âmbito da Cultura Material, é importante explorar o impacto que a materialidade tem na própria cultura. Isso porque os artefatos "não são apenas produtos, mas vetores de relações sociais" $" 83$. Por meio do conceito de cultura material olha-se a escola em sua globalidade ${ }^{84}$. Para Margarida Felgueiras “estudar a educação hoje significa prestar atenção à densidade histórica do sistema educativo, nos contextos históricos de realização, expressos numa cultura material, que, simultaneamente, traduz as concepções de uma sociedade e manifesta as condições em que puderam ocorrer" ${ }^{\prime 25}$. Felgueiras alerta para a quantidade de pesquisas sobre o "interior" da instituição escolar.

A instituição escolar foi-se constituindo ao longo da sua trajetória como objeto material e imaterial [...] O edifício escolar, que se foi destacando da habitação comum, erguia-se na paisagem das cidades e das aldeias e, progressivamente, estruturava a vida das crianças. Mas o seu interior permanecia opaco à sociedade que o criara ${ }^{86}$.

\footnotetext{
${ }^{80}$ Idem, p. 158

${ }^{81}$ Idem, p. 160

${ }^{82}$ Idem, p. 161

${ }^{83}$ MENESES, Ulpiano T. Bezerra de . A exposição museológica e o conhecimento histórico. In: Figueiredo, Betênia Gonçalves \& Vidal, Diana Gonçalves. (Org.). Museus. Dos gabinetes de curisoidades à museologia moderna. $1^{\mathrm{a}}$. Ed. Belo Horizonte / Brasília: Argumentum / CNPq, 2005, p.18

84 FELGUEIRAS, Margarida. Materialidade da cultura escolar. A importância da museologia na conservação/comunicação da herança educativa. Campinas, Universidade Estadual de Campinas, Faculdade de Educação. Revista Pro-Posições, v.16, n.1 (46), jan./abr. 2005, p. 67-102.

${ }^{85}$ Idem, p.94

${ }^{86}$ Idem, p.96
} 
O interior da escola e, sobretudo, da sala de aula é colocado em evidência nos estudos que se interessam pela materialidade desses espaços. Nas palavras de Escolano, os objetos da escola "são eles mesmos, dispositivos visíveis da escola, por meio dos quais, uma coletividade foi educada e instruída" ${ }^{\natural 7}$.

A partir da História Conectada ${ }^{88}$, considero o processo de difusão mundial da escola $^{89}$ no século XIX, destacando o investimento sistemático do Estado em educação. A preocupação com a escolarização da população brasileira, nesse período, não pode ser apartada da "construção de uma educação higienizada"90 que tem como uma de suas importantes vertentes a adoção de um mobiliário que não cause problemas e deformidades nos alunos.

Os estudos de Diana Vidal, desenvolvidos na perspectiva da História Conectada, são referências fundamentais, aqui, sobretudo, nos modos de operar. Para a autora,

Compreender os objetos no espectro do possível da materialidade, das concepções pedagógicas e científicas e das negociações comerciais supõe um conhecimento sobre as técnicas produtivas, as populações escolares e a riqueza das nações (de seu aparelho público) e sobre as escolhas administrativas e políticas que determinam os investimentos econômicos [...] Espraia-se também pelo debate acerca das formas de internacionalização existentes, bem como sobre as maneiras de construir inteligibilidades para essas relações multilaterais, no seu caráter histórico ${ }^{91}$.

As "escolhas administrativas" e os "investimentos econômicos" são elementos importantes para a discussão que se pretende empreender. Por que em dado momento da história da escola paulista, certos móveis, objetos e materiais pareciam ser imprescindíveis ao funcionamento da instituição escolar? Por que a opção por um mobiliário e não outro? Como entender a quantidade significativa de objetos, mobiliário e materiais registrados nos inventários de escolas paulistas como provenientes de outros países?

\footnotetext{
${ }^{87}$ ESCOLANO, op. cit., p.21.

${ }^{88}$ SUBRAHMANYAM, Sanjay. Connected histories: notes towards a reconfiguration of early modern Eurasia. In: LIEBERMAN, V. Beyond binary histories. The University of Michigan Press, 1999, p.289316.

${ }^{89}$ NÓVOA, António; SCHRIEWER, Jürgen (eds.). A difusão mundial da escola. Lisboa: EDUCA, 2000

${ }^{90}$ GONDRA, José G. Conformando o discurso pedagógico: a contribuição da Medicina. In: FARIA FILHO, Luciano (et AL.). Educação, modernidade e civilização: fontes e perspectivas de análises para a história da educação oitocentista. Belo Horizonte: Autêntica, 1998, p. 35-71.

${ }^{91}$ VIDAL, Diana. Culturas escolares: estudo sobre práticas de leitura e escrita na escola pública primária (Brasil e França, final do século XIX). Campinas, São Paulo: Autores Associados, 2005, p.39 - (Coleção Memória e Educação.
} 
No campo da História Econômica, a carteira é uma lente ${ }^{92}$ que permite ver as relações entre a nascente indústria escolar e a escola como mercado consumidor. Configura-se, aí, um trinômio que tem se mostrado fundamental para compreender a racionalização do Estado para criar a escola de massa: Estado - Indústria - e obrigatoriedade da educação escolar ${ }^{93}$.

Nesta investigação, os investimentos econômicos na escola serão analisados considerando fatores exógenos e endógenos à economia ${ }^{94}$. Seguindo a perspectiva de Barros quando afirma que, a partir da metade do século $\mathrm{XX}$, a tendência da historiografia econômica é atribuir importância "tanto a fatores exógenos como a fatores endógenos ao mesmo tempo em que as explicações tendem a entremear de forma equilibrada a dedução teórica e a demonstração empírica, com ampla utilização de metodologias estatísticas, mas sem dispensar as análises qualitativas" ${ }^{95}$. Isso porque "surge uma História Econômico-Social profundamente preocupada com a repercussão dos fatos econômicos da vida social" ${ }^{\text {" }}$. Em outras palavras, Tomás Szmrecsányi afirma que "a história econômica só pode ser adequadamente estudada na medida em que tiver como pano de fundo o processo histórico como um todo, e não apenas seus aspectos econômicos" $"$.

Referência fundamental neste trabalho, Kula Witold entende que ao analisar os problemas do ponto de vista econômico, o historiador deve considerar "o papel dos fatores extra-econômicos nas transformações econômicas" "98. Assim sendo, no tratamento do objeto, o historiador econômico pode se valer das contribuições de outras

\footnotetext{
92 VIDAL, Diana Gonçalves \& FARIA FILHO, Luciano Mendes de. As lentes da história: estudos de história e historiografia da educação no Brasil. São Paulo: Autores. Associados, 2005, 139p. (Coleção Memória da Educação); REVEL, Jacques (org). Jogos de Escala. A experiência da microanálise. Tradução Dora Rocha. Rio de Janeiro: FGV, 1998.

93 Diana Vidal tem chamado a atenção para esta relação em trabalhos como: Fronteiras e mestiçagens culturais: a circulação de objetos, pessoas e modelos pedagógicos como problemática em história da educação (Brasil, EUA, França e Portugal no final do século XIX). Estudos do Século XX, v. 6, p. 43-55, 2006; VIDAL, Diana Gonçalves . O museu escolar brasileiro: Brasil, Portugal e França no âmbito de uma história conectada (final do século XIX). In: LOPES, FARIA FILHO, FERNANDES. (Org.). Para a compreensão histórica da infância. Belo Horizonte: Autêntica, 2007, v. 1, p. 199-220; VIDAL, Diana. A invenção da modernidade educativa: circulação internacional de modelos pedagógicos, sujeitos e objetos no Oitocentos. In: CURY, Cláudia Engler; MARIANO, Serioja (orgs.). Múltiplas visões: cultura histórica no oitocentos. João Pessoa: Editora Universitária da UFPB, 2009, p. 37-54.

94 BARROS, José D’Assunção. História Econômica. Considerações sobre um campo disciplinar. Revista de Economia Política e História Econômia. Ano 4, n.11, jan.2008, p.5-51.

${ }^{95}$ Idem, p. 25

${ }^{96}$ Idem, p. 24

97 SZMRECSÁNYI, Tomás. História Econômica, Teoria Economica e História Aplicada. Revista de Economia Política, vol.12. n.3 (47), julho-setembro, 1992, p.131.

98 KULA, Witold. Problemas y Métodos de La Historia Económica. Barcelona, Península, trad. Esp., 1977, p.54 - “el papel de los factores extraeconómicos en las transformaciones económicas”.
} 
disciplinas históricas, como a história política, a história da cultura material, do direito e dos movimentos sociais.

Desse modo, falar de uma história econômica da escola significa dar destaque aos aspectos econômicos que impõem limites e possiblidades à expansão da instrução pública, sem dissociá-los das questões legais, sociais, culturais e políticas.

Além disso, não existe o fato econômico apartado de outros fatores. "Os fatos econômicos frequentemente acham-se imbricados com fatos políticos, sociais, culturais, institucionais, ou mesmo ligados às mentalidades" 99 .

Como métodos da História Econômica Barros destaca a serialização ${ }^{100}$ e a quantificação $^{101}$. Dentre as fontes apresentadas pelo autor, as que mais interessam ao desenvolvimento desta pesquisa são os documentos aduaneiros e de compra e venda.

É necessário elucidar que apresentar as contribuições de cada área para esta investigação não significa que elas serão tomadas de forma apartada. "Tradicionalmente, os historiadores culturais atribuíram menos atenção à cultura material que às ideias, deixando aquele campo aos historiadores econômicos [...] Por sua vez, os historiadores econômicos costumavam deixar de lado os aspectos simbólicos $[\ldots]^{\prime 102}$.

Aqui, história econômica também se relaciona com história política. Interessa pensar a atividade do Estado como comprador de móveis e material escolar, a estruturação da administração estatal para equipar as instituiões de ensino, asseguando ou não a expansão da escola. Vale lembrar que, não raro, os administradores públicos alegam que as dificuldades econômicas são entraves para o investimento na educação.

Acerca da interdependência das disciplinas históricas, Kula Witold defende que

não há nenhuma disciplina histórica capaz de dar a luz a seus próprios problemas, utilizando apenas seus materiais e métodos próprios. Por outro lado, a dependência entre a história econômica e a história dá cultura material é, neste caso, bilateral. Por exemplo, não pode haver uma solução para o problema da difusão de qualquer técnica de produção, sem a análise prévia do cálculo do investidor, o qual só pode ser levado a cabo pela História Econômica. Mas não há nenhuma

\footnotetext{
${ }^{99}$ Idem, p.26

100 Uma série é um determinado conjunto de fontes estabelecido pelo historiador com vistas à quantificação e serialização de dados, sendo estas fontes necessariamente assinaladas por uma relação de 'continuidade' e, frequentemente, abundantemente disponíveis para o historiador (BARROS, 2008, p.3031).

${ }^{101}$ História dos Preços, Estatísticas oficiais de preços de um determinado período, livros contábeis" referentes aos registros administrativos de instituições, hospitais, mosteiros, casas nobiliárquicas, fazendas (BARROS, 2008, p.32).

${ }^{102}$ BURKE, Peter. O que é a história cultural? Tradução: Sérgio Goes de Paula. Rio de Janeiro: Jorge Zahar Ed.2005, p.90.
} 
análise econômica do cálculo do investidor sem o conhecimento do correspondente cálculo técnico ${ }^{103}$.

Embora reconheça "os traços distintos destas disciplinas"104, Witold insiste na importância de tratar dos problemas de pesquisa em sua integridade. Não é desprezível as contribuições mútuas entre a história econômica e a história do direito. "Esta última deveria usar os resultados das explorações histórico-econômicas para esclarecer as causas de aparecimento e desaparecimento de determinadas normas"105. A história econômica, por sua vez, "deveria usar os resultados das indagações da história do direito, já que as regras vigentes em uma determinada sociedade constituem, em parte, o quadro no qual se desenvolve sua vida econômica"106.

Nesta pesquisa, por exemplo, a carteira é analisada em sua materialidade. Considero as inovações técnicas aplicadas a este objeto a fim de torná-lo mais higiênico e confortável. A carteira não é somente um objeto escolar, mas uma mercadoria que consitui um mercado promissor no fim do século XIX, comercializada entre Estados e empresas, digna da proteção jurídica por meio de patentes de invenção.

O objetivo não é captar os movimentos/os rastros da carteira em diferentes áreas, mas entre diferentes áreas. Apontando para a história da constituição e organização do sistema de ensino em São Paulo, a carteira é um objeto que circula entre saberes (educação, medicina), entre culturas e países, entre mercados e capital. Tomá-la como fio para seguir estes movimentos é o desafio desta pesquisa.

O texto foi divido em cinco capítulos. No Capítulo 1, a carteira escolar é abordada como um objeto que circula entre saberes. Circulação internacional de discursos e saberes sobre o corpo infantil, sobre o corpo do cidadão escolarizado, a higiene pública e escolar. A escola moderna, obrigatória e de massa deveria ser estruturada em sua localização, arquitetura e mobiliário de acordo com as prescrições da Higiene Pública, defendida em manuais por educadores, médicos, arquitetos,

${ }^{103}$ WITOLD, op. cit. p.68 - "no existe ninguna disciplina histórica capaz de dar luz a sus propios problemas, utilizando sólo sus proprios materiales y sus proprios métodos. Por otra parte la dependencia entre la historia econômica y la historia da cultura material es, en este caso, bilateral. Así, por ejemplo, no puede haber solución al problema de la difusión de cualquier técnica de la producción sin un análisis previo del cálculo inversionista, el qual sólo puede ser realizado por la historia econômica. Pero não hay ningún análisis económico del cálculo inversionista sin el conocimiento del correspondiente cálculo técnico".

${ }^{104}$ Idem, ibidem - "los rasgos distintos de estas disciplinas".

${ }^{105}$ Idem, p.65 - "Esta última devería aprovechar los resultados de las exploraciones histórico-económicas para esclarecer las causas de la aparición y desaparición de unas normas determinadas".

${ }^{106}$ Idem, ibidem - "tendría que aprovechar los resultados de la indagaciones de la historia del derecho ya que las reglas vigentes em una sociedad determinada constituyen en parte el marco en el qual se desarrolla su vida econômica". 
engenheiros. As carteiras funcionam, então, como a materialização das preocupações em relação às atitudes dos alunos ao sentar a fim de evitar moléstias que se adquirem devido à postura dos escolares, as quais podem comprometer o desenvolvimento deles.

Essa circulação internacional se dá não somente por meio de livros, revistas e manuais, mas também nas Exposições Universais. A internacionalização da educação se mostra nas Exposições Universais, nos congressos de instrução, nos vapores e viagens marítimas, que permitem a circulação de pessoas, ideias e objetos. No Capítulo 2 discorro, a partir de Catálogos das indústrias de mobiliário escolar, sobre os modelos de carteira mais hegemônicos expostos nas Exposições Universais do século XIX. Dou destaque às empresas norte-americanas e francesas que assumiram a liderança do mercado de mobiliário escolar.

Ainda no fim do século XIX, em 1883, foi realizada uma Exposição Pedagógica no Brasil, mais precisamente no Rio de Janeiro. Nela, diversos países contribuíram com exemplares de carteiras. No âmbito desse evento, o Relatório do Jury sobre os móveis expostos, constitui uma fonte fértil pelos detalhes que traz acerca das características técnicas e higiênicas que, no Brasil, estavam sendo apreciadas na fabricação das carteiras. Traz importantes informações sobre os países que participaram com móveis escolares, o tipo de carteira exposto e as indústrias brasileiras que tomavam a Exposição do Rio de Janeiro como espaço privilegiado de propaganda, inserção ou manutenção no mercado.

É preciso saber como as carteiras exibidas nas Exposições Universais e Nacionais chegaram às escolas paulistas. Num primeiro momento, chegaram via importação e, para tanto, os administradores públicos e escolares se valeram de viajantes, mediadores e tradutores culturais ${ }^{107}$ (representantes e agentes comerciais, casas importadoras). $\mathrm{O}$ destaque será dado às empresas estrangeiras que forneceram material e mobiliário escolar para as escolas paulistas. Assim, a proveniência da carteira escolar, que sinaliza os caminhos da modernidade educativa, será objeto de estudo no Capítulo 3.

A importação, entretanto, não foi o único modo pelo qual o governo paulista adquiriu mobiliário escolar. No Capítulo 4, mostro que, juntamente com a expansão da escola de massa, surge a indústria de mobiliário escolar nacional. O destaque será dado às empresas nacionais que se tornaram fornecedores de carteira para as escolas

\footnotetext{
${ }^{107}$ Uma melhor definição destas categorias será dada no Capítulo 3.
} 
paulistas. Na relação entre indústria, Estado e educação, a escola sofre limitações de acordo com aquilo que o mercado pode oferecer-lhe. Mas, a escola também movimenta o mercado quando o Estado desponta como comprador dos materiais e do mobiliário já oferecidos no comércio. Não somente isso, a escola impulsiona a criação de novos serviços e objetos. E, além disso, o mercado cria necessidades e objetos de desejo para as escolas.

A corrida das empresas pela proteção e garantia de mercado pode ser percebida nas solicitações de patentes de carteira. A carteira é tomada como um objeto que circula entre mercados e capitais. A quantidade expressiva de catálogos de mobiliário escolar e solicitação de patentes dá, por um lado, uma dimensão da relevância que as indústrias e fábricas de mobiliário escolar tiveram para o suprimento material da escola e, como corolário para sua expansão. Por outro, evidencia-se o quanto a escola foi um consumidor importante para a expansão desta atividade econômica.

$\mathrm{Na}$ formação da escola de massa, a indústria assume um papel fundamental que é a de poder oferecer, num curto espaço de tempo, uma grande quantidade de móveis e de materiais necessários à expansão escolar. Na criação das condições físicas da escola de massa, a indústria tem o seu papel, já que um sistema de ensino pressupõe a padronização.

Dentro desse sistema, se a Escola Normal seria responsável pela padronização da formação docente, a indústria seria pelo material e mobiliário escolar. O capítulo 4 foi escrito para destacar esta relação entre a indústria escolar e a escola de massa, pontuando a importância das inovações técnicas para fabricação das carteiras e das patentes para a especialização, proteção e expansão do mercado de mobiliário escolar. Em outras palavras, o capítulo versará sobre as relações entre indústria escolar, as inovações técnicas que propiciaram a produção em massa de carteira e as patentes que sinalizam a efervescência e rentabilidade do mercado do mobiliário escolar num período de expansão da escolaridade obrigatória.

Para efetivar a obrigatoriedade da educação escolar, a Administração Pública precisava se estruturar a fim de criar escolas com condições físicas de funcionamento. O crescente interesse do Estado na escola se materializa no investimento feito em um item indispensável à expansão de um certo modelo de escola (a escola graduada) - a carteira. No Capítulo 5, analisando ofícios e correspondências entre os administradores do ensino, investigo as práticas administrativas da Província e do Estado de São Paulo para, por meio do suprimento mobiliário, dar conta da escolaridade obrigatória. Ao 
mesmo tempo, destaco que as necessidades materiais da escola, por sua vez, contribuíram para mudanças na organização e estrutura da administração pública a fim de tornar possível a escola moderna de massa e ampliar a capilaridade do Estado.

Tornar obrigatória a presença de todas as crianças na escola, a partir de uma faixa etária, é uma ampliação do poder do Estado sobre os corpos. No entanto, "este poder se exerce de maneira tão invisível que nos esquecemos de sua existência e aqueles que se submetem são os primeiros a ignorar a existência dele, pois ele só é exercido apenas na medida em que ignoramos a sua existência"108.

A coerção inicial não precisa ser permanente porque "esta instituição que tem o poder extraordinário de produzir um mundo social ordenado sem necessariamente dar ordem, sem exercer coerção permanente"109. De modo que há um "acordo entre as estruturas cognitivas incorporadas (inconscientes), os horários, por exemplo, e as estruturas objetivas que é o verdadeiro fundamento do consenso sobre o sentido do mundo, da crença, da opinião, da doxa"110. Isso se dá, segundo Bourdieu, pela função simbólica do Estado. "Para compreender esta dimensão simbólica do efeito do Estado, é necessário compreender a lógica do funcionamento do universo de agentes do Estado que fazem o discurso do Estado"111 produzindo efeitos de racionalidade.

Não são os fatores higiênicos, pedagógicos e ergonômicos os únicos considerados para escolha do mobiliário escolar, do tipo de carteira. O estudo da documentação evidencia que fatores de ordem econômica (o comércio local, a indústria, o mercado, as relações comerciais externas) e a própria organização administrativa da Província, e depois, do Estado de São Paulo são condicionantes do tipo de mobiliário que efetivamente chega aos estabelecimentos de ensino.

Como resultado, evidencia-se que: a) o mobiliário e os objetos escolares não expressam ou ilustram as relações glocais $^{112}$, eles constituem as próprias relações; b) as

\footnotetext{
${ }^{108}$ BOURDIEU, Pierre. Sur l'État. Cours au Collège de France (1989-1992). Paris, Seuil, 2012, 656 p.259. Ce pouvoir qui s'exerce de manière si invisible qu'on em oublie même l'existence et que ceux qui le subissent sont les premiers à em ignorer l'existence puisqu'il ne s'exerce que dans la mesure ou l'on ignore l'existence.

${ }^{109}$ Idem, p.264 - "cette institution qui a le pouvoir extraordinaire de produire un monde sõuial ordonné sans nécessairement donner d'ordres, sans exercer de coercition permanente".

${ }_{110}$ Idem, p.276 - "l'accord entre ces structures cognitives incorporées, devenues complètement inconscientes - par exemple, lês horaires -, et les structures objectives qui est le véritable fondement du consensus sur le sens du monde, de la croyance, de l'opinion, de la doxa".

${ }^{111}$ Idem, p.277 - "Pour comprendre cette dimension symbolique de l'effet d'État, il faut comprendre la logique du fonctionnement de cet univers d'agents d'État qui ont fut le discours d'État".

112 CANCLINI, Nestor. Introdução à edição de 2001. As culturas híbridas em tempos de globalização. Culturas híbridas. São Paulo: EDUSP, 2003, p. XVII-XL. Canlini propõe a categoria glocal para pensar a relação entre culturas para além do par de oposições global e local. A glocalização diz respeito às síntese
} 
carteiras escolares são vetores $^{113}$ de relações pedagógicas, higiênicas, culturais, administrativas e econômicas. Portanto, além de um objeto escolar, ela é também um artefato industrial mostrando que a história e a configuração da escola não se definem somente no interior dela, mas na relação com o mundo externo, com questões econômicas, políticas e sociais. Isso significa que as políticas públicas e práticas administrativas voltadas para a escola não devem levar em conta somente as questões internas à instituição, mas também as extraescolares.

entre o local e o glocal que se operam no trânsito planetário de pessoas, bens, tecnologias, processos industriais e culturas. Corroborando com Canclini, Serge Gruzinski (2001) entende que os deslocamentos entre o local e o global são vários de modo que "esses mundos se unem em frentes onde menos esperamos", revelando "paisagens misturadas, muitas vezes confusas e imprevisíveis" (GRUZINSKI, Serge. Les mondes mêlés de la monarchie catholique et autres "connected histories". Annales. Histoire, Sciences Sociales, 56e. Année, nr.1, jan.-fev. 2001, p.87).

113 MENESES, Ulpiano T. Bezerra de . A exposição museológica e o conhecimento histórico. In: Figueiredo, Betênia Gonçalves \& Vidal, Diana Gonçalves. (Org.). Museus. Dos gabinetes de curisoidades à museologia moderna. 1a. Ed. Belo Horizonte / Brasília: Argumentum / CNPq, 2005 - "A chamada 'cultura material' participa decisivamente na produção e reprodução social. No entanto, disso temos consciência superficial e descontínua. Os artefatos, por exemplo, são não apenas produtos, mas vetores de relações sociais. Que percepção temos desses mecanismos? Não se trata, apenas,portanto, de identificar quadros materiais de vida, listando de objetos móveis, passando por estruturas, espaços e configurações naturais, a 'obras de arte'. Trata-se, isto sim, de entender o fenômeno complexo de apropriação social de segmentos da natureza física - e, mais ainda, de apreender a dimensão material da vida social" (MENESES, 2005, p. 18). 


\section{CAPÍTULO 1 \\ A CARTEIRA ESCOLAR: UM DIPOSITIVO HIGIÊNICO}

Na parte 1 do vol. I do seu Dictionaire, Ferdianand Buisson define a Hygiène como uma ciência capital, mas é "desconhecida da maior parte dos nossos cidadãos"114. A higiene deve atingir a vida, ações e atividades públicas e privadas dos indivíduos. A higiene individual compreende a "Alimentação. Bebidas. Vestuário. Habitação: localização, ventilação, aquecimento e iluminação. Exercício e descanso. Acordar e dormir. Limpeza do Corpo e banho. Trabalho intelectual e manual. Higiene das Profissões" ${ }^{\prime 15}$. Já a higiene pública é tratada no verbete quase que como sinônimo de higiene escolar visto que é a única instituição que merece a atenção do pedagogo francês.

Neste capítulo, discorro sobre a circulação internacional de um discurso higiênico-educacional sobre o corpo dos alunos e a organização do espaço da sala de aula em relação à carteira escolar. Analisando manuais pedagógicos, livros e regulamentos, sobretudo da França, Estados Unidos e São Paulo, coloco em evidência a internacionalização $^{116}$ de modos de conceber a difusão mundial da escola ${ }^{117}$. Não porque os discursos nesses diferentes países sejam homogêneos, mas porque, a despeito das diferenças e semelhanças, eles são elucidativos quanto às concepções de escola e de aluno, às políticas educativas e aos embates na constituição dos sistemas de ensino. $\mathrm{O}$ destaque dado às publicações da França e dos Estados Unidos justifica-se pela quantidade significativa de material e mobiliário escolar que o governo paulista importou deles, como se demonstrará no Capítulo 3.

Por isso, neste primeiro capítulo tratarei da carteira escolar como dispositivo higiênico que fez parte da estruturação da escola pública paulista no período delimitado. Tendo isso em vista, abordarei tanto as discussões internacionais quanto locais.

A preocupação com a mobília escolar, com o corpo infantil, com as maneiras pelas quais outros países estavam organizando o espaço da sala de aula e o espaço individual do aluno fica bem evidente nos livros A Hygiene na Escola, publicado em

\footnotetext{
114 BUISSON, Ferdinand. Dicionário de Pedagogia e da Instrução Primária. Parte I, Tomo I. Paris: Librairie Hachette \& Cie., 1887, p.1299. "inconnue de la plupart de nos concitoyens".

115 Idem, ibidem.

${ }^{116}$ SCHRIEWER, Jürgen. L'internationalisation des discours sur l'éducation: adoption d'une «idéologie mondiale » ou persistence du style de « réflexion systémique » spécifiquement nationale ? Revue Française de Pédagogie, ${ }^{\circ}$ 146, janvier-février-mars 2004, 7-26.

${ }^{117}$ NÓVOA, Anónio; SCHRIEWER, Jürgen. A difusão mundial da escola. Lisboa: Educa História, 2000.
} 
1902, pelo médico e Inspetor Sanitário, Balthazar Vieira de Mello; e no livro Pedagogia e Methodologia do Padre Camillo Passalacqua, publicado em $1887^{118}$. De acordo com esses autores, os estudos sobre a higiene escolar em diversos países tiveram contribuições e influências significativas na concepção e produção do mobiliário escolar.

Depois desses estudos, sentar não era mais somente uma questão de acomodar o aluno em qualquer banco, não devia mais ser uma ação aleatória. A "Hygiene” passou a prescrever modos racionais e institucionalizados de sentar e ordenar o espaço do aluno. Dessa maneira, nos dois livros, os autores além de detalharem como deveria ser o edifício escolar (situação, construção, aspecto, dimensões, vizinhança, ambientes) e a sala de aula (quanto à iluminação, ventilação, limpeza, temperatura, disposição dos bancos e mesas, pintura e desinfecção); dão realce à mobília escolar como elemento essencial ao "desenvolvimento intellectual e physico da infancia e da mocidade"119.

Fundamentados na racionalidade científica e em princípios médico-higiênicos, veiculados nesses manuais, os educadores, no intuito de corrigir e evitar as deformidades, deveriam cuidar do alinhamento do corpo dos alunos e alunas em relação à carteira, mesa, papel, livros ${ }^{120}$.

Sendo assim, tanto Mello quanto Passalacqua defendem que não é a criança que deve se acomodar ao banco, mas o banco à criança a fim de evitar as moléstias, auxiliar no desenvolvimento por igual dos órgãos e facilitar a aquisição dos conhecimentos do programa de ensino. Considerando que a mobília e os modos de sentar têm papel preponderante na produção ou não das moléstias escolares, como a miopia e os desvios na coluna vertebral, os dois livros oferecem ilustrações de modelos de carteiras e de modos de sentar.

Segundo Passalacqua, "cada nação tem um modo especial de mobiliar suas escolas" "121. Apesar de reconhecer que a Alemanha, a Suíça, a França e os Estados Unidos têm se empenhado para "amenizar a vida escólar, já modificando a antiga

\footnotetext{
${ }^{118}$ Agradeço a Profa. Dra. Diana Vidal a cessão de uma cópia do Manual do Padre Camillo Passalacqua (1887) Pedagogia e Methodologia (Theorica e Pratica) - Compreendendo a Hygiene Escolar, Organisação geral e a direcção particular das escolas, de acordo com os systemas de ensino e com os princípios das sciencias Physiologicas, Psychologicas e Moraes e do livro A Hygiene na Escola de Balthazar Vieira de Mello.

${ }^{119}$ MELLO, Balthazar Vieira de. A Hygiene na Escola. São Paulo: Typographia do "Diario Official", 1902 , p.20.

${ }^{120}$ ROCHA, Heloísa; GONDRA, José. A escola e a produção de sujeitos higienizados. Perspectiva, n.2. Florianópolis, jul./dez/ 2002, v.20, p. 493-512.

${ }^{121}$ PASSALACQUA, Padre Camillo. Pedagogia e Methodologia (Theorica e Pratica). São Paulo: Typographia a vapor de Jorge Seckler \& Comp., 1887, p.63.
} 
mobilia, já criando novas peças, de accôrdo com a natureza, organisação e condições das crianças" ${ }^{122}$, Passalacqua assegura que "[...] os bancos e mesas americanas do Norte, são, nos parece, os que nos servem a nós"123.

As concepções sobre higiene e mobiliário escolar, semelhantes às desenvolvidas por esses dois autores brasileiros, também circularam em Portugal, em período semelhante, como demonstra Maria de Fátima Machado em sua Dissertação de Mestrado que teve por objeto as carteiras escolares do ensino primário naquele país. Ela discorre, dentre outras coisas, sobre a relação ortopédica entre a higiene e o mobiliário escolar; a preocupação com a presença do corpo da criança dentro da escola; sobre a disciplina do corpo como mecanismo pedagógico de controle do corpo social; e a função das carteiras enquanto veículo disciplinar e de regulação individual e coletiva. Neste capítulo, algumas destas questões serão contempladas.

\subsection{Um local próprio para a escola: Higiene da escola e da sala de aula}

A exigência de um espaço próprio para o funcionamento da escola está intimamente relacionada com os movimentos higienistas do século XIX que viram na escola o local, por excelência, para disseminar e promover a higiene pública. A intervenção de médicos e higienistas na definição de como deveria ser cada detalhe da construção da escola era justificada pela necessidade de prevenção de epidemias, moléstias e promoção da saúde moral e física dos alunos. Neste sentido,

a aparição dos movimentos higienistas em meados do século XIX, as transformações sociais e educativas ligadas ao processo de escolarização e o estudo científico da infância, deram também origem à necessidade de regulamentar medidas relativas à construção dos edifícos da escola, do equipamento escolar e do controle sanitário" ${ }^{\text {"124 }}$.

Os difíceis problemas sanitários e de saúde pública advindos da Revolução Industrial tornaram-se problemas da Higiene moderna e dos Estados.

O movimento higienista também alcançou a escola [...] o desenvolvimento da higiene escolar com a realização de estudos sistemáticos sobre a higiene dos edifícios, o mobiliário e os materiais escolares, o estudo do crescimento das crianças ou das patologias detectadas nos escolares, assim como sua internacionalização por

\footnotetext{
${ }^{122}$ Idem, p.57

${ }^{123}$ Idem, p.63

${ }^{124}$ MACHADO, op. cit., p. 216.
} 
meio da implantação dos serviços médico-escolares, começaria a produzir-se a partir da segunda metade do século XIX ${ }^{125}$.

É importante perceber que a higiene escolar é um dos ramos da higiene e da saúde pública.

Por uma boa parte do século XIX, em várias regiões do mundo, e inclusive no Brasil, as doenças e a salubridade das cidades vinham sendo problematizada sob diversos aspectos [...] As intervenções urbanas empreendidas no século XIX pelo corpo de médicos (e também engenheiros) responsáveis pelo saneamento das cidades no Brasil encontram sua fundamentação, como em outras partes do mundo (e desde o final do século XVIII), na teoria miasmática. O assunto "miasmas" era muito debatido entre os profissionais porque a palavra traduzia quase tudo o que tinha relação com insalubridade, além de ser algo desconhecido: acreditava-se serem os miasmas emanações nocivas invisíveis que corrompiam o ar e atacavam o corpo humano. Os miasmas seriam gerados pela sujeira encontrada nas cidades insalubres, e também por gazes formados pela putrefação de cadáveres humanos e de animais ${ }^{126}$.

A escola, como fenômeno urbano, como lugar de aglomeração de pessoas, exerceria um papel importante no saneamento das cidades. Conforme asseverou

Giovana Mastromauro, esta era uma preocupação presente em várias regiões do mundo e no Brasil ${ }^{127}$.

Tratando do caso carioca e argentino, José Claúdio Sooma afirma que "a partir do último quartel do XIX, de modo cada vez mais intenso, passou a ocorrer um entrelaçamento das instâncias médico-higiênicas com as políticas de remodelação urbana"128. Com os ditames da salubridade pública almejava-se que "as características arquitetônicas facultassem as condições para as doenças serem prevenidas" ${ }^{129}$. A teoria dos miasmas e as teorias bacteriológicas de Pasteur e Koch foram largamente usadas

\footnotetext{
${ }^{125}$ MARTINEZ, Pedro. Presentación. Cuerpo, higiene, educación e historia. Ediciones Universidad Salamanca. Historia de la Educación. Revista interuniversitaria. n.28, 2009, p.23-36. El movimento higienista también alcanzó a la escuela [...] el desarrollo de la higiene escolar con la realización de estúdios sistemáticos sobre la higiene de los edifícios, el mobiliário y los materiales escolares, el estúdio del crecimiento de lós niños o de las patologias detectadas en los escolares, así como su institucionalización por meio de la implantación de los servicios médico-escolares, comenzaría a producirse a partir de la segunda mitad del siglo XIX (MARTINEZ, 2009, p.27).

${ }_{126}$ MASTROMAURO, Giovana Carla. Surtos epidêmicos, teoria miasmática e teoria bacteriológica: instrumentos de intervenção nos comportamentos dos habitantes da cidade do século XIX e início do XX. Anais do XXVI Simpósio Nacional de História - ANPUH • São Paulo, julho 2011.

${ }^{127}$ MASTROMAURO, op. cit.

${ }^{128}$ SILVA, José Claudio Sooma. Teatros da Modernidade: representações de cidade e escola primária no Rio de Janeiro e em Buenos Aires nos anos 1920. 308 f. Tese (Doutorado). Faculdade de Educação da Universidade do Estado do Rio de Janeiro, 2009, p.212.

${ }^{129}$ Idem, p. 213.
} 
para "legitimar a política de intervenção no espaço público"130 e remodelar as cidades, evitando, assim, a profusão de epidemias.

Por isso, as casas improvisadas, sem ventilação e iluminação adequadas deveriam dar lugar a edifícios planejados. A partir do fim do século XIX, o local para construção da escola deveria ter características específicas, e a sala de aula, uma disposição e uma arquitetura próprias. A reconfiguração da arquitetura e organização da sala de aula comporia o cenário idealizado no qual a carteira seria um dispositivo fundamental.

A esse respeito, a tese de Josette Peyranne sublinha que, no caso francês, em 1880, “Jules Ferry proibiu as classes de 60, 80 e 100 alunos, as classes deviam, imperativamente, ser limitadas a 50 alunos" ${ }^{\prime 131}$.

Pedro Martinez, tratando do caso espanhol, também identifica a segunda metade do século XIX como período decisivo na discussão da relação corpo, higiene e educação, no âmbito do processo de extensão da escolarização obrigatória. Neste processo, ele destaca o estudo científico da infância, a progressiva ação pública e privada em favor da proteção à infância, a constituição de sociedades científicas, a emergência de novas profissões, a celebração de diversos congressos, a aprovação de leis, a proliferação de revistas, livros, tratados pedagógicos e manuais de higiene.

Assim, "a progressiva intensificação da vinculação entre higiene e educação constituiu um fator influente no processo de modernização dos sistemas educativos"132. A modernização do sistema educativo se evidenciaria no corpo do cidadão escolarizado, "um corpo controlado e sujeito à civilidade e às boas maneiras, isto é, alcançava tanto os hábitos corporais higiênicos como o terreno dos costumes, o que implicava tanto uma ética quanto uma estética diferentes"133.

A arquitetura escolar não é objeto central deste trabalho, mas ela não pode ser desconsiderada ao pensar as transformações no mobiliário escolar, para entender o conjunto de mudanças que se operava na própria escola. "A escola do século XIX é, assim, uma escola em plena mutação em seu conceito arquitetônico e na disposição de

\footnotetext{
${ }^{130}$ Idem, ibidem.

${ }^{131}$ PEYRANNE, op. cit. p. 197 - “Jules Ferry interdit les classes de 60, 80 et 100 élèves, lês classes doivent impérativement être limitées à 50 élèves".

${ }^{132}$ MARTINEZ, op. cit, p.25 - "La progresiva itensificación de la vinculación entre higiene y educación constituyó um factor influyente en el proceso de modernización de los sistemas educativos".

${ }^{133}$ MARTINEZ, op. cit, p.25 - "un cuerpo controlado y sujeto a la civilidad y las buenas maneras, es decir, que alcanzaba tanto a los hábitos corporales higiênicos como al terreno de las costumbres, lo que implicaba tanto una ética como una estética diferentes".
} 
seus espaços" ${ }^{134}$. As mudanças que se pretendia operar na escola devem ser entendidas no bojo do saneamento das cidades. De acordo com Hugo Segawa, sanear e embelezar eram termos típicos do fim do século XIX significando um "neologismo que se consagraria mais tarde, urbanizar"" apelando para a necessidade de saneamento da cidade, nos moldes das práticas vigentes na Europa oitocentista, justificadas pela questão da salubridade dos ambientes"136, dentre eles, a escola.

Passalacqua, citando o manual de Hygiene Scolaire do Dr. Riant, afirma que o edifício da escola deve se distinguir de outros tipos de habitação. "[...] tudo faz da escola uma construção especial não só sob o ponto de vista arquitetônico, como hygienico"137. O tamanho do edifício deveria comportar a quantidade de crianças a serem atendidas. Como referencial, o autor ressalta que "As construções escolares da França e da America do Norte (Estados Unidos) são enormes"138.

Mas o primeiro elemento a ser levado em consideração na construção do edifício era o "local próprio para uma escola"139. A questão tornou-se tão complexa que "A legislação austríaca determina que o local escolhido para uma escola não póde ser definitivo enquanto o médico a quem incumbe a inspeção escolar não der o seu parecer sobre a conveniência do terreno, no ponto de vista sanitário" ${ }^{\text {140 }}$. Somente depois do médico é que o plano seria examinado por uma "comissão composta de pessoas competentes em pedagogia, techonologia e hygiene medica" $" 141$.

Os critérios a observar na localização da escola nos centros menos e mais populosos são diferentes. Nas localidades pouco populosas a escola deve ocupar a parte central. Já nos centros populosos, as ruas ou praças com menos trânsito "para o fim de evitar o ruido e subtrahir as creanças ao perigo dos carros e outros vehiculos" ${ }^{142}$. Recomendação semelhante Peyranne observa que é feita para as escolas francesas acerca do lugar de construção: "É necessário evitar a proximidade das usinas,

\footnotetext{
134 - "L'école du XIX siècle est ainsi une école en pleine mutation par son concept architectural et l'aménagement de ses locaux" (PEYRANNE, 2001, p.201).

${ }^{135}$ SEGAWA, Hugo. Prelúdio da Metrópole. São Paulo; Ateliê Editorial, 2004, p.16

136 p. 17

137 PASSALACQUA, op.cit., p.29

${ }^{138}$ Idem, p. 30.

${ }^{139}$ Idem, ibidem.

${ }^{140}$ MELLO, op. cit., p. 3.

${ }^{141}$ Idem, ibidem

${ }^{142}$ Idem, p. 7
} 
cemitérios, hospitais, mercados públicos, de cursos de água pouco profunda, de pastagens pantanosas e dos estabelecimentos barulhentos"143.

Segundo Mello, “o Codigo Sanitario do Estado ${ }^{144}$, em seus artigos 184-202, estabelece normas para a situação e construção dos edifícios escolares, as quaes estão de

143 "Il faut éviter la proximité des usines, du cimetière, de l'hôpital, du marche public, des cours d'eau peu profonde, des prairies marécageuses et des établissements bruyants" (PEYRANNE, 2001, p. 203).

${ }^{144}$ DECRETO N. 233, DE 2 DE MARÇO DE 1894. Estabelece o Código Sanitário.CAPITULO VIII ESCOLAS

Artigo 184. - Os edificios para escolas devem ser cuidadosamente construídos em local, cujo solo esteja perfeita e completamente saneado, de accôrdo com o que fica estabelecido em relação ás habitações em geral.

Artigo 185. - Deverão ser collocados, longe dos hospitaes, cemiterios, fabricas, egrejas, prisões, etc, etc. Artigo 186. - Deverão ficar situados em ruas pouco concorridas e o mais distante possível da agglomeração urbana.

Artigo 187. - Não deverão ser sombreados por outros edificios ou arvoredos.

Artigo 188. - A orientação variará conforme a direç̧ão dos ventos reinantes, devendo entretanto ficar sempre abrigadas dos ventos prejudiciaes

Artigo 189. - Sempre que fôr possível, as escolas deverão ler um só pavimento.

Artigo 190. - As salas de classe deverão estar collocadas acima do solo, 1 a 2 metros, no maximo.

Artigo 191. - As escadas deverão ser largas, rectas ou quebradas em angulos rectos com patamares e os degraus não deverão ter mais de 15 a 16 centimetros de altura.

Artigo 192. - As portas de entrada deverão ser amplas e altas e communicarão com espaçoso vestibulo. Artigo 193. - Os corredores deverão ser evitados tanto quanto fôr possivel.

Artigo 194. - As dimensões das salas de classes devem variar, segundo o numero de alumnos que as frequentam ; no entretanto nenhuma sala de classe deverá admittir mais de 50 alumnos.

Artigo 195. - Cada alumno disporá de 1 metro e 25 centimetros quadrados de superficie em uma sala, cuja altura fôr de 4 a 5 metros e deverá, dispor no minimo de 30 metros cubicos de ar renovado por hora.

Artigo 196. - A ventilação da sala deverá ser feita de modo o mais completo e continuo e as correntes de ar deverão ser taes, que não prejudiquem a saúde das creanças.

Artigo 197. - A illuminaçao da sala deve ser unilateral esquerda, sendo tolerada a bilateral, comtanto que não proceda de faces parallelas.

Artigo 198. - Será boa a illuminação quando do logar menos favorecido, puder se divisar o horisonte em uma extensão vertical de 30 centimetros.

Artigo 199. - A unica illuminação artificial que, sem inconvenientes, pode ser adoptada, é a electrica. São entretanto toleradas a illuminação a gaz ou petroleo, sem embargo de serem anti-hygienicas.

Artigo 200. - As janellas das salas de classe deverão ser abertas na altura de 1.m 20 sobre o soalho e se approximarão do tecto, tanto quanto fôr possivel.

Artigo 201. - Os vãos entre as janellas deverão ter a menor largura possivel

Artigo 202. - A fórma da sala de classe deve ser de preferencia a rectangular e a largura do rectangulo deverá ser calculada de modo que a illuminaçao satisfaça os requisitos hygienicos.

Artigo 203. - A mobilia escolar deve ser cuidadosa e escrupulosamente escolhida e as suas dimensões variarão com o tamanho dos alumnos. Tambem deverá ser cautelosamente escolhido o material de ensino.

Artigo 204. - As horas de trabalho deverão ser interrompidas para que os alumnos tenham repouso.

Artigo 205. - As gymnastica devera ser obrigatoria e de accôrdo com o methodo que mais vantagens offerecer.

Artigo 206. - Deverá haver nas escolas pateos e jardins, que servirão de recreio e offerecerão todas as vantagens hygienicas exigiveis.

Artigo 207. - Nos pateos e jardins deverá haver logares abrigados, de fórma que não sejam os alumnos privados de exercicios nos dias chuvosos.

Artigo 208. - As installações hygienicas das escolas deverão ser collocadas longe dos pontos frequentados, obedecerão rigorosamente aos preceitos preestabelecidos para as habitações em geral e deverão ser severa e cuidadosamente fiscalizadas.

Artigo 209. - $\mathrm{O}$ asseio no interior do estabelecimento, nos jardins, pateos e quaesquer outras dependencias, deverá ser cuidadosamente observado em seus mais insignificantes detalhes.

Artigo 210. - Não deverão ser admittidos á matricula nas escolas os alumnos não vaccinados. 
accordo com o que se acha compendiado nos diversos paizes" ${ }^{2145}$. Ao ler o Capítulo VIII, do Decreto n. 233, de 2 de março de 1894, que estabelece o Código Sanitário do Estado de São Paulo, somos obrigados a concordar com Vieira de Mello. As normas legais estão em total consonância com as normas médico-higiênicas do período, em diversos países. "Diversos paizes", via de regra, compreendia a França e os Estados Unidos.

O médico francês Dr. Riant, por exemplo, prescrevia que "Como toda casa, a escola é um abrigo que deve proteger aqueles que a habitam contra as vicissitudes atmosféricas, as variações ou os excesso de temperatura ou de humidade, contra a agitação do ar"146.

No entanto, as normas para construção dos edifícios escolares prescritas nos países europeus, por exemplo, não poderiam ser rigorosamente observadas devido às diferenças de climáticas em relação ao Brasil. "Assim, ao passo que as leis que regem a materia, em paizes frios, occupam-se largamente dos meios de ventilação natural e artificial, o nosso código apenas preceitua que as janellas deverão aproximar-se tanto quanto possível do soalho e do tecto"147.

O terreno deveria ser elevado e nunca baixo ou úmidos "porque nestes nunca as condições climatológicas são taes, que favoreçam á salubridade"148.

O professor da Cadeira de Pedagogia e Methodologia da Escola Normal de S. Paulo assegura que as experiências feitas pelo Dr. Riant demonstram que "o local sendo baixo, escuro e humido não só é apto para a produção dos miasmas, mas até os propaga" ${ }^{\prime 49}$. E mais, a atmosfera corrompida transmite as moléstias epidêmicas e contagiosas.

Estas condições deveriam ser de conhecimento não somente dos arquitetos, dos médicos e higienistas, mas também dos professores. O manual "para uso dos alumnos da Escola Normal de S. Paulo" foi escrito pelo referido professor, pois no Brasil não havia "um compendio escripto em vernáculo e na altura dos progressos actuaes dessa

\footnotetext{
Artigo 211. - Deverá ser interdicta a frequencia na escola aos alumnos que soffrerem ou forem acommettidos de molestia transmissivel.

Artigo 212. - Os internatos estão sujeitos ás leis das escolas e das habilitações collectivas

${ }^{145}$ MELLO, op. cit., p.3

${ }^{146}$ RIANT, 1897, p.21“Comme toute maison, l'école est um abri qui doit proteger ceux qui l'habitent contre les vicissitudes atmosphérique, les variations ou les excès de température ou d'humidité, contre l'agitation de l'air".

${ }^{147}$ MELLO, op.cit., p.4

${ }^{148}$ PASSALACQUA, op.cit., p.30.

${ }^{149}$ Idem, p.31
} 
sciencia educadora, o qual servisse de thema ou de base ás explicações de um professor, vendo-se este obrigado a socorrer-se de autores estrangeiros [...] quando o Brazil já póde ter em todas as disciplinas autores de casa" ${ }^{\text {"150 }}$. Nessa direção, o autor defende que "é de alta necessidade que o professor publico conheça quaes os processos aptos para a construção de edificios escolares, qual a sua hygiene e outras condições indispensáveis" $" 151$.

Sendo a Higiene Escolar um dos braços da Higiene Pública era necessário, conforme aponta Vieira de Mello, "que o professor tenha conhecimentos de hygiene publica, para cooperar efficazmente nessa grande empreza social"152. O Dr. B. Vieira de Mello foi sócio benemérito da Policlínica Geral do Rio de Janeiro, membro correspondente do Círculo Médico Argentino de Buenos Aires, redator da "União Médica" do Rio de Janeiro (1882-1890) e do "Annual of the Universal Medical Sciences" de Filadelfia e diretor de hospitais em várias epidemias e inspetor sanitário.

Se para Passalacqua o Manual do Dr. Riant foi uma fonte fundamental, Vieira de Mello acrescenta o regulamento austríaco sobre ensino escolar como uma referência importante. Tal regulamento "exige dos professores conhecimento daquella materia [hygiene publica], tendo em vista que a escola deve desenvolver harmonicamente, não só as forças intelectuais, senão também as faculdades physicas" ${ }^{\text {"153 }}$. Daí a necessidade de criação de cadeiras de higiene nas escolas normais. O autor lembra que, em São Paulo, “a lei n.374 de 3 de setembro de 1895 , no art. $5^{\circ}$ dispõe sobre a $8^{\text {a }}$ Cadeira conste de historia natural, anatomia, physiologia e noções de hygiene. Melhor fora que ella abrangesse a hygiene privada e publica" ${ }^{\prime 154}$.

O que os normalistas e as normalistas aprenderiam, a partir do Manual do Padre Passalacqua e de Vieira de Mello, sobre a construção de um edifício escolar?

Além do local adequado, deveriam conhecer da "Exposição do edifício escolar". "Entendemos por exposição a orientação que deve dar-se ao edifício em relação aos ventos e á ação do sol”155. Isso porque os ventos interferem na temperatura escolar. "Quanto ao sol, a exposição escolar deve ser tal, que os muros do edifício recebão de chapa os raios solares" ${ }^{\prime 156}$. A exposição ao nascente (o sol da manhã) era recomendada

\footnotetext{
${ }^{150}$ Carta do Padre Senna Freitas ao autor. In. Passalacqua, 1887, p.XII.

${ }^{151}$ PASSALACQUA, 1887, p.33.

${ }^{152}$ MELLO, op. cit. p. VI

${ }^{153}$ MELLO, op. cit. p.VI

${ }^{154}$ Idem, ibidem.

${ }^{155}$ PASSALACQUA, op. cit, p.34.

${ }^{156}$ Idem, ibidem.
} 
por ser mais saudável. Caso as condições do terreno não permitissem a orientação desejada, "procura-se ao menos dotar o edifício da precisa ventilação"157. Enquanto Passalacqua aponta critérios gerais quanto à orientação da escola, Mello define que a melhor orientação das escolas na Capital (São Paulo) seria a do nordeste, "devendo-se evitar por todos os meios a orientação sul, por serem os ventos desse lado frios, humidos e doentios" ${ }^{\prime 158}$.

Os futuros professores e as futuras professoras deveriam aprender sobre o tamanho do terreno escolar. "Tamanho é a área occupada pelo edifício da escola e suas adjacencias" $" 159$. O terreno deve ter de superfície "nunca menos de um metro quadrado por alumno"160. Neste ponto, também, faz referências às "legislações sobre Instrução dos paizes mais adiantados da Europa e da America do Norte"161.

Retomando a questão da especificidade do edifício escolar, Passalacqua enfatiza que

o aspecto da escola denota a marcha do ensino; com effeito o aspecto das escolas é um sinal evidente do amor pela instrução [...] A casa escolar deve ser tal que a ella sejão attrahidos os alumnos e nunca arrastados [...] E não se diga que o aspecto das casas escolares é indifferente. Quem não vê que cada construção tem uma feição particular, conforme o fim a que se destina? Os edifícios públicos não devem ter a mesma feição ou aspecto que os particulares. As escolas publicas não podem ter o mesmo exterior que os outros edifícios ${ }^{162}$.

Além disso, as escolas modernas deveriam possuir ambientes, tais como: lavatórios; cabides para os alunos colocarem seus chapéus; pórtico para os jogos ginásticos; latrinas (sanitários); alpendre; uma sala específica para a merenda, o refeitório para que os alunos não comam de pé. Vieira de Mello demonstra preocupação maior com o local para refeições entendendo que

a falta de salas para refeições dos alumnos constitui lacuna importante em nossas escola publicas. De ordinário essas refeições são feitas nos recreios, sobre bancos, ou mesmo no solo, e, attendendo á inexperiência das creanças, não é diffícil suppor que muita vez o alimento seja posto em contacto com aquellas superfícies, podendo dahi resultar a contaminação do mesmo por germens morbigenos alli depositados pelas roupas ou pelo calçado. Outra vantagem de refeitórios regularmente installados é que os alumnos fariam suas refeições na presença dos professores,os quaes fiscalizariam o asseio

\footnotetext{
${ }^{157}$ Idem, p.36

${ }^{158}$ MELLO, op. cit. p.8

${ }^{159}$ PASSALACQUA, op. cit, p.37

${ }^{160}$ Idem, ibidem.

${ }^{161}$ Idem, p. 36

${ }^{162}$ Idem, p.39, 40.
} 
das suas mãos, antes e depois das refeições, e lhes dictariam regras de bem estar à mesa, de bem mastigar, para bem digerir [...] Ainda os refeitorios poderiam servir para guardar as bolsas e cestas contendo alimentos, os quaes nunca devem ser conservados nas salas de classe, porquanto não sómente prejudicam o asseio e viciam o ar atmospherico, pelas suas exhalações, como ainda têm a desvantagem de perturbar a disciplina, a creança sendo tentada a comer as provisões que se acham ao alcance de suas mãos" ${ }^{163}$.

Os argumentos levantados para sustentar a necessidade do refeitório passam por duas vertentes: a higiene (evitar doenças decorrentes da contaminação do alimento pelas mãos sujas dos alunos ou pelo contato do mesmo com a superfície onde ele será depositado) e a disciplina, já que o cheiro exalado pelos alimentos desviaria a atenção dos alunos.

Outro ambiente indispensável à escola moderna era o lavatório. Porém, ao mesmo tempo em que os aparelhos sanitários (dejectorios e mictorios) eram imprescindíveis, eles deveriam ficar fora do edifício, "communicando por uma galeria bem ventilada, afim de impedir que as exhalações dos exgottos prejudiquem a salubridade das classes e das demais dependencias"164.

Passalacqua assevera que "nas escolas da Suissa, pelas quaes as nossas devião se modelar, estão muito em uso os lavatorios" ${ }^{\prime 165}$. O autor ilustrou como deveriam ser as instalações sanitárias.

\footnotetext{
${ }^{163}$ MELLO, op. cit., p.6.

${ }^{164}$ Idem, ibidem.

${ }^{165}$ Passalacqua, 1887, p.43
} 
Figura 1 - Modelo suíço de privada ou latrina escolar

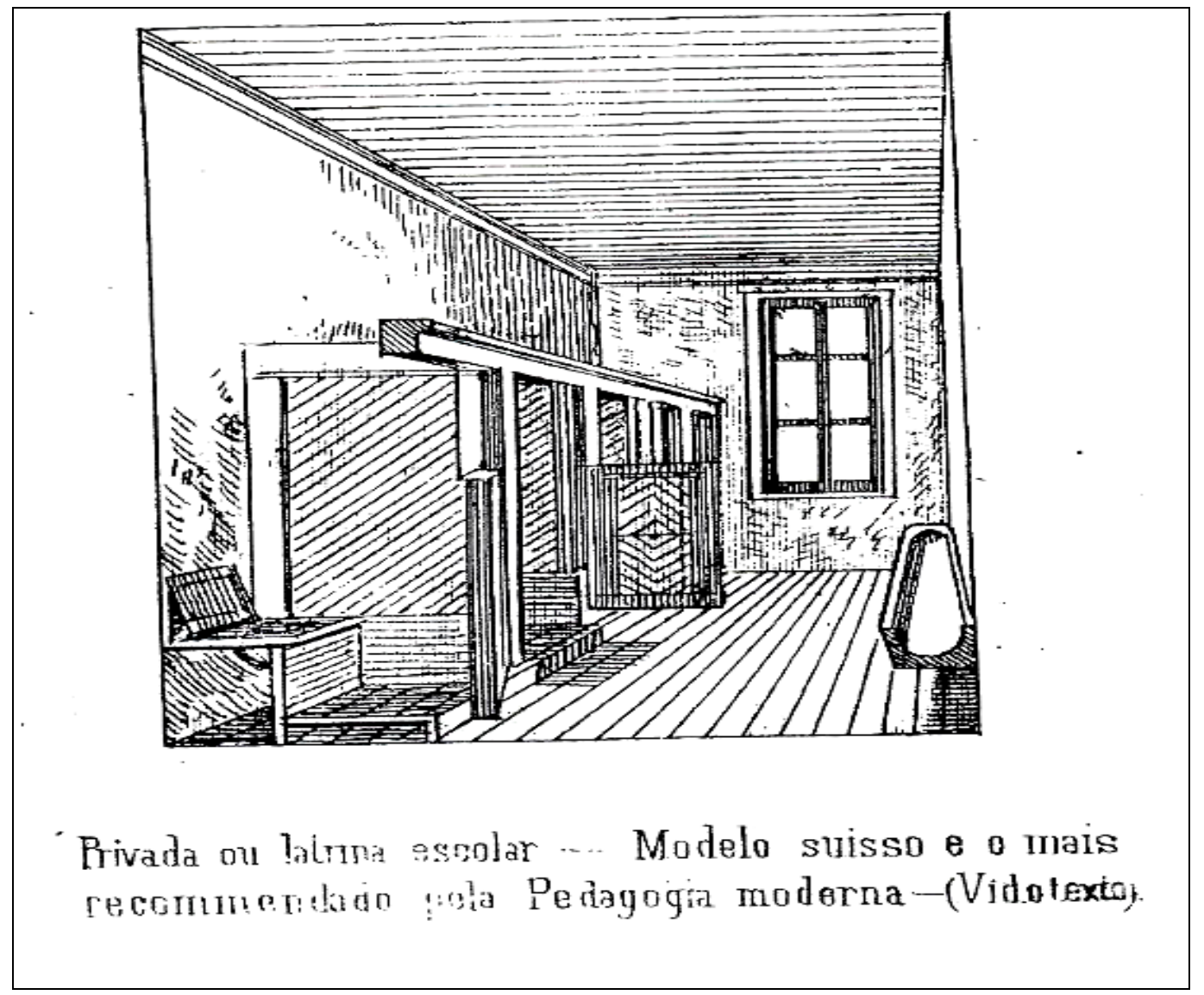

Fonte: Passalacqua, 1887, p.43. 
Figura 2 - Detalhe de uma privada

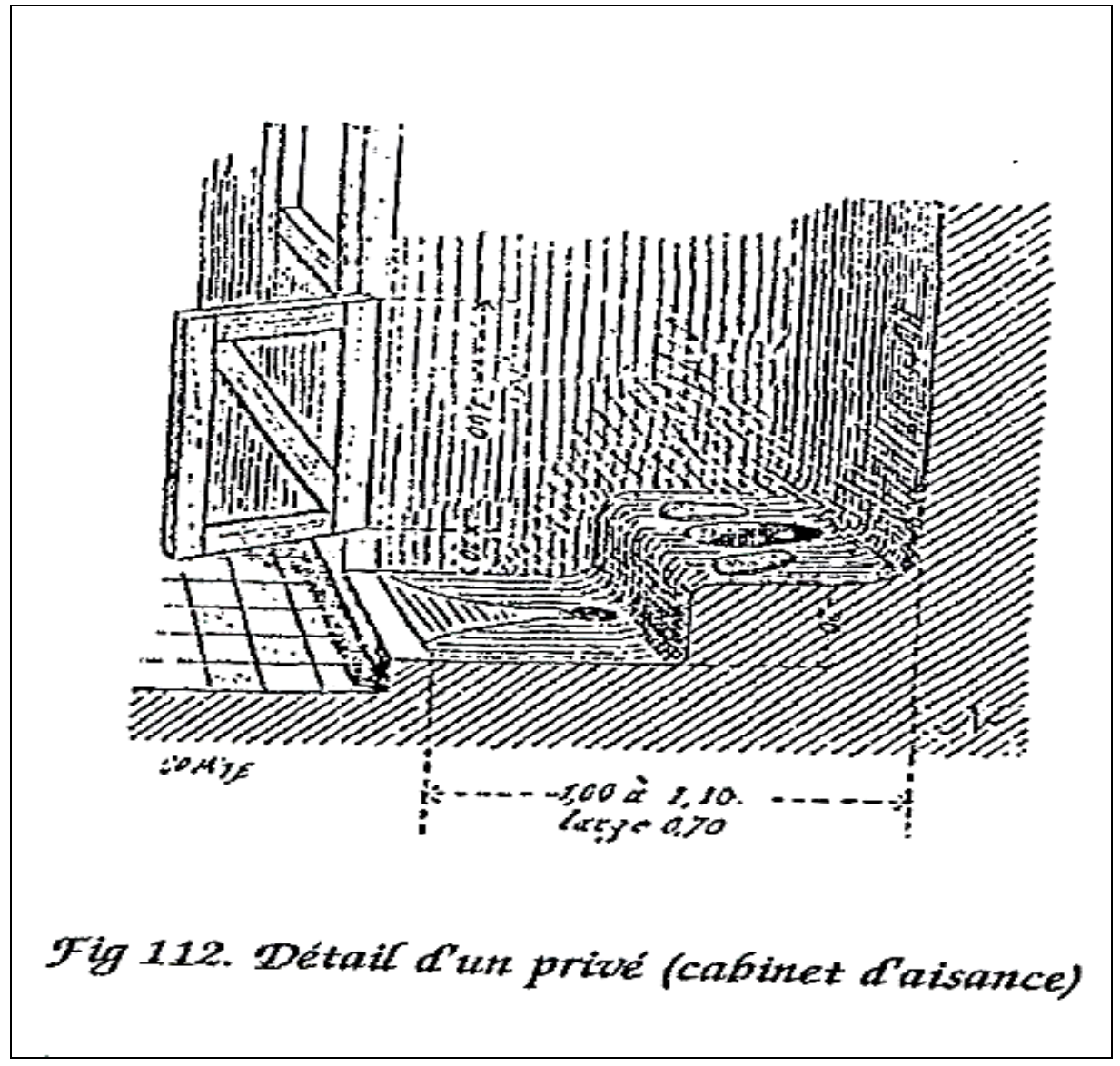

Fonte: Peyranne, 2001, p.208.

O professor Passalacqua reproduz o modelo suisso de privada ou latrina escolar, "o mais recommendado pela Pedagogia moderna" afirmando ser este um "ponto que merece toda a attenção da parte do constructor de edificos escolares [...] a sua importância educativa-physica e moral dispensa-nos qualquer observação"166.

O arquiteto Émile Guillot esclarece, a partir de documentos oficiais da França, os requisitos para construção dos edifícios públicos (escolas, igrejas) ${ }^{167}$. Citando o artigo 36 da Lei de 25 de julho de 1893 e o Decreto de 25 de outubro de 1894, o autor enfatiza que "toda escola deverá ser munida de privadas"168, confirmando que a necessidade deste espaço na construção da escola é apontada internacionalmente.

\footnotetext{
${ }^{166}$ PASSALACQUA, op. cit., p.42.

${ }^{167}$ Agradeço ao Prof. Dr. Hugo Segawa a cessão do documento Édifices Publics pour villes et villages, de Émile Guillot.

${ }^{168}$ GUILLOT, Émile. Édifices Publics pour villes et villages. Paris: H. Dunod et E. Pinat, Editeurs, 1912, p.108 - "Tout école devra être munie de privés".
} 
Em sua pesquisa, tratando da higiene dos espaços escolares no século XIX, Peyranne, citando o Regulamento de Jules Ferry descreve uma estrutura muito semelhante: "A tabuleta, posicionada a 30 centímetros ou mais acima do chão, evita a sujeira da urina graças a sua forma oval [...] As privadas são fechadas por duas portas de 1 metro de altura e elevadas de 20 a 25 centímetros a fim de controlar, de maneira decente, as crianças suscetíveis de tumulto"169. As latrinas devem ser constituídas de privadas e urinóis situados no centro da recreação e cobertos para proteger os alunos da chuva $^{170}$.

Vieira de Mello detalha outras características para tais instalações. A altura dos assentos dos dejectórios deveria ser igual à dos bancos respectivos de cada classe, de 30 a 45 centímetros. Os mictórios e os dejectórios deveriam ser independentes com a altura proporcional às respectivas classes. A cada grupo de 25 alunos deveria ter um dejectório.

As considerações tanto para a escola paulista, quanto para a escola francesa, no fim do século XIX, põem em evidência a historicidade dos espaços escolares. O período é rico de informações para pensar a constituição daquilo que hoje consideramos estruturas indispensáveis ao funcionamento das instituições de ensino.

Mas essa não era uma demanda restrita ao espaço escolar. A discussão vem no bojo de uma preocupação com a higiene social. O crescimento das cidades e a aglomeração de pessoas em cortiços favoreciam o surgimento e a propagação de moléstias e epidemias. Os higienistas e médicos, no fim do século XIX, intentavam evitar a propagação das doenças, as quais prejudicavam inclusive a economia.

Em uma comunicação do presidente da Câmara Municipal o problema das epidemias veio à tona, quando alguns cônsules e vice-cônsules estrangeiros lhe dirigiram uma representação, solicitando providências que pudessem "cessar o depósito de imundices e matérias fecais nas praias". Eles atribuíam o aparecimento da febre amarela em alguns navios atracados no porto à falta de limpeza do litoral ${ }^{171}$.

O uso das privadas ou latrinas seria importante no interesse do comércio, do desenvolvimento urbano e da saúde pública. "A concepção de cidade moderna passava pela ideia de cidade saudável" ${ }^{\prime 172}$. Citando Wilma Andrade, Carina Pedro afirma que

\footnotetext{
${ }^{169}$ PEYRANNE, op. cit. p.208.

170 PEYRANNE, op. cit.

171 PEDRO, Carina Marcondes. Casas importadoras de Santos e seus agentes: comércio e cultura material (1870-1900). São Paulo: Faculdade de Filosofia, Letras e Ciências Humanas. Tese USP, 2010, p.27.

${ }_{172}$ Idem, ibidem.
} 
"um dos momentos mais difíceis para a municipalidade [Santos] foi o ano de 1889, quando a população foi atingida por cinco tipos de doenças: febre-amarela, impaludismo, peste bubônica, varíola e tuberculose" $" 173$. Por isso, o porto foi interditado, “o que desencadeou protestos da Câmara, ciente dos prejuízos que este tipo de ação podia causar à cidade portuária e seu comércio. De fato, o problema das epidemias só foi resolvido com as obras de saneamento custeadas pelo Estado no ínicio do século $\mathrm{XX}, 174$.

Para afastar as doenças e epidemias um conjunto de profissionais (médicos, educadores, engenheiros, dentre outros) explicitava a urgência do saneamento da cidade e do edifício escolar.

O saneamento deveria começar pela construção da escola. Os preceitos da Higiene definiam pontos a serem observados pelo arquiteto na construção da sala de aula, dentre eles, as dimensões, o ar, a ventilação, a temperatura e a claridade. Quanto às dimensões, "cada alumno deve occupar de superfície 1 metro quadrado"175. Esta dimensão deve ser um pouco maior na opinião de Mello. Para ele cada aluno deve dispor de " 1 metro e 25 centimetros quadrados e superficie e 5 a 6 metros cúbicos de ar, ou 30 metros cúbicos por hora" ${ }^{\text {176. }}$.

Para tratar da composição do ar atmosférico respirável pelos alunos, Passalacqua cita Lavoisier que "mostrou a conversão, operada pelo oxigênio, do sangue venoso em sangue arterial, do sangue negro impróprio para a vida em sangue vermelho positivo"177. Com isso, o professor conclui que "em uma sala escólar onde não se respirasse oxigênio, produzir-se-ia, n'um certo numero de horas, a morte por axphixia"178. Citando Lavoisier, sem, contudo, mostrar a referência, Passalacqua defende que aqueles que habitam as altas montanhas, onde o ar é vivo e subtil têm "mais facilidade no respirar, mais leveza no corpo, mais serenidade no espírito; os prazeres são menos ardentes, as paixões mais moderadas" $" 179$.

\footnotetext{
${ }^{173}$ Idem, p. 27

${ }^{174}$ Idem, ibidem.

${ }^{175}$ PASSALACQUA, 1887, p.43

${ }^{176}$ Idem, p.4.

${ }^{177}$ Idem, p.44

${ }^{178}$ Idem, ibidem.

${ }^{179}$ Idem, p.45
} 
Se o ar puro "é um grande auxiliar da vida" 180 é necessário que ele seja regenerado. Daí, a importância da ventilação. Para esse fim, há “diversos systemas de janellas escólares" ${ }^{\prime 181}$. Porém ,

de todas ellas as mais recomendadas pelo Dr. Riant, hábil hygienista, são as que se abrem para os lados. Tem ellas algum inconveniente, que fica sanado pelos ventiladores. A parte superior destas janellas deve ter uma parte movediça, ou bandeira, cujo movimento se possa graduar, conforme a intensidade dos ventos ${ }^{182}$.

As bandeiras movediças também são recomendadas por Vieira de Mello para auxiliar na ventilação natural. Já as venezianas e persianas, apesar de serem apropriadas quando se trata de ventilação, são desaconselhadas pela desvantagem de escurecer a sala. O inspetor sanitário destaca a ideia de um vidraceiro francês que construiu vidros perfurados, os quais "têm a dupla vantagem de entreter ventilação permanente e manter excellente illuminação"183. Porém, ele defende que "preferível ainda é o systema de vidros parallelos, de aberturas contrariadas, as quaes permittem a entrada incessante do ar no interior das salas, sem produzir correntes" ${ }^{\prime 184}$.

O Dr. Riant foi uma referência fundamental no período em estudo, pois além de ser citado por Passalacqua, aparece de forma recorrente em Peyranne em sua tese de Doutorado, quando trata da higiene dos espaços da escola francesa no século XIX. Quanto à ventilação, por exemplo, ele diz:

Insensiveis, se respiramos o ar livre, onde o equilíbrio é restabelecido sem cessar, estas modificações são logo manifestas, quando respiramos em um espaço constante o ácido carbônico, exala, não demora a tornar $\mathrm{o}$ ar perigoso para respiração, ou mesmo absolutamente irrespirável, quer dizer incapaz de manter a vida ${ }^{185}$.

Daí a necessidade de ventilar não somente a sala, mas o edifício escolar a fim de remediar males como: depleção de sangue, escrófula, palidez, estrangulamento das glândulas, abscesso, fluxo de orelha, etc. ${ }^{186}$.

\footnotetext{
${ }^{180}$ Idem, ibidem.

${ }^{181}$ Idem, p. 47.

${ }^{182}$ Idem, ibidem.

${ }^{183}$ MELLO, op. cit. p.10

${ }^{184}$ Idem, ibidem.

${ }^{185}$ RIANT, 1874, p. 62-63 - Insensibles, si on respire à l'air libre, où l'equilibre se rétablit sans cesse, ces modifications sont bientôt manifestes, quando on respire dans un espace constante de l'acide carbonique, exhalé, ne tardent pas à rendre l'air dangereux à respirer, ou même absolument irrespirable, c'est à dire incapable d'entretenir la vie.

${ }^{186}$ PEYRANNE, 2001.
} 
A importância do sistema de ventilação natural residia também no fato de que ela é um dos elementos do controle de temperatura das salas. A temperatura seria o resultado da ventilação e do calor. "No verão, o ar produzido pela ventilação vem refrescar agradavelmente a sala; no inverno o calor mecânico estabelecerá uma temperatura regular" ${ }^{187}$. Passalacqua diz que o "thermometro centigrado, inventado pelo Physico Sueco Celsio" é o mais recomendado para medir exatamente o grau de calor reinante na sala de aula. Para Mello cada sala deveria estar munida de um termômetro não só para medir a temperatura do ambiente, mas "para graduar a quantidade de ar entrado e indicar quando as janellas devem ser de novo fechadas" ${ }^{\prime 188}$.

A claridade ou a luz escolar é outro elemento da higiene da sala de aula, pois "A doença entrará onde a luz não tiver entrado" ${ }^{189}$. A claridade tem direta relação com a orientação do edifício.

A luz póde projectar-se n'uma sala escólar ou por um lado só, ou por ambos os lados. Assim, temos o systema de luz unilateral e o systema bilateral. Um grande numero de hygienistas pedagogicos sustentão o systema unilateral, isto é, a luz projectada pelo lado esquerdo. É este systema, dizem, racional, porque qualquer que seja a collocação de quem escreve, a penna deve correr livre de toda a sombra ${ }^{190}$.

Citando o Dr. Riant, Passalacqua afirma: "é mister ainda que a luz seja tanta que possa vivificar os órgãos dos alunos"191 . E, para não prejudicar os "órgãos da vista", recomenda-se também que a "luz nunca deve dar de frente nos alumnos"192. O sistema pode ser visualizado na imagem abaixo, retirada de Josette Peyranne.

\footnotetext{
${ }^{187}$ PASSALACQUA, op. cit. p.48

${ }^{188}$ MELLO, op. cit., p.10

${ }^{189}$ PASSALACQUA, op. cit., p.52.

${ }^{190}$ Idem, ibidem.

${ }^{191}$ PASSALACQUA, op. cit. p.54

192 Idem, ibidem.
} 
Figura 3 - Iluminação da classe

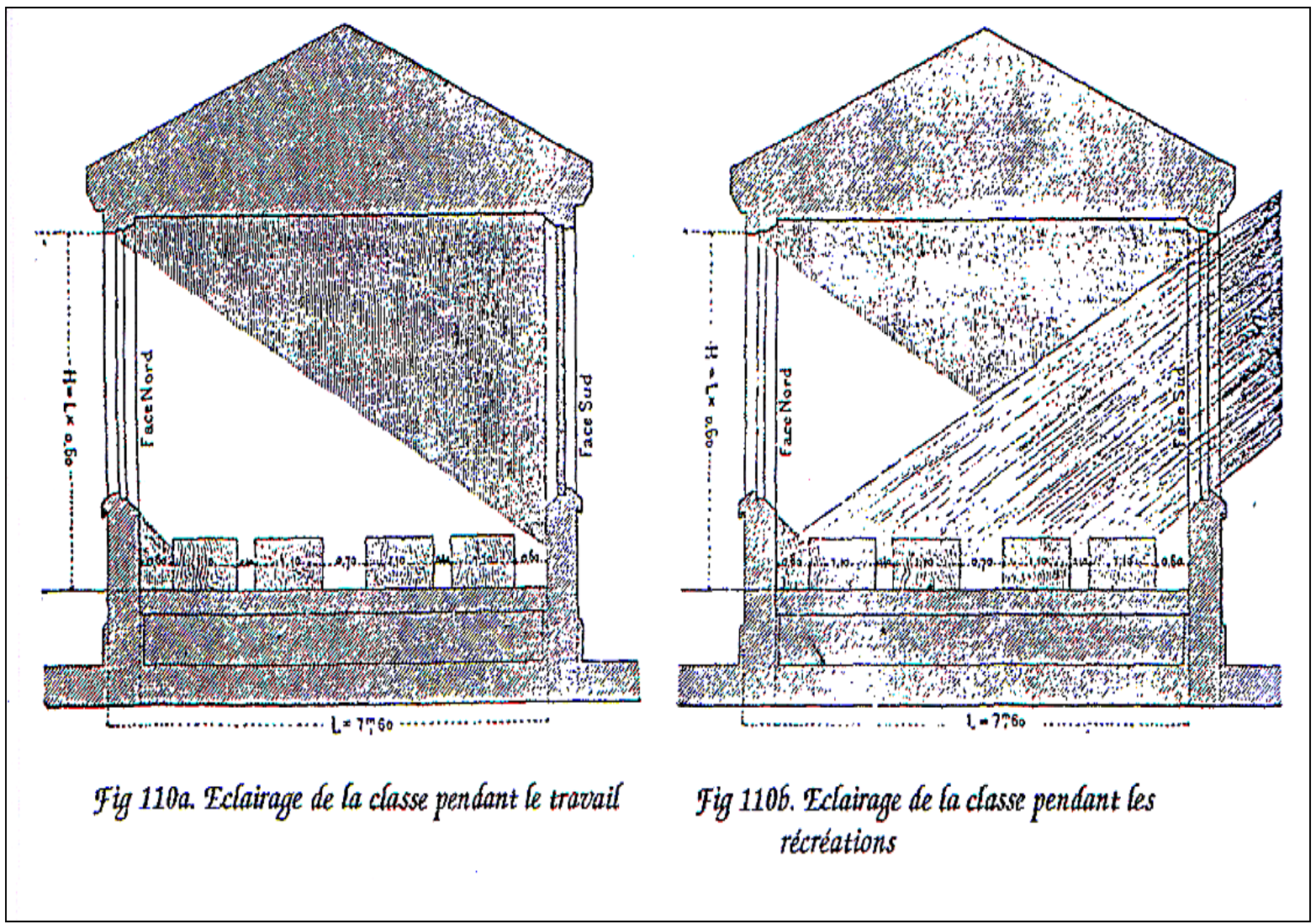

Fonte: PEYRANNE, 2001, p.206

Na compreensão do médico Vieira de Mello, a iluminação das salas é um elemento importante da higiene das escolas, pois "quanto mais luz houver, menos myopes haverá" ${ }^{193}$. Ele concorda com Passalacqua no sentido de que a luz não deve vir de frente para não ofuscar os alunos e impedi-los de ver o que o mestre escreve. Também não pode vir de trás, pois "offusca o mestre e se vem do lado direito, faz sombra aos que escrevem"194. Se não for possível obter a iluminação bilateral, "a iluminação pelo lado esquerdo deve ser imposta nas escolas"195.

\footnotetext{
${ }^{193}$ MELLO, op. cit. p.11

${ }^{194}$ Idem, p. 12

195 Idem, ibidem.
} 
Figura 4 - Sala iluminada pelo lado esquerdo

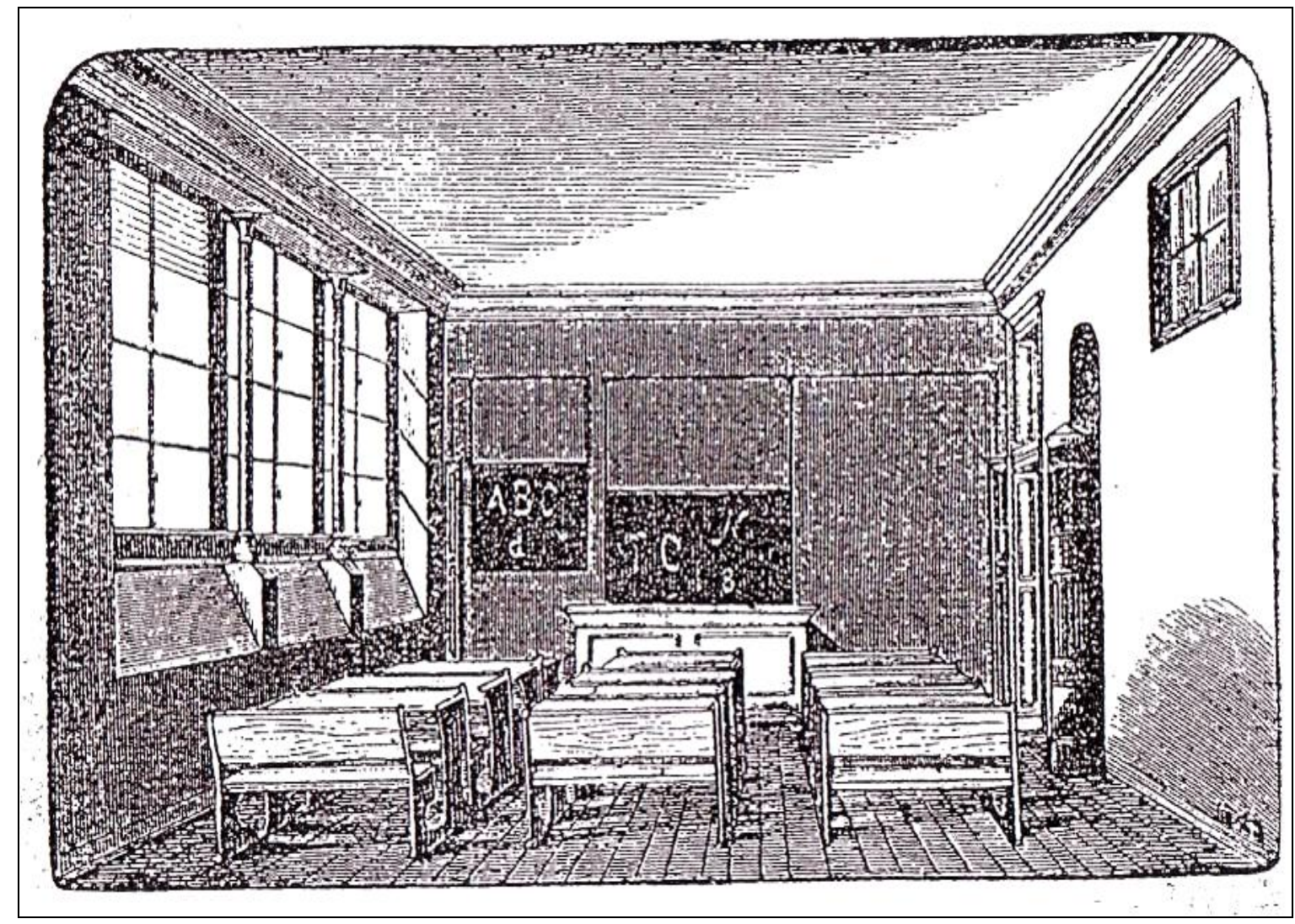

Fonte: Mello, 1902, p. 11 - Sala iluminada pelo lado esquerdo

A imposição justificava-se por uma urgência social, visto que a insuficiência ou má distribuição de luz na sala de aula e nos domicílios levariam, de acordo com Mello, à miopia e outras moléstias da vista.

A mesma prescrição encontra-se em Rui Barbosa:

Relativamente à iluminação diurna das classes, o voto adotado pelo Congresso Internacional do Ensino em 1880 é este: "Em regra, as salas de aula serão clareadas, de dia por janelas abertas de um só lado. À esquerda dos alunos, e dispostas de modo que todos os lugares fiquem plena e igualmente claros, reservados os meios de arejamento".

Em um notável tratado de arquitetura das escolas normais, dado à estampa, há dois anos, entre as publicações oficiais da repartição federal do ensino, nos Estados Unidos, encontramos consagrada a mesma solução $[\ldots]^{196}$.

Citando Beaconsfield, então Primeiro Ministro do Reino Unido, Rui Barbosa estabelece o lugar da higiene escolar: "as questões de higiene sobre-excedem, pela sua

\footnotetext{
${ }^{196}$ BARBOSA, Rui. Obras Completas. V. X. 1883. Tomo IV. Reforma do Ensino Primário. p.15.
} 
importância, a todas as outras, e para um estadista realmente prático não as há superiores" $^{197}$.

O saber médico/higiênico ditou até as características desejáveis da cor da parede e do assoalho. Quanto à primeira, recomenda-se a cor verde-clara, que "é mais usada por ser ella mais agradavel e alegre e não offender o órgão da visão"198. Mello não recomenda apenas uma cor, mas afirma que "as paredes devem ser pintadas a óleo, de côr cinzenta, esverdeada ou azulada, não tóxica" ${ }^{\text {199 }}$. Os higienistas e educadores levavam a urgência da higiene escolar a tal ponto que defendiam a decoração das paredes das salas de aula com "preceitos de higiene escolar e privada, no que diz respeito especialmente ás posições e attitudes, ao asseio corporal e das habitações"200. Além disso, os outros temas dignos de ocupar a parede da classe eram os quadros históricos e as inscrições sobre os deveres do aluno para consigo e a sociedade.

Quanto ao assoalho, os conselhos do Dr. Riant são:

O soalho de uma escóla deve ser disposto de sorte que possa preservar os pés dos alumnos não só do frio mas principalmente da humidade. Inutil é dizer que os soalhos de chão puro são insalubres, como o são os ladrilhados e os de tijolos, nos quaes, além da friagem que lhes é natural, o pisar constante de muitos alumnos levanta camadas de pó que vão affectar o órgão da respiração. $O$ soalho deve ser de madeira escolhida como pinho, etc. Seria para desejar que fosse encerado ou envernisado para impedir que a humidade nelle penetre. As madeiras sendo muito porosas absorvem não só a humidade, como os maus cheiros e os miasmas, os quaes facilmente dilatão-se e contraem-se ${ }^{201}$.

De igual modo, Mello esclarece que o "soalho deve ser de madeira resistente, afim de impedir o mais possível o desprendimento de partículas sob a fórma de pó" ${ }^{202}$. Por razão semelhante, na limpeza das escolas, as vassouras e espanadores deveriam ser,

\footnotetext{
197 BARBOSA, 1883, tomo IV, p.1 - REFERÊNCIAS CITADAS POR RUI BARBOSA SOBRE HIGIENE ESCOLAR.

RIANT: Hygiène scolaire, pâgs. 935. 278. — N A R J O U X : Les écoles publiques en Suisse (1879). pág. 107. — N A R J O U X : Les écoles publiques en Belgique et en Hollande. 1878. — LIEBREICH : School life in its influence on sight. Apud NARJOUX: Les écol. publ. en France et en Anglct. 1877. pág. 219. 2212. - NARJOUX : Écoles primaires et salles cTasyle 1879. pág. 114. - N A R JOUX : Eclairage. Rapport. No vol. Congr. Internat, de l'Enscign.. 6me. sect., pâq. 25. — BUCK : A Treatise on Hyn.. and Public Health, vol. II. pâgs. 610, 613. — BUISSON : Rapport de Vienne, pág. 48. - J. KÒRÕSI : Comment doit être organisé le service médicale dans les écoles? Rapport. $\mathrm{N}$ o vol. Congr. Int. de FEns.. 6me, sect., pág. 186. — BUISSON : Rapport de Philadelphie, pâgs. 182. 184. 186.

${ }^{198}$ PASSALACQUA, 1887, p.55

${ }^{199}$ MELLO, op. cit., p.5

${ }^{200}$ MELLO, 1902, p. 8

${ }^{201}$ PASSALACQUA, 1887, p.56 - Passalacqua faz uma tradução de parte do texto do Dr. Riant sobre "Le plancher de la classe" que se encontra no livro Hygiène Scolaire (1874) nas páginas 96 e 97.

${ }^{202}$ MELLO, op. cit. p.5
} 
na opinião do inspetor sanitário, "banidas das escolas, porquanto só fazem deslocar o pó de um para outro ponto"203.

A limpeza das classes deveria ser diária com um pano umedecido em água quente ou emulsão de creolina. Os corredores e vestíbulos deviam ser lavados uma vez por semana, enquanto os dejectórios e mictórios, diariamente. "Do rigoroso asseio nas escolas resultam para a saude dos alumnos e mestres vantagens inestimaveis"204.

Nas concepções dos educadores, médicos e higienistas, brasileiros e estrangeiros, apresentadas anteriormente, fica em evidência a disseminação de uma higiene pública e popular aplicada ao meio escolar, afetando o indivíduo em sua integralidade. Segundo Peyranne, "o século XIX construiu os fundamentos da higiene pública"205 que se reveste de dois aspectos diferentes: a) mobilização autoritária pela defesa da nação, de seu futuro, da grandeza da pátria; b) o Estado como prestador de serviços deve ser o mediador da proteção do indivíduo, prevenir o mal e prolongar a vida $^{206}$.

O interesse do Estado na Escola, na saúde das crianças e no bem-estar dos cidadãos não pode ser visto como algo natural e óbvio. O Estado como um prestador de serviços públicos, no caso de São Paulo, é uma realidade que vai florescendo ao longo do século XIX. Por isso, Vieira de Mello vai defender que

Ao estado, em geral, compete velar pela saúde das creanças, preparando-lhes mocidade florescente, afim de augmentar o bem estar geral, a força activa e a força defensiva da nação. E o Estado de S. Paulo, em particular, que tanto se tem avantajado em todos os ramos da actividade humana, attrahindo, por isso mesmo, forte corrente immigratoria, assignalará mais um marco, dotando as suas escolas de todos os requisitos da engenharia sanitária, dando-lhes boas leis sobre hygiene escolar e preparando professores para comprehendel-as e divulgal-as ${ }^{207}$.

A preocupação com a saúde coletiva, popular e dos indivíduos aplicada ao meio escolar é um dos aspectos da atuação do Estado como um prestador de serviço. Não é mais suficiente um Estado absolutista que é servido, mas um Estado Liberal que serve.

\footnotetext{
${ }^{203}$ Idem, p. 13

${ }^{204}$ Idem, ibidem.

${ }^{205}$ PEYRANNE, op. cit., p.193

${ }^{206}$ PEYRANNE, 2001.

207 MELLO, 1902, p.VII
} 
"Ele deve ser o mediador da proteção do indivíduo. Ele deve prevenir os males e prolongar a vida",208.

A emergência deste estado prestador de serviço fica bem configurada no Decreto n. 91, de 13 de outubro de 1890. O Decreto Executivo consiste em uma revogação da Lei n. 54 de 1888, a qual concedeu uma loteria de benefício líquido de dois mil contos de réis (2.000:000\$000) para auxiliar a construção de uma nova igreja catedral, na capital paulista. Em 1888, a destinação da verba para a construção de uma igreja justificava-se por ser oficial a religião católica. Mas,

Considerando que a Escola Normal e as escolas modelo, aquella reformada, e estas creadas pelo decreto n. 27 de 12 de Março do corrente anno não poderão preencher convenientemente seus fins, em quanto não forem installadas em edificio apropriado, que contenha as accommodações neccessarias ao seu funccionamento regular, ficando até antão incompleta a reforma $[\ldots]^{209}$.

A quantia, recolhiada ao Tesouro e depositada "em conta corrente ao juro de 3\% ao anno", deveria ser empregada na construção do "templo matriz da instrucção publica no Estado"210. Em 2 de agosto de 1894 "foi inaugurado o edifício da Escola Normal, na Praça da República"211. Nesse ano, o Decreto de 26 de julho preconizava:

Artigo 15. - A mobilia escolar constará da que fôr determinada pelo Conselho Superior, devendo sua construcção ter por base os modelos que mais facilitem a vigilancia do professor, a responsabilidade individual do alumno e a satisfação dos preceitos hygienicos. Artigo 16. - A disposição dos bancos e das mesas ou carteiras nas salas das aulas terá por base a projecção da luz, devendo o alumno recebel-a principalmente do lado esquerdo e do alto ${ }^{212}$.

O Conselho Superior ${ }^{213}$ deveria escolher a mobília levando em conta não só os preceitos da higiene, mas a facilitação da vigilância pelo professor. Constituía, por parte do aluno, falta disciplinar o danificar as paredes do edifico, mobília e utensílios da escola, com escritas ou pinturas, ou de qualquer forma ${ }^{214}$.

\footnotetext{
${ }^{208}$ PEYRANNE, op. cit., p.93 - "Il doit être le médiateur de la protection de l'individu. Il doit prevenir les maux et prolonger la vie".

${ }^{209}$ SÃO PAULO. Decreto Executivo n. 91, de 13 de outubro de 1890.

${ }^{210}$ Idem, Art. $1^{\circ}$.

${ }^{211}$ REIS FILHO, 1981, p.141

${ }^{212}$ SÃO PAULO. DECRETO N. 248, DE 26 de julho de 1894, arts. 15 e 16.

${ }^{213}$ Acerca das funções do Conselho Superior ver Capítulo V

${ }^{214}$ SÃO PAULO. DECRETO N. 397, DE 9 de outubro de 1896, Art.19, $3^{\circ}$.
} 
No interior da sala de aula, a responsabilidade pela fiscalização era do professor. $\mathrm{Na}$ escola, a responsabilidade pelo asseio e conservação do edifício, da mobília e utensílios, bem como pelo inventário, era do porteiro ${ }^{215}$.

Com a República e a expansão da escolarização se criariam novas condições sociais, pela intervenção do Estado no corpo e na mente, pela disciplina e controle social do "corpo limpo, saudável e civilizado"216. Para esse fim, a arquitetura cumpriria um papel indispensável e, associada a ela, no interior da sala de aula, a carteira escolar.

\section{2. "A carteira deve se adaptar ao aluno" - Higiene e mobiliário escolar}

A construção de uma nova visão social sobre o aluno e sua saúde torna necessário um mobiliário especifico para a sala de aula. Por isso, em sua tese de Doutorado Josette Peyranne (2001), dizendo que a carteira nem sempre existiu, se interroga: "Qual é sua gênese e como foi concebido o primeiro mobiliário escolar? As modalidades de construção do mobiliário escolar no século XIX são idênticas àquelas que preconizamos hoje? Os valores subjacentes à elaboração deste mobiliário escolar são os mesmos?"217

Atentando para as questões de Peyranne, interrogo: Quais os valores de saúde subjacentes aos modelos de carteira escolar do século XIX? Sobre esta questão me debruçarei neste tópico.

A frase de Ferdinand Buisson na Exposição Universal de Viena em 1873 "O banco deve se adaptar ao aluno e não mais o aluno ao banco" ${ }^{218}$ funcionou, no período em estudo, como um slogan acerca de um ideário da relação corpo-mobiliário escolar.

Ela é reproduzida no manual Pedagogia e Methodologia como uma pergunta retórica: "Quem não sabe que a mobília sendo proporcional aos alumnos e não estes proporcionaes á mobília, o funccionamento physiologico será mais regular?"219. Podemos concluir que este princípio da higiene escolar chegou a São Paulo não só pelos

\footnotetext{
${ }^{215}$ Idem, art.60, $2^{\circ}$ e $3^{\circ}$.

${ }^{216}$ MARTINEZ, 2009, p.34

217 PEYRANNE, op. cit. p.2 - Quelle est sa genèse et comment était conçu le premier mobilier scolaire? Les modalities de construction du mobilier scolaire au siècle precedent sont-elles identiques à celles que nous préconisons aujourd'hui? Les valeurs sous-jacentes à l'élaboration de ce mobilier sont-elles toujours les memes?

218 BUISSON, Ferdinand. Rapport sur l'instruction primaire à l'Exposição Universelle de Vienne em 1873. Paris, 1875,p.55 - "Le banc doit s'accomoder à l'enfant et non plus l'enfant au banc".

${ }^{219}$ PASSALACQUA, 1887, p.58.
} 
manuais estudados na Escola Normal Caetano de Campos, mas também pelos pareceres de Rui Barbosa, pois ele também assevera que "O sistema dominante até então, e que ainda hoje predomina, consistia em acomodar o aluno ao banco. A higiene escolar, porem, assentou o princípio de que "é o banco que se há-de acomodar ao aluno"220.

Mais uma vez se insiste sobre a necessidade deste estudo ser feito sob a perspectiva da internacionalização, pois, no século XIX, "os diferentes conceitos e resultados de experimentos sobre o mobiliário escolar circulam além das fronteiras"221.

Princípios higiênicos denotavam uma preocupação com as patologias escolares provocadas pela posição ao sentar, pelo mobiliário e a posição do corpo que ele impunha e pelos espaços escolares. Peyranne salienta que "os médicos deram uma grande importância à higiene na escola" 222 e "os higienistas elaboraram estratégias na construção do mobiliário a fim de prevenir as doenças escolares [...] O mobiliário higiênico do século XIX é concebido a partir dos conceitos de saúde da época e da identificação das moléstias escolares"223. O mobiliário existente até então é denunciado como "nefasto à saúde das crianças"224.

No caso paulista, ao tratar da "Hygiene escolar, organisação geral e direção particular das escolas, de acordo com os systemas modernos de ensino e com os princípios das sciencias”225, o professor catedrático de Pedagogia e Metodologia da Escola Normal de S. Paulo, Padre Camillo Passalacqua, no manual Pedagogia e Methodologia, afirma que

A importância da mobília escolar é maior do que commumente se pensa. Um systema racional de mobília não só melhora as condições physicas do estabelecimento e do alumno, mas muito principalmente acompanha as manifestações orgânicas da criança cem igualdade ${ }^{226}$.

No século XIX "nós recenseamos as moléstias, produzimos dados estatísticos, assistimos ao nascimento de toda uma epidemiologia escolar; o saber médico intervém a serviço da criança"227. A carteira deveria ser adaptada às diferentes atividades: escrita,

\footnotetext{
${ }^{220}$ BARBOSA, 1883, p.25.

${ }^{221}$ PEYRANNE, 2001, p. 160

${ }^{222}$ PEYRANNE, op. cit., p.99 - “[...] les médicins donnent alors une importance grandissante à l'hygiène dans les écoles".

${ }^{223}$ PEYRANNE, op. cit., p. 94 - "Le mobilier hygiénique du XIX" siècle est conçu à partir des concepts de santé de l'époque et de l'indentification des maladies scolaires".

${ }^{224}$ Idem, ibidem.

${ }^{225}$ PASSALACQUA, 1887

226 Idem, p. 58.

${ }^{227}$ PEYRANNE, op. cit., p.95 - "Au XIX e siècle, on recense les maladies, on produit des données statistiques, on assiste à la naissance de toute une épidémiologie scolaire; le savoir médical se met au service de l'enfant".
} 
leitura e desenho. "A posição na escrita poderia deformar a coluna e provocar problemas orgânicos [...] A posição imóvel sobre um banco é igualmente considerada como nefasta, ela favorece a preguiça intestinal, provoca um sofrimento do aparelho circulatório" 228 .

Quanto aos problemas visuais, a mesa-banco deve permitir a adoção espontânea da boa posição: "Para leitura, o livro deve fazer uma perpendicular com o eixo visual, ou seja, formar um ângulo de $45^{\circ}$ com a horizontal" 229 .

Para evitar as deformidades provenientes ou agravadas no meio escolar, duas grandezas deveriam ser levadas em conta na fabricação da carteira: a Distância e a Diferença.

A “distância horizontal da borda anterior do assento ao alinhamento vertical da mesa" ${ }^{230}$, ou seja, a altura entre a mesa e o banco. Na acepção de Cardot, a "distância deve ter em conta a espessura do corpo das crianças e, esta, varia de acordo com a idade",231.

A diferença "é a distância vertical do banco à mesa"232. Os bancos ou mesas com alturas reguláveis serviriam para modular essa distância vertical do banco à mesa evitando uma postura como a que se vê na figura abaixo. Essa diferença deveria ser "medida pela altura do cotovello [...] Se o antebraço ficar em posição horisontal, a mesa é reputada de boa altura; se ficar um pouco inclinado para deante, é que a mesa é muito baixa; se, ao contrário, ficar inclinado para traz, é porque é muito alta"233. A figura abaixo, presente na Revue Pedagogique de 1879, mas também destacada por Peyranne ilustra uma posição nefasta para o corpo saudável.

\footnotetext{
${ }^{228}$ PEYRANNE, op. cit., p.99-100 - “[...] La position d'écriture pouvait à La fois déformer le rachis ET provoquer des troublés organiques [...] La position immobile sur um banc est également considérée como néfaste, elle favorise la paresse intestinale, provoque une souffrance de l'appareil circulatoire".

${ }^{229}$ PEYRANNE, op. cit. p.103 - "Pour la lecture, le livre doit faire une perpendiculaire avec l'axe visuel, c'est à dire former um angle de $45^{\circ}$ avec l'horizontale".

230 "[...] la distance horizontale du bord antérieur du siege à l'alignement vertical de la table" (PEYRANNE, 2001, p.151).

${ }^{231}$ Cardot, 1881 apud PEYRANNE, 2001, p.155 - "La distance doit tenir compte de l'épaisseur Du corps des enfants, celle-ci varie em fonction de l'âge".

${ }^{232}$ PEYRANNE, op. cit. p. 150 - "La différence est La distance verticale du banc à La table".

${ }^{233}$ MELLO, 1902, p.17
} 
Figura 5 - Posição considerada nefasta, segundo Bagnaux

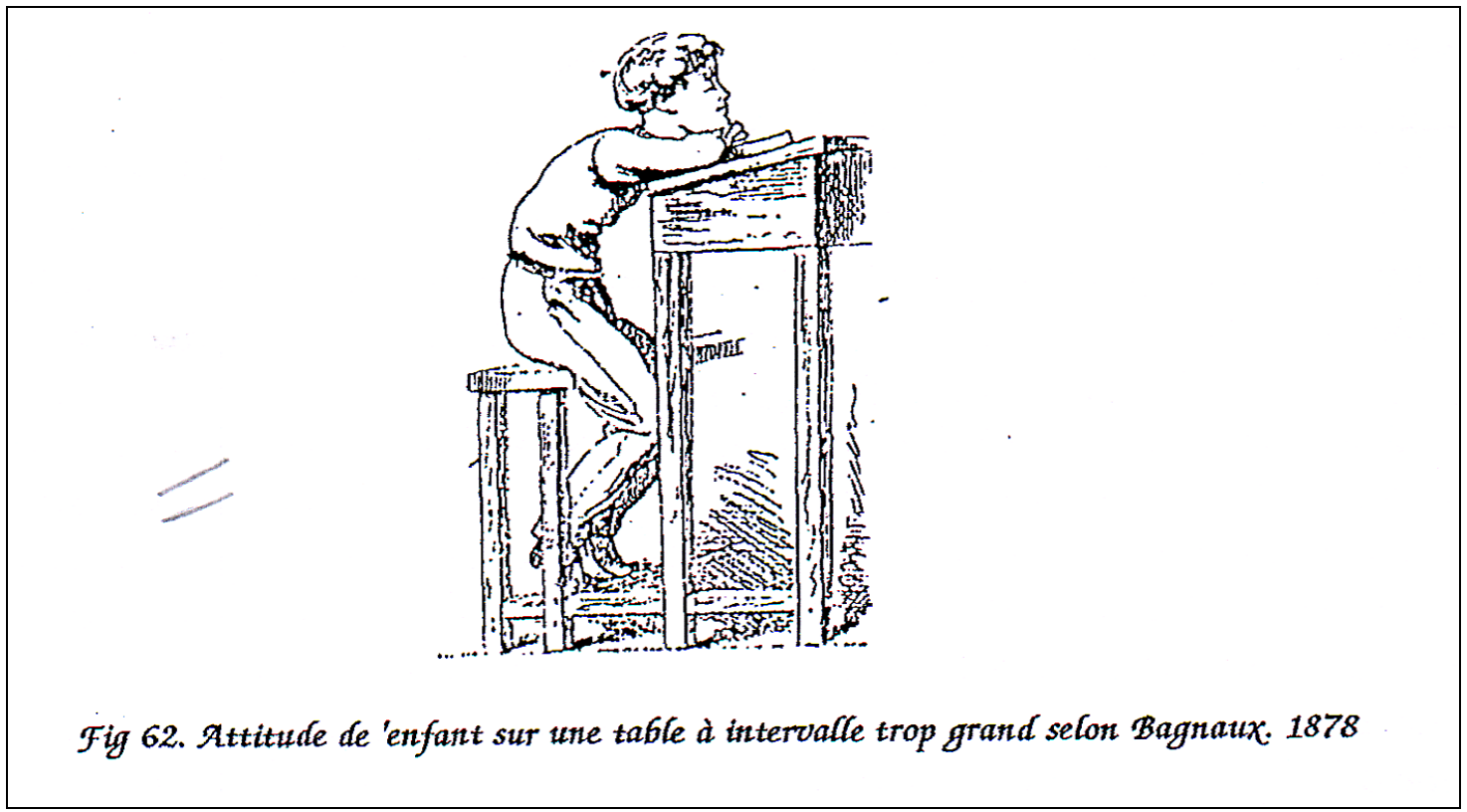

Fonte: Revue Pedagogique, 1879, p.115 e PEYRANNE, 2001, p.154.

Em relação à distância há três classificações, como se observa na figura abaixo. A distância positiva, quando existe um intervalo entre a mesa e o banco; a negativa, quando a mesa avança sobre o banco; e, a nula, quando a mesa e o assento estão alinhados sob uma mesma vertical. 
Figura 6 - Diferentes tipos de distância entre mesa e carteira

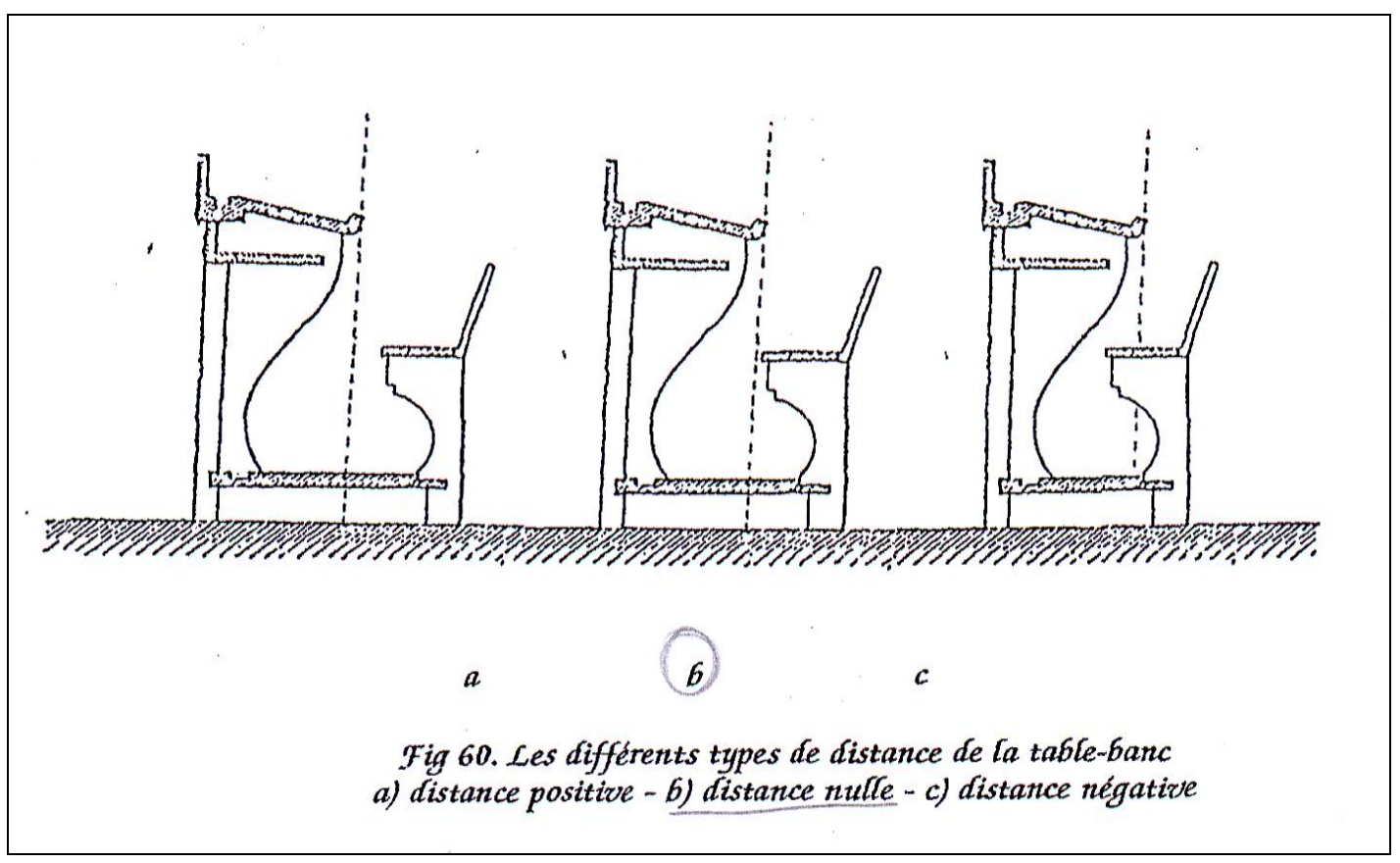

Fonte: PEYRANNE, 2001, p.152.

Fazendo referência às produções de Narjoux, Buisson e ao Congresso Internacional de Ensino de Bruxelas em 1880, Rui Barbosa esclarece que

$\mathrm{Na}$ investigação das leis que deviam presidir à construção normal do banco-mesa, o mais importante movel da escola, três objetos chamaram, desde o começo destes estudos, a atenção da medicina: a separação entre a aresta anterior do assento e o alinhamento vertical da mesa, separação a que Fahrner pôs e a que ficou o nome peculiar de distância; a diferença de altura entre a mesa e o banco, a que se ligou a denominação técnica de diferença; a inclinação da superfície da mesa. Estudando as relações entre cada um destes elementos da questão e as dimensões da estatura dos alunos nas várias idades. ${ }^{234}$

Além da distância e da diferença, a definição da inclinação da mesa era fundamental para evitar a miopia. O médico oculista inglês Liebreich preconizou que "nas atividades de leitura a tabuleta deve ser inclinada a $40^{\circ}$ e nas atividades de escrita, uma inclinação de $20^{\circ}$ é suficiente. Também, a distância da mesa ao assento deve ser de 5 polegadas $(12,5 \mathrm{~cm})$ para ler e nulo para escrever, ${ }^{, 235}$.

\footnotetext{
${ }^{234}$ BARBOSA, Rui. Obras Completas. V. X. 1883. Tomo IV. Reforma do Ensino Primário. p.26 (grifo meu).

${ }^{235}$ PEYRANNE, op. cit., p. 156 - "dans l'activité de lecture La tablette doit être inclinée à $40^{\circ}$ ET dans l'activité d'écriture, une inclinaison de $20^{\circ}$ suffit. Il precise également que La distance Du pupitre au siège devait alors être de 5 pouces $(12,5 \mathrm{~cm})$ pour livre et nulle pour écrire".
} 
Figura 7 - Inclinações ideais de carteira

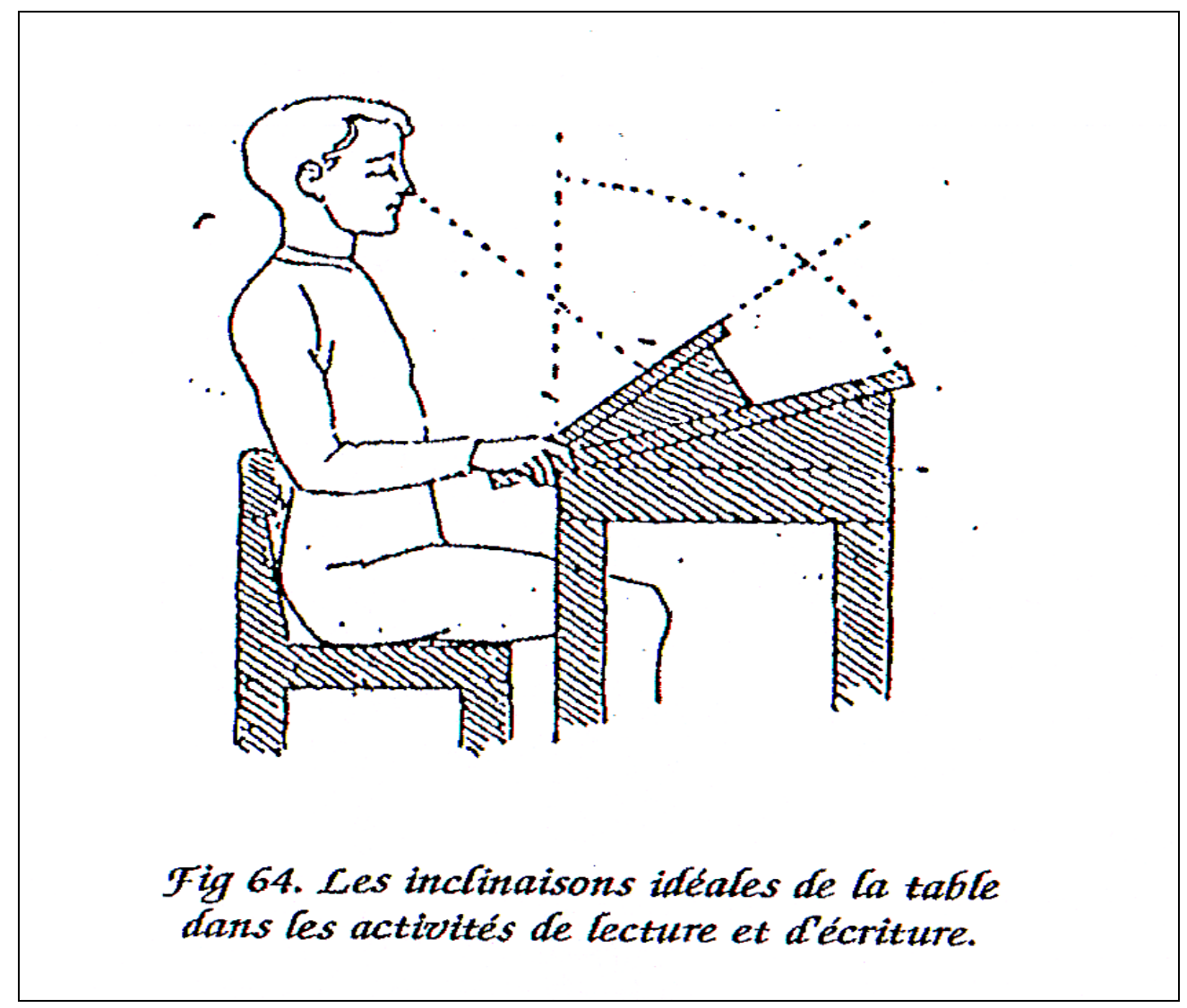

Fonte: PEYRANNE, 2001, p.156

"Esta inclinação da tabuleta deve permitir à criança conservar uma distância entre o olho e a carteira de 30 a 40 centímetros, distância reconhecida saudável para a preservação da vista"236. Isso exigiria um mobiliário com uma altura regulável, o que aumentaria o custo.

A carteira higiênica deveria ter "uma boa altura do banco e da mesa, a distância permite ao tronco de permanecer direito e em apoio sobre a lombar durante a escrita e leitura. A carteira impõe uma distância de visão ideal e os pés repousam sobre a barra de apoio",237. $^{, 2}$.

\footnotetext{
${ }^{236}$ PEYRANNE, op. cit., p. 156 - "Cette inclinaison e la tablette doit permettre à l'enfant de conserver une distance entre l'oeil et le pupitre de 30 à 40 centimètres, distance reconnue saine pour la préservation de la vue".

${ }^{237}$ Idem, p. 158 - "Il est à bonne hauteur du banc et du pupitre, la distance permet au tronc de rester droit et en appui sur le dossier lombaire pendant l'écriture ou la lecture. Le pupitre impose une distance de vision idéale, les pieds reposent sur la barre d'appui".
} 
Billard, professor de trabalho manual ${ }^{238}$ da Escola Turgot projetou uma carteira modulável. "Oferecer um único modelo para todos os tamanhos foi um verdadeiro progresso da indústria do mobiliário. A carteira modulável a menor custo conquistou um grande sucesso" 239 .

As modificações nas práticas educativas, nos meios de aprendizagem e nos programas exigiu um novo mobiliário no fim do século XIX. "O bom mobiliário deve responder às regras de higiene a fim de não prejudicar a saúde das crianças [...] Ele deve também ser adaptado aos métodos e práticas educativas em uso na época” ${ }^{\text {"240 }}$. Os antigos bancos, tão criticados, reúnem três características: ausência de encosto, de apoio para os pés e largura insuficiente do assento ${ }^{241}$. Nas três situações, o banco torna-se uma fonte de fadiga, pois o aluno não tem possibilidade de repousar.

\footnotetext{
${ }^{238}$ Elemento curioso é a participação dos professores de Trabalho Manual na inovação do mobiliário escolar. Vale lembrar que Eduardo Waller, professor de Trabalho Manual da Escola Americana, em São Paulo, era um dos donos da Fábrica de Mobiliário Escolar Eduardo Waller \& Cia, que produziu carteiras para as escolas públicas paulista.

${ }^{239}$ PEYRANNE, op. cit., p.167 - "Proposer un Seul modèle pour toutes les tailles était alors un véritable progress dans l'industrie du mobilier. La table-banc modulable à moindre coût a ainsi remporté un grande succès".

${ }^{240}$ Idem, p.142 - "Le bon mobilier devait répondre aux règles de l'hygiène afin de ne pas nuire à la santé des enfants [...] Il devait aussi être adapte aux pratiques éducatives en usage à l'époque".

${ }^{241}$ PEYRANNE, op. cit.
} 
Figura 8 - Má postura durante a escrita

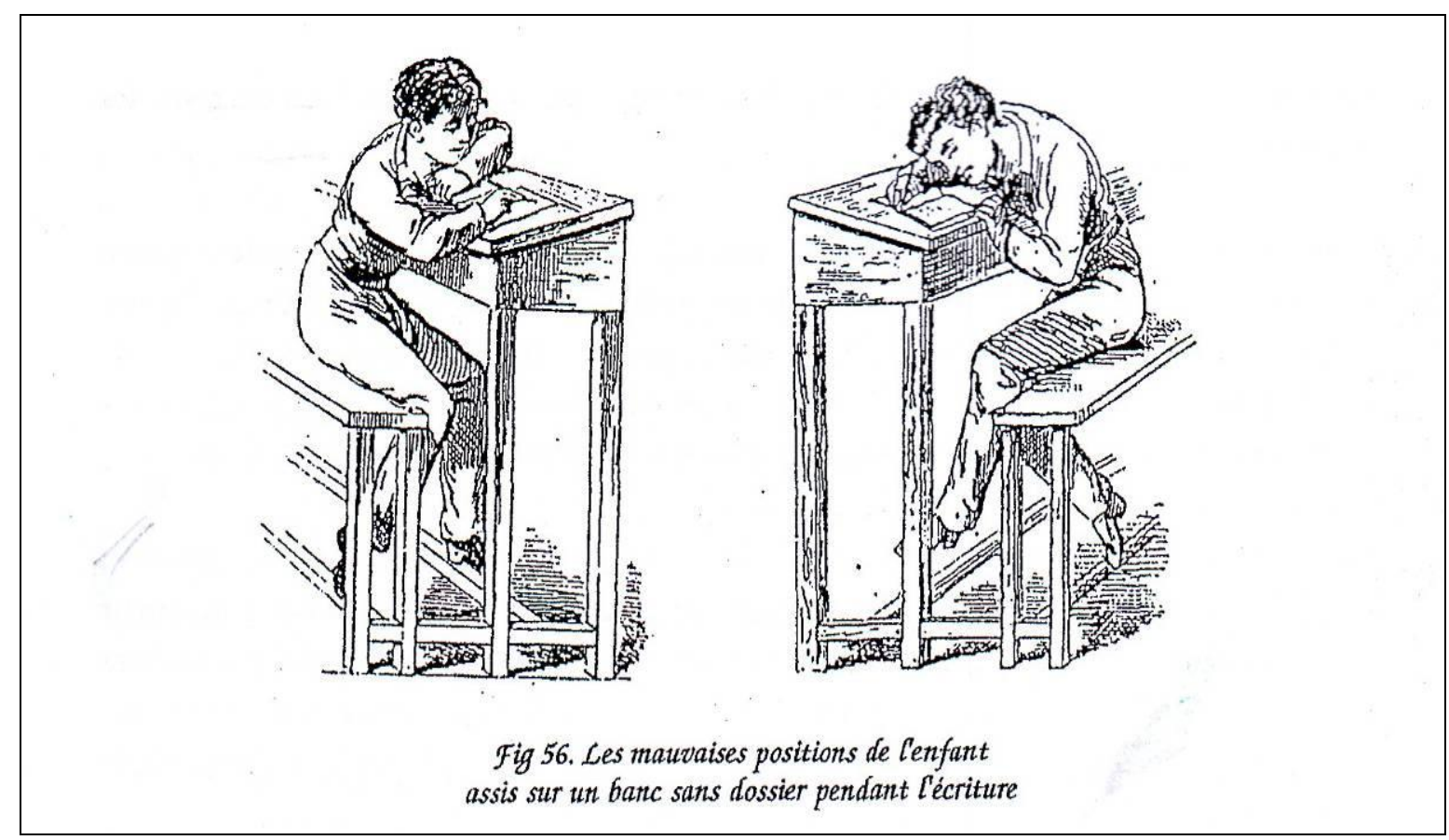

Fonte: Revue Pedagogique, 1879, p.116, 117; PEYRANNE, 2001, p.148

A falta de apoio para os pés, por exemplo, "obriga a criança mover-se para a frente do banco se ele está longe [... $]^{\prime 242}$.

A carteira que favorece uma posição ideal, apresentada em um dos mais conhecidos manuais de higiene $\operatorname{escolar}^{243}$, no período, atende a três requisitos essenciais: apoio para os pés, encosto e profundidade do assento.

\footnotetext{
${ }^{242}$ Idem, p.149 - "obligeait l'enfant à se déplacer à l'avant du banc si elle était trop éloignée [...] les hygiénistes se sont interesses à déterminer la hauteur à laquelle le banc devait arriver par rapport au corps de l'enfant assis en position à angles droits pendant lês activités d'écriture ou de lecture".

${ }^{243}$ RIANT, A. Hygiène Scolaire: Influence de l'École sur la santé des enfants. Paris: Librairie Hachette \& Cie, 1874.
} 
Figura 9 - Posição ideal ao assentar-se

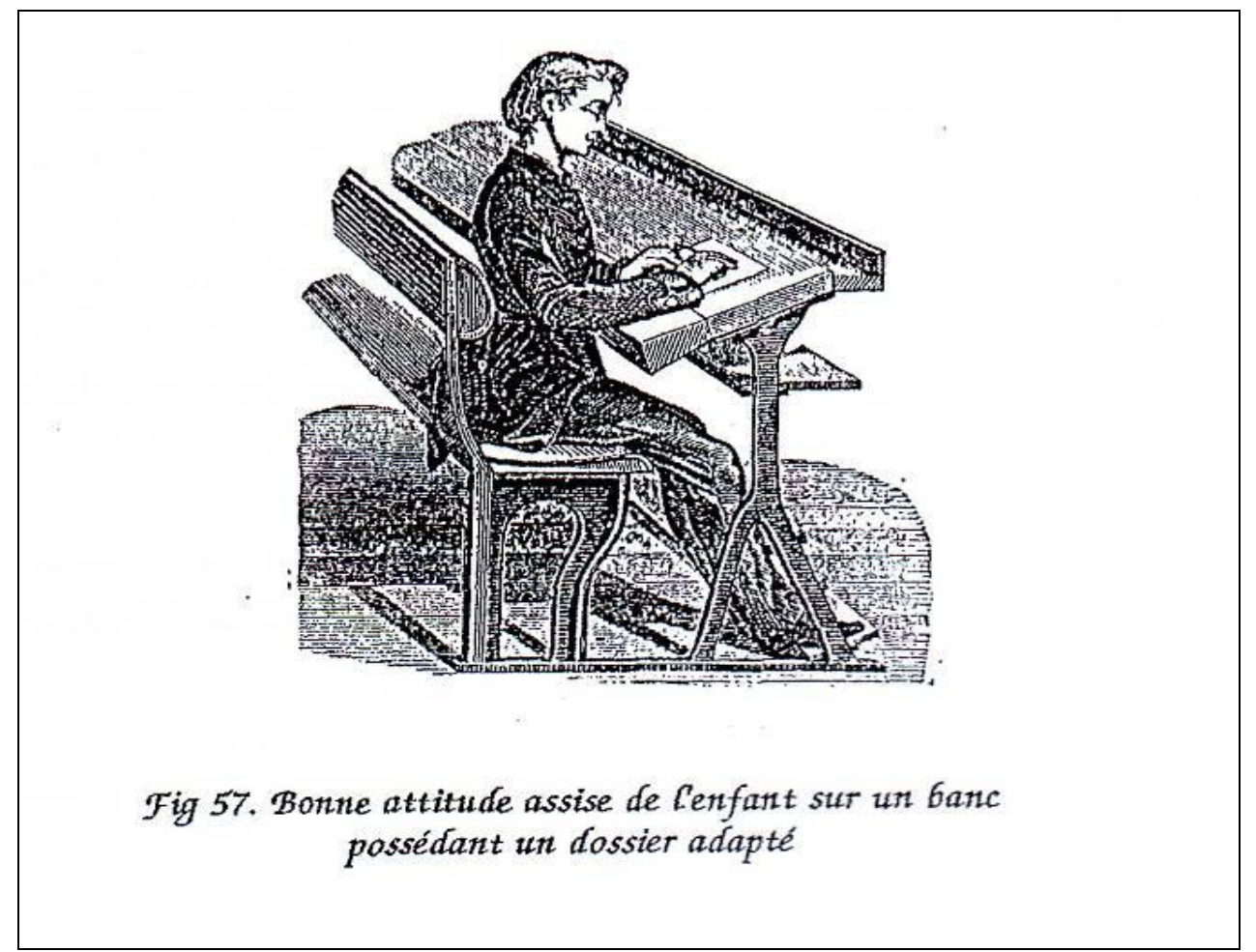

Fonte: RIANT, 1874, p.117

"Variar a profundidade do assento" 244 foi uma das primeiras preocupações do francês Cardot. Cardot se destaca nas pesquisas e experimentos sobre o mobiliário escolar. Seus modelos mostram mudanças na concepção e construção do mobiliário escolar. Seu primeiro mobiliário era fixo, com dois lugares, inteiramente em madeira.

\footnotetext{
${ }^{244}$ PEYRANNE, op. cit, p.161 - "il s'intéresse en premier lieu à faire varier la profondeur du siège".
} 
Figura 10 - Primeira carteira escolar de Cardot

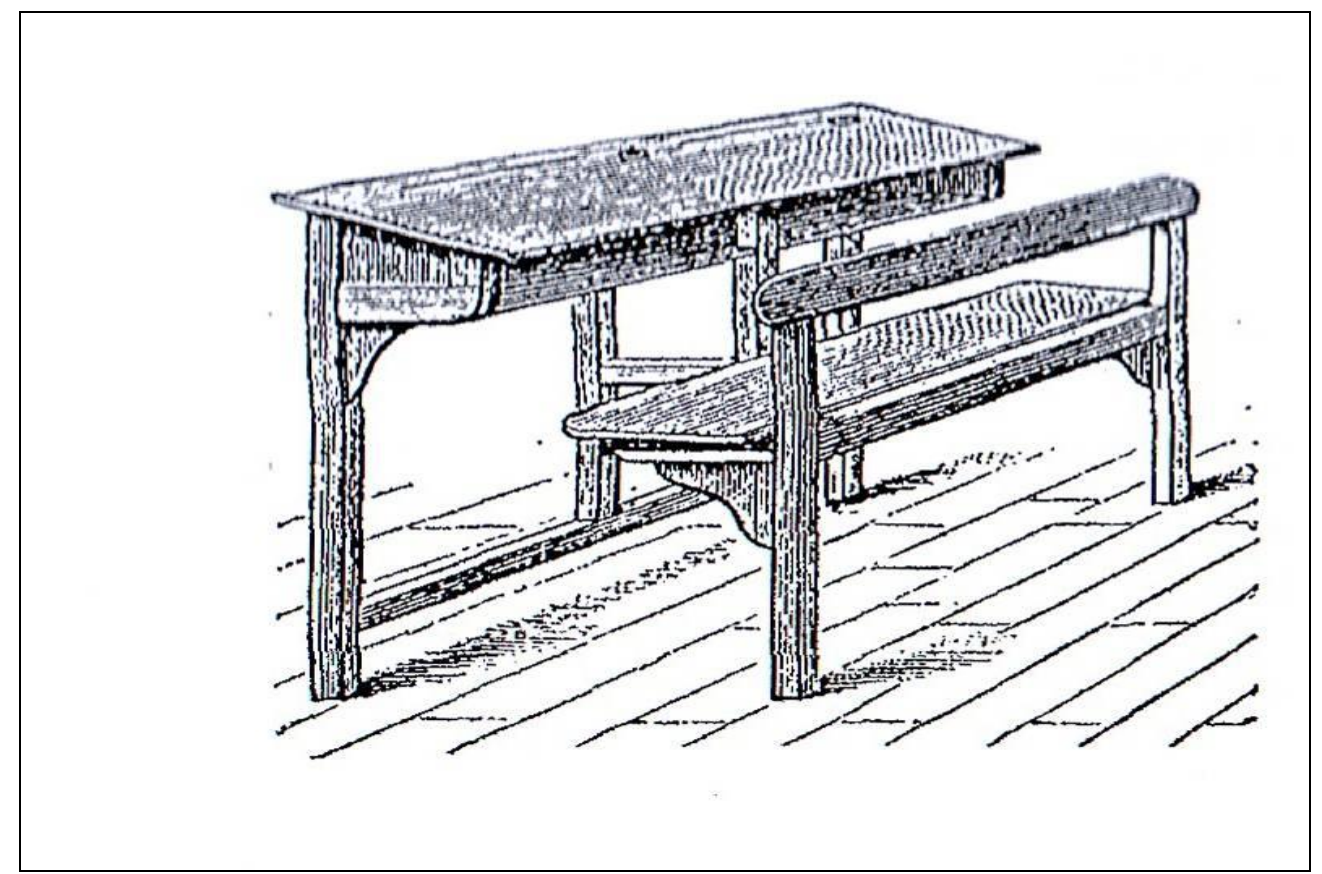

Fonte: PEYRANNE, 2001, p.162

O modelo abaixo, "Carteira Cardot com mesa móvel”, apresentado na Exposição Universal de Viena, "possui uma tabuleta móvel para frente e para trás" 245 adaptável às atividades de recitação, escrita e leitura.

\footnotetext{
${ }^{245}$ Idem, p.163 - "Celui-ci possède une tablette móbile em avant et em arrière".
} 
Figura 11 - Carteira Cardot com mesa móvel

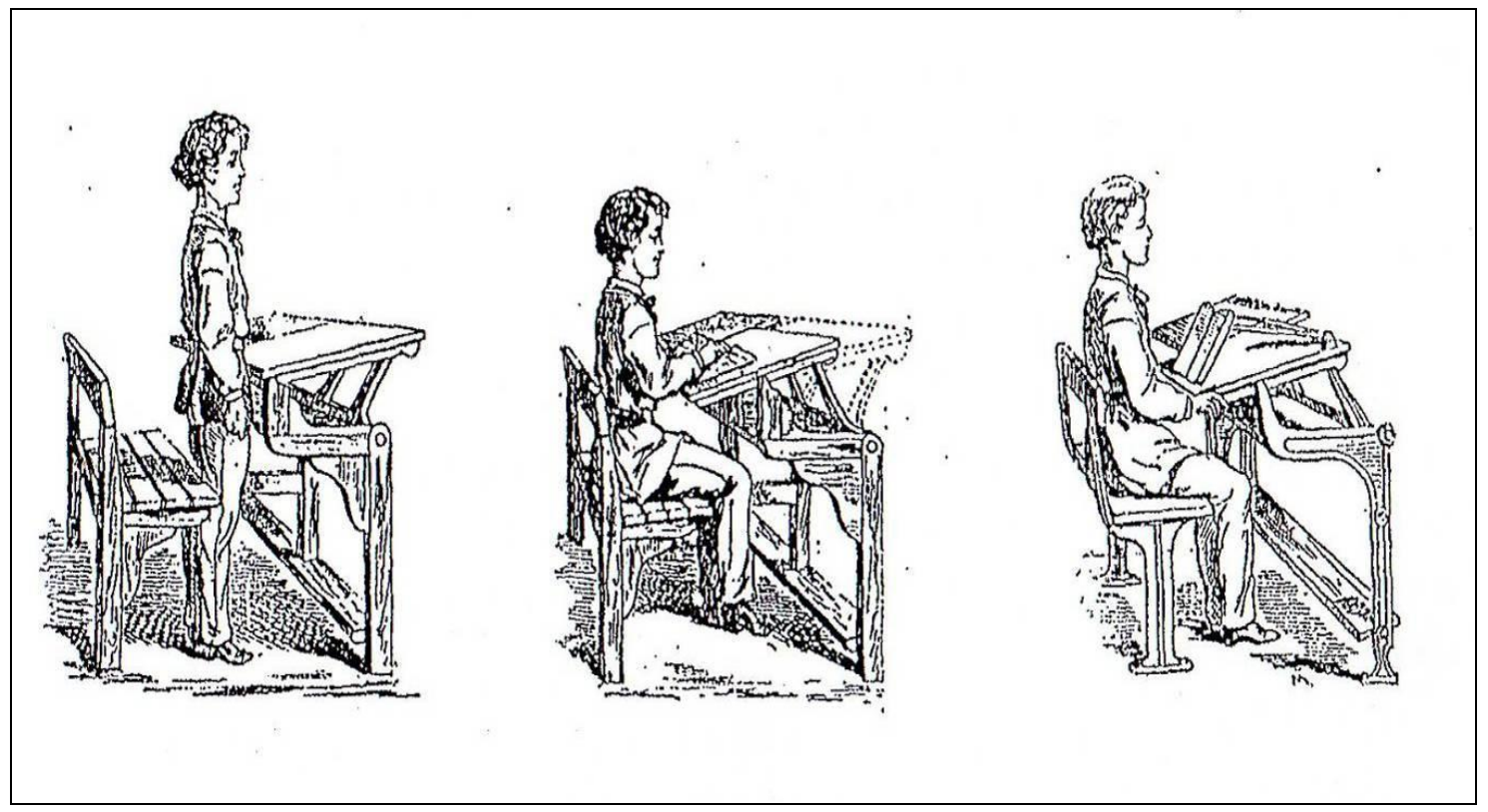

Fonte: PEYRANNE, 2001, p.163

Cada resultado de pesquisas efetuadas sobre a saúde da criança em relação a posição sentada e o mobiliário é levado em conta na construção das carteiras [...] O mobiliário escolar, no século XIX, foi modificando em função das necessidades educativas, dos resultados das pesquisas no domínio da saúde, e do avanço da tecnologia"246.

Ferdinand Buisson, inspetor geral do ensino primário, em seu Dicionário de Pedagogia e da Instrução Primária ${ }^{247}$, estabelece dois principais fundamentos que devem presidir a reforma do mobiliário escolar: 1) Conciliar o assento e a mesa de modo que a vertical avance para fora da borda dianteira da mesa encontrando a borda do assento; 2) Tornar confortável o repouso na posição assentada, primeiro dando à carteira uma inclinação entre 15 e 18 graus proporcionando ao aluno um ponto de apoio para as costas e para os pés (barra de apoio) e, finalmente, adequando exatamente o tamanho das crianças e a altura da mesa-banco.

Ao espaçamento inadequado da mesa e do banco e, em segundo lugar, à desproporção entre o tamanho da criança e a altura da mesa que Buisson atribui as atitudes viciosas dos estudantes e, consequentemente, as deformações da coluna vertebral e a miopia. Ou seja, à distância e à diferença. Somente atendendo a esses dois

\footnotetext{
${ }^{246}$ Idem, p. 164 - "Chaque résultat des recherches effectuées sur la santé de l'enfant en rapport avec la position assise et le mobilier est pris em compte dans la construction de ces tables-bancs [...] Le mobilier scolaire au XIXe siècle était évolutif en fonction des besoins éducatifs, des résultats des recherches dans le domaine de la santé, et de l'avancement de la technologie".

${ }^{247}$ BUISSON, Ferdinand. Dicionário de Pedagogia e da Instrução Primária. Parte I, Tomo I. Paris: Librairie Hachette \& Cie., 1887, p. 1305.
} 
fundamentos pode o mestre exigir dos alunos que guardem, durante a escritura ou leitura, uma atitude normal, conforme prescreve o Dr. Liebreich. Tais prescrições, apresentadas por Buisson, também são reproduzidas por Rui Barbosa:

O cotovelo assenta na mesa, perto do bordo. Em consequiência, a parte superior do corpo, volvida sobre si mesma para a direita, debruça-se mais ou menos para a frente, segundo o grau de distância existente entre a carteira e o banco. À mão direita poisa no caderno, enquanto o cotovelo direito vem apoiar-se de encontro às costelas. Até aqui a cabeça ainda se acha ereta.

Começa a cabeça a pender para a mesa, abatendo-se gradualmente; o cotovelo é arrastado para diante; a parte superior do corpo acha-se ainda mais torcida para a direita. As costelas do lado esquerdo apoiam-se ao bordo da mesa.

O 3. ${ }^{\circ}$ O caderno do aluno, especialmente o seu Bordo direito, é impelido para a frente, de modo que cessa de estar paralelo ao bordo da mesa, e forma com ele um ângulo de 45 graus, às vezes ainda mais. A cabeça está inclinada e virada de tal arte que o olho esquerdo fica algumas polegadas apenas distante do livro; a face esquerda chega quasi a tocar a mão, e muitas vezes até descansa no punho; o tórax acha-se como que suspenso à espádua direita e às costelas do mesmo lado, que se apoiam no rebordo da mesa, ultrapassando-o ${ }^{248}$.

Para estabelecer a distância e a diferença adequadas, bem como a atitude normal, as contribuições da ergonomia e da antropometria eram indispensáveis. De acordo com Peyranne "Construir um mobiliário apropriado às diferentes estaturas não se pode fazer sem medidas antropométricas" 249 .

O Traité d'Hygiène ${ }^{250}$, em seu volume VI, trata especificamente da higiene escolar. Os autores Méry e Genèvrier entendem que, para evitar e diagnosticar doenças nos escolares, "o exame antropométrico deve preceder a todas as outras investigações acerca da constituição ou da saúde da criança" ${ }^{251}$.

O regulamento de Jules Ferry, redigido por Gréard, Buisson e Narjoux, estabeleceu que:

as carteiras serão de um ou dois lugares, de preferência um lugar; a tabuleta deverá ser inclinada de $15^{\circ}$ a $18^{\circ}$, jamais inferior a $15^{\circ}$; o banco e o encosto serão integrados; o banco é fixo e ligeiramente inclinado para trás; todas as bordas serão abatidas; a tabuleta pode ser fixa ou móvel; uma gaveta deve ser colocada sobre a tabuleta e o engradado na lateral ${ }^{252}$.

\footnotetext{
${ }^{248}$ BARBOSA, Rui. Obras Completas. V. X. 1883. Tomo IV. Reforma do Ensino Primário. p.17-18.

${ }^{249}$ PEYRANNE, op. cit., p.167.

${ }^{250}$ Agradeço ao professor Dr. Hugo Segawa a cessão do Traité d'Hygiène. VI - Hygiène Scolaire.

${ }^{251}$ MÉRY, H; GENÈVRIER, J. Traité d'Hygiène. VI - Hygiène Scolaire. Paris: Librairie Baillière et Fils, 1914, p.420 - "L'examen antropometrique doit précéder toutes autres investigations relatives à la constitution ou à la santé de l'enfant".

${ }^{252}$ Idem, p. 169 - "Ce règlement precise également: les tables-bancs seront à une ou deux places, de préférence à une place; La tablette devra être inclinée de $15^{\circ}$ à $18^{\circ}$, jamais inférieure $15^{\circ}$; le banc et le
} 
Os elementos que deveriam ser observados em cada carteira eram: 1) superfície de trabalho, com inclinação ou não, com gaveta ou não; 2) o assento e sua profundidade, dobrável ou não; 3) encosto; 4) apoio de pé; 5) a distância vertical; 6) a diferença horizontal.

A não observância destes elementos poderia causar diversas afecções nos escolares, como pode ser visto nos manuais nacionais (Passalacqua, 1887; Mello, 1902) e internacionais (Riant, 1874; Narjoux, 1877; Cardot, 1881; Méry e Genèvrier, 1914), além dos catálogos de mobiliário escolar (Catalogue Delagrave, 1890, 1892; Union School Furniture Company, 1889; The National School Furniture Co., 1872; EDWARD E. BABB \& CO., 1897-1898; BOBRICK, 1892) ${ }^{253}$ que usam como propaganda a satisfação daqueles elementos.

Na divulgação da Nouvelle Table Scolaire System LHUILLIER, as vantagens descritas para o produto são: "Higiene, moral, comodidade, elegância". A carteira tem por autor um oficial da Instrução Pública e diretor de uma escola importante do Seine.

Nesta qualidade, ele constatou os incovenientes de um mobiliário escolar defeituoso e se aplicou a pesquisar os melhoramentos que precisavam ser feitos. Higiene. - Nem deformidades nem miopia com a carteira de M. Lhuillier. Estes cinco diferentes tipos satisfazem plenamente todos os requisitos de uma boa higiene. Assento com encosto, inclinação da mesa para a escrita, e uma pequena mesa portátil para leitura, dimensões relativas aos diferentes tamanhos de alunos, etc., Contribuindo para o bem-estar e o desenvolvimento normal do corpo e das capacidades físicas da criança ${ }^{254}$.

dossier seront continus; le banc est fixe et légèrement incline vers l'arrière; toutes lês arêtes seront abattues; La tablette peut être fixe ou móbile; um casier doit être aménagé sous la tablette et à claire voie du cote opposé à l'élève".

${ }^{253}$ BOBRICK, G. A. Hygienic Requirements of School Furniture. New York: Press of Exchange Printing Co., 1892. Esta obra é muito rica no tratamento da relação hygiene e mobiliário escolar no século XIX.

254 "En cette qualité, il a été à même de constater souvent les inconvénients d'un mobilier scolaire défectueux, et s'est appliqué a rechercher les améliorations qu'il fallait y apporter. Hygiène. — Plus de difformités ni de myopie avec la table de M. Lhuillier. Ses cinq types satisfont pleinement à toutes les exigences d'une bonne hygiène. Siége a dossier, inclinaison du plateau pour l'écriture, et d'un petit pupitre portatif pour la lecture, dimensions en rapport avec les différentes tailles des élèves, etc., tout contribue au bien-être ainsi qu'au développement normal du corps et des facultés physiques de l'enfant" (DELAGRAVE, 1890, p.4). 
Figura 12 - Carteira sistema LHUILLIER

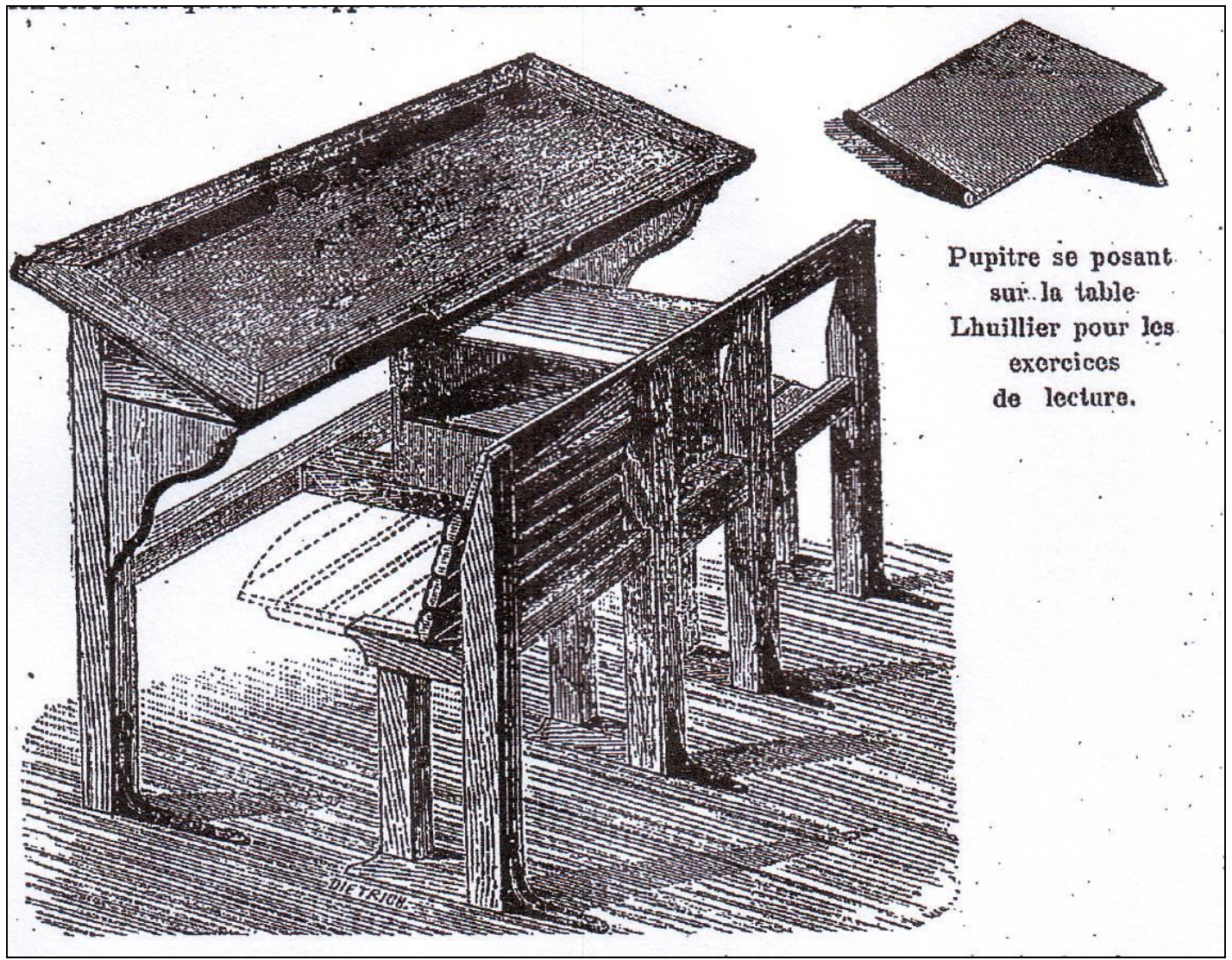

Fonte: Catalogue Delagrave, 1890, p.4.

A mesma empresa, no catálago de 1892 anuncia o monopólio do sistema "A. Savary et L. Nisius, já amplamente utilizado e apreciado na França e no exterior"255. Possuir o monopólio de um sistema é colocar-se como a única empresa capaz de garantir as exigências da Higiene no setor do mobiliário escolar. Enfatizar a satisfação de tais exigências constitui uma boa propaganda. Por isso, no texto de abertura do catálogo, lê-se:

Há dez anos, constatou-se que a má disposição do mobiliário causa tanto mal quanto a falta de ar e luz e a instalação material das escolas sofreu uma transformação completa. A miopia, tornou-se um perigo público, deformações corporais, especialmente entre as meninas, são devidas, em geral, aos seus bancos e mesas que não são de nenhuma maneira proporcionais ao tamanho dos escolares. Daí, uma reforma que continua, mas que irá contra a sua finalidade, se nos dirigimos ao primeiro empresário, ao invés de escolher mesas e bancos fabricados de acordo com regras exatas, como as que são apresentadas neste catálogo ${ }^{256}$.

255 “A. Savary et L. Nisius, très répandus déjà et fort appréciés en France et à l'étranger” (DELAGRAVE, 1892, p.2).

${ }^{256}$ DELAGRAVE, 1892, p.2 - Depuis une dizaine d'années, l'on s'est aperçu que la mauvaise disposition du mobilier cause autant de mal que le défaut d'air et de lumière et l'installation matérielle des écoles a 
Figura 13 - Carteira sistema Savary

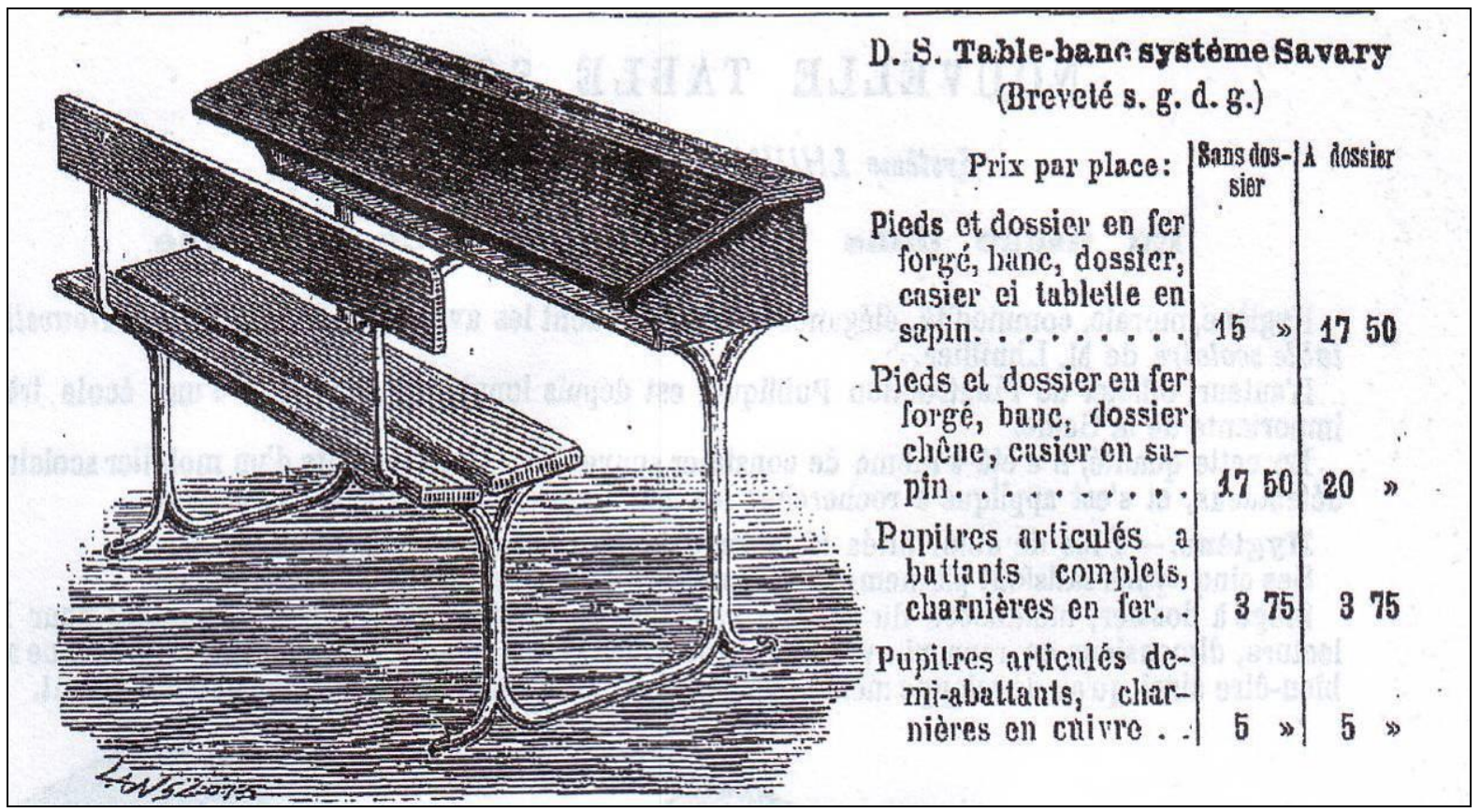

Fonte: Catalogue Delagrave, 1892, p.10

A Union School Furniture Company, de Michigan, em seu catálogo de 1889, expõe como a primeira vantagem da carteira "The Automatic" a indução a uma posição higiênica.

1. SAÚDE - Todas as outras carteiras devem ser colocadas longe o suficiente para permitir que os alunos entrem e saiam dos lugares quando os assentos estão abaixados. Elas estão tão afastadas para permitir que eles se debrucem sobre suas atividades, além de deformarem de forma permanente seus corpos, induzindo-os a doenças do tórax, dos pulmões e dos olhos. Com a carteira "Automatic", o aluno se fixa facilmente em seu assento, o qual se move para baixo e para frente conforme ele se senta, levando-o convenientemente para perto da mesa em frente, o que lhe assegura uma posição ereta. Nenhum outro banco feito possui essa peculiaridade e nenhuma diretoria escolar ou comitês de construção que apreciam a saúde dos alunos deveriam subestimá-lo ${ }^{257}$.

subi une transformation complète. La myopie, devenue un danger public, les déformations corporelles, si frequentes surtout chez les jeunes filles, sont dues, en général, à ce que les tables et tes bancs ne sont nullement proportionnés à la taille des écoliers. De là une réforme qui se poursuit, mais qui ira contre son but si l'on s'adresse au premier entrepreneur venu, au lieu de faire choix de tables et bancs exécutés selon des règles exactes, comme le sont ceux que nous présentons dans ce catalogue.

257 1. HEALTH. - All other desks must be placed far enough apart to allow pupils to get into and out of the seats when the seats are down. They are then so far apart as to cause the pupils to stoop over their work, thus permanently deforming the body, and inducing diseases of the chest, lungs, and eyes. With the "Automatic" desk, the pupil stops easily to his seat, which moves down and forward as he sits down, thus bringing him conveniently near to the desk in front, and securing an erect position. No other seat made possesses this peculiarity, and no school officers or building committees who appreciate the health of the pupils should undervalue it (UNION SCHOOL FURNITURE COMPANY, 1889, p.5). 
De igual modo, o engenheiro civil Bobrick, tratando dos "Hygienic Requirements of School Furniture" revela a preocupação com as partes do corpo que poderiam sofrer devido ao mobiliário escolar.

Ombros curvados, coluna vertebral inclinada, dificuldade de respiração, distorção da parte superior do corpo e outras deformidades físicas que estragam a simetria da estrutura corporal muitas vezes aparecem em crianças em crescimento e, se a causa não for descoberta e removida, o adulto pode apresentar durante sua vida uma aparência disforme, quando, na infância, ele podia ter sido perfeito. Esses males não há muito atraíram a atenção de cientistas na Europa, os quais fizeram um estudo sobre si próprios e descobriram que na maioria dos casos eles são rastreáveis para o uso, - enquanto o corpo ainda está sem forma e suscetível a todas as influências externas, de carteiras e assentos, na escola e em casa $[\ldots]^{258}$.

As preocupações com as atitudes dos alunos ao sentarem-se a fim de evitar moléstias que se adquirem devido à postura dos escolares, as quais podem comprometer seu desenvolvimento físico, levaram os médicos e higienistas a elencarem um conjunto de doenças originadas ou agravadas na escola. Todas elas se repetem nos manuais do fim do século XIX e início do XX e foram bem sistematizadas por Maria de Fatima Machado.

"A fadiga muscular seria considerada uma das grandes causas das diferentes doenças escolares. Ela provinha [da] total desarmonia entre as suas [crianças] estaturas e as dimensões das mesas e dos bancos em que se sentavam"259. Dentre as afecções dos escolares a autora destaca:

1 - Problemas digestivos - "resultantes da pressão exercida nos órgaos da região abdominal quando o aluno se tinha de inclinar sobre a mesa para escrever, e que se caracterizavam por dificuldades em fazer a digestão ou mesmo em falta de apetite" 260 . 2 - Problemas com as funções respiratória e circulatória - “devido à pressão exercida contra a mesa na região torácica, sobretudo por as mesas serem demasiado altas e

\footnotetext{
${ }^{258}$ Round shoulders, curvature of the spine, difficulty of respiration, distortion of the upper part of the body, and other physical deformities which mar the symmetry of the frame, frequently make their appearance among growing children, and, if the cause be not discovered and removed, the adult may bear through life a misshapen form, when in infancy he may have had a perfect one. These evils not long since attracted the attention of scientists in Europe, who made a study of them and found that in most cases they are traceable to the use, - while the body is yet unformed and susceptible to all external influences, — of desks and seats, in school and at home [...] (BOBRICK, 1892, p.1).

${ }^{259}$ MACHADO, 2004, p. 157.

${ }^{260}$ Idem, p. 158.
} 
demasiado afastadas do banco [...] uma pressão muito dolorosa contra a parte anterior do corpo, impedindo o peito de se dilatar de maneira conveniente"261.

3 - Goître scolaire (papeira), dores de cabeça e hemorragias nasais - causada por uma “dificuldade da circulação sanguinea na zona do pescoço [...] quando o aluno procurava uma posição de descanso para a cabeça sobre os ombros" ${ }^{, 262}$.

4 - Frúnculos e abcessos - "causados por bancos demasiado altos para as crianças, obrigando-as ou a ficarem com as pernas penduradas ou a aposiarem-se no bordo do banco, criando em qualque um dos casos um corte na circulação sanguinea das coxas",263

5 - Desvios na coluna vertebral (cifose e escoliose). "A profilaxia das deformidades da coluna vertebral consistia na adopção de medidas que impusessem uma posição correcta ao aluno, durante os trabalhos escolares: luminosidade, mobiliário adequado, escrita direita, etc"264 Para isso, era necessária uma "vigilância constante dos aluns na sala e aula",265.

6 - Miopia - “era para além da escoliose, considerada também uma das doenças escolares com mais expressão nas escolas do ensino primário. Aliás, higienistas escolares do início do século XX afirmavam mesmo que a escola é uma fábrica de miopes e corcovados"266.

As atitudes viciosas impostas às crianças pelos diversos métodos de escrita aplicados nas escolas primárias é o tema da comunicação de Ph. Tissié, inspetor de exercícios físicos da academia de Bordeaux, proferida no Congresso de Proteção da Infância em 1895 e publicada na Revue Pedagogique de $1896^{267}$.

No Brasil, o médico e inspetor sanitário Vieira de Mello dedica parte significativa do seu manual A Hygiene na Escola a tratar das posições e atitudes dos escolares, das moléstias que se adquirem (desvios da coluna vertebral, moléstias oculares e da nutrição) e das moléstias que se propagam (febres eruptivas, moléstias das vias respiratórios, moléstias dos intestinos, moléstias dos órgãos dos sentidos, moléstias parasitárias da pele e dos pelos, moléstias nervosas e convulsivas) no meio escolar.

\footnotetext{
${ }^{261}$ Idem, p.159.

${ }^{262}$ Idem, ibidem.

${ }^{263}$ Idem, ibidem.

${ }^{264}$ Idem, p. 164.

${ }^{265}$ Idem, ibidem.

${ }^{266}$ Idem, p. 173

267 Agradeço à Dra. Diana Vidal a cessão do documento: Revue Pedagogique, Tomo XXIX, v.7, 1896, p. 49-57.
} 
Já o professor da Escola Normal de S. Paulo, Camillo Passalacqua, traz em seu manual Pedagogia e Methodologia, muitas ideias do Dr. Riant ${ }^{268}$ sobre a relação entre o espaço da sala de aula, a mobília e o desenvolvimento das doenças escolares. Intentei mostrar neste primerio capítulo a circulação internacional de um saber médicohigiênico-pedagógico sobre o mobiliário escolar associado ao espaço da sala de aula, da escola e ao próprio corpo do aluno.

Menos do que a concretização de tais ideias nas escolas paulistas, interressou pensar a circulação de um saber que acompanhou a "constituição dos sistemas públicos e nacionais de educação" ${ }^{\text {,69 }}$. Isso porque, como afirma Martinez,

A progressiva intensificação da vinculação entre higiene e educação constituiu um fator influente no processo da modernização dos sistemas educativos. No processo de expansão da escolarização obrigatória, a escola assume um papel importante na consecução de um corpo limpo, saudável e civilizado ${ }^{270}$.

É sobre este "projeto de gestão do corpo infantil” que Heloisa Rocha (2009) nos fala em seu artigo "Entre a ortopedia e a civilidade: higienismo e educação do corpo no Brasil’"271. Tal projeto fica evidenciado nos pareceres elaborados por Rui Barbosa entre os anos de 1882 e 1883, quando ele trata do mobiliário, da localização e construção dos prédios escolares, em comparação com o que se dava na Europa e nos Estados Unidos.

Os Estados Unidos e alguns países da Europa foram os grandes propagadores dos modelos higiênicos de carteira escolar nas Exposições Universais. A comparação entre os diversos modelos, no sentido de estabelecer qual deles atendia melhor os preceitos da higiene, era uma estratégia para conquista do mercado consumidor. Portanto, a carteira circula nas grandes feiras universais não somente pelo valor higiênico, mas também comercial. Esses valores se imbricavam nas propagandas de mobiliário escolar, fazendo das carteiras objetos de desejo e de necessidade para a escola moderna.

\footnotetext{
${ }^{268}$ RIANT, A. Hygiène Scolaire. Influence de l'école sur la santé des enfants. Paris: Librairie Hachette \& Cie, 1874.

${ }^{269}$ COSTA RICO, Antón. Mobiliario, dotación y equipamiento escolar en el siglo XIX. Salamanca: Revista interuniversitaria Historia de la Educación. n. 16, 1997, p.91-112.

${ }^{270}$ MARTINEZ, op. cit., p. 34 - "La progressiva intensificación de la vinculación entre higiene y educación constituyó um factor influyente en el proceso de la modernización de los sistemas educativos. No processo de expansão da escolarização obrigatória, a escola assume um papel importante en la consecución de un cuerpo limpio, saludable y civilizado".

${ }^{271}$ ROCHA, Heloisa Helena Pimenta. Entre a ortopedia e a civilidade: higienismo e educação do corpo no Brasil: Higienismo e educação do corpo no Brasil. Salamanca: Revista interuniversitaria Historia de la Educación. N. 28, 2009, p.109-134.
} 


\section{CAPÍTULO 2 \\ A INTERNACIONALIZAÇÃO DE OBJETOS DE DESEJO E OBJETOS DE NECESSIDADE}

Ao tratar de objetos de desejo e objetos de necessidade não se pretende estabelecer de forma alguma uma distinção entre objetos que seriam definidos como necessários, indispensáveis à escola e outros que consideraríamos, a priori, supérfluos. O propósito é chamar a atenção para a via de mão dupla da relação entre escola, indústria e Exposições Universais.

De um lado, a escola movimenta o mercado e suas necessidades fazem com que ele se adapte para atender a demanda. Novos serviços se organizam e lucram tendo o Estado como comprador privilegiado. De outro lado, o mercado cria objetos de desejos para a escola. O Estado dele depende para produção, em grande quantidade e em curto tempo, de um mobiliário padronizado que corrobore para a expansão do ensino.

As Exposições Universais são disseminadoras de objetos de desejo e necessidade, criadora de "certificados de qualidade" de produtos, no âmbito da educação escolar. Daí, a relevância de investigar os modelos de carteira nelas expostos.

Segundo Kuhlmann Júnior, a “educação esteve presente em todos [os eventos] desde 1862, em Londres, quando ganhou espaço para figurar ao lado da exibição da produção industrial e artística e da demonstração de novidades tecnológicas" ${ }^{272}$. Nelas, a educação foi prestigiada como "signo de modernidade" e como "um dos pilares centrais para a normatização e edificação controlada da sociedade ocidental moderna",273.

No fim do século XIX, fica em evidência a natureza tripla da modernidade, apontada por SCHRIEWER: a) a transmissão de uma ideologia da educação e do desenvolvimento particularmente moderna; b) a aceitação global de modelos racionais de escolarização pública, conduzida pelo Estado; c) e, finalmente, o processo mundial de uma expansão educacional pela escolaridade obrigatória.

Essa modernidade se expressa nos objetos escolares, adquiridos pelos Estados para promover a expansão educacional e a escolaridade obrigatória. Para propagação dos objetos escolares, as Exposições Universais contribuíram decisivamente.

\footnotetext{
${ }^{272}$ KUHLMANN JÚNIOR, Moysés. As grandes festas didáticas - a educação brasileira e as exposições internacionais (1862-1922). Bragança Paulista: Editora da Universidade São Francisco, 2001, p.9. (Coleção Estudos CDAPH. Série Historiografia).

${ }^{273}$ Idem, ibidem.
} 
Visto na perspectiva da cultura material e do contexto da sociedade industrial, o século XIX é período de mudanças culturais expressivas, especialmente ligadas à visualidade, para cujo entendimento, análises sobre museus e exposições são estratégicas $^{274}$. É preciso considerar a confluência do iluminismo e do experimentalismo em Francis Bacon que lançam as bases filosóficas para a ciência e o museu modernos.

Heloisa Barbuy ${ }^{275}$ defende que tanto os museus, quanto às exposições podem ser mais bem compreendidos quando vistos em seu desenvolvimento histórico, desde os gabinetes de curiosidades, a partir do século XVI, até atingir a conformação com que se disseminam no século XIX. Os precursores, no início do século XX, dos estudos sobre os Gabinetes de Curiosidades - de David Murray ${ }^{276}$ e Julius Von Schlosser ${ }^{277}$ - apontam o contexto do florescimento do museu moderno: o renascimento e a curiosidade pelas coisas do mundo. Os Gabinetes, assim como as posteriores Exposições Universais, pretendiam ser um microcosmo ou resumo do mundo dentro de um ambiente. Almejava-se entender o mundo por meio de sua materialidade, da natureza. Desse modo, no Renascimento põe-se a questão: Como a natureza funciona?

Para atender a essa curiosidade, os Gabinetes - conjunto de fenômenos visíveis do mundo - se constituíam em um universo material e simbólico; em coleções reunidas por homens curiosos (os Colecionadores eram, via de regra, príncipes, aristocratas, literatos e artistas); em elementos materiais, chaves do mistério da criação divina e base para a criação humana. As conformações e sentidos das coleções; a tipologia e sentidos dos objetos de coleções conduzem a uma categoria central para a História Natural e, por conseguinte, para a organização dos museus escolares de História Natural - a classificação.

O intuito de classificar permite que se entendam as coisas pela observação das mesmas. Por isso, o Museu do século XIX consiste em uma série de coisas materiais organizadas em conjunto para serem compreensíveis. Classificar é conhecer. Dar nomenclatura, visibilidade. O museu, no fim do século XIX, é sinônimo de ciência, de modernização. Os museus representam um investimento na valorização das ciências

\footnotetext{
274 BARBUY,1999.

275 Anotações de aula da disciplina História cultural do museu moderno, dos gabinetes de curiosidades ao século XIX, ministrada pela profa. Dra. Heloisa Barbuy, no primeiro semestre de 2010, na Faculdade de Filosofia, Ciências e Letras (Prédio da História) e no Museu Paulista.

276 MURRAY, David. Museums, their history and their use. London: Routledge: Thoemmes Press, 1996 ( 1 a edição Glasgow: James Maclehose and Sons, 1904).

277 Schlosser, Julius Von. Las camaras artísticas y maravillosas del renacimiento tardio: uma contribución a La historia Del coleccionismo. 2ed esp. Trad. espanhola por José Luis Pascual Arranz. Madrid: Akal, 1998 (1 ${ }^{a}$ edição Leipzig: Klinkhardt und Biermann, 1908).
} 
naturais. É, portanto, um lugar de instrução, com função pública, ensino científico e vulgarização científica. Integrados ao sistema de ensino, os museus escolares constituíam um equipamento essencial ao ensino moderno (observação/lição de coisas).

No período que mais interessa à minha pesquisa, final do século XIX, foi de fundamental importância o estudo das Exposições Universais para a compreensão da cultura material no contexto da sociedade industrial Oitocentista. A intrínseca relação do homem com a materialidade revela-se, com grande expressividade, não somente nos Gabinetes de Curiosidades e nos museus, mas também nas Exposições Universais. Nessas últimas, um conjunto de material e mobiliário escolar, dentre eles, as carteiras escolares aparecem em abundância como exemplos do progresso científico, técnico e material no campo da educação. Nesse momento, os modelos apresentados nas Exposições são aqueles que deveriam figurar nas escolas e países que pretendessem estar em dia com o progresso, também no campo da instrução.

Quanto à ideia de progresso, vale destacar a obra Artilugio de la Nación Moderna: México en las exposiciones universales (1880-1930), de Mauricio Tenório Trillo. Ainda que seja examinada a presença do México nas Exposições Universais com o objetivo de avaliar como tal presença sinaliza o conceito em formação de uma nação moderna; ainda que não trate do caso específico da participação do Brasil, o livro é representativo ao mostrar o impulso dos países em direção à modernidade. A corrida em direção à modernidade é evidenciada pelo autor quando ele expõe verdades universais da segunda metade do século XIX e início do XX, que atravessam também as exposições: a) a liberdade (veneração do livre comércio); b) o progresso (fundamentado na ciência e na indústria); c) o nacionalismo (ostentação de uma pretensa superioridade racial e cultural, o nacionalismo se tornou um requisito quase ontológico da modernidade).

$\mathrm{Na}$ análise dos deslocamentos entre o local (São Paulo) e o global ${ }^{278}$ (países com os quais São Paulo mantém vínculos econômicos ou educacionais), os três elementos citados podem ser categorias chaves. A liberdade permite avaliar o modo como se deram as trocas comerciais de objetos e materiais escolares entre os países. A ideia de progresso está imbuída na própria adoção de novos objetos e móveis escolares que favoreçam uma aprendizagem e um ensino mais científico. É nesse espaço que se insere a indústria visando o fornecimento de tais materiais. O nacionalismo, por sua vez, é

\footnotetext{
${ }^{278}$ CANCLINI, Nestor. Introdução à edição de 2001. As culturas híbridas em tempos de globalização.
} Culturas híbridas. São Paulo: EDUSP, 2003, p. XVII-XL. 
perseguido, dentre outros meios, pelo investimento na educação como forma de superação das deficiências do país, do Estado ou da cidade. Também com esse objetivo, não somente o México, mas outros países compareciam às Exposições Universais.

Considerando que as Exposições eram representações universais do que se concebia como progresso e modernidade, são tomadas como espaços privilegiados para examinar o modo pelo qual a modernidade produziu uma imagem de si mesma. Se, para países como a França, as Exposições eram espaços em que poderiam comparecer como o árbitro da cultura e da política no fim do século XIX; para países como o México e Brasil, tal participação pode ser entendida como uma estratégia de consolidação política e econômica, constituindo um grupo de especialistas em Exposições Universais, apto para construir uma imagem moderna para o país. Nesse sentido, participar das exposições era uma das melhores maneiras de mudar a tão difundida impressão de um país violento e incivilizado. Além disso, refletia também a esperança de encontrar uma saída para suas matérias-primas na moderna economia mundial ${ }^{279}$.

Outra observação de Trillo, importante para esta pesquisa, é o papel da ciência. O autor vai mostrando como as grandes Exposições, antes de tudo, versavam sobre ciência. Daí a tendência ocidental de enumerar todo conhecimento em formato científico. Ele examina as exposições científicas do México nas feiras universais para analisar o manejo mexicano da linguagem da ciência em suas diferentes formas. A estatística se converteu na tecnologia do poder e no fundamento da política científica no final do XIX. As cifras davam o conhecimento de noções concretas da sociedade e do Estado. Assim, para governar uma nação moderna de forma científica, a estatística era fundamental. Para ele, a Exposição de Paris 1889 foi uma festa de cifras.

No final do XIX, o desenvolvimento das ciências químicas, biológicas e médicas reforçavam o estudo da natureza dentro de um paradigma evolucionista. Cada exibição incluía suas estatísticas: higiene, criminologia, produção agrícola, industrial, antropologia, economia social, geografia, salubridade, educação. O objetivo principal dos dados, no caso mexicano, era atrair investimento estrangeiro e a imigração criando a imagem de uma promissora nação moderna. Uma nação moderna, dentre outras ações,

\footnotetext{
${ }^{279}$ TRILLO, Mauricio Tenório. Artilugio de la Nación Moderna: México en las exposiciones universales (1880-1930). México: Editorial Fondo de Cultura Económica, 1998.
} 
deveria investir em educação adquirindo materiais e mobiliário que fossem, cientificamente, recomendados.

Pensar o mobiliário escolar nas Exposições ajuda a entender a escolaridade obrigatória, a partir de uma história econômica da escola, e, ilumina aspectos relevantes da constituição da escola pública paulista. O final do século XIX e as Exposições deste período (importante expressão da sociedade industrial) traziam uma ordem universal articulada pelo comércio, pela tecnologia e pela mercadoria.

Por isso, é importante indagar: Quais empresas comercializavam carteiras escolares? Que tecnologias e materiais empregavam em suas mercadorias? Que argumentos eram usados pelos industriais para conquistas os diferentes Estados e suas respectivas escolas como mercado consumidor?

\subsection{A carteira escolar nas Exposições Universais do século XIX}

As Exposições Universais do século XIX foram o lugar, por excelência, onde as nações apresentaram ao mundo seus progressos nas mais diversas áreas. $\mathrm{Na}$ área educacional não era diferente. Elas se constituíram em espaço privilegiado de divulgação e propaganda de novos objetos cujos fabricantes tinham como alvo a escola.

As carteiras ali expostas ganhavam o status do que havia de mais moderno e, portanto, objeto de desejo de educadores e dos próprios Estados. A aquisição dos materiais e mobiliário propagados nestas grandes festas sinaliza a contribuição destes eventos na constituição da escola paulista.

A primeira Exposição Universal ocorreu em Londres no ano de 1851. No entanto, de acordo com Moysés Kuhlmann Júnior foi na terceira Exposição, a de 1862, também em Londres, que a educação "ganhou espaço para figurar ao lado da exibição da produção industrial e artística e da demonstração de novidades tecnológicas" ${ }^{\text {"280 }}$. Mas, dentro do sub-tema da educação, quando o mobiliário escolar passaria a ter destaque? Quem eram os expositores de destaque? Quais os modelos de carteira e suas respectivas propostas?

\footnotetext{
${ }^{280}$ KUHLMANN JÚNIOR, 2001, p.9.
} 
Peyranne aponta a relevância de duas exposições para a questão do mobiliário escolar. A de 1867, em Paris; e, a de 1873 em Viena. O Brasil participou das duas ${ }^{281}$, sendo que o tema desta última foi "Cultura e educação". Participação de destaque nos grupos sobre educação teve Ferdinand Buisson, diretor do ensino primário francês. Em seu Dictionnaire de Pédagogie et d'instruction primaire ${ }^{282}$, no verbete "Mobiliário Escolar”, o autor salienta que há muito tempo se reconhece na França a necessidade de estabelecer um mobiliário escolar em condições que as crianças pudessem ler e escrever, preservando-os de atitudes viciosas. Segundo Buisson,

Quase todos os móveis são inadequados e em estado deplorável. Há apenas uma cadeira para o professor, alguma mesa ruim sem encosto, nem tinteiros e bancos e bancos ao longo das paredes para as crianças que não podem ter mesas. Vemos escolas suntuosas com um mobiliário miserável. As carteiras são disjuntas, ou muito altas para os pequenos ou muito baixas para os grandes ${ }^{283}$.

Para o inspector geral do ensino primário, a questão não foi realmente posta na França até a Exposição Universal de 1867. Isso porque em outros países, como nos Estados Unidos,

em 1854, a obra de Henry Barnard tinha chamado a atenção para a importância da boa mobília escolar; na Alemanha, por volta de 1858, o Dr. Schreber; finalmente, de 1863 a 1865, o Dr. Fahrner para Zurique e o Dr. Guillaume em Neuchâtel, fizeram uma reforma nas carteiras indicando os danos à saúde dos alunos ${ }^{284}$.

Ainda segundo Peyranne, depois desse período, "toda uma cultura nasce em torno da carteira" "285. Na Exposição de 1867, "uma sala é reservada ao espaço escolar. Modelos de carteira inteiramente novos são apresentados",286. Na ocasião, "a grande

\footnotetext{
281 A participação do Brasil é mencionada por SCHOROEDER-GUDEHUS, Brigitte; RASMUSSEN, Anne. Les fastes Du progrès: guide dês expositions universaelles, 1851-1992. Paris: Flammarion, 1992, p. 78 e 86.

${ }^{282}$ BUISSON, F. Dictionnaire de Pédagogie et d'instruction primaire. Paris: Librairie Hachette et Cie. 1888, Parte I, Tomo II.p.1940-1949.

${ }^{283}$ BUISSON, 1888, p.1941 - Presque partout le mobilier est insuffisant et dans un état déplorable. Il consiste uniquement dans une chaise pour le maître, quelques mauvaises tables sans casier, ni encriers et des bancs le long des murs pour les enfants qui ne peuvent tenir aux tables. On voit des écoles somptueuses avec un mobilier miserable. Les tables sont disjointes, ou trop hautes pour les petits ou trop basses pour les grands

284 BUISSON, 1888, p.1941 - dès 1854, l'ouvrage de Henry Barnard avait appelé l'attention sur l'importance d'un bon mobilier scolarie; en Allemagne, vers 1858, le Dr. Schreber, enfin, de 1863 à 1865 , le D' Fahrner à Zurich et le Dr. Guillaume à Neuchâtel, avaient provoque une réforme des bancs-tables en signalant le tort causé à la santé des élèves.

${ }^{285}$ PEYRANNE, 2001, p.132 - "Toute une culture naît autour de la table-banc".

${ }^{286}$ Idem, ibidem - "une salle est réservée à l'espace scolaire. Des modeles de table-banc tout à fait nouveaux sont presentes".
} 
superioridade dos modelos americanos é reconhecida" ${ }^{287}$. Tomando como fonte o relato de visita feito por C. Defodon, para quem os modelos mais marcantes provieram da América, Peyranne afirma que o destaque foi a mesa-banco americana de Illinois.

O modelo americano apresentado em Paris é de um lugar, descrevemos um banco sólido e confortável, cada carteira é fixada sobre um sólido suporte de ferro [...] uma das novidades é no banco, ele se eleva de maneira a deixar cada criança tomar seu lugar mais facilmente. Os suportes, munidos de um sistema de cremalheira, permitem ajustar a altura da mesa ao tamanho das crianças, é a primeira carteira de altura variável ${ }^{288}$.

Figura 14 - Mesa-banco americano (Illinois) 1867

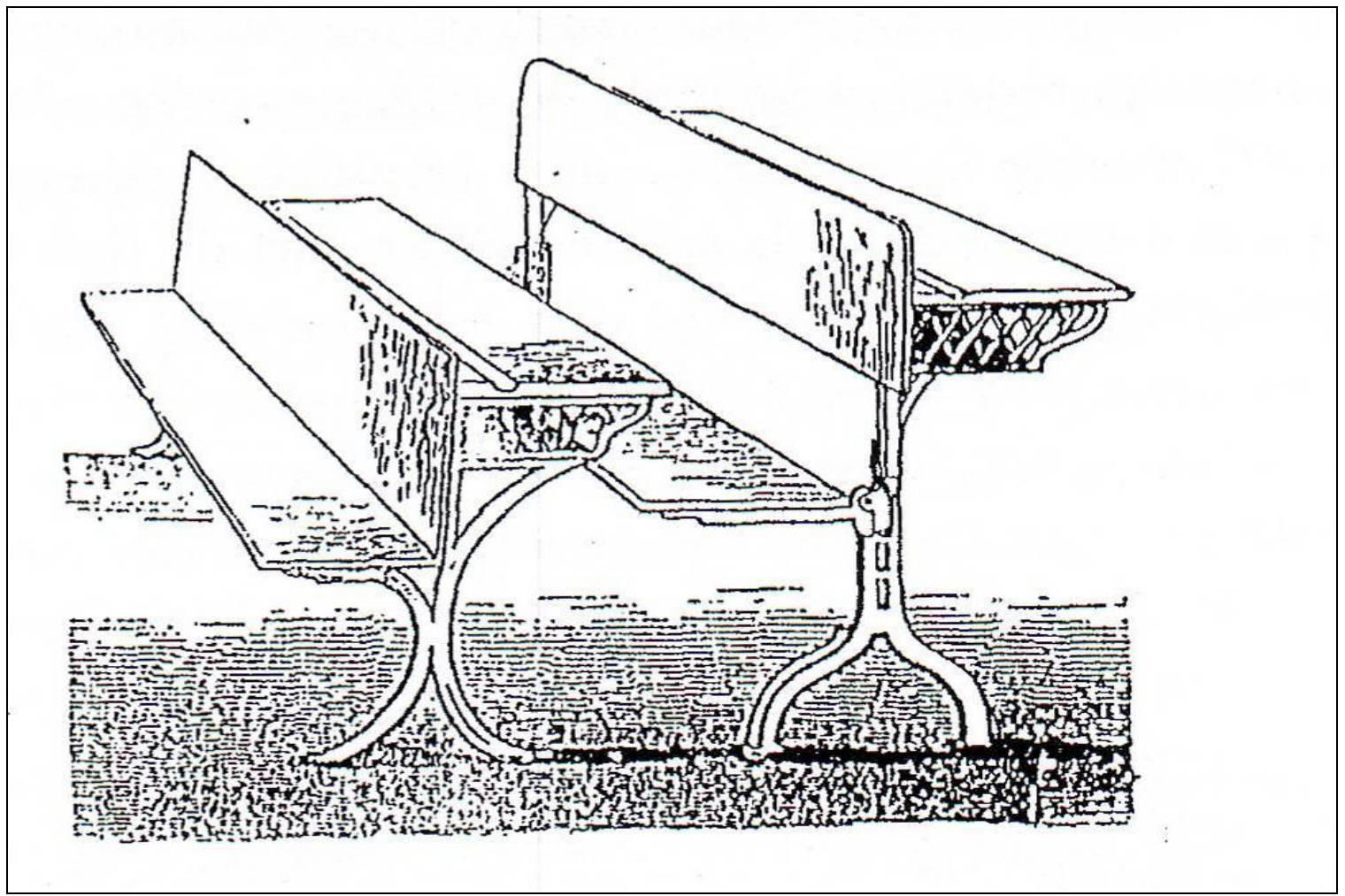

Fonte: Riant, 1874, p.124; Peyranne, 2001, p.133

Outro modelo destacado foi o norueguês, pois diante da mesa, um triângulo se eleva e serve de porta livros. Porém, foi considerado inadaptável na França devido ao alto custo de sua construção.

\footnotetext{
287 "La grande supériorité des modeles américains est reconnue" (Idem, ibidem).

${ }^{288}$ Idem, ibidem - "Le modèle américain presente à Paris est à une place, on lui décrit um banc solid et commode, chaque table est fixée sur de solides supports en fer [...] une des nouveautés est dans le banc, Il se releve de façon à laisser chaque enfant prendre place plus aisément. Les supports, munis d'uns système à crémaillère, permettent d'adapter la hauteur de la table à la taille des enfants, c'est la première tablebanc à hauteur variable".
} 
Figura 15 - Carteira e banco de aluno em uma escola sueca - 1867

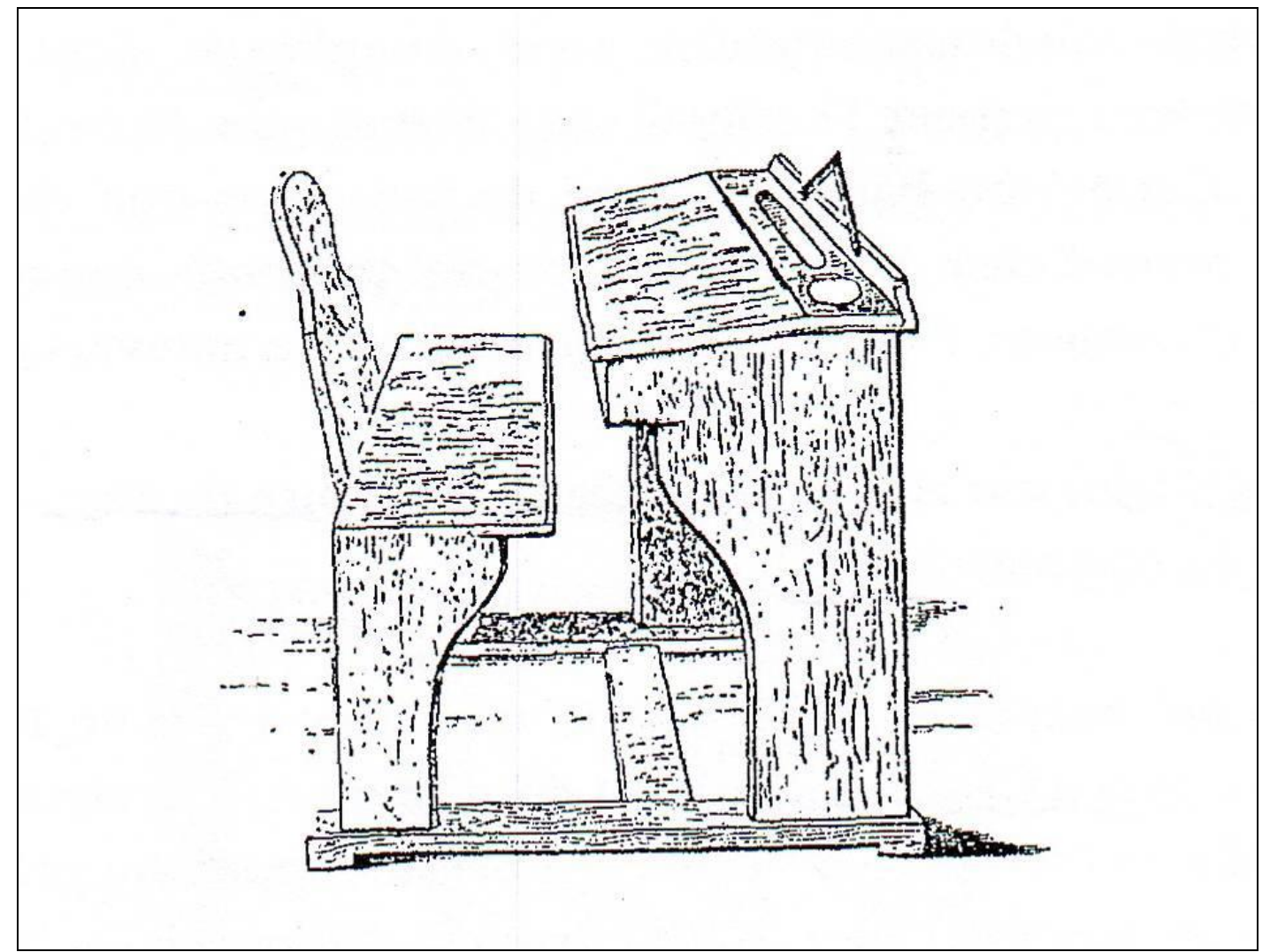

Fonte: Riant, 1874, p.132; Peyranne, 2001, p.133

A Inglaterra apresentou o modelo Windsor, considerado funcional - uma mesa de quatro lugares com um longo banco que faz corpo com a mesa no meio de um pé de ferro. 
Figura 16 - Carteira Windsor, 1867

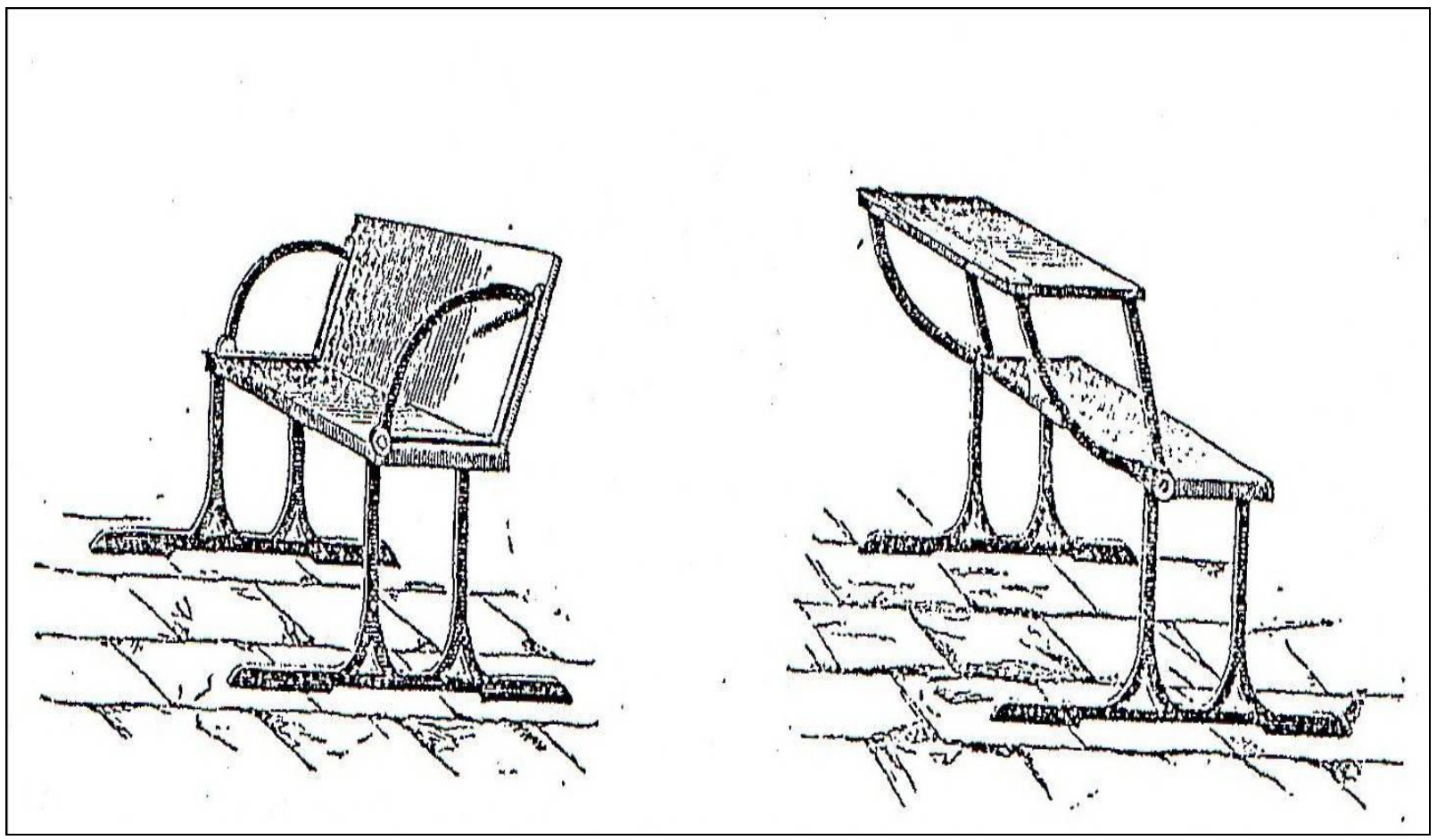

Fonte: Riant, 1874, p.128; Peyranne, 2001, p.134

Peyranne situa aí o nascimento de um novo comércio, quando os modelos americanos são comprados, depois do fim da Exposição, pela Hachette et Cie. Outra mudança ocorreu em "12 de dezembro de 1871, uma loja de material escolar é criada por uma proposta de Octave Gréard"289, diretor de ensino primário em Paris. "A precariedade do espaço e do mobiliário escolar torna-se uma preocupação das mais importantes no meio educacional [...] o antigo mobiliário será definitivamente repudiado em 1880 pelo regulamento de July Ferry" ${ }^{290}$.

Se em 1867 nenhuma observação foi feita sobre o mobiliário francês, em 1873, na Exposição Universal de Viena, “A França participa ativamente e apresenta suas novas carteiras" ${ }^{291}$. Em duas salas de exposição da seção francesa havia 47 espécies de bancos $^{292}$.

\footnotetext{
${ }^{289}$ PEYRANNE, op. cit. - "12 décembre 1871, um magasin scolaire est crée sur la proposition d'Octave Gréard".

${ }^{290}$ Idem, p.135 - "La précarité des locaux et du mobilier scolaire devient une préoccupation de plus em plus importante dans le milieu de l'education [...] le mobilier ancien sera définitivement répudié em 1880 par le règlement de Jules Ferry".

${ }_{291}^{29}$ Idem, ibidem.

${ }^{292}$ PEYRANNE, op. cit.
} 
Se em 1867 há o nascimento do comércio internacional do mobiliário escolar com o predomínio americano; em 1873, há o nascimento da concorrência não só quanto às propostas e conceitos de carteira escolar, mas também de mercado consumidor.

Ferdinand Buisson associa a "rivalidade que se exprime no domínio do mobiliário escolar"293 à expressiva participação da França, nesse domínio, a partir de então.

Numerosos países participaram desta exposição, a carteira se diversificou, ela pode ser fixa ou com tabuleta móvel, o assento ou ambos. A invenção e originalidade são homenageadas; cada um apresentou seu mobiliário e argumentou as vantagens de sua própria criação. A França, na escolha dos modelos expostos, afirma uma certa experiência neste domínio ${ }^{294}$.

Peyranne apresenta quatro modelos postos à venda ou testados nas escolas francesas: Primeiro, o novo modelo das escolas de Paris, concebido por O. Gréard, um mobiliário fixo, com três lugares, possuindo os assentos isolados.

${ }^{293}$ BUISSON, 1875, p.91, "rivalité qui s'exprime jusque dans le mobilier scolaire".

${ }^{294}$ PEYRANNE, op. cit. p.135 - De nombreux pays participent à cette exposition, la table-banc se diversifie, elle peut être fixe ou móbile par la tablette, l'assise ou les deux. L'invention et l'originalité sont à l'honneur; chacun présente son mobilier et argument les avantages de sa propre creation. La France, dans le choix des modèles exposés, affirme une experience certain dans ce domaine. 
Figura 17 - Novo modelo das escolas de Paris

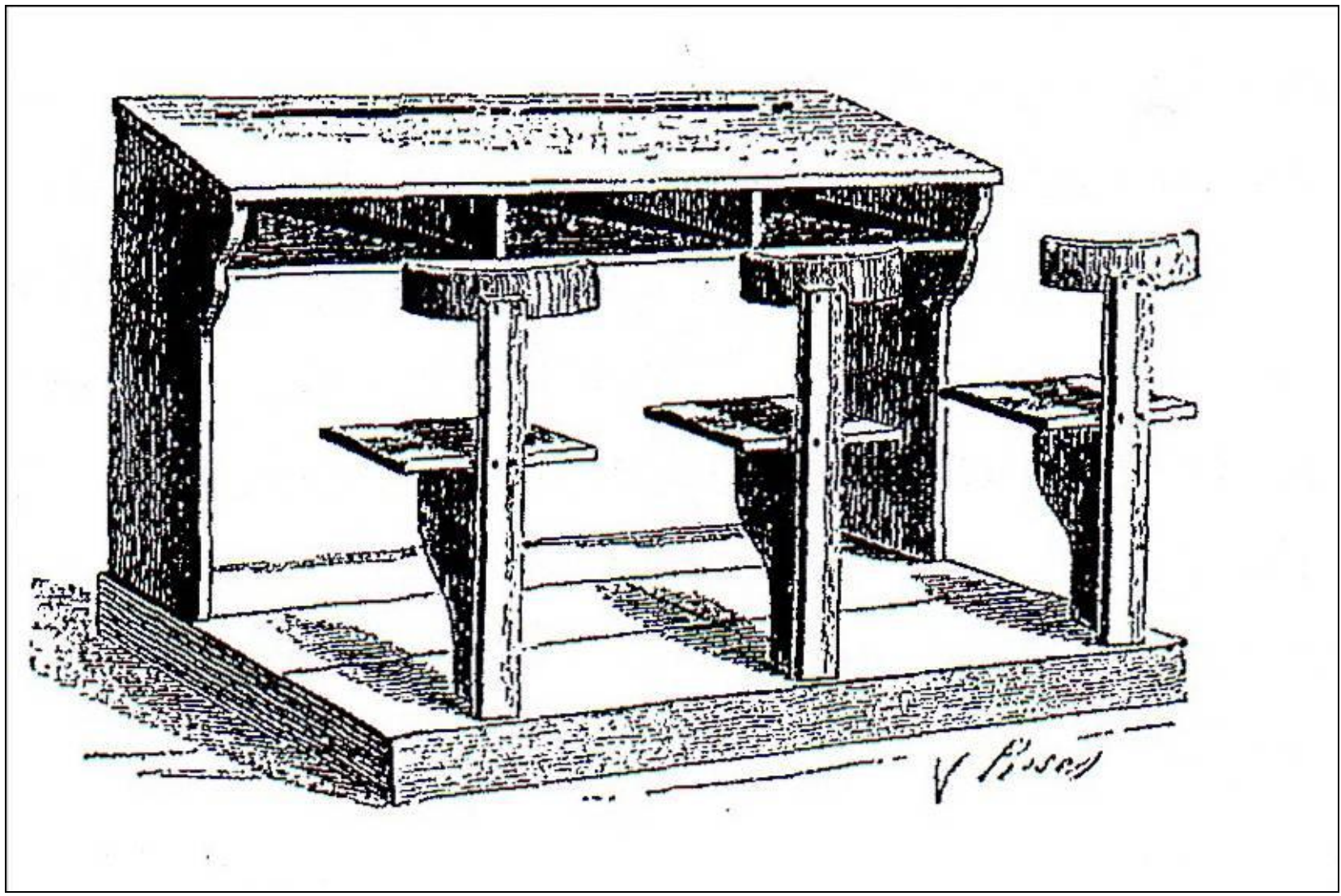

Fonte: Riant, 1874, p.164; Peyranne, 2001, p.135

O modelo mais elogiado da Exposição Universal de 1873 foi o Bapterosses, premiado com diploma de mérito ${ }^{295}$. Cardot expôs dois modelo. Uma carteira em teste na Direção de Ensino Primário de Paris ${ }^{296}$ e um móvel que servia de carteira e banco.

295 O diploma de mérito, de acordo com SCHOROEDER-GUDEHUS, Brigitte; RASMUSSEN, Anne (1992, p. 88), era semelhante às menções honrosas premiadas às exposições precedentes, recompensa certos produtos cujos méritos não são suficientes para obtenção de medalhas. Em Viena foram concedidos 10.066 diplomas de mérito.

${ }^{296}$ Imagens das carteiras Cardot e Bapterosses podem ser vistas nas páginas 129 e 130 deste trabalho. 
Figura 18 - Sistema Cardot - mobiliário de pátio com encosto móvel

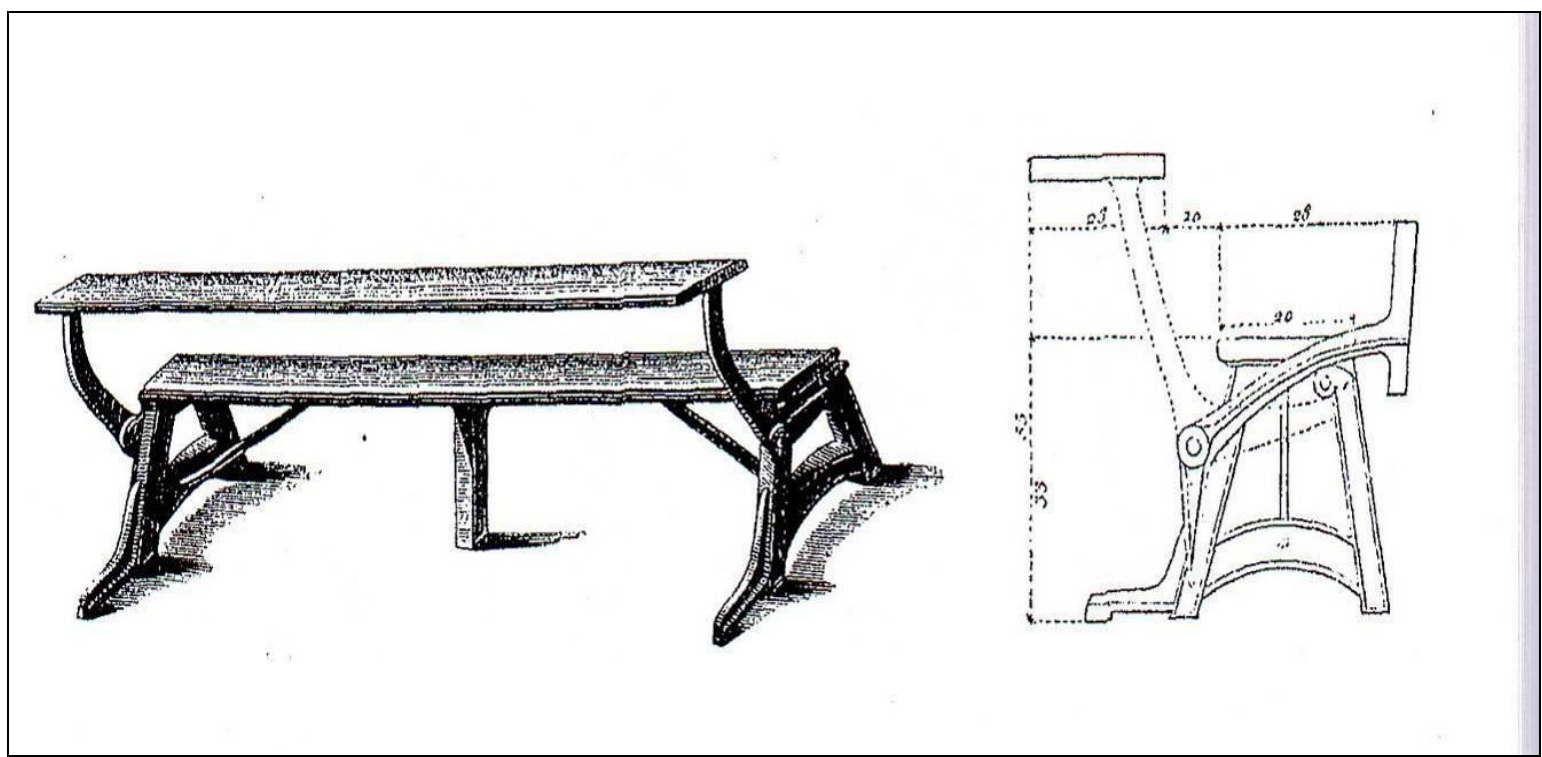

Fonte: Peyranne, 2001, p.137

Figura 19 - Sistema Cardot - banco em posição abaixada

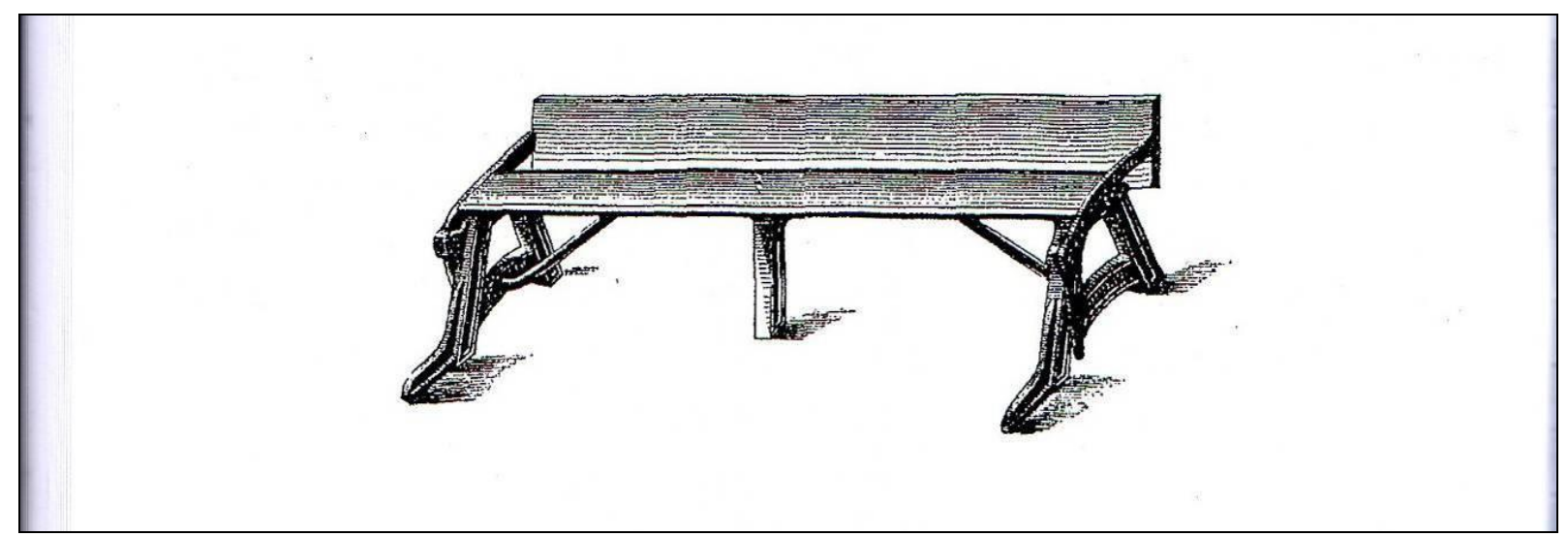

Fonte: Peyranne, 2001, p. 138

O mesmo móvel possuía duas funções: banco e carteira. "O banco, em posição abaixada serve de assento às crianças durante a recreação; em posição levantada, serve de mesa para o almoço dos escolares" ${ }^{, 297}$. As duas placas de madeiras eram ligadas por uma dobradiça que permitia a articulação do encosto.

Apesar de ser considerada como uma novidade, estas carteiras "apresentam semelhanças com o quadro de Windsor exibida em Paris em 1867"298.

\footnotetext{
${ }^{297}$ PEYRANNE, op. cit. p.137 - "Ce mobilier doit servir soit de banc, soit de table-banc. Un système de deux plateaux avec une charnière assure le pivotement du dossier. Ce banc, en position abaissée sert de siege aux enfants pendant la recreation; en position relevée, il sert de table pour le déjeuner des écoliers". ${ }^{298}$ Idem, ibidem - "presente d'étonnantes similitudes avec la table Windsor exposée à Paris en 1867".
} 
Além dos modelos franceses, Peyranne apresenta os modelos mais representativos de outros países. Os vindos dos Estados Unidos "adquiriram, à época, uma reputação inigualável pela elegância e solidez"299.

A carteira Andrew, de Chicago, possui uma base de ferro. "A mesa é integrada com o banco do aluno sentado à frente dele. Ela é munida de um tinteiro e uma gaveta fechada por uma grade" ${ }^{300}$.

Figura 20 - Da esquerda para direita, sistema Andrew e sistema Stevens

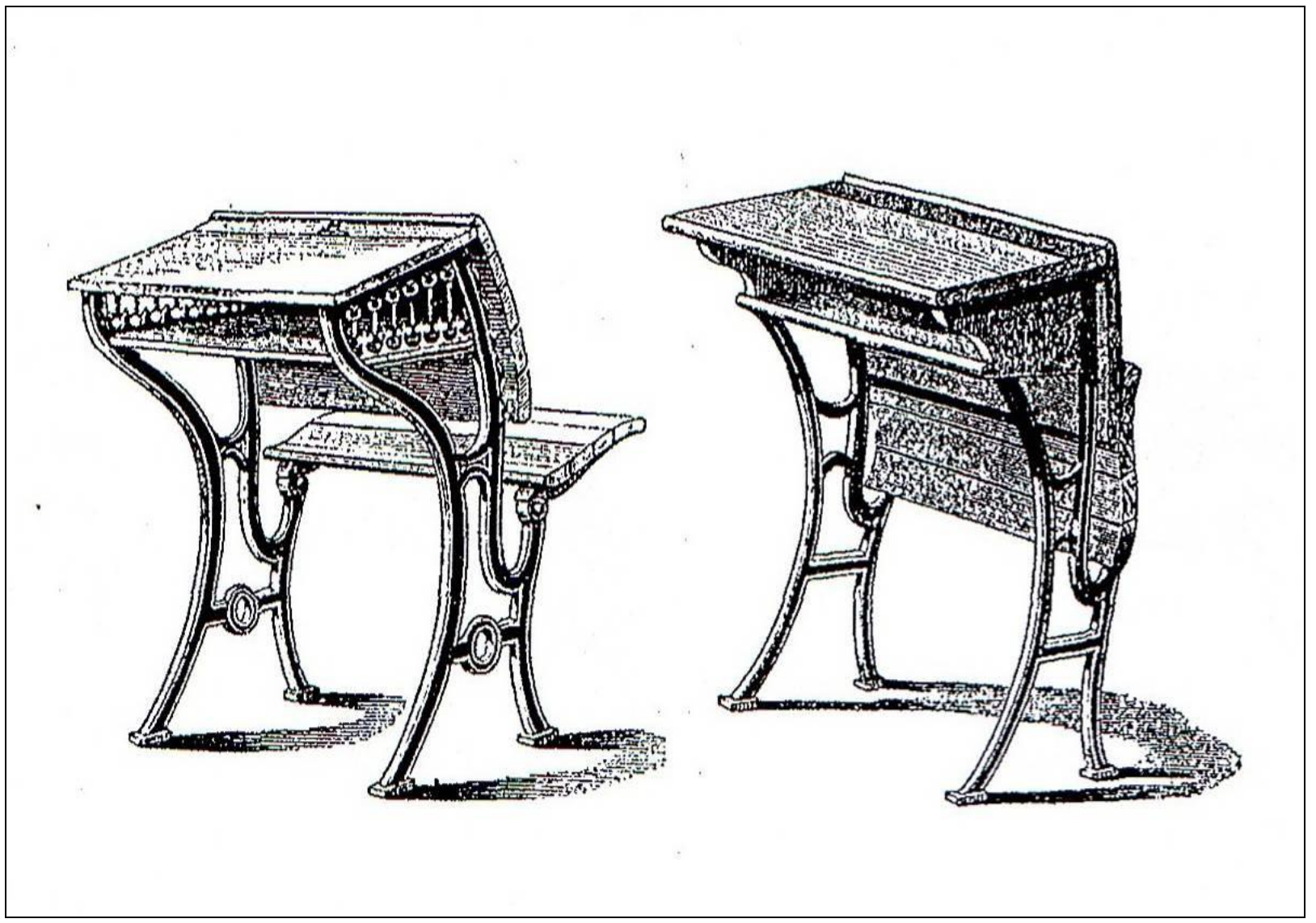

Fonte: Peyranne, 2001, p.138

Observa-se que o modelo do sistema Stevens é semelhante a do sistema Andrew. Segundo a mesma autora, os americanos ganharam duas distinções. O diploma de mérito concedido ao mobiliário da escola superior e da escola normal de Boston; e, uma medalha de mérito ${ }^{301}$, atribuída a Joseph Ross de Boston por sua coleção de carteira.

\footnotetext{
${ }^{299}$ PEYRANNE, op. cit. p.138 - “acquièrent, à l'époque, une réputation inégalée pour leur élégance et leur solidité".

${ }^{300}$ Idem, ibidem - La table fait corps avec le banc de l'éleve place devant lui. Elle est munie d'un encrier et d'un casier fermé par un grillage.

${ }^{301}$ A medalha de mérito, de acordo com SCHOROEDER-GUDEHUS, Brigitte; RASMUSSEN, Anne (1992, p. 88), recompensa a qualidade e o acabamento do trabalho, a importância da produção, a abertura
} 
Figura 21 - Carteira de Boston (Sistema Ross)

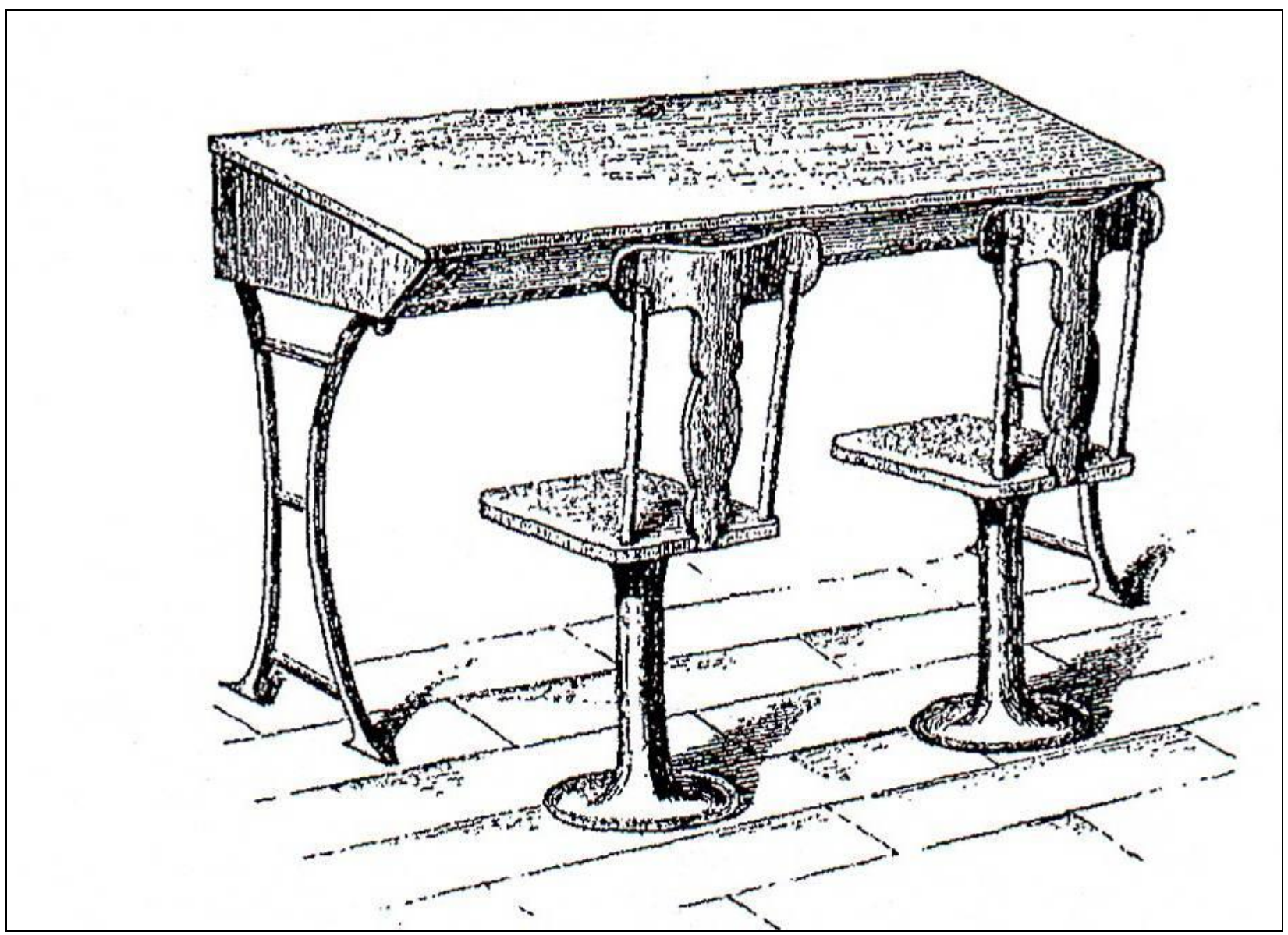

Fonte: Riant, 1874, p. 121; Peyranne, 2001, p.139

Estes modelos possuem assentos independentes equipados com encosto; eles são fixos no chão por um pé de ferro. Os franceses reconhecem a grande solidez do ferro e a originalidade destes modelos, mas consideram muita despesa para que estes mobiliários sejam adotados nas nossas escolas ${ }^{302}$.

Além do modelo premiado, no Illustrated Catalogue of Ross'Improved School, Church, and Vestry Furniture, de 1872, constam outros modelos, o material de fabricação, dimensão das carteiras, dentre outros.

de novos mercados, o emprego de ferramentas e de máquinas avançadas ou o bom preço dos produtos depois da primeira participação de seus expositores em uma exposição universal. Em Viena foram concedidas 8.687 medalhas de mérito.

302 PEYRANNE, op. cit., p.139 - Ces modeles possèdent des sièges indépendants munis d'un dossier; ils sont fixes au sol par un pied en fonte. Les français reconnaissent la grande solidité de la fonte et l'originalité de ces modeles, mais considèrant la dépense trop importante pour que ces mobiliers soient adoptés dans nos écoles". 
As manufaturas são do próprio Joseph L. Ross que tem sua sede em Boston, Mass. Na abertura do Catálogo o proprietário se dirige aos oficiais da escola, professores e educadores explicando que "sempre foi seu objetivo melhorar o mobiliário, - não em detrimento de uma qualidade barata; e ele agora acredita que, em seus móveis a perfeição está muito próxima de ser atingida"303. Resistência, durabilidade e adequação à idade e à estrutura do escolar são, segundo Ross, as grandes características desses móveis, combinado com um estilo de acabamento que não pode ser ultrapassado. A força e durabilidade são atribuídas à combinação da madeira com o ferro, utilização de operários experientes, máquinas engenhosas e o melhor material.

O "designer e manufacturer" de mobiliário escolar ainda informa que a maioria dos moveis foi desenhada por ele mesmo desde 1847. Isso atesta a durabilidade do trabalho, já que "as escolas que adquiriram o mobiliário naquele ano ainda o têm em uso, com eficiência intacta" ${ }^{\text {,04 }}$. Por isso, os móveis Ross são propagados no Catálogo como os mais baratos do mercado, quando se conjugavam o preço, a qualidade e estilo de acabamento. Outro atrativo é acrescido para aqueles que pretendiam fazer encomendas à distância, a manutenção do preço.

Após as informações de caráter propagandístico, são dadas as instruções de como fazer a encomenda do mobiliário escolar: 1) Devem ser indicadas a altura das mesas e cadeiras e também a quantidade necessária de cada altura, conforme o catálogo. 2) Apesar da existência de estoque, é necessário fazer a solicitação com certo prazo, pois as encomendas são crescentes. 3) Os preços indicados incluem todos os parafusos necessários para as mesas e cadeiras dos alunos. 4) Os tinteiros para as carteiras dos alunos têm preço adicional. 5) No preço é considerado o tipo de madeira utilizado cerejeira ou carvalho, envernizada ou oleada no grão de madeira. 6) O encaixotamento terá preço extra.

Os catálogos, via de regra, traziam figuras de planos de disposição das carteiras na sala de aula.

Outra importante empresa americana, "The National School Furniture C", propôs um modelo de carteira móvel, com pé de ferro e lugar individual. "A mesa é

\footnotetext{
${ }^{303}$ ROSS, Joseph L. Illustrated Catalogue of Ross'Improved School, Church, and Vestry Furniture. Boston: HOLLIS \& GUNN, BOOK AND JOB PRINTERS, 1872 - "It has always been his aim to improve his Furniture,- - not to sacrifice quality to cheapness; and he now believes that, in his Furniture, perfection is very nearly attained" (ROSS, J. L. 1872, p.5).

${ }^{304}$ Idem, ibidem.
} 
integrada com o banco do aluno assento à frente, ela dobra-se na parte de trás do assento dianteiro" ${ }^{, 305}$.

Figura 22 - Carteira da "The National School Furniture C", de Nova York.

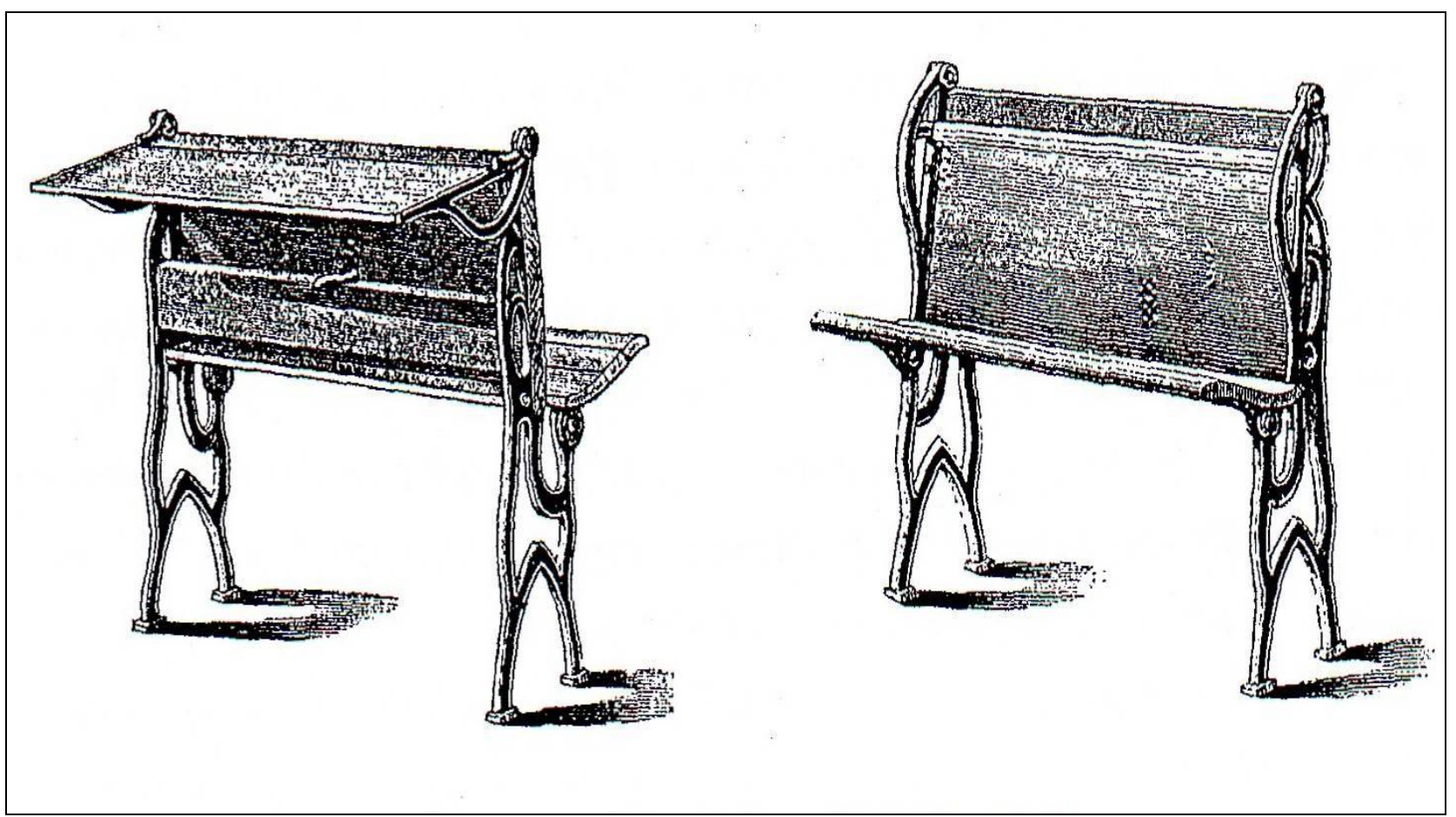

Fonte: Fonte: Peyranne, 2001, p.139

A empresa desenvolvia suas atividades tanto em Nova York, quanto em Chicago, conforme o Ilustrated Catalogue of New and Improved Styles of School and Church Furniture. O Catálogo que data de 1872, portanto, um ano antes da exposição de Viena, acrescenta informações importantes sobre o modelo exposto em Viena e outros.

Todas as carteiras tinham o novo assento dobrável, patenteado em 20 de fevereiro de 1872. Não fugindo ao costume do comércio, o conjunto do mobiliário escolar é apresentado como o melhor do mercado. O modelo apresentado em Viena, The Peard Desk and Settee Combined é descrito como "o mais aprovado estilo de Mobiliário Escolar no Mercado"306.

\footnotetext{
305 "La table fait corps avec le banc de l'élève placé devant lui, elle se rabat sur le dossier de la place de devant" (PEYRANNE, 2001, p.139).

306 "the most approved style of School Furniture in the market" (Ilustrated Catalogue of New and Improved Styles of School and Church Furniture, p.5).
} 
Figura 23 - The Peard Desk and Settee Combined

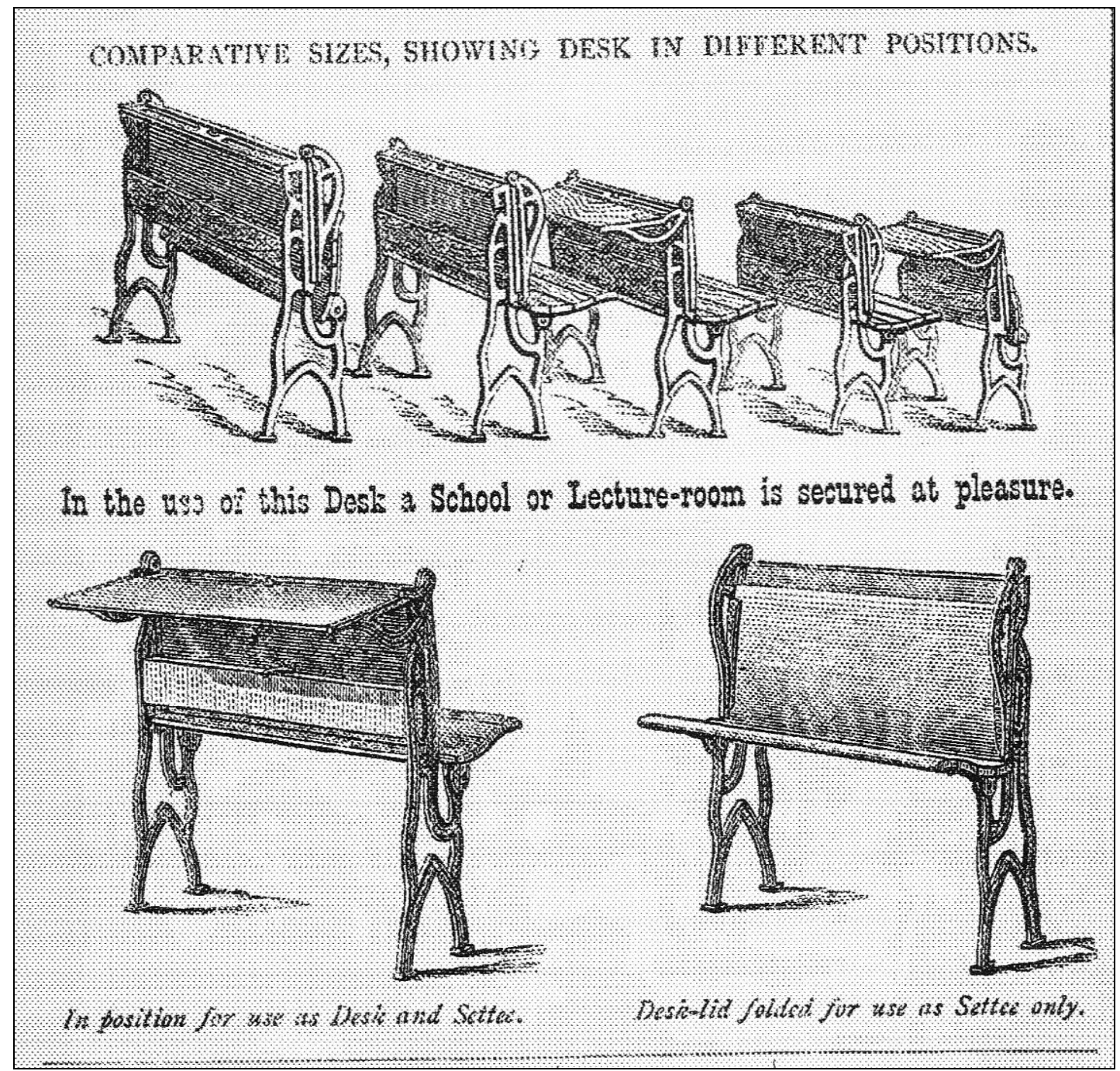

Fonte: The National School Furniture $\mathrm{C}^{\mathrm{o}}, 1872$, p.5

No texto de introdução do catálogo é manifesta a intenção de fabricar mobiliário para todo o país e também para os clientes ocidentais. Por isso, foi estabelecida uma fábrica em Chicago, com venda na loja A.S. Barnes \& $\mathrm{C}^{\mathrm{o}}$. O titular das patentes das carteiras dobráveis era John Peard, supervisor direto do Departamento de produção. Conforto e elegância são as características atribuídas às carteiras da The National School Furniture $C^{o}$. Semelhante a Ross, informa que os pedidos devem ser feito com antecedência devido à grande demanda por parte de escolas e igrejas ${ }^{307}$.

\footnotetext{
${ }^{307}$ Não encontrei nenhum catálogo francês cujo industrial fabricasse móveis para escolas e igrejas. No caso americano, há um número considerável. Há anúncio de móvies para igreja nos seguintes catálogos: 1) ROSS, Joseph L. Illustrated Catalogue of Ross'Improved School, Church, and Vestry Furniture. Boston: HOLLIS \& GUNN, BOOK AND JOB PRINTERS, 1872. 2) The National School Furniture $C^{\circ}$. Illustrated Catalogue of New and Improved Styles of School and Church Furniture. New York/Chicago, 1872. 3) BROOKE, J. C. Church School \& Hall Furniture. Cincinnatio, 1884. 4) WILLIAM O. HASKELL \& SON. Illustrated Catalogue of the Boston School Furniture. Boston, 1872.
} 
A quantidade de expositores de cada país que comparecia às Exposições permite concluir que o mercado do mobiliário escolar, nas últimas décadas do século XIX, não era desprezível. Da oferta deste objeto dependia a expansão da escola de massa; e, para atender às demandas, cada fábrica e empresa deveria ser eficiente na propaganda dos seus produtos.

The National School Furniture $C^{o}$, por exemplo, relacionou em seu catálago nove vantagens de suas carteiras sobre todas as outras no mercado. Essas razões são indicativas tanto do que a indústria do mobiliário podia oferecer, quanto do que a escola e os educadores almejavam encontrar na carteira escolar. Por isso, apesar da vasta lista, é elucidativo apresentá-la:

$\mathbf{1}^{\mathbf{0}}$. Ela economiza espaço. Não há carteira que feche tão compacta- e comodamente, ocupando, quando dobrada, apenas nove polegadas de espaço e que garanta vias de passagem entre as mesas de dois pés e meio. Quando dobrada como Settee a capacidade do assento é um terço maior que a dos estilos comuns.

$\mathbf{2}^{\mathbf{0}}$. Limpeza, uma das considerações mais importantes na sala de aula, é obtida com dificuldade onde a mesa fixa é usada, mas com a Carteira Peard é uma questão de perfeita facilidade garantir uma sala arrumada e limpa; varrer não é mais difícil do que em um salão aberto. $3^{\text {o }}$. A prateleira de livro está sempre acessível - uma vantagem não encontrada em nenhuma outra carteira dobrável.

$4^{\mathbf{0}}$. A dobra da mesa aumenta muito sua durabilidade porque está fora do alcance de danos.

$\mathbf{5}^{\mathbf{0}}$. Elas são construídas com referência especial para o conforto e a saúde do aluno e o assento e o encosto são assim moldados para garantir facilidade ao educando que, inconscientemente, é obrigado a assumir uma posição ereta e saudável.

$\mathbf{6}^{\mathbf{0}}$. A dobradiça do assento (nossa patente) é silenciosa e é construída de forma a ser facilmente apertada quando, através do uso longo e contínuo, o assento fica solto e frouxo no cilindro. Assim, um conjunto perfeitamente silencioso é garantido enquanto o mobiliário está em uso. É absolutamente a única dobradiça no mercado que é silenciosa, e continuará a ser assim.

$7^{\mathbf{0}}$. A escola pode com prazer ser transformada em uma espaçosa, confortável e elegante sala para palestras e reuniões com propósitos para adultos. Em muitas localidades essa é uma das mais importantes características, pois, assim, a Câmara Municipal e a sala de aula são produzidas como resultado de um esforço. Professores de escolas seriadas também vão apreciar essa vantagem, na qual salas de assembleia são necessárias em cada departamento.

$\mathbf{8}^{\mathbf{o}}$. Elas são feitas da melhor madeira seca em estufa, com acabamento elegante; são perfeitamente simples na construção; nenhum mecanismo, como em qualquer outro estilo de carteira dobrável. 
9. Quando comprar partes das carteiras desejando-as prontas para aparafusar no chão, economizará mais da metade da despesa de frete, levando os Móveis Peard ${ }^{308}$.

Foram destacadas as vantagens não somente das carteiras, mas das peças fundidas:

Note estas peças fundidas nas seguintes indicações:

$\mathbf{1}^{\mathbf{0}}$. As peças fundidas são de peso extra (sendo 25 por cento mais pesadas do que as de qualquer outra carteira) e são largas para assegurar a maior força possível.

$\mathbf{2}^{\mathbf{2}}$. Os pés sobre os quais as peças fundidas repousam no chão são muito grandes e irão, se desejado, admitir quatro parafusos em cada um, garantindo estabilidade perfeita para a carteira.

$3^{\text {}}$. Chamamos especial atenção a nossa Patente de Assento Conjunto (patenteado em 20 de fevereiro de 1872), o qual, por meio de uma aplicação de pastilhas, é totalmente livre de ruído e é, sem exceção, a mais forte dobradiça no mercado. Ela nunca se tornará ruidosa e é o único assento dobrável sobre o qual isso pode ser dito.

$4^{\text {'}}$. Observe a curva bonita do braço do assento, que alcançamos através do número de lâminas utilizadas.

$5^{\circ}$. Observe o que uma forma compacta da carteira pressupõe quando o braço do assento e o tampo da mesa são dobráveis. Não existem saliências de ferro perigosas deixadas expostas, como é o caso de todas as outras carteiras dobráveis, e o espaço ocupado é apenas de metade de qualquer outro estilo. As vantagens deste mobiliário não podem deixar de ser evidentes para todos os diretores de escola. Não pode-se também exaltá-la muito em sua apreciação. ${ }^{309}$.

\footnotetext{
308 1st. It economizes room. There is no desk that closes as compactly and conveniently, occupying as it does when folded only nine inches of space, and securing passage-ways between the desks of two-and-ahalf feet. When folded as Settee the seating capacity is one-third greater than that of the common styles.

2d. Cleanliness, a most important consideration in the school-room, is attained with difficulty where the stationary desk is used, but with the PEARD DESK it is a matter of perfect ease to secure a neat and clean room, for sweeping is no more difficult than in an open hall.
}

3d. The Book-rack is always accessible - an advantage found in no other folding-desk.

4th. The folding of the desk adds greatly to its durability for it is out of the way of damage.

5th. They are constructed with special reference to the comfort and health of the Pupil, and the seat and back are so shaped as to secure ease to the scholar, who unconsciously is compelled to assume an erect and healthful position.

6th. The seat-hinge (our patent) is noiseless, and is so constructed as to be easily tightened when through long-continued use the seat works too readily or loosely in the socket. Thus a perfectly noiseless joint is secured as long as the furniture is in use. It is absolutely the only hinge in the market that is noiseless, and will continue to be so.

7th. The School can at pleasure be transformed into a roomy, comfortable, and elegant hall for Lecture and Assembly room purposes for Adults. In many localities this is a most important feature, for thus Town Hall and School-room are produced as the result of one outlay. Teachers of graded schools will also fully appreciate this advantage where assembly rooms are necessary in each department.

8th. They are made of the best kiln-dried lumber, elegant in finish, and are perfectly simple in construction, no machinery about them, as in every other style of folding-desk.

9th. When parties purchasing desks desire them shipped ready to screw to the floor, they will save more than half the expense of freight by taking the Peard Furniture (Ilustrated Catalogue of New and Improved Styles of School and Church Furniture, p.6).

${ }^{309}$ Notice these castings in the following particulars:

1st. The castings are of extra weight (being 25 per cent, heavier than those of any other desk), and are so flanged as to secure the greatest possible strength. 
Segundo a Companhia, a Gem Desk combina conforto, elegância e durabilidade, sendo a mais perfeita do mercado.

Figura 24 - The Gem Desk

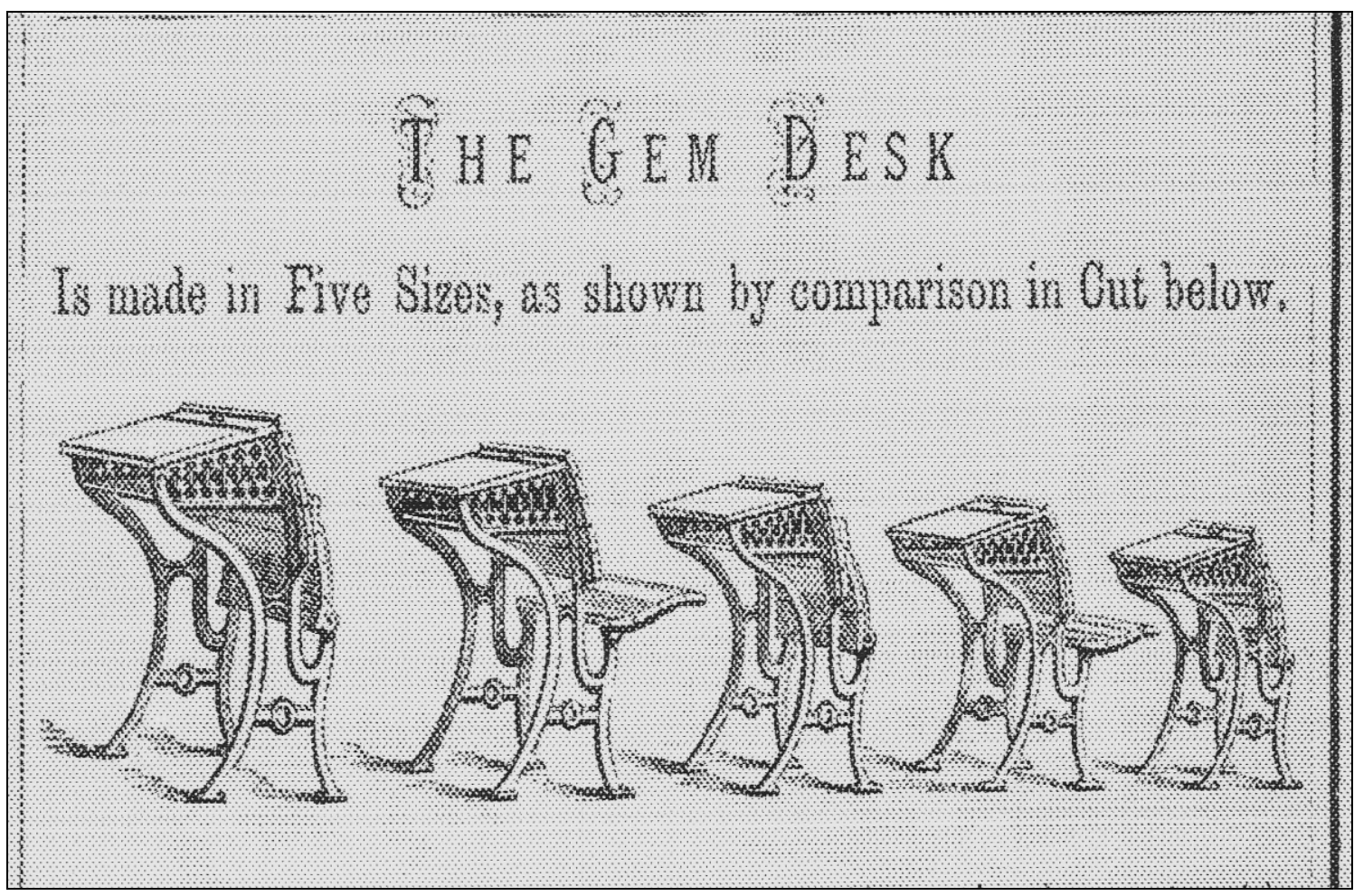

Fonte: The National School Furniture $\mathrm{C}^{\mathrm{o}}, 1872$, p.10

Na descrição da "The Study Desk" a preocupação é menos com a elegância e mais quanto às questões higiênicas:

Como vamos evitar que nossos alunos, inclinando-se sobre seus livros enquanto envolvidos no estudo, evitem a encurvadura dos ombros e a compressão do peito? É um problema que há muito confunde o cérebro de cada educador que tem levado o bem-estar físico dos seus alunos em consideração, mas que finalmente está completamente resolvido com a produção da "The Study Desk", como mostrado nos cortes que acompanha.

2d. The feet upon which the castings rest upon the floor are very large, and will, if desired, admit of four screws in each foot, insuring perfect stability to the desk.

3d. We invite special attention to our Patent Seat-Joint (patented Feb. 20, 1872), which by an application of pads is entirely free from noise, and is, without exception, the strongest hinge in the market. It will never become noisy, and is the only seat-hinge of which this can be said.

$4^{\text {th }}$. Note the beautiful curve of the seat-arm, which we attain through the number of slats used.

$5^{\text {th }}$. Observe what a compact form the desk assumes when both seat-arm and desk-lid are folded. There are no dangerous iron projections left exposed, as is the case with every other folding-desk, and the space occupied is only about half that of any other style. The advantages of this Furniture can but be apparent to every school officer. We cannot too highly commend it to their consideration. (Ilustrated Catalogue of New and Improved Styles of School and Church Furniture, p.7). 
É uma carteira dobrável com gancho de cavalete integrado, de tal forma que, quando seu tampo é dobrado, o cavalete é apresentado diretamente diante do aluno, permitindo-lhe, quando o livro é colocado sobre a mesa, assumir uma posição fácil e ereta, enquanto que o livro é colocado sobre uma linha com um ângulo de visão sem que seja necessário qualquer encurvatura do pescoço ou da cabeça. Recomendamos essa mesa especialmente para uso em Escola Normal, Ensino Médio e Academias. É muito elegante no acabamento, bem durável e pode se tornar bastante requisitada ${ }^{310}$.

Figura 25 - The Study Desk

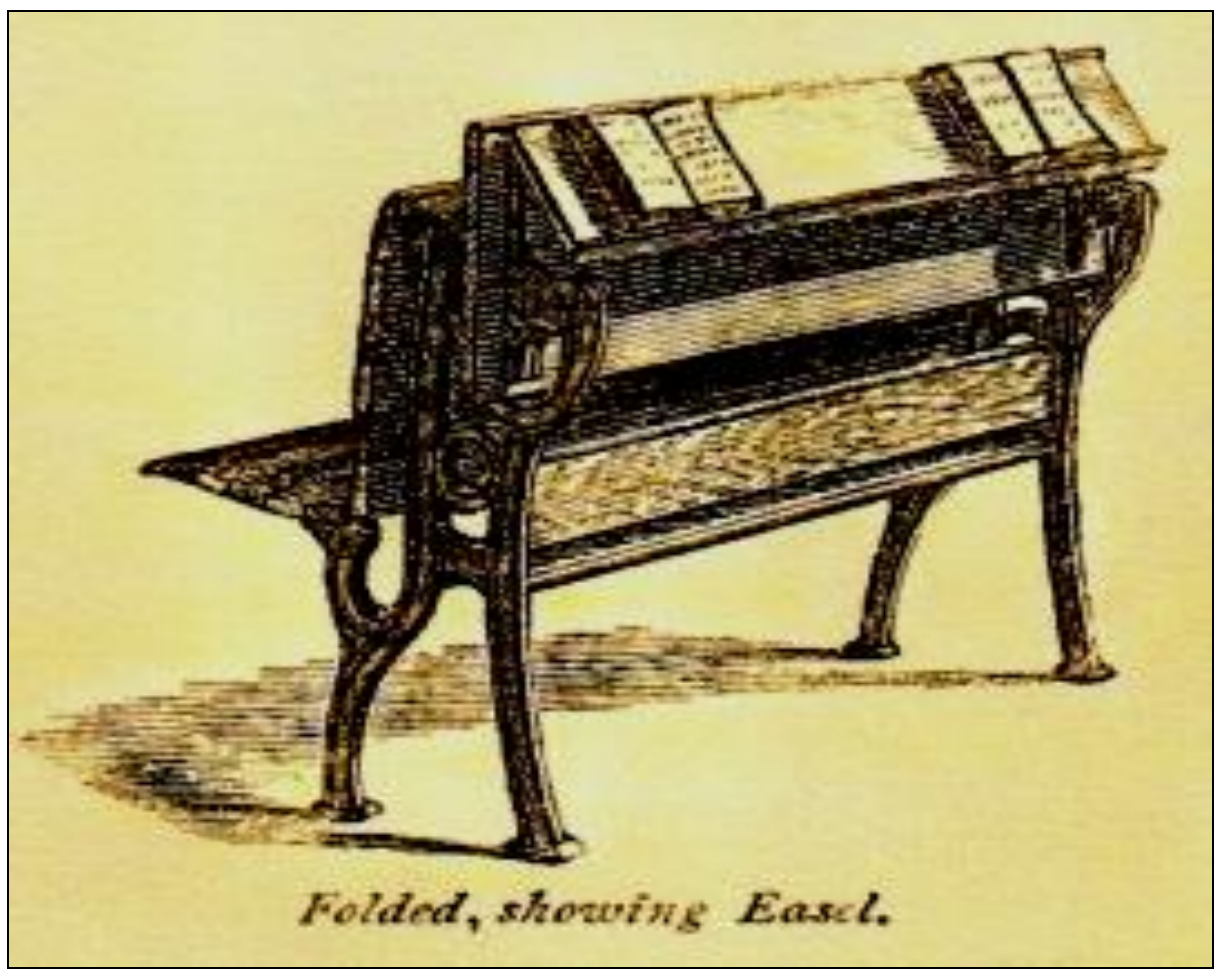

Fonte: The National School Furniture $\mathrm{C}^{\mathrm{o}}, 1872$, p.11

Cada carteira possuía um diferencial seja no banco, no encosto, no apoio de pé, na superfície de trabalho, na gradação da altura e cada um deles servia de elemento de propaganda. A "The Study Desk" é apresentada como a mais aprovada e desejável do mercado para escolas normais, secundárias e academias. No entanto, não possuía

\footnotetext{
310 "How shall we prevent our pupils from, leaning- over their books while engaged in study, thus inducing rounding of the shoulders and compressing the chest?" Is a problem which has long puzzled the brain of every educator who has had the physical well-being of his scholars at heart ; but is at last fully solved in the production of "The Study Desk" as shown in the accompanying cuts.

It is a folding-desk with hook-easel attached, and so arranged that when the desk-lid is folded the easel is presented directly before the pupil, enabling him, when the book is placed upon it, to assume an easy, erect position, while the book is brought on a line with the angle of vision ' without necessitating any bend of the neck or head. We recommend this desk especially for use in Normal, High Schools, and Academies. It is very elegant in finish, and thoroughly durable, and can but become a favorite (Ilustrated Catalogue of New and Improved Styles of School and Church Furniture, p.11).
} 
elevação do tampo da superfície de trabalho. Essa característica poderia ser encontrada na "High and Normal School Desks", como se observa abaixo.

Figura 26 - High and Normal School Desks

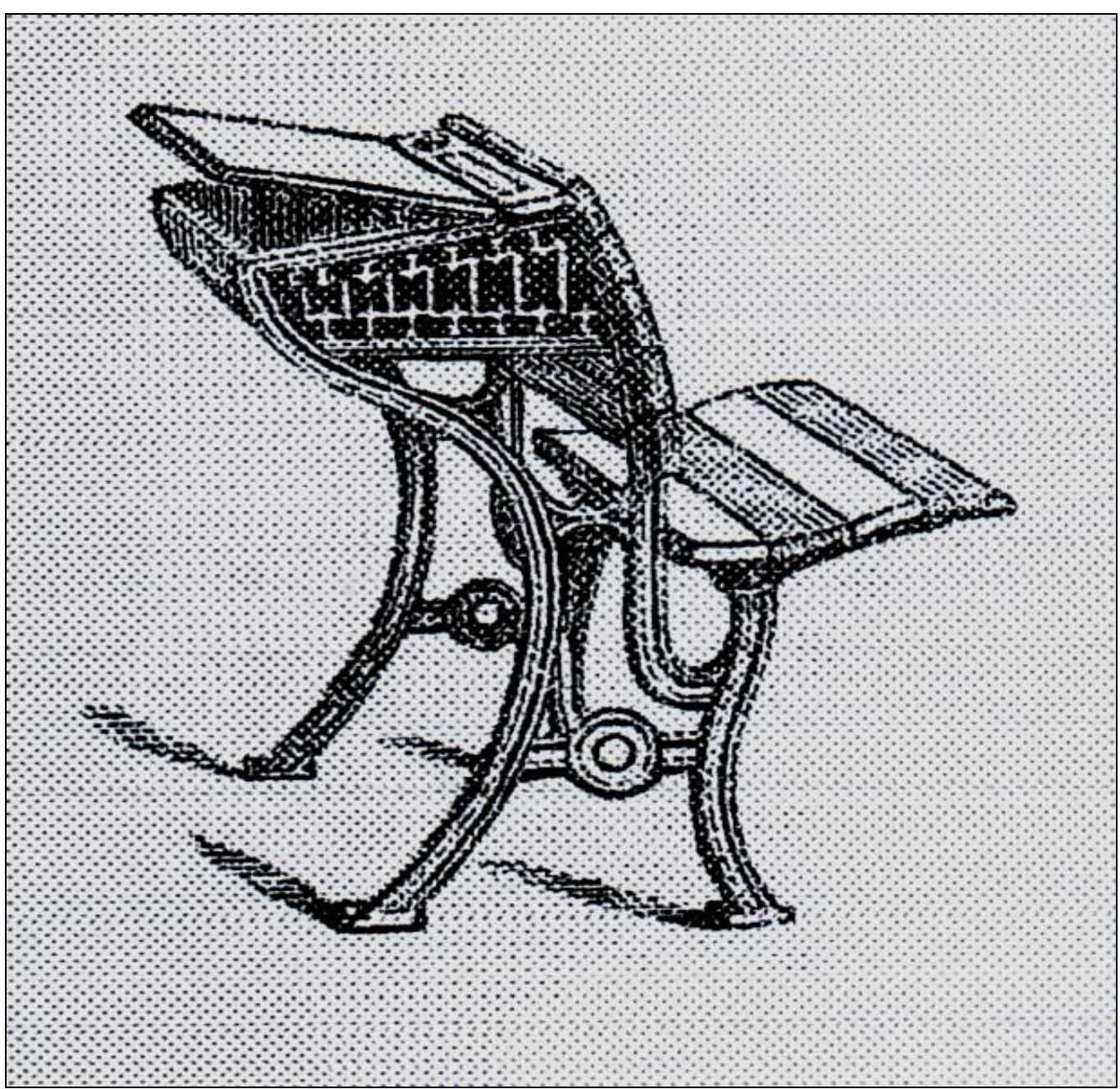

Fonte: The National School Furniture $\mathrm{C}^{\mathrm{o}}, 1872$, p.13 
Por meio do Offical Catalogue of the American Department ${ }^{311}$, referente à Viena, tem-se notícia de todos os expositores americanos que, no período, atuavam no ramo do mobiliário escolar. Quais sejam ${ }^{312}$ :

Relatório de Instruções em Bairros e Cidades, Distrito de Boston ${ }^{313}$.

16 - "Mobiliário de escola compreendendo carteiras simples e cadeiras de duas dimensões e modelos diferentes para os alunos; uma carteira par desenhar, uma mesa de professor com uma carteira par ensinar $[\ldots]^{, 314}$.

Manufacturers of School Furniture, Apparatus, \& C.

799 - A. H. Andres \& Co., Chicago, Illinois

Três caixas de Mobiliário escolar, carteiras, bancos \& $C^{315}$.

800 - National School Furniture Co. New York City

Completo conjunto de Móveis para uma Sala de aula, incluindo Carteiras de Professores e 48 carteiras e bancos para alunos ${ }^{316}$.

801 - NEW-YORK SILICATE BOOKSLATE Co. New York City

Ardósias em silicato para as escolas ${ }^{317}$.

802 - S. W. Nichols, Boston, Massachusetts.

Uma Carteira de parede ${ }^{318}$.

803 - H. A. OESTERLE, PHILADELPHIA, Pennsylvania

${ }^{311}$ BREWER, Eben. Vienna Universal Exhibition.1873. Offical catalogue of the American Department. Edited by Eben Brewer for the United States Commision. Printed and Published by J. M. Johnson \& Sons, p.99-114. O Catálogo é escrito em inglês e em francês.

${ }^{312}$ Aqui, optei por manter a ordem da relação conforme aparece no Catálogo.

${ }^{313}$ Rapports of Instruction in District and City. Ville de Boston

314 BREWER, Eben, 1873, p.100 - Mobilier d'écoles comprenant des pupitre simples et chaises pour eléves de 2 dimensions et modèles differents; un pupitre à dessiner, un pupitre de maître une table pour enseigner.

${ }^{315}$ Three cases of Furniture of Schools, Desks, Seats \& C.

${ }^{316}$ Complete set of Furniture for a School-room, including Teacher's Desks, and 48 Desks and Seats for Pupils.

${ }^{317}$ Silicate Slates for Schools

${ }^{318}$ One Wall-Desk. 
Conjunto de Livros de Mão e de Bolsas a Tiracolo para Livros Escolares ${ }^{319}$

804 - ROBERT PATON, New York City

Carteira escolar ${ }^{320}$.

805 - H. REFFETT, Hoboken, New-Jersey

Moldura fracionada, "Moldura Russa Doppel” e Máquina Calculadora ${ }^{321}$.

806 - JOSEPH L. ROSS, Boston, Massachusetts

Móveis escolares de vários tipos ${ }^{322}$.

807 - G. W. SHATTUCK, Boston, Massachusetts

Carteiras escolares, bancos \& $\mathrm{C}^{323}$.

808 - W. A. SLAYMAKER, Atlanta, Georgia

Carteira escolar e outros móveis ${ }^{324}$.

809 - JOHN CHARLES SPARR.

Tinteiro melhorado ${ }^{325}$.

810 - F. SOCHNER, Hamilton, Ohio.

Patente Ruler ${ }^{326}$.

811 - E.M.THURSTON \& Co. Providence, Rhode Island

Carteira escolar e bancos ${ }^{327}$.

812 - JOSEPH TROLL, Belleville, Illinois

Telúrio Automático do "Troll" 328

\footnotetext{
${ }^{319}$ Combined Book-Handle and Strap for carrying School Books

${ }^{320}$ School Desk. Pupitre d'école

${ }^{321}$ Fractional Frame, "Doppel Russian Frame" and Calculating Machine

${ }^{322}$ School Furniture of various kinds

${ }^{323}$ School Desks, Seats, \& C.

${ }^{324}$ School Desk and other furniture

${ }^{325}$ Improved Inkstand

${ }^{326}$ Patent Ruler. Régle brevetée

${ }^{327}$ School desks and seats
} 
813 - WHITE, R. Boston, Massachusetts

Ventilador Patenteado para uso em salas de aula não fornecido com hélices ventilantes $^{329}$.

814 - WILLIAMS, T.H. Plymouth, Indiana

Carteira escolar \& $\mathrm{C}^{330}$.

A relação de expositores e industriais americanos na Exposição de Vienna permite o cruzamento de informações com os catálogos produzidos por estas fábricas de mobiliário escolar. Mais que isso, nas Exposições, os Estados Unidos não deixam dúvidas quanto ao seu domínio na produção da carteira escolar fazendo com que outros países, na corrida pelo domínio dos mercados, buscassem também seu destaque seja pela semelhança (produção de carteira pé de ferro fundido) seja pela diferença (carteira toda em madeira).

A questão das críticas entre os países pode ser vislumbrada no catálogo sobre $L e$ Mobilier Scolaire a l'Exposition Internationale de 1878, em Paris. Apesar de ser um catálogo de preços do mobiliário do sistema Lenoir, na Introdução faz uma abordagem sobre o desenvolvimento do mobiliário escolar até aquele ano, além de uma breve descrição do mobiliário apresentado por outros países.

Para o autor do catálogo, desde a publicação do trabalho do Dr. Riant na Exposição de 1867, nada novo havia surgido. Essa crítica parecia valer especialmente para os ingleses. Diz ele: "Paramos por um longo tempo na seção ingleza [...] A Inglaterra não aprendeu nada e não tem nada selecionado, pelo menos que nos interessa aqui ${ }^{\text {} 331}$. Em páginas anteriores, a crítica foi ainda mais contundente:

$\mathrm{Na}$ Inglaterra, a questão da educação pública permanece estacionada. Parece que a arte do mobiliário escolar tende a se mover somente na direção da desarticulação. Na verdade, a maioria dos objetos móveis descritos nesta seção foram criados por palhaços ${ }^{332}$.

\footnotetext{
${ }^{328}$ Troll's Automatic Tellurium

${ }^{329}$ Patent Ventilator for use in School-rooms not provided with ventilating flues

${ }^{330}$ Schools Desks, \& C.

331 "Nous nous sommes bien longtemps arrêté dans la section anglaise [...] L'Angleterre n'a rien appris et n'a rien retenu, du moins en ce qui nous préoccupe ici" (Catalogue. "Le Mobilier Scolaire a l'Exposition Internationale de 1878”. Systema Lenoir. p.9).

332 "En Angleterre, la question d'instruction publique reste stationnaire. Il semblerait que l'art du mobilier scolaire ne tend à progresser que dans le sens de la désarticulation. En vérité, la plupart des objets de mobilier exposés dans cette section n'a été créée que pour des clowns" (Catalogue. "Le Mobilier Scolaire a l'Exposition Internationale de 1878'. Systema Lenoir. p.8).
} 
Os fabricantes estrangeiros destacados são da Bélgica, Luxemburgo, Suiça, Áustria, Dinamarca, Rússia, Suécia, Inglaterra e Canadá, Buenos Aires, Japão e França. Enfatiza-se o progresso da Bélgica somente naquilo em que a França pôde cooperar, já que no catálogo da Bélgica constava sobre o sistema Lenoir "ofereceu-se para a Bélgica após o Congresso de Professores em Bruxelas em $1875^{333}$.

O mobiliário do sistema Lenoir é apresentado como o que havia de melhor no ramo, pois "Nós vimos a Exposição de 1867, a de Viena e Filadélfia, todos vimos os mesmos estudos e erros, os esforços infrutíferos que encontramos, para nossa surpresa, na Exposição de $1878^{, 334}$.

O objetivo do texto introdutório Catalogue Le Mobilier Scolaire a l'Exposition Internationale de 1878 - Systema Lenoir é fazer uma breve descrição dos tipos de carteira apresentados pelos países acima citados, uma exaltação ao sistema Lenoir e uma depreciação das carteiras inglesas.

Na França, como em outros lugares, não nos podemos permitir envolver em perpétuas mudanças ou substituições de mobiliário. É o dinheiro público que lhes paga. Estamos trabalhando desde o princípio para unir o sólido ao útil, guardando-nos de esquecer a elegância e simplicidade da aparência. O mobiliário inglês nunca foi projetado para as salas de aula. Ele é imaginado, construído e tratado como façanhas de engenhosidade, que aqui e acolá um colecionador ou um museu pedagógico quer admitiu em sua coleção ${ }^{335}$.

As carteiras do sistema Lenoir, ao contrário, preenchiam os seguintes objetivos:

A altura da mesa e banco, a rígida observação dos ângulos retos, infligidas aos alunos mais ou menos formados parece uma ideia um pouco fantasiosa. Assumimos com razão que estudantes de todas as idades, de todo tamanho, mais ou menos formados, chegam juntos ao mesmo nível de instrução. Então, o ensino do mesmo grau comportaria uma diferença de mobiliário relacionada com o tamanho de cada um. Esta aplicação, com base em cálculos de risco e até mesmo quimérico de estatura ou de leis de equilíbrio, é uma visão. $\mathrm{O}$

\footnotetext{
333 “offert à la Belgique à l'issue du Congrès des Instituteurs à Bruxelles en 1875” (Catalogue. "Le Mobilier Scolaire a l'Exposition Internationale de 1878”. Systema Lenoir. p.6)

334 "Nous avons vu l'Exposition de 1867, celles de Vienne et Philadelphie, partout nous avons vu les mêmes tâtonnements, les mêmes errements, les efforts infructueux que nous retrouvons, à notre profonde stupéfaction, dans l'Exposition de 1878" (Catalogue. Le Mobilier Scolaire a l'Exposition Internationale de 1878. Systema Lenoir. p.12)

335 En France, comme autre part, nous ne pouvons nous permettre de nous livrer, à de perpétuels changements ou remplacements de mobilier, ce sont les deniers publics qui les payent. Nous nous efforçons, dès le principe, d'unir le solide à l'utile, en nous gardant bien d'oublier l'élégance et la simplicité d'aspect. Le mobilier anglais n'a jamais été conçu pour les classes, Il est imaginé, traité et construit à titre de tours de force d'ingéniosité, que par ci par là un amateur ou quelque musée pédagogique voudra bien admettre dans sa collection (Catalogue. "Le Mobilier Scolaire a l'Exposition Internationale de 1878”. Systema Lenoir. p.9).
} 
mais importante é oferecer para o aluno, quer ele seja pequeno, raquítico ou mesmo disforme, quer seja dotado de uma bela e grande estatura, os meios de estudo uniformemente cômodos ${ }^{336}$.

A despeito das disputas entre franceses e ingleses em assuntos que extrapolavam o mercado do mobiliário escolar e, concomitantemente, o atingia; o grande rival continuavam os Estados Unidos, como se reconhece nesse documento.

Por mais de vinte anos, a questão do mobiliário escolar foi suscitada nos Estados Unidos. Desde então, outros países se dedicaram ao estudo científico desta importante questão no desenvolvimento das escolas em termos de higiene e bom ensino. O mobiliário para escolas tornou-se então objeto de atenção por todas as nações preocupadas com a emulação louvável. Esta preocupação geral teve o efeito imediato de dar à luz a uma indústria especial aquela da fabricação do mobiliário escolar. ${ }^{337}$

Segundo A. Lenoir, a França, somente em 1867, na Exposição Universal, viu nascer, entre sistemas anormais e pretensiosos, “a grande razão de adaptar o banco à criança e não mais a criança ao banco. Vimos aparecer a solução do problema no objeto do sistema Lenoir [...] o sistema Lenoir tomou seu lugar à frente do progresso",338.

Apesar do autor do Catálogo estabelecer 1876 como marco dos primeiros resultados da instrução pública francesa, no domínio do mobiliário escolar, Peyranne afirma que "nenhum comentário é feito ao mobiliário francês" 339 nessa Exposição. Mas, como os demais países, a França queria concorrer com os Estados Unidos pelo rentável mercado do mobiliário escolar.

\footnotetext{
${ }^{336}$ La hauteur de la table et du banc, la rigide observation des angles droits, infligées aux élèves plus ou moins bien conformés nous semble une idée quelque peu fantasque. Nous supposons avec juste raison qu'il est des élèves de tout âge, de toute taille, plus ou moins bien conformés, arrivés ensemble au même degré d'instruction. Alors l'enseignement du meme degré entrânerait donc une différence de mobilier en rapport avec-la taille de chacun. Cette application, basée sur des calculs risqués et même chimériques de stature ou de lois d'équilibre, est une vision. Il importe avant tout d'offrir à l'élève, qu'il soit petit, chétif ou même difforme, comme à celui doué d'une belle et grande taille, des moyens d'étude uniformément commodes (Catalogue. "Le Mobilier Scolaire a l'Exposition Internationale de 1878". Systema Lenoir. p.10).

${ }^{337}$ Depuis plus de vingt ans, la question du mobilier scolaire a été soulevée en Amérique. Depuis, d'autres pays se sont livrés à l'étude scientifique de cette importante question de l'aménagement des écoles au point de vue de l'hygiène et du bon enseignement. Le mobilier des écoles est alors devenu l'objet d'une attention soutenue, par toutes les nations qui s'en sont préoccupées avec une louable émulation. Cette sollicitude générale a eu pour effet immédiat de donner naissance à une industrie spéciale, "celle de la fabrication du mobilier scolaire" (Catalogue. "Le Mobilier Scolaire a l'Exposition Internationale de 1878". Systema Lenoir. p.13).

338 "la grande raison d'accommoder le banc à l'enfant et non pas l'enfant au banc. On vit apparaître la solution du problème en l'objet même du système Lenoir [...] le système Lenoir prit résolument sa place en tête du progrès" (Catalogue. "Le Mobilier Scolaire a l'Exposition Internationale de 1878". Systema Lenoir. p.14).

${ }^{339}$ PEYRANNE, 2001, p.132 - "aucune remarque n'est faite sur le mobilier français".
} 
Figura 27 - Sistema Lenoir

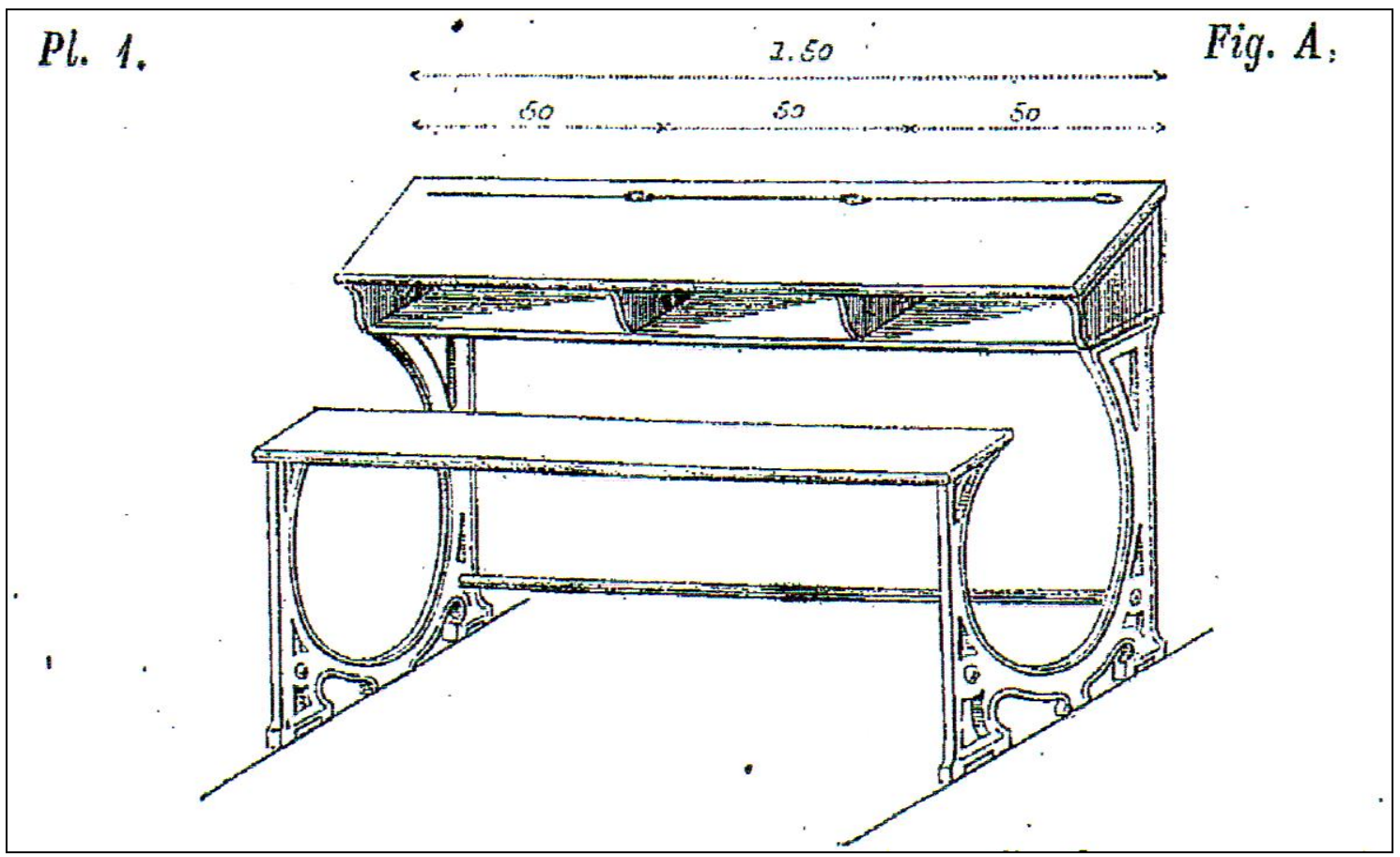

Fonte: Le Mobilier Scolaire a l'Exposition Internationale de 1878. Systema Lenoir. p.17

O lugar de destaque que o mobiliário escolar adquiriu nas Exposições Universais sinaliza que a escola ganhou a atenção não somente dos Estados, mas da indústria que viu nela um poderoso mercado consumidor. Daí, a quantidade de fábricas especializadas na produção de diferentes modelos de carteira.

Segundo Martin Lawn, “(...) há um discurso poderoso sobre a escola como lugar de consumo, crescente ao longo de décadas, especialmente em períodos de construção e de inovação escolares, mas presente agora na nova forma de encarar a educação como um serviço lucrativo"340.

Com isso empresas comerciais reconheceram a escola como lugar de publicidade e de desenvolvimento de novos clientes ${ }^{341}$. Fazendo uma exploração histórica das exibições educacionais Ian Grosvenor afirma que "educação no mundo contemporâneo significa negócios" ${ }^{\text {342 }}$. As exposições, para ele, permitem pensar a

\footnotetext{
${ }^{340}$ LAWN, Martin; GROSVENOR, Ian. Materialities of Schooling: Design, Technology, Objects, Routines. Oxford: Symposium Books, 2005, p.8 - [...] there is a powerful discourse about schools as sites of consumption, growing over the decades, especially in periods of school building or innovation, but present now in new way of viewing education as a profit making service.

${ }^{341}$ LAWN, Martin. op. cit.

${ }^{342}$ GROSVENOR, Ian. Pleasing to the Eye and at the Same Time Useful in Purpose: a historical exploração of educational exhibitions. In: LAWN, Martin; GROSVENOR, Ian. Materialities of Schooling: Design, Technology, Objects, Routines. Oxford: Symposium Books, 2005, p.165.
} 
relação entre educação e consumo e tem um papel importante na promoção de ideias educacionais, objetos e práticas. “A proposta era 'ver' e através do ver, acreditar e, acreditando, ter um modelo de uma boa prática para seguir",343.

Cada empresa objetivava que os clientes acreditassem no seu modelo de carteira como o mais inovador e higiênico. A respeito destas disputas no âmbito das Exposições, Josette Peyranne afirma:

Estas primeiras Exposições são muito inovadoras nos mobiliários apresentados. Cada país desejava ser referência neste domínio. Eles se copiavam, criticavam, concebiam, propunham claramente, tentavam vender. As várias honras e os prêmios distribuídos na Exposição de Viena traduzem o novo interesse em relação à carteira. De fato, mobiliário escolar é uma parte integrante da sociedade infantil escolarizada de meados do século XIX ${ }^{344}$.

Proteger suas invenções de cópias era fundamental para a sobrevivência das empresas. A busca pela conquista de novos mercados consumidores se torna evidente nas Exposições Universais e, a Exposição de 1873 em Viena, é exemplar a esse respeito. Entretanto, para entender a corrida dos países, sobretudo Estados Unidos e França, pela hegemonia no mercado de mobiliário escolar, é preciso não desconsiderar as patentes de carteira escolar.

\subsection{Patentes e empresas norte-americanas e francesas de mobiliário escolar}

A proteção dos direitos de propriedade intelectual tem início no fim do século XIX, com as Convenções de Paris (1883 - Propriedade Industrial) e Berna (1886 Obras Literárias e Artísticas) ${ }^{345}$, ambas com fins preponderantemente jurídicos. Das invenções dependiam não só "a expansão industrial e tecnológica" 346, mas também o domínio de um setor do mercado por um país ou uma empresa. "O aumento da proteção do direito de propriedade intelectual e a certeza da proteção ensejaram o incremento do poder do mercado e o desenvolvimento do comércio internacional”347.

\footnotetext{
${ }^{343}$ Idem, p. 174

${ }^{344}$ PEYRANNE, op. cit. p. 141 - Ces premières expositions sont très innovantes dans les mobiliers presentes. Chaque pays souhaitait être um référent dans le domaine, on se copie, on critique, on conçoit on propose bien entendu on essaie de vendre. Les différentes distinctions et les prix délivrés à l'exposition de Vienne traduisent le nouvel intérêt porté à la table-banc. En fait, le mobilier scolaire fait partie integrante de la societé enfantine scolarisée des le milieu du XIX ${ }^{\mathrm{e}}$ siècle.

345 BASSO, Maristela. O Direito Internacional da Propriedade Intelectual. Porto Alegre: Livraria do Advogado, 2000.

${ }^{346}$ Idem, p.23.

${ }^{347}$ Idem, p.26.
} 
No fim do século XIX, a expressão "propriedade industrial” designaria

os direitos privados para defesa da indústria e do comércio, como os direitos de patentes, de desenhos e modelos de fábrica ou ornamentais, desenhos e modelos de utilidade e marcas, defesa contra a concorrência desleal e contra as falsas indicações de proveniência dos produtos e outros regras afins ${ }^{348}$.

A descrição, muitas vezes minuciosa, das carteiras, de sua fabricação e peças nas exposições e catálogos servia como poderosa ferramenta de propaganda, mas gerava como efeito colateral, a possibilidade e a realidade do plágio, da cópia dos modelos por marceneiros e outras empresas, de pequeno porte ou não. Poderiam os visitantes das exposições ou aqueles que tinham acesso aos catálogos, como por exemplo, educadores de diversos países, de posse dos desenhos das carteiras, mandar reproduzi-las, lançando mão de uma opção local, mais barata e com menor custo de frete. Essa opção, via de regra, eram os marceneiros, que também se proliferavam com a expansão das cidades nas últimas décadas do século XIX e início do XX.

Não é por acaso que muitas indústrias e fábricas de mobiliário escolar possuem patentes de suas carteiras e não hesitam em mencionar nos catálogos as punições e processos nas quais incorriam aqueles que assim procedessem. Com isso, o público é advertido:

O público está prevenido contra as produções ou as compras de qualquer mobiliário escolar com o tampo da carteira virado contra $\mathrm{o}$ encosto do banco, então formando o assento, presente em outras que não a Perad's, bem como contra todas as demais infrações em suas 'Patentes; e aqueles que venderam ou compraram serão processados de acordo com as penas da lei ${ }^{349}$.

Outra forma de abrir novos mercados nos países mais distantes era oferecer carteiras com custo mais baixo, mantendo algumas características do mobiliário mais sofisticado, porém, com material inferior. É o caso da The Economic Desk, produto da The National School Furniture $C^{o}$ para aqueles que desejassem "um estilo barato e ainda substancial de mobiliário" 350 .

\footnotetext{
${ }^{348}$ Idem, p.69

349 "The Public are cautioned against the manufacture our purchase of any School Furniture with desk-lid turning over to lie against back of seat, thus forming settee, other than Peard's, as all such are infringements on his "Patents; and those selling or purchasing will be prosecuted to the full extent of the law". Ilustrated Catalogue of New and Improved Styles of School and Church Furniture, 1872, p.7.

350 "a cheap and yet substantial style of furniture" Ilustrated Catalogue of New and Improved Styles of School and Church Furniture, 1872 p.12.
} 
O assento dessa carteira era feito de ripas, curvado, dobrável, com a mesma articulação conjunta e silenciosa das melhores mesas. "Nós fornecemos esta carteira a um preço 20 por cento menor que a de nossos estilos regulares e muito abaixo do preço de qualquer outra carteira fabricada",351. Era um modelo para desafiar e dispensar qualquer competidor.

A questão da propriedade industrial estava de tal modo vinculada às Exposições Universais que, em 1889, houve, no âmbito da Exposição Universal de Paris, o Congresso Internacional da Propriedade Industrial, na mesma cidade, sob a direção do Ministério do Comércio, da Indústria e das Colônias.

Por que dedicar um capítulo à patentes de carteira escolar numa pesquisa desenvolvida na área de História da Educação?

Este trabalho se propõe a fazer, ainda que de forma inicial, uma história econômica da escola e, o caso das patentes de carteiras escolares evidencia, de modo ímpar, a estreita relação que se foi estabelecendo, a partir da segunda metade do século XIX, entre escola e indústria.

Isso porque a patente é um privilégio de invenção cuja concessão tem como um dos requisitos a "industriabilidade". "A invenção deve ser suscetível de exploração industrial. Deve ter utilidade" ${ }^{352}$. Em outras palavras, "a industriabilidade é a qualidade da invenção de permitir uma aplicação industrial, isto é, de ser utilizada em um ramo qualquer de produção"353.

Este "diploma oficial que assegura o monopólio da exploração do invento"354 é de suma relevância para a indústria e para o inventor.

A patente confere ao seu titular o direito de impedir terceiro, sem o seu consentimento, de produzir, usar, colocar à venda, vender ou importar com estes propósitos: I - produto objeto de patente; II - processo ou produto obtido diretamente por processo patenteado ${ }^{355}$.

Pode-se imaginar a importância deste instituto no contexto das exposições universais e da expansão da escola de massa no mundo ocidental. Os catálogos dos diversos fabricantes circulavam pelo mundo, eram apresentados aos clientes pelos representantes e agentes comerciais.

\footnotetext{
351 "We supply this Desk at a price twenty per cent less than that of our regular styles, and far below the price of any Desk of other manufacture" Ilustrated Catalogue of New and Improved Styles of School and Church Furniture, 1872, p.12.

${ }_{352}^{35}$ REQUIÃO, 2011, p.366

${ }^{353}$ Idem, p. 367

${ }^{354}$ Idem, p. 360

${ }^{355}$ Idem, p. 373
} 
É o que ocorre em 21 de novembro de 1894, quando o diretor da Escola Normal de São Paulo, Gabriel Prestes, envia ao Secretário de Estado dos Negócios do Interior, Cesário Motta Junior, a relação dos instrumentos para o ensino de mecânica e astronomia elementar, conforme tipos e preços extraídos "do Catálogo da ancienne Maison Rousseau" ${ }^{356}$. O diretor pede no ofício autorização para fazer diretamente a encomenda.

O pedido é atendido, pois em 4 de dezembro do mesmo ano, Gabriel Prestes escreve ao representante comercial da Maison Rousseau, Charles Vautelet encarregando-o do fornecimento dos instrumentos "o mais breve possível, nas condições das outras encomendas anteriormente feitas, recomendando porém que o "Theodolito de Gurley" seja americano, que corresponde ao numero 8 do catálogo da Casa W.L.E. Gurley (Troy Inglaterra)"357.

Os catálogos eram imprescindíveis para as compras à distância. Como já afirmado, não seria difícil qualquer Estado ou proprietário de escola particular contratar um marceneiro ou indústria local para reprodução dos "melhores" modelos de carteira escolar. Os Estados Unidos logo tomaram providências para solucionar este problema.

Em 1870 muitas indústrias de carteira escolar norte-americanas já possuíam patentes de seus produtos - patentes dos tinteiros, assentos dobráveis, dentre outros. Nos Estados Unidos, “em 1787, sua Constituição assegurou o direito dos inventos como um estímulo ao desenvolvimento industrial" $" 358$. Referência mundial no ramo, quais as novidades produzidas pelas indústrias americanas de mobiliário escolar?

A empresa GEO. \& C. W. Sherwood, em seu catálogo de 1864, destaca um elemento patenteado da Pupils' desks. "A empresa GEO. \& C. W. Sherwood, em seu catálogo de 1864, destaca um elemento patenteado da Pupils' desks. "Esta carteira é bem acabada, geralmente feita de cerejeira, produzida com nosso tinteiro patenteado, parafusos de fixação, tudo completo" ${ }^{\text {359 }}$.

\footnotetext{
${ }^{356}$ Fonte: Acervo Histórico da Caetano de Campos em São Paulo. Correspondência da Diretoria (18931895) - Ofício n. 110 - Anexo n.1

${ }^{357}$ Fonte: Acervo Histórico da Caetano de Campos em São Paulo. Correspondência da Diretoria (18931895) - Ofí́cio n. 115 - Anexo n.2

${ }^{358}$ REQUIÃO, 2001, p.361

${ }^{359}$ GEO. \& C. W. SHERWOOD. A descriptive and illustrated catalogue of school furniture. Chicago, 1864, p. 8 - This Desk is nicely finished - usually made of cherry - supplied with our Patent Ink Well, screws for fastening, all complete.
} 
Joseph L. Ross era outro importante negociante americano do ramo de carteira. Ele também obteve a patente de um tinteiro. "O melhor em uso! Superior a qualquer tinteiro usado até então e possui todos os méritos atribuídos a ele" ${ }^{\text {"360. }}$.

A Casa de Mobiliário Escolar, J.A.Bancroft \& Co., de igual modo, arrogava para si o melhor tinteiro patenteado. O “Andrew's New Patent Ink Well”, "O novo e melhor tinteiro que não só combina as excelências e as soluções dos defeitos daqueles atualmente em uso, mas que também adiciona vários recursos novos e importantes, nunca antes vistos ${ } 361$. Além do tinteiro, havia duas carteiras patenteadas, como: Soper's Patent School Desk; Andrews' Patent Graduated Desk. Nota-se que a patente agregava de tal forma valor ao produto que passava a compor o nome do mesmo.

Algumas empresas americanas produziam mobiliário tanto para a escola como para igrejas. É o caso da J.C. BROOKE Manufacturers. Sua principal carteira era a New Excelsior Desk, feita em seis tamanhos. “A dobradiça do assento é certamente a melhor no mercado, patenteada em 8 de abril de 1879. Ela funciona perfeitamente, de forma suave e sem fazer barulho" ${ }^{362}$.

A Union School Furniture Company, na propaganda de sua carteira Automatic, também destaca a dobradiça, assegurando que é uma carteira notável, pois

embora no mercado há relativamente pouco tempo, ela já foi adotada por muitas das principais escolas do país, e já conquistou o seu caminho em Estados distantes e em outros países. Ela cria entusiasmo sempre que apresentada, não só porque é nova, mas porque é tão obviamente superior, em princípio, e em construção do que qualquer outro banco. Desde que os assentos rebatíveis foram inventados, o problema tem sido o de melhorar a dobradiça ${ }^{363}$.

\footnotetext{
${ }^{360}$ ROSS, Joseph L. Illustred Catalogue of improved school, church, and vestry furniture. Illustred catalogue of Ross' improved furniture. Manufactured at Ross' school furniture works. Office, 42 Chardon, opp. Hawkins street, Boston. Boston: Hollis \& Gunn, book and job printers, No. 25 Hawley Street. 1872, p.51 - The best in use! Superior to any Ink-Well heretofore used, and possesses all the merits claimed for it.

${ }^{361}$ J.A.BANCROFT \& CO. Descriptive and Illustrated Catalogue of School Merchandise, Furniture, apparatus, Charts, \&C. Philadelphia, s/d, p.17 - new and greatly improved Ink Well, which not only combines the excellencies and remedies the defects of those now in use, but also adds several new and important features, not before seen.

${ }^{362}$ BROOKE, J.C. Catalogue church school and hall furniture. cincinatio, 1884, p.8 - The hinge. Is certainly the best one made. Patented April 8th, 1879. It works perfectly, smooth, and noiseless.

${ }^{363}$ UNION SCHOOL FURNITURE COMPANY. Descriptive catalogue of school furniture and supplies. Manufactured by Union School Furniture Company. Factory and Office, Battle Creek, Michgan - 1889, p.4 - Although in the market for comparatively a short time, it has already been adopted by a multitude of the leading schools of the country, and has already won its way into distant States and other Countries. It creates enthusiasm wherever presented, not merely because it is novel, but because it is so obviously superior in principle and construction to any other Seat. Ever since folding seats were invented, the problem has been to improve the hinge.
} 
A Union School Furniture Company promete ter resolvido o problema, de que é prova sua patente. Segundo a empresa, as patentes dos assentos das carteiras de outras empresas "são para vários dispositivos a fim de tornar a articulação mais forte, menos suscetível ao desgaste e menos ruidosa" ${ }^{\text {364 }}$. Todavia, essas insatisfações permanecem em todos os antigos modelos. Na Automatic, "toda dificuldade é afastada [...] Não há mais fraqueza, flacidez, movimento desajeitado e ruído. Há, em vez disso, resistência, durabilidade, um movimento natural, fácil, e nenhum ruído"365.

O catálogo dessa empresa é de 1889, mas, nele, não é possível identificar de que ano é a patente da dobradiça tão aclamada. O emprego da dobradiça parece ter sido uma atrativa inovação técnica que tornava a carteira com assento dobrável diferenciada. Em 1872, The National School Furniture Co., também obteve a patente de seus assentos dobráveis. Esta informação encontra-se em uma nota inicial de advertência ao público quanto a

Certos vendedores inescrupulosos de móveis comuns que estão se esforçando para impressionar a comunidade com a ideia de que eles controlam todas as combinações de elevação do assento. Advertimos o público contra essa fraude audaciosa e insistimos nas vantagens de nossos assentos integrados ${ }^{366}$.

Do excerto acima se depreende que o industrial, ao explicitar que o seu produto, ou parte ele, era patenteado tinha em vista não somente a proteção do mesmo. A patente era um elemento de vantagem na corrida pela garantia e conquista de mercado. Os Estados Unidos estavam tão à frente na produção industrial do mobiliário escolar que, ainda em 2 de fevereiro de 1869, foi patenteada a Peard's Desk. John Peard era o titular da patente da carteira dobrável e também o supervisor do departamento de produção da The National School Furniture Co., que possuía uma fábrica em Nova York e outra em Chicago. A Sterling School Furniture $C^{o}$, tinha uma dobradiça patenteada na carteira The Peerless ${ }^{367}$.

\footnotetext{
${ }^{364}$ Idem, ibidem - Nearly all School Seat patents are for various devices to render the hinge more strong, less liable to wear, or less noisy.

${ }^{365}$ Idem, ibidem - The hinge, by a simple device, is discarded entirely and with it disappears the whole tribe of evils and difficulties which have been connected with it. There is no longer weakness, sagging, awkward movement, and noise. There is, instead, strength, durability, a natural, easy movement, and no noise.

${ }^{366}$ THE NATIONAL SCHOOL FURNITURE CO. Illustrated catalogue of new and improved styles of school and churche furniture and school apparatus. Manufactured by The National School Furniture Co. New York and Chicago, 1872 - Certain unscrupulous venders of common furniture are endeavoring to impress the community with the idea that they to control all lift-seat combinations. We would caution the public against this audacious fraud, and urge upon them the advantages of our seat-joint.

${ }^{367}$ STERLING SCHOOL FURNITURE CO. Price list of school furniture. Albany, New York, 1875, p.4
} 
O grande adversário das carteiras dobráveis era o tempo, que as deixava barulhentas e desconfortáveis. A Peard's Desk foi "construída para ser facilmente apertada ao longo do tempo". Por isso, "é absolutamente a única dobradiça silenciosa do mercado, e continuará a ser assim"368.

Diversas patentes podiam ir se justapondo em um mesmo produto, pois a novidade poderia estar em suas engrenagens e partes. No caso da Peard's Desk, em 20 de fevereiro de 1872, foi patenteado seu assento integrado. Apesar da patente já implicar em proibição, a terceiros, de "produzir, usar, colocar à venda, vender ou importar com estes propósitos produto objeto de patente", em seus catálogos, muitos industriais reforçam as punições a que estariam sujeitos aqueles que assim procedessem.

O público está alertado contra a produção ou compra de qualquer Mobiliário Escolar com o tampo da mesa virando contra o encosto do banco, formando, assim, o assento, exceto a Peard's, como todas as infracções a suas patentes, e essas vendas ou compras serão processadas em toda a extensão da lei ${ }^{369}$.

Essa empresa possuía outra carteira patenteada, The Study Desk", em 23 de maio de 1871. Sua armação tinha a finalidade de evitar a "encurvatura dos ombros e compressão do tórax" ${ }^{, 370}$.

Isso porque as questões ergonômicas e higiênicas não eram alvo somente das preocupações de educadores, médicos e higienistas. "Para os higienistas, o corpo é uma máquina produtora de energia, em seu desenvolvimento, esperamos regenerar a raça" ${ }^{371}$. O discurso sobre o corpo do cidadão também era utilizado como meio de propaganda das carteiras - um produto que não gerava deformidades no corpo da criança.

No caso francês, foi patenteada, por exemplo, a Nouvelle Table Scolaire, de M. Lhuillier $^{372}$. São três as características destacadas nesta carteira: a higiene, a moralidade e a comodidade. Ela satisfazia "plenamente todas as exigências da boa higiene [...] contribui para o desenvolvimento normal do corpo e das faculdades físicas da

\footnotetext{
368 THE NATIONAL SCHOOL FURNITURE CO, 1872, p.6 - The seat-hinge (our patent) is noiseless, and is so constructed as to be easily tightened when through long-continued use the seat works too readily or loosely in the socket. Thus a perfectly noiseless joint is secured as long as the furniture is in use. It is absolutely the only hinge in the market that is noiseless, and will continue to be so.

${ }^{369}$ Idem, p.7 - The public are cautioned against the manufacture or purchase of any School Furniture with desk-lid turning over to lie against back of seat, thus forming settee, other than Peard's, as all such are infringements on his "Patents; and those selling or purchasing will be prosecuted to the full extent of the law.

${ }^{370}$ Idem, p.11- rounding of the shoulders and compressing the chest.

${ }^{371}$ PEYRANNE, 2001, p.105 - Pour les hygiénistes, Le corp est une machine productice d'énergie, en la développant, on peut espérer régénerer la race.

${ }^{372}$ Catalogue spécial de mobilier et materiel scolaire et acessoires de classes. Paris, Librairie Delagrave. Deuxieme partie, 1890, p.4.
} 
criança",373. No aspecto moral, apesar de ter dois lugares, "os assentos são separados por uma caixa que isola os ocupantes" ${ }^{\text {374 }}$. O mais importante, "a parte de baixo da mesa é sem proteção, a criança permanece descoberta e nenhum de seus movimentos pode escapar aos olhos atentos do mestre" 375 .

Embaixo da carteira, sempre foi o lugar da subversão do aluno. Embaixo da carteira pode ser o lugar da "cola", mas não era essa a preocupação no século XIX. "A masturbação era um problema na sociedade do século XIX ${ }^{\text {376 }}$. Era considerada uma degeneração. Controlando o corpo do aluno, intenta-se "regenerar a raça", por isso, a necessidade de uma carteira que oferecesse como vantagem a moralidade, a possibilidade do professor controlar esse "vício", "mortal e contagioso".

A masturbação, longe de ser um problema isolado é um problema social: "descobrimos, há alguns anos, em uma cidade, uma sociedade inteira de rapazes entre 14 e 15 anos que se reuniam para praticar esse vício e toda a escola foi infectada (S. Tissot, 1864)". A criança que se entrega a esta prática funesta e facilmente reconhecida: "O crescimento se dá de uma maneira viciosa ou incompleta: "o diâmetro do peito se encolhe; o tamanho que sofre, às vezes, curvas inadequadas, e se produz no desenvolvimento desarmonias também prejudiciais à regularidade das formas que mantém a saúde" ${ }^{, 377}$.

O professor poderia perceber esses sinais do "masturbador" e, nessa tarefa, o design da carteira poderia ajudar ou atrapalhar.

A propaganda da carteira de M. Lhuillier no Catalogue Delagrave é exemplar da relação intrínseca entre economia, higiene e educação na expansão da escola de massa e dos sistemas de instrução pública.

No Brasil, quais as inovações técnicas patenteadas no ramo do mobiliário escolar? Que diferencial/novidade possuíam as carteiras privilegiadas com patente? Quem eram os fabricantes e empresários que atuavam no mercado de mobiliário escolar? Dentre outras, serão estas as questões contempladas no Capítulo 4.

Associados às Exposições Universais, os congressos nacionais e internacionais de educação também contribuíram significativamente para os processos de modernização dos equipamentos da escola, como discorrerei a seguir.

\footnotetext{
${ }^{373}$ Idem, ibidem - satisfont pleinement à toutes les exigences d'une bonne hygiene [...] tout contribue au bien-être ainsi qu'au développement normal du corps et des facultés physiques de l'enfant.

${ }^{374}$ les sièges sont séparés par un casier qui isole les occupants.

${ }^{375}$ Le dessous de la tablette étant complètement dégarni, l'enfant resté à découvert et aucun de ses mouvements ne peut échapper à l'oeil attentif du maître.

${ }^{376}$ PEYRANNE, 2001, p.104 - L'onanisme était un problem de société du XIX ${ }^{\mathrm{e}}$ siècle.

${ }^{377}$ Idem, p. 104 e 105.
} 


\subsection{Primeira Exposição Pedagógica do Rio de Janeiro (1883)}

O Brasil não somente participou das Exposições Universais, Pedagógicas e dos Congressos de Instrução, mas também os realizou. Maria Cristina Machado (2005) afirma que, na segunda metade do século XIX, o "Estado brasileiro faz da educação um grande espetáculo, promove conferências - populares, públicas, literárias, pedagógicas ou de professores; organiza congressos, exposições pedagógicas, museus escolares e pedagógicos",378.

Dentre os eventos ocorridos no Brasil, selecionei a Primeira Exposição Pedagógica do Rio de Janeiro de $1883^{379}$. O

Imperador Pedro II convoca um congresso para tratar de questões que interessem à instrução pública na corte e nas províncias [...] A presidência do Congresso da Instrução ficou a cargo do Príncipe Conde D'Eu [...] em 13 de janeiro de 1883, o Conde D'Eu propôs a realização de uma Exposição Pedagógica ${ }^{380}$.

De acordo com Moysés Kuhlmann Jr, as “instituições de educação popular foram destaque durante a Exposição Industrial no Rio de Janeiro, em 1881, que contou com uma seção da Instrução Pública"381. O autor ainda acrescenta que "a Exposição Industrial de 1881 foi o primeiro impulso para a realização da Exposição Pedagógica, em 1883, que também pretendia abrigar o Congresso de Instrução" ${ }^{\text {382 }}$. O congresso não foi realizado ${ }^{383}$, mas os pareceres elaborados acerca dos objetos expostos são documentos férteis para identificação dos países participantes e das percepções dos pareceristas acerca da relevância de certos materiais para a escola moderna.

378 MACHADO, Maria Cristina Gomes. A educação como espetáculo. In: STEPHANOU, Maria; BASTOS, Maria Helena C (orgs). Histórias e memórias da educação no Brasil, Vol II: século XIX. Petrópolis, RJ: Vozes, 2005, p.116.

379 "Inaugurada em 29 de julho de 1883, contou com a participação de vários países: Bélgica; Itália; França; EUA; Uruguai, Chile; Argentina; Áustria; Espanha; Portugal; Suíça; Holanda; Alemanha; Inglaterra; Suécia; e os Estabelecimentos dos Irmãos da Doutrina Cristã” (BASTOS, 2002, p. 263).

${ }^{380}$ MACHADO, Maria Cristina Gomes. 2005, p.121

${ }^{381}$ KUHLMANN JR, Moysés. A educação infantil no século XIX. In: STEPHANOU, Maria; BASTOS, Maria Helena C (orgs). Histórias e memórias da educação no Brasil, Vol II: século XIX. Petrópolis, RJ: Vozes, 2005, p.73.

382 Idem, ibidem.

${ }^{383}$ Sobre os motivos da não realização do Congresso ver: COLLICHIO, Therezinha A. F. Dois eventos importantes para a História da Educação Brasileira: a Exposição Pedagógica de 1883 e as Conferências Populares da Freguesia da Glória. Revista da Faculdade de Educação/USP. São Paulo, 13(2):514,jul/dez.1987, p.7 
No âmbito dessa Exposição, o Relatório do Juri sobre o Grupo 3 - Mobiliário Escolar, traz uma contribuição importante a este trabalho por, pelo menos, cinco razões: 1) Permite conhecer as características que o júri ${ }^{384}$ considerou essencias na mobília escolar; 2) Expõe detalhes da mobília escolar apresentada pelos países participantes (Bélgica, França, Inglaterra, Alemanha, Suecia, Estados Unidos), já que o juri estudou os modelos de carteira, tomando como referência as características previamente estabelecidas; 3) Destaca os colégios particulares brasileiros que procuram "caminhar em paralelo com estes melhoramentos" na carteira; 4) Explicita os critérios segundos os quais foram premiados os expositores; 5) Dá a conhecer os expositores que obtiveram diplomas e menções honrosas.

Na Primeira Exposição Pedagógica do Rio de Janeiro, os jurados definiram, primeiramente, as características essenciais da mobília escolar, em número de 5:

$1^{\circ}$. Proporcionalidade das dimensões dos bancos e mesas com a estatura dos alumnos; $2^{\circ}$. Jogo, a que as peças destes moveis estão sujeitos; $3^{\circ}$. Numero de logares em cada móvel; $4^{\circ}$. Simplicidade da sua construção e conservação; $5^{\circ}$. Natureza da sua pintura ${ }^{385}$.

Dentre todas "O primeiro característico é o mais importante, porque affecta uma propriedade hygienica dos moveis"386 . A segunda característica "refere-se á mobilidade ou fixidez das peças de que se compõe um banco-carteira"387. A comissão opta pela fixidez das peças justificando que "a experiência demonstra que, sempre que o alumno tem na mobília á sua disposição peças moveis, com que possa distrair-se ou brincar, os estragos são freqüentes e a conservação dispendiosa"388.

Quanto ao número de lugares da carteira, a comissão estabelece que:

os bancos-carteiras de um só logar devem ser preferidos, ou pelo menos constituem um novo ideal para o qual se deve tender em questão de mobília escolar, e sempre que algum motivo econômico não determine o contrário. O alumno está ao abrigo de uma infinidade de perturbações, como sejam: a conversa, a indisciplina, as distracções, e mesmo, sem parecer exageração, a immoralidade; elle tem por assim dizer, o seu pequeno domínio para si tão sómente, e pelo qual é responsável. Mas, como o obstáculo econômico é de muito peso, usa-se frequentemente dos moveis de dous logares; com effeito, os de um logar tomam mais espaço na sala que os de dous; exigem

\footnotetext{
${ }^{384}$ PRIMEIRA EXPOSIÇÃO PEDAGÓGICA DO RIO DE JANEIRO. Typographia Nacional, 1884, p.55

- "Os referidos grupos e comissões ficaram organizados pela seguinte forma: Mobília Escolar - Dr. A. de Paula Freitas, Dr. João Pedro de Aquino, Dr. Manoel Velloso Paranhos Pederneiras".

${ }^{385}$ RIO DE JANEIRO, Exposição Pedagógica, 1883. Conferências effectuadas na exposição pedagógica. Rio de Janeiro: Imprensa Nacional, 1884, p.25.

${ }^{386}$ Idem, p.26

${ }^{387}$ Idem, p. 28

${ }^{388}$ Idem, p. 29
} 
portanto uma despeza maior de construcção do edifício relativamente ao mesmo numero de alumnos; custam mais caros, porque dous bancos-carteiras separados exigem mais mão de obra e material que um só com os dous logares ${ }^{389}$.

A simplicidade é exigida em oposição à "solução da phantasia, baseada muitas vezes em combinações arbitrarias, porque d'ahi provêm disposições na mobília, que a tornam defeituosa ou imprestável para os fins a que se destina"390.

Vê-se que o preço da fabricação, conservação/manutenção do mobiliário não é desprezível para o Estado e seus agentes, diante de um item cujo valor, em quantidade, é elevado. Por isso, a comissão vai defender que "O essencial em um móvel-escolar é que elle seja solido, simples e firme, para não encarecer o fabrico, nem a conservação"391 .

Se há um aspecto que o Estado valoriza na carteira, por questões econômicas, é a sua durabilidade. O alto investimento deve ser compensado ao longo do tempo. Ele não pode se repetir a cada ano ou mesmo a cada década. Não localizei relatórios do júri de outras Exposições Universais ou Pedagógicas que permitissem analisar o lugar conferido à durabilidade da carteira. Para a comissão do grupo Mobília Escolar, da Exposição do Rio de Janeiro, a durabilidade era uma característica essencial à carteira. Talvez porque em um país no qual muitas escolas não dispunham sequer de mobília, conservar por longo tempo àquelas que já existiam, era fundamental.

A conservação dizia respeito ao móvel como um todo e às suas partes. Era preciso evitar a constante renovação das peças. $\mathrm{O}$ uso do ferro fundido, tão disseminado no período, é desaconselhado pela comissão, também por uma questão econômica - a manutenção do mobiliário. De acordo com o júri, “[...] o uso do ferro não é sempre conveniente, mórmente o ferro fundido, que é muito sujeito a quebrar-se com qualquer choque [...] $]^{392}$. No entanto, países como Belgica, Estados-Unidos, Inglaterra e Allemanha apresentaram carteiras fabricadas com ferro fundido. A "dificuldade das reparações" fez com que em alguns paizes o uso do ferro fundido fosse banido.

Tal dificuldade não se daria com as carteiras de madeira, pois

Não ha villa ou aldeia, que não disponha de um carpinteiro ou marceneiro, que seja capaz de reparar um banco ou uma mesa de madeira; mas o mesmo não acontece com o ferro fundido. A necessidade de reparações é portanto uma das previsões, que não se

\footnotetext{
${ }^{389}$ Idem, ibidem.

${ }^{390}$ Idem, ibidem.

${ }^{391}$ Idem, ibidem.

${ }^{392}$ Idem, p. 30
} 
póde deixar de tomar em consideração, pelo menos para as escolas ruraes, que nem sempre dispõem nas suas proximidades de officinas para aquelles trabalhos ${ }^{393}$.

A razão é puramente econômica, já que o uso das carteiras com peças de ferro fundido não é desaconselhado nas escolas urbanas "que disponham dos recursos para as reparações de que venham a carecer" ${ }^{394}$.

Relacionada à conservação, estava a facilidade para a limpeza. Para tanto, a comissão recomenda que a pintura seja a óleo fervido ou que as carteiras sejam envernisadas.

Depois de estabelecidos os critérios de julgamento das carteiras, a comissão passa ao estudo dos modelos expostos pelos diversos países.

A Bélgica apresentou cinco bancos-carteiras inventados pelo arquiteto BlandotGrayet para escolas de meninas. Os bancos-carteiras eram envernizados, "inteiramente de madeira, com dous logares cada móvel peças fixas e proporcionaes aos alumnos que os devem occupar ${ }^{\text {} 395}$. Havia também um modelo para escolas de meninos, dois modelo para meninos e meninas das escolas normais.

Cabe aqui, a respeito destes moveis, uma observação importante. A caixa da carteira a principio era móvel, escorregando horizontalmente afim de augmentar ou diminuir a sua distancia ao banco, de sorte a permittir ao alumno ficar de pé entre o banco e a carteira; mas, como esta disposição mostrou graves inconvenientes, segundo refere Narjoux, tratou-se logo de substituir a mesa móvel por outra fixa; provando-se assim a conveniência da fixidez das peças da mobília escolar ${ }^{396}$.

$\mathrm{O}$ arquiteto francês Felix Narjoux atuou durante o exercício de Jules Ferry como Ministro da Instrução Pública. Jules Ferry sancionou o Regulamento para a construcção e mobiliamento das casas de escola, em 17 de julho de 1880. Tomando esse documento como referência, Narjoux escreveu regulamentos para a construção e mobiliamento de escolas na França e Inglaterra. Ele era especialista em mobiliário escolar. Tornou-se autoridade no assunto, mesmo fora da França, a ponto de carteiras escolares na Bélgica serem modificadas devido às instruções dele.

\footnotetext{
${ }^{393}$ Idem, p. 30

${ }^{394}$ Idem, ibidem.

${ }^{395}$ Idem, p.31

${ }^{396}$ Idem, p.32
} 
Os móveis expostos agradaram ao júri brasileiro e atenderam às características exigidas, pois o Ministério da Instrução Pública da Bélgica recebeu diploma de honra "por ter sido a Bélgica o País que mais sobressaiu na Exposição - Pelos especimens de mobílias escolares" ${ }^{\text {397. }}$.

Além dos bancos-carteiras, este país exibiu mesa e cadeira de professor, escabelo (único país a expor este objeto), armário-biblioteca, cabides, lavatório e pedras (tableaux).

Da França, duas fábricas enviaram seus produtos: Crédit des écoles, Walcker \& Cia. e Garcet \& Nisius. A primeira recebeu diploma de honra "Pela mobília escolar fabricada de conformidade com as disposições regulamentares do governo francês, de 17 de junho de $1880^{, 398}$. O material de fabricação da carteira era madeira, pintada de cores escuras. Tinha dois lugares, bancos e peças fixas "com inclinação, e uma estante para livros. A distancia da carteira ao banco é nulla" ${ }^{\text {399 }}$.

Garcet \& Nisius, construtores e editores de Paris, apresentaram carteiras de dois lugares, com tampo móvel, assento fixo, distância nula, polido e pintado de escuro. No Catálogo Mobilier Scolaire et Materiel d'Enseignement de P. Garcet \& Nisius ${ }^{400}$, publicado em 1882, há dois modelos de carteiras que poderiam ser fabricadas com tampo móvel. Um deles, talvez fosse o mesmo móvel exposto um ano depois na Exposição Pedagógica do Rio de Janeiro.

\footnotetext{
${ }^{397}$ Idem, p.60-61

${ }^{398}$ Idem, p.70

${ }^{399}$ Idem, p.33

${ }^{400}$ GARCET \& NISIUS. Mobilier scolaire et Matériel d'enseignement. Conforme à l'arrêté ministériel du 17 juin 1880. Paris, Catalogues. 1882.
} 
Figura 28 - Modelo da cidade de Paris

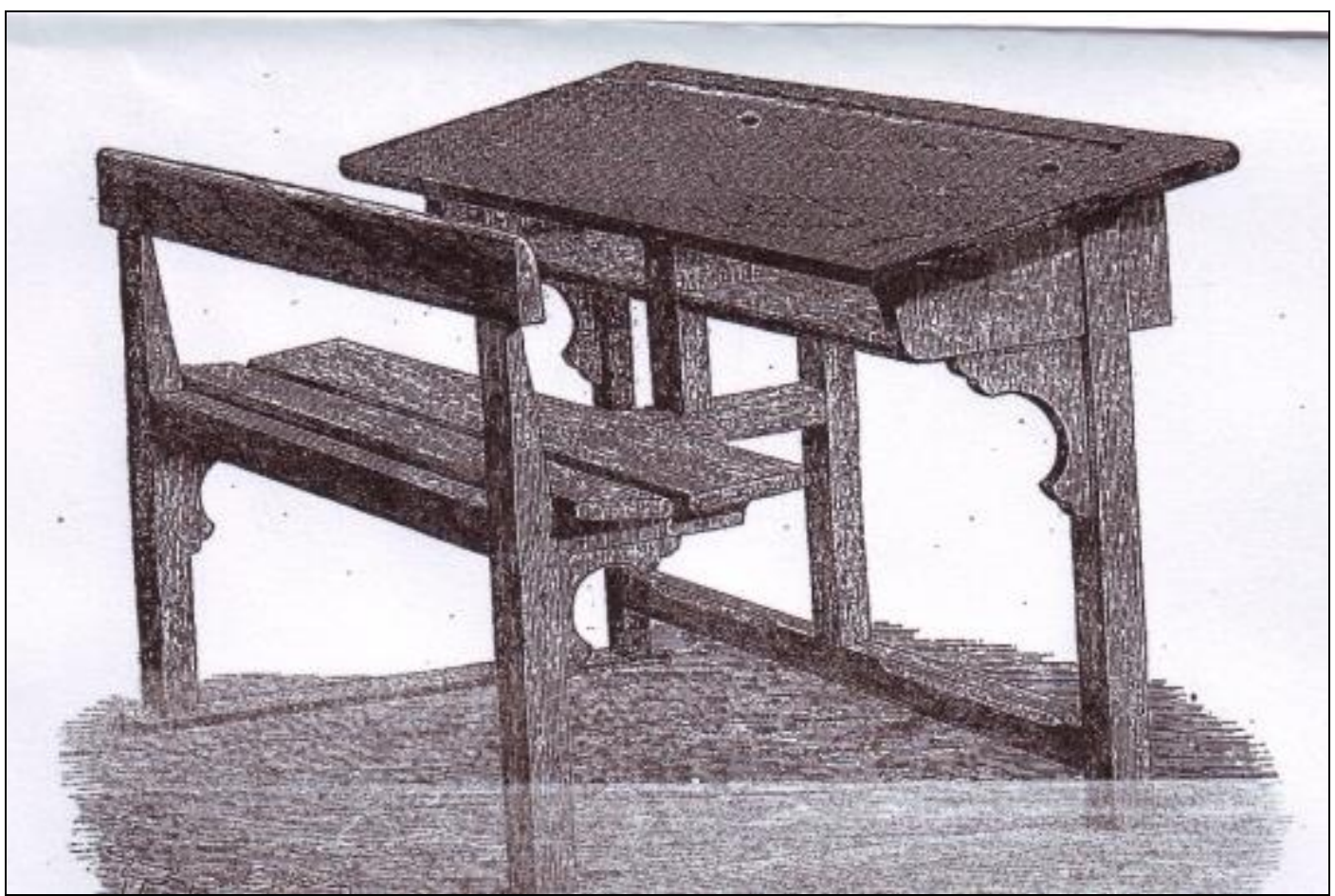

Fonte: GARCET \& NISIUS, 1882, p.6

O modelo para uso em escolas infantis e primárias custava 10 francs por assento. A carteira para dois alunos custaria 20 francs. Se a mesma carteira for solicitada com tampo articulado, o valor passaria a ser 28 francs. A carteira para escola Normal também poderia ser fabricada com tampo articulado. 
Figura 29 - Carteira para Escola Normal

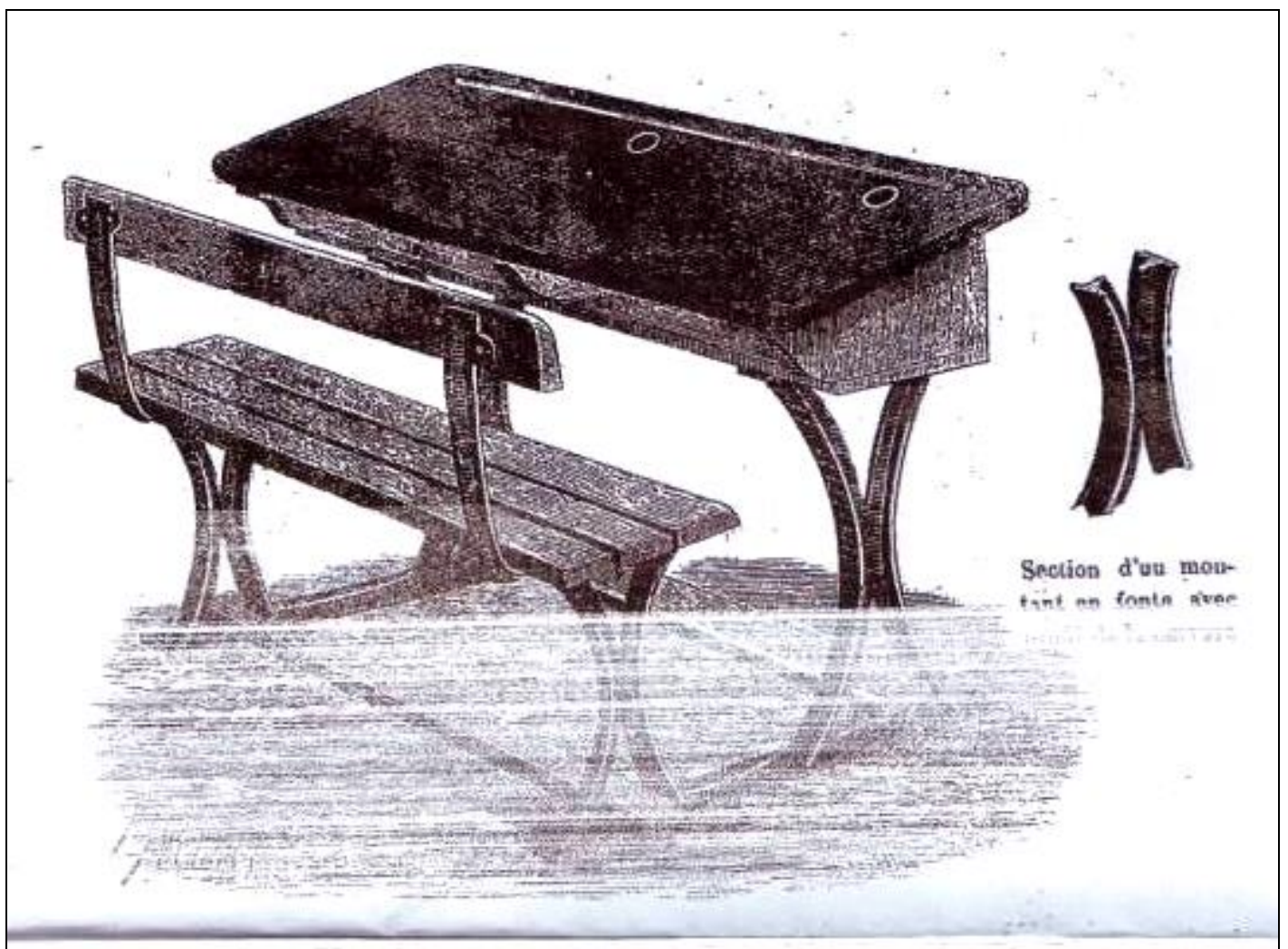

Fonte: GARCET \& NISIUS, 1882, p.9

Diferente da anterior, era fabricada com pés de ferro e custava 5 francs. a mais por assento. Com tampo articulado, a carteira para dois alunos seria 38 francs.

Figura 30 - Tampo articulado

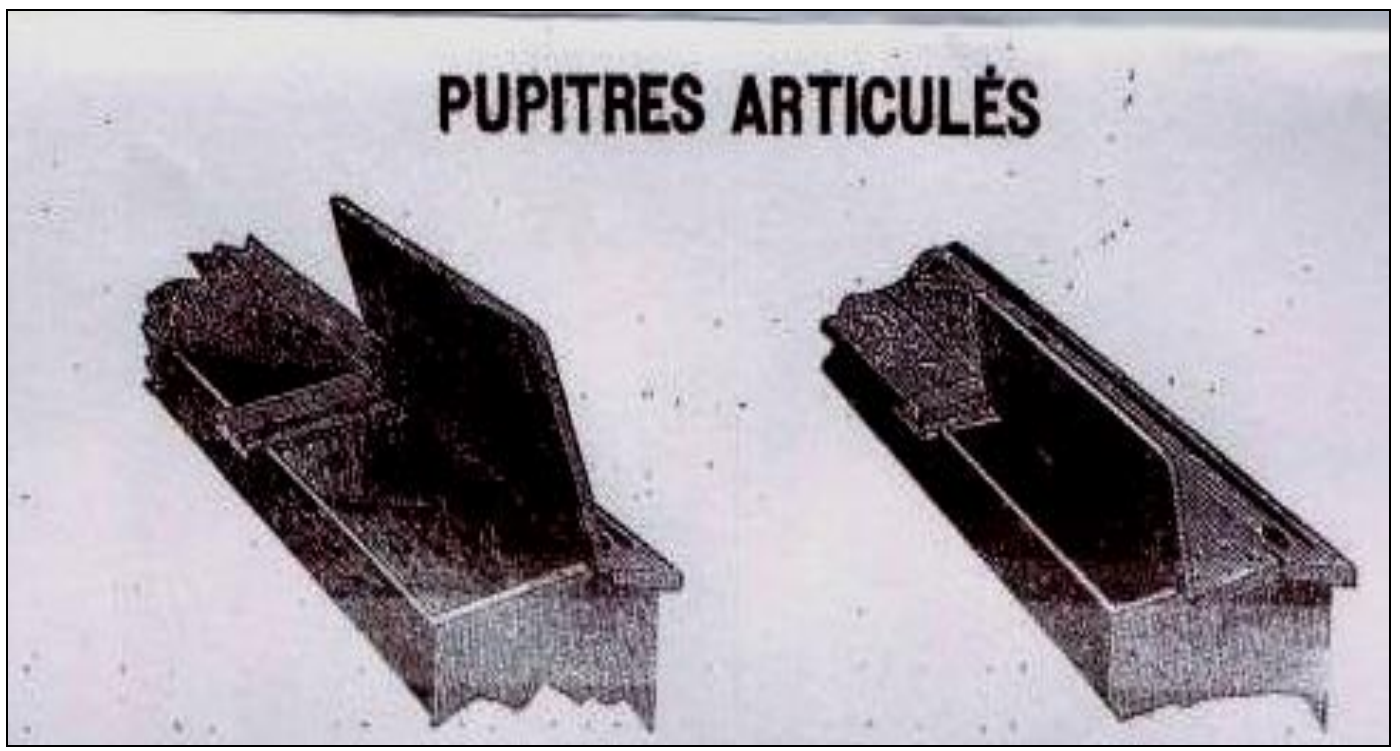

Fonte: GARCET \& NISIUS, 1882, p.11 
O tampo móvel ou articulado acrescia 4 francs ao preço total da carteira. Cada dispositivo ou tecnologia empregada fazia a mercadoria ficar mais cara e acessível a poucas escolas. Garcet \& Nisius receberam menção honrosa na Exposição de Paris, em 1878, e medalhas de prata, sendo duas em 1880 (Melun e Le Mans) e uma em 1881 (Tours), provavelmente, Exposições locais ou nacionais.

Para convencer o leitor e/ou cliente que as carteiras produzidas estão de acordo com o Regulamento de Jules Ferry, os construtores destacam nas páginas iniciais do Catálogo artigos do Règlement Ministériel du 17 juin $1880^{401}$. O Art. 90, por exemplo, estabelecia que a carteira deveria ser de um ou dois lugares; o art. 96 prescrevia que a distância entre o assento e a superfície de trabalho deveria ser nula ${ }^{402}$. O Regulamento de 1880 prescrevia, ainda, um espaço abaixo do tampo da mesa para guardar os livros (art.97) e um tinteiro móvel de vidro ou porcelana, adaptado à mesa e colocado à direita do aluno (art.98).

Atender a cada um destes quesitos tornava o custo final do produto mais elevado para o cliente, o que poderia transformar algumas carteiras, premiadas por satisfazer diversas exigências higiênicas, em objeto de contemplação nas Exposições e não em objeto da escola. No Rio de Janeiro, Garcet \& Nisius receberam diploma de honra "pelos moveis que expos para escolas maternaes, fabricados segundo as prescrições regulamentares do governo francês, de 2 de agosto de 1881 ",403.

Inglaterra foi o país que enviou maior quantidade de móveis escolares. Da fábrica inglesa Geo, M. Hammer \& Cia, fundada em 1858, se encontravam na Exposição um modelo de banco-carteira do sistema Moss, um modelo Phoenix (patenteado), um modelo Moss para jardim de infância, um banco-carteira com estante para livros, um modelo para meninas, um modelo de caixa dupla, a carteira individual Louise, a carteira conversível Osborne, uma mesa pedestal para professor (combinação de mesa e armário com gavetas), uma carteiras com armário para professor, uma carteira para adjunto contendo um armário com porta, bancos de escola com pés de ferro fundido, tinteiros e tampos, bule de tinta, porta-canetas, gancos e cavaletes para mapas, cavaletes para pedras, pedras móveis e fixas. Esta casa comercial de Londres recebeu diploma de honra "pela variedade de modelos de moveis que expoz para

\footnotetext{
${ }^{401}$ Regulamento Ministerial de 17 de junho de 1880.

${ }^{402}$ Idem,p.1 - ART. 90. - Les tables-bancs seront à une ou deux places, mais de préférence à une place. ART. 96. - La distance entre le banc et la tablette sera nulle, c'est-à-dire que la verticale tombant de l'arête de la table rencontrera le bord antérieur du banc.

${ }^{403}$ RIO DE JANEIRO, Exposição Pedagógica, 1883. Conferências effectuadas na exposição pedagógica. Rio de Janeiro: Imprensa Nacional, 1884, p.76.
} 
escolas primarias e da infância, professores, adjuntos, e vários accessorios de uma classe, e nos quaes se acham attendidos vários preceitos de hygiene" ${ }^{\text {} 404}$.

Outra fábrica de Londres, $H \&$ \&. Edwards, fundada em 1823, expôs dois modelos de carteira, mesa para professor e adjunto, banco conversível e banco para igreja. "Foram também expostos - cavalletes para desenho, e para pedras fixas, pedras moveis, tinteiros e porta-tinteiros; mas a commissão não os descreverá, por serem semelhantes aos da fabrica Hammer \& Cia" ${ }^{, 405}$.

$\mathrm{Na}$ diversidade de produtos ingleses havia também objetos de lavatórios e privadas das escolas primárias.

O lavatório é uma peça com bacias de louça, que se póde collocar junto a uma parede qualquer; é munido de torneiras para água e de esgoto para cada bacia.

O urinário é uma peça de ferro, barro cozido e lousa, que póde ser completamente armada e desarmada, e é feita de fórma a occupar uma pequena área com 3 compartimentos.

As latrinas são preparadas para serem completamente inodoras por um modo especial em que empregam os grandes pactos d'agua. Infelizmente a commissão expositora não recebeu todas as peças destes apparelhos ${ }^{406}$.

A Casa $H \& G E d w a r d s$ recebeu diploma de honra "pela moblia que expoz para alumnos, professores e adjuntos; pelos quadros de historia natural" ${ }^{\text {"407 }}$. Estes, não receberam apreciação da comissão do grupo 3, Mobília Escolar, por não comporem a categoria.

A comissão se delongou na análise da mobília americana. Parecia haver uma expectativa da comissão quanto às carteiras enviadas pelos Estados Unidos. De acordo com os avaliadores, a exposição americana de mobília escolar estava incompleta, pois

não se póde, pelo que foi exposto, fazer ideia da variedade immensa que os Estados-Unidos têm imaginado em assumpto de mobília com apropriação ás escolas de differentes categorias, que alli existem, e é isto tanto mais de lastimar, quanto é sabido que foi aquella poderosa e colossal nação, que inaugurou, com os conselhos de Bernard, a reforma no material escolar ${ }^{408}$.

Há duas caracterísitcas distintivas da mobília americana que, no entendimento da comissão, já eram conhecidas do Brasil: "o emprego do ferro fundido em toda a sua

\footnotetext{
${ }^{404}$ Idem, ibidem.

${ }^{405}$ Idem, p. 37

${ }^{406}$ Idem, ibidem.

${ }^{407}$ Idem, p.77.

${ }^{408}$ Idem, p. 38.
} 
armação, entrando a madeira para formar o tampo da mesa, a pequena estante sobre a mesa, e o assento e encosto dos bancos" $" 409$ e "o encosto do banco de um alumno forma as costas da carteira de outro" ${ }^{\natural 10}$.

O relatório da comissão é tão favorável à mobília americana a ponto de afirmar que ela vai "além dos limites que a hygiene prescreve"411. Para a comissão, isso se revela nos detalhes dos móveis.

Incontestavelmente toda a mobília escolar americana é feita com um cuidado particular, desde o banco-carteira até a pedra ou quadro ardosiado e a própria esponja para esta pedra: acha-se no menor detalhe a applicação do útil e do confortável [...] Os educadores, nos Estados Unidos querem, conforme diz Braun, que o alumno se ache na escola tão commodamente instalado, tão independente, como na sua própria casa, como si elle se sentisse realmente em sua residência ${ }^{412}$.

O conforto também é proporcionado pela carteira individual - "ultima palavra do progresso em moveis escolares do systema americano"413. Apesar do predomínio americano no mercado de carteira escolar somente uma empresa participou da Exposição Pedagógica do Rio de Janeiro, em 1883.

A Casa Baker, Pratt \& Comp., de Nova York, expôs três modelos: 1) The National folding-seat desk, uma carteira individual fabricada em cinco categorias. A n.1, para alunos entre 14 e 20 anos; a n.2, para alunos entre 12 e 14 anos; a n.3, para alunos entre 10 e 12 anos; a n.4, para alunos entre 8 e 10 anos; a n.5, para alunos entre 4 e 8 anos. 2) The Triumph School Desk, premiada na exposição de Paris de 1878, "tem a vantagem de uma armação de ferro com madeira, a mais forte, compacta e duradoura, que se tenha até o presente imaginado" ${ }^{414}$. 3) The new folding-lid study-desk, diferencia-se das demais por ter o tampo móvel, "prestando-se assim á leitura" ${ }^{415}$. A Casa recebeu premiação no Rio de Janeiro "pela engenhosa mobilia que expoz, denominada - the National folding-seat desk"416.

A Suécia expôs um único modelo classificado pela comissão como "digno de nota", por três razões. Era feito todo em madeira, de um só lugar e atendia às prescrições higiênicas a respeito da distância entre o banco e a carteira. Como todos os

\footnotetext{
${ }^{409}$ Idem, p.39.

${ }^{410}$ Idem, ibidem.

${ }^{411}$ Idem, ibidem.

412 Idem, ibidem.

${ }^{413}$ Idem, ibidem

${ }^{414}$ Idem, p.40

415 Idem, ibidem.

${ }^{416}$ Idem, p. 76.
} 
outros países, a Suécia recebeu menção honrosa. Somente a Alemanha não recebeu nenhuma premiação, apesar dos quatro modelos de carteira exibidos. De acordo com a comissão "toda essa mobília é composta de differentes peças moveis", o que gera dois incovenientes: São

motivos de distracção, e póde ser causa de magoar os dedos de um dos alumnos que ocuppam o móvel; os bancos são também moveis, e recuam com qualquer impulso, mas são mais do que as carteiras, motivos de distracção para os alumnos como por exemplo, pondo-os em movimento só para produzirem o choque de encontro ás travessas do movel $^{417}$.

A crítica da comissão recaiu sobre o excesso de movimento das peças. Dentre os expositores brasileiros, somente o Colégio Abílio não recebeu menção honrosa. $\mathrm{O}$ referido colégio expôs carteiras americanas singulares. No parecer da comissão, "o sistema mobiliar deste importante colégio é todo americano, e os seus diretores não cessam de adquirir e realizar todos os melhoramentos que a experiência aconselha" ${ }^{\natural 18}$.

Alguns brasileiros expuseram carteiras de fabricação própria, outros, exibiram carteiras adaptadas de modelos estrangeiros. Ainda houve quem apresentasse os móveis utilizados em suas escolas e colégios, porém, fabricados por outras empresas.

Duas profesoras receberam menção honrosa "pelo móvel escolar que fez construir" - D. Amalia Justa dos Passos Coelho e Silva ${ }^{419}$ e D. Octavia Emilia Coelho e Silva $^{420}$. Um professor, Gustavo José Alberto, foi premiado "pelos dois moveis conversíveis que fez construir" ${ }^{\prime 421}$.

As fábricas de móveis que compareceram foram: Fabrica de Moveis de Manoel Monteiro Bentim \& Irmão ${ }^{422}$, cujo banco-carteira era de "muito luxo, perfeitamente trabalhado", mas não preenchia, do ponto de vista da comissão, as "condições hygienicas e classicas do movel”. O Dr. Carlos Dr. Carlos Augusto de Carvalho, expresidente da província do Paraná, tornou-se fabricante de móveis para as escolas públicas de Curitiba. Para a comissão, tratava-se de um homem ilustrado com "ampla e variada esphera de conhecimento" 423 , que iniciou e promoveu "a reforma no antiquado

\footnotetext{
${ }^{417}$ Idem, p.38

${ }^{418}$ Idem, p.41

${ }^{419}$ Idem, p.86

${ }^{420}$ Idem, p.87

${ }^{421}$ Idem, p.89

422 Conforme o Almanak Administrativo, Mercantil e Industrial do Rio de Janeiro, do ano de 1898, p.1498, tratava-se de uma fábrica de móveis à vapor.

${ }^{423}$ Idem, p.44
} 
systema mobiliar" em uso no Paraná. Ele foi premiado "pelo banco-carteira de dois lugares" ${ }^{, 24}$. O móvel tinha as seguintes caracterísitcas:

O movel, que imaginou e fez executar, é de dous logares, de pinho, tenho a mesa e o banco moveis, de sorte a adaptal-os á estatura dos alumnos. Os dous bancos estão separados, e por isso no seu intervallo se colloca uma escarradeira.

A commissão conforme mostrou, é contraria á mobilidade das peças dos moveis escolares, salvo quando ellas tenham de prestar-se a certos fins especiaes. Não deixa, porém, de apreciar os louváveis esforços do expositor em beneficio da instrucção primaria ${ }^{425}$.

Um terceiro fabricante foi Dulcerio José Machado, conhecido pela construção de bancos-carteira "segundo o systema americano e adoptados nas escolas publicas da Provincia do Rio de Janeiro, conforme annuncia o seu constructor" ${ }^{\text {" } 26}$.

A atividade econômica desenvolvida pelos expositores põe em evidência os sujeitos interessados e envolvidos no mercado de carteira escolar. São poucos os professores e professores, em número de três. São três os industriais com fabricação própria de móveis escolares. Entre os importadores de objetos escolares estavam duas livrarias: Livraria Faro \& Lino e a Livraria Alves \& $C^{a}$.

A Livraria Faro \& Lino, por exemplo, expôs "vários moveis escolares da fabrica Hachette \& Comp. de Paris, como sejam: 1 banco-carteira sistema Cardot" ${ }^{\circledR 27}$, mesa Hachette para desenhar, mesa do adjunto do professor, dentre outros. A Casa recebeu premiação "pelos modelos de mobília Hachette, Cardot, de Paris para jardins de infância" 428 .

O modelo Cardot foi lançado na Exposição Universal de 1873, em Viena. "Este ex-prefeito do XX distrito de Paris propôs um mobiliário com mesa móvel e assento fixo" 429 .

\footnotetext{
${ }^{424}$ Idem, p.77.

${ }^{425}$ Idem, p.43

${ }^{426}$ Idem, p.44

${ }^{427}$ Idem, p. 41

${ }^{428}$ Idem, p.89

${ }^{429}$ PEYRANNE, 2001, p.136 - Cet ancien maire du $\mathrm{XX}^{\mathrm{e}}$ arrondissement de Paris propose um mobilier à table mobile et assise fixe.
} 
Figura 31 - Modelo Cardot proposto em Paris

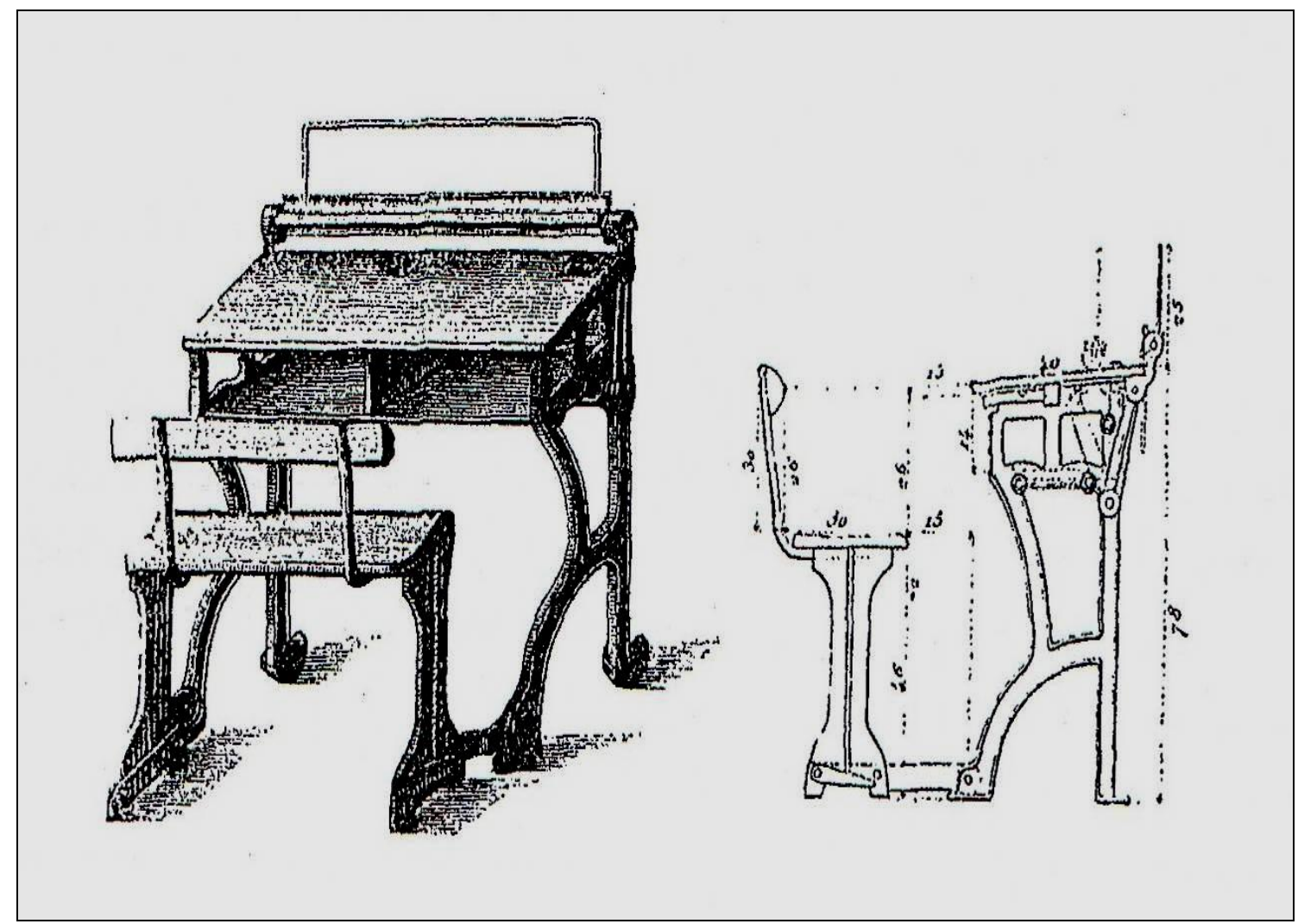

Fonte: Peyranne, 2001, p.136

A superfície de trabalho em posição elevada servia para desenhar; em posição semi-elevada, para colocar o livro de leitura; em posição rebatida, fecha os tinteiros.

A Livraria Alves \& $C^{a}$, "este antigo e conhecido estabelecimento de livros classicos" ${ }^{430}$, apresentou outras carteiras em uso na França, conhecidas nas Exposições Universais. Eram os modelos de M. Bapterosses e "de M. André, constructor em Neuilly, e baseado em uma disposição, que já havia sido tentada por Mlle. Lecour e Cardot em 1873"431.

O modelo Bapterosses foi o mais notável da Exposição Universal de 1873, em Viena. Segundo Peyranne, em seu relatório, Buisson o qualificou como o teste mais satisfatório dos países europeus e o júri o premiou com o diploma de mérito.

\footnotetext{
${ }^{430}$ Idem, p.43

${ }^{431}$ Idem, ibidem
} 
Figura 32 - Modelo de mesa-banco Bapterosses

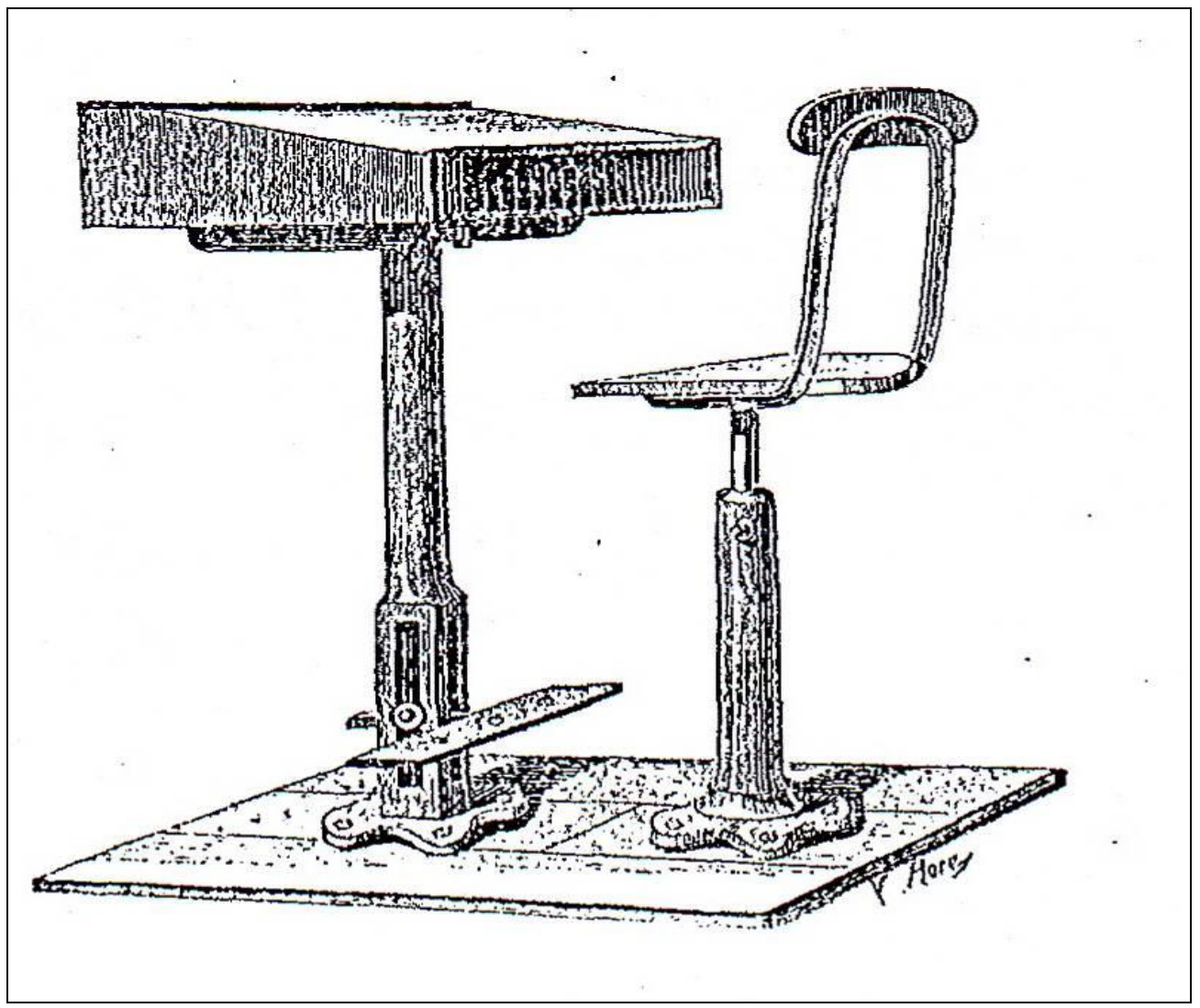

Fonte: Riant, 1874, p.157; Peyranne, 2001, p.137

Como se vê, a mesa fixa é acompanhada de um banquinho regulável em altura. “Os pés da mesa e do banco são de ferro [...] O apoio para os pés é um patim de ferro montado sobre um eixo de suporte, ele desliza em um revestimento igualmente bloqueado para parafuso [...] Só o mestre possui a chave especial para regular o assento" 432 .

Entre os modelos de carteira reguláveis e adaptáveis a todos os tamanhos destaca-se o modelo "apresentado por Bagnaux em sua conferência sobre o mobiliário da classe em 1878. Projetado por André, construtor de Neuilly, este modelo possui uma mesa fixa e um assento móvel [...]",433.

\footnotetext{
${ }^{432}$ PEYRANNE, op. cit. p.136 - "Les pieds de la table et du tabouret sont em fonte [...] L'appui pour les pieds est un patin de fonte monté sur une tige-support, il glisse dans un fourreau également bloqué par vis [...] Seul le maître possède la clef spéciale pour régler le siège”.

433 "presente par Bagnaux dans as conferénce sur le mobilier de classe en 1878. Conçu par André, constructeur à Neuilly, ce modèle possède une table fixe et une assise mobile" (PEYRANNE, 2001, p.165).
} 
Figura 33 - Carteira modelo André

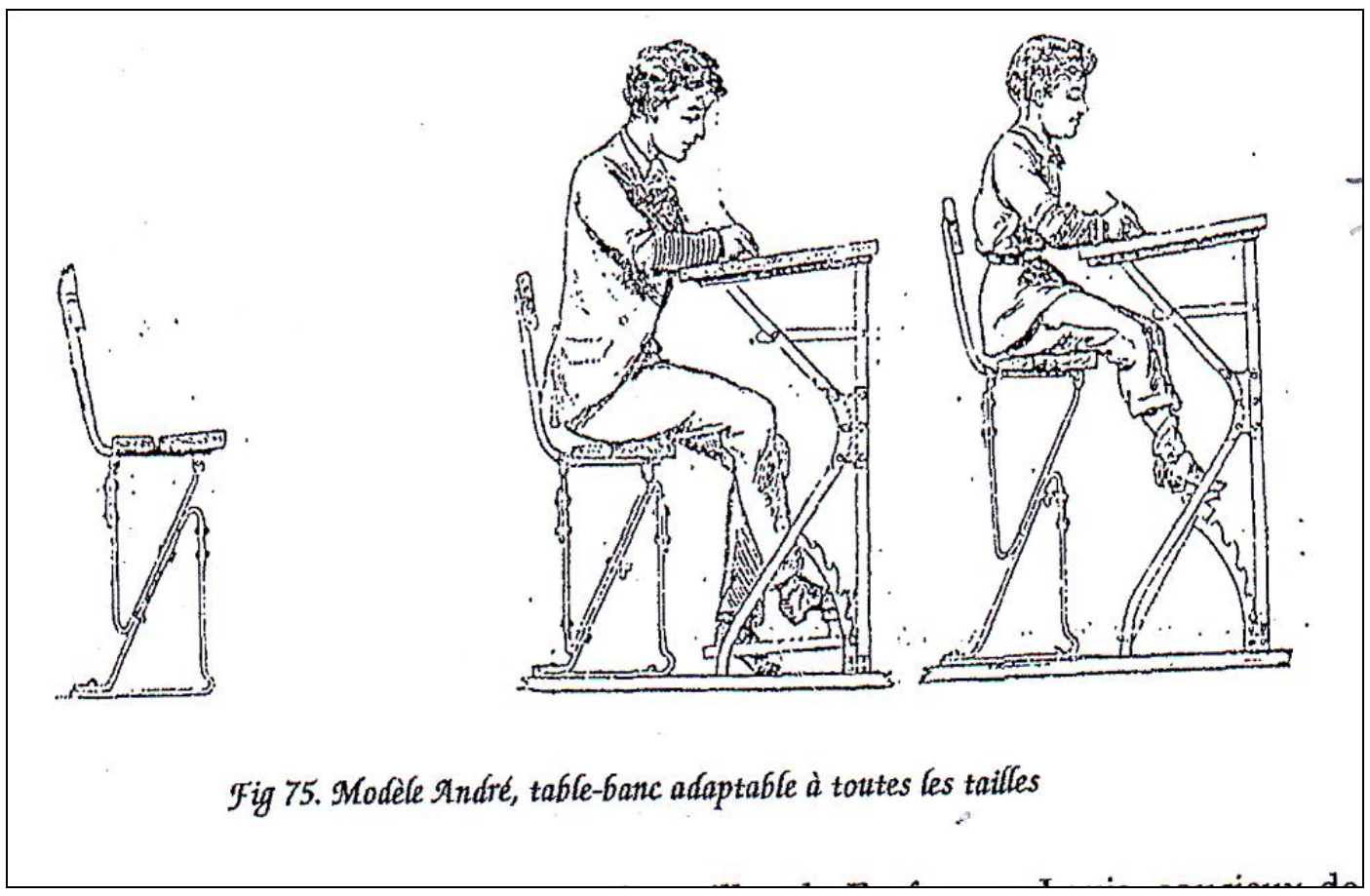

Fonte: PEYRANNE, 2001, p.165 e Revue Pedagogique, 1879, p.132

Outra qualidade do modelo era o apoio para os pés que tinha a finalidade de evitar os problemas circulatórios ${ }^{434}$. É o próprio De Bagnaux que publica um resumo de sua "conferência sobre o mobiliário escolar em 1878 "435 na Revue Pedagogique de 1879 e afirma que "A carteira André, que é preferível a todos as outras, na qual o princípio é o mesmo, poderia ao contrário ser adotada utilmente nas classes onde os alunos tenham idade para ajustar eles mesmo a sua altura"436.

Por fim, há dois diretores e proprietários de instituição de ensino, Menezes Vieira e o diretor do Externato Silva Ramos, não nomeado no documento. Este último, não parece ter chamado a atenção da comissão para quem "os moveis expostos por este estabelecimento não têm todas as condições essenciais d'uma mobília escolar, entretanto mostram os esforços empregados pelo seu director em realisar os melhoramentos, que tem soffrido o material escolar" ${ }^{\natural 37}$.

\footnotetext{
${ }^{434}$ PEYRANNE, op. cit.

${ }^{435}$ Idem, p. 165

436 "La table André, qui est préférable à toutes les autres tables dont le príncipe est le même, pourrait au contraire être adoptée utilement dans des classes où les eleves seraient assez âgés pour l'ajuster euxmêmes à leur taille" (DE BAGNAUX. Le mobilier scolaire. Revue Pedagogique, 1879, p.132)

${ }^{437}$ Revue Pedagogique de 1879, p.44
} 
Menezes Vieira destacou-se com a exibição de 5 móveis. Uma mesinha e cadeirinha para aluno do jardim da infância, “imitação do modelo Bapterosses ${ }^{438}$ [...] com modificações introduzidas pelo distinto diretor do Colégio" ${ }^{439}$. Mesa e banco para dois alunos do jardim, modelo Hachette; Carteira e banco para dois alunos semelhante ao modelo Triumph dos Estados Unidos; "Mesa com tampo quadriculado para um alumno do jardim, modelo e fabrico norte-americano" "440; e, "bancos-carteiras americanos comunos" ${ }^{\prime 41}$. A adaptação de material e mobiliário escolar era uma marca do trabalho de Menezes Vieira ${ }^{442}$.

Menezes Vieira, além da menção honrosa "pelos moveis que fez construir, segundo seu plano para os jardins da infância"443, recebeu o diploma de Primeira Classe. Dentre outros produtos, ele expôs tinteiros e móveis ${ }^{444}$. A despeito de se tratar de um Colégio no Rio de Janeiro e, não em São Paulo, vale destacar a participação do seu proprietário e diretor, Menezes Vieira, nas exposições nacionais e internacionais. Como educador, diretor do Pedagogim e homem de negócios ele adaptou e, fez no circular no Brasil, material e mobiliário escolar de fabricação estrageira e exposto nas grandes feiras universais ${ }^{445}$.

De acordo com Bastos, ele envia trabalhos

à Exposições Universal de Buenos Aires (1882); da Antuérpia (1883);

à Exposição Internacional de Higiene e Educação, realizada em Londres em 1884 [...] Na Exposição Universal de Paris em 1889, Menezes Vieira teve uma participação significativa. No catálogo oficial do Brasil na Exposição Universal, consta como membro da comissão brasileira de estudos. Na lista de delegados estrangeiros, seu nome aparece como diretor da Escola Normal do Rio de Janeiro ${ }^{446}$.

\footnotetext{
${ }^{438}$ Ver o modelo na página 130.

${ }^{439}$ RIO DE JANEIRO, Exposição Pedagógica, 1883. Conferências effectuadas na exposição pedagógica. Rio de Janeiro: Imprensa Nacional, 1884, p.41.

${ }^{440}$ Idem, ibidem.

${ }^{441}$ Idem, ibidem.

${ }^{442}$ A esse respeito ver VIDAL, Diana Gonçalves. O museu escolar brasileiro: Brasil, Portugal e a França no âmbito de uma história conectada (final do século XIX). In: Rogério Fernandes; Alberto Lopes; Luciano Mendes de Faria Filho. (Org.). Para a compreensão histórica da infância. 1ed.Porto: Campo das Letras, 2006, v. 1, p. 239-264.

${ }^{443}$ RIO DE JANEIRO, Exposição Pedagógica, 1883. Conferências effectuadas na exposição pedagógica. Rio de Janeiro: Imprensa Nacional, 1884, p.77.

444 BASTOS, Maria Helena Camara. Pro Patria Laboremus: Joaquim José de Menezes Vieira (18481897). Bragança Paulista: EDUSF, 2002, 350p.

${ }^{445}$ Sobre o assunto ver: VIDAL, Diana Gonçalves . O museu escolar brasileiro: Brasil, Portugal e França no âmbito de uma história conectada (final do século XIX). In: LOPES, FARIA FILHO, FERNANDES. (Org.). Para a compreensão histórica da infância. Belo Horizonte: Autêntica, 2007, v. 1, p. 199-220.

${ }^{446}$ Idem, p. 47.
} 
No Rio de Janeiro (1883), apesar de representar um Colégio brasileiro, ele “expôs relativamente à lição de coisas e à ornamentação escolar uma variedade de material estrangeiro" 447 .

A primeira pesquisa sobre a Exposição Pedagógica de 1883 é feito por Therezinha Collichio. Segundo ela, a exuberância da Exposição entra em conflito com "a pobreza das instituições escolares e a desorganização do sistema de ensino no período" 448 .

A pretensão de realizar um Congresso da Instrução evidencia o interesse de “integrar o Brasil na modernidade liberal”, vulgarizar as modernidades educacionais e os conhecimentos ${ }^{449}$, tendo por base sociedades de referência como os Estados Unidos, França, Inglaterra, Belgica, Áustria, dentre outros.

No evento chama a atenção a ausência de expositores paulistas ou mesmo de outros estados. Havia somente professores, diretores de escola e negociantes cariocas e um fabricante paranaense.

Como mostrarei no Capítulo 4, a Eduardo Waller, maior fábrica paulista de móveis escolares, só foi criada em 1896. Pelo que se sabe até aqui, a primeira patente de carteira escolar no Brasil, foi concedida a Amando de Araújo Cintra Vidal, em 1889. A partir desse ano, até o ano de 1907, localizei vinte pedidos de privilégio para carteira escolar, evidenciando que, nas duas últimas décadas do século XIX, há uma efervescência no mercado de mobiliário escolar.

É possível que a Exposição Pedagógica do Rio de Janeiro tenha tornado mais visível aquilo que só os que podiam visitar as Exposições Universais sabiam - fabricar e vender carteiras e objetos escolares era um negócio rentável. Isso porque as Exposições Nacionais aproximam, para uma parcela da população, o que só se vislumbrava de longe nas Exposições Universais. Elas são, de um lado, "veículo para instruir (ou industriar) as massas sobre os novos padrões da sociedade industrial" ${ }^{450}$; e, de outro, "fórum para atividades comerciais ligadas à indústria"451.

Nem todos os professores, diretores de escola, e mesmo negociantes, poderiam ter acesso às "materializações de uma visão de mundo que se quer, conscientemente,

\footnotetext{
${ }^{447}$ Idem, p.71.

${ }^{448}$ COLLICHIO, Therezinha A. F. Dois eventos importantes para a História da Educação Brasileira: a Exposição Pedagógica de 1883 e as Conferências Populares da Freguesia da Glória. Revista da Faculdade de Educação/USP. São Paulo, 13(2):5-14,jul/dez.1987, p.6

${ }^{449}$ BASTOS, 2002, p.153

${ }^{450}$ BARBUY, H. A Exposição Universal de 1889 em Paris: visão e representação na sociedade industrial. 1. ed. São Paulo: Loyola / História Social USP, 1999. v. 1. , P.17

${ }^{451}$ Idem, ibidem.
} 
difunfir " 452 nas Exposições Universais. Assim, as Exposições Nacionais trazem para mais perto as questões higiênicas, pedagógicas, técnicas e econômicas que subjazem à presença dos novos e modernos objetos escolares.

A difusão, por meio das Exposições, desses valores e conhecimentos acerca do novo universo material que invadiu a escola no fim do século XIX, contribuiu para a proliferação de indústrias e empresas dedicadas à fabricação e comercialização de objetos escolares. Quando, porém, a produção interna não atendia às necessidades cada vez crescentes da escola moderna, foi preciso recorrer a outros meios para equipá-la. Sobre eles tratarei no capítulo seguinte.

${ }^{452}$ Idem, ibidem. 


\section{CAPÍTULO 3 MODERNIDADE A TODO VAPOR}

A proveniência da carteira escolar está intimamente relacionada à facilitação das viagens transcontinentais. Os vapores se tornam elementos fundamentais para circulação de pessoas e objetos. As Exposições Universais da segunda metade do século XIX só podem ser "Universais" na proporção em que pessoas de todo o mundo podem chegar até elas e levar os produtos de seus respectivos Estados. Para Margarida Neves as exposições são "universais na medida em que esses são os países [países da Europa Ocidental e Estados Unidos] portadores dos valores do progresso" "453. Além disso, elas foram "manifestações da universalidade das mudanças na técnica e na ciência, na cultura e na arte, na política social e nas relações internacionais" $" 454$.

Na acepção de Maria Inez Turazzi, “o que conferia universalidade às exposições [...] era não só o seu caráter internacional, mas, sobretudo, a sua abrangência, pois as exposições francesas iriam englobar, além da indústria e agricultura, as belas-artes ${ }^{455}$.

O "desejo de modernidade" significava, de acordo com Neves, "viabilizar uma nova ordem presidida pelos valores do progresso e da civilização" ${ }^{456}$. As exposições "constroem a ilusão do progresso como realidade tangível para aqueles que as visitam ou delas têm notícias através da imprensa" 457 . Enquanto "enciclopédia em ação", elas deveriam "compendiar as realizações do engenho humano e finalmente divulgar entre todos os povos o que de melhor produzira o espírito e o trabalho dos povos civilizados $" 458$.

Tudo isso, no entanto, não eliminava os interesses comerciais daqueles que visitavam e expunham os seus produtos. Conforme assevera Heloisa Barbuy, elas são "fórum para atividades comerciais ligadas à indústria", mas também "vão muito além disso e propõem-se como formas poderosas de educação doutrinária", visto que "se constroem como verdadeiras materializações de uma visão de mundo que ser quer,

\footnotetext{
${ }^{453}$ NEVES, Margarida de Souza. As vitrines do progresso: o conceito de trabalho na sociedade brasileira na passagem do século XIX ao século XX; a formação do mercado de trabalho na cidade do Rio de Janeiro. Rio de Janeiro, 1986, p.26

${ }^{454}$ Idem, p.33

${ }^{455}$ TURAZZI, Maria Inez. A euforia do progresso e a imposição da ordem: a engenharia, a indústria e a organização do trabalho na virada do século XIX ao XX. Rio de Janeiro: COPPE; São Paulo: Marco Zero, 1989 , p.56

${ }^{456}$ NEVES, op. cit. p.17

${ }^{457}$ Idem, p. 18

${ }^{458}$ Idem, p.41
} 
conscientemente difundir" ${ }^{\text {"459 }}$. Receber uma medalha e reconhecimento do júri internacional equivalia a um certificado de qualidade do produto, da supremacia da casa comercial, indústria ou empresa.

Os objetos expostos eram submetidos a uma avaliação realizada por um corpo de jurados internacional, e os expositores condecorados com medalhas e diplomas de honra [...] A medalha de ouro em uma Exposição passou a representar um certificado internacional de qualidade para referendar a comercialização dessas mercadorias" $" 460$

Na nota de compra ${ }^{461}$ dos materiais importados pela Escola Normal da Capital, em 27 de abril de 1894, da Casa Paul Rousseau e Cie, de Paris, há diversas referências à participação dessa fábrica de material escolar nas Exposições Universais. Segundo Bandeira Junior “[...] o industrial faz questão de collocar em logar de honra os diplomas das Exposições e Comicios Industriais" ${ }^{462}$.

Há na cártula da nota de compra uma marca vermelha de carimbo (impressão colorida) informando que a empresa foi hors concurs e "Membro do juri (classe 45) 463 ", na Exposição Universal de 1889 em Paris. Também recebeu medalha de ouro na Exposição de Higiene do Havre, em 1887; diploma de honra na Exposição Internacional de Toulouse, em 1887; medalha de prata na Exposição de Cerveja Francesa, em 1887; medalha de ouro na Exposição de Higiene Naval do Havre, em $1887^{464}$. O empresário era "árbitro especialista do Tribunal do Comércio do Sena, Oficial da Instrução Pública e cavalheiro da Ordem da Rosa do Brasil" ${ }^{\prime 465}$.

A modernidade estava representada tanto nos objetos adquiridos pela escola e ofertados pelas empresas, quanto nos modos como os materiais eram comercializados e chegavam à escola.

\footnotetext{
${ }^{459}$ BARBUY, Heloisa. A exposição universal de 1889 em Paris. São Paulo: Edições Loyola, 1999. Série Teses, p.17

${ }^{460}$ KUHLMANN JÚNIOR, Moysés. As grandes festas didáticas - a educação brasileira e as exposições internacionais (1862-1922). Bragança Paulista: Editora da Universidade São Francisco, 2001. (Coleção Estudos CDAPH. Série Historiografia), p.26.

461 Anexo n. 3

${ }^{462}$ BANDEIRA JUNIOR, Antonio Francisco. A Indústria no Estado de São Paulo em 1901. São Paulo, Diário. Oficial, 1901, p. XIV.

${ }^{463}$ A classe 45 estava inserida no grupo V (Industries extractives, produits bruts et ouvrés) e compunha os "Produits chimiques et pharmacie", conforme Brigitte Schroeder-Gudehus e Anne Rasmussen: les fastes du progres: le guide des Expositions universelles, 1851-1992. Paris, Flammarion, 1992, p.116

${ }^{464}$ Fonte: APESP. Série Manuscritos. Secretaria do Interior. 3 ${ }^{a}$. Secção. Escola Normal - Caixa 530 - Ano 1892. Ordem 7135

${ }^{465}$ Fonte: APESP. Série Manuscritos. Secretaria do Interior. Escola Normal - Ano 1892. Caixa 530 Ordem 7135.
} 
A Companhia Paul Rousseau, especializada, sobretudo, na venda de instrumentos de física e produtos químicos ${ }^{466}$, teve um papel importante na modernização da rotina escolar pelo fornecimento de materiais que também ficavam em exposição permanente no Pedagogium ${ }^{467}$. Além disso, foi um importante fornecedor da Escola Normal de São Paulo. Há pelo menos três remessas de material da Paul Rousseau para aquela instituição de ensino ${ }^{468}$. Todas, vindas pelos vapores: California, Matapan e Bellanock ${ }^{469}$.

Os vapores identificados nos Ofícios e Correspondências da Escola Normal Caetano de Campos e da Secretária do Interior elucidam os países com os quais a administração pública paulista comercializava material e mobiliário escolar.

O vapor Ville de Ceará pertencente à "Chargeurs Reunis (Sociedade Anonima) Companhia Francesa de Navegação a Vapor", com "serviço regular para o Brazil e Rio do Prata pelos vapores de $1^{\text {a }}$ classe ${ }^{\natural 70}$, dentre eles, o Ville de Ceará, Entre-Rios, Corrientes e Sully ${ }^{471}$. Todos transportaram encomendas direcionadas à Escola Normal de São Paulo. Aos sábados, os vapores partiam do Havre para Lisboa, Pernambuco, Maceió, Bahia, Rio de Janeiro e Santos.

O vapor Bellanock compunha a frota da Companhia "Lamport \& Holt Line Liverpool, Brazil, River Plate Steamers"472. Possuía "serviço quinzenal de vapores rápidos para carga [...] de Glasgow, Manchester e Liverpool para os portos do Brazil»"473. Também realizava serviço separado e quinzenal de carga de Antuérpia e Londres. Califórnia, pertencente à "Chargeurs Reunis (Société Anonyme) - Compagnie Française de Navigation a Vapeur”, com partidas de Paris e Havre, em direção ao porto de Santos.

O vapor Matapan fazia parte da "Comp. Messageries Maritimes", com sede em Paris. Os vapores Port Darwin e Euclid, dos quais não localizei mias informações, eram proveniente dos Estados Unidos.

\footnotetext{
${ }^{466}$ Almanak, 1895, p. 1705

${ }^{467}$ Almanak, 1896, p.1330

${ }^{468}$ Anexos n. 4, n.5 e n.6

${ }^{469}$ Anexos n.7 e n.8

${ }^{470}$ Almanak, 1891, p. 1452

${ }^{471}$ Anexo n.9

${ }^{472}$ Anexo n.10

${ }^{473}$ Almanak, 1910, p. 1708
} 
De acordo com Carina Pedro, "a inserção de portos brasileiros nas rotas mundiais de navegação marítima se deu de forma gradativa ao longo do século XIX"474. Como marco temporal fundamental para essa inserção destaca-se o ano de 1808, quando se deu a abertura dos portos e o fim da exclusividade do comércio marítimo da colônia com a coroa portuguesa.

No caso paulista, foi na segunda metade do século XIX que o Porto de Santos começou a participar de forma mais intensa do comércio nacional e internacional ${ }^{475}$. O crescimento do Porto, nas três últimas décadas dos oitocentos, é atribuído por Carina Pedro às mudanças econômicas no mundo e, sobretudo, na Província de São Paulo ${ }^{476}$. A “ligação comercial entre São Paulo e Santos foi importante tanto para a manutenção do comércio de produtos ligados ao consumo interno como daqueles que se destinavam à exportação" ${ }^{477}$.

Tão expressiva se tornou essa ligação em torno do café que, a partir da última década do século XIX, "arrebata ao Rio sua posição hegemônica, tornando-se o grande eixo de comercialização do produto-rei da exportação brasileira"478. De acordo com Barros e Moizo,

a partir de meados do século XIX, o café passou a ser o mais privilegiado item da pauta de exportações brasileiras, favorecendo basicamente o porto do Rio de Janeiro por ser ele o maior escoadouro da produção cafeeira paulista. Com a inauguração da São Paulo Railway (1867), o centro de comercialização do produto se deslocou para a capital paulistana e região santista. Em 1886, a produção da Província foi de 10,3 milhões de arrobas, das quais 9,9 milhões foram exportadas pelo porto de Santos. O eixo São Paulo-Santos iniciava sua afirmação como o mais dinâmico da econômica brasileira ${ }^{479}$.

Essa expansão da economia cafeeira teve impacto no desenvolvimento, na cultura material e na vida urbana da cidade de São Paulo. A escola de massa e as transformações materiais pelas quais ela passou podem ser entendidas, ao mesmo tempo, como uma expressão e uma mola propulsora da vida e cultura urbanas. Isso

\footnotetext{
${ }^{474}$ PEDRO, Carina Marcondes Ferreira. Casas importadoras de Santos e seus agentes: comércio e cultura material (1870-1900). Dissertação de mestrado, Departamento de História da Faculdade de Filosofia, Letras e Ciências Humanas da Universidade de São Paulo. São Paulo, 2010, p.11.

${ }^{475}$ PEDRO, 2010.

${ }^{476}$ Cidades como Santos e São Paulo "passaram por diversas transformações economicas e sociais com a expansão da produção de café na segunda metade do século XIX" (PEDRO, 2010, p.16).

${ }^{477}$ Idem, p. 17.

${ }^{478}$ SINGER, Paul. Desenvolvimento econômico e evolução urbana. São Paulo: Editora Nacional/Editora da Universidade de São Paulo, 1968, p.26.

${ }^{479}$ BARROS, Liliane Schrank Lehmann; MOIZO, Rosana Pires Azanha. Formação administrativa da cidade de São Paulo, 1554 - 1954. Revista do Arquivo Municipal, São Paulo, volume 199, 1991, p.35
} 
porque a escola não somente se beneficiou da possibilidade de importação de material e mobiliário, mas também porque passou a demandar novas mercadorias movimentando a economia. Assim, modernidade educativa e modernização da cidade podem ser tomadas como vias de mão dupla.

Na perspectiva de Cezar Honorato, embora haja muitos e excelentes trabalhos sobre a modernização trazida pelas ferrovias, o mesmo não acontece com os portos.

O processo jurídico-político necessário ao surgimento de um complexo portuário coerente com a articulação do Brasil às economias centrais capitalistas, as dificuldades para a montagem de empresas concessionárias dos serviços portuários, as opções tecnológicas, o próprio movimento portuário, etc., particularmente no Império, não são contemplados com destaque na historiografia econômica nativa, embora seja consensual o caráter de dependência da economia brasileira ao mercado internacional [...] É no período republicano que os portos nacionais foram modernizados, embora toda a estruturação jurídica imperial acerca do tema tenha sido mantida e aplicada pela nova ordem ${ }^{480}$.

A modernização dos portos também corrobora com a modernização da escola pela possibilidade de trazer, de outros países novos objetos e mateirias escolares. Segundo Honorato, “o porto no correr do Império, é bom que se diga, não passava de um conjunto desarticulado e mal construído de trapiches de madeira, onde encostavam as 'lanchas' que eram carregadas para levar os produtos até o navio que ficava fundeado ao largo"481. Foi o Decreto n.1.746 do ano de 1869 que autorizou "o Governo a contractar a construção, nos diferentes portos do Império, de dócas e armazéns para carga, descarga, guarda e conservação das mercadorias de importação e exportação"482.

Isso foi importante para a instrução pública, pois, não estando São Paulo equipado para a produção do mobiliário e do material escolar necessários à expansão do ensino, precisou, num primeiro momento, lançar mão de outro meio, a importação.

\subsection{Os caminhos da modernidade educativa - a proveniência da carteira escolar}

\footnotetext{
${ }^{480}$ HONORATO, Cezar T. O Estado Imperial e a modernização portuária. In: SZMRECSÁNYI, Tomás; LAPA, José Roberto do Amaral (orgs). História Econômica da Independência e do Império. São Paulo: Hucitec, 1996, v.2. p.161-176, p.161

${ }^{481}$ Idem, p. 167.

${ }^{482}$ Idem, p. 172
} 
Nos anos finais do século XIX, a escola assiste a uma profusão material cuja proveniência sinaliza os diversos caminhos percorridos em busca da modernidade educativa. A invenção da modernidade educativa se fez sentir na circulação internacional de modelos pedagógicos, sujeitos e objetos ${ }^{483}$. Essa "modernidade educativa" carregava a ideia de progresso que associava, segundo a autora, desenvolvimento científico e educativo à ampliação material escolar. Com isso, o Estado emerge como comprador de materiais escolares e a escola como mercado consumidor de móveis e objetos produzidos por uma indústria escolar ${ }^{484}$.

$\mathrm{Na}$ tentativa de propagar e expandir a escolarização à população infantil, a ampliação material não estava desvinculada da busca pela racionalização do ensino e da eficiência escolar - mesmo imaginário produtivo da revolução industrial. No entendimento de Diana Vidal, a indústria foi convocada a participar da obra de difusão do ensino e é por isso que uma indústria escolar floresceu alimentada pelo fenômeno da escolarização obrigatória.

Se o governo não dispunha de fábricas próprias para produção do material e do mobiliário escolar, se o pequeno comércio local não oferecia os novos objetos que se tornaram tão necessários aos Grupos Escolares e Escolas Modelo, era preciso acionar um conjunto de atores - viajantes, mediadores e tradutores culturais - e relações comercias internas e externas para criar as condições físicas dessa nova escola, cujos requisitos, iam se afastando do "mínimo necessário" anteriormente descrito.

No entanto, a despeito da propaganda e incentivo para adoção de um mobiliário moderno que se adequasse ao corpo dos alunos e lhes criasse posturas saudáveis, a uniformização das carteiras escolares não atingiu, simultaneamente, todas as escolas paulistas. Observando-se os inventários de bens da Escola Normal do Brás e da Praça da República, e mesmo os pedidos de móveis das escolas, percebe-se que, ainda no fim do século XIX, as modernas carteiras e os tão criticados bancos e mesas coexistiam na organização da sala de aula. Nas últimas décadas do século XIX, a ampliação material para garantir a eficiência escolar parecia ser possível somente via importação, como se observa na Correspondência do diretor da Escola Normal de São Paulo, Caetano de Campos, ao Presidente da Província, Jorge Tibiriçá:

\footnotetext{
483 VIDAL, DIANA Gonçalves. A invenção da modernidade educativa: circulação internacional de modelos pedagógicos, sujeitos e objetos no Oitocentos. In: CURY, Cláudia Engler; MARIANO, Serioja (orgs.). Múltiplas visões: cultura histórica no oitocentos. João Pessoa: Editora Universitária da UFPB, 2009. p. 37-54.

${ }^{484}$ VIDAL, 2009.
} 
Quadro 1 - Encomenda de material no exterior

\section{AO THESOURO DO ESTADO PARA INFORMAR COM URGENCIA SECRETARIA DO GOVERNO DE S. PAULO, 12 de fevereiro de 1891}

Diretoria da escola normal de São Paulo, em 7 de fevereiro de 1891

\section{À $1^{a}$. Secção}

Não é mais objeto de duvida para os espíritos esclarecidos que o ensino escolar não pode ser feito proficientemente sem o material indispensável à sua comprehensao - aquillo que é muito bem explicado pela palavra, é entretanto mal compreendido pelo alumno, enquanto este não ver a prova material do que diz o professor, ou não pode reproduzir por suas próprias mãos o que julga saber, por ter apprendido de oitiva.

Se em todas as casas de ensino o processo de intuição exigem um bom material escolar, em uma escola normal sobe de pronto essa necessidade, pois que ahi se ensina a professores, e a estes não é licito deixar de conhecer com perfeição tudo que deverão ensinar.

D'ahi provem a urgência de abastecer o nosso único estabelecimento de ensino para professores com um material profuso, e quiça superabundante, pois que não temos paizes visinhos, onde possamos ir buscar o que de momento nos falta.

Não é, porem, a superabundância o que tenho agora em vista: é o estritamente necessário. A reforma iniciada há um anno nada encontrou no edifício da escola. O que ali existe hoje foi pela maior parte obtido depois da reforma, principalmente na escola modelo, que foi creada do nada. Não foi possível iniciar os novos planos com todo o aperfeiçoamento desejável. Muitos dos objetos encomendados do estrangeiro não puderam vir; outros foram deixados de lado para quando melhor se conhecesse o fornecimento segundo as procedências; outros finalmente só foram julgados indispensáveis depois de iniciados os estudos e quando a pratica os reputou preciosos.

Venho hoje, pois, solicitar vosso patriótico apoio e indispensável authorisacao para proceder a acquisição dos objetos constantes da lista junta e a reparos e creação de algumas consumodidades nos edifícios da Escola Normal.

Poucos desses objetos attingem a um valor apreciável como despesa. São desse numero os pianos - que basta serem aceitáveis, embora com algum uso; o telheiro e algum material de gymnastica; a lanterna de projeção e um armário para colecções mineralógicas. Tudo o mais consiste em objetos de preço ínfimo, mas essencialmente indispensáveis, e que nem avultaria como despesa, se eu as pudesse mandar vir gradualmente por conta da verba do expediente. A distancia dos centros fornecedores, e a precisão de comprar para longo praso é que me aconselham fazer de uma vez um abastecimento mais abundante.

Escudado em vossa authorisacao em próprio me incumbirei de fazer as encomendas com escrupulosa economia para que, sobre as contas e faturas ao seo tempo apresentadas, ordeneis ao Thesouro o seu pagamento.

Lis para o que venho impetrar vossa solicitude e benevolência.

Saúde e Fraternidade

Ao ilustre cidadão

Dr. Jorge Tibiriça Piratininga

Digníssimo governador do Estado de S. Paulo

O diretor

Antonio Caetano de Campos

Fonte: APESP - Série Manuscrito - Escola normal de São Paulo; 1849-1855; 1886-1989/ Ordem -

5131. Grupo - Gestão Financeira; Série - Propostas orçamentárias (grifo meu). 
Os vários trechos que destaco na correspondência do diretor da Escola Normal indicam os anseios materiais das escolas modelares nos anos iniciais da República. A satisfação de todos esses anseios não poderia se dar nem no mercado local, nem nos países vizinhos. Era na Europa ou nos Estados Unidos que a escola paulista ia buscar o que lhe faltava para "iniciar os novos planos com todo o aperfeiçoamento desejável". Todavia, encomendar objetos "do estrangeiro", no fim do século XIX, não era tão simples.

A distância dos centros fornecedores trazia, pelo menos, três problemas: a) o valor do frete e encaixotamento; b) a diferença de câmbio; c) o volume, a fragilidade ou peso dos materiais, todos estes fatores encareciam a encomenda podendo ser um entrave para equipar e modernizar a escola.

No orçamento que o diretor da Escola Normal de São Paulo, Antônio Caetano de Campos, faz ao Thesouro, em 24 de março de 1891, os três problemas podem ser observados $^{485}$.

No documento ${ }^{486}$, registra-se a diferença de câmbio que acrescia significativamente a soma a ser paga pelo Tesouro, chegando a cerca de $30 \%$ do valor total. O valor do material foi de $4.225 \$ 000$ e o câmbio foi de $1.775 \$ 000$, totalizando $6.000 \$ 000$. Foram encomendados três pianos, cujo transporte exigia cuidados. No caso do transporte de um grande número de carteiras, ainda que desmontadas, o volume seria significativo, acrescendo no valor do frete e encaixotamento.

O câmbio, juntamente com a proteção alfandegária, na perspectiva de Edgar Carone, serviram como proteção à indústria. A flutuação do câmbio "é resultado da oscilação entre os valores da importação e da exportação. Conforme o superávit ou o déficit existente, temos valorização ou depreciação da moeda"487.

Acerca do tema, Caio Prado Jr. assevera que a queda do câmbio, desde a independência, "provocando o encarecimento das mercadorias de importação formará por seu turno um dos estímulos à produção nacional"488.

Já a política aduaneira, com leis tarifárias que "impõem taxas variáveis para a importação de mercadorias similares existentes no Brasil" somada ao "preço alto das mercadorias estrangeiras que vão entrar no país tornam proibitiva a sua aquisição pela

\footnotetext{
${ }^{485}$ Anexo n.11

${ }^{486}$ APESP. Série Propostas Orçamentária - Ordem: 5131

487 CARONE, Edgar. A evolução industrial de São Paulo (1889-1930). São Paulo: Editora SENAC São Paulo, 2001, p.80.

${ }^{488}$ PRADO JR., Caio. História Econômica do Brasil. 14 ed. São Paulo: Brasiliense, 1971, p.264.
} 
maioria da população" ${ }^{489}$. Isso signfica que a importação dos modernos materiais e móveis escolares custava muito ao governo. Mesmo assim, Moacyr Primitivo atesta que "muitos dos materiais usados na escola foram importados dos Estados Unidos e da França, e, já estão quase esgotados. Será indispensável providenciar-se no sentido de mandar buscar aquilo que aqui não se pode comprar" 490 .

Por todas essas dificuldades era necessária a intermediação de viajantes, mediadores e tradutores culturais. São tomados, aqui, como viajantes, brasileiros, inseridos no contexto escolar, ou não, que em suas viagens de férias aceitam encomendas dos administradores da Instrução Pública para compra de material e mobiliário escolar. Entende-se por mediadores culturais os estrangeiros, residentes em São Paulo, inseridos de alguma maneira no contexto escolar paulista e de seu local de origem que, também, fizeram aquisições para a escola pública em outros países. E, os tradutores são as casas importadoras, agentes ou representantes comerciais, os negociantes cujas relações com a escola nos diferentes países limitam-se ao campo econômico.

\subsubsection{Um viajante que traz a Modernidade Educativa}

A dificuldade na importação era tamanha que era necessário aproveitar qualquer oportunidade para fazê-la. Em viagem de férias à Paris, o diretor da Escola Normal, Paulo Bourroul responsabiliza-se pela aquisição de materiais para a referida instituição.

Constata-se uma troca direta de ofícios entre os diretores da referida escola, o presidente da Província e o Thesouro Provincial ${ }^{491}$. Em 3 de abril de 1883, Paulo Bourroul, informa ao Tesouro Provincial que foi autorizado pelo Exmo. Sr. Conselheiro Francisco de Carvalho Soares Brandão a

fazer a compra de moveis necessários a escola sob minha direção, rogo a v.exa. que se digne dar as ordens necessárias para que, pelo Thesouro Provincial, seja posta a minha disposição a quantia de um conto e quinhentos mil reis (1:500\$000), para ser aplicada a compra dos ditos moveis, e também a compra e encadernação de livros de português destinados a biblioteca da dita escola ${ }^{492}$.

\footnotetext{
${ }^{489}$ Idem, p.81.

${ }^{490}$ MOACYR, Primitivo. A instrução pública no estado de São Paulo (1890-1893). 1 vol. São Paulo: Companhia Editora Nacional, 1942, p.264.

${ }^{491}$ Anexos n. 12 e n. 13

${ }^{492}$ Fonte: Série Propostas Orçamentária - Ordem: 5131 (APESP).
} 
Em 24 de abril de 1883, o Tesouro Provincial autoriza o diretor Paulo Bourroul a realizar o pagamento da despesa dos móveis (1.500\$000) diretamente aos fornecedores e em vista de contas e recibos ${ }^{493}$. O próprio Presidente da Província solicita ao diretor da Escola Normal, Paulo Bourroul, que faça a compra de material escolar durante sua estada em Paris ${ }^{494}$.

De Paris, Paulo Bourroul, quase dois anos depois do pedido feito pelo antigo diretor, Caetano de Campos, envia uma correspondência ${ }^{495}$ ao Presidente da Província, o Conselheiro Francisco do Carvalho Soares Brandão, dando ciência da

lista do conteúdo de 9 caixas E.N. n. 1-9, e de 4 caixas ENP - n. 1-4. Ficão em meu poder para prestação de contas, as faturas originaes com os respectivos recibos. Os conhecimentos destas 13 caixas e das que ainda restam, serão enviadas diretamente a v. ex. pelos senrs. Pinto \& Braga, comissários desta praça ${ }^{496}$.

De posse dessa informação, o Tesouro da Fazenda deveria enviar ordens à Alfandega de Santos para despachar e enviar as encomendas à Capital ${ }^{497}$.

Com isso, percebe-se que os caminhos da modernidade educativa, tanto dos materiais e utensílios, quanto do mobiliário passavam pela Alfândega de Santos e chegavam à vapor, como demonstrado anteriormente. Em 21 de fevereiro de 1883, a informação de "três caixões com mercadorias destinadas á Escola Normal, embarcadas no vapor francez SULLY ${ }^{498}$ com direção ao porto de Santos" ${ }^{\text {"499 }}$, dá uma dimensão desse movimento. Isto é, em viagem para Paris, o diretor da Escola Normal de São Paulo, Paulo Bourroul faz a aquisição do material que ele mesmo solicitou ao Presidente da Província de São Paulo. Autorizada a aquisição, ele compra e envia por meio de vapores até a Alfândega de Santos, de onde serão as encomendas remetidas à São Paulo, depois de expedidas as ordens pelo Tesouro da Fazenda.

Segundo Carvalho, não pode ser subestimada a participação destes "assíduos viajantes" 500 na renovação educacional. Os "intelectuais ilustrados: homens públicos,

\footnotetext{
${ }^{493}$ Anexo n.14.

494 Anexo n.15.

495 Anexo n.16

${ }^{496}$ Fonte: Manuscritos. Escola Normal de São Paulo. Anos 1886-1889. Caixa 3; Ordem 5131.

497 Ver Anexo n.13

498 O vapor Sully também fazia parte da frota da Companhia Francesa de Navegação à Vapor. A única informação obtida acerca do mesmo é que ele partia do porto do Havre.

${ }^{499}$ Fonte: APESP. Série Manuscritos. Escola Normal de São Paulo. Ano 1886-1889. Caixa 3 - Grupo Gestão - Série Propostas Orçamentárias. Ordem = C05131

${ }^{500}$ CARVALHO, M. M. C. Por uma história cultural dos saberes pedagógicos. apud SOUZA, M. \& CATANI, D. Práticas educativas, culturas escolares, profissão docente. In: II CONGRESSO LUSOBRASILEIRO DE HISTÓRIA DA EDUCAÇÃO. São Paulo: Escrituras, 1998, p.40
} 
reformadores, juristas, proprietários de escolas, diretores e professores" ${ }^{\text {"501 são }}$ "personagens-chave na elucidação dos processos materiais de produção, circulação e apropriação dos saberes pedagógicos no Brasil”, ${ }^{, 502}$.

Outro caso exemplar é o de José Eduardo de Macedo Soares. Ele remete ao Diretor da Instrução Pública do Estado de São Paulo, em 7 de janeiro de 1895, um orçamento dos aparelhos e objetos necessários ao ensino de física e química ${ }^{503}$.

Professor de química e física na Escola Normal Caetano de Campos, Macedo Soares também realizou diversas viagens ao exterior, o que o tornava um homem de "boas relações" para, seja nas viagens, seja por meio dos catálogos, fazer encomendas de material às casas comerciais na Europa. Mais que isso, em 1894, ele fez um "valioso donativo" de objetos para o gabinete de física e laboratório de química da Escola Normal Caetano de Campos ${ }^{504}$. Estes elementos tornavam Macedo Soares apto para indicação do material necessário para as aulas de física e química da Escola Complementar de Itapetininga, conforme solicitação do Diretor da Instrução Pública.

As novidades trazidas pelos viajantes ${ }^{505}$ poderiam vir em forma de objetos ou relatórios. Em 1883, por exemplo, “o Inspetor Geral da Instrução Pública, Souza Bandeira Junior, publicou relatório sobre viagem que havia realizado para obter informações sobre o jardim-de-infância e outras instituições de educação infantil na França, Suiça, Áustria e Alemanha" ${ }^{\circ 06}$.

De igual modo, Menezes Vieira, diretor do Pedagogium e o criador do primeiro jardim de infância no Brasil,

Para imprimir ao seu colégio o que mais moderno havia na época, Menezes Vieira buscou subsídios em literatura bastante atual e especializada [...] Realizou várias viagens à Europa para conhecer e

\footnotetext{
${ }^{501}$ SCHELBAUER, Analete Regina. O método intuitivo e lições de coisas no Brasil do século XIX. In: STEPHANOU, Maria; BASTOS, Maria Helena C. (orgs). Histórias e memórias da educação no Brasil, Vol II: século XIX. Petrópolis, RJ: Vozes, 2005, p.136.

${ }^{502}$ CARVALHO, op cit, p.40

${ }^{503}$ Anexo n.17.

${ }^{504}$ Anexo n.18.

505 Importante trabalho sobre as viagens pedagógicas é desenvolvido por PINTO, Inára de Almeida Garcia. Um professor em dois mundos: a viagem do professor Luiz. Augusto dos Reis à Europa (1891). São Paulo: Faculdade de Educação da USP. Tese, 2011. A autora também analisa "documentação referente ao comércio estabelecido entre a Inspetoria de Instrução e a iniciativa privada, intermediada pela ação de inspetores de ensino e professores primários da Capital Federal" (p.131), ponto discutido ainda neste capítulo.

${ }^{506}$ KUHLMANN JR., Moysés. O jardim-de-infância e a educação das crianças pobres. Final do século XIX, iníci do século XX. In: MONARCHA, Carlos (org). Educação da infância brasileira (1875-1983). Campinas: Autores Associados, 2001, p.3
} 
visitar os principais centros educacionais, de onde trouxe as inovações pedagógicas implantadas na sua escola ${ }^{507}$.

Dentre as inovações que poderiam acentuar o aspecto daquele colégio como moderno estava o mobiliário.

Segundo o vice-diretor J. Pereira Pinto, tudo o que o colégio possuía tinha sido importado da Europa e dos Estados Unidos. Por exemplo, o mobiliário do curso secundário é do tipo Victoria, o que em si caracteriza o estabelecimento como um dos mais modernos da Corte $^{508}$.

$\mathrm{Na}$ sala de português "constavam 18 bancos-carteiras (tipo Victoria) [...] Nas aulas de ciências físicas e naturais havia uma sala especial com seis bancos-carteiras para dois alunos cada um (tipo Victoria)"," No9 grande salão, “carteiras dispostas em séries de três no sentido longitudinal"510. O parecer da comissão na Exposição Pedagógica, em 16 de outubro de 1883 expõe, acerca do Colégio Menezes Vieira, que "a mobília adotada é a do modelo das escolas maternais francesas, porém fabricada no país [Brasil]",511.

A citação do caso deste viajante, educador e homem de negócios carioca confirma a ideia da modernização da escola via adoção de carteiras europeias ou norteamericanas. Também sinaliza a adaptação dos modelos de mobiliários estrangeiros pelos educadores e negociantes brasileiros, bem como a circulação de tais modelos em diversas partes do país. Entretanto, a circulação não é somente de objetos. A circulação internacional de pessoas corrobora para que, educadores, médicos e higienistas estrangeiros participem decisivamente nos processos de modernização da escola paulista.

\subsubsection{Mediadores Culturais da Modernidade Educativa}

São chamados aqui de mediadores culturais os estrangeiros residentes em São Paulo que, tendo envolvimento com a instrução em seu país de origem e no Brasil,

\footnotetext{
507 BASTOS, Maria Helena Camara. Pro Patria Laboremus: Joaquim José de Menezes Vieira (18481897). Bragança Paulista: EDUSF, 2002, 350p, p.78

508 Idem, p.79

${ }^{509}$ Idem, p.84

${ }^{510}$ Idem, ibidem.

${ }^{511}$ RIO DE JANEIRO. Atas da Exposição Pedagógica, 1884, p.227.
} 
serviram de intermediários entre fornecedores e o governo, ou, que também em viagem ao país de origem, fizeram a aquisição de material para a escola pública paulista. São dois exemplos de mediadores culturais - a diretora da Escola Modelo anexa à Escola Norma da Praça da República, miss. Marcia Browne e o diretor da Escola Americana, Horace Lane. Ambos, americanos, foram importantes peças na busca pela modernidade educativa.

Pelo menos desde 1890, pode ser constatada a atuação desses personagens em prol da instrução na cidade de São Paulo. Vimos anteriormente que Caetano de Campos explicita na sua correspondência diversas dificuldades para equipar a escola, sendo a distância dos fornecedores uma dessas dificuldades. Os mediadores culturais ajudavam a minimizar esse entrave tornando possível a chegada dos objetos até à escola. Esse é o papel desenvolvido pelos americanos, ligados à Escola Americana.

Em 30 de outubro de 1890, o vice-diretor da Escola Normal da Capital, Doutor José E.C. de Sá e Benevides, solicita ao Presidente do Estado de São Paulo o pagamento devido ao Diretor da Escola Americana, A. Waddul, no valor de 372\$600. Ele forneceu caixões de material àquela Escola Normal. Nota-se que esse pedido foi feito em um primeiro momento pelo próprio Caetano de Campos.

A solicitação de material ao Diretor da Escola Americana é uma evidência das redes de sociabilidade que envolviam dirigentes do ensino público paulista e dirigentes da Escola Americana; mas também da crença no aparato pedagógico que esta última exibia.

O diretor da Escola Americana com relação mais estreita com os dirigentes do ensino público paulista foi, sem dúvida, Horace Lane. Ele encomendou material de ensino para a Escola Modelo, anexa à Escola Normal, em 27 de outubro de $1894^{512}$. Horace Manley Lane foi diretor do Mackenzie College. Era educador, médico, lavrador e negociante. No posicionamento sócio-político era abolicionista e republicano ${ }^{513}$.

De acordo com Barbanti, o Dr. Lane, diretor da Escola Americana, era uma figura que exercia múltiplas atividades como negociante, médico e professor. Sendo um liberal e republicano tinha o apoio das vanguardas paulistas da época. Porém, "seu tirocínio de administrador consolidou a posição do colégio como um centro educacional

\footnotetext{
512 Anexo n.19.

513 GOLDMAN, Frank P. Os Pioneiros Americanos no Brasil: Educadores, Sacerdotes, Corvos e Reis. São Paulo: Pioneira, 1972.
} 
dos mais avançados da Província de São Paulo"514. Segundo a autora, "a Escola Americana forneceu ao Estado Paulista [...] o material pedagógico adequado ao ensino intuitivo. Em várias ocasiões, o Dr. Lane foi intermediário na compra de aparelhos nos Estados Unidos" $" 515$.

Em 16 de dezembro de 1895, há uma solicitação de pagamento de Gabriel Prestes, em favor de Horace Lane, no total de 96 dólares, devido a uma encomenda de móveis para a Escola Complementar Modelo ${ }^{516}$. É possível que aquela soma em dinheiro fosse referente ao trabalho de Lane e não ao valor dos móveis.

Isso porque ele encomendou nos Estados Unidos uma quantidade tão expressiva de móveis e aparelhos de ensino que foram necessárias 128 caixas ${ }^{517}$. Supõe-se que Horace Lane precisou investir um tempo significativo para, em sua viagem, providenciar tantas encomendas. Talvez porque, como salientou anteriormente Caetano de Campos, "A distância dos centros fornecedores, e a precisão de comprar para longo praso é que me aconselham a fazer de uma vez um abastecimento mais abundamente" 518 . Foi por intermédio de Horace Lane e da Casa Guarany que a Escola Normal obteve o material solicitado pelo diretor Caetano de Campos, em 24 de março de $1891^{519}$. Talvez esse fosse um, dentre os vários negócios do Dr. Lane. Ele não só era diretor da Escola Americana, mas também médico e tendo vasta experiência na área da higiene popular, poderia indicar o mobiliário que evitasse moléstias e deformidades ao corpo dos alunos.

Nos Estados Unidos,

Dr. Lane exerceu por alguns anos a profissão médica. Foi ainda presidente da Jasper Country Medical Society, Secretário da Southwest Missouri Medical Society, membro da Junta de Higiene de Jasper Country e da Commission of Collective Investigation on Disease of the Medical Association of the State of Missouri. Vicepresidente dessa instituição, também foi sócio permenante da American Medical Society, membro Honorário do Kansas State Medical Society e redator-chefe do periódico de higiene popular, Health at Home ${ }^{520}$

\footnotetext{
514 BARBANTI, Maria Lúcia. Escolas Americanas de Confissão Protestante na Província de São Paulo: Um Estudo de suas origens. São Paulo: Dissertação de Mestrado. FEUSP, 1977, p.167.

515 Idem, p. 181.

516 Anexo n.20.

517 Anexo n.21.

518 Fonte: APESP - Série Manuscrito - Escola normal de São Paulo; 1849-1855; 1886-1989/ Ordem 5131. Grupo - Gestão Financeira; Série - Propostas orçamentárias.

${ }^{519}$ Anexo n.22 combinado com Anexo n.11

${ }^{520}$ GOLDMAN, op. cit., p. 16
} 
Ao localizar algumas correspondências citando o nome do diretor da Escola Americana, Horace Lane, percebe-se que a atuação desses mediadores culturais não foi esporádica. Importante atuação teve também a americana que, por indicação do Dr. Lane se tornou diretora da Escola Modelo anexa à Escola Normal de São Paulo - Miss. Márcia Browne. Após três anos de "constante trabalho" na Escola Modelo, Miss Browne solicita ao Secretário dos Negócios do Interior, Cesário Motta, autorização para viagem a seu país de origem, onde visitaria a Exposição Universal de Chicago no ano de $1893^{521}$. A pretensão de Miss Browne era

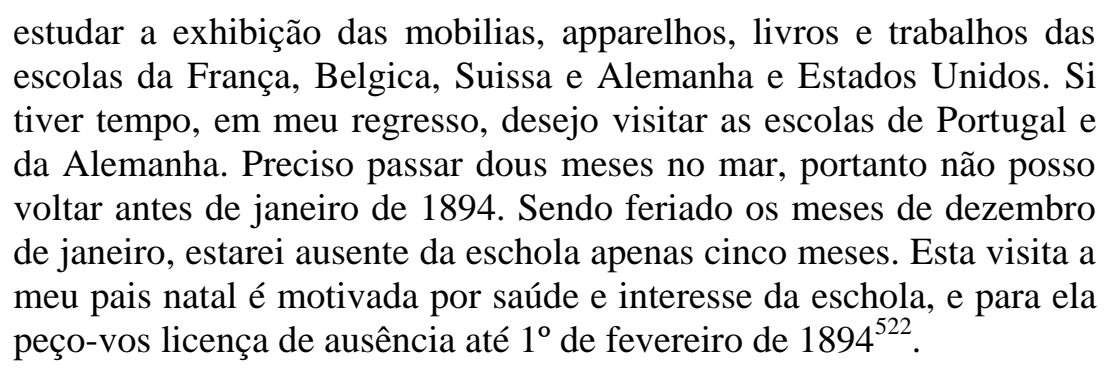

Para justificar a ausência de cinco meses, a diretora da Escola Modelo associa a sua necessidade pessoal ao interesse da escola. Seria útil a ela e à escola o estudo das mobílias e objetos escolares de diversos países, sociedades de referências, cujos sistemas educacionais modernos ganharam aceitação global ${ }^{523}$.

A viagem da diretora, assim como as de Horace Lane, resultou em um investimento material na escola pública paulista, pois algumas remessas foram sendo feitas por Miss. Browne durante a sua estadia no exterior.

Em 9 de maio de 1894, foram embarcadas no vapor Corrientes, com destino a Santos, três caixas com peças anatômicas, além da mobília e do material escolar que foram encomendados e aguardavam despacho ${ }^{524}$. O material contido nas três caixas era proveniente da casa Emile Deyrolle de Paris. Sabemos, entretanto, pelas informações do ofício n.38 de 9 de maio de 1894 que, além de peças de anatomia humana, as caixas continham modelos de frutas e flores.

Essas compras não constituem "meras relações de troca internacional de

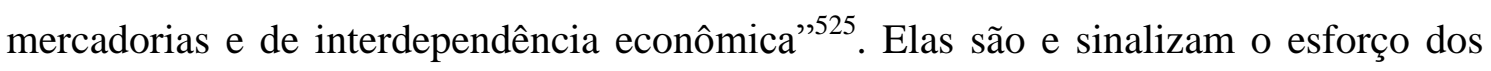
Estados para se constituírem pela centralidade de uma modernidade educativa ${ }^{526}$.

\footnotetext{
521 Anexo n.23.

${ }^{522}$ Fonte: APESP. Série Manuscritos. Secretaria do Interior. Escola Normal. Ano 1892. Ordem 7135

523 SCHRIEWER, 2000.

524 Anexo n.24 e n.25

${ }^{525}$ SCHRIEWER, 2000, p.107.
} 
O trabalho dos mediadores culturais era árduo. Pela correspondência de Miss. Browne a Cesário Motta depreende-se que o percurso total de ida e volta do Brasil a Europa ou aos Estados Unidos seria de dois meses no mar. Logo, um mês para ir e outro para retornar. Além do esforço financeiro, havia um esforço físico que impedia a constância de tais viagens. Sendo assim, as casas importadoras, os agentes e representantes comerciais funcionaram como uma outra opção para equipar a escola.

\subsubsection{Tradutores culturais da modernidade educativa}

Como já foi explicitado anteriormente, são aqui chamados de "tradutores" as casas importadoras, agentes e representantes comerciais cujas relações com a escola nos diferentes países limitam-se ao campo econômico. Eles atuam em diversas áreas do comércio, sendo a escola apenas mais um mercado consumidor lucrativo.

Ao tratar destes personagens, dou visibilidade à ideia de que a escola movimenta o mercado interno, seja pela aquisição de materiais locais ou produzidos em outros países. Ela é um bom mercado consumidor devido à soma dos produtos que adquire, sempre em grande quantidade, e à constância, repetidamente.

A representação comercial é outro importante meio de aquisição de objetos escolares. Os representantes comerciais faziam a intermediação entre os fabricantes e os administradores escolares.

Pela análise das Correspondências da Escola Normal Caetano de Campos observa-se que há uma quantidade expressiva de material fornecido por agentes e representantes comerciais ${ }^{527}$. Entretanto, havia dois fabricantes franceses que se tornaram hegemônicos no fornecimento de material e objetos escolares às escolas paulistas: Emile Deyrolle ${ }^{528}$ e a Paul Rousseau \& Cia. ${ }^{529}$, ambos de Paris. Enquanto o representante da primeira era o Sr. Etienne Collet, o representante da segunda era a Sociedade Mercantil E. Charles Vautelet e Comp.

Os fornecedores do governo paulista são as casas comerciais da Europa, dos Estados Unidos, os agentes e representantes comerciais com sede do Rio de Janeiro, as

\footnotetext{
526 VIDAL, 2009.

527 Anexo n.26.

${ }^{528}$ Importante casa comercial do ramo de material escolar, a Emile Deyrolle tem sido objeto dos estudos de Diana Vidal. Por isso, não serão apreciadas neste trabalho as atividades daquela empresa.

${ }^{529}$ A Paul Rousseau \& Cia. é objeto dos estudos de Paulo Coelho Mesquita Santos.
} 
casas comerciais de São Paulo, além dos prestadores de serviços como encanadores, eletricistas, marceneiros e carpinteiros que realizaram reparos de móveis escolares.

Esta escola obrigatória e de massa movimenta o mercado e a economia. São acionadas diferentes indústrias a fim de atender às novas demandas desta instituição. No caso do mobiliário, por exemplo, estão implicados diferentes ramos do comércio e do setor produtivo. São os negociantes de madeira, de ferro, de ferragens, profissionais liberais como médicos, arquitetos, educadores.

Dentre os fornecedores enumerados, discorrerei brevemente sobre a atuação de alguns que julgo mais exemplares para tratar da proveniência do mobiliário e material escolar no fim do século XIX e, como corolário, desta relação escola-mercado.

Sediados no Rio de Janeiro, os mais importantes representantes no ramo do comércio com a escola foram, como já disse, E. Charles Vautelet \& Cia e Etienne Collet, agente do Syndicato de Mobilias Escolares.

Dois documentos ${ }^{530}$ da Junta Comercial da Capital Federal, à época, Rio de Janeiro, trazem as informações devidas ao Registro Comercial da E. Charles Vautelet \& Cia. É preciso esclarecer que "a junta comercial do Rio de Janeiro tinha jurisdição sobre o Município e Províncias de São Paulo, Minas Gerais, Paraná, Goiás e Mato Grosso"531.

Tratava-se de uma Sociedade Mercantil Solidária que fizeram entre si Charles Etienne Joseph Vautelet (60\%); Paulo Moreira da Silva e João Pedro Fausto de Alcantara. A Razão Social era E. Charles Vautelet e Compa ${ }^{\mathrm{a}}$ e poderia ser usada por qualquer dos sócios. O objeto era a “importação, comissões, consignações, representações de drogarias e fabricas estrangeiras, como qualquer outro negocio que apresente vantagem para a sociedade ${ }^{, 532}$. Sem filial, o Capital social era de sessenta contos de reis e a duração da sociedade seria de 5 anos, ou seja, a terminar em 1900, podendo ser alterado com o consenso dos sócios.

O documento da Série Indústria e Comércio traz outro resumo das atividades sociais: "Comercio - conta própria, agencia e representações de casas européas"; bem como o endereço: "Domicilio - Rua do Hospicio n. 107"; e a data de começo das operações: 1 de janeiro de 1895, sendo que o Contrato social - "foi archivado em 7 de março de 1895".

\footnotetext{
530 1) Junta comercial. Ano - 1897; Livro 342, Registro - 45181 - Charles Vautelet \& Cia.

2) Série Indústria e Comércio - IC ${ }^{3}$ 101. n.3567, 22 de abril de 1895.

${ }^{531}$ BORGES, Urquiza Maria. Negociantes na cidade de São Paulo (1875-1880). São Paulo. Faculdade de Filosofia, Letras e Ciências Humanas. Dissertação de Mestrado, 1979, p.43.

${ }^{532}$ Arquivo Nacional. Livro de Registro de firmas commerciais, na forma do art. 11 do Dec n. 916 de 24 de outubro de 1890. Junta Comercial da Capital Federal, 15 de janeiro de 1895.
} 
O começo das operações da Sociedade é 1 de janeiro de 1895. No entanto, as Correspondências da Caetano de Campos indiciam que o Sr. Charles Vautelet, antes da formação da Sociedade, já realiza o comércio de produtos europeus. Isso porque, em 17 de outubro de $1894^{533}$, ele adquire aparelhos de ginástica para a referida instituição e, em 4 de dezembro do mesmo ano ${ }^{534}$, instrumentos de mecânica e astronomia.

É importante notar que, até o fim do ano de 1894, consta apenas o nome do Sr.

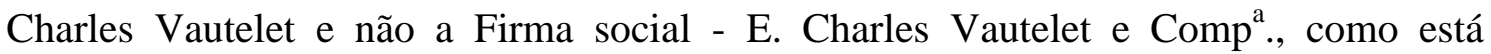
registrado em uma fatura de 22 de março de $1895^{535}$. É provável que ele tenha adquirido experiência suficiente no ramo de agência e representação de casas comerciais, tornando possível a formação da Sociedade.

No mesmo ano da constituição, se deu o distrato do contrato pela retirada do sócio Joao Pedro Fausto de Alcantara, "continuando todavia a firma a gyrar sob a mesma razão até a forma designada no referido contrato",536 e os sócios Charles Etienne Joseph Vautelet (residente em Paris) e Paulo Moreira da Silva (residente no Rio de Janeiro) tomaram a si toda responsabilidade do ativo e passivo.

À medida que a estrutura administrativa do Estado e da Instrução Pública ia se tornando mais complexa também tornava-se menos comum a realização de negócios/contratos mais informais, com sujeitos individuais. Por isso, a constituição de uma Sociedade era, de um lado, garantia para o Estado-comprador, e propaganda para a Sociedade.

O Registro do comércio, ou, o Registro Público das empresas mercantis tem, dentre outras, as finalidades de "dar garantia, publicidade, autenticidade, segurança e eficácia aos atos jurídicos das empresas mercantis, submetidos a registro",537.

No Almanak Administrativo, Mercantil e Industrial do Rio de Janeiro encontramos informações sobre E. Charles Vautelet. No Almanak de 1891, aparece como "Empreza Geral de Anúncios"538. No mesmo ano, está na seção de agentes

\footnotetext{
${ }^{533}$ Anexo n.27

${ }^{534}$ Anexo n. 28

535 Anexo n. 29 - Vale calcular o tempo decorrido da solicitação do material junto ao representante comercial (17 de outubro de 1894 e 4 de dezembro de 1894) à chegada do mesmo à escola. Somente em 7 de setembro de 1895 a encomenda foi embarcada no porto do Havre (Anexo n.30). Se, considerarmos o longo tempo que o vapor levaria para chegar a Santos e, depois, ser enviado à Escola Normal de São Paulo, podemos concluir que cerca de um ano seria o prazo para a chegada do material encomendado. Assim, a opção de suprir materialmente uma escola em expansão quantitativa, via empresas de importação e representação comercial, poderia ser pouco eficaz.

${ }^{536}$ Arquivo Nacional. Junta Comercial. Ano - 1897; Livro 342; Registro 45181 - Charles Vautelet \& Cia.

${ }^{537}$ REQUIÃO, 2011, p.146

${ }^{538}$ Almanak Administrativo, Mercantil e Industrial do Rio de Janeiro, 1891, p.512.
} 
comerciais como "agentes de drogas, produtos chimicos, preparações pharmaceuticas, vasilhame, utensilos e aparelhos para pharmacia, tintas e vernizes" ${ }^{\circ 39}$. No Almanak de 1895, consta no Grupo 6 - Indústria ${ }^{540}$, com grande anúncio, como representante de uma indústria de material e mobília escolar, sediada em Paris, e que fornece para escolas superiores, museus, etc ${ }^{541}$.

Em 1896 está no rol das drogarias ${ }^{542}$. Nesse ano, continua como representante no Rio de Janeiro de uma indústria de material e mobilia escolar, localizada em outro endereço de Paris: Maison Paul Rousseau \& Cia, 16, R. des Fossés, St. Jacques. Sua presença nas Notabilidades Comerciais corrobora o que diz Martin Lawn: as "empresas comerciais reconheceram a escola como lugar de publicidade e de desenvolvimento de novos clientes" ${ }^{, 543}$.

\footnotetext{
${ }^{539}$ Idem, p.500.

${ }^{540}$ Almanak Administrativo, Mercantil e Industrial do Rio de Janeiro, 1895, p.1323

${ }_{541}^{541}$ Anexos n.31-33.

${ }^{542}$ Almanak Administrativo, Mercantil e Industrial do Rio de Janeiro, 1896, p.776.

${ }^{543}$ LAWN, op. cit., p. 146
} 
Figura 34 - Casa Paul Rousseau \& Cie

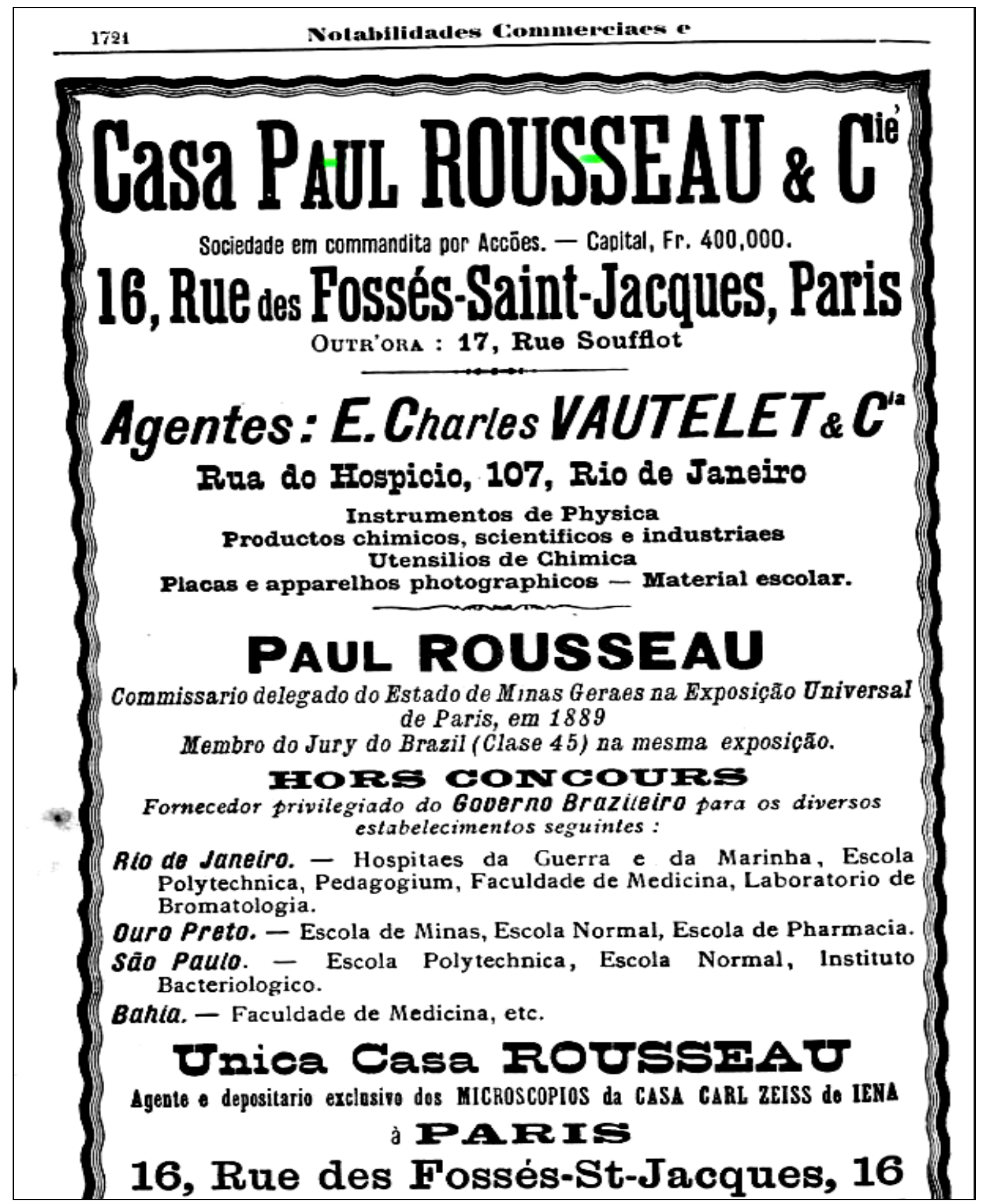

Fonte: Almanak Administrativo, Mercantil e Industrial do Rio de Janeiro, 1896, p.1724 -

Notabilidades Commerciais e Industriais da França.

A relação desta empresa com a escola pública era tão significativa que mereceu destaque em um anúncio de Notabilidade Comercial e Industrial da França. Paul 
Rousseau era "fornecedor privilegiado do GOVERNO BRASILEIRO" para diversos estabelecimentos. No Rio de Janeiro, por exemplo, fornecia para o Pedagogium, onde tinha uma exposição permanente. Em São Paulo, para Escola Normal Caetano de Campos $^{544}$.

O Syndicato de Mobilias Escolares com sede social à rua Saint-Benois, Paris, era representado no Rio de Janeiro por Charles Vautelet e, também, por Etienne Collet $^{545}$.

Este era o único agente, no Rio de Janeiro, de uma provável concorrente da Paul Rousseau, a Champigny \& C., especialista em produtos farmacêuticos, químicos e higiênicos. Champigny \& C. pode ter sido o fornecedor quando, em 1893, Etienne Collet foi "encarregado da compra dos apparelhos necessários ao ensino de physica, mechanica e chimica da Escola Normal"

Pelo Almanak Administrativo, Mercantil e Industrial do Rio de Janeiro (1894, 1895, 1896, 1897, 1898) sabemos que Etienne Collet era um negociante versátil. Ele atuava como engenheiro civil, representante comercial e possuía um depósito de móveis e trastes.

Enquanto Charles Vautelet \& Cia. era representante da Paul Rousseau, Etienne Collet era, conforme documentação da Caetano de Campos ${ }^{547}$, representante da Emille Deyrolle e, de acordo com o Almanak Administrativo, Mercantil e Industrial do Rio de Janeiro (1897), agente de A. Champigny \& C. e do Syndicato de Mobilia e Material Escolares.

Quais as casas comerciais que compunham este sindicato? O anúncio sobre o trabalho de Etienne Collet elucida esta importante questão.

\footnotetext{
${ }^{544}$ Anexo n.34

${ }^{545}$ Anexos n.35 e n. 36

${ }^{546}$ Anexo n.37

${ }^{547}$ Anexo n.38
} 
Figura 35 - Syndicato de Mobilia e Material Escolares

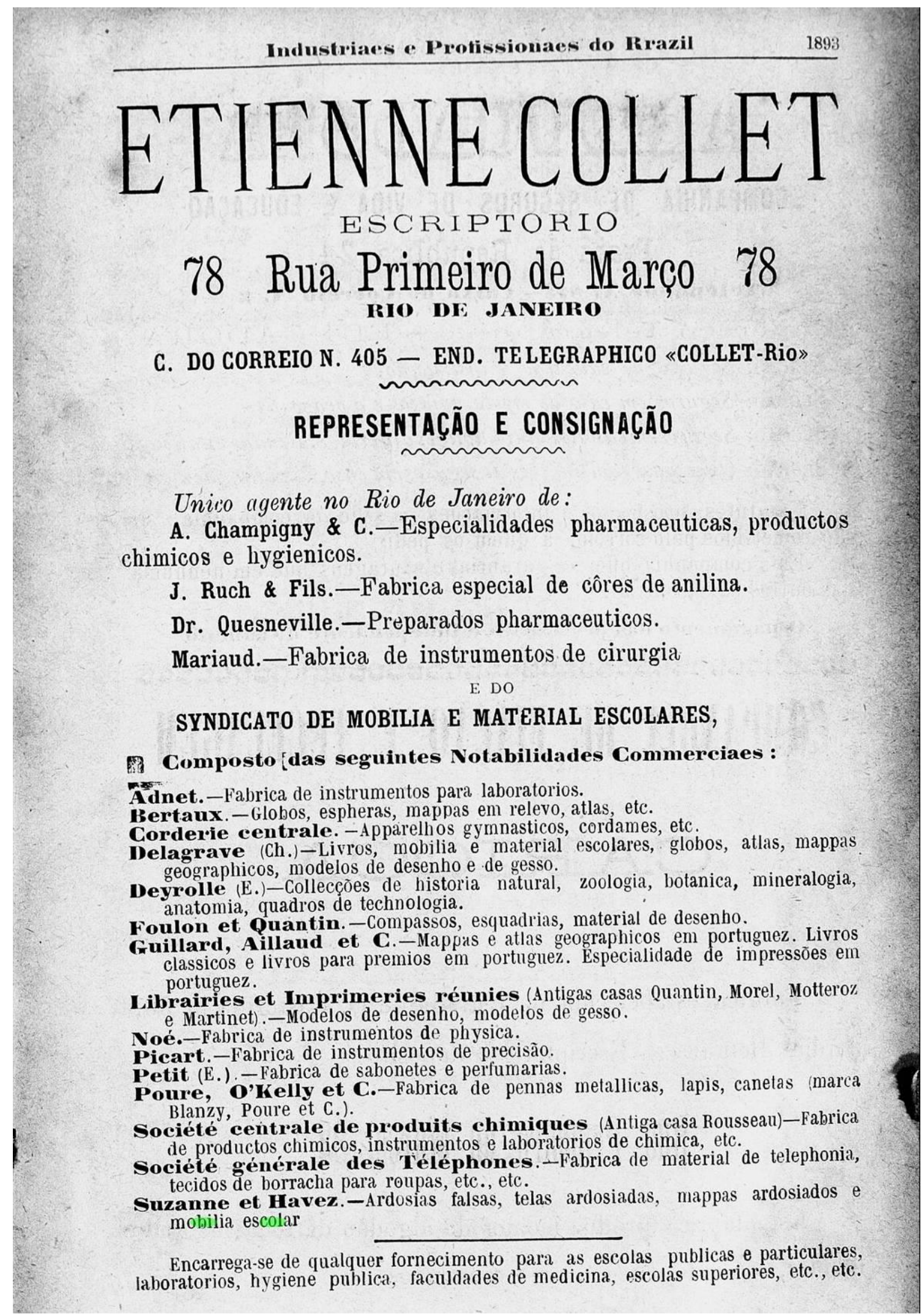

Fonte: Almanak Administrativo, Mercantil e Industrial do Rio de Janeiro, 1893, p.1893 
Como representante comercial do Syndicato de mobília e material escolares, Etienne Collet tinha um negócio rentável, já que representava casas comerciais de renome na Europa, como as francesas Emile Deyrolle e Delagrave.

A representação comercial e a agência integram "a categoria dos chamados contratos de colaboração empresarial" ${ }^{\natural 48}$. São contratos entre empresários, um representante e o outro, representado. Um, fabricante, e o outro, distribuidor.

Considerando as somas das importações no fim do século XIX, ser agente ou representante de casas comerciais estrangeiras era um bom negócio. A comissão de Charles Vautelet \& $\mathrm{Cia}^{549}$ pela representação comercial da Paul Rousseau, por exemplo, era de $5 \%$.

É também compreensível que São Paulo tenha feito a aquisição de material e mobiliário escolar por meio de agentes e representantes sediados no Rio de Janeiro. Havia uma concentração econômica no porto do Rio de Janeiro. Ele era o “desaguadouro da atividade econômica da Província do Rio de Janeiro, Minas Gerais e parte da Província de São Paulo e o maior pólo importador do país" ${ }^{\text {"50 }}$. Todavia, no Segundo Reinado, "se observa o impressionante aumento do peso relativo da alfândega de Santos, corolário do desenvolvimento da cafeicultura do Oeste Paulista" ${ }^{\text {"551 }}$. Pelo porto de Santos chegam o material e o mobiliário encomendados pelos viajantes.

Assim como no comércio mais geral, no âmbito da escola, os representantes comerciais, importadores e as casas comerciais eram, em sua maioria, imigrantes. Eles detinham o domínio das línguas estrangeiras para realizar as transações comerciais e, seus padrões de consumo e organização escolar se tornaram objeto de desejo da administração pública paulista.

O uso da importação dos materiais e mobiliário por meio de representantes, agentes e casas comerciais importadoras parecia ter se tornado uma praxe. Em ofício de 25 de agosto de $1893^{552}$, José Sá Benevides, vice-diretor da Escola Normal da Praça, solicita autorização "para por encomenda e por intermédio de alguma casa comercial importadora fazer na Europa a acquisição dos mesmos"553. Uma importante casa de

\footnotetext{
${ }^{548}$ FRANCO, Vera Helena de Mello. Contratos: Direito Civil e Empresarial. 4ed. São Paulo: Editora Revista dos Tribunais, 2013, p.253.

${ }^{549}$ Ver Anexo n.29

${ }^{550}$ COSTA, Wilma Peres. A questão fiscal na transformação republicana - continuidade e

descontinuidade. Economia e Sociedade, Campinas, (10): 141-73, jun. 1998, p.155

${ }^{551}$ Idem, ibidem.

552 Anexo n.39.

553 APESP, Secretaria do Interior, 3ª Secção, Escola Normal - ano 1892 - Ordem - 7135 - Série manuscritos.
} 
importação, a Companhia Mecânica e Importadora de São Paulo, no ano de 1892, fez aquisição de móveis para a Escola Modelo anexa à Escola Normal de São Paulo ${ }^{554}$.

Segundo Bandeira Jr. (1901), fundada em 1890 "é um dos mais importantes estabelecimentos industriais da América do Sul. O seu capital social é de 5.000:000\$000"555. Conforme informações do autor, o maquinismo era o mais aperfeiçoado e moderno que se conhecia, sendo que mais de 600 pessoas, todas do sexo masculino, nacionais e estrangeiros, nela trabalham.

A Companhia Mechanica e Importadora de São Paulo era de propriedade do industrial imigrante Alexandre Siciliano. Nascido em San Nicolà Arcella, cidade da Baía de Salerno, chegou a São Paulo em 1869, com nove anos de idade. Estabeleceu-se em Piracicaba com um tio e um irmão mais velho, onde abriram uma casa de comércio e o jovem Alexandre começou a trabalhar. Casou-se com a filha de um rico e influente fazendeiro e, juntamente com o irmão, formou uma sociedade com João Conrado Engelberg a fim de produzirem a máquina de beneficiar café de Engelberg.

Após a venda da patente desta máquina nos Estados Unidos, Siciliano mudou-se para a capital e participou da fundação de três companhias: um novo banco; uma casa importadora e uma oficina mecânica e de fundição. "A nova empresa de Siciliano, a Companhia Mecânica e Importadora foi construída em grande escala, a maior que São Paulo já vira"556. Tal era a estrutura da Companhia:

Incluída uma fundição, uma seção de máquinas, uma serraria, uma carpintaria e uma olaria. Produzia vagões de estrada de ferro, máquinas de benefício e outras máquinas agrícolas, e estava apetrechada para executar toda a sorte de obras de engenharia civil [...] Siciliano conseguiu contratos para a construção de edifícios públicos, construiu pontes para as ferrovias de propriedade de fazendeiros [...] A companhia importava equipamento mecânico de materiais de construção, inclusive locomotivas, automóveis, geradores, trilhos de estrada de ferro e cimento ${ }^{557}$.

Nesta longa lista de atividades parece que se pode acrescentar mais uma forneceu mobiliário para escolas públicas de São Paulo. Até então não é possível afirmar se o mobiliário foi importado, já que se tratava de uma Companhia Importadora, ou se foi fabricado no próprio estabelecimento de Alexandre Siciliano. O que se pode afirmar é que a solicitação do mobiliário não foi feita pelo Almoxarifado, mas pelo

\footnotetext{
${ }_{554}^{554}$ Anexo $\mathrm{n} .40$

${ }^{555}$ BANDEIRA JUNIOR, op. cit., p.218.

${ }^{556}$ DEAN, Warren. A industrialização de São Paulo (1880-1945). Trad. Octávio Mendes Cajado. $3^{\text {a }}$. Ed. Difel, 1970, 83.

${ }^{557}$ Idem, ibidem.
} 
vice-diretor da Escola Normal da Capital, em consequência da requisição de Miss Browne.

Muitas casas comerciais, importadoras e fornecedores das escolas públicas estavam situados na Rua da Imperatriz, dentre elas, a Companhia Mechanica. "Essa rua tão famosa de S. Paulo que durante tanto tempo foi a principal artéria do Triângulo, quando a cidade era só aquilo, o centro era só aquele encontro de três ruas - São Bento, Direita e 15 de Novembro" 558 . A rua, durante os dois reinados, chamou-se Imperatriz, pois foi por ela que passou a imperatriz durante sua visita a São Paulo. Com o advento da República a rua passou a ser denominada de 15 de novembro. "O comércio mais ou menos chic localizou-se nela e foi avançando “[...] Armarinhos, secos e molhados, oficinas pequenas, pelo século XIX, fizeram o orgulho da primitiva rua da Imperatriz. Depois vieram as lojas de mais luxo as confeitarias e casas importadoras [...]"559.

Importante trabalho sobre as três principais ruas comerciais da cidade de São Paulo é realizado por Heloisa Barbuy. Entre o fim do século XIX e início do XX, o comércio desenvolvido neste triangulo contribuiu para a modernização da cidade e foi uma "atividade propulsora e dinamizadora dos modos de urbanização levados a efeito" $" 560$.

As figuras do importador e das casas importadoras são de extrema importância por duas facetas diferentes, mas complementares. Sob um aspecto, supriram a necessidade momentânea das escolas e do governo que não possuía uma fábrica estatal de produção de material escolar. Sob outro, eles funcionaram como uma mola propulsora para o nascimento da indústria escolar. Esses dois pontos são fundamentados a partir do estudo de Warren Dean acerca da industrialização de São Paulo (1880-1945). As fontes aqui trabalhadas corroboram as afirmações do referido autor quando mostra que os negócios de importação não constituíam obstáculo ao desenvolvimento da indústria $^{561}$.

Pelo contrário, os importadores tiveram uma contribuição fundamental para a criação da empresa industrial por, pelo menos, três razoes: 1) A importação requeria certo número de operações realizadas in loco. O importador se via obrigado a completar no local a manufatura de artigos cujo perigo, peso e volume tornavam o estoque e a embarcação muito caros. Quando as operações de remate poderiam ser feitas com

\footnotetext{
${ }^{558}$ VITOR, Manoel. São Paulo de Antigamente. Grafisyl Editora Gráfica Ltda, 1976., p.235

${ }_{559}$ Idem, p. 237.

${ }^{560}$ BARBUY, 2006, p. 28.

${ }^{561}$ DEAN, 1971.
} 
matérias-primas obtidas de modo menos dispendioso em São Paulo do que embarcadas, o importador investia em novos produtos ou naqueles de que ele necessitava.

De acordo com Dean, tem-se, então, um "gênero de atividade industrial, essencialmente decorrente das operações do importador" ${ }^{\text {"562 }}$. 2) Devido a sua posição estratégica na estrutura no comércio, o importador "possuía todos os requisitos do industrial bem sucedido: acesso ao crédito, conhecimento do mercado e canais para distribuição do produto acabado" ${ }^{\text {"563 }}$. 3) Frequentemente os importadores converteram suas agências de vendas em fábricas autorizadas. Além disso, os importadores eram negociantes que, se compravam de fabricantes franceses, alemães e ingleses, comprariam também dos fabricantes brasileiros. Apesar de parecer paradoxal um importador investir em manufatura nacional, "em alguns casos, sua participação financeira na manufatura lhe assegurava o direito de distribuição exclusiva. Em outros casos, o importador era o empresário industrial" ${ }^{, 564}$.

Para reforçar seu argumento, Dean cita um conjunto de firmas importadoras que, no início do século $\mathrm{XX}$, se empenharam em atividades manufatureiras ou nelas investiram capitais. "Os importadores paulistas tendiam a perder sua identidade como

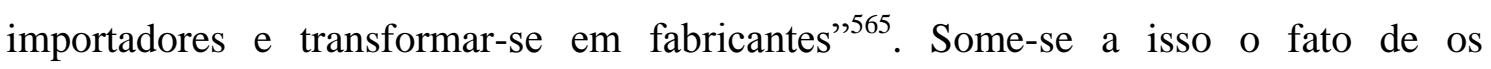
importadores de São Paulo se voltaram para indústria à medida que a importação se tornava mais difícil. Em resumo, muitos importadores passaram a fabricar os produtos que importavam.

Vale ressaltar que esses importadores eram, segundo Dean, em sua maioria imigrantes. Para ele a preponderância dos imigrantes no comércio se devia aos seguintes fatores: a) "ausência quase completa de um quadro de paulistas nativos com um estilo de vida urbano" 566 ; b) o empresariado imigrante estava familiarizado com os gostos e hábitos dos nascidos na Europa (experiência comercial anterior). O padrão de consumo europeu (no mobiliário, nos alimentos e na roupa) se tornou marca de status e objeto de desejo dos brasileiros ${ }^{567}$.

Acerca do comércio em São Paulo nas últimas décadas do século XIX, Heloisa Barbuy defende que

\footnotetext{
${ }^{562}$ Idem, p. 26

${ }^{563}$ Idem, p. 27

${ }^{564}$ Idem, p.31

${ }^{565}$ Idem, p.35

${ }^{566}$ Idem, p.58

${ }^{567}$ BASTOS, apud Dean, 1971, p.60.
} 
o raciocínio segundo o qual é a indústria que antecede e impulsiona a expansão do comércio não se aplica de todo ao nosso caso. Ao contrário, pode-se entender que a presença de um sem-número de artigos variados de origem externa oferecidos pelo comércio é que pode ter impulsionado o desenvolvimento de uma indústria local ${ }^{568}$.

Tendo por objeto o Triângulo Paulistano, a pesquisadora expõe que "em 1860 o comércio ainda se caracterizava pela oferta de gêneros de primeira necessidade" ${ }^{, 56}$. A diversificação se faz sentir nas últimas décadas do século XIX quando "muitas lojas comerciais iam sendo instaladas e povoadas por um crescente contingente de artigos industrializados - estrangeiros ou nacionais de padrões estrangeiros -, que correspondiam a novos interesses e se voltavam para o modo de vida burguês de modelo europeu",570.

Sobre esta relação entre comércio, indústria e vida urbana, Marisa Deaecto afirma que "avaliando as casas comerciais que mais progridem no Triângulo somos levados a concluir que elas são, em grande parte, relacionadas direta ou indiretamente com as empresas de importação e exportação",571. É o comércio que viabiliza, na passagem do século XIX para o XX, a abertura de São Paulo para o capitalismo internacional $^{572}$.

A modernidade, evidenciada nas grandes feiras universais, chegava ao Brasil a vapor. Comerciantes e empresários eram os agentes intermediários das "sociedades de referência" ${ }^{573}$. Neste capítulo, pretendi demonstrar os diferentes modos de proveniência da carteira e outros objetos escolares. Viajantes, mediadores culturais e tradutores foram, sem dúvida, figuras-chave na constituição de uma escola que se pretendia moderna.

Todo esse arrazoado ilumina, de alguma forma, o caso da indústria escolar em São Paulo. Pode-se afirmar que, no último quartel do século XIX, importadores e casas de importação eram responsáveis pelo suprimento material das escolas paulistas, também no que se refere ao mobiliário. Posteriormente, a partir dos modelos

\footnotetext{
${ }^{568}$ BARBUY, Heloisa. A cidade-exposição: comércio e cosmopolitismo em São Paulo, 1860 - 1914 (estudo de história urbana e cultura material). São Paulo: Editora da Universidade de São Paulo, 2006, p.28.

${ }^{569}$ Idem, ibidem.

${ }^{570}$ Idem, ibidem.

${ }^{571}$ DEAECTO, Marisa Midori. Comércio e vida urbana na cidade de São Paulo (1889-1930). São Paulo: Editora Senac São Paulo, 2002, p.22-23.

${ }^{572}$ SANTOS (1994, P.43) apud Deaecto (2002, p.27).

${ }^{573}$ GRUZINSKI, Serge. Les monds mêles de la monarchie catholique et autres connected histories. In: Annales. Histoire, Sciences Sociales, 56 e. Anné, nr. 1, jan. - fev. p. 85 - 117, 2001.
} 
importados, parte dos objetos escolares passou a ser produzida no Brasil, dando ensejo não só à indústria escolar exógena, mas também nacional, como se verá a seguir. 


\section{CAPÍTULO 4 INDÚSTRIA ESCOLAR E ESCOLA DE MASSA}

Neste capítulo, abordo a indústria de carteira escolar nacional, evidenciando a importância da mesma para a expansão da escola de massa, visto que a padronização dos modelos de carteira e a produção em massa permitiram ao Estado equipar, em menor tempo, um maior número de escolas. A quantidade expressiva de catálogos de mobiliário escolar e solicitação de patentes dá uma dimensão da relevância que as indústrias e fábricas de mobiliário escolar tiveram para o suprimento material da escola e, como corolário, para sua expansão. Também, elucida o quanto a escola foi um consumidor importante para a expansão desta atividade econômica.

O governo paulista ensaiou diversas possibilidades para mobiliar as escolas: viajantes, mediadores, tradutores culturais. Outra possiblidade desponta quando, nas últimas décadas do século XIX, surgem indústrias nacionais dedicadas à produção de mobiliário escolar. Assim, a importação e aquisição de carteira no estrangeiro vão dando lugar a produção local. Destas indústrias nacionais, o governo paulista passa a adquirir móveis para suas escolas.

Quais fábricas e fabricantes de mobiliário escolar atuaram no Brasil no fim do século XIX? Que modelos de carteira eles propunham? Que preceitos higiênicos esses modelos intentavam satisfazer? Os pedidos de patente contribuem significativamente para elucidar essas questões que serão debatidas a seguir.

\subsection{A "Terceirização" da fabricação da carteira escolar}

Nos dias atuais, a terceirização de serviços pela administração pública tem um caráter de descentralização da atividade pública por meio da contratação de empresas que realizem tarefas acessório-subsidiárias enquanto o Estado cuida das principais, evitando assim o "crescimento desmesurado da máquina administrativa",574.

\footnotetext{
${ }^{574} \mathrm{O}$ art. 10, parágrafo $7^{\circ}$, Decreto-Lei no $200 / 1967$ tem a seguinte redação:

Para melhor desincumbir-se das tarefas de planejamento, coordenação, supervisão e controle, e com o objetivo de impedir o crescimento desmesurado da máquina administrativa, a administração procurará desobrigar-se da realização material de tarefas executivas, recorrendo, sempre, que possível à execução indireta, mediante contrato, desde que exista, na área, iniciativa privada suficientemente desenvolvida e capacitada a desempenhar os encargos de execução.
} 
A terceirização consiste na prática de transferir a um terceiro, detentor de um conhecimento especializado, de uma tecnologia, por meio de contrato, a realização de determinada atividade, "objeto de execução indireta" ${ }^{\text {"575 }}$, tendo em vista os princípios da eficiência e da economicidade.

Não é carregado de todos esses elementos que o termo é aqui usado quando me refiro ao ato do poder público contratar empresas para fabricação ou importação do mobiliário e do material escolar no fim do século XIX e início do XX.

Tal contratação no período estudado tem a ver menos com a descentralização da atividade pública e mais com a incipiente organização do Estado para garantir o serviço principal, a oferta da instrução gratuita e do ensino obrigatório.

Ao contratar fábricas detentoras de tecnologia e conhecimento especializado para fabricar/fornecer as carteiras escolares também não está em questão a preocupação com o crescimento desmesurado da máquina administrativa. A política do governo paulista, sobretudo a partir da Proclamação da República, foi atender a demanda das escolas por mobiliário através da contratação de empresas privadas.

Quais foram as indústrias responsáveis pelo suprimento mobiliário da escola pública neste momento de sua institucionalização? Como se deu a relação/prestação de serviço delas com o Estado?

Duas carteiras preservadas no Centro de Memória da Faculdade de Educação da USP (CME-FEUSP) ofereceram os primeiros indícios acerca destas indústrias. Ambas as carteiras tem o pé de ferro fundido, a superfície de trabalho e o assento feito em madeira. No ferro fundido estão gravados os nomes dos fabricantes: na carteira Brazil, Eduardo Waller \& Comp., na carteira Paulista, Mellone, como se pode observar nas figuras a seguir.

\footnotetext{
${ }^{575} \mathrm{O}$ art. $3^{\circ}$ da Lei $5.645 / 70$ regulamenta:

Art. $3^{\circ}$. As atividades relacionadas com transporte, conservação, custódia, operação de elevadores, limpeza e outras assemelhadas serão, de preferência, objeto de execução indireta, mediante contrato, de acordo com o art. $10, \S 7^{\circ}$ do Dec. 200/67.
} 
Figura 36 - Carteira Brazil

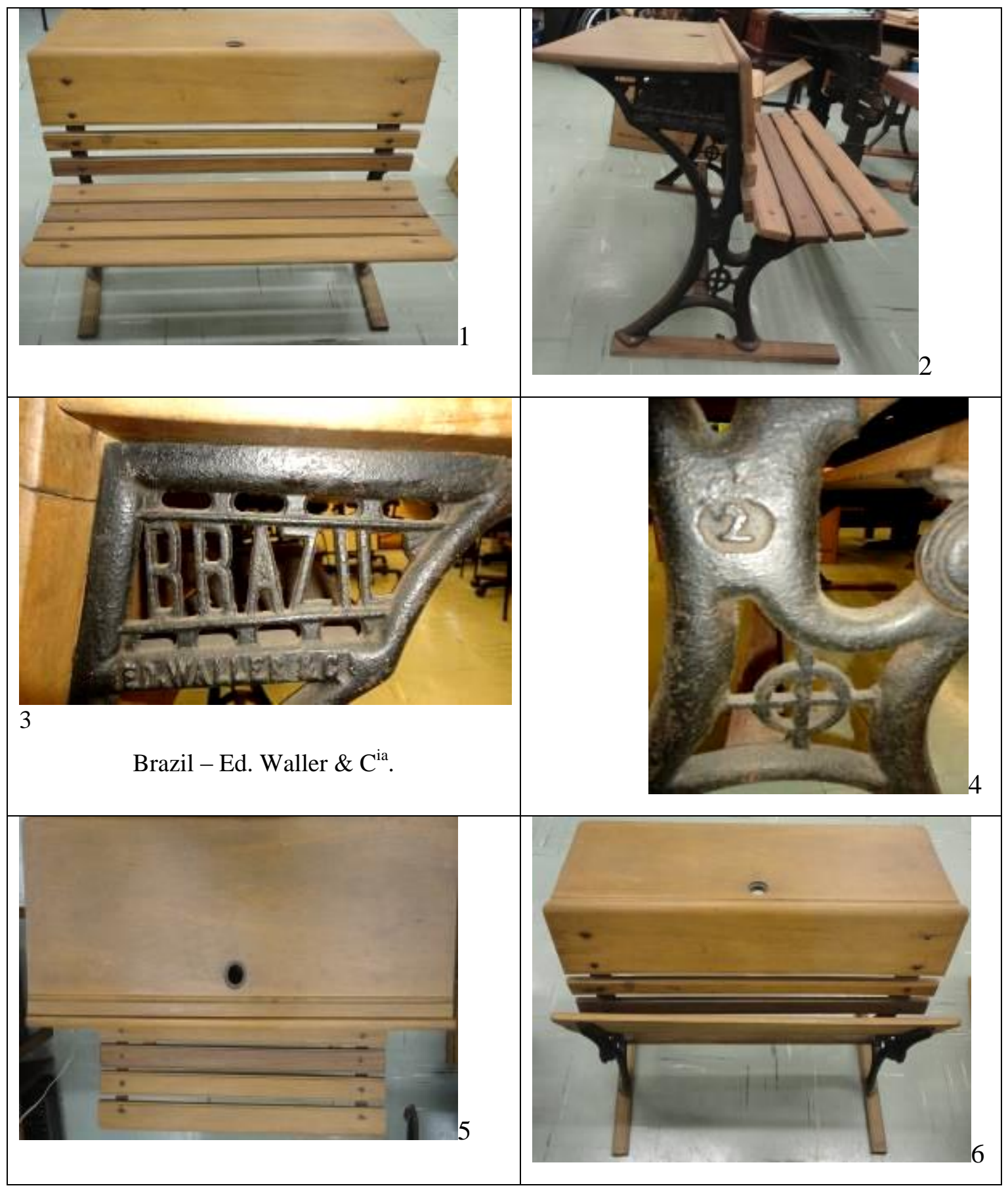

Fonte: Centro de Memória da Faculdade de Educação da USP 
Figura 37 - Carteira Paulista

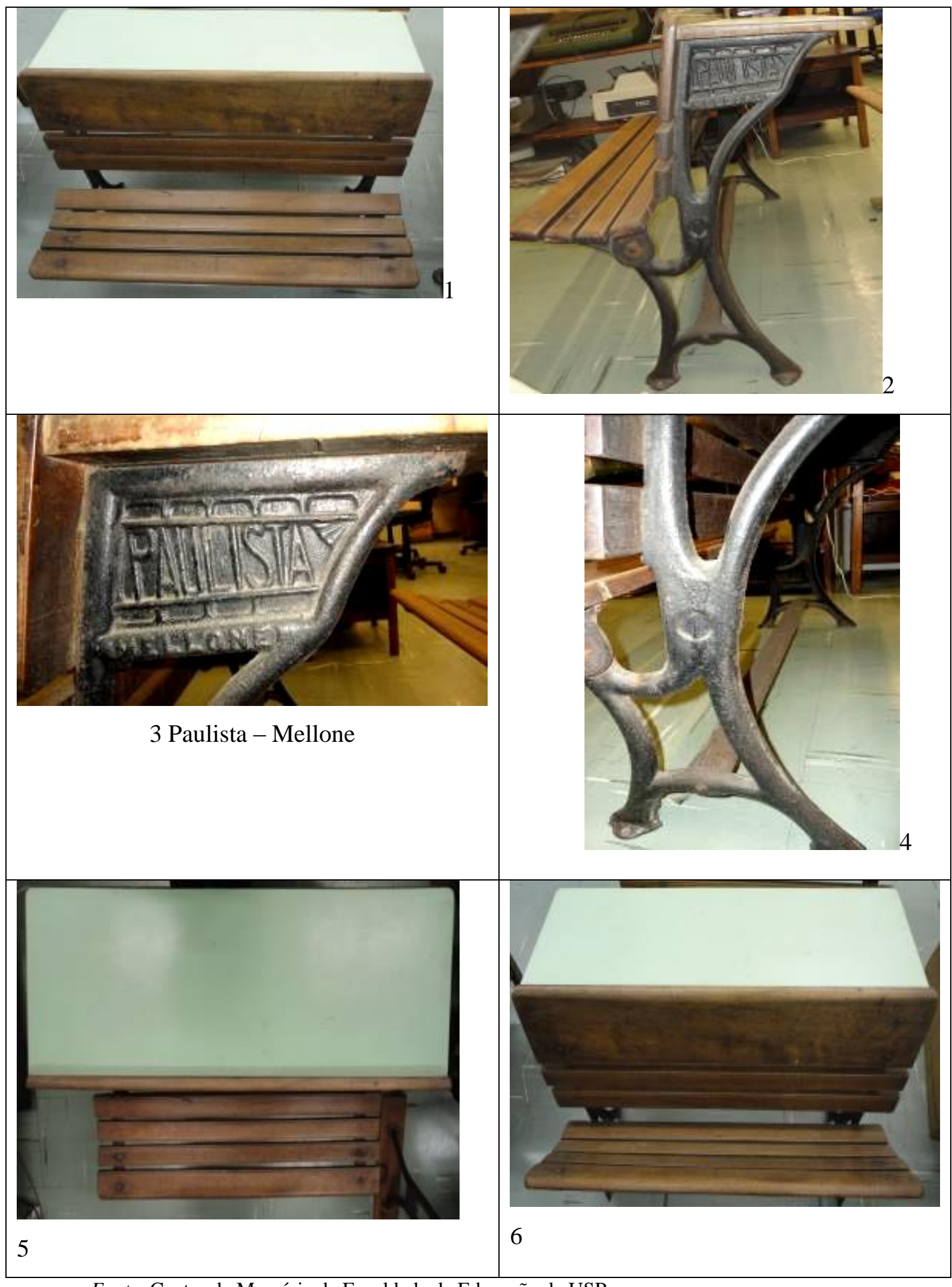

Fonte: Centro de Memória da Faculdade de Educação da USP 
Há semelhança nas dimensões e características dos dois modelos. Como se vê nas fotografias anteriores, ambas possuem as mesmas dimensões no assento, no encosto e no apoio para escrita. Também possuem o assento dobrável. Apresentam, no entanto, pelo menos duas diferenças - a carteira Waller possui no apoio para escrita espaço apropriado para tinteiro e a carteira Paulista possui um tampo verde e liso. Uma possui o n. 2 e a outra, o n. 1 gravado no ferro.

Em 1901, Bandeira Junior faz um levantamento das indústrias e fábricas existentes em São Paulo no fim do século XIX e início do século XX. Dentre elas, está a Fábrica de Móveis Escolares Eduardo Waller \& Comp. Ele informa:

No gênero de construcção de mesas, cadeiras, bancos e quadros para demonstrações, é esta a mais importante que existe no Estado. Fundada em 1895, á rua da Consolação n. 178, por Eduardo Waller \& Comp., não só forneceu o material do seu fabrico ás escholas publicas e particulares do Estado, como a algumas da Capital Federal, Minas Geraes, Bahia e outros pontos do norte da República.

Tudo quanto é concernente a mobílias, accessorios e ornamentos de casas de ensino, é ali fabricado com materiaes nacionaes, sobresahindo nelles a segurança e a perfeição; por modelos e systemas quasi todos privilegiados por cartas patentes, taes como:

As carteiras hygienicas, privilegiadas pelo governo federal com a patente n. 2012 de 12 de fevereiro de 1896.

Carteiras: - Adjustable - Brazil-Paulista e as Hygienicas - que se elevam ou descem conforme a altura do alumno.

Carteira com mesa e assentos, moveis para uma, duas e mais pessoas. Quadros negros - Hyloplate - imitando a ardosia natural.

Cadeiras e escrivaninhas para professores; para salas de conferencias, com mesa ao lado para notas.

Cadeiras com assento que automaticamente se fecham, no gênero das que fabricou para o teatro Sant'Anna, desta cidade.

Todas essas mobílias são de madeira e ferro nacional, sendo também nacionaes os tinteiros das mesas e carteiras.

Todos os moveis podem ser armados com a maxima presteza, assim também pode-se substituir qualquer peça inutilisada.

Não se pode determinar o limite do fabrico, porque sendo considerável o stock de materiaes, trabalhando a fabrica com maquinas a vapor, attende a qualquer encommenda, por mais considerável $^{576}$.

Considerando o embrionário desenvolvimento do comércio, da manufatura e indústrias no fim do século XIX, uma fábrica para atender a demanda do Estado, que fazia solicitações em grande quantidade e, pouco planejadas, deveria ter um significativo potencial de produção.

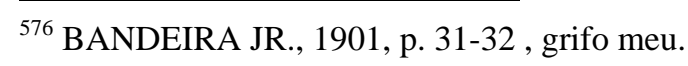


A fábrica Waller utilizava a mesma técnica produtiva europeia, isto é, a máquina a vapor, que favorecia uma produção em larga escola e em curto espaço de tempo. Assim, poderia atender "a qualquer encommenda, por mais considerável". Para distribuição nas escolas, inclusive do interior do Estado, não haveria maiores dificuldades, pois os móveis “podem ser armados com a máxima presteza".

Pela descrição das atividades do estabelecimento identificam-se pelos menos dois modelos. A carteira Ajustável, com dois tipos - a Brazil e a Paulista; e a Hygienica. Carteira com mesa e assentos móveis, para uma, duas ou mais pessoas. As carteiras Waller (Carteira Brazil) e americana aparecem em quantidade significativa nos inventários de bens da Escola Normal do Braz e da Praça da República. No Livro de Inventário Geral de material escolar, móveis e utensílios da Escola Normal Caetano de Campos, com registros de 1895 e 1896, consta a seguinte relação:

Quadro 2 - Inventários da Escola Normal Caetano de Campos

\begin{tabular}{|c|c|}
\hline \multicolumn{2}{|c|}{ ESCOLA NORMAL CAETANO DE CAMPOS } \\
\hline \multicolumn{2}{|c|}{ ANO } \\
\hline 1895 & 1896 \\
\hline 363 carteiras escolares americanas & $\begin{array}{l}48 \text { cadeiras austríacas, amarelas, assento de } \\
\text { palhinha }\end{array}$ \\
\hline 355 bancos escolares americanos & $\begin{array}{l}120 \text { cadeiras de braço, envernizadas, que servem } \\
\text { no salão nobre }\end{array}$ \\
\hline $\begin{array}{l}120 \text { cadeiras americanas que servem no } \\
\text { salão nobre }\end{array}$ & $\begin{array}{l}82 \text { cadeiras americanas, amarelas com assento de } \\
\text { palhinha }\end{array}$ \\
\hline $\begin{array}{l}120 \text { cadeiras americanas de braço que } \\
\text { servem no amphitheatro }\end{array}$ & $\begin{array}{l}5 \text { cadeiras de braço, de canela preta e assento de } \\
\text { marroquino }\end{array}$ \\
\hline 11 carteiras americanas para professores & 2 cadeiras de balanço, austríacas \\
\hline 11 cadeiras americanas de mola e palhinha & 4 cadeiras estofadas, com assento de morroquino \\
\hline 5 carteiras escolares estragadas & 4 cadeiras pretas com assento de couro da Russia \\
\hline 8 bancos escolares estragados & $\begin{array}{l}1 \text { cadeira de mola com assento e encosto de } \\
\text { palhinha }\end{array}$ \\
\hline $\begin{array}{l}3 \text { carteiras de canela preta encerada, com } \\
\text { grades, para amanuenses }\end{array}$ & $\begin{array}{l}3 \text { carteiras de canela preta, com grades, para } \\
\text { amanuenses }\end{array}$ \\
\hline $\begin{array}{l}3 \text { cadeiras com assento e encosto de couro } \\
\text { da Russia }\end{array}$ & 30 bancos com pés de ferro, modelo 550 \\
\hline 2 cadeiras de balanço, austríacas & \\
\hline $\begin{array}{l}48 \text { cadeiras austríacas envernizadas de } \\
\text { amarelo }\end{array}$ & \\
\hline $\begin{array}{lll}51 \text { cadeiras americanas envernizadas de } \\
\text { amarelo }\end{array}$ & \\
\hline 3 cadeiras de braço estofadas a morroquino & \\
\hline 1 cadeira de mola, austríaca & \\
\hline 28 bancos para jardim, modelo 550 & \\
\hline
\end{tabular}

Fonte: Elaboração da autora a partir do Inventário de Bens da Escola Normal Caetano de Campos (1895 e 1896). 
No Livro de Inventário da Escola Normal do Brás ${ }^{577}$, com registros de 1913 e 1924, são muitas as carteiras Waller, como se lê no quadro a seguir:

Quadro 3 - Inventários da Escola Normal do Brás

\begin{tabular}{|c|c|}
\hline \multicolumn{2}{|c|}{ ESCOLA NORMAL DO BRÁS } \\
\hline \multicolumn{2}{|c|}{ ANO } \\
\hline 1913 & 1924 \\
\hline 1 cadeira giratória no Gabinete do Diretor & 1 cadeira giratória no Gabinete do Diretor \\
\hline 4 cadeiras austríacas na secretaria & 1 cadeira giratória no Gabinete do Vice-Diretor \\
\hline 1 cadeira giratória na portaria & 6 cadeiras austríacas na secretaria \\
\hline 9 cadeiras austríacas na portaria & 2 cadeiras giratórias na secretaria \\
\hline $\begin{array}{l}9 \text { bancos de madeira com pernas de ferro no } \\
\text { corredor }\end{array}$ & 10 cadeiras austríacas na biblioteca \\
\hline 11 cadeiras austríacas na sala VI & 3 cadeiras na biblioteca \\
\hline 1 cadeira de braço na sala VI & 1 cadeira giratória na biblioteca \\
\hline $\begin{array}{l}12 \text { cadeiras com encosto de marroquino no } \\
\text { Salão n.1 }\end{array}$ & 2 banquetas e um banquinho na biblioteca \\
\hline 15 cadeiras de braço austríaco no Salão n.1 & 59 bancos de madeira no "pateo" \\
\hline 90 cadeiras presas no Salão n.1 & 2 carteiras no arquivo \\
\hline 4 cadeiras austríaca no Salão n.1 & 201 cadeiras austríacas no Salão \\
\hline 1 cadeira giratória na sala II & 35 poltronas no Salão \\
\hline 8 cadeiras austríacas na sala II & 7 poltronas com encosto marroquino no Salão \\
\hline 45 carteiras simples Waller na sala II & $\begin{array}{lllll}2 \text { cadeiras de braço no Gabinete dos } \\
\text { professores }\end{array}$ \\
\hline 45 bancos simples Waller na sala II & 1 cadeira austríaca no Gabinete dos professores \\
\hline 1 cadeira giratória na sala III & $\begin{array}{l}1 \text { cadeira de vime para docentes no Gabinete } \\
\text { dos professores }\end{array}$ \\
\hline 1 cadeira austríaca na sala III & 1 cadeira giratória na portaria \\
\hline 45 carteiras simples Waller na sala III & 6 cadeiras austríacas na portaria \\
\hline 45 bancos simples Waller na sala III & $\begin{array}{l}1 \text { cadeira americana para dentista no Gabinete } \\
\text { Dentário }\end{array}$ \\
\hline 1 cadeira giratória na sala IV & 1 cadeira austríaca no Gabinete Dentário \\
\hline 1 cadeira austríaca na sala IV & $\begin{array}{l}1 \text { cadeira austríaca com braços na Sala de } \\
\text { Gymnastica }\end{array}$ \\
\hline 45 carteiras simples Waller na sala IV & 6 cadeiras nos corredores \\
\hline 45 bancos simples Waller na sala IV & 13 bancos de madeira na sala de arrecadação \\
\hline 1 cadeira giratória na sala $\mathrm{V}$ & 15 carteiras na sala de arrecadação \\
\hline 1 cadeira austríaca na sala $\mathrm{V}$ & 1 cadeira austríaca com braços na sala I \\
\hline 35 carteiras simples Waller na sala V & 2 cadeiras austríacas na sala I \\
\hline 35 bancos simples Waller na sala $\mathrm{V}$ & 45 carteiras simples Waller na sala I \\
\hline 1 cadeira giratória na sala VIII & 45 bancos simples Waller na sala I \\
\hline 1 cadeira austríaca na sala VIII & 1 cadeira austríaca na sala III \\
\hline 35 carteiras simples Waller na sala VIII & 45 carteiras simples Waller na sala IV \\
\hline 35 bancos simples Waller na sala VIII & 45 bancos simples Waller na sala IV \\
\hline 1 cadeira giratória na sala IX & 1 cadeira de braços na sala IV \\
\hline 45 carteiras simples Waller na sala IX & 1 cadeira de braços na sala $\mathrm{V}$ \\
\hline 45 bancos simples Waller na sala IX & 1 cadeira austríaca na sala $\mathrm{V}$ \\
\hline 1 cadeira giratória na sala $X$ & 45 carteiras simples Waller na sala V \\
\hline 35 carteiras simples Waller na sala $X$ & 45 bancos simples Waller na sala $\mathrm{V}$ \\
\hline
\end{tabular}

${ }^{577}$ Sobre a Escola Normal do Bras ver a Dissertação de Mestrado de Alcântara, 2008. 


\begin{tabular}{|c|c|}
\hline 1913 & 1924 \\
\hline 35 bancos simples Waller na sala $\mathrm{X}$ & 13 cadeiras na sala VII \\
\hline 1 cadeira giratória na sala XI & 1 cadeira austríaca com braços na sala VIII \\
\hline 1 cadeira austríaca na sala XI & 45 carteiras simples Waller na sala VIII \\
\hline 45 carteiras simples Waller na sala XI & 45 bancos simples Waller na sala VIII \\
\hline 45 bancos simples Waller na sala XI & 3 cadeiras austríacas (uma de braço) na sala IX \\
\hline 11 cadeiras de braço austríacas na sala XII & 45 carteiras simples Waller na sala IX \\
\hline 95 cadeiras austríacas na sala XII & 45 bancos simples Waller na sala IX \\
\hline 1 cadeira giratória na sala XIII & 4 cadeiras austríacas (uma de braço) na sala $\mathrm{X}$ \\
\hline 1 cadeira austríaca na sala XIII & 45 carteiras simples Waller na sala $X$ \\
\hline 45 carteiras simples Waller na sala XIII & 45 bancos simples Waller na sala $X$ \\
\hline 45 bancos simples Waller na sala XIII & 4 cadeiras austríacas (uma de braço) na sala XI \\
\hline 1 cadeira giratória na sala XVI & 46 carteiras simples Waller na sala XI \\
\hline 1 cadeira austríaca na sala XVI & 46 bancos simples Waller na sala XI \\
\hline 35 carteiras simples Waller na sala XVI & 2 cadeiras austríacas (uma de braço) na sala XII \\
\hline 35 bancos simples Waller na sala XVI & 1 cadeira na sala XIII \\
\hline 5 carteiras simples Waller no arquivo & 45 carteiras simples Waller na sala XV \\
\hline 1 carteira simples Waller no arquivo & 45 bancos simples Waller na sala XV \\
\hline 2 bancos simples Waller no arquivo & 1 cadeira giratória na sala $\mathrm{XV}$ \\
\hline 5 bancos simples Waller no arquivo & 2 cadeiras na sala $\mathrm{XV}$ \\
\hline 2 cadeiras austríacas no arquivo & 45 carteiras simples Waller na sala XVI \\
\hline 30 taboas para carteira no arquivo & 45 bancos simples Waller na sala XVI \\
\hline \multirow[t]{25}{*}{3 cadeiras austríacas na cozinha } & 1 cadeira giratória na sala XVI \\
\hline & 2 cadeira austríaca na sala XVI \\
\hline & 45 carteiras simples Waller na sala XVII \\
\hline & 45 bancos simples Waller na sala XVII \\
\hline & 1 cadeira giratória na sala XVII \\
\hline & 2 cadeira austríaca na sala XVII \\
\hline & 35 carteiras simples Waller na sala XVIII \\
\hline & 35 bancos simples Waller na sala XVIII \\
\hline & 1 cadeira giratória na sala XVIII \\
\hline & 2 cadeira na sala XVIII \\
\hline & 35 carteiras simples Waller na sala XXI \\
\hline & 35 bancos simples Waller na sala XXI \\
\hline & 1 cadeira giratória na sala XXI \\
\hline & 2 cadeira na sala XXI \\
\hline & 45 carteiras simples Waller na sala XXII \\
\hline & 45 bancos simples Waller na sala XXII \\
\hline & 1 cadeira giratória na sala XXII \\
\hline & 2 cadeira na sala XXII \\
\hline & 45 carteiras simples Waller na sala XXIV \\
\hline & 45 bancos simples Waller na sala XXIV \\
\hline & 1 cadeira giratória na sala XXIV \\
\hline & 2 cadeira na sala XXIV \\
\hline & $\begin{array}{l}1 \text { cadeira de braços no Laboratório de Physica e } \\
\text { Chimica }\end{array}$ \\
\hline & $\begin{array}{l}2 \text { cadeiras simples no Laboratório de Physica e } \\
\text { Chimica }\end{array}$ \\
\hline & 2 cadeiras na sala de Anatomia \\
\hline
\end{tabular}

Fonte: Elaboração da autora a partir do Inventário de Bens da Escola Normal do Brás (1913 e 1924). 
Nos inventários percebe-se a representatividade das carteiras do mobiliário americano e Waller, dentre os tipos de bancos, cadeiras e carteiras descritos. O inventário da Caetano de Campos, do ano de 1895, foi elaborado considerando o total de carteiras e bancos escolares americanos que a instituição possuía.

Já os inventários da Normal do Brás mencionam quantas carteiras Waller ocupavam algumas salas da escola. Essa forma de organização permite supor que os espaços com 35 ou 45 carteiras e bancos simples Waller eram destinados às salas de aulas e que, estes eram, provavelmente, o número de alunos que formavam uma classe. É o caso das salas III, IV, V, VIII, IX, X, XI, XIII e XVI conforme inventário de 1913. O inventário de 1924 sinaliza a reorganização do uso dos espaços escolares. As salas I, XV, XVII, XVIII, XXI, XXII e XXIV transformam-se em sala de aula.

Um modelo da carteira da empresa Eduardo Waller \& Comp. pode ser visto no site do Centro de Referência em Educação Mário Covas, onde também se lê:

Móvel escolar fabricado na cidade de São Paulo, por Eduardo Waller \& C., estabelecido em 1896 à Rua Maria Antonia, próximo à Escola Americana (atual Universidade Mackenzie), onde Eduardo Waller era professor de trabalhos manuais. Até pelo menos 1911, Brasil se grafava com Z, daí tal inscrição na carteira, cuja data podemos afirmar que é anterior a essa época. Madeira e ferro fundido, Ed. Waller \& C., $1900^{578}$.

${ }^{578}$ http://www.crmariocovas.sp.gov.br/txt_html/mem/obj/obj_a/f08_04.html. 
Figura 38 - Carteira Brazil

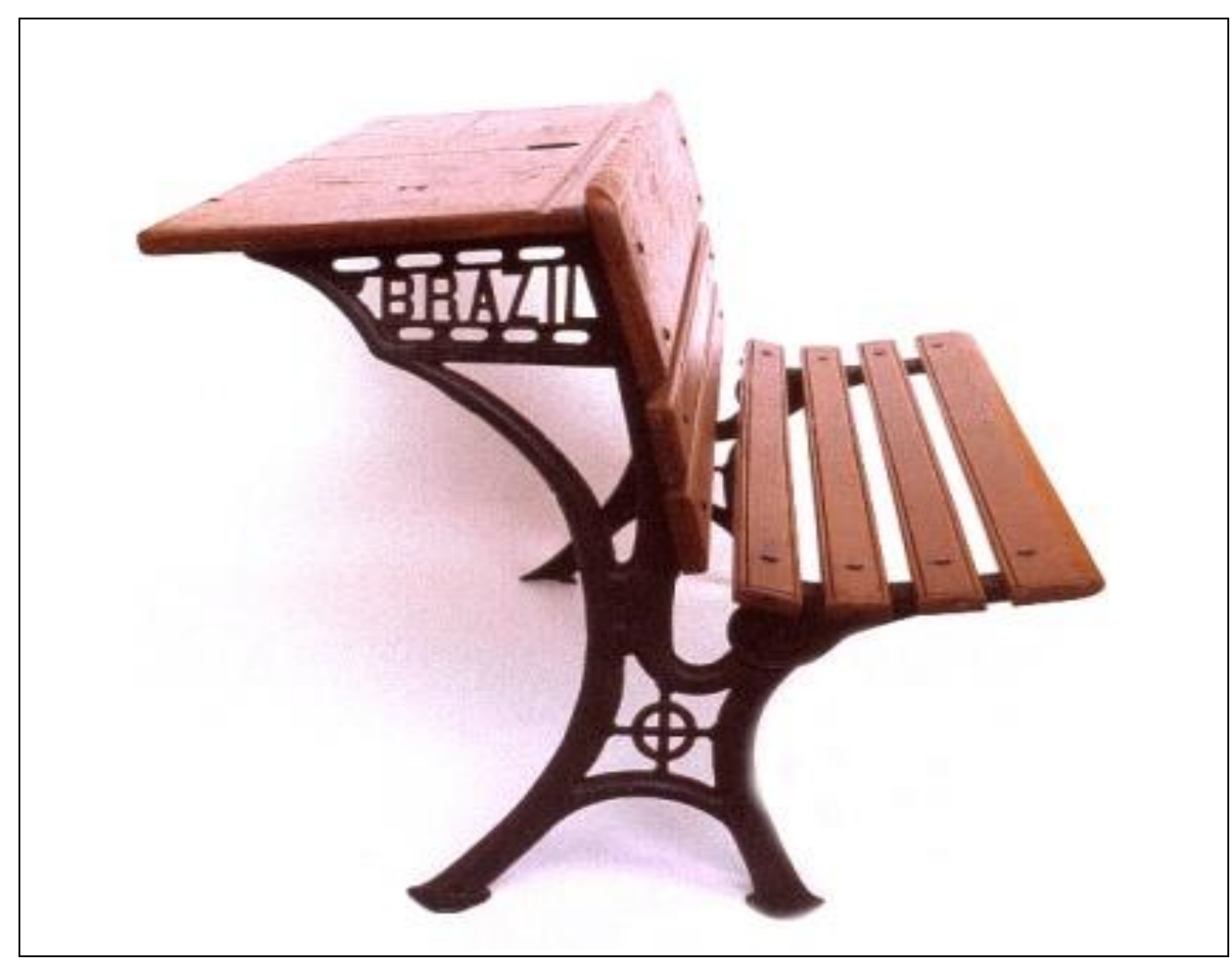

Fonte: Centro de Referência em Educação Mário Covas

É provável que essa não fosse a carteira que compunha o acervo mobiliário da Escola Normal do Brás. Como se observa nos inventários, onde há a descrição de 45 carteiras simples Waller, segue o mesmo número de banco simples Waller. Isso significa que o móvel descrito nos inventários de 1913 e 1924 não possuía o assento integrado à carteira, como se vê na carteira Brazil.

Dentre todas as indústrias de mobiliário escolar que comercializam com a administração pública paulista, a de maior porte, pelo menos de acordo com o que as fontes até aqui localizadas indiciam, é a Eduardo Waller \& Cia. Isto é atestado por Bandeira Junior quando diz que, no gênero, "esta é a mais importante que existe no Estado" 579 .

Não somente fabricava, mas criava seus próprios modelos de carteira, tendo obtido patente de duas delas, sobre o que falaremos na segunda parte deste capítulo. Se a empresa não era da propriedade de brasileiros e comercializava com o poder público e para escolas brasileiras, era importante enfatizar que seus produtos eram fabricados

\footnotetext{
${ }^{579}$ BANDEIRA JUNIOR, op. cit, p.31.
} 
“com materiais nacionaes”, "todas essas mobílias são de madeira e ferro nacional, sendo também nacionaes os tinteiros das mesas e carteiras" ${ }^{\text {"50 }}$. Além disso, detinha a última tecnologia no ramo - a máquina à vapor, o que garantia rapidez, maior produção em menor tempo, produção em massa para atender "a qualquer encomenda por mais considerável" ${ }^{\prime 581}$.

Dentre as carteiras fabricadas por esta indústria, a mais conhecida e popularizada foi a carteira Brazil, cujo modelo seguia os padrões das carteiras americanas: pé de ferro fundido, assento e superfície de trabalho em madeira.

Tendo iniciado suas atividades em 1895, sabemos que até 1920 ela ainda funcionava, conforme informa o autor da postagem da propaganda a seguir. No entanto, nessa época, é provável que já pertencesse a outro dono, João Gualberto de Oliveira.

${ }_{581}^{580}$ BANDEIRA JUNIOR, op. cit, p.31-32.

${ }^{581}$ Idem, p. 32. 
Figura 39 - Fábrica de Móveis Escolares Eduardo Waller

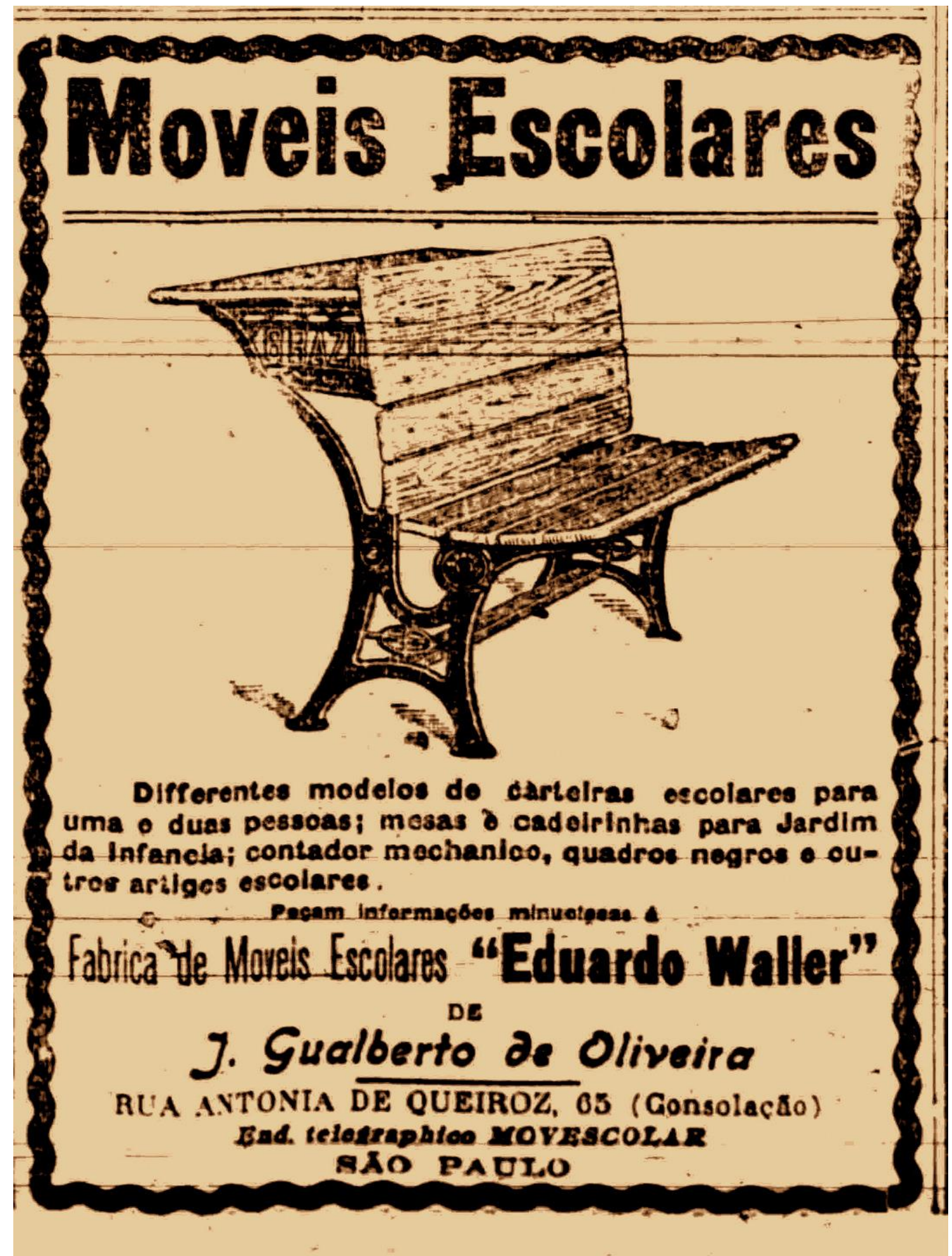

Fonte: http://tokdehistoria.wordpress.com/tag/carteiras-escolares-da-decada-de-1920/ Autor - Rostand Medeiros , junho de 1921

João Gualberto de Oliveira, secretário geral do Centro Cultural Brasil-Suécia, advogado, escritor e jornalista escreveu, em 1952, o livro Suecos no Brasil. Dentre os 
biografados está Eduardo Waller. Antes de narrar a história de "estimados vultos nórdicos" ${ }^{\text {582 }}$, o autor faz um "Panorama da Suécia", explicando dentre outros pontos, a questão econômica daquele país. Ele apresenta os suecos como povo especializado com o manejo da madeira. Segundo ele, "grande parte da indústria sueca baseia-se nas matérias-primas extraídas de seus ricos e seculares bosques. A produção de madeiras de diferentes qualidades, de pasta, celulose e papel alcança normalmente $25 \%$ da indústria do País" "583.

Trabalhar com madeira também era uma das especialidades de Eduardo Waller. Nascido em uma região bucólica da Suécia em 1860, após o curso primário, Eduardo Waller foi estudar no Seminário de Nääs. Nessa escola, “ensinava-se desenho linear e geométrico, lavragem de madeira bruta para a feitura de móveis, construções racionalizadas de móveis domésticos, além de tapêtes e outros trabalhos manuais" Ele conclui o "artesanato, curso que os suecos chamam de 'slöjd', e que inclui os mais variados trabalhos manuais" ${ }^{585}$. Assim, tornou-se proprietário de uma carpintaria. É para desenvolver essa profissão que ele vem para o Brasil.

Ele vem à convite de "um brasileiro empreendedor, um paulista" ${ }^{586}$, chamado Inácio de Mendonça Uchoa. Viajando pela Escandinávia, o brasileiro conhece os móveis de Eduardo Waller e "resolvera contratar um mestre para sua grande serraria na capital da Província” ${ }^{, 57}$ - a Serraria e Fábrica de Móveis São José.

Apesar do sucesso no trabalho, tinha aborrecimentos e prejuízos por causa do nome. Era "comprido e difícil para os brasileiros". Por isso, com permissão do Governo da Suécia, que "resolvera permitir a seus filhos a livre adoção de nome diferente, mais claro, mais fácil de distinguir, em lugar dos vulgarissimos Gustavson, Abrahamson, Anderson, etc.", o carpinteiro mudou seu nome. Ele se chamava Andreas Edvard Petterson. "Eduardo eliminou o Andreas, aportuguesou o Edvard e escolheu o sobrenome Waller. Daí por diante ficou sendo, e para sempre, Eduardo Waller. Foi sob êsse nome que São Paulo o conheceu, estimou e admirou"588.

582 OLIVEIRA, João Gualberto de. Suecos no Brasil. São Paulo: Revista dos Tribunais, 1952, p.12.

583 Idem, p. 23

584 Idem, p.104-105.

585 Idem, p.105.

586 Idem, p.106.

587 Idem, ibidem.

588 Idem, p.107-108. 
Ele chegou ao Brasil em 1888 e, em 1890, “começou a sua obra como professor. Trouxe para nós a maravilha sueca que é o 'slöjd' (pronuncie-se eslóide)" ${ }^{\text {"589 }}$. De 1890 a 1905 lecionou na Escola Americana. "Transmitiu aos jovens de São Paulo a velha técnica de lavrar madeira, isto é, de transformar o lenho bruto nos móveis que adornam e proporcionam confôrto às nossas casas" ${ }^{, 590}$. As aulas para os alunos externos e internos “eram dadas na Rua Maria Antônia, numa construção de madeira, misto de salão de aula e de moradia" $" 591$.

Nesta mesma região, na rua da Consolação, fundou em 1896, "pequena fábrica de moveis escolares". A respeito da relação da fábrica de Eduardo Waller com a instrução pública, João Gualberto de Oliveira assevera:

A instrução pública, notadamente a primária, com o advento da República tomara novos rumos e incrementos em nossa terra. Apareciam os grupos escolares pelos bairros, pelas cidades do interior. E Eduardo Waller era quem fornecia o mobiliário para as classes. O material por êle usado era de primeira ordem e corresondia ao novo espírito educacional. Por isso, seu nome tornou-se acatado de norte a sul do Brasil, a tal ponto que, em 1908, o industrial sueco adquiriu um vasto terreno na Rua Antônia de Queirós, antigo n. 65, no bairro da Consolação, e para ali transferiu a sua oficiana. Nessas novas instalações chegou a contar com sessenta operários a seu serviço.

Era artesão por excelência, com muito engenho e muita arte [...] Eduardo Waller, como professor, artista, técnico, foi melhorando, incessantemente a sua produção. Devemos-lhe a criação de um tipo original de carteira escolar, a que ele deu o nome de "Brasil". E a "Adjustable", ajustável à altura e à conformação física do escolar. Esse material, nas diversas feiras nacionais e estrangeiras em que se expôs foi premiado com as mais altas distinções. E com justificados motivos pois representava grande e admirável inovação na pedagogia daquele tempo ${ }^{592}$.

Além de proprietário de uma fábrica de mobiliário escolar, Eduardo Waller desenvolveu diversas outras atividades econômicas na promissora São Paulo. No Almanak Administrativo, Mercantil e Industrial do Rio de Janeiro ele aparece como médico, atuando na rua da Consolação n. 178. Não consta apenas que Eduardo Waller é médico, mas que esta atividade é desenvolvida por Eduardo Waller \& $\mathrm{C}^{593}$. Na Exposição Nacional de 1908, o Almanak Administrativo, Mercantil e Industrial do Rio de Janeiro o noticia como participante do décimo primeiro grupo, moveis comuns e de luxo, bilhares. Juntamente com o Lyceu de Artes e Officios recebeu "Grandes 
Premios" ${ }^{\text {594 }}$. Entre os fabricantes e negociantes de móveis está Eduardo Waller \& C. Considerando o importante papel que os médicos desempenharam na discussão da higiene urbana e corporal no fim do século XIX, não é de se estranhar que um médico tivesse conhecimento sobre padrões higiênicos para fabricação de carteiras e móveis. O que permitia até que ele inventasse um mobiliário.

Porém, além de médico e negociante de móveis, Eduardo Waller também era vice-cônsul da Suécia em São Paulo, atendendo na rua Maranhão n.1. Esta atividade, todavia, aparece só posteriormente em $1917^{595}$ e consta até $1923^{596}$. Uma das funções do cônsul é promover o comércio entre seu Estado de origem e o lugar onde reside.

Citando Vanessa Bivar, Carina Pedro esclarece que

um dos objetivos dos cônsules e agentes consulares era informar o seu país sobre as oportunidades de crescimento do comércio nas cidades onde estavam instalados [...] Essa comunicação era feita por relatórios e cartas destinados ao Ministério dos Negócios Estrangeiros na França ${ }^{597}$.

Se o cônsul era um sujeito conhecedor das boas oportunidades de comércio, a opção de Eduardo Waller em se dedicar ao comércio de mobiliário escolar, significa que este era um negócio rentável no período, sobretudo em um Estado em expansão urbana e populacional como São Paulo. O cônsul era, sem dúvida, um indivíduo que estabelecia relações entre mundos.

\begin{abstract}
Além das preocupações voltadas para o comércio e para a navegação mercante, esses homens podiam também cuidar dos interesses dos cidadãos franceses estabelecidos no Brasil, como vistos de passaporte, certificados de origem, inventários, etc. Sobre a província de São Paulo, especificamente, a autora afirmou que, havia na região, agentes consulares situados junto ao Porto de Santos e na cidade de São Paulo, todos subordinados ao consulado do Rio de Janeiro. Foi no final do século XIX que a capital paulista recebeu um consulado permanente, passando a controlar também as agências do Paraná, Santa Catarina e Rio Grande do Sul. No caso de serem nomeados comerciantes para este tipo de atividade, Bivar (2007) deduziu que tal seleção refletia um interesse por parte do governo francês em economizar nas despesas de manutenção do representante consular em outro país, além de que os negociantes detinham maior conhecimento e experiência comercial sobre o local em que atuavam ${ }^{598}$.
\end{abstract}

\footnotetext{
${ }^{594}$ Almanak Administrativo, Mercantil e Industrial do Rio de Janeiro, 1909, p.2374.

${ }^{595}$ Almanak Administrativo, Mercantil e Industrial do Rio de Janeiro, 1917, p. 4401

${ }^{596}$ Almanak Administrativo, Mercantil e Industrial do Rio de Janeiro, 1923, p.681.

597 PEDRO, Carina Marcondes Ferreira. Casas Importadoras de Santos e seus agentes: comércio e cultura material (1870-1900). Universidade de São Paulo. Dissertação de Mestrado, 2010, p.37.

${ }^{598}$ BIVAR, 2007, p.111-115, apud PEDRO, 2010, p.37-38.
} 
Embora Vanessa Biver e Carina Pedro abordem o caso francês, suas pesquisas são elucidativas das funções e atuações dos cônsules e da presença de representantes de governos estrangeiros atuando também como comerciantes.

Inára Garcia identificou, no Rio de Janeiro, relações entre o consulado da Suécia e a Instrução Pública: Em

1878, o cônsul geral da Suécia e Noruega, Leonardo A. Dkertblom ofereceu ao Conselho de Instrução da parte de Augusto Abrahansen —uma colleção de modelos em trabalhos de marcenaria para servirem ao Instituto dos surdos e mudos ou a qualquer outro estabelecimento de educação" ${ }^{\text {599 }}$.

Proprietário de uma fábrica de porte considerável para o período, a intimidade com o comércio não faltaria a este homem de negócios. Mas quem seria o sócio ou os sócios que com Eduardo Waller firmaram uma Companhia? "Todos os atos do comércio praticados por estrangeiros residentes no Brasil serão regulados e decididos pelas disposições" do Código Comercial de 1850 (LEI N 556, DE 25 DE JUNHO DE 1850, Art.30).

Não tendo localizado o Registro do Comércio desta Companhia nem na Junta Comercial do Estado de São Paulo (JUCESP), nem na Junta Comercial do Rio de Janeiro, não foi possível identificar os sócios e o capital social da empresa. Entretanto, outras informações podem ser obtidas, a partir do nome empresarial ou comercial. A Eduardo Waller \& Cia., funciona sob firma social e não denominação.

Enquanto a denominação forma-se por um nome fantasia, a firma ou razão social é formada pelo nome de um dos sócios, alguns deles ou de todos eles. Na ausência do nome de um dos sócios é acrescida a expressão "\& Companhia", ou abreviada, "\& Cia". Cabem expressões similares como "\& Filhos", "\& Irmãos”. O nome da sociedade está intimamente relacionado com o tipo ou a forma social. Funcionando sob firma, a Eduardo Waller \& Cia poderia ser uma Sociedade em nome coletivo ou uma Sociedade em Comandita Simples.

$\mathrm{Na}$ primeria hipótese, todos os sócios deveriam ser pessoas físicas que respondessem solidária e ilimitadamente pelas obrigações sociais. Na segunda, há dois tipos de sócios, os comanditados e os comanditários. Os primeiros deveriam ser pessoas físicas que responderão solidária e ilimitadamente pelas obrigações da sociedade; os comanditários poderiam ser pessoas físicas ou jurídicas com a responsabilidade da

${ }^{599}$ GARCIA, 2011, p.135. 
integralização do capital social que subscreveram ${ }^{600}$. O mais provável é que a Fábrica de Móveis Escolares fosse uma Sociedade em nome coletivo. Todavia, como não aparecem na firma ou razão social, a dificuldade de identificar os demais sócios persiste.

Outra lacuna nesta pesquisa é que não se pode precisar quem foi o fabricante ou fornecedor das carteiras americanas, presentes em quantidade significativa no Inventário de bens da Escola Normal Caetano de Campos do ano de 1895.

Em 1894, o Secretário do Interior autoriza o inspetor do $18^{\circ}$ distrito literário a adquirir carteiras americanas para as escolas de Itu, sendo 60 carteiras americanas para o Primeiro Grupo Escolar (sexo masculino) de Itu; e, 45 carteiras americanas para o Segundo Grupo Escolar Dr. Cesário Motta (sexo feminio) de Itu ${ }^{601}$.

Em 1896, os cadernos e as carteiras americanas aparecem como utensílios e móveis “indispensáveis para o Grupo Escolar Luiz Leite de Amparo", que solicita 30 carteiras americanas ${ }^{602}$. Nesse mesmo ano, o Secretário do Interior recomenda ao Diretor Geral Interino da Instrução Pública e ao almoxarifado a providência de 200 carteiras americanas para o Grupo Escolar de S. José dos Campos e para as quatro escolas da cidade de Bragança ${ }^{603}$.

No Jornal $O$ Vulgarisador ${ }^{604}$, publicação carioca entre os anos de 1877 e 1880, há notícias sobre as carteiras americanas. Na edição 29 do ano de 1878, numa discussão sobre "Material de ensino", o assunto central é a higiene da escola. Dentro dele, a mobília. $\mathrm{O}$ autor do texto cita das palavras do diretor do ensino primário na França, no relatório de 1871 a 1872 .

Não se conhecia até aqui nas escolas senão compridas e pesadas mesas, fincadas por assim dizer ao sólo, que só difficilmente se podiam concertar sem arredal-as, a não transportal-as pelas janellas, visto a deficiência das portas. Em bancos de 6 a 7 metros de comprimento, os alumnos, especialmente nas classes inferiores, assentavam-se em fileiras de 15, 18 ou 20. Mal podiam mover-se. Bastava que um se desarranjasse para todos ficarem em desordem. Era impossível ao professor sentar-se no banco, para corrigir uma escripta, rectificar uma posição contrafeita, dar um conselho especial. Estas mesas são hoje substituídas nas novas escolas por outras de 3,4 e 5 lugares, sufficientemente solidas, porém moveis e leves, próprias para estar unidas quando o local absolutamente o exigir; mas que regularmente devem estar collocadas a distância umas das outras, de modo a proporcionar as crianças a liberdade de seus movimentos, aos professores a facilidade da vigilância e do ensino, e de maneira

\footnotetext{
${ }^{600}$ COELHO, Fábio Ulhoa. Manual de Direito Comercial. 17. ed. São Paulo: Saraiva, 2006

${ }^{601}$ Anexo n.41.

${ }^{602}$ Anexo n.42.

${ }^{603}$ Anexos n.43 e n.44.

${ }^{604}$ Agradeço à Inára Garcia Pinto a cessão desta documentação.
} 
também a obviar as aglomerações que originam e propagam as doenças epidêmicas ${ }^{605}$.

Após ressaltar os defeitos da mobília antiga, o autor destaca a relevância da organização material da classe.

É parte essencial da educação; porque d'alli devem resultar para a criança hábitos de civilidade, de limpesa, de posição conveniente. Uma classe bem mobiliada, bem ordenada, onde o menino entre com sentimento de prazer entremeiado de respeito, dispôe-n'o e obriga-o moralmente, por assim dizer, á applicação e ao trabalho ${ }^{606}$.

Para realizar esta tarefa de "melhorar as condições hygienicas, bem como a mobilia das escolas" públicas foi preciso convocar o setor privado:

[...] segundo nos consta, a casa commercial dos Srs. Cunha, Guimarães \& C., á rua da Quitanda, n.68, que importa grande porção destes gêneros [carteiras] americanos, tem fornecido já, por ordem da presidência da provinca do Rio de Janeiro, á directoria da instrução publica, carteiras-bancos para mais de trinta escolas [...] O Collegio Pedro II comprou 100 carteiras-bancos para 136 alumnos. A Escola Polytechinica comprou em 1876 carteiras americanas para 200 alumnos e este anno mais 150 para igual numero, achando-se por consequência regularmente mobiliada ${ }^{607}$.

Esta mobília ainda tinha como grande vantagem sua adaptação a diversas situações.

${ }^{605} \mathrm{O}$ vulgarisador, n.29-30 de out. de 1878 , p.227-228.

${ }^{606} \mathrm{O}$ vulgarisador, n.29-30 de out. de 1878, p.228.

${ }^{607} \mathrm{Idem}$, ibidem. 
Figura 40 - Carteiras americanas

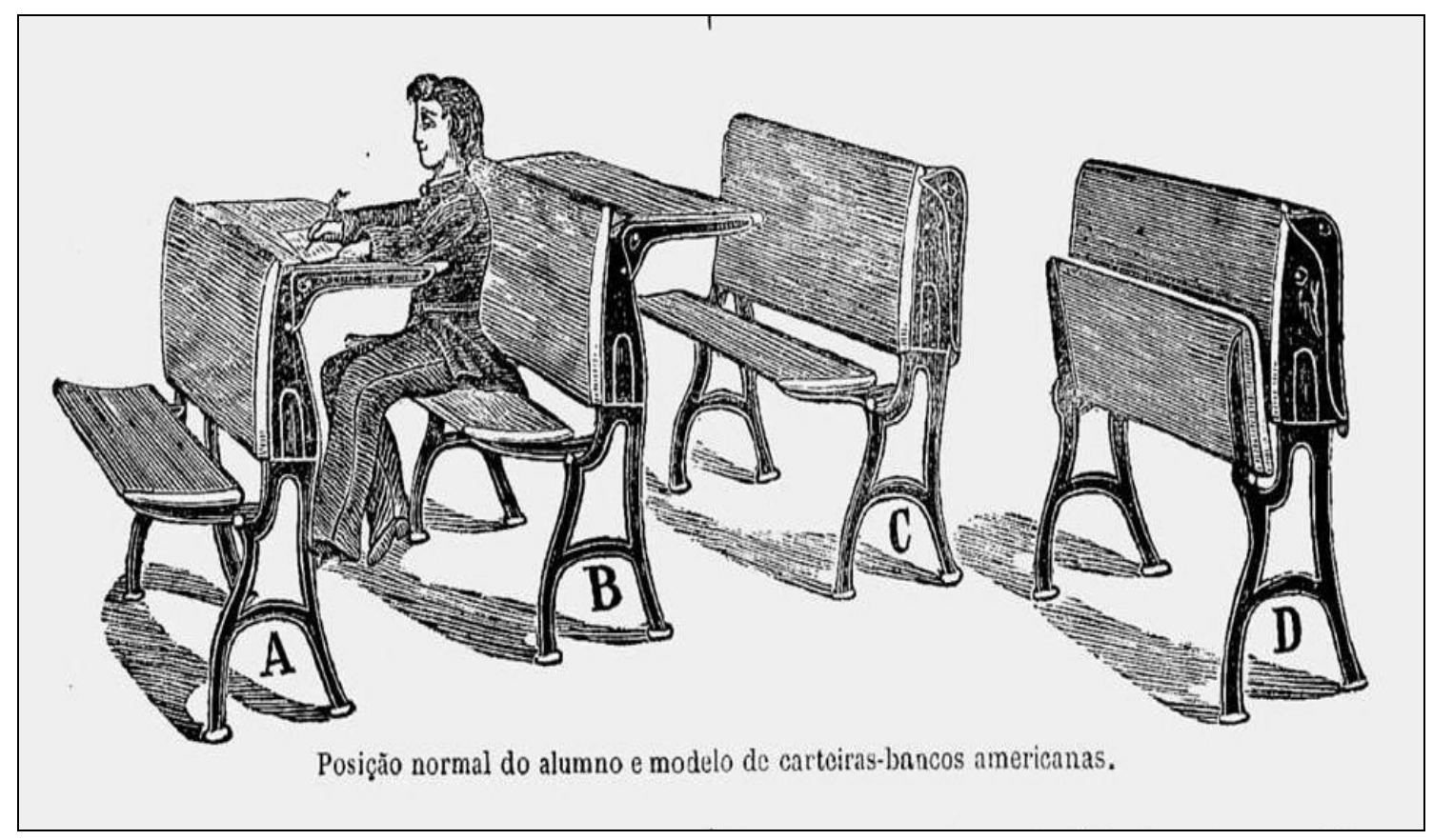

Fonte: Rio de Janeiro, O vulgarisador, n.29 - 30 de out. de 1878, p.229

As figuras A e B representam a posição normal na escrita. Disposta conforme a figura C, a carteira prestava aos trabalhos de agulha das escolas para meninas. Completamente fechada (figura D), a carteira-banco "é commodo para se poder varrer e lavar o assoalho" ${ }^{\circ 08}$.

Equipar todas as escolas existentes e as que deveriam ser criadas com mobiliário importado não era fácil. Assim, "para dotar de mobilia apropriada a todas as escolas, é preciso dinheiro, e só o corpo legislativo é que póde conceder autorisação para que o ministro o possa convenientemente dispender" ${ }^{\circ 09}$.

As famosas carteiras, muitas premiadas nas Exposições Universais e/ou patenteadas custavam caro. Por isso, muitas vezes, buscou-se adaptá-las obedecendo às condições econômicas locais. É o que nos fala Garcia, citando a opinião de Frazão sobre o tema. Segundo ele, o mais recomendável seria mandar fazer a mobília inglesa no país.

Nada há como a simplicidade e a economia das mobílias inglesas. Duas pernas de ferro fundido, presas por parafusos ao soalho da casa e sobre as quais se adaptão duas taboas[...] A mão de obra reduz-se a duas taboas lisas para serem parafusadas nas pernas de ferro ${ }^{610}$.

\footnotetext{
${ }^{608}$ Idem, p. 229.

${ }^{609}$ Idem, ibidem.

${ }^{610}$ GARCIA, 2011, p.140.
} 
Esta parece ter sido a opção do Sr. Abílio Cesar Borges que, de acordo com Garcia, mandou vir da Inglaterra somente as pernas de ferro fundido. Adaptar e "construir esse mobiliário nas oficinas do Rio de Janeiro" significava atender "às condições específicas de cada escola e às condições econômicas do Estado" ${ }^{\text {"611 }}$.

Posição diversa assumiu Roiz Carneiro quando

Aconselhou que o modelo a ser seguido fosse o dos móveis escolares dos Estados Unidos, o qual consiste em dar-se uma pequena mesa a cada alluno e a sua competente cadeira, o que, além de outras vantagens, traz o isolamento tão necessário ao estudo em seus diferentes grãos ${ }^{612}$.

As carteiras americanas compuseram a materialidade das escolas tanto paulistas quanto cariocas. Se a casa comercial Cunha, Guimarães \& C. era a fornecedora no Rio de Janeiro, não foi possível precisar o fornecedor desta mobília em São Paulo. Não se pode ratificar se a ação de Horace Lane encomendando as carteiras americanas para as escolas públicas paulista foi esporádica ou contínua.

Bandeira Junior dá notícia de outra fábrica destinada ao fabrico de móveis escolares, fundada em 1888 à rua Piratininga, $\mathrm{n}^{\text {os }}$. 10, 12 e 14 no Brás. Trata-se da Fábrica de Móveis Irmãos Refinetti. Além de móveis escolares, produzia, também, móveis para

uso doméstico, geralmente usado, sem estylo, com materiaes em sua maioria nacionaes. $\mathrm{O}$ seu machinismo é todo a vapor, impellido por um motor da força de 8 cavallos. Completa o estabelecimento uma oficina de empalhar e lustrar. O stock é regular, variando o pessoal operário entre 40 e 50 homens em maioria estrangeiros ${ }^{613}$.

A Fábrica dos Irmãos Refinetti aparece nas "Notabilidades do Estado de S. Paulo" no Almanak Administrativo, Mercantil e Industrial do Rio de Janeiro do ano de 1905.

\footnotetext{
${ }^{611}$ GARCIA, 2011, p.141

612 Idem, ibidem.

${ }^{613}$ BANDEIRA JR., 1901, p.33.
} 
Figura 41 - Fábrica de Móveis José Refinetti \& Irmão

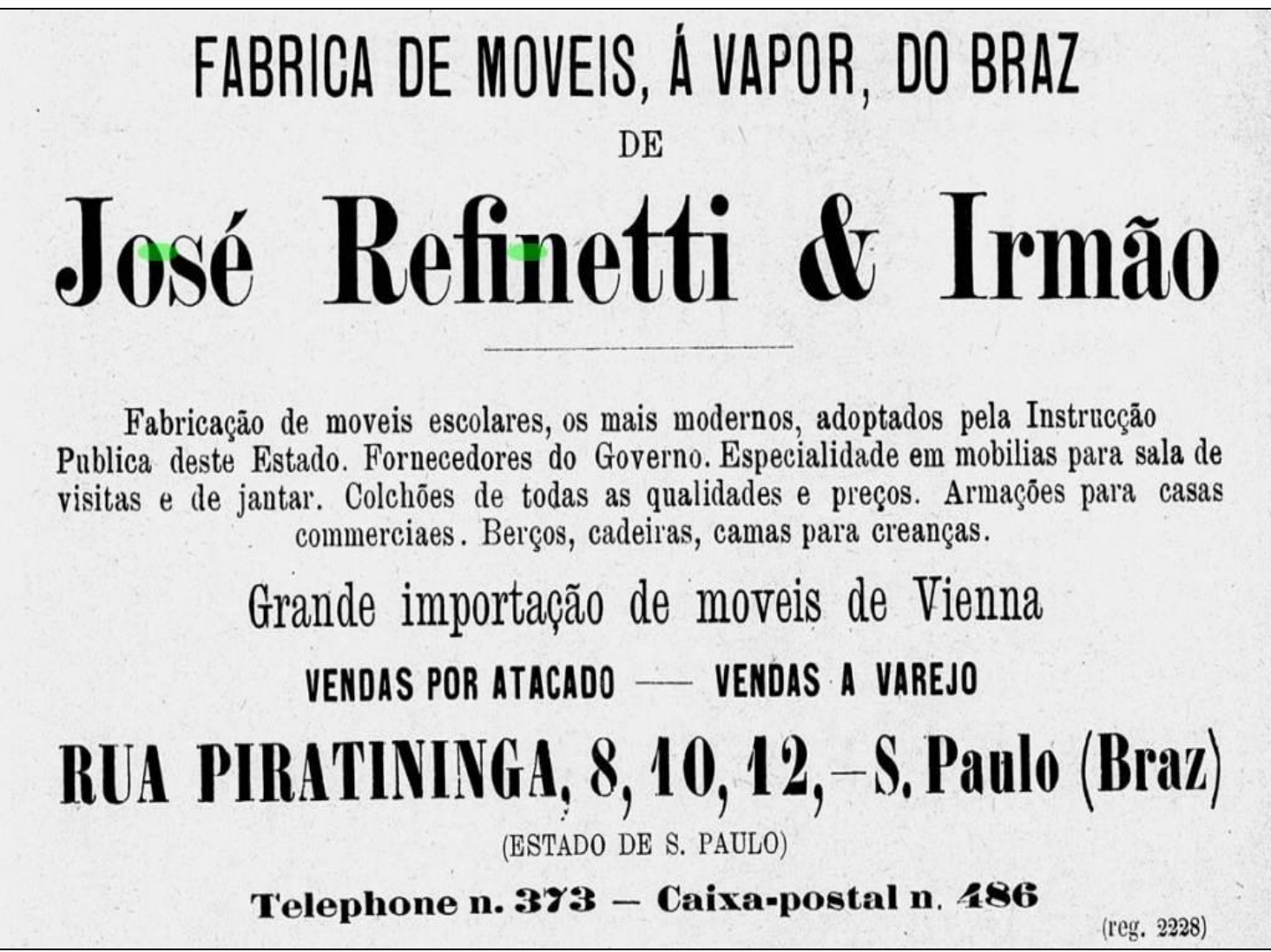

Fonte: Almanak Administrativo, Mercantil e Industrial do Rio de Janeiro do ano de 1905, p.2224

No anúncio é destacado o uso da máquina à vapor para fabricação dos móveis. É possível que essa tenha sido uma estratégia para convencer o cliente que precisava de uma mercadoria em curto prazo e grande quantidade. A máquina à vapor é um dos maiores símbolos da Revolução Industrial. Ela permite uma produção em larga escala e em curto período de tempo. Dentre os clientes, estava o governo paulista, como se lê no texto da propaganda.

A produção de móveis escolares era apenas uma das atividades de José Refinetti \& Irmão. No entanto, é a que aparece em primeiro lugar na lista dos tipos de mercadorias fabricadas por esta indústria. Os móveis escolares produzidos são "os mais modernos".

Situada em um bairro que à época era reconhecido pela concentração de indústria, o Braz, a José Refinetti \& Irmão, além de produzir móveis, importava-os de Viena, o que mais uma vez corrobora a ideia da relação entre importação e nascimento da indústria local. 
Uma propaganda da Revista A Cigarra, de 1916, traz ilustrações das carteiras por ela produzidas.

Figura 42 - Fábrica de Móveis de Luxo e Material Escolar

\section{Guantie Fabrich de Moveis de Luxo e Material Essolar}

Premiada nos Exposiçóes Nacional do Rio de Janeiro-1908. con Medaltha de Oiro: Internacional Turim-1911. Diplomn de Honra e Medalha de Dra-ta: Internacional Roma - 1911, com Medulha de Ouro.

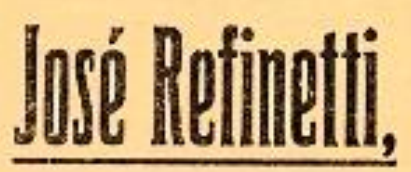
Imã̃ \& \& 2 .
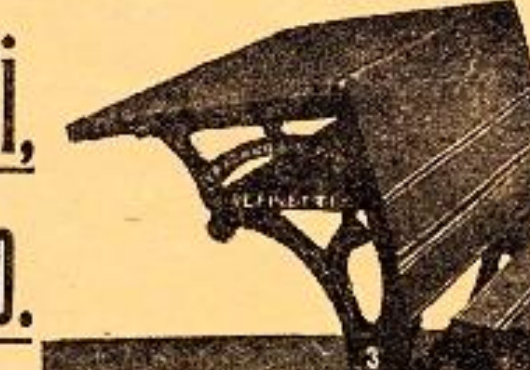

Fornecedores do Governo do Estado de S. Paulo e outros Eslados, Collegios. Academias, eic.
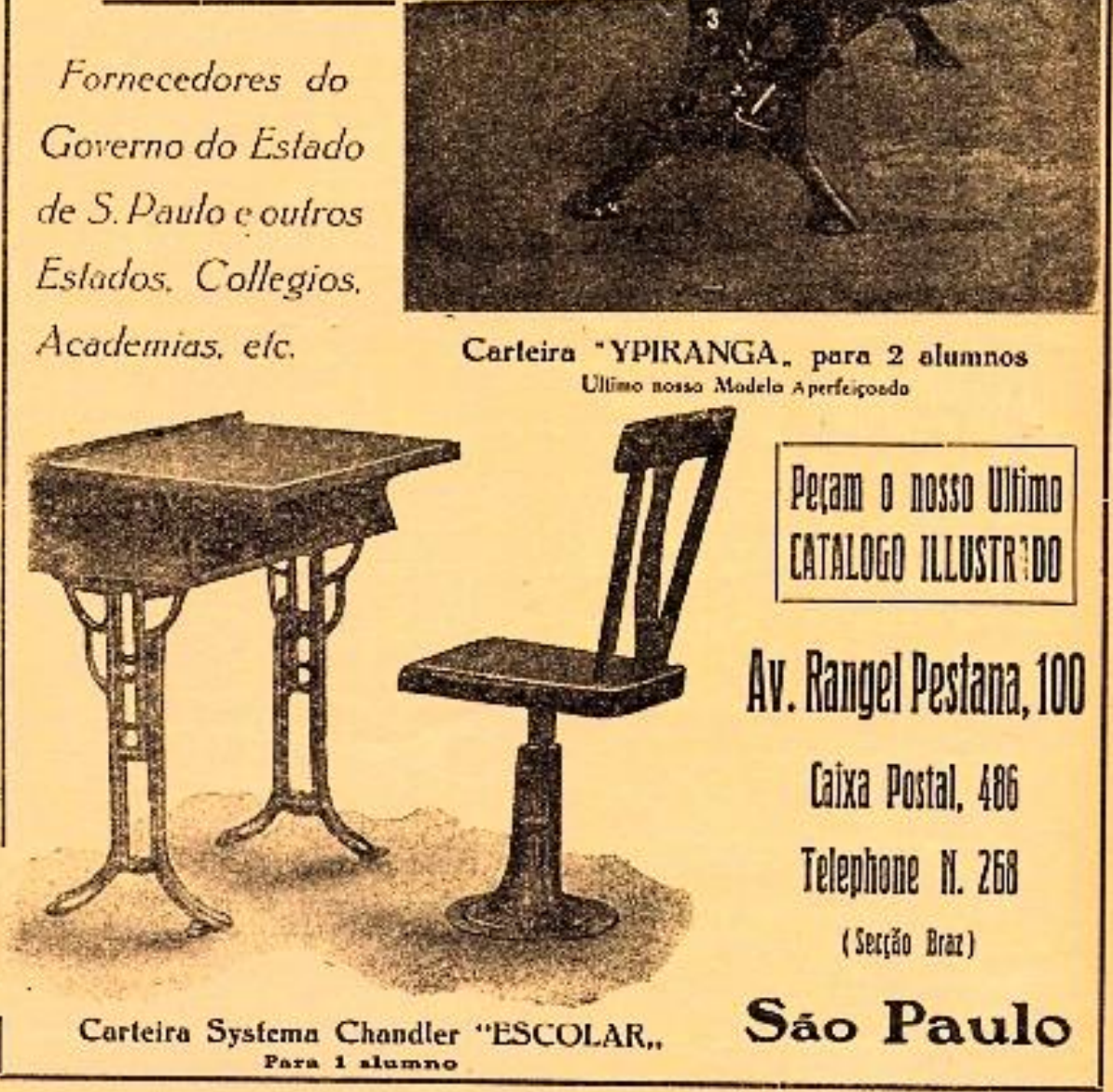

Fonte: Revista A Cigarra, edição de 9 de novembro de 1916. Extraído do site http://martaiansen.blogspot.com.br/2012/09/moveis-escolares-antigos.html 
A carteira Chandler, que aparece na propaganda, é frequentemente solicitada pelo Grupo Escolar Luiz Leite da cidade de Amparo. Sendo a carteira Chandler de origem americana, ela deixou de ser um tipo, uma marca e passou a ser um modelo que foi reproduzido no Brasil, por exemplo.

Consoante Carlos Monarcha, havia carteira Chandler nos cursos preliminares e complementares da Escola Normal da Praça:

As salas têm capacidade para 45 alunos e estão montadas com o maior esmero e rigor pedagógico. Dispõem elas de bancos, carteiras, isolados, sistema americano Chandlers, mapas murais e quadros para o ensino intuitivo de Deyrolle e Mm. Carpentier ${ }^{614}$.

É possível que o fornecedor desta carteira tenha sido José Refinetti, o qual forneceu outros objetos para o almoxarifado da Instrução Pública ${ }^{615}$. Em 26 de maio de 1896, o chefe da seção do almoxarifado, Francisco Botelho, registra o tipo, quantidade e valor dos objetos fornecidos por José Refinetti. Isso significa que, tal qual a Eduardo Waller \& Cia, a fábrica José Refinetti, Irmão \& Co. funciona desde o fim do século XIX e, portanto, disputava o rentável mercado de carteira escolar em São Paulo. A carteira mais divulgada desta empresa foi a Chandler.

A ficha técnica que Maria Fátima Machado ${ }^{616}$ elabora sobre a carteira Chandler nos oferece informações mais detalhadas e, ao mesmo tempo, permite a comparação do design da Chandler produzida por José Refinetti, Irmão \& Cia, e a Chandler de origem americana.

\footnotetext{
${ }^{614}$ MONARCHA, Carlos. Escola Normal da Praça: o lado noturno das luzes. Campinas, SP: Editora da Unicamp, 1999, p.193.

${ }^{615}$ Anexo n.45.

${ }^{616}$ MACHADO, Maria de Fátima Costa Monteiro de Sá. Maneiras de Sentar - Contributo para a História das carteiras escolares do ensino primário em Portugal (1835-1970). Lisboa: Faculdade de Psicologia e de Ciências da Educação, 2004 (Dissertação de Mestrado).
} 
Figura 43 - Carteira Chandler

FICHA $N^{\circ} 30$

Ano $1896 \quad$ Origem USA, Boston e América Latina
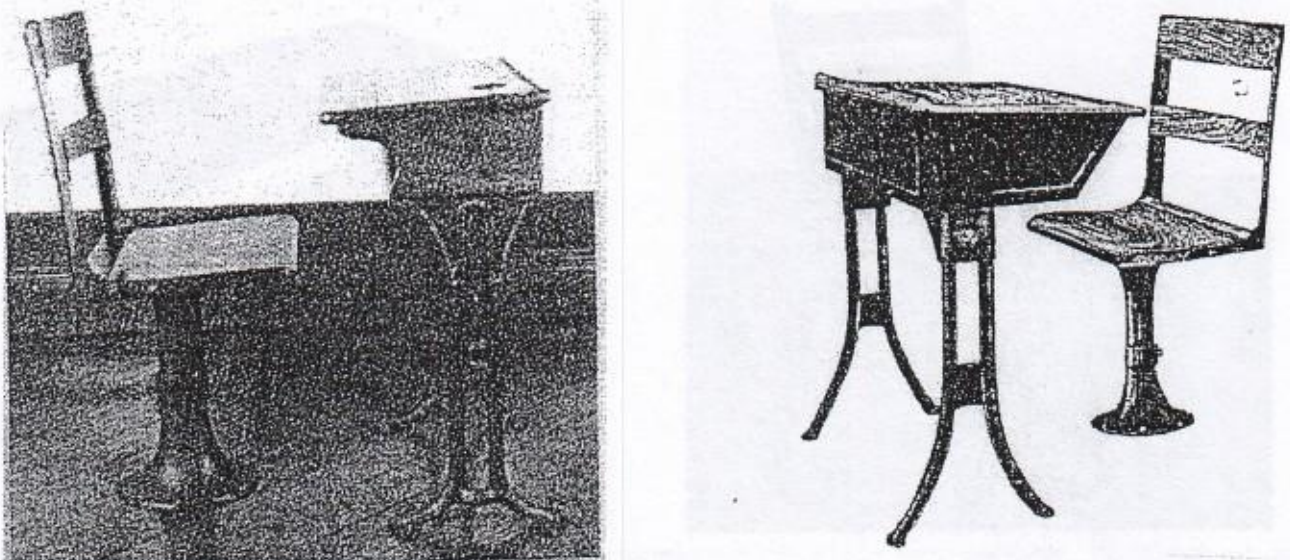

\section{Fonte}

Catálogo do Museu da Escola de Minas Gerais - 1998 e

Dufestel, Dr. L., (1933). Hygiène Scolaire. Paris: G. Doin \& Cie, p.106.

Tipo Mesa e cadeira separados

Const Madeira e Ferro fundido

Mesa Móvel

Banco Móvel

\section{$N^{\circ}$ Lugares 1 \\ Tinteiro Sim \\ Encosto Sim}

Fixa ao chão Sim

Prateleira Sim Apoio de pés Não

Medidas
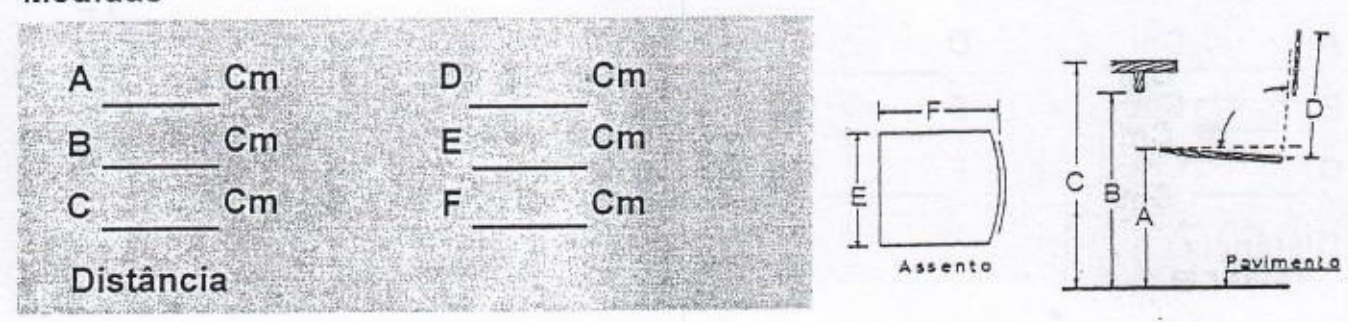

Observações

Carteira individual "Chandler"

Era um modelo que possibilitava a adaptação da mesa e da cadeira às medidas dos alunos.

Através de um grosso pé em tubo de ferro, a cadeira podia subir ou descer, bem como a mesa, segundo o mesmo sistema.

Fonte: MACHADO, 2004, p.294

A carteira Chandler teve uma circulação internacional. De origem americana, é utilizada nas escolas de Portugal. Conforme a ficha elaborada por Machado, é apreciada por franceses já que consta no manual de Hygiène Scolaire de Dufestel; e, foi utilizada 
no Brasil. Temos notícias de sua presença tanto nas escolas paulistas quanto nas mineiras (Catálogo do Museu de Minas Gerais).

Há uma terceira fábrica, Mellone, que forneceu a carteira Paulista. Como demonstrado, "Mellone" é o nome que aparece grafado no ferro da carteira Paulista, localizada no CME-FEUSP. Há notícia da carteira "Paulista" num Livro de Almoxarifado de 1899. Nele, registra-se, por exemplo, que a Escola da Estação da Lapa faltava receber 16 carteiras Paulista.

A empresa aparece no Almanak de 1918 como uma fábrica de móveis localizada à rua São Caetano e depois Oriente. Apesar da propaganda abaixo informar que a casa produz material escolar desde 1912, sabe-se que Luiz Mellone é fornecedor das escolas públicas paulista desde o fim do século XIX. 
Figura 44 - Propaganda de 3 de dezembro de 1933

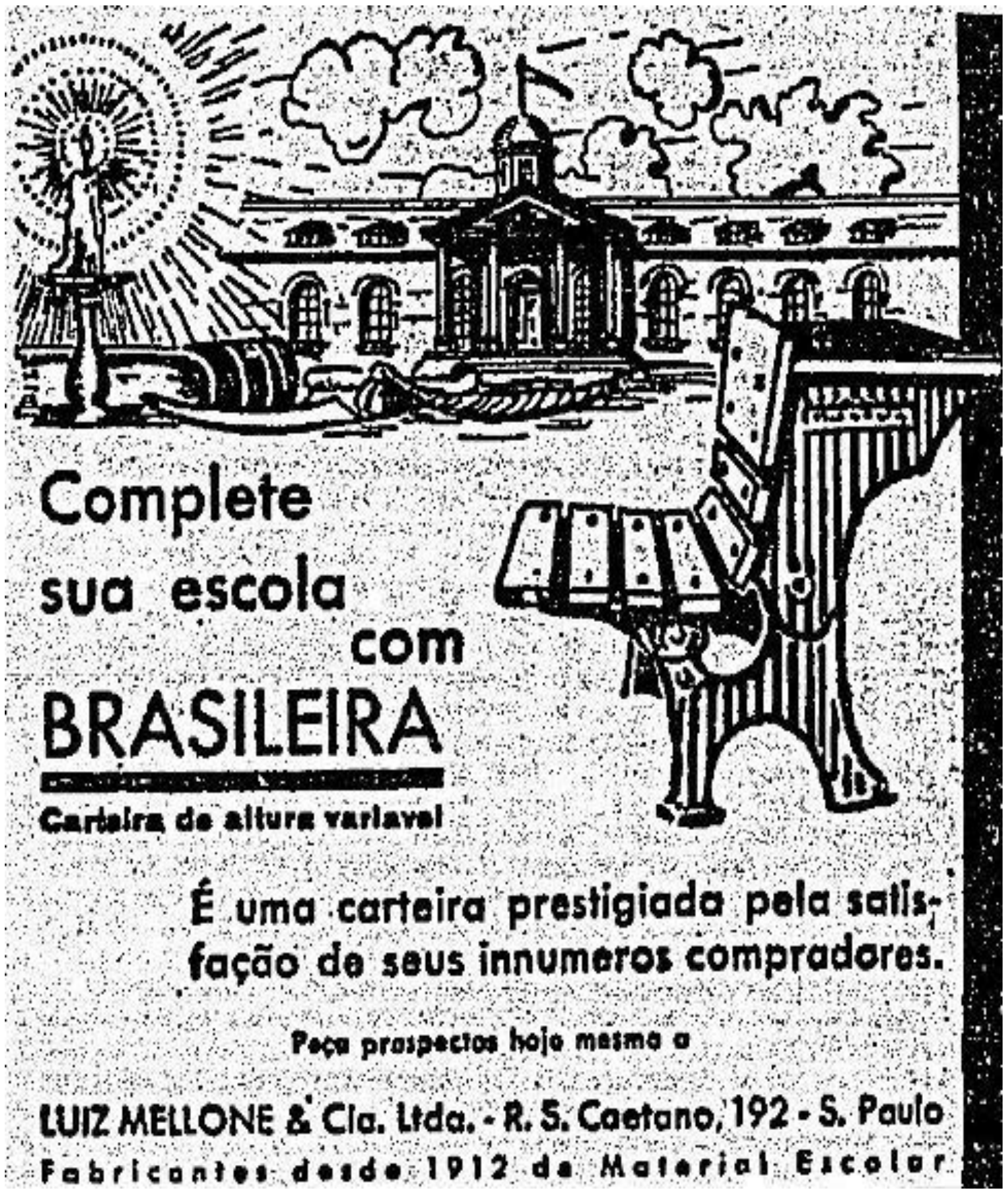

Fonte: http://blogs.estadao.com.br/reclames-do-estadao/page/2/?s=1933\&submit=OK

Postado em 1 de fevereiro de $2011 \mid$ 7h31 - Cley Scholz. Acessado em 08 de outubro de 2013

O texto da propaganda diz: "Complete sua escola com Brasileira, carteira de altura variável. É uma carteira prestigiada pela satisfação de seus inúmeros compradores. Luiz Mellone \& Cia, Rua São Caetano, 192, São Paulo. Fabricante desde 1912 de material escolar". 
A empresa pode ter sofrido modificações subjetivas (nas pessoas dos sócios) que levaram a mudança no nome empresarial, pois consta também no Almanak de 1918 como Luiz Mellone \& Irmão, ainda no endereço da rua São Caetano, mas no n. 176 e não 192 como está na propaganda acima. Sofreu também mudança na denominação da carteira que deixou de se chamar "Paulista" e passou a ser "Brasileira".

Em 1895, o inspetor do $22^{\circ}$ distrito solicita a substituição da "antiga mobília por nova mobília avaliando em 60 carteiras do tipo Paulista"617. Vinte e três carteiras tipo Paulista são soliticadas para as escolas de Atibaia ${ }^{618}$.

É possível que o fabricante tenha encontrado dificuldades para a entrega da mercadoria, pois o Secretário do Interior, Alfredo Pujol informa ao Diretor Geral da Instrução Pública, em ofício de 21 de setembro de 1895, que “o contrato de 1200 carteiras tem despertado reclamações superiores á sua capacidade"619. Ou seja, à capacidade do fabricante da carteira Paulista cumprir o contrato. Por isso, há uma substituição de fornecedor: "comunico-vos que, a 19 deste mez, foi o cidadão José Maragliano encarregado de construir 1.500 carteiras devendo ser lavrado contrato nos termos do primitivo" ${ }^{\text {620. }}$.

A única informação encontrada sobre José Maragliano é que era juiz de paz no norte da Sé. Não foi possível obter maiores detalhes sobre o comércio dele. José Maragliano foi inventor de outra carteira Paulista e, dela, obteve uma patente de invenção em 13 de julho de 1896, como mostrarei posteriormente.

Em maio de 1896, Francisco Botelho, chefe da seção de Almoxarifado, informa ao Diretor Geral da Instrução Pública, quanto aos móveis, “já providenciei dando ordens ao fornecedor José Maragliano que está prestes a cumpri-la como me avisa`“621. Além de fabricar carteiras, Maragliano também negociava tinta para tinteiros e quadros$\operatorname{negros}^{622}$.

É considerável o valor a ser pago ao Major José Maragliano. Observando-se o Quadro Orçamento do diretor Caetano de Campos, no Capítulo 3, averigua-se que o valor total dos objetos, incluindo 3 pianos, mais o valor da diferença do câmbio, foi a metade (6.000\$000) da importância que deveria ser paga a Maragliano (12:140\$000).

\footnotetext{
${ }^{617}$ Ordem 4492, Instrução publica - ofícios do governo ao inspetor geral. Anos = 1894-1896

${ }^{618}$ Anexos n.46 e n.47

${ }^{619}$ Ordem 4492, Instrução publica - ofícios do governo ao inspetor geral. Anos = 1894-1896

${ }^{620}$ Ordem 4492, Instrução publica - ofícios do governo ao inspetor geral. Anos = 1894-1896

${ }^{621}$ Anexo n.48.

${ }^{622}$ Anexo n.49 e n.50.
} 
Embora a comparação seja entre materiais escolares e móveis (carteiras), ela serve para mostrar que, dentre todos os objetos necessários à escola moderna e de massa, a carteira era o mais dispendioso, aquele que exigiria um aumento significativo do orçamento da instrução pública, não pelo valor individual do produto, mas pela quantidade necessária para mobiliar todas as escolas públicas.

Além de ser o objeto mais caro para a escola, seu volume e peso acrescentavam muito ao valor do frete. Este é, sem dúvida, um dos elementos que desencorajou a importação das carteiras e mesmo o uso exclusivo das indústrias da capital paulista como fornecedores únicos para o Estado. Transportar as carteiras para as cidades e vilas mais distantes da capital, encareceria o valor real do objeto ${ }^{623}$. Daí as marcenarias locais terem se tornado uma opção, talvez a melhor, para o fabrico dos móveis escolares.

Quando o grupo escolar de Ribeirão Preto solicita dois armários, recebe do chefe do almoxarifado, Francisco Botelho, a seguinte resposta:

Como economia, se deveria autorisar a acquisição na localidade marcando o preço por armário, como possível.

A remessa de São Paulo tem sempre o inconveniente do transporte longo, frete, baldeações, e mesmo o preço que é igual ao do interno cresce sempre na parcela das engradadas e carrecto, por mais que se queira fiscalizar.

Qualquer voluminho remetido de São Paulo, um caixão vira carrecto. Por estes fundamentos me parece, dever-se-ia dar autorisação na localidade longínqua, sobre os armários ${ }^{624}$.

O chefe do almoxarifado ao dizer que o preço do transporte longo de material cresce muito, quer se referir não meramente a uma questão econômica, mas também à fiscalização. Ao afirmar "por mais que se queira fiscalizar", ele está levantando suspeitas quanto ao superfaturamento na comercialização ou transporte do material escolar. Ou seja, ao remeter material do almoxarifado em São Paulo para as localidades longínquas, o preço final do produto crescia muito devido ao que se cobrava com encaixotamento e carreto.

Assim, mesmo que houvesse no almoxarifado o objeto solicitado, seria mais econômica a produção local, no caso das escolas que ficavam distantes da capital. É nesse espaço que se inserem os marceneiros das pequenas e médias cidades. Estes atores desconhecidos, ao reproduzirem os modelos de carteira idealizados na Europa e Estados

\footnotetext{
${ }^{623}$ Anexo n.50 e n.51

${ }^{624}$ ORDEM 7037 - Caixa 432 - Serie manuscrito - Secretaria do interior - Relatórios diversos - ano 1897.
} 
Unidos, ou nas grandes fábricas brasileiras, contribuíram para a expansão do ensino obrigatório, equipando as escolas das cidades longínquas. Estas, dificilmente receberiam as carteiras importadas, até pelas dificuldades apresentadas pelo chefe do almoxarifado. No entanto, a fabricação local favorecia, de um lado, a expansão do comércio por causa das demandas trazidas pela escola moderna e de massa. De outro, a expansão do ensino, pela criação das condições físicas para o funcionamento da escola.

Entre os anos de 1895 e 1896 são fornecidos móveis e carteiras fabricados por, pelo menos, quatro industriais diferentes. Em algumas solicitações de mobiliário feitas por diretores de escola ou inspetores há a especificação do tipo de carteira almejado, em outras, não há definição de tipo. Há fornecimento de carteira Chandler, Paulista, Waller e americana. Isso significa que, do ponto de vista da escola de massa, ela foi se expandindo pelo Estado sem padronização ou uniformização do mobiliário e materiais escolares distribuídos. Do ponto de vista do comércio, a concorrência entre os fabricantes, exigia que cada industrial não somente divulgasse seus modelos, mas também agissem no sentido de protegê-los da reprodução indevida. Para proteção e garantia do mercado, os fabricantes não hesitaram em fazer pedidos de privilégio, em solicitar patentes de invenção.

\subsection{Indústria, patentes, e contrafacção: a corrida pela proteção e garantia de mercado}

Sobre as raízes históricas da legislação brasileira de propriedade industrial, Denis Borges Barbosa expõe:

Temos uma lei de patentes desde 28 de abril de 1809, um Alvará de D. João VI aplicável somente ao Estado do Brasil, o que nos coloca como uma das quatro primeiras nações, no mundo, a ter uma legislação sobre o tema. Tal Alvará Régio foi possivelmente também o nosso primeiro Plano de Desenvolvimento Econômico.

Com a chegada da Corte, estávamos num momento em que se teria de fazer a reforma patrimonial do Estado. Os privilégios que então havia, monopólios de exploração de indústrias tradicionais, tinham de ser reformados, de forma a fazê-los trabalhar por um objetivo determinado, o desenvolvimento econômico, em particular o desenvolvimento industrial ${ }^{625}$.

${ }^{625}$ Barbosa D.B. A Legislação de Propriedade Intelectual em Vigor. Universo Jurídico, Juiz de Fora. 2007 Jan 19 [acesso 2013 out 16] ano XI. Disponível em: <http://uj.novaprolink.com.br/doutrina/2873/A_LEGISLACAO_DE_PROPRIEDADE_

INTELECTUAL_EM_VIGOR. 
Uma das medidas tomadas por D. João VI foi a criação de um "sistema de incentivos ao desenvolvimento da tecnologia, através de patentes industriais de concessão prevista em lei, em substituição ao sistema de privilégios individualizados, anteriormente existentes - com vistas a trazer para o Brasil novas indústrias" ${ }^{\$ 26}$.

No Brasil, a Constituição imperial

garantiu que os inventores, terão a propriedade de suas descobertas ou das suas produções e que a lei lhes assegurará um privilégio exclusivo temporário. O art. 179, inciso XXVI, estabelece:"XXVI - os inventores terão propriedade de suas descobertas ou das produções. A lei lhes assegurará um privilégio exclusivo e temporário ou lhes remunerará em ressarcimento da perda que hajam de sofrer pela vulgarização. Em 1830, a Lei de 28 de agosto, regulou o preceito constitucional ${ }^{627}$.

Atentando para o período compreendido por esta pesquisa, foram levantadas patentes de carteira escolar entre os anos de 1889 a 1910. Portanto, nesse lapso temporal, a concessão das patentes estava sob o regime jurídico da lei no 3.129, de 14 de outubro de 1882, regulamentada pelo decreto $\mathrm{n}^{\circ} 8.820$, de 30 de dezembro de 1882 . Estas normas também devem ser interpretadas não somente levando em consideração os desafios do contexto nacional, mas também os debates internacionais sobre a propriedade industrial.

No campo internacional, o Brasil tomou participação ativa no Congresso Internacional da Propriedade Industrial (realizado em Paris em 1878) e, tornando-se, em 1883, um dos países signatários originais do primeiro tratado internacional sobre propriedade industrial - a Convenção da União de Paris - que ordenou princípios ainda hoje válidos sobre patentes, marcas, nomes comerciais e indicações de procedência. Internamente, foi aprovada, em 1882, uma nova lei de patentes em consonância com as resoluções do Congresso Internacional das Patentes de Invenção, reunido em Viena (1873) e as do Congresso Internacional da Propriedade Industrial, harmonizandose com as deliberações da Conferência de Paris, realizada em $1880^{628}$.

O diploma legal aprovado em 1882, Lei $\mathrm{n}^{\circ} 3.129$, de 14 de Outubro de 1882, "vigorou até 1923, quando o Serviço de Patentes começou a ser reorganizado por força do artigo 80, inciso 19 da Lei $n^{\circ} .4 .632$, de 6 de Janeiro do mesmo ano; e pela edição do

\footnotetext{
${ }^{626}$ Barbosa, D.B., op cit.

${ }^{627}$ Idem, ibidem.

${ }^{628}$ MENDONÇA, 1963, p. 121-122 apud COSTA, Edilaine Vieira. Nos tempos de Capanema*, a saúva e os direitos de monopólio. Cadernos de História da Ciência - Instituto Butantan - Vol. VII (1) Jan/jun 2011, p.107.
} 
Decreto $\mathrm{n}^{\circ} 16.254$, de dezembro de 1923, que criou a Diretoria Geral de Propriedade Industrial $[\ldots]]^{\prime 629}$.

No que concerne à natureza jurídica do privilégio e seus requisitos, a lei de 1882 pouco difere da vigente lei de patentes, a Lei 9.279, de 14 de maio de 1996. Em seu artigo $1^{\circ}$, a lei 3.129 define a natureza jurídica da patente. Ela garante a "concessão de uma patente ao autor de qualquer invenção ou descoberta a sua propriedade e uso exclusivo". Ou seja, "o inventor é o sujeito do direito sobre a invenção, de que é resultante o direito de obter a patente, isto é, do reconhecimento do Estado ao privilégio de uso exclusivo".

O $\S 1^{\circ}$ ao especificar o que Constitui uma invenção ou descoberta, também estabelece os requisitos para obtenção para os efeitos desta lei:

$1^{\circ} \mathrm{A}$ invenção de novos productos industriaes;

$2^{\circ}$ A invenção de novos meios ou a applicação nova de meios conhecidos para se obter um producto ou resultado industrial;

$3^{\circ} \mathrm{O}$ melhoramento de invenção já privilegiada, si tornar mais facil o fabrico do producto ou uso do invento privilegiado, ou si lhe augmentar a utilidade.

Entendem-se por novos os productos, meios, applicações e melhoramentos industriaes que até ao pedido da patente não tiverem sido, dentro ou fóra do Imperio, empregados ou usados, nem se acharem descriptos ou publicados de modo que possam ser empregados ou usados ${ }^{630}$.

Semelhante aos requisitos atuais, "para ser concedida a patente, que é o título da concessão do privilégio de invenção ou modelo de utilidade" ${ }^{\text {631 }}$ requer-se:

a) ORIGINALIDADE - Se confunde com a palavra invenção. É “o elemento criador que a invenção encerra, e esta se concebe, justamente, como uma criação que resulta da atividade inventiva do homem"632.

b) NOVIDADE - diferente de originalidade, pois "a invenção pode ser nova sem ser original". $\mathrm{Na}$ novidade "não tem precedentes" ou "quando não compreendidas pelo estado da técnica"633. Esse requisito fica claro na repetição da palavra "nova" nos três incisos.

\footnotetext{
${ }^{629}$ Idem, p.110.

${ }^{630}$ BRASIL. Lei n.3.129, de 14 de outubro de 1882 - Regula a concessão de patentes aos autores de invenção ou descoberta industrial. Secretaria de Estado dos Negocios da Agricultura, Commercio e Obras Publicas, 1882.

${ }^{631}$ REQUIÃO, 2011, p.362

${ }^{632}$ Idem, p.363.

${ }^{633}$ Idem, p.363, 364
} 
c) INDUSTRIABILIDADE - “A invenção deve ser suscetível de exploração industrial. Deve ter utilidade" ${ }^{, 634}$. De acordo com os incisos, o produto deve ser industrial, ter resultado, aplicações ou melhoramentos industriais.

d) LICITUDE - Encontra-se no $\S 2^{\circ}$ da Lei 3.129. Não podem ser objecto de patente as invenções: $1^{\circ}$ Contrarias á lei ou á moral; $2^{\circ}$ Offensivas da segurança publica; $3^{\circ}$ Nocivas á saúde publica [exame feito pela Junta Central de Higiene Pública]; $4^{\circ}$ As que não offerecerem resultado pratico industrial.

O tempo de duração do privilégio seria de até 15 anos (Lei 3.129/1882, Art. $2^{\circ} \S$ $4^{\circ}$ ). No catálogo (on line) do acervo de privilégios industriais do Arquivo Nacional (RJ), encontramos, resumidamente, as formalidades para obtenção da patente, no período de 1870 a $1910:$

[...] os pretendentes de patentes de invenções deveriam depositar no Arquivo Público "um exemplar em duplicata de relatórios, desenhos, modelos e amostras, caso os três últimos fossem indispensáveis ao exato conhecimento da invenção". Esse depósito tinha por finalidade estabelecer o direito de prioridade, fixado no livro de termos de depósitos lavrado no Arquivo Público, onde se mencionava a hora, dia, mês e ano da apresentação, o nome do apresentante e número de ordem desse registro.

Pelo decreto $\mathrm{n}^{\circ}$ 547, de 17 de setembro de 1891, a parte dos serviços que cabia ao Arquivo Público foi transferida para a Diretoria de Comércio da Secretaria de Estado dos Negócios da Agricultura, Comércio e Obras Públicas ${ }^{635}$.

Quem concedia a patente era o Poder Executivo, "depois de preenchidas as formalidades prescriptas nesta lei e em seus regulamentos" (Lei 3.129/1882, Art. $1^{\text {o }} \S$ $\left.3^{\circ}\right)$. $\mathrm{O}$ artigo $3^{\circ}$ trata dos procedimentos a serem executados pelo inventor:

Art. $3^{\circ} \mathrm{O}$ inventor, que pretender patente, depositará em duplicata, na repartição que o Governo designar, sob envolucro fechado e lacrado, um relatorio em lingua nacional, descrevendo com precisão e clareza a invenção, o seu fim e modo de usal-a, com as plantas, desenhos, modelos e amostras que sirvam para o exacto conhecimento dessa invenção e intelligencia do relatorio, de maneira que qualquer pessoa competente na materia possa obter ou applicar o resultado, meio ou producto de que se tratar. O relatorio designará com especificação e clareza os caracteres constitutivos do privilegio ${ }^{636}$.

\footnotetext{
${ }^{634}$ Idem, p.366.

${ }^{635}$ Arquivo Nacional (Brasil). Coordenação de documentos Escritos. Equipe de documentos do

Executivo e Legislativo. Coleção: Privilégios Industriais (PI): inventário analítico - conteúdo por notação / Equipe de documentos do Executivo e Legislativo;. 2a ${ }^{\mathrm{a}}$. ed. rev. - Rio de Janeiro : o Arquivo, 2013. 1.692 p.

${ }^{636}$ Lei n. 3.129 , de 14 de outubro de 1882 , Art. $3^{\circ}$.
} 
De forma sucinta, o catálogo de Privilégios Industriais do Arquivo Nacional expõe toda a tramitação dos pedidos de privilégio:

Desde a primeira Lei de Patentes, de 28 de agosto de 1830, ficava assegurado ao descobridor ou inventor de uma indústria útil à propriedade e o uso exclusivo da sua descoberta ou invenção. Esse direito era concedido através de um decreto que o tornava público e ao inventor era passada a carta-patente, assinada pelo governante e referendada pelo ministro, ao qual estava afeta a concessão desse privilégio. Foram encarregados de tal serviço, no período de 1830 a 1910, os ministérios do Império (até 1860), da Agricultura, Comércio e Obras Públicas (até 1891), da Indústria, Viação e Obras Públicas (até 1906) e, por fim, o Ministério da Agricultura, Indústria e Comércio. Ao pretender uma patente, o inventor ou seu procurador depositava, em duplicata, no Arquivo Público, o relatório descritivo do invento, bem como os desenhos, modelos e amostras, que permitiam o seu exato conhecimento. Esse depósito era ali registrado, em livro próprio, assinalando-se a hora, dia, mês e ano da apresentação do invólucro, recebendo então um número de ordem, mencionado neste inventário como número de registro, que assegurava ao inventor a prioridade sobre esse invento [...] Cumpridas todas as exigências da lei, era concedido o privilégio através de decreto e, ao inventor, era passada a carta patente ${ }^{637}$.

O relatório descritivo do invento, ou memorial descritivo, juntamente com os desenhos, era de suma relevância para a análise das novidades apresentadas pelos inventores na fabricação das carteiras.

No caso brasileiro, pelo que se tem notícia até aqui, a primeira solicitação de privilegio de invenção de carteira é solicitada em $1889^{638}$. No período compreendido em 1889 e 1910, foram localizados doze autores de inventos de carteira escolar e vinte solicitações de registro de patente, como se vê no quadro a seguir.

\footnotetext{
${ }^{637}$ Arquivo Nacional (Brasil). Coordenação de documentos Escritos. Equipe de documentos do Executivo e Legislativo. Coleção: Privilégios Industriais (PI): inventário analítico - conteúdo por notação / Equipe de documentos do Executivo e Legislativo;. 2 ${ }^{\mathrm{a}}$. ed. rev. - Rio de Janeiro : o Arquivo, 2013. $1.692 \mathrm{p}$.

${ }^{638}$ Mesmo ano do Congresso Internacional da Propriedade Industrial, em Paris.
} 
Quadro 4 - Patentes de carteira escolar localizadas no Arquivo Nacional - RJ ${ }^{639}$

\begin{tabular}{|c|c|c|c|c|c|c|}
\hline Descrição & Autor & Domicílio & Requerente & Relatório/ano & Registro & Patente \\
\hline $\begin{array}{l}\text { Carteira para } \\
\text { uso de escolas e } \\
\text { colégios, } \\
\text { denominada } \\
\text { Aparelho } \\
\text { Mechanico } \\
\text { Amando }\end{array}$ & $\begin{array}{l}\text { VIDAL, Amando } \\
\text { de Araújo Cintra } \\
\text { (F) }\end{array}$ & $\begin{array}{l}\text { Brasil, } \\
\text { Rio de } \\
\text { Janeiro, } \\
\text { Rio de } \\
\text { Janeiro }\end{array}$ & $\begin{array}{l}\text { VIDAL, } \\
\text { Amando de } \\
\text { Araújo Cintra } \\
\text { (F) }\end{array}$ & $\begin{array}{l}\text { Rio de Janeiro, } \\
31 / 10 / \mathbf{1 8 8 9}\end{array}$ & 1128 & 792 \\
\hline $\begin{array}{l}\text { Móvel } \\
\text { denominado } \\
\text { BANCO- } \\
\text { CARTEIRA } \\
\text { ESCOLAR }\end{array}$ & $\begin{array}{l}\text { CARVALHO, } \\
\text { Bernardo Pereira } \\
\text { de (F) }\end{array}$ & ? & $\begin{array}{l}\text { CARVALHO, } \\
\text { Bernardo } \\
\text { Pereira de (F) }\end{array}$ & $\begin{array}{l}\text { Rio de Janeiro, } \\
\text { 08/06/1894 } \\
\text { Rio de Janeiro, } \\
\text { 02/06/1902 }\end{array}$ & ? & 1748 \\
\hline $\begin{array}{l}\text { Banco-carteira } \\
\text { escolar } \\
\text { aperfeiçoado } \\
\text { denominado } \\
\text { BANCO } \\
\text { AULER. }\end{array}$ & $\begin{array}{l}\text { AULER, } \\
\text { Cristóvão } \\
\text { William (F) }\end{array}$ & $\begin{array}{l}\text { Brasil, } \\
\text { Rio de } \\
\text { Janeiro, } \\
\text { Rio de } \\
\text { Janeiro }\end{array}$ & $\begin{array}{ll}\text { Jules } & \text { Géraud } \\
\& & \text { Leclerc } \\
(\text { PROC })(J)\end{array}$ & $\begin{array}{l}\text { Rio de Janeiro, } \\
\text { 14/01/1896 }\end{array}$ & 2875 & $\begin{array}{l}\text { Patente } \\
1996 \\
\text { Decreto } \\
\text { 28/01/1896 }\end{array}$ \\
\hline $\begin{array}{l}\text { Sistema } \\
\text { aperfeiçoado de } \\
\text { Carteira e } \\
\text { cadeira } \\
\text { escolares. }\end{array}$ & $\begin{array}{l}\text { WALLER, } \\
\text { Eduardo (F) }\end{array}$ & $\begin{array}{l}\text { Brasil, } \\
\text { São } \\
\text { Paulo, } \\
\text { São Paulo }\end{array}$ & $\begin{array}{ll}\text { Jules } & \text { Géraud } \\
\& & \text { Leclerc } \\
(\text { PROC })(J)\end{array}$ & $\begin{array}{l}\text { Rio de Janeiro, } \\
10 / 02 / 1896\end{array}$ & 2894 & $\begin{array}{l}\text { Patente } \\
2012 \\
\text { Decreto } \\
\text { 19/02/1896 }\end{array}$ \\
\hline $\begin{array}{l}\text { Banco-carteira, } \\
\text { denominada } \\
\text { PAULISTA,para } \\
\text { serviço de } \\
\text { escolas. }\end{array}$ & $\begin{array}{l}\text { MARAGLIANO, } \\
\text { José (F) }\end{array}$ & $\begin{array}{l}\text { Brasil, } \\
\text { São } \\
\text { Paulo, } \\
\text { São Paulo }\end{array}$ & $\begin{array}{ll}\text { Jules } & \text { Géraud } \\
\& & \text { Leclerc } \\
(\text { PROC })(J)\end{array}$ & $\begin{array}{l}\text { Rio de Janeiro, } \\
\text { 23/06/1896 }\end{array}$ & 2980 & $\begin{array}{l}\text { Patente } \\
2077 \\
\text { Decreto } \\
13 / 07 / 1896\end{array}$ \\
\hline $\begin{array}{l}\text { Banco-carteira } \\
\text { denominado } \\
\text { Banco-carteira } \\
\text { Adriano } \\
\text { Nogueira }\end{array}$ & $\begin{array}{l}\text { NOGUEIRA, } \\
\text { Adriano Júlio } \\
\text { dos Santos (F) }\end{array}$ & $\begin{array}{l}\text { Brasil, } \\
\text { Rio de } \\
\text { Janeiro, } \\
\text { Rio de } \\
\text { Janeiro }\end{array}$ & $\begin{array}{lr}\text { Jules } & \text { Géraud } \\
\& & \text { Leclerc } \\
(\text { PROC })(J)\end{array}$ & $\begin{array}{l}\text { Rio de Janeiro, } \\
\text { 08/12/1896 }\end{array}$ & 3110 & $\begin{array}{l}\text { Patente } \\
2172 \\
\text { Decreto } \\
21 / 12 / 1896\end{array}$ \\
\hline $\begin{array}{l}\text { Sistema de } \\
\text { carteira, para } \\
\text { uso das escolas, } \\
\text { denominada } \\
\text { CARTEIRA } \\
\text { PROGRESSO }\end{array}$ & $\begin{array}{l}\text { CARVALHO, } \\
\text { João Paulo B. de } \\
\text { (F) }\end{array}$ & $\begin{array}{l}\text { Brasil, } \\
\text { Rio de } \\
\text { Janeiro, } \\
\text { Rio de } \\
\text { Janeiro }\end{array}$ & $\begin{array}{lr}\text { Jules } & \text { Géraud } \\
\& & \text { Leclerc } \\
(\text { PROC })(J)\end{array}$ & $\begin{array}{l}\text { Rio de Janeiro, } \\
\text { 14/09/1897 }\end{array}$ & 3398 & $\begin{array}{l}\text { Patente } \\
2373 \\
\text { Decreto } \\
14 / 10 / 1897\end{array}$ \\
\hline $\begin{array}{l}\text { Carteira escolar } \\
15 \text { DE } \\
\text { NOVEMBRO }\end{array}$ & PERRY, Luis (F) & ? & $\begin{array}{l}\text { PERRY, Luis } \\
\text { (F) }\end{array}$ & $\begin{array}{l}\text { Rio de Janeiro, } \\
09 / 11 / 1897\end{array}$ & $?$ & 2411 \\
\hline $\begin{array}{l}\text { Carteira escolar } \\
\text { portátil e } \\
\text { econômica }\end{array}$ & $\begin{array}{l}\text { CORREIA \& } \\
\text { CIA. (J) }\end{array}$ & $\begin{array}{l}\text { Brasil, } \\
\text { Minas } \\
\text { Gerais, } \\
\text { Juiz de } \\
\text { Fora }\end{array}$ & $\begin{array}{lr}\text { Jules } & \text { Géraud } \\
\& & \text { Leclerc } \\
(\text { PROC })(\mathrm{J})\end{array}$ & $\begin{array}{l}\text { Rio de Janeiro, } \\
17 / 11 / 1897\end{array}$ & 3478 & $\begin{array}{l}\text { Patente } \\
2423 \\
\text { Decreto } \\
25 / 11 / 1897\end{array}$ \\
\hline $\begin{array}{l}\text { Banco escolar } \\
\text { PAULISTA }\end{array}$ & $\begin{array}{l}\text { BRENNE, } \\
\text { Rudolf (F) }\end{array}$ & $\begin{array}{l}\text { Brasil, } \\
\text { São } \\
\text { Paulo, } \\
\text { São Paulo }\end{array}$ & $\begin{array}{l}\text { Jules Géraud } \\
\text { \& Leclerc } \\
(\text { PROC) }(\mathrm{J})\end{array}$ & $\begin{array}{l}\text { Rio de Janeiro, } \\
07 / 04 / 1899\end{array}$ & 4017 & 2808 \\
\hline
\end{tabular}

\footnotetext{
${ }^{639} \mathrm{http} / / /$ www.portalan.arquivonacional.gov.br/media/Privil\%C3\%A9gios\%20Industriais\%20\%20Conte\% C3\%BAdo\%20abril\%2013.pdf
} 


\begin{tabular}{|c|c|c|c|c|c|c|}
\hline Descrição & Autor & Domicílio & Requerente & Relatório/ano & Registro & Patente \\
\hline $\begin{array}{l}\text { Três bancos- } \\
\text { carteiras } \\
\text { escolares } \\
\text { denominados } \\
\text { MUNICIPAL, } \\
\text { REPÚBLICA } \\
\text { e ESTRELA }\end{array}$ & $\begin{array}{l}\text { SILVA, João } \\
\text { de Castro } \\
\text { Lima e (F) }\end{array}$ & $\begin{array}{l}\text { Brasil, Rio } \\
\text { de Janeiro, } \\
\text { Rio de } \\
\text { Janeiro }\end{array}$ & $\begin{array}{l}\text { SILVA, João } \\
\text { de Castro Lima } \\
\text { e (F) }\end{array}$ & $\begin{array}{l}\text { Rio de Janeiro, } \\
13 / 11 / 1900\end{array}$ & $?$ & 3226 \\
\hline $\begin{array}{l}\text { Melhoramento } \\
\text { na invenção } \\
\text { que faz objeto } \\
\text { da Patente } \\
\text { número 3226- } \\
\text { BANCOS- } \\
\text { CARTEIRAS } \\
\text { ESCOLARES }\end{array}$ & $\begin{array}{l}\text { SILVA, João } \\
\text { de Castro } \\
\text { Lima e (F) }\end{array}$ & $\begin{array}{l}\text { Brasil, Rio } \\
\text { de Janeiro, } \\
\text { Rio de } \\
\text { Janeiro }\end{array}$ & $\begin{array}{l}\text { SILVA, João } \\
\text { de Castro Lima } \\
\text { e (F) }\end{array}$ & $\begin{array}{l}\text { Rio de Janeiro, } \\
\text { 30/09/1901 }\end{array}$ & $?$ & 3226 BIS \\
\hline $\begin{array}{l}\text { Banco-carteira } \\
\text { para uso } \\
\text { escolar }\end{array}$ & $\begin{array}{l}\text { CARVALHO, } \\
\text { João Paulo } \\
\text { Batista de (F) }\end{array}$ & $\begin{array}{l}\text { Brasil, Rio } \\
\text { de Janeiro, } \\
\text { Rio de } \\
\text { Janeiro }\end{array}$ & $\begin{array}{l}\text { CARVALHO, } \\
\text { João Paulo } \\
\text { Batista de (F) }\end{array}$ & $\begin{array}{l}\text { Rio de Janeiro, } \\
\text { 06/10/1896 } \\
\text { Rio de Janeiro, } \\
\text { 20/04/1900 }\end{array}$ & 4450 & 3080 \\
\hline $\begin{array}{l}\text { Banco-carteira } \\
\text { escolar } \\
\text { aperfeiçoado }\end{array}$ & $\begin{array}{l}\text { PAGLIARO, } \\
\text { Francesco (F) } \\
\text { SANTORO, } \\
\text { Giuseppe (F) }\end{array}$ & $\begin{array}{l}\text { Brasil, Rio } \\
\text { de Janeiro, } \\
\text { Rio de } \\
\text { Janeiro }\end{array}$ & $\begin{array}{l}\text { JULES } \\
\text { GÉRAUD, } \\
\text { LECLERC \& } \\
\text { CIA. (J) }\end{array}$ & $\begin{array}{l}\text { Rio de Janeiro, } \\
26 / 11 / 1907\end{array}$ & 7580 & 5223 \\
\hline $\begin{array}{l}\text { Móvel } \\
\text { denominado } \\
\text { CARTEIRA } \\
\text { UNIVERSAL }\end{array}$ & $\begin{array}{l}\text { CARVALHO, } \\
\text { Bernardo } \\
\text { Pereira de (F) }\end{array}$ & $\begin{array}{l}\text { Brasil, Rio } \\
\text { de Janeiro, } \\
\text { Rio de } \\
\text { Janeiro }\end{array}$ & $\begin{array}{l}\text { CARVALHO, } \\
\text { Bernardo } \\
\text { Pereira de (F) } \\
\text { Administr.(s) } \\
\text { COCHRANE, } \\
\text { Tomás Wallace } \\
\text { da Gama } \\
\text { VALDETARO, } \\
\text { José } \\
\text { Crispiniano }\end{array}$ & $\begin{array}{l}\text { Rio de Janeiro, } \\
23 / 10 / \mathbf{1 8 9 7}\end{array}$ & 3457 & $\begin{array}{l}\text { Observações } \\
\text { Consta do } \\
\text { envelope: } \\
\text { "Aberto e } \\
\text { encerrado } \\
\text { para serem } \\
\text { reformados } \\
\text { os desenhos. } \\
\text { 24/1/1898. } \\
\text { Th. } \\
\text { Cochrane. } \\
\text { J.C. } \\
\text { Valdetaro. } \\
\text { Bernardo } \\
\text { Pereira de } \\
\text { Carvalho". }\end{array}$ \\
\hline
\end{tabular}




\begin{tabular}{|c|c|c|c|c|c|c|}
\hline Descrição & Autor & Domicílio & Requerente & Relatório/ano & Registro & Patente \\
\hline $\begin{array}{l}\text { Banco-carteira } \\
\text { aperfeiçoada }\end{array}$ & $\begin{array}{l}\text { PAGLIARO, } \\
\text { Francesco (F) } \\
\text { SANTORO, } \\
\text { Giuseppe (F) }\end{array}$ & $\begin{array}{l}\text { Brasil, Rio } \\
\text { de Janeiro, } \\
\text { Rio de } \\
\text { Janeiro }\end{array}$ & $\begin{array}{l}\text { JULES } \\
\text { GÉRAUD, } \\
\text { LECLERC \& } \\
\text { CIA. (J) }\end{array}$ & $\begin{array}{l}\text { Rio de Janeiro, } \\
28 / 09 / \mathbf{1 9 0 7}\end{array}$ & 7457 & $?$ \\
\hline $\begin{array}{l}\text { Banco-carteira } \\
\text { escolar } \\
\text { denominado } \\
\text { SISTEMA } \\
\text { CRISTÓVÃO }\end{array}$ & $\begin{array}{l}\text { AULER, } \\
\text { Cristóvão } \\
\text { William (F) }\end{array}$ & & $\begin{array}{l}\text { AULER, } \\
\text { Cristóvão } \\
\text { William (F) }\end{array}$ & $\begin{array}{l}\text { Rio de Janeiro, } \\
17 / 11 / 1894\end{array}$ & 2545 & $?$ \\
\hline $\begin{array}{l}\text { Pé } \\
\text { aperfeiçoado } \\
\text { para bancos de } \\
\text { carteiras } \\
\text { escolares e } \\
\text { outros bancos } \\
\text { de assento } \\
\text { levadiço }\end{array}$ & $\begin{array}{ll}\text { AULER } & \text { E } \\
\text { CIA. (J) } & \end{array}$ & $\begin{array}{l}\text { Brasil, Rio } \\
\text { de Janeiro, } \\
\text { Rio de } \\
\text { Janeiro }\end{array}$ & $\begin{array}{l}\text { JULES } \\
\text { GÉRAUD, } \\
\text { LECLERC \& } \\
\text { CIA. (J) }\end{array}$ & $\begin{array}{l}\text { Rio de Janeiro, } \\
02 / 05 / \mathbf{1 9 0 3}\end{array}$ & 5579 & $?$ \\
\hline $\begin{array}{l}\text { Melhoramento } \\
\text { introduzido na } \\
\text { invenção } \\
\text { privilegiada } \\
\text { pela Patente n. } \\
2172 \text { (banco- } \\
\text { carteira) }\end{array}$ & $\begin{array}{l}\text { NOGUEIRA, } \\
\text { Adriano Júlio } \\
\text { dos } \text { Santos } \\
\text { (F) }\end{array}$ & $\begin{array}{l}\text { Brasil, Rio } \\
\text { de Janeiro, } \\
\text { Rio de } \\
\text { Janeiro }\end{array}$ & $\begin{array}{l}\text { JULES } \\
\text { GÉRAUD \& \& } \\
\text { LECLERC } \\
(\text { PROC })(\mathrm{J})\end{array}$ & $\begin{array}{l}\text { Rio de Janeiro, } \\
25 / 11 / \mathbf{1 8 9 8}\end{array}$ & & 2172 \\
\hline $\begin{array}{l}\text { Pé } \\
\text { aperfeiçoado } \\
\text { para bancos de } \\
\text { carteiras } \\
\text { escolares e } \\
\text { outros bancos } \\
\text { de assento } \\
\text { levadiço }\end{array}$ & $\begin{array}{l}\text { AULER E } \\
\text { CIA. (J) }\end{array}$ & $\begin{array}{l}\text { Brasil, Rio } \\
\text { de Janeiro, } \\
\text { Rio de } \\
\text { Janeiro }\end{array}$ & $\begin{array}{l}\text { JULES } \\
\text { GÉRAUD, } \\
\text { LECLERC \& } \\
\text { CIA. (J) }\end{array}$ & $\begin{array}{l}\text { Rio de Janeiro, } \\
30 / 05 / \mathbf{1 9 0 3}\end{array}$ & 5610 & \\
\hline
\end{tabular}

Fonte: Elaboração da auotra a partir da Coleção: Privilégios Industriais (PI): inventário analítico - conteúdo por notação / Equipe de documentos do Executivo e Legislativo;. $2^{\text {a }}$. ed. rev. - Rio de Janeiro : o Arquivo, 2013. 1.692 p. Arquivo Nacional (Brasil). Coordenação de documentos Escritos. Equipe de documentos do Executivo e Legislativo.

Quem eram os inventores e fabricantes de carteira escolar no Brasil? Amando de Araújo Cintra Vidal era professor em Pilares, Inhaúma ${ }^{640}$. Seu filho era escrevente da Companhia de aprendizes artífices ${ }^{641}$. Amando de Araújo Cintra Vidal Junior era também major e fiscal no $2^{\circ}$ regimento de cavalaria da Guarda Nacional do Distrito Federal $^{642}$.

\footnotetext{
${ }^{640}$ Almanak Administrativo, Mercantil e Industrial do Rio de Janeiro do ano de 1891, p. 22.

${ }^{641}$ Almanak Administrativo, Mercantil e Industrial do Rio de Janeiro do ano de 1891, p.210.

${ }^{642}$ Almanak Administrativo, Mercantil e Industrial do Rio de Janeiro do ano de 1903, p.214; 1909, p.1953.
} 
Bernardo Pereira Carvalho foi tesoureiro do Centro Industrial do Brazil ${ }^{643}$; compunha, como presidente, a diretoria da Comp. Marcenaria Brazileira "antiga fábrica Moreira Santos (Moreira Carvalho \& C. $)^{644,}$, cujo capital era de 1.000:000 $\$ 000$. Tratava-se de uma "grande fábrica de móveis de luxo, a primeira da República, e que fornece ás principaes casas desta Capital" ${ }^{, 645}$. Sua profissão constava como industrial e proprietário $^{646}$.

Adriano Júlio dos Santos Nogueira era proprietário, no Rio de Janeiro, de uma oficina e depósito de móveis, mobílias e trastes ${ }^{647}$. Deste inventor é possível obter mais informações no Almanak Administrativo, Mercantil e Industrial do Rio de Janeiro, 1895 , p.882; 1896, p.965; 1897, p.557; 1889, p.476. Fazia parte da comissão mista de árbitros da alfândega, na classe 12, madeira em bruto e preparada. Também possuía uma casa de molhados e toda sorte de bebidas ${ }^{648}$. Era agente e negociante com licença para vender selos e fórmulas de franquia ${ }^{649}$.

João Paulo Batista de Carvalho era médico, lente catedrático e professor de fisiologia da Faculdade de Medicina do Rio de Janeiro ${ }^{650}$. Foi também diretor do Instituto dos Surdos-mudos ${ }^{651}$ e contínuo na Diretoria Geral de Fazenda ${ }^{652}$.

João de Castro Lima e Silva era professor primário ${ }^{653}$ e conservador da Faculdade de Medicina do Rio de Janeiro ${ }^{654}$.

Não foi possível localizar nenhuma informação de Auler, Perry, Pagliaro e Santoro, Correia \& Cia, que permitisse circunscrever a atuação dos sujeitos que se dedicavam à fabricação de carteira escolar.

Como foi explicado anteriormente, uma das formalidades a serem cumpridas na solicitação do registro de patente era a entrega de um relatório mostrando as inovações técnicas, as novidades e os desenhos que as comprovassem. Os relatórios descritos e desenhos são importantes porque é com base neles, observado "o teor das

\footnotetext{
${ }^{643}$ Almanak Administrativo, Mercantil e Industrial do Rio de Janeiro do ano de 1891, 1333.

644 Almanak Administrativo, Mercantil e Industrial do Rio de Janeiro do ano de 1891, p.1385; 1891, p.1860-1861.

${ }_{645}$ Almanak Administrativo, Mercantil e Industrial do Rio de Janeiro do ano de 1897, p.768.

${ }^{646}$ Almanak Administrativo, Mercantil e Industrial do Rio de Janeiro do ano de 1898, p.1282; 1908, p. 1495 .

${ }^{647}$ Almanak Administrativo, Mercantil e Industrial do Rio de Janeiro do ano de 1894, p.818.

${ }^{648}$ Almanak Administrativo, Mercantil e Industrial do Rio de Janeiro do ano de 1902, p.446.

${ }^{649}$ Idem, p. 1560.

${ }^{650}$ Almanak Administrativo, Mercantil e Industrial do Rio de Janeiro do ano de 1891, p.228.

${ }^{651}$ Almanak Administrativo, Mercantil e Industrial do Rio de Janeiro do ano de 1897, p.213.

${ }^{652}$ Almanak Administrativo, Mercantil e Industrial do Rio de Janeiro do ano de 1897, p.261.

${ }^{653}$ Almanak Administrativo, Mercantil e Industrial do Rio de Janeiro do ano de 1899, p.585.

${ }^{654}$ Almanak Administrativo, Mercantil e Industrial do Rio de Janeiro do ano de 1892, p.1589.
} 
reivindicações", que se estabelece a "extensão da proteção conferida pela patente"655 . Tomando os relatórios como fonte, o destaque será dado às patentes obtidas por Eduardo Waller e José Maragliano, fornecedores das escolas paulistas.

\subsubsection{Carteira Escholar Hygienica - Patente 2012 de 1896}

Invenção do médico Eduardo Waller, a Carteira Escholar Hygienica foi patenteada em 1896, sob o número 2012. Tratava-se de um "Systema aperfeiçoado de Carteira e Cadeira Escholares".

Consiste a invenção em uma nova disposição de carteira escholar e competente cadeira, que denominei "Carteira (e cadeira) Escholar Hygienica", sendo essas duas peças combinadas para permittir elevalas ou abaixal-as conforme a altura dos alumnos que as devem occupar.

No início do memorial descritivo, Eduardo Waller já evidencia que o móvel por ele aperfeiçoado pode ser adaptado aos alunos de diferentes estaturas.

Na figura abaixo vê-se que "a carteira é constituída por uma caixa A [figuras 1 e 2] sustentada por dous pés lateraes 1 e 2 formando pedestaes e fixadaos ao chão" (figuras 1 e 3). A caixa é "construída preferencialmente de madeira nacional" e as laterais de ferro fundido e fixadas no chão.

${ }^{655}$ REQUIÃO, 2011, p.373. 
Figura 45 - Carteira Escolar Hygiênica - Desenho técnico anexo ao Memorial Descritivo

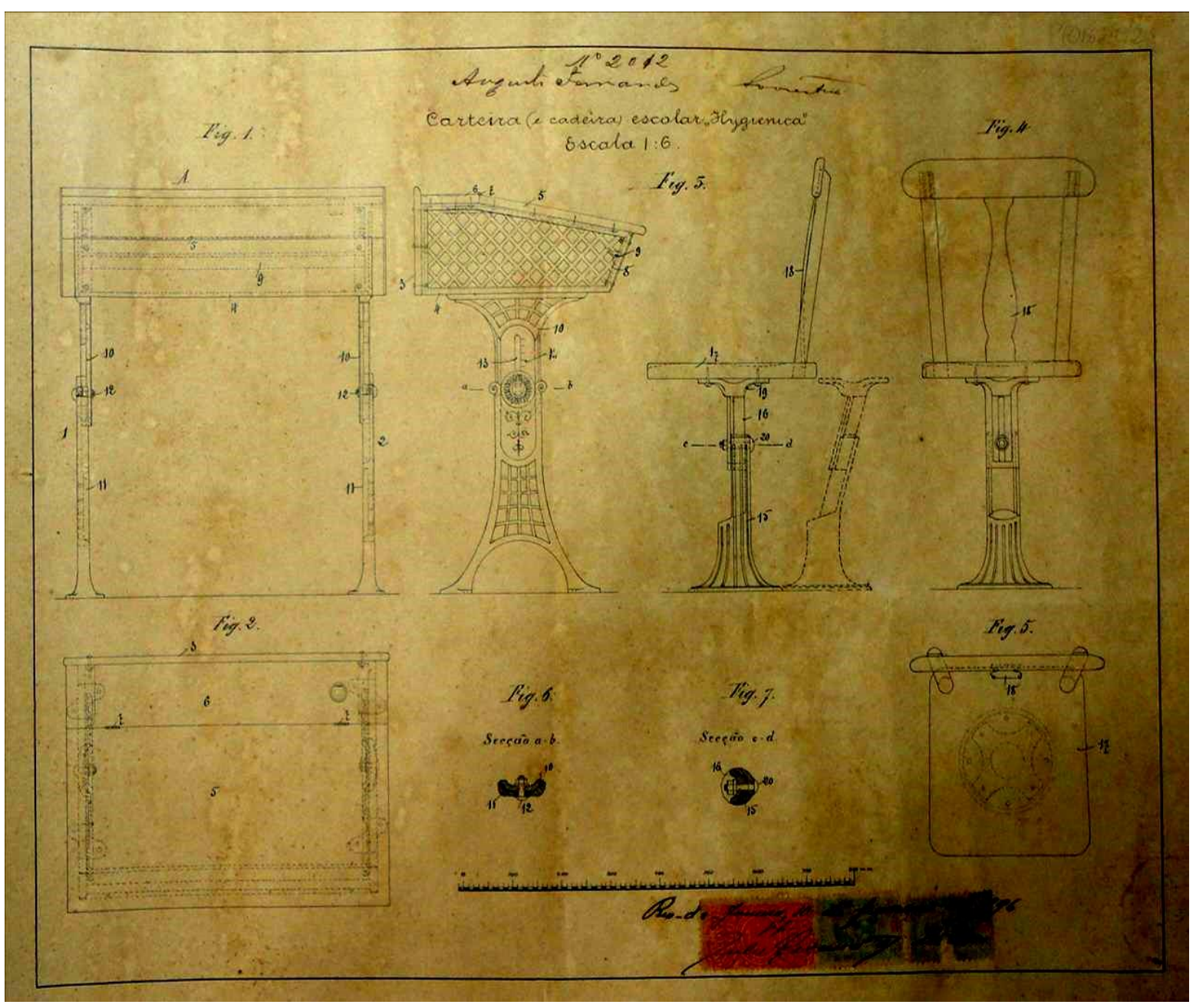

Fonte: Arquivo Nacional, Privilégios Industriais/Notação: PI 1624

O uso de parafuso e dobradiça permite "ajustar o pedestal no comprimento proprio a sustentar a carteira em altura conveniente para o alumno" (figuras 3, 4, 6 e 7). 
Figura 46 - Carteira Escolar Hygiênica - Sistema de parafuso e dobradiça.

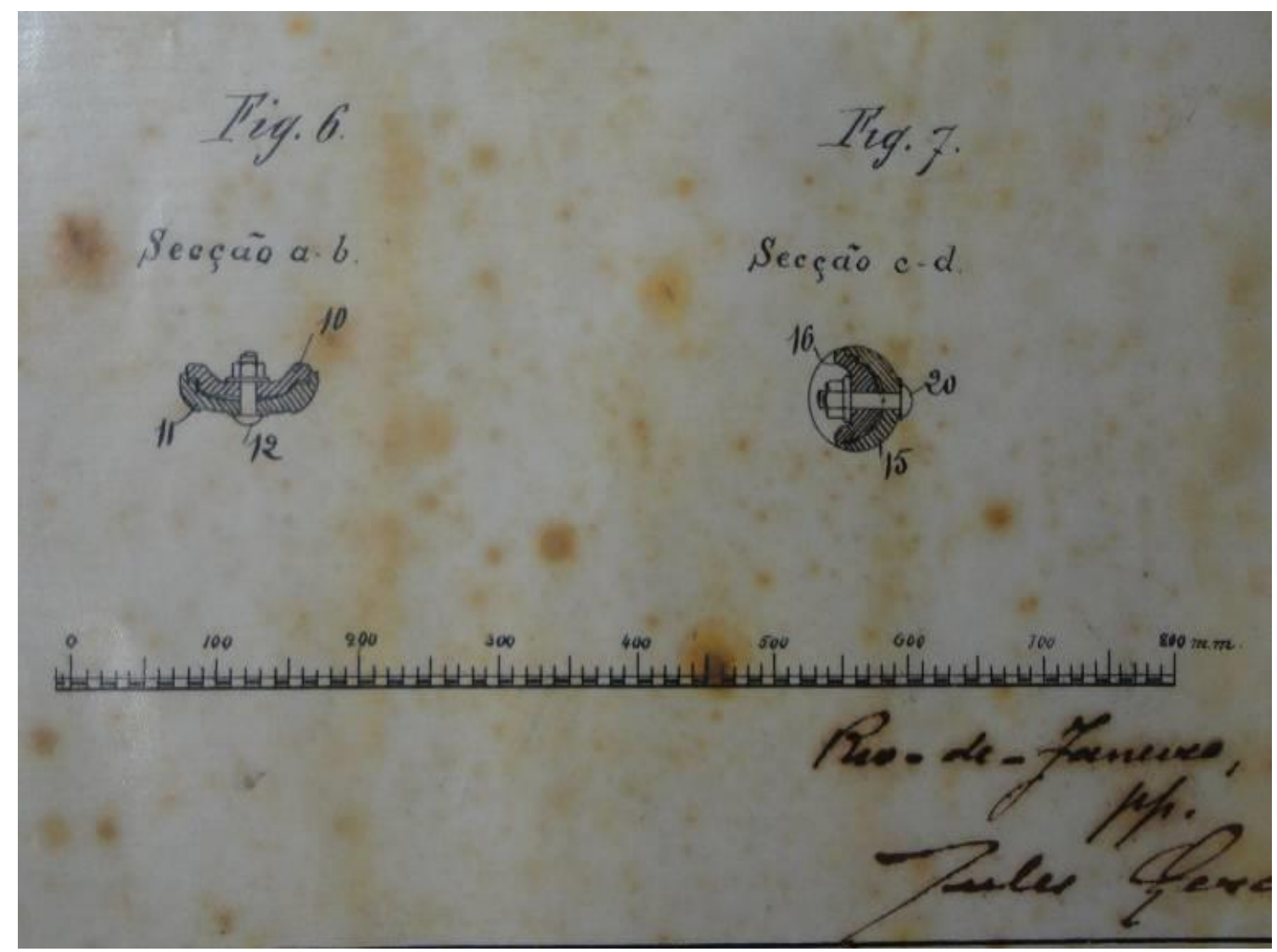

Fonte: Arquivo Nacional, Privilégios Industriais/Notação: PI 1624

Aqui, visualisa-se a importância do parafuso. Ele compõe o funcionamento das dobradiças e dos mecanismos que conferem não somente movimento ao objeto, como também, a gradação da altura para adaptação do móvel à altura do aluno. O parafuso e as dobradiças foram invenções técnicas fundamentais para a concretização deste preceito higiênico.

Após a descrição de cada parte da cadeira, Eduardo Waller, no relatório, explicita a intencionalidade que subjaz à arquitetura da mesma. $\mathrm{O}$ assento e o encosto possuem "curvas hygienicas", pois a convexidade para as costas do aluno dá apoio á espinha dorsal do mesmo.

Esta carteira pretendia ser higiênica não só em relação ao corpo do aluno, mas também no que se refere à organização da sala de aula: “As tampas das carteiras podem ser feitas de modo a poderem correr para frente, permittindo assim regular á vontade o espaço entre as cadeiras e as tampas ou mezas das carteiras". 
Figura 47 - Carteira Escolar Hygiênica - Tampo

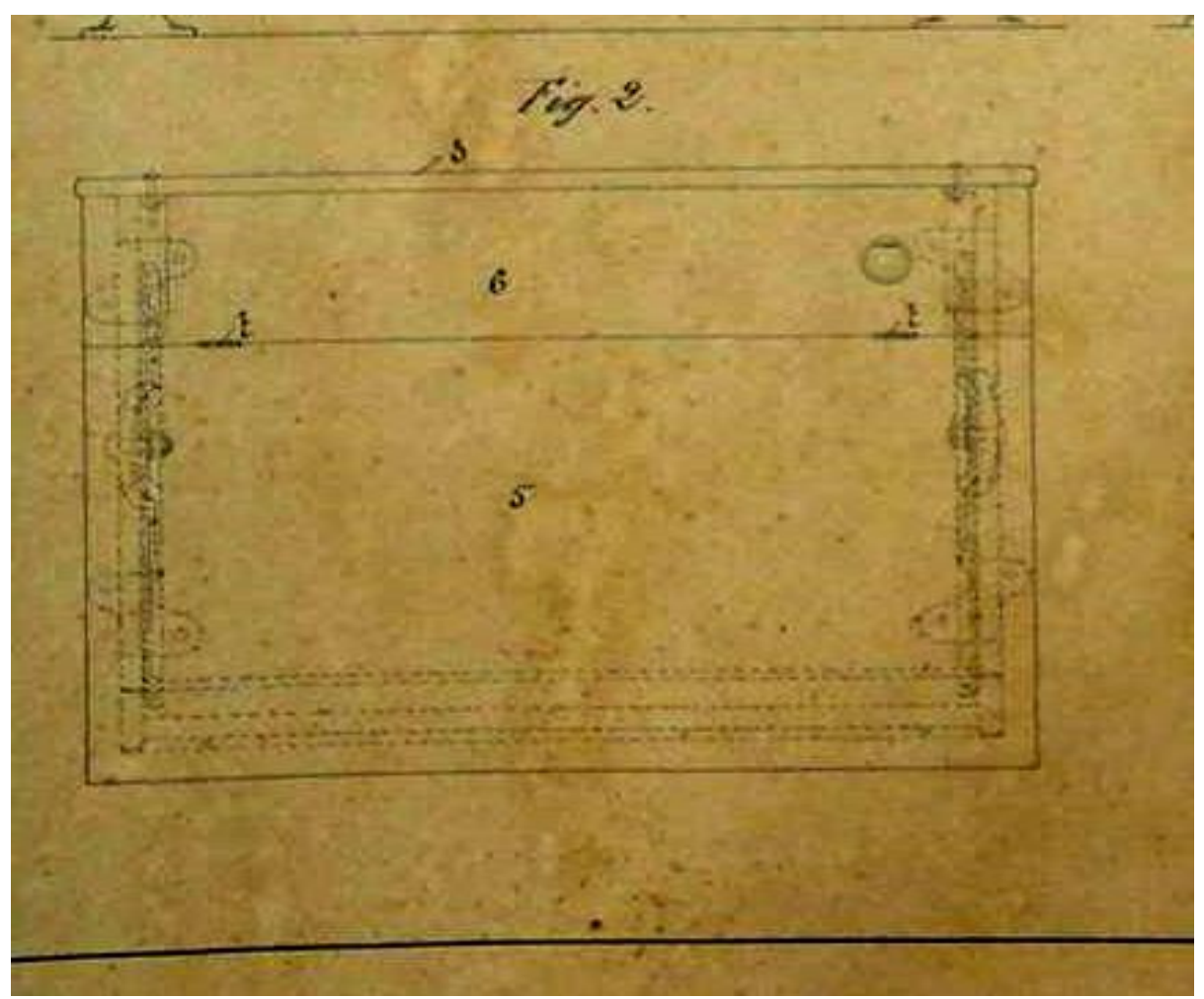

Fonte: Arquivo Nacional, Privilégios Industriais/Notação: PI 1624 
O inventor destaca também a praticidade da carteira para aquele que quiser adquiri-la, pois "todas as partes da carteira são unidas com simples parafusos, [...] de modo que, não existindo na carteira partes colladas, póde ser ella toda desmontada para o transporte, e armada de novo por qualquer trabalhador".

A carteira era fabricada em três modelos, sendo eles suficientes para ajustar-se a qualquer altura do aluno.

Pelo emprego das carteiras e cadeiras de minha invenção, a composição da mobília escholar acha-se muito simplificada e aproveitada, pois que basta adoptar os três modelos differentes sómente nos tamanhos conforme os quaes construo esses moveis, para suprir com grandes vantagens os bancos-carteiras actualmente empregados e construídos de quatorze tamanhos para corresponderem ás diversas alturas dos alumnos ${ }^{656}$.

Isso era uma grande vantagem diante de outros tipos de carteira adaptável à altura do aluno, as quais possuíam um modelo para cada altura de aluno.

Em resumo, reivindico como pontos e caracteres constitutivo da invenção:

Em um "Systema aperfeiçoado de carteira e cadeira escholares denominada Hygienica":

$1^{\text {o }}$ Uma carteira e sua cadeira supportadas separadamente por pedestaes extensíveis fixados ao chão, com o fim de poder á vontade regular a altura d'essas duas peças, acima do chão conforme as conveniências;

$2^{\circ}$ Os pedestaes da reivindicação acima, construídos cada um em duas peças unidas, por meio de um parafuso, pelas suas extremidades, apresentando largar faces de contacto côncavo-convexas corredias, e rasgo na extremidade da peça superior permittindo-lhe correr sobre a inferior para subir e descer facilmente: Escalas divididas nas beiras dos rasgos dos pedestaes da carteira;

$3^{\circ}$ A caixa da carteira formada sobre os lados constituindo as extremidades superiores dos pedestaes de ferro fundido, sendo as taboas d'essa caixa presas, exclusivamente por meio de parafusos, em asas ou nervuras existindo para esse fim sobre os ditos lados;

$4^{\circ}$. Na caixa da carteira: a tampa fixa, ou a tampa de abrir e fechar formando meza, disposta para correr ao lado da cadeira ou frente da carteira; a taboa fechando a dita frente com prateleira, e o tinteiro de ferro nikelado de uma só peça embutida na tampa da carteira;

$5^{\circ} \mathrm{O}$ espaldar ou encosto convexo da cadeira dando apoio ás costas dos alumnos;

$6^{\circ} \mathrm{O}$ pedestal supportando a cadeira, construído com as partes corredias inclinadas, de modo que a cadeira se afaste da carteira á medida que se vae levantando;

Tudo como acima descripto e representado no desenho annexo para os fins especificados ${ }^{657}$.

\footnotetext{
${ }^{656}$ Fonte: Arquivo Nacional, Privilégios Industriais/Notação: PI 1624. Memorial Descritivo.

${ }^{657}$ Fonte: Arquivo Nacional, Privilégios Industriais/Notação: PI 1624. Memorial Descritivo.
} 
A longa citação detalha os elementos inventivos daquela que talvez tenha sido a primeira carteira com preocupação higiênica e ergonômica, no Brasil. Ela possuía altura regulável, encosto convexo para apoio às costas, partes corredias inclinadas para a cadeira se afastar à medida que o aluno fosse se levantando. Não localizei nenhum documento com solicitação deste móvel, por parte da administração pública. Suas características (altura regulável, emprego do ferro fundido, tinteiro, curvas higiênicas no assento e encosto) fazem crer que se tratava de uma carteira com valor considerável.

\subsubsection{Banco-Carteira Paulista - Patente 2077 de 1896}

A carteira de José Maragliano é descrita como "um systema prático e higiênico". Era fabricada em três tamanhos "servindo aos alumnos de classes differentes, e comportando cada banco-carteira dous alumnos" $" 658$.

O tampo da carteira era em madeira com um furo para ser colocado o tinteiro, conforme figura A. O assento, também em madeira, era parafusado em dois braços de ferro, "fechado com movimento livre para abrir e fechar o assento" ${ }^{\text {,659 }}$. A figura a seguir mostra detalhes do móvel.

\footnotetext{
${ }^{658}$ Fonte: Arquivo Nacional, Privilégios Industriais/Notação: PI 1700. Memorial Descritivo ${ }^{659}$ Fonte: Arquivo Nacional, Privilégios Industriais/Notação: PI 1700. Memorial Descritivo
} 
Figura 48 - Banco Carteira Paulistano

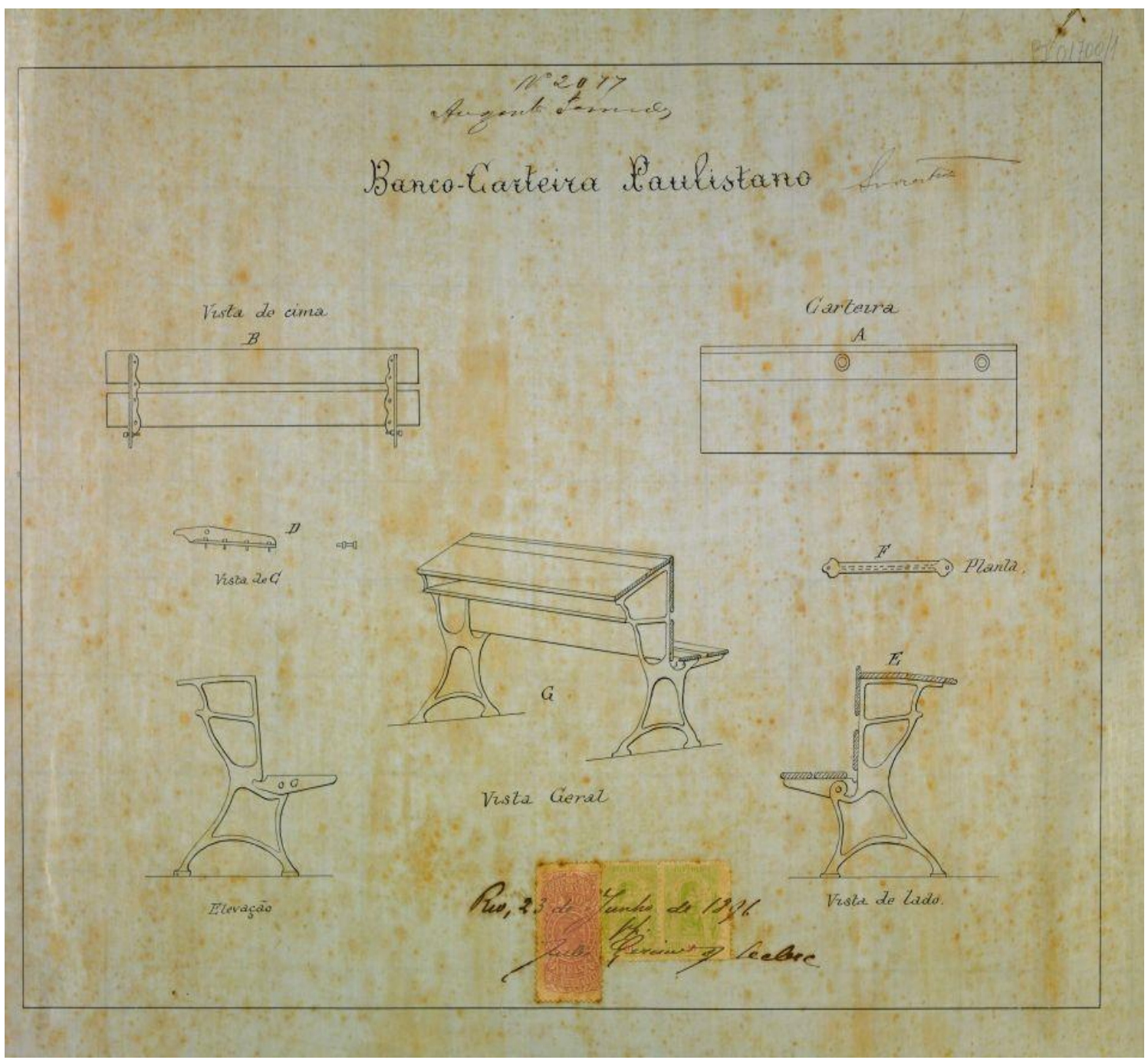

Fonte: Arquivo Nacional, Privilégios Industriais/Notação: PI 1700. Desenho técnico

De acordo com José Maragliano, as inovações e invenções do seu produto eram:

A formação e construção geral do banco-carteira, como da figura $\mathrm{G}$, em ferro, madeira ou outra qualquer composição; os pés com os competentes braços em ferro batido, fundido ou de qualquer outra composição, como das figuras $\mathrm{C}$ e $\mathrm{D}$, que formam a parte principal da invenção dos Bancos-carteiras ${ }^{660}$.

Os caracteres alegados como inventivos são apenas dois. O que o inventor chama de "construção geral do banco" e dos pés. A construção geral, possivelmente, dizia respeito à versatilidade do uso dos materiais na fabricação do banco-carteira. A

${ }^{660}$ Arquivo Nacional, Privilégios Industriais/Notação: PI 1700. Memorial Descritivo. 
parte principal da invenção era, de acordo com o memorial descritivo, "os pés com os competentes braços em ferro batido"661.

A garantia de mercado, proveniente da patente de invenção, não era obtida apenas pela proteção do invento, mas também pelo valor propagandístico da concessão do privilégio, atestando a qualidade do produto e da empresa que o fabricava. Talvez por isso, também, solicitar o privilégio de invenção era uma boa estratégia, mesmo quando os caracteres inventivos eram pouco destacáveis.

Além das patentes dos inventores paulistas, há registro de um privilégio concedido a um mineiro e a diversos inventores cariocas. Delas, apresento um resumo, elaborado a partir do Memorial Descritivo, que acompanhava o pedido de privilégio.

\subsubsection{Outras patentes de carteira escolar}

\section{Apparelho Mechanico Amando - Patente 792 de $1889^{662}$}

A primeira patente de carteira escolar, de que se tem notícia, foi concedida a Amando de Araújo Cintra Vidal, em 1889. O móvel foi denominado Apparelho Mechanico Amando e destinava-se ao uso "dos meninos”, em escolas e colégios.

Carteira e cadeira eram unidas por meio de corrediças, parafusos e porcas que permitiam graduar "a cadeira em relação à carteira, e na altura relativa a idade e ao desenvolvimento physico do menino"663. Para que "a posição do menino seja natural [...] elava-se gradualmente a carteira e a cadeira, de modo que a altura de um corresponda a do outro e a distancia em que se collocarem, torne natural a posição do alumno"

As corrediças propiciavam um movimento semicircular à mesa oferecendo uma “inclinação gradual necessária para o trabalho graphico e calligraphico",665. Elas também foram empregadas para diminuir ou aumentar a largura do assento. $\mathrm{O}$ assento

\footnotetext{
${ }^{661}$ Arquivo Nacional, Privilégios Industriais/Notação: PI 1700. Memorial Descritivo.

${ }^{662}$ Desenho não localizado.

${ }^{663}$ Arquivo Nacional, Privilégios Industriais/Notação: PI 426. Memorial Descritivo.

${ }^{664}$ Arquivo Nacional, Privilégios Industriais/Notação: PI 426. Memorial Descritivo.

${ }^{665}$ Arquivo Nacional, Privilégios Industriais/Notação: PI 426. Memorial Descritivo.
} 
"sobe e desce em toda a extensão das corrediças "E" e adianta-se ou recua para diminuir ou augmentar a superfície do assento da cadeira"666.

O móvel oferecia a vantagem da portabilidade, pois poderia ser facilmente montado e desmontado. Embora não fosse um elemento que devesse constar no Memorial Descritivo, o inventor esclarece que o preço de cada Apparelho "será muito inferior ao dos imperfeitos apparelhos importados do estrangeiro" ${ }^{, 667}$.

Como elementos inventivos, Amando Vidal desta as corrediças, parafusos e porcas, por meio dos quais "obtemos os movimentos de ascenção, descensão, flexão e semicircular, ficando assim preenchido um grande vácuo que existe em todos os nossos estabelecimentos de educação, quer públicos, quer particulares",668.

Pela descrição, constata-se que este móvel pode ser tomado como um divisor de águas em relação aos antigos bancos de madeira e prego. "Mechanico" é o termo que bem designaria as novas carteiras escolares. Não se tratava mais de um móvel artesanal, fabricado com pregos, mas de um aparelho mecânico, que, nas palavras do inventor, seguia à "risca as regras da Pedagogia Moderna".

\section{Banco-carteira escolar - Patente 1748 de $1894^{669}$}

Junto ao Relatório ou memorial descritivo do Banco-carteira escolar não foi encontrado no Arquivo Nacional o desenho do mesmo, como era exigido.

Pelo relatório, sabe-se que foi um invento de Bernardo Pereira de Carvalho, com "movimento de fechar e abrir pelo mesmo systema em dous sypos, sendo que o modelo A tem tríplice movimento nas seguintes partes: carteira, prateleira e assento; e o modelo B o movimento só de assento, sendo as outras partes firmes"

Além destas partes também possuía encosto, tinteiro com tampa e pés. O móvel foi feito em dois modelos, "A" mais industrial com emprego de parafusos e metais, e "B", feito em madeira.

\footnotetext{
${ }^{666}$ Arquivo Nacional, Privilégios Industriais/Notação: PI 426. Memorial Descritivo.

${ }^{667}$ Arquivo Nacional, Privilégios Industriais/Notação: PI 426. Memorial Descritivo.

${ }^{668}$ Arquivo Nacional, Privilégios Industriais/Notação: PI 426. Memorial Descritivo.

${ }^{669}$ Pedido de privilégio não acompanhado dos desenhos.

${ }^{670}$ Arquivo Nacional, Privilégios Industriais/Notação: PI 1343. Memorial Descritivo
} 
Nos dois modelos, o "assento e encosto são formados por meio de reguas de madeira que são ligadas a duas travessas que se adaptam á duas meias - luas de metal por meio de chapas e o competente pivôt"671.

A "superioridade mecânica" do modelo "A" estava, também, na prateleira de livros: "a prateleira no modelo A é de movimento, isto é, tem dous SS que a firmam na parte inferior, os quaes fecham simultaneamente dando assim movimento á carteira; ao passo que no modelo B esta prateleira é firme e presa na parte inferior dos $\mathrm{SS}^{\text {"672. }}$.

As inovações que o autor reivindicou foram:

Banco - Carteira escolar de abrir e fechar: systema Carvalho; O modelo A tem tríplice movimento á saber: na carteira, na prateleira e no assento; O modelo $\mathrm{B}$ só tem assento movel; Os pés são de desarmar por meio de parafusos, porcas de metal ou de ferro, ou ainda cuntas ou palmetas de madeira; As peças de movimento gyrão em dobradiças e pivôts de metal ou ferro ${ }^{673}$.

É importante considerar que as características pelas quais se buscava o privilégio eram novidades no Império do Brasil, já que nos Estados Unidos, por exemplo, o assento móvel, as peças que se moviam por meio de dobradiças não seriam originais. Não há neste invento, pelo menos no relatório, qualquer menção a preocupações de ordem higiênica ou ergonômica.

\section{Banco-Carteira Adriano Nogueira ${ }^{674}$ - Patente n. 2172 de 1896}

Em São Paulo, o Major José Maragliano foi fornecedor de carteiras para as escolas pública. No Rio de Janeiro, encontramos outro Major atuando, também, como fabricante de mobiliário escolar - o Major Adriano Julio dos Santos Nogueira, residente na Capital Federal.

Apesar de poucos, o inventor também destaca elementos de cuidado com o corpo do aluno e com a organização do espaço. "O assento 4 do banco [representado

\footnotetext{
${ }^{671}$ Arquivo Nacional, Privilégios Industriais/Notação: PI 1343. Memorial Descritivo

${ }^{672}$ Arquivo Nacional, Privilégios Industriais/Notação: PI 1343. Memorial Descritivo.

${ }^{673}$ Arquivo Nacional, Privilégios Industriais/Notação: PI 1343. Memorial Descritivo.

${ }^{674}$ Deste inventor é possível obter mais informações no Almanak, 1895, p.882; 1896, p.965; 1897, p.557; 1889, p.476. Oficinas e depósitos de moveis, mobílias, trastes. Fazia parte da comissão mista de árbitros da alfândega, na classe 12, madeira em bruto e preparada. Também possuía uma casa de molhados e toda sorte de bebidas (1902, p.446). Era agente e negociante com licença para vender selos e formulas de franquia (1902, p.549).
} 
abaixo] é articulado ás columnas 3 por meio de dobradiças 5 permittindo levantal-o quando necessário" ${ }^{\text {675 }}$.

Esta carteira ajudaria a organizar o trabalho em sala de aula, pois no topo da caixa da carteira, há uma tábua disposta de tal forma que as canetas e os lápis sobre ela colocados "nunca chegam a rolar fóra da carteira".

Possui também descanso para os pés que

póde ser mais baixo e mais inclinado do que aquelle indicado, como também entre as sapatas podem ser dispostos dois ou três sarrafos para as crianças porem os pés. Egualmente póde variar o tamanho do banco-carteira segundo as conveniências e idades dos alumnos que d'elle se devem utilisar, como também póde ser fabricado de modo a servir a dois ou mais alumnos ${ }^{676}$.

Um diferencial é apresentado em relação a outros sistemas, principalmente os modelos americanos: "no Banco-Carteira Adriano Nogueira o banco ligado á carteira acha-se em frente da própria carteira emquanto que em outros diversos systemas o banco é collocado nas costas da carteira servindo de assento a um alumno que se utilisa de uma outra carteira não ligada a este banco"677.

Os caracteres da invenção pelos quais se reivindicava o privilégio eram:

$1^{\circ}$. A carteira ligada com o respectivo banco por meio de sapatas onde são fixados os pedestaes da carteira e as columnas do banco;

$2^{\circ}$. A combinação com a caixa da carteira, de uma tampa, gyrando e tomando a posição conveniente para que a sua face interna se possa utilisar para servir de estante;

$3^{\circ}$. A taboa, servindo de deposito de canetas, lapis, etc. inclinada para traz e dotada de um rebordo com o fim de não permittir as canetas, lapis, etc. sobre ella depositadas, rolar fóra da dita taboa;

$4^{\circ}$. A carteira podendo ser construída com contos arredondados ${ }^{678}$.

Há invenções relacionadas ao design e outras relacionadas à tecnologia empregada na carteira. Tudo era tão incipiente que até os "cantos arredondados" poderiam constituir novidade. A tecnologia neste móvel não se refere ao uso de complexos mecanismos, mas à possibilidade de transformação da caixa da carteira em estante. Vale notar que os mecanismos mais sofisticados estavam nas carteiras fabricadas com ferro fundido do que nas carteiras completamente em madeira. As carteiras com altura regulável, inovação significativa, eram, via de regra, usavam o ferro em sua fabricação. É o caso da Carteira Escolar 15 de Novembro. 


\section{Carteira Escolar 15 de Novembro - Patente n.2411 de 1897}

Invento de Luis Perry, a "Carteira Escolar 15 de Novembro", sela em sua marca uma homenagem à proclamação da República. O seu encosto é recortado com um desenho representando as armas brasileiras ${ }^{679}$.

Os preceitos higiênicos satisfeitos pela carteira são a regulação da altura e o apoio para os pés. Luis Perry concentra-se em descrever a engrenagem que permite afastar ou aproximar a cadeira da mesa.

A carteira de minha invenção consiste em uma carteira combinada com uma cadeira corrediça em um estrado articulado que supporta as columnas da carteira, permittindo esta disposição approximar a cadeira da carteira e dobrar a parte da base ou estrado que se acha assim livre, afim de, sendo levantada prendel-a encostada ás pernas da cadeira, quando o movel esteja desocupado ${ }^{680}$.

A carteira era em madeira, porém o estrado para a cadeira corrediça era em ferro. A regulação da altura poderia ser obtida por mecanismos existentes tanto na cadeira quanto na mesa. A cadeira podia ser aproximada ou distanciada da mesa por meio de uma engrenagem ao centro e, a mesa, poderia subir ou descer.

Os pontos constitutivos da invenção, pelos quais se reivindicou o privilégio de invenção, foram:

$1^{\circ}$ Uma carteira e uma cadeira combinadas com uma base formada por sapatas articuladas dotadas de rasgos onde giram as pernas da cadeira, com uma engrenagem ao centro que permitte afastar ou aproximar a cadeira;

$2^{\circ}$ Sapatas articuladas combinadas com a cadeira corrediça, permittindo levantar e prender á dita cadeira a parte do estrado desocupado pelo mesmo quando se acha encostado á carteira;

$3^{\circ}$ Com o assento e encosto da cadeira a combinação das pernas da mesma cadeira descansos ou chapuses;

$5^{\circ}$ A estante recortada com rasgos de guia e parafusos de porca pelo interior da carteira par adar-lhe mais ou menos altura. A taboa da frente recortada;

$6^{\circ}$ A carteira sustentada sobre columnas com o fim de permittir augmentar a sua altura; uma taboa de apoio para os pés ${ }^{681}$.

Todo o movimento de aproximação e distanciamento da cadeira e mesa dependia da engrenagem situada na base formada por sapatas articuladas ${ }^{682}$. É um mobiliário

\footnotetext{
${ }^{679}$ Anexo n.53.

${ }^{680}$ Arquivo Nacional, Privilégios Industriais/Notação: PI 2026. Memorial Descritivo.

${ }^{681}$ Arquivo Nacional, Privilégios Industriais/Notação: PI 2026. Memorial Descritivo.
} 
bastante engenhoso e complexo do ponto de vista mecânico. A engrenagem com que era fabricada esta carteira faz pensar que seu uso não favoreceria a agilidade e praticidade necessárias ao cotidiano da sala de aula.

\section{Carteira Escolar Portátil Econômica - Patente n.2423 de 1897}

Esta carteira é uma invenção de Corrêa \& Cia., residente em Juiz de Fóra (Minas Gerais). Com exceção deste, todos os demais pedidos de privilégio de invenção são de inventores do Rio de Janeiro e São Paulo.

O objeto da invenção é uma carteira portátil de construcção solida e economica, para o uso escolar, constando de uma meza, de uma prateleira, para depositar os livros e cadernos e de um assento; sendo essas diversas peças supportadas e articuladas n'um cavallete, também articulado de modo a constituir um móvel susceptível de ser fácil e rapidamente aberto ou fechado, apresentando-se, notavelmente, n'este ultimo caso, com uma espessura de, apenas, alguns centímetros, o que permitte effetuar a arrumação das diversas carteiras d'esse systema, formando a mobília de uma sala de escola, em espaço diminuto da própria sala, deixando assim livre, para qualquer mister, a quasi totalidade da superfície da mesma sala ${ }^{683}$.

Móvel engenhoso, serve-se de inovações tecnológicas, no período, aplicadas com sucesso no ramo dos móveis escolares. Dentre elas: dobradiças, parafusos corrediças e, sobretudo, o conceito de portabilidade e multifuncionalidade em um mesmo objeto.

É uma carteira portátil não somente porque pode ser transportada de um lugar a outro, como muitas carteiras. Ela é mais leve, não tem os pés ou suportes de ferro fundido, e é facilmente dobrável. É econômica na medida em que serve a vários fins de uso escolar, mesa, prateleira, assento ${ }^{684}$.

Foi a única que, ainda no fim do século XIX, expressou a ideia dos fabricantes da carteira não ser fixa para permitir o rearranjo da sala de aula "para qualquer mister" ${ }^{\circ 85}$.

\section{Carteira Progresso $^{686}$ - Patente n.2373 de 1897}

\footnotetext{
${ }^{682}$ Anexo n.54

${ }^{683}$ Arquivo Nacional, Privilégios Industriais/Notação: PI 2038. Memorial Descritivo.

${ }^{684}$ Anexo n.55

${ }^{685}$ Arquivo Nacional, Privilégios Industriais/Notação: PI 2038. Memorial Descritivo.
} 
Invenção do capitão João Paulo B. de Carvalho, residente na Capital Federal, a Carteira Progresso,

consiste em uma carteira combinada com um banco corredio n'uma base articulada supportando as columnas da carteira; permittindo essa disposição aproximar o banco da carteira e dobrar a parte da base, que se acha assim livre, afim de, sendo levantada prendel-a encostada ás pernas do banco, quando o móvel deve estar desoccupado ${ }^{687}$.

Também tem altura regulável "de conformidade ao desenvolvimento de quem se serve da mesma" ${ }^{688}$. O sistema de acessibilidade (sentar e levantar/sair da carteira) era, sem dúvida, uma novidade.

Quando se quer occupar o banco-carteira, o banco se affasta da carteira; quando deve ficar desoccupado, corre-se o banco pelas suas pernas, nos rasgos das sapatas na direção da carteira até ultrapassar as dobradiças de articulação, podendo-se então levantar a parte a' da base assim desoccupada e prendel-a por meio da aldraba 36.

Como já dito, João Paulo B. de Carvalho era médico, professor de fisiologia da Faculdade de Medicina do Rio de Janeiro ${ }^{689}$, diretor do Instituto dos Surdos-Mudos ${ }^{690}$, membro titular da Academia Nacional de Medicina ${ }^{691}$. Tanto a Carteira Higiênica quanto a Carteira Progresso são inventos de médicos. A complexidade e os problemas que pretendem resolver, seja relacionado ao corpo do aluno, seja na sala de aula, evidenciam que não se trata apenas de comerciantes/negociantes, mas especialistas, médicos, educadores, que viram na produção de carteira uma negócio promissor.

\section{Banco escolar paulista ${ }^{692}$ - Patente n. 2808 de 1899}

Quando o banco sem encosto já era um móvel que higienistas, médicos e educadores pretendiam extirpar da sala de aula, Rudolf Brenne, morador de São Paulo, cria um novo tipo de banco. $\mathrm{O}$ inventor precisa pontuar a diferença da sua criação em relação aos velhos bancos: “A mesa e o assento formam um conjunto, sem que seja

\footnotetext{
${ }^{686}$ Anexos n.56 e n.57

${ }^{687}$ Arquivo Nacional, Privilégios Industriais/Notação: PI 1996. Memorial Descritivo.

${ }^{688}$ Arquivo Nacional, Privilégios Industriais/Notação: PI 1996. Memorial Descritivo.

${ }^{689}$ Almanak, 1891, p.228; 1898, p.1412

${ }^{690}$ Almanak, 1897, p.213

${ }^{691}$ Almanak, 1897, p.818

${ }^{692}$ Anexo n.58.
} 
preciso de fazer-se um obstáculo na entrada para o assento em forma de grossa taboa reforçada, como costumava ser antigamente" ${ }^{\circ 93}$.

Mas, o que o autor reivindica como novidade e caracteres de invenção?

$1^{\circ}$. Um banco de collegio caracterisado por uma meza com taboa curvada na fórma, de maneira que esta mesa mostra no meio do lugar do assento uma curvatura, aos lados, porém, azas salientes; de igual maneira está também formada a taboa debaixo da gaveta, emquanto a do assento, fixamente unida com a meza é de tal modo formada, que a curvatura da mesma combina quasi com a da meza;

$2^{\circ}$. Um banco de collegio, cujo assento por ganchos salientes pode ser unido e facilmente desprendido da travessa do banco seguinte;

$3^{\circ}$. Um banco de collegio cujo apoio é formado, ou pelo banco seguinte mesmo ou, se necessário fôr, collocado por si e fixado por meio dos ganchos ${ }^{694}$.

Um dos principais problemas dos bancos persiste: a ausência de encosto para descanso do aluno.

\section{Banco Carteira Aperfeiçoado $^{695}$ - Patente 5223 de 1907}

A invenção de Francesco Pagliaro e Giuseppe Santoro, domiciliados na cidade do Rio de Janeiro, é mesmo a junção de um banco e uma carteira. Apesar do descanso para os pés, o móvel possui uma distância significativa entre o assento e a mesa.

Essa arquitetura obrigaria o aluno de menor estatura a levantar os ombros para alcançar a superfície de trabalho, postura muito criticada à época, como já se mostrou no Capítulo 1 desta tese.

Os autores entenderem que havia cinco novidades e caracteres de invenção no produto que fabricaram:

$1^{\circ}$ - Com um quadro armação comprehendendo lados 1 e 2 e uma travessa central providos de tacos de extremidades e ligados por uma taboa para descanço dos pés, a combinação de: uma meza carteira e de um banco;

$2^{\circ}$ - Um banco comprehendendo pés emmalhetados nos lados e travessa de armação, e ligados: por uma travessa de cima, combinada com os assentos nella articulados e por uma travessa trazeira combinada com os encostos emmalhetados nesta travessa;

$3^{\circ}$ - Uma meza carteira comprehendendo: pés emmalhetados nos lados da armação e sustentando uma travessa apresentando para o descanço

\footnotetext{
${ }^{693}$ Arquivo Nacional, Privilégios Industriais/Notação: PI 2438. Memorial Descritivo.

${ }^{694}$ Arquivo Nacional, Privilégios Industriais/Notação: PI 2438. Memorial Descritivo.

${ }^{695}$ Anexo n.59.
} 
dos pés uma face inclinada; uma prateleira e uma travessa de frente ligadas aos pés na parte superior e combinadas com uma meza formada pela travessa superior á qual estão articuladas as tampas das carteiras combinadas cada uma com: a) uma charneira-compasso provida de uma lingueta articulada a uma das pernas do compasso e combinada com uma cremalheira formada na outra perna; b) um descanço articulado na divisão entre as duas carteiras;

$4^{\circ}$ - A applicação a cada um dos lados: a) de meios permittindo guardar um chapéo de chuva junto á meza carteira e comprehendendo um pires de descanço combinado com uma alça ou com um prendedor comprehendendo duas rodinhas supportadas por uma mola fixada numa placa de fixação; b) de um cabide ou gancho;

$5^{\circ}$ - A applicação de escarradeiras ao banco de assentos e meios para segural-a juntas aos pés do banco ${ }^{696}$.

Diferente dos demais móveis, este propõe acoplar uma escarradeira: “Ao pé exterior de cada taboa de assento está fixada uma alça $\underline{\mathrm{i}}$ e um suporte $\mathrm{i}$ adaptado para receber uma escarradeira $\underline{e}^{, 697}$.

A produção em série de carteiras escolares atendia às necessidades da expansão da escola para o conjunto da população. A passagem de uma tímida produção artesanal de bancos para uma produção em grande escala foi possível "pelo extraordinário desenvolvimento duma civilização mecânica, a partir do século XIX. Ora o progresso das técnicas, esteve desde a sua origem numa estreita relação com o progresso da industrialização"698.

Nas exposições universais ficava em evidência a estreita relação entre industrialização, as inovações técnicas e os inventos científicos. As patentes, enquanto proteção dos inventos, são, talvez, a melhor expressão dessa relação.

Se os antigos e longos bancos eram feitos em madeira, as carteiras, sobretudo as de origem americana, se serviram muito do ferro fundido. Os materiais de que são feitas as carteiras são aqueles cuja tecnologia foi dominada pelo homem, o ferro e o parafuso, por exemplo.

As novidades poderiam estar nos materiais, no design, na tecnologia empregada, dentre outros. Segundo Machado,

o avanço tecnológico dos materiais levou a que a junção das diferentes peças constituintes da carteira fosse modificando ao longo dos tempos. Por exemplo, no caso dos modelos mais antigos que utilizavam o ferro, a ligação entre as diferentes partes era feita através de rebites e

\footnotetext{
${ }^{696}$ Arquivo Nacional, Privilégios Industriais/Notação: PI 6519. Memorial Descritivo.

${ }^{697}$ Arquivo Nacional, Privilégios Industriais/Notação: PI 6519. Memorial Descritivo.

${ }^{698}$ MACHADO, op. cit., p. 184
} 
mais tarde, após a descoberta da soldura, as peças de ferro eram soldadas entre $\mathrm{si}^{699}$.

As tecnologias empregadas com os parafusos poderiam ser determinantes para a escolha de um ou outro modelo de carteira. Diferente do prego, o parafuso permitia a montagem e desmontagem dos móveis. Isso facilitava o comércio internacional, pois as carteiras seriam encaixotadas desmontadas para serem montadas no local de destino. Poderiam ser guardadas desmontadas no almoxarifado na capital para serem montadas nas escolas das regiões mais longínquas.

Adquirir carteiras rebatíveis cujas dobradiças tivessem pouca durabilidade não seria um bom investimento para o Estado, já que as carteiras tinham um custo elevado e sua durabilidade deveria ser condizente com o montante do investimento feito.

O uso do ferro no Estado de São Paulo está “intimamente "ligado à expansão ferroviária" ${ }^{\$ 700}$. Sabemos que outro importante emprego deste metal foi na fabricação de carteiras, tanto por causa da durabilidade e resistência do material, quanto pelo que ele representava, a modernidade. Segundo Beatriz Kühl, "a novidade da arquitetura do ferro era um sinal de modernidade e de progresso tecnológico, e era geralmente aceita

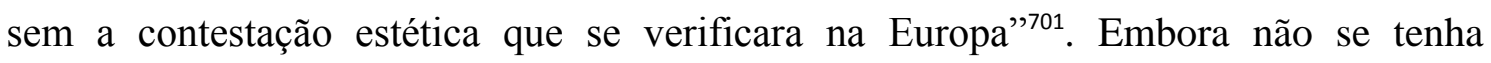
verificado nenhuma contestação estética do uso do ferro fundido na carteira, há uma ressalva, evidenciada no parecer do júri da Exposição Pedagógica do Rio de Janeiro (1883), quanto ao uso desse material nos móveis escolares devido à dificuldade de manutenção.

De todo modo, com a Revolução Industrial, a

utilização do ferro em maior escala deu-se somente a partir da segunda metade do século XVIII, com o advento de novos métodos industriais de fabrico, que permitiram aumentar quantitativa e qualitativamente sua produção, assim como diminuir seu custo. As peças de ferro no mundo ocidental eram, até então, feitas em pequenas dimensões, e tanto o desenvolvimento tecnológico quanto os custos de fabricação não permitiam que se obtivessem peças maiores. A quantidade de ferro produzida era pequena, tornando-o um material raro e caro ${ }^{702}$.

No fim do século XIX, uma inovação técnica permitiria "o aumento da produção e o fabrico de peças maiores e mais pesadas" - o uso da força hidráulica para acionar os

\footnotetext{
${ }^{699}$ Idem, p. 188

${ }^{700}$ KÜHL, Beatriz Mugayar. Arquitetura do ferro e arquitetura ferroviária em São Paulo: reflexões sobre a sua preservação. São Paulo: Ateliê Editorial: FAPESP: Secretaria da Cultura, 1998, p.13.

${ }^{701}$ Idem, p.83.

${ }^{702}$ Idem, p. 19.
} 
foles de ventilação e para alçar os martelos. Em 1709, também na Inglaterra, Abraham Darby, filho de serralheiro, criou "uma técnica para empregar o carvão mineral, em vez do vegetal, a fim de converter o minério de ferro em ferro fundido"703. Mas, "foi somente com as modificações introduzidas na Inglaterra, durante o século XVIII - o uso do coque em lugar do carvão vegetal como combustível e a produção do ferro fundido de segunda fusão no forno de revérbero - que o emprego do ferro se difundiu na construção"704.

O ferro fundido não foi usado somente nas construções de prédios. "O aumento da produção e o barateamento do produto fez com que a arquitetura do ferro, na primeira metade do século XIX, fosse dominada pelo emprego, em grande escala, do ferro fundido". Na segunda metade do século XIX, ele foi largamente usado na fabricação de carteiras escolares. Em São Paulo, a maior utilização do ferro se deu, sem dúvida, nas ferrovias.

Entreposto comercial [...] São Paulo só passaria a conhecer maior crescimento a partir do último quartel do século XIX [...] A cidade ganhou em importância, e o aumento do fluxo imigratório proporcionou o aparecimento, na cidade, de grande número de profissionais habilitados no ramo da construção, tais como engenheiros, arquitetos, mestre de obras, pedreiros, marceneiros e carpinteiros $^{705}$.

Em São Paulo também foram idealizados modelos de carteira que tinham como um dos seus materiais o ferro fundido, com predileção pelo ferro nacional, ao certo, não pela sua qualidade. A Ed. Waller \& Cia, empresa pertencente a estrangeiro, poderia minimizar este fatores, afirmando em suas propagandas que os materiais de fabrico da carteira, ferro e madeira, eram nacionais.

Acerca das fábricas de móveis, Edgar Carone vincula o crescimento das cidades e a "demanda de produtos de mobiliário também aumenta",706. A abundância da matériaprima, a madeira, era outra situação favorável a esse comércio.

Da peroba, destacam-se as variedades rosa, amarela, branca, parda, preta e graúda vermelha. Esta última produz fibras retas, regulares, rachando com regularidade. Produz toras de até $10 \mathrm{~m}$ de comprimento, por $1,80 \mathrm{~m}$ de diâmetro. Serve para taboados de casas e outras utilidades. De maneira geral, todas as espécies da peroba produzem taboados de primeria qualidade. A cabreúva apresenta duas variedades: a amarela e a vermelha; ela chega a produzir toras de $10 \mathrm{~m}$

\footnotetext{
${ }^{703}$ Idem, p. 22.

${ }^{704}$ Idem, p. 20

${ }^{705}$ Idem, p. 103

${ }^{706}$ CARONE, op. cit. p. 121
} 
a $12 \mathrm{~m}$ de comprimento, com $0,80 \mathrm{~m}$ ou $1,00 \mathrm{~m}$ de diâmetro, sendo comumente usada para vigas, esteios e pranchões. O cedro apresenta as seguintes variedades: o amarelo, o branco e o vermelho; ele chega a produzir todas de $10 \mathrm{~m}$ a $12 \mathrm{~m}$, por 0,80 a $1,20 \mathrm{~m}$ de diâmetro, sendo geralmente usado para caixas, molduras de quadros, esculturas, mobílias e tábuas de forro" ${ }^{\text {707. }}$.

Diversas fábricas estão implicadas no processo de produção da carteira: a indústria do ferro, da madeira, do parafuso. $\mathrm{O}$ crescimento e estruturação da indústria local corrobora para o aumento do número de escolas providas de mobiliário.

O que se pode observar é a "terceirização" mais sistematizada do serviço de produção do mobiliário escolar pós 1895, quando são criadas indústrias locais especializadas na fabricação de carteiras. Se fornecedores garantiam a produção das carteiras, se esse serviço já estava mais sistematizado, como estava a organização administrativa de São Paulo e da Instrução Pública para garantir a distribuição das carteiras, o provimento material das escolas? Quanto o governo investia para o equipamento mobiliário da escola? 


\section{CAPÍTULO 5 \\ PRÁTICAS ADMINISTRATIVAS E OBRIGATORIEDADE DO ENSINO: DESAFIOS DO INVESTIMENTO NA EDUCAÇÃO PÚBLICA}

Atualmente, no Estado de São Paulo, a produção e distribuição do material e do mobiliário escolar estão a cargo de uma Fundação que, nas palavras do gerente de suprimentos funciona como um "braço operacional da Secretária de Educação",708. A Fundação para o Desenvolvimento da Educação (FDE) só foi criada em 23 de junho de 1987. Sua função é

viabilizar a execução das políticas educacionais definidas pela Secretaria da Educação do Estado de São Paulo, implantando e gerindo programas, projetos e ações destinadas a garantir o bom funcionamento, o crescimento e o aprimoramento da rede pública estadual de ensino. Ao responsabilizar-se pela aplicação das políticas públicas da Secretaria da Educação, seja auxiliando na administração de recursos, implementando obras, oferecendo soluções pedagógicas ou provendo equipamentos e materiais à Rede Pública estadual de ensino, a FDE desempenha papel essencial na gestão da Educação ${ }^{709}$.

A Fundação, ao assegurar o suprimento material da escola, está tornando possível o seu funcionamento, o trabalho dos diretores, professores e alunos.

Por meio da FDE, a Secretaria da Educação constrói e equipa novas escolas e faz a manutenção e implementa melhorias em todos os prédios que compõem a rede de ensino do Estado de São Paulo. Também, por intermédio da FDE, são adquiridos e distribuídos, entre outros, materiais didáticos, pedagógicos, de consumo, equipamentos eletroeletrônicos e mobiliário ${ }^{710}$.

De acordo com o gerente de suprimentos da FDE, Antônio Henrique Filho, a aquisição de produtos (papelaria, limpeza) para a escola pode ser feita de modo célere pelo diretor da instituição. Com a verba disponibilizada para cada escola, o diretor realiza compras online em empresas fornecedores cadastradas pela Fundação. Esse modelo gerencial propicia não só a agilidade no suprimento das necessidades materiais da escola, mas também o controle qualitativo e quantitativo da verba escolar pela

\footnotetext{
${ }^{708}$ Entrevista realizada com Antônio Henrique Filho, gerente de suprimentos da FDE, em 15 de março de 2012. A Gerência de suprimentos é subordinada à Diretoria Administrativa e Financeira da FDE. Para ver o organograma da FDE consultar

http://file.fde.sp.gov.br/portalfde/Arquivo/Organogramasetembro2010.pdf . Acessado em 14 de novembro de 2013.

${ }^{709} \mathrm{http} / / / \mathrm{www}$. fde.sp.gov.br/pagespublic/InternaQuemSomos.aspx? contextmenu=quemso

${ }^{710}$ http://file.fde.sp.gov.br/portalfde/Arquivo/DocRedeEnsino/manual_ouvidoria.pdf. Acessado em 14 de novembro de 2013.
} 
Fundação: O que está sendo adquirindo pelas escolas da rede? Em que quantidade? A escola que gasta pouco está deixando de investir internamente?

Quanto à contratação de empresas para fabricação do mobiliário escolar, ela se dá por meio do pregão eletrônico. Acerca do pregão eletrônico e contratações de serviços contínuos pela Administração Pública, Freitas e Maldono afirmam que com a regulamentação desta ferramenta, "a partir de 2005 (Decreto no 5.450/2005), as licitações para aquisição de bens e serviços comuns, incluindo as contratações de serviços contínuos" ${ }^{\text {"711 }}$ devem, preferencialmente, dela fazer uso.

O pregão eletrônico caracteriza-se pela utilização de recursos de tecnologia de informação nos procedimentos licitatórios, proporcionando a comunicação e a interação a distância, pela internet, entre os agentes públicos responsáveis pela licitação (pregoeiro e equipe de apoio) e os licitantes (empresas interessadas em fornecer ou contratar com a Administração). Destacam-se entre as vantagens proporcionadas por este instrumento a maior celeridade dos procedimentos, a ampliação do leque de interessados e a maior transparência e publicidade dos atos administrativos ${ }^{712}$.

Mas, como o Estado de São Paulo foi se organizando em suas práticas administrativas, burocráticas e políticas públicas para equipar as escolas e, como corolário, assegurar a obrigatoriedade escolar e a expansão do ensino?

O estudo do século XIX é fundamental para pensar a institucionalização da escola pública primária, a organização da administração pública e escolar e o investimento do poder público na educação. Estas questões, embora amplas, serão abordadas de forma inicial e interligadas neste capítulo. Isso porque a expansão da escola moderna de massa e obrigatória exigiu uma melhor estruturação da administração pública e um maior investigmento do governo para atender às demandas dela.

No Brasil Imperial, o Ato Adicional de 12 de agosto de 1834 deixou sob a responsabilidade das Províncias o ensino primário e secundário ${ }^{713}$. No caso da Província

\footnotetext{
${ }^{711}$ FREITAS, Marcelo de; MALDONADO, José Manuel. O pregão eletrônico e as contratações de serviços contínuos. Revista de Administração Pública. Rio de Janeiro 47(5):1265-281, set./out. 2013, p.1265.

${ }_{712}^{7}$ Idem, p.1271.

${ }^{713}$ No texto "A descentralização determinada pelo ato adicional de 1834 e suas conseqüências para o desenvolvimento da educação no império: uma abordagem", Sonia Nogueira $(1999$, p.70) afirma, com base no Art. 10, $2^{\circ}$, do Ato Adicional de 1834, que a competência delegada às províncias "era concernente ao ensino primário e secundário, excluindo-se o ensino superior e o ensino do município Neutro, sede do Império". Sobre a competência das províncias para legislar, o Ato Adicional de 1834 dispõe: Art. 10. Compete às mesmas Assembléias legislar: $2^{\circ}$ ) Sobre instrução pública e estabelecimentos próprios a promovê-la, não compreendendo as faculdades de medicina, os cursos
} 
de São Paulo, a obrigatoriedade do ensino primário é estabelecida pela Lei n. 9 de 22 de março de 1874 , que define em seu artigo $1^{\circ}$ : “O ensino primário é obrigatório para todos os menores de 7 a 14 annos do sexo masculino, e 7 a 11 do sexo feminino, que residirem dentro de Cidade ou Villa em que houver escola publica ou particular subsidiada, não tendo elles impossibilidade physica ou moral". Para o inspetor geral da Instrução Pública, a Lei de 1874 inaugura uma nova fase de esperança e prosperidade, pois

Nesse anno foram tomadas medidas importantes, e desde então acham-se consagrados entre nós os seguintes elementos: ensino livre, instrução obrigatória, escola-normal para fornecer professores e professoras, inspetor geral e parciaes para fiscalizarem a fiel observância do regimem escolar, faltando-nos o conselho superior para zelar sobre a parte scientífica e methodologica, e conferencias pedagógicas para discutirem acerca de conveniência ou conveniências da prática, de modo a serem apurados os melhores methodos e systemas $^{714}$.

Após a lei de obrigatoriedade, a lei n.55 de 30 de março de 1876 "mandou que fossem construídos prédios apropriados para as escolas publicas" ${ }^{\text {"715 }}$. Porém, além da construção de prédios apropriados, a mobília era importante ao cumprimento da obrigatoriedade escolar já que ela é um dos elementos indispensáveis da criação, do funcionamento e da expansão da escola. A verba votada nos orçamentos para tal fim, entretanto, era insuficiente.

Quanto à mobília das escolas, assumpto sobre o qual me tenho exprimido por diversas vezes, é forçoso confessar que nos achamos em deplorável estado. A verba de quatro contos que continua a ser votada nos orçamentos é de todo ponto insuficiente para satisfazer a necessidade. Os móveis e utensis se estragam com a acção do tempo, e o numero das escolas tem crescido consideravelmente, e com elle o numero das reclamações que de todos os pontos chegam a essa Repartiçao, e sobem ao Governo sem que possam ser attendidas, apezar da justiça com que são feitas, em consequiência da limitação da verba destinada para este serviço ${ }^{716}$.

jurídicos, academias atualmente existentes e outros quaisquer estabelecimentos de instrução que, para o futuro, forem criados por lei geral.

${ }^{714}$ Relatorio da Instrução Pública da Província de São Paulo de 1879, apresentado ao Presidente da Província pelo Inspetor Geral da Instrução Pública, Francisco Aurélio de Souza Carvalho, anexo ao Relatório apresentado à Assembléa Legislativa Provincial de S. Paulo pelo presidente da provincia, Laurindo Abelardo de Brito, no dia 5 de fevereiro de 1880. Santos, Typ. a Vapor do Diario de Santos, 1880, p.6 (grifo meu).

715 Idem, p. 7.

${ }^{716}$ Idem, p. 13 . 
Sem destinação de espaço físico apropriado, subsidiada muitas vezes pela professora, essa educação escolar se dá no "âmbito do privado"717 . Tratando do ensino obrigatório na província de São Paulo, Maria Lucia Hilsdorf afirma que

É no interior das escolas domésticas ou das casas familiares, enquanto assunto das famílias ou dos indivíduos - mesmo quando sob o patrocínio estatal, na aula pública, portanto - que se desenrola a história da educação brasileira em meados do século XIX. O outro nome dessa condição é, precisamente, a desobrigatoriedade escolar, que vigia na sociedade paulista à época ${ }^{718}$.

A autora chama a atenção ainda para os diversos modos e agentes por meio dos quais poderia ocorrer o acesso à cultura escrita, nem sempre passando pela escola. Esta, era uma das possibilidades de aprendizagem das primeiras letras ${ }^{719}$. Aquilo que Candeias expõe sobre o ensino em Portugal, é elucidativo, neste ponto, para o caso brasileiro e paulista. Segundo ele, é somente "a partir de meados do século XIX [que a escola] se organiza em rede e se articula com outras formas de educação, sob o comando político, pedagógico e administrativo do Estado",720. A responsabilidade pela escolarização seria, então, assumida pelo Estado, cabendo à família somente o dever de enviar seus filhos à escola. Dificuldades de diversas ordens se apresentam na efetivação da lei da obrigatoriedade do ensino.

Nas palavras de Diana Vidal, "não é possível supor, entretanto, que, uma vez promulgada, a obrigatoriedade do ensino foi instaurada nas respectivas Províncias" ${ }^{\text {,721. }}$. Isso devido às

[...] condições materiais da administração provincial, como precariedade orçamentária, ausência de professores habilitados, dispersão territorial, dentre outras razões citadas como limitantes à plena aplicação da obrigatoriedade escolar ou como justificativas do descompromisso dos governos provinciais $[\ldots]^{722}$.

Tornar o ensino obrigatório exigiria um maior investimento do Estado na instrução pública, a começar pela criação de escolas e pelo suprimento material das mesmas. Isso teria um impacto nas finanças e no orçamento da Província. Então, uma

\footnotetext{
${ }^{717}$ HILSDORF, 2013.

${ }^{718}$ HILSDORF, Maria Lucia S. A doce violência: notas para a história do ensino obrigatório na província de São Paulo. p.321-341. In: VIDAL, Diana; SÁ, Elizabeth F.; GASPAR, Vera (orgs.). Obrigatoriedade escolar no Brasil. Cuiabá: Edufmt, 2013, p.323.

${ }^{719}$ HILSDORF, 2013

${ }^{720}$ CANDEIAS, 2004, p.43, apud HILSDORF, 2013, p.324

${ }^{721}$ VIDAL, Diana; SÁ, Elizabeth F.; GASPAR, Vera (orgs.). Obrigatoriedade escolar no Brasil. 1. ed. Cuiabá: EdUFMT, 2013. v. 1. 442p .p.14

${ }^{722}$ Idem, p. 15 .
} 
questão recorrente era: "a receita da província é suficiente"723? Além dessa de cunho econômico, outras tinham lugar, como: "se uma lei provincial pode legislar sobre finanças, matéria de lei geral"724 ou "se o Estado pode constranger as famílias",725 a colocarem os filhos na escola. Estas eram apenas algumas das questões que permearam os longos debates acerca do tema na Assembleia Legislativa Provincial de São Paulo.

Ao redor de 1870, a elite sociopolítica da província aglutinava-se em torno de duas posições divergentes [...] sobre o "ensino obrigado" [...] o ensino secundário provincial paulista foi decretado livre das responsabilidades e interferências do Estado e entregue inteiramente à iniciativa privada[Lei n. 54 de 15 de abril de 1868].

Já no caso do ensino elementar continuava o debate. Ainda circulavam manifestações de resistência aos posicionamentos pró-obrigatoriedade $[\ldots]^{726}$.

O ensino obrigatório só foi "aprovado na terceira rodada de discussão regimental, que se deu já no início da legislatura de 1874-5 (sessão de 7/2/1874) [...] Impunha pelo art. $1^{\circ}$, sob pena de multa, o ensino primário para meninos de 7 a 14 anos e meninas de 7 a $11^{, 727}$.

A relação obrigatoriedade da instrução e investimento material na escola não é óbvia, mas foi sendo construída à medida que se foi percebendo que só a existência de uma lei deixando a cargo das províncias a criação das escolas elementares não garantiria a existência real e funcional de instrução da população brasileira.

Para atender à escolaridade obrigatória, a Província e, posteriormente, o Estado de São Paulo foi, paulatinamente, estruturando algo inexistente até então, o sistema de ensino. Para criação da escola de massa um elemento foi indispensável - o mobiliário escolar, mais precisamente as carteiras, que tornavam a existência e o funcionamento da escola possível.

No entanto, não tendo a Província e o Estado uma fábrica própria de produção do mobiliário escolar, era preciso reunir os meios necessários a fim de prover as escolas. Nesse ponto é que se pode dizer que a produção, proveniência e o destino dado às carteiras escolares apontam a maneira pela qual Estado, Indústria e Obrigatoriedade escolar compõem um tripé que corrobora para a expansão do ensino e de sua sistematização em São Paulo entre o fim do século XIX e início do século XX.

\footnotetext{
${ }^{723}$ HILSDORF, op. cit., p.335.

${ }^{724}$ Idem, ibidem.

${ }^{725}$ Idem, ibidem.

${ }^{726}$ HILSDORF, op. cit., p.331 e 332

${ }^{727}$ HILSDORF, op. cit, p.337.
} 
O papel da indústria de mobiliário já foi abordado nos capítuos III e IV. Neste capítulo, tomo a carteira como um fio para pensar a concretização ou não da obrigatoriedade escolar, encabeça pelo Estado, com destaque para dois elementos. Primeiro, as questões administrativas; depois, as econômicas.

Por essa razão, a carteira ajuda a perceber, de um lado, como foi se efetivando ou não a obrigatoriedade do ensino em São Paulo; e, de outro, como se organizava a máquina administrativa paulista para não somente criar a escola, mas fazê-la funcionar.

\subsection{Fábrica de Ferro Ipanema: uma tentativa de produção estatal da carteira}

Nas últimas décadas do século XIX, a carteira foi-se tornando um objeto cada vez mais indispensável ao funcionamento da escola. Se muitas escolas, até então, funcionavam com mobiliário improvisado pelos alunos e professores, equipar as existentes e as novas a serem criadas, exigiria um investimento signficativo do Estado, a menos que houvesse uma produção estatal do mobiliário escolar.

$\mathrm{Na}$ década de 1870, houve uma tentativa de prover o mobiliário das escolas através da Fábrica de Ferro Ipanema, como se lê na correspondência do professor da Escola Anexa à Normal ao Inspetor da Instrução Pública. 
Quadro 5 - Fábrica de Ferro Ipanema

São Paulo, 19 de agosto de 1878

Accusando a recepção da Portaria de V.Sa. data de 14 do corrente e a 16 recebida, sob n. 267 e cumprindo o que na mesma me é ordenado ....... à V.Sa. a inclusão relação dos móveis , construidos na Fábrica de Ferro de Sam Joao de Ipanema, que foram colocados pelo próprio presidente da província $\mathrm{Sr}$, Sebastião José Pereira na sala de aula anexa à Escola Normal, da qual sou um humilde professor, indo o mesmo acompanhado de V.Sa. conforme me informaram pessoas da vizinhança.

Ignoro até hoje a ordem de que me foram fornecidos esses moveis somente podendo afirmar que no dia seguinte ao da colocação, entrando para a aula já os achei dentro e removidos para o saguão da entrada do Edificio, os bancos velhos que nela estarão servindo dos quais ainda vejo algum no mesmo lugar.

Algum tempo depois mandou V.Sa. entregar ao professor Elias de Paula Santos a mesa e a cadeira velha que n'aula existirão substituindo-as por outras mais novas e da melhor construção que nelas existem.

É o que sei e tenho a honra de informar a V.Sa.

Ao inspetor da Instrução Pública O professor da Escola Anexa á Normal

Fonte: APESP. (Série Manuscrito - Escola Normal de São Paulo; 1849-1855; 18861989/Ordem - 5131 Grupo Gestão Financeira; Série - Propostas orçamentárias).

Os móveis construídos na Fábrica de Ferro Ipanema e entregues na Escola Normal de São Paulo provavelmente eram mesas e bancas. Isso pode ser depreendido da correspondência e do inventário da fábrica de ferro, feito em 1876, no qual constam os utensílios que existiam na escola que funcionava em Ipanema, dentre eles, mesas e bancas. Segundo Assunção (2005), a escola possuía os seguintes objetos:

6 estojos pequenos de desenho, 16 (?) livros $3^{\circ}$ de Abílio, 8 (?) livros $2^{\circ}$ de Abílio, 1 caixa de lápis de pedra, 29 gramáticas de Ortiz e Pardal, 11 traslados (...), 35 volumes do Livro do Povo (oferecido pelo autor), 8 (?) $2^{\circ}$ de Abílio, 23 (?) $3^{\circ}$ de Abílio, 7 Catecismos, 6 ditos, 14 Gramáticas de Pinheiro, 22 Gramáticas de Ortiz e Pardal, 1 Aritmética, 16 Compêndios de Desenho Geométrico mandados pela Secretária da Guerra, 21 traslados de Escrita Inglesa. Sob a denominação de Utensílios Diversos aparecem: 1 tinteiro de vidro com bocal de latão, 1 tinteiro de vidro, 6 Ardósias, 7 lápis de Pedra, 1 Mesa com capa de oleado, 1 cadeira de palhinha, 1 banco pequeno, 1 Dito de areia, 8 bancas para escrita, 6 bancas compridas para sentar, 1 pedra para cálculo, 1 Armário, 1 lampião para querosene (para cima da mesa), 6 lampiões pequenos para querosene, 1 Bule de folha para querosene \& Depósito de querosene, 1 Espanador ${ }^{728}$.

Quando em 1878 a Fábrica fornece móveis para as escolas paulistas, o governo Imperial já havia transferido a companhia, em 1877, para o Ministério de Agricultura,

\footnotetext{
${ }^{728}$ ASSUNÇÃO, Martha A. Todeschini de. Real Fábrica de Ferro de São João de Ipanema: um episódio na educação paulista. São Paulo: Faculdade de Educação da USP (Dissertação de Mestrado), 2005, p.145
} 
Comércio e Obras Públicas, na tentativa de garantir um mercado privilegiado para os seus produtos $^{729}$. De acordo com Santos, na década de 1870 era unânime a opinião na Câmara dos Deputados quanto ao investimento que o governo deveria continuar fazendo na Fábrica.

Tais investimentos eram feitos na expectativa de utilizar o ferro de Ipanema nas ferrovias estatais, sem deixar de lado o fornecimento feito aos arsenais e aos particulares que fizessem encomendas. Contudo, no fim da década de 1880, diante do desempenho econômico da fábrica, ganharam força as ideias de arrendamento e, até mesmo fechamento da companhia. Apesar disso, o governo continuou mantendo Ipanema até o fim da Monarquia em 1889 e a companhia foi fechada pelo governo Republicano, em $1895^{730}$.

Segundo Assunção, os republicanos sucumbiram "à concorrência desleal do ferro inglês", apesar da qualidade do ferro de Ipanema que "chegou ao fim do Império produzindo para os arsenais do Exército, as estradas de ferro e os particulares, tendo a qualidade da sua produção apresentada e premiada em Exposições Nacionais e Internacionais, o que no meu entendimento, é um atestado da qualidade de seu ferro e prova o sucesso de sua produção",731.

Além dos fins enumerados por Santos, outra finalidade poderia ter sido vislumbrada pela Câmara dos Deputados para a fábrica - a produção e fornecimento do mobiliário escolar. Na correspondência do professor da Escola Normal ao Inspetor pelo menos dois elementos chamam a atenção quanto ao provimento mobiliário da escola paulista.

Primeiro, modo assistemático e arbitrário. O professor esclarece ao inspetor que não teve nenhum conhecimento anterior de que os móveis seriam fornecidos de maneira que ele foi informado da troca do mobiliário pela vizinhança da escola, provavelmente, os pais de seus alunos.

A expressão "humilde professor", além de ser, no período, uma fórmula corrente nas cartas dos professores, pode significar uma ironia e um aborrecimento com a alegação da insignificância do professor a ponto de ele não ser informado que haveria a troca do mobiliário da própria sala de aula em que trabalhava. Arbitrariamente, os

\footnotetext{
${ }^{729}$ SANTOS, 2009, p.164.

730 SANTOS, 2009.

${ }^{731}$ ASSUNÇÃO, 2005, p.165.
} 
móveis foram, de acordo com o professor, "colocados pelo próprio presidente da província Sr, Sebastião José Pereira na sala de aula anexa à escola normal",732.

Talvez, não podendo fazer a reclamação diretamente ao presidente da província, o professor dirige-se ao inspetor não só por uma questão de proximidade, como porque a vizinhança informou que o inspetor também estava presente juntamente com o presidente. Com isso, percebe-se que o professor entende que deve participar do processo de organização e estruturação da sala de aula e que esse movimento não cabe somente aos dirigentes.

Segundo, é que a ação do presidente da Província pode indicar uma das primeiras tentativas do governo para assumir não apenas o fornecimento, mas também a produção do material e mobiliário escolar. Nesse momento, talvez, menos por iniciativas planejadas e, mais, por tentativa de conciliar dois problemas ao mesmo tempo. De um lado, a Província estava fazendo elevados investimentos na Fábrica de Ferro Ipanema que continuava com desempenho econômico deficitário; de outro, a expansão do ensino exigia a criação das condições físicas da permanência da escola. Assim, se a companhia fabricasse os bancos e mesas, o provimento mobiliário da escola poderia se dar sem que mais verba fosse aplicada com serviço de terceiro. A própria fábrica poderia realizar tal intento.

Para tanto, seria necessário resolver problemas estruturais: I -o transporte, já que a fábrica não estava situada próxima aos centros urbanos. II - A estrutura comercial adequada para a venda do ferro. "Enquanto as casas comerciais tinham muitos anúncios publicitários e ofereciam varias facilidades, como a entrega dos produtos e vendas a prazo para atrair compradores, Ipanema apenas constava no anuário com um anúncio muito simples e não oferecia nenhuma vantagem especial aos consumidores. III - A fábrica não contava com escritórios ou ponto comercial próximo dos centros urbanos, onde as pessoas pudessem fazer encomendas"733. IV - Some-se ainda o estágio de desenvolvimento tecnológico, pois "enquanto as fundições européias utilizavam-se do vapor e do carvão mineral, Ipanema era movida pela força hidráulica e seus fornos funcionavam com carvão vegetal" ${ }^{134}$.

\footnotetext{
${ }^{732}$ APESP, Ordem 5131.

${ }^{733}$ SANTOS, 2009, p.165.

734 Idem, ibidem.
} 
A Fábrica de Ferro Ipanema, de acordo com Santos, "teve uma trajetória repleta de contradições, problemas e alguns momentos de prosperidade",735. A expansão da lavoura canavieira paulista no interior da província criou um mercado consumidor importante e relativamente próximo para os produtos de Ipanema o que deu à fábrica um primeiro momento de prosperidade entre 1836 e 1842. Contudo, pouco tempo depois a fábrica começa a enfrentar severas dificuldades apontadas por Santos: a) as reduzidas dimensões do mercado interno brasileiro para os produtos de Ipanema; b) a lentidão com que este mercado, após abastecido, gerava novas demandas por ferro; c) a dificuldade em transportar produtos feitos com ferro por tropas de mulas; d) a distância dos principais centros urbanos do período; e) avanço das pequenas fundições de ferro no interior do país. Apesar dessas dificuldades, como já afirmado, o governo fez investimentos consideráveis na fábrica.

Por isso, o autor busca entender a ação do governo como administrador da Fábrica e as razões que o levaram a investir grandes somas em um estabelecimento pouco promissor.

O governo está ciente dos obstáculos existentes em Ipanema e, dadas a urgência da guerra [do Paraguai] e a impossibilidade dos estabelecimentos estatais, como os arsenais e as fábricas de armas abastecerem sozinhos o Exército, foram utilizados fornecedores particulares, de quem o país comprava quase tudo que era preciso para o conflito ${ }^{736}$.

A fábrica de Ipanema não somente fazia fornecimento aos arsenais, mas também foi "gerida pelo Ministério da Guerra",737 e estava "ligada à formação dos oficiais. Foi incluída nos exercícios práticos que deveriam ser realizados pelos alunos da Escola Militar, no processo de profissionalização do ensino instituído pelo Regulamento de 1858, e que permaneceu em vigor até o final do Império",738.

Se as carteiras foram produzidas em 1878, Ipanema estava sobre o controle do Ministério da Agricultura, Comércio e Obras Públicas, era dirigida pelo Capitão de Engenheiros Joaquim de Sousa Mursa, "formado pela Escola Central do Rio de Janeiro [...] e com especialização em Ciências Montanísticas e Metalúrgicas na Escola de Minas

\footnotetext{
${ }^{735}$ SANTOS, Nilton Pereira. A fábrica de ferro São João do Ipanema: economia e política nas últimas décadas do Segundo Reinado; 1860-1889. São Paulo: Tese de doutorado, 2009, p.162.

${ }_{737}^{736}$ SANTOS, op. cit., p.163.

${ }^{737}$ Idem, p.38

${ }^{738}$ Idem, p. 31-32
} 
de Freiberg, na Alemanha, onde se matriculou em 1860"739; "militar ilustrado, progressita e defensor da educação popular,"740.

Por ora, é possível afirmar que somente na segunda metade do século XIX vislumbrou-se a possibilidade de produção de carteira em Ipanema, pois quanto ao rol de materiais produzidos pela fábrica em 1820, Assunção elenca:

Ela produz, tanto para revenda como para consumo próprio, desde armamento militar - acha-se reduzido quase todo o ferro que agora se tem fundido a obra de modelar principalmente se acha já feito uma grande quantidade de balas ocas conforme a nova recomendação da Corte - até utensílios e ferramentas para engenhos, como martelas, pás, balanças, manivelas, fechaduras, cravos de ferrar, argolas, dobradiças, enxadas, facões, serras, marcas, cunhas, bigornas, malhos, parafusos, agulhas de atalhar, ferraduras, taxas, correntes, colheres, espumadeiras, apitos, grampos, fornos, trancas, ferragens para moinho, algavizes, craveiros, compassos, cavadeiras, fivelas, rodos, pares de rosetas, brocas, rodas dentadas, cabrestos de ferro, ancoras, vigas, manilhas, vazados, travadeiras, grades, ferragens para cômodas, ferro de arado, grelhas e cruz $^{741}$.

Dentro os objetos produzidos não se encontra a carteira escolar de cuja produção em Ipanema só se tem indícios da segunda metade do século XIX. No entanto, o fechamento da fábrica vai impor que a administração pública encontre outros caminhos para o provimento mobiliário e consequente expansão do ensino. Se a Fábrica de Ferro Ipanema poderia ter sido uma possibilidade de, já no século XIX, o próprio governo produzir o mobiliário escolar, faltou a estrutura que tornaria tal pretensão factível.

Em resumo, quanto aos modos de aquisição da carteira, identifiquei no período, pelo menos três ações do governo paulista: a) a já citada produção na Fábrica de Ferro Ipanema; b) a importação via agentes e representantes comerciais; c) a "terceirização" a indústrias nacionais.

Para além dos modos de aquisição, interessa saber como estava organizada a administração pública, como funcionava a burocracia e hierarquia estatal para aquisição e distribuição do mobiliário escolar. Isto é, como a carteira, dispositivo de higienização do corpo do cidadão escolarizado, mercadoria exibida e divulgada nas Exposições Universais e Nacionais, produto rentável das indústrias de mobiliário escolar, chegava às escolas.

\footnotetext{
${ }^{739}$ Idem, p. 103

${ }^{740}$ Idem, p. 148

${ }^{741}$ Idem, p.68-69.
} 


\subsection{A centralização como prática administrativa}

A centralização como prática administrativa diz respeito, aqui, à concentração das decisões e autorizações para aquisição de material e mobiliário escolar nas mãos de uma única pessoa, via de regra, o chefe maior do executivo paulista. A produção e a distribuição do mobiliário escolar não foram problemas de fácil solução para o governo paulista.

Duas questões, uma econômica e outra administrativa, podem ser apontadas como entrave à prestação desse serviço: a verba destinada nos orçamentos para aquisição de móveis escolares e a estrutura da máquina administrativa que tornava pouco eficiente o conhecimento das escolas desprovidas destes objetos, bem como o rápido atendimento das necessidades das escolas. Desses dois elementos dependia, em alguma medida, a criação, o funcionamento e a expansão das escolas. Primeiro, abordarei as questões administrativas e, por fim, das questões econômicas.

É acirrado, no período, o debate entre os partidários da centralização e descentralização na condução dos negócios públicos. No clássico Ensaio sobre o Direito Administrativo, publicado em 1862, Paulino Soares de Souza, o Visconde de Uruguai, defende que "a centralização política é essencial. Nenhuma nação pode existir sem ela. Nos governos representativos obtém-se a unidade na legislação e na direção dos negócios políticos pelo acordo das Câmaras e do Poder Executivo" "742. A descentralização, na perspectiva do Visconde de Uruguai, só funciona no país "que adquiriu com a educação e o tempo aquele senso prático que é indispensável para tratar os negócios", nas nações acostumadas "ao gozo prático de certas liberdades locais",743.

Entretanto, o também presidente da Província do Rio de Janeiro, apesar de ser um defensor da centralização, admite que ela pode ser perigosa quando ocorre o fortalecimento do poder executivo, além do necessário, e a interferência na liberdade dos cidadãos.

Para ele, é inevitável "de se achar o poder administrativo pelo menos o geral, reunido ao político e governamental" ${ }^{144}$ nas mãos do poder executivo. O perigo, nesse caso, é a invasão dos interesses políticos e conveniências pessoais na administração. "A

\footnotetext{
${ }^{742}$ VISCONDE DE URUGUAI (Paulino Soares de Souza). Ensaio sobre o Direito Administrativo. Rio de Janeiro, 1862. p.348.

${ }^{743}$ Idem, p.352.

${ }^{744}$ Idem, p.28.
} 
administração torna-se o vasto campo dos favores, e o meio de procurar e firmar apoio político, às vezes com grande desmoralização"745.

As críticas do Visconde de Uruguai à organização do estado não tem a finalidade de "provar a tendência anarquicamente descentralizadora dessas épocas" "746. Ele pretende destacar a importância do projeto de reforma da Constituição de 1824.

As teses de Paulino Soares de Souza são importantes para compreender a organização do Estado, o funcionamento do poder executivo no Império. Quanto às formas de operar, o autor esclarece que o poder executivo atua, em um aspecto, como poder político ou governamental; e, em outro, como poder administrativo. Na primeira acepção, isto é, como governo, “o Poder Executivo aplica por si só e diretamente as leis de ordem política" ${ }^{747}$. Na segunda acepção, refere-se aos órgãos e conjunto de agentes que atuam, nas palavras do autor, como "instrumento principal do Poder Executivo governamental",748.

É este aspecto do Poder Executivo que interessa aqui. A organização da máquina administrativa e a ação dos seus agentes e órgãos ajudam a compreender o alcance e as prioridades do investimento do Estado na instrução pública.

Em linhas gerais, a administração é a estruturação e organização do Estado, estabelecendo competência de órgãos e agentes, tendo em vista a prestação de serviços públicos. Numa visão atual sobre administração, mas válida, neste ponto, para o funcionamento do Estado no século XIX, Hely Lopes Meirelles expõe que a administração pratica atos de execução e não atos de governo $^{749}$.

Esses atos de execução se centralizavam no presidente da província, de modo que quanto mais próximas as decisões estivessem do topo da hierarquia do poder executivo, maior será a centralização. Assim, a centralização a que me refiro não é aquela da Administração Direta, ou seja, a exercida pelos órgãos que compõem a estrutura de cada esfera do poder, como as secretarias e os ministérios. A centralização própria da Administração Direta era, no século XIX, pouco funcional porque muitas vezes invadida por elementos de informalidade e pessoalidade. Essa centralização administrativa estava em consonância com a centralização política do Império.

\footnotetext{
${ }^{745}$ Idem, p. 28.

${ }^{746}$ Idem, p.378

${ }^{747}$ Idem, p. 25

${ }^{748}$ Idem, p. 26

749 MEIRELLES, Hely Lopes. Direito Administrativo Brasileiro. Editora Malheiros. 32º edição. São Paulo, 2006. p. 64-65
} 
A centralização era um problema que perpassava a administração pública brasileira. No plano nacional, “As críticas mais comuns recaíam sobre a centralização excessiva do regime monárquico, que restringia a liberdade política e econômica das províncias" ${ }^{, 750}$.

A centralização é severamente criticada por Tavares Bastos em A Província: estudo sobre a descentralização no Brasil, cuja primeira edição é de 1870. Para ele, a centralização tem "por alvo tudo dominar" e ainda supõe ser "o melhor método de administrar um país"751 . No bojo das discussões acerca da monarquia e da república, da centralização e da descentralização, Tavares Bastos defende que "a centralização é a fonte perene de corrupção",752. Por meio dela, fica "o governo das províncias preso por mil liames ao governo supremo, as dependências da centralização, os interesses formados à sua sombra $[\ldots]^{, 753}$.

Posicionando-se contra "a nossa odiosa concentração política administrativa", ele advoga a favor da descentralização e da forma federativa por constituir "uma organização onde o poder coletivo deixe de ser o avaro tutor de interesses locais" ${ }^{\text {754, }}$ que a tudo domina.

Tavares Bastos reconhece o avanço político obtido por meio do Ato Adicional de 1834, mas salienta que ele gerou "dificuldades práticas. Isso "porque não estabelecia a federação, mas um regímen que participava de ambos os sistemas, centralizador e descentralizador, ${ }^{, 755}$.

$\mathrm{Na}$ perspectiva do sociólogo colombiano, no clássico estudo $O$ Minotauro Imperial, durante o Império, no plano nacional, após o Ato Adicional de 1834, “o grau de descentralização política é impressionante: as legislaturas provinciais conquistaram a faculdade de definir as políticas mais essenciais [...]"756. Na província,

o movimento da descentralização foi, todavia, incompleto, na medida em que não ocorreu a indispensável e paralela descentralização administrativa. Ao lado das legislaturas provinciais de inquestionável

\footnotetext{
${ }^{750}$ COSTA, Frederico Lustosa da; ZAMOT, Fuad (orgs.). Brasil - 200 anos de Estado, 200 anos de administração pública. Revista de Administração Pública. Rio de Janeiro 42(5): 829-74, set./out., 2008, p.839.

${ }^{751}$ TAVARES BASTOS, op. cit., p.18.

${ }^{752}$ Idem, p. 28

${ }^{753}$ Idem, ibidem.

${ }^{754}$ Idem, p.48 (grifo do autor).

${ }^{755}$ Idem, p.65

${ }^{756}$ URICOECHEA, Fernando. O Minotauro Imperial. A burocratização do Estado Patrimonial brasileiro no século XIX. Rio de Janeiro/São Paulo: Difel, 1978, p.110.
} 
caráter local, brotou o presidente provincial nomeado pela autoridade central $[\ldots]^{\prime \prime 757}$.

A despeito de todo o discurso a favor da descentralização, sobretudo nos últimos anos do Império, a centralização persiste como política de governo e prática administrativa. Fernando Uricoechea não tem opinião diferente de Tavares Bastos acerca do chefe maior do executivo na Província. Segundo ele, o Presidente da Província, era o representante maior da Coroa, cujos interesses "não eram predominantemente os da província mas os do centro político"758. Para Uricoechea, "é difícil minimizar o papel do presidente provincial como um instrumento do centro político" 759 .

Tavares Bastos elucida a visão dos liberais acerca do Presidente da Província:

O Presidente exerce hoje uma dupla autoridade: delegado do governo central, administra e inspeciona os negócios gerais na província; executor das resoluções da assembleia, dirige e promove os interesse peculiares da província. Confundidas atualmente nas mãos de um só funcionário, essas duas fontes de poder conspiram para convertê-lo em um verdadeiro vice-rei ${ }^{760}$.

Uricoechea, a partir do conceito de burocracia patrimonial de Max Weber, se propõe a "reexaminar a organização política brasileira do século XIX",761 . O minotauro é a figura que ilustrada a Guarda Nacional, instituição por meio da qual o autor analisa as "duas metades" da organização política brasileira:

de um lado, a existência de um aparato administrativo controlado burocraticamente pelo estado e impulsionando a burocratização total do governo e, de outro lado, a existência paralela de um aparato administrativo controlado patrimonial pelas classes locais e exercendo pressão para a prebendalização de $\operatorname{cargos}^{762}$.

Entendo que essa imbricação entre o público e o privado, na estruturação da administração pública imperial, para a qual Fernando Uricoechea chama atenção, é operatória para entender a documentação analisada neste capítulo (ofícios e correspondências entre os órgãos do governo) e as solicitações de material e mobiliário escolar nela contidas.

\footnotetext{
${ }^{757}$ Idem, ibidem.

${ }^{758}$ Idem, p.110-111.

${ }^{759}$ URICOECHEA, op. cit., p. 110.

${ }^{760}$ BASTOS, op. cit., p.89.

${ }^{761}$ URICOECHEA, op. cit., p.14.

${ }^{762}$ Idem, p.14-15.
} 
No entanto, Fernando Uricoechea trata de uma "tensão inerente e estrutural" entre as autoridades locais e a autoridade do governo no "processo de desenvolvimento do estado burocrático moderno" ${ }^{, 763}$. Mas esse amálgama entre o público e o privado nem sempre se deu em forma de tensão. As relações pessoais entre agentes públicos, por vezes, se sobrepõem à hierarquia e burocracia estatal na tentativa de resolver problemas com maior celeridade.A República poria fim à interferência destas afinidades pessoais nos negócios públicos? Tornaria mais racional, burocrática e hierarquizada a administração, no que concerne à Instrução Pública? Destinara órgãos e funcionários para tornar mais eficaz a compra e distribuição do material escolar? Entendo que para todas as questões há mudanças e permanências.

Não dá para tratar de mudanças e permanências nos primeiros anos de República sem considerar a estrutura administrativa herdada do Império e sem definir o que significa a racionalização e complexificação da administração pública para equipar materialmente a escola.

Entendo por complexificação a criação de órgãos e a definição de agentes ou funcionários públicos, com a competência e a função específica de arcar com o suprimento material das instituições de ensino.

Marco Paulo, tratando da organização administrativo-burocrática da instrução pública paulista, com destaque para o Regulamento de 1910, se vale das categorias weberianas de racionalização e organização burocrática, que são operatórias neste trabalho.

A racionalização, tomando as palavras de Paulo, quando cita Weber,

significa a estruturação de um modo de pensar e agir, fundamentado no cálculo, na eficácia, na produtividade e no lucro, para o que a organização burocrática funciona estritamente como um meio, um instrumento desse modo (WEBER, 2000). Daí que, a crescente racionalização da vida moderna cria as organizações burocráticas ${ }^{764}$.

A racionalização e complexificação se caracterizariam, então, pela divisão de competências e funções, pela hierarquização e diferentes instâncias de poder. Dessa forma, a moderna burocracia racional-legal se organiza "a partir de áreas de jurisdição

\footnotetext{
${ }^{763}$ Idem, p. 14.

${ }^{764}$ PAULO, Marco Antônio Rodrigues. A organização administrativo-burocrática da instrução pública paulista: Estudo sobre o Regulamento da Diretoria Geral de 1910. Tese (Doutorado em Educação).2007, p.11.
} 
fixas e oficiais, ordenadas de acordo com regulamentos, ou seja, leis ou normas administrativas"765.

A legitimidade que mantém o poder se explica pela "crença na racionalidade que se manifesta no plano da burocracia» ${ }^{, 766}$. Essa crença dá sustentação à autoridade burocrática, que se estrutura a partir da hierarquia das atribuições e dos deveres oficiais $^{767}$.

Elaborados a partir da legislação do século XIX, os organogramas apresentados nesta parte do texto, visam destacar a organização burocrática e hierárquica da administração da instrução pública paulista.

A primeira lei de instrução primária da Província de São Paulo, lei n.34 de $1846^{768}$, nada dispõe sobre os móveis escolares. Apenas estabelece, acerca da estrutura física da escola, no artigo 45, que

O governo procurará fornecer edificios proprios para n'elles se estabelecerem as escolas, havendo-os publicos; e não os havendo fará promover a promplificação d'elles por meio de subscripções nas localidades. Fornecerá aos professores os utensilios precisos. Em quanto o governo não puder fornecer edificios, e nem conseguir por meio das subscripções, continuarão as aulas a este respeito como actualmente.

Pode-se considerar que a primeira lei a dar "um importante passo no processo de modernização do controle da instrução pública paulista na Província de São Paulo",769 foi o Regulamento n.8 de novembro de $1851^{770}$. "Essa legislação instituiu o cargo de Inspetor Geral, profissional efetivamente responsável pela administração e fiscalização da instrução pública na Província [...]"771 . A Inspetoria Geral da Instrução Pública, segundo Paulo e Warde, “tomou a forma de uma repartição pública, com um Inspetor Geral, um secretário, dois amanuenses e um porteiro, todos remunerados",772.

Não é o objetivo aqui discorrer sobre as muitas leis que modificaram a organização da instrução pública no Império. Destacarei apenas os últimos dispositivos legais, anteriores à Proclamação da República, pois para afirmar que houve

\footnotetext{
${ }^{765}$ WEBER, M. Ensaios de Sociologia. Rio de Janeiro: Guanabara, 1982, p.229.

${ }^{766}$ PAULO, op. cit. p.13.

${ }^{767}$ WEBER, 1982.

768 RODRIGUES, J. L. Retrospecto histórico. In: Anuário do Ensino do Estado de São Paulo de 1907/1908. S,„o Paulo: Typ. Augusto Siqueira \& C., 1909, p. XI.

${ }^{769}$ PAULO, Marco A.; WARDE, Mirian. A instalação do serviço de inspeção escolar na Província de São Paulo (1835-1887). Cadernos de História da Educação, v.12, n.1 - jan/jun 2013, p.271.

${ }^{770}$ No Anuário do Ensino do Estado de Sáo Paulo de 1907/1908, João Lourenço Rodrigues detalha as funções dos auxiliares do governo na direção do ensino publico.

${ }^{771}$ Idem, p.271-272.

${ }^{772}$ PAULO; WARDE, 2013, p.259.
} 
modernização e racionalização, é necessário comparar a organização do aparato administrativo-burocrático estabelecido nos anos iniciais da República com a estrutura herdada do Império.

Assim, de acordo com a Lei n.81, e 6 de abril de 1887 e o Regulamento de 22 de agosto de 1887, o organograma da administração seria o seguinte:

Figura 49 - Organograma da administração pública de acordo com o Regulamento de 1887

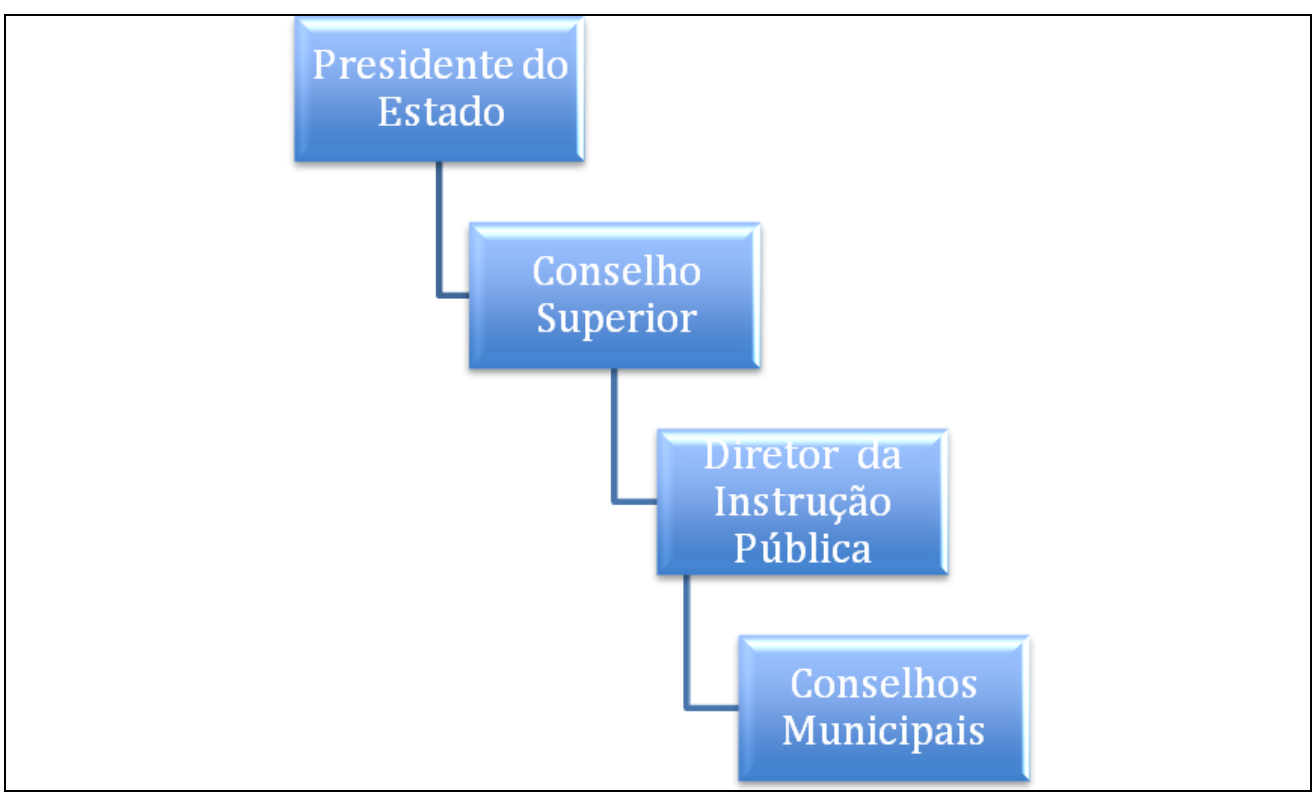

Fonte: Elaboração da autora a partir da Lei n. 81, de 6 de abril de 1887 e do Regulamento de 22 de agosto de 1887.

Os pontos principais da reforma de 1887 foram a criação do Conselho Superior do Ensino, dos Conselhos Municipais, do fundo escolar e a reforma da Secretaria de Instrução Pública.

Se a organização racional-legal se aprofunda com o regime republicano, não dá para dizer que no Império o esforço de estruturação da administração pública e escolar inexiste. A lei de 1887 e o respectivo regulamento, além da criação de órgãos, especificam as atribuições dos agentes públicos.

Nessa estrutura, o Diretor Geral da Instrução Pública “é o funccionario encarregado de executar as deliberações do presidente da província e do conselho 
superior, como chefe da repartição de instrucção publica"773. Para auxiliar o Diretor Geral, organizar-se-ia uma secretaria composta de um secretário, dois oficiais, três amanuenses, um porteiro e um contínuo. Os três primeiros nomeados pelo governo, sob proposta do diretor da instrução (Lei n. 81, de 6 de abril de 1887, Art.17).

Quanto aos Conselhos Municipais, reza o artigo 70 do Regulamento de 1887:

As necessidades das escolas publicas de cada município, em relação a casos em que funccionem, acquisição de moveis, utensis e outros objectos preciosos serão suppridas pelos Conselhos Municipaes por conta das quotas arrecadadas no respectivo fundo escolar ${ }^{774}$.

Os Conselhos Municipais, de acordo com João Lourenço Rodrigues, funcionaram no período de 1874 a $1892^{775}$. Eles desempenhavam uma inspeção coletiva desacreditada por alguns que ocupavam a direção do ensino. O Inspetor Geral da Instrução Pública, Dr. Arthur Cesar Guimarães, segundo Rodrigues, “considerava um mal a divisão da responsabilidade em qualquer ramo de serviço",776.

A crítica mais contundente é aos Conselhos Municipais, pois, nas palavras do Presidente da Província, Francisco de Paula Rodrigues Alves, "os conselhos municipais, em que, parece, depositáveis tanta confiança, ou não se constituem, ou se constituídos não se instalam, sendo certo que os poucos que conseguem completar a sua formação não têm estabilidade e cumprem deficientemente suas atribuições"777.

Outro Presidente de Província, Dr. Pedro Vicente de Azevedo, no início de 1889, afirmou que "a ação do governo e da directoria de Instrucção Publica é muitas vezes nullificada pelos Conselhos Municipaes que a lei colocou entre taes executors e a escola publica".

Se os Conselhos Municipais não funcionavam bem, sua função de aquisição de móveis e utensílios para as escolas, não deve ter sido muito eficiente.

Os Conselhos Municipais e a estrutura administrativa herdada do Império, por meio da reforma de 1887, vigorariam por mais de dois anos após a Proclamação da República, quando em 1892, se dá uma nova reforma do ensino público paulista.

No plano político e jurídico, a Proclamação da República

instituiu o federalismo e inaugurou o regime presidencialista. A separação de poderes ficou mais nítida. O Legislativo continuava bicameral, sendo agora formado pela Câmara dos Deputados e pelo Senado, cujos membros passaram a ser eleitos para mandado de

\footnotetext{
${ }^{773}$ Lei n. 81, de 6 de abril de 1887, art 7.

${ }^{774}$ Sobre o fundo escolar tratarei no ponto seguinte.

${ }^{775}$ Anuário 1907/1908, op. cit., p.XXII

${ }^{776}$ Anuário 1909, p.XXIV

777 Anuário, op. cit. p.25
} 
duração certa. Ampliou-se a autonomia do Judiciário. Foi criado o Tribunal de Contas para fiscalizar a realização da despesa pública. As províncias, transformadas em estados, cujos presidentes (ou governadores) passaram a ser eleitos, ganharam grande autonomia e substantiva arrecadação própria ${ }^{778}$.

O aumento da arrecadação da Província de São Paulo é uma mudança significava obtida após a República, pois, com o regime republicano, "uma substancial parte das rendas previamente administradas pelo governo central passou para a alçada local e estadual" ${ }^{, 79}$. Entretanto, somente no ponto seguinte, acerca do investimento do governo na instrução pública, discutirei, por meio dos orçamentos, se o aumento da arrecadação da Província de São Paulo redundou em aumento da verba para educação.

Agora, interessa pensar as mudanças e permanências na administração dos negócios da educação. Com a República, permaneceu a descentralização herdada do Ato Adicional de 1834, ficando a instrução primária sob a responsabilidade de cada província.

Quanto às mudanças, Casemiro dos Reis Filho, informa que "entre 1890 e 1896 realizou-se o mais intenso esforço de racionalização político-administrativo no governo de São Paulo. Como parte desse processo, organizou-se o ensino público paulista" ${ }^{\text {,780 }}$.

Em sua tese de doutorado acerca do regulamento da diretoria geral de 1910, Marco Antonio Paulo, entende que as mudanças na estrutura administrativo-burocrática que tiverem início, no caso paulista, em setembro de 1892, foram constantes ao longo da Primeira República.

A primeira mudança é introduzida pelos Decretos do Executivo n.28 e n. 29, de $1^{\circ}$ de março de 1892. Do ponto de vista de Rosiley Souto, a partir dos Decretos n.28 e n.29, "percebe-se uma descentralização dos serviços por parte do presidente do Estado, mas, por outro lado, é constituído um controle cada vez maior, por meio das instituições que passariam a regular toda a vida social" ${ }^{, 781}$.

A partir deles, seria a seguinte a hierarquia da Administração Pública ou do Executivo Paulista:

\footnotetext{
${ }^{778}$ Idem, ibidem (grifo meu).

779 LOVE, Joseph. A locomotiva: São Paulo na federação brasileira (1889-1937). Trad. Vera Alice Cardoso da Silva. Rio de Janeiro: Paz e Terra, 1982, p.174.

${ }^{780}$ REIS FILHO, Casimiro dos. A Educação e a ilusão liberal. São Paulo: Cortez, Autores Associados, 1981, p.19.

${ }^{781}$ SOUTO, Rosiley Teixeira. 2005. Recrutamento e qualificação de professores primários na Instrução Pública paulista (1892-1933): um estudo das tecnologias do estado. São Paulo (Tese de Doutorado). PUC/SP, p.40.
} 
Figura 50 - Organograma da administração pública de acordo com os Decretos do Executivo n.28 e 29 de 1892

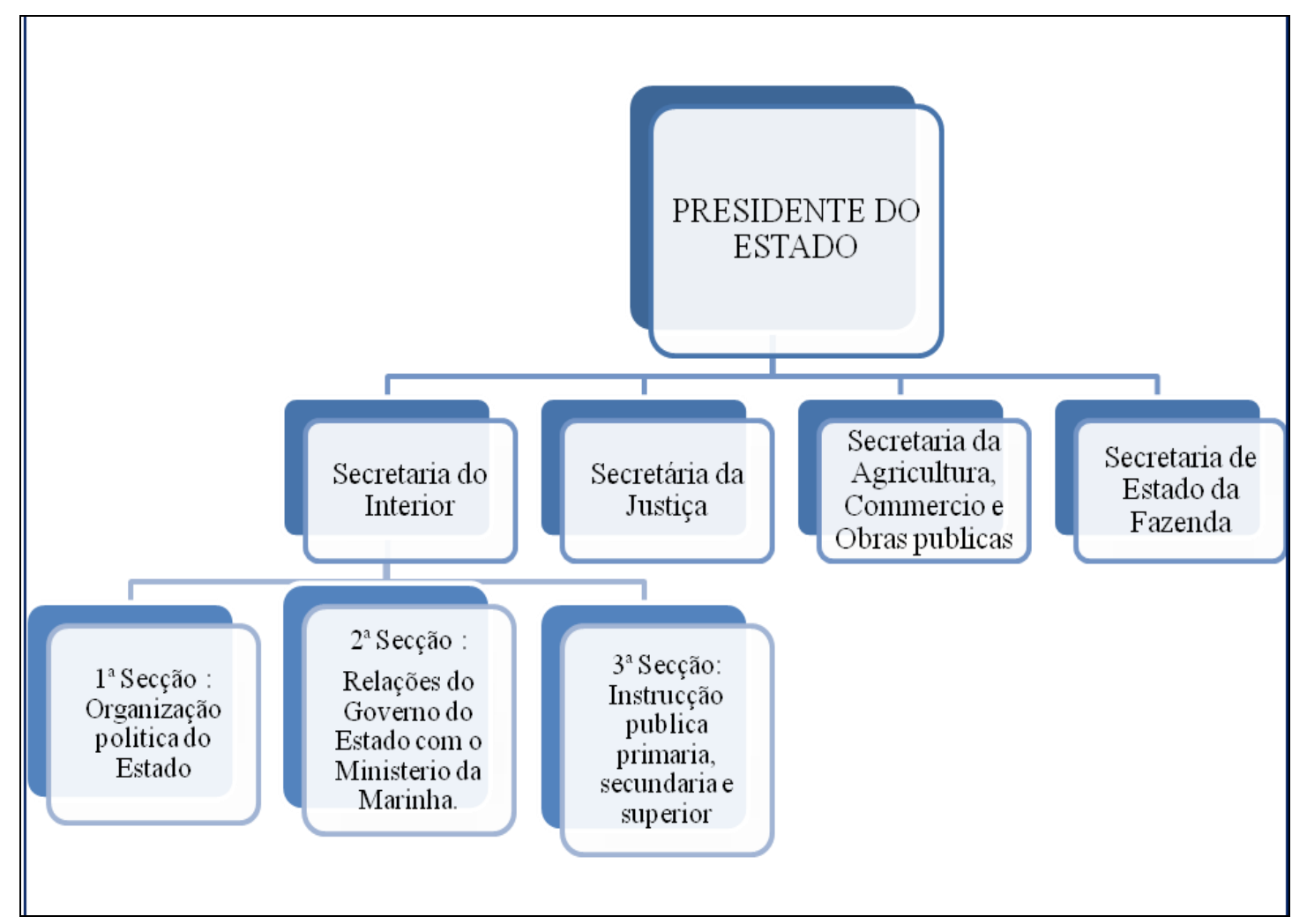
1892.

Fonte: Elaboração da autora por meio dos Decretos do Executivo n. 28 e 29, de $1^{\circ}$ de março de

Segundo Reis Filho, em 1892, Secretaria do Interior "passava, então, a subordinar os serviços da Instrução Pública, por intermédio da $3^{\text {a }}$ Seção. Era imensa a esfera de atribuições dessa Secretaria"782. O conjunto de serviços e repartições incorporados pela Secretaria do Interior é um exemplo da complexificação, racionalização e burocratização da administração estadual.

A Secretaria de Negócios do Interior foi instituída pela Lei ${ }^{\circ} 15$, de 11 de novembro de 1891. No ano seguinte, em razão do Dec. $\mathrm{n}^{\circ} 28$, de $1^{\circ}$ de março, ela foi reorganizada e dividida em três seções - à primeira correspondiam a organização política, a representação do estado no Congresso Federal, a instrução pública e as eleições; à segunda correspondiam os assuntos relativos à higiene e polícia sanitária, aos serviços de vacinação, ao socorro público, aos cemitérios e às relações do Governo do Estado com os ministros da Marinha e da Guerra; e à terceira, a educação (instrução pública

\footnotetext{
${ }^{782}$ Idem, p. 20 .
} 
primária, secundária e superior), as bibliotecas e a Repartição de Estatística e do Arquivo do Estado ${ }^{783}$.

A complexificação da administração nos primeiros anos republicanos (1892 e 1893) se mostra, também no conjunto de órgãos e agentes públicos com a função de auxiliar o presidente do Estado, a quem cabia a direção suprema do ensino. Ele seria auxiliado pelo Secretário dos Negócios do Interior, pelo Conselho Superior, pelo Diretor Geral da Instrução Pública, os Inspetores de Distrito e as Câmaras Municipais.

Nova estrutura hierárquica estabeleceu-se ainda em 1892. A Lei n.88, de 8 de setembro desse mesmo ano, reformou a Instrução Pública e acarretou, por sua vez, a reestruturação da Secretaria Geral da Instrução Pública, “órgão de registro burocrático, subordinado ao Diretor Geral da Instrução Pública" ${ }^{984}$.

Figura 51 - Organogramada administração pública de acordo com a Lei n.88 de 1892

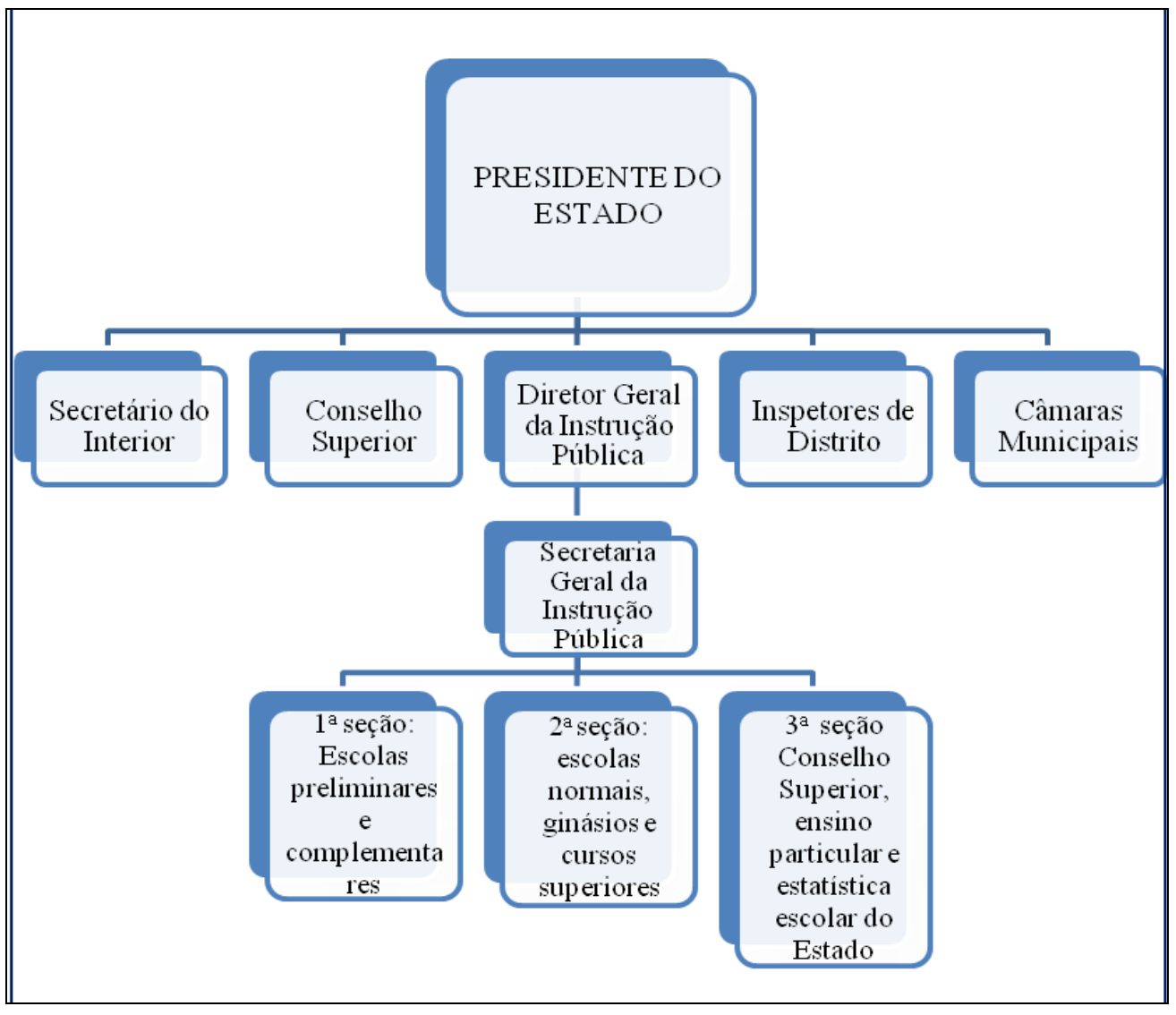

1892.

Fonte: Elaboração da autora a partir de REIS FILHO, 1981 e da Lei n. 88, de 8 de setembro de

\footnotetext{
${ }^{783} \mathrm{http}: / / \mathrm{www}$.arquivoestado.sp.gov.br/guia ficha.php?fundo=123\&palavra $=$ acessado em 21/12/2013

${ }^{784}$ REIS FILHO, op. cit., p.21
} 
Para Reis Filho, "é manifesto o esforço de racionalização das atividades governamentais, no regime republicano" ${ }^{, 785}$.

Ao chefe do executivo, Presidente do Estado, cabia, dentre outras funções, nomear o pessoal docente e administrativo das escolas e dos órgãos de direção e inspeção do ensino.

O Secretário do Interior dirige e fiscaliza todos os negócios relacionados com o ensino. Era o auxiliar direto e imediato e de confiança do Presidente do Estado. Escolhido, nomeado e demitido por ato de vontade do Presidente do Estado.

O Conselho Superior é órgão consultivo das instâncias superiores e retém funções deliberativas para operacionalização das normas e regulamentos. Suas deliberações dependem de aprovação superior do Secretário do Interior.

Como órgão de execução de serviços manteve-se a Diretoria Geral da Instrução Pública e foram criadas as inspetorias de distrito.

As Câmaras Municipais, como órgãos político-administrativo dos municípios, deveriam cooperar no progresso da instrução pública no âmbito de seus respectivos municípios ${ }^{786}$.

A descrição das atribuições dos órgãos e agentes é importante, pois esta estrutura administrativa do ensino foi o "suporte organizatório criado pela reforma republicana, do ensino paulista, para implantar e expandir os diversos tipos de escolas e todos os níveis de ensino" ${ }^{, 787}$.

De acordo com Marco Paulo, em 1893, Cesário Mota Junior foi nomeado Secretário dos Negócios do Interior com a finalidade de executar a Lei n.88 e o Decreto n. 144B, que a regulamentou. O novo secretário propôs a lei n.169, de 7 de agosto de 1893. O Decreto n.218 de novembro do mesmo ano aprovou o novo regulamento da instrução pública, redefinindo o aparato administrativo-burocrático do ensino paulista $^{788}$.

O Regulamento da Instrução, aprovado pelo Decreto n. 218 de 27 de novembro de 1893, foi elaborado, do ponto de vista de João Lourenço Rodrigues, com inspiração no Código de Ensino Primário de 1857. Segundo ele, redigido por uma comissão composta de doutores “o Código do Ensino não chegou a ser posto em execução, talvez

\footnotetext{
${ }^{785}$ Idem, ibidem.

${ }^{786}$ Idem, p. 22.

${ }^{787}$ Idem, ibidem.

${ }^{788}$ PAULO, Marco Antonio R. A organização administrativo-burocrática da instrção pública paulista: estudo sobre o regulamento da diretoria geral de 1910. 2007. Tese (Doutorado em Educação). PUC/SP, São Paulo.
} 
por exigir a creação de um pessoal para cujo pagamento os recursos do erário não ofereciam margem" ${ }^{, 789}$.

A estrutura hierárquica estabelecida em 1893 se constitui a partir vários agentes que seriam auxiliares do Presidente da Província, todos eles com atribuições e funções bem estabelecidas. Como repetição do artigo 40 da lei n.88 de 8 de setembro de 1892 , ao Presidente do Estado cabia a direção suprema do ensino, auxiliado por um conjunto de atores: Secretário do Interior, Conselho Superior, Diretor Geral da Instrução Pública, Inspetores de Distrito e Câmaras Municipais.

A estrutura da máquina administrativa, definida pelas leis, decretos e regulamentos de 1892 e 1893, foi a mais complexa organização do executivo paulista, até então. Aprofundou-se a hierarquização e a criação de instâncias intermediárias entre a administração escolar e o Presidente do Estado. O estabelecimento de secretarias e repartições ${ }^{790}$ poderia tornar mais eficiente o conhecimento das necessidades materiais da escola e a distribuição mais equitativa dos mesmos.

A Secretaria Geral da Instrução Pública foi organizada como repartição pelo Decreto n.144A, de 30 de dezembro de 1892, que regulamentou a Lei n.88, de 8 de setembro de 1892. Composta de três seções, esboçadas no organograma acima, a "essa repartição cabia a análise, tramitação e arquivos de documentos relativos à instrução pública paulista, além da elaboração das normas referentes à administração da instrução pública do Estado" ${ }^{, 791}$.

Não porque a maior burocratização redunde em maior eficiência do poder público, mas porque a expansão da escola primária exigia uma melhor organização da administração pública e escolar para atender às novas e crescentes demandas de mobiliário, por exemplo.

No entanto, essa complexa estrutura sofreria nova simplificação em 1896. O organograma abaixo, elaborado por Marco Paulo, a partir da Lei n. 430, de 1 de agosto de 1896 e do Decreto n. 382, de 3 de setembro de 1896, mostra a nova estrutura da Secretaria de Estado dos Negócios do Interior, que permaneceria até setembro de 1901.

\footnotetext{
${ }^{789}$ No Anuário do Ensino do Estado de Sáo Paulo de 1907/1908, João Lourenço Rodrigues detalha as funções dos auxiliares do governo na direção do ensino publico, p.XXI.

790 "No início da República teria sido consagrada a expressão repartição, ao menos, no sentido de designar o local onde deveriam ser executadas as funções oficiais e onde as atividades deveriam estar voltadas para os fins do próprio Estado" - Paulo, 2007, p.57.

${ }^{791}$ PAULO, 2007, p.57
} 
Figura 52 - Organograma da administração pública, conforme Lei n. 430 de 1896.

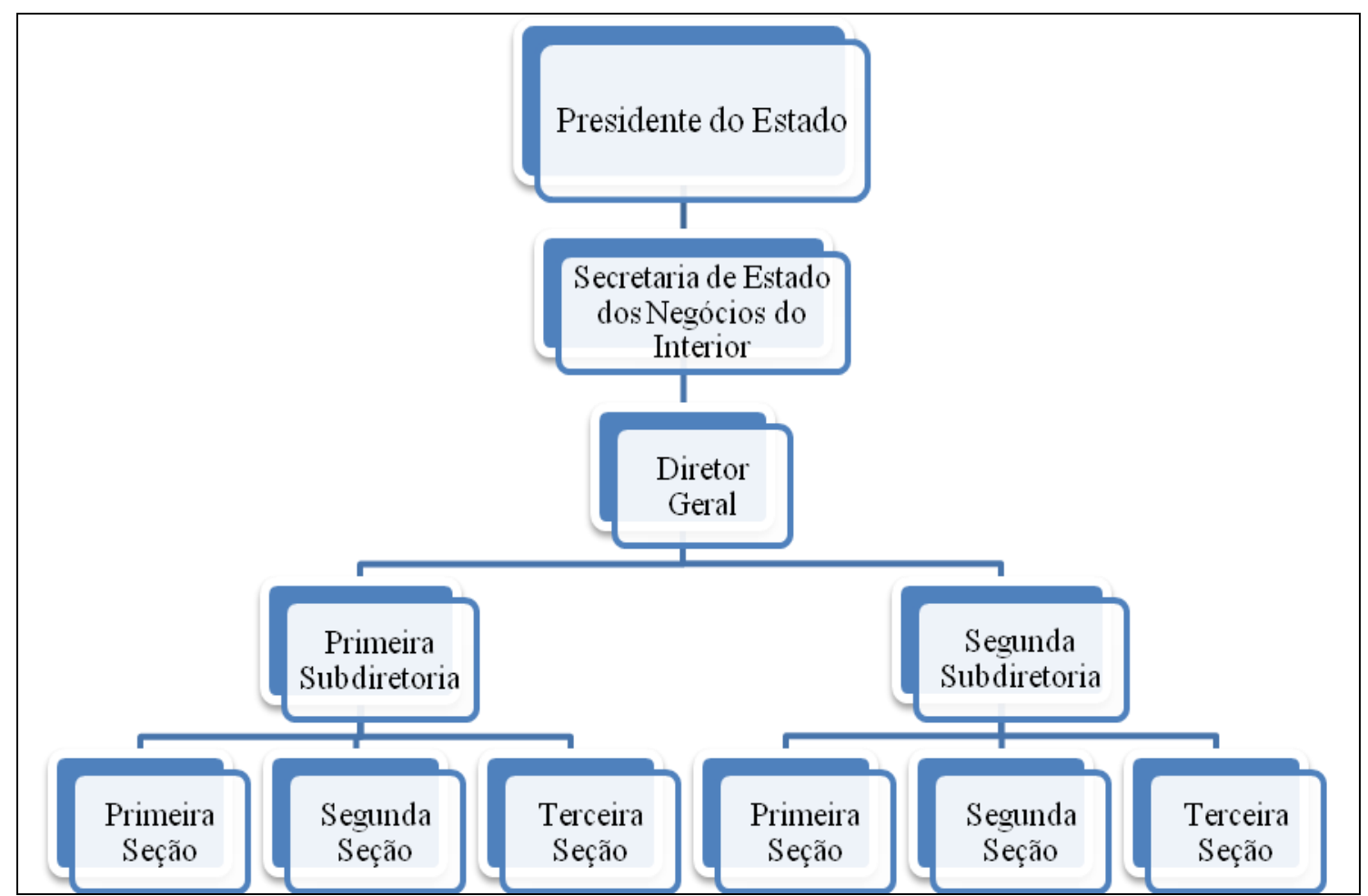

Fonte: PAULO, 2007, p.65

A Lei n.430 no seu artigo $1^{\circ}$, suprimiu o cargo de Diretor da Instrução Pública e a respectiva Secretaria. O Art. $2^{\circ}$ estabeleceu: "Passarão a ser directamente exercidas pelo Secretário do Interior as attribuições especificadas no artigo 30, §§ 1, 2, 4, 5, 6, 7, 9, 10, 11, 16, 17, 19 e 24 do decreto n. 218 de 27 de Novembro de 1893,792. As demais

\footnotetext{
${ }^{792}$ As antigas atribuições do Diretor Geral, de acordo com o Decreto 218, eram:

$\S 1 .^{\circ}$ - Mandar publicar annualmente o programma detalhado de cada cadeira das escolas normaes (art. $42, \S 1 .^{\circ}$, da lei n. 88 , e art. 23 da lei n. 169).

$\S 2 .^{\circ}$ - Providenciar sobre a publicação de uma revista annual, em que os professores sejam informados a respeito do progresso do ensino (art. $42, \S 22^{\circ}$, da lei n. 88).

$\S 4 .^{\circ}$ - Apresentar todos os annos ao Secretario do Interior um relatorio circumstanciado sobre o estado de ensino, fazendo-o acompanhar dos dados estatisticos necessarios á demonstração dos progressos obtidos (art. 42 - 4 da lei n. 88).

$\S 5 .^{\circ}$ - Propor ao Congresso, por intermedio de Secretario do Interior, a creação ou suppressão de cadeiras (art. 42 - 5 da lei n. 88).

$\S 66^{\circ}$ - Orçar as despesas com a instrucção publica e submetter o orçamento ao Congresso por intermedio do Secretario do Interior (art. 42 - 6 da lei n. 88).

$\S 7 .^{\circ}$ - Propor a nomeação dos adjunctos das escolas preliminares.

$\S 9 .^{\circ}$ - Propor ao Presidente do Estado as aposentadorias, permutas e remoções requeridas pelos professores (art. 42 - 7 da lei n.88).

$\S 10$. - Inspeccionar as escolas normaes, os gymnasios (art. 42 - 9 da lei n. 88) e quaesquer outras instituições de ensino primario e secundario do Estado.
} 
atribuições, não transferidas ao Secretário do Interior, seriam "exercidas pelos funccionarios que em regulamento forem designados" (Lei n.430, Art.2 $2^{\circ}, \S 2^{\circ}$ ). O artigo

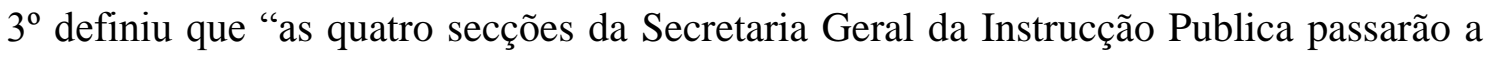
constituir secções da Secretaria do Interior".

As $2^{\text {a }}$ Subdiretoria da Secretaria dos Negócios do Interior assumiu as atribuições das quatro seções da Secretaria Geral da Instrução Pública, portanto, se "encarregaria dos serviços relativos à instrução púbica primária, secundária e superior, além das associações literárias e estabelecimentos congêneres, bibliotecas e museus"793. Entretanto, "não ficaram definidas as atribuições de cada seção que compunha as subdiretorias",794.

Nesta organização, é visível a concentração das atribuições e o enxugamento da máquina administrativa. Na perspectiva de Casemiro dos Reis Filho (1974), em 1896, tem fim "a época dos reformadores"795. O processo de "concentração de poderes nos órgãos superiores"796 continua em 1897, quando a Lei n.520, de 26 de agosto, suprimiu o Conselho Superior da Instrução Pública (Lei n.520, art. $1^{\circ}$ ) e as Inspetorias de Distrito (Lei n.520, art. $2^{\circ}$ ). A Lei n. 520 foi regulamentada pelo Decreto n. 518, de 11 de janeiro de 1898, ficando a hierarquia da administração pública organizada conforme o organograma abaixo.

$\S 11$. - Nomear, mediante proposta dos inspectores de districto, substitutos para a regencia dos escolas preliminares e intermedias, cujos professores se tornarem impedidos por mais de trinta dias, caso não tenham adjunctos.

$\S 16$. - Levar ao conhecimento do Presidente do Estado o resultado dos concursos para base das nomeações.

$\S 17$. - Propor ao Secretario do Interior, a requerimento dos interessados, e quando a julgar nos casos de lei, a declaração de vitaliciedade dos professores em geral.

$\S 19$. - Receber queixas, reclamações e representações sobre o ramo de serviço a seu cargo e tomar as devidas providencias ou propol-as ao Governo ou ao Conselho Superior, conforme a ordem de sua competencia.

$\S 24$. - Tomar conhecimento dos recursos interpostos pelos professores publicos contra a recusa de attestados de exercicio (art. $5^{\circ}, \S 2 .^{\circ}$ da lei n. 169).

${ }^{793}$ PAULO, op. cit., p.65

${ }^{794}$ PAULO, op. cit., p.65

${ }^{795}$ REIS FILHO, 1974, p.37

${ }^{796}$ REIS FILHO, 1974, p.37 
Figura 53 - Organograma da administração pública, conforme Decreto n.518 de 1898

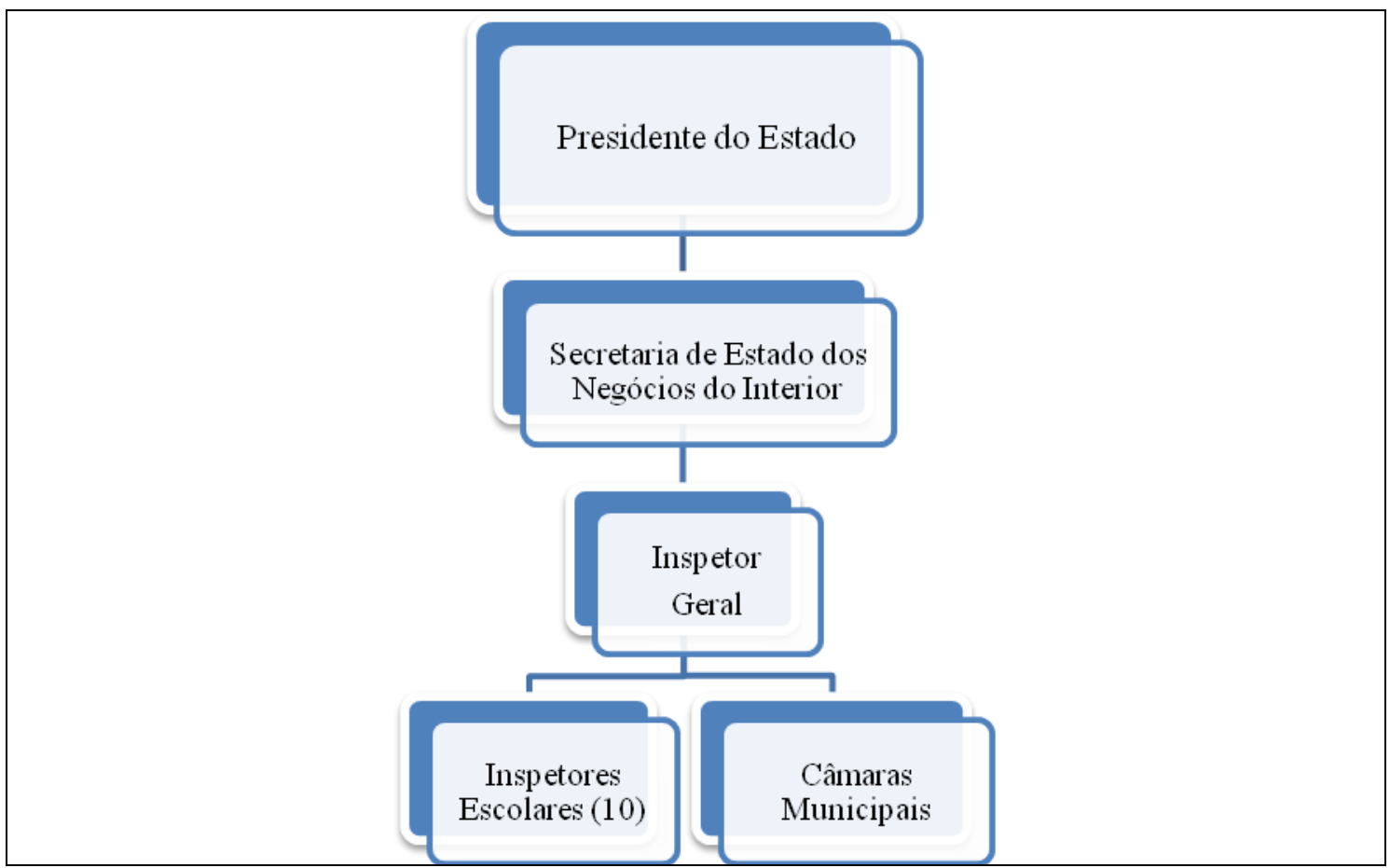

Fonte: Elaboração da autora a partir do Decreto n. 518, de 11 de janeiro de 1898.

Apesar de simplificada, uma novidade do Decreto 518 foi a definição do agente responsável pela providência dos móveis e materiais escolares. Conforme o Art.23, $3^{\circ}$, ao inspetor escolar cabia

verificar quaes as escolas que devam fazer parte do grupo e providenciar no sentido da reunião das mesmas, solicitando do Secretario de Estado dos Negocios do Interior as necessarias ordens para esse fim e requisitando os moveis, livros didacticos e de escripturação, utensilios e objectos escolares que forem indispensaveis á organização material do estabelecimento.

Em 1898 havia no Estado de São Paulo, conforme Mensagem do Presidente do Estado, 1.156 escolas providas, "com uma frequência média de 22671 alunos de ambos

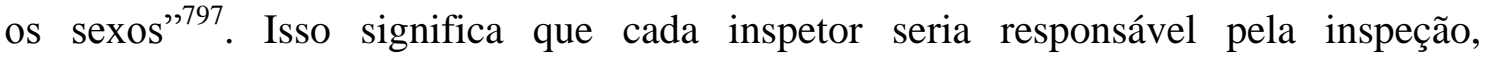
fiscalização e pelo suprimento material e mobiliário de mais de 100 escolas, tarefa de difícil realização.

\footnotetext{
797 SÃO PAULO. Mensagem do Presidente do Estado Fernando Prestes de Albuquerque enviada ao Congresso Legislativo em 07 de abril de 1899. São Paulo: Typografia do Diário Oficial, 1899, p.7.
} 
Por isso, é razoável afirmar que a estrutura burocrático-administrativa do Estado pode se constituir em um entrave à expansão da escola pública, obrigatória e de massa.

Neste capítulo não interessa saber, apenas, como estava organizada burocraticamente e hierarquicamente a administração da instrução pública. Isso já foi feito em outros estudos ${ }^{798}$. Ainda que de forma inicial, interessa ver, para além da estrutura estabelecida na lei, os órgãos da instrução pública em funcionamento.

Assim, é sob o olhar da estrutura administrativa estabelecida nas leis, nos decretos e regulamentos que se dará a análise do Livro de Móveis e Utensis, dos ofícios e das correspondências entre os órgãos da Administração Pública e escolar. Isso permitirá compreender a dinâmica da relação entre esses diversos órgãos e as escolas; os limites e as possibilidades que essa estrutura administrativa, com suas práticas e políticas, trouxe à organização e expansão, bem como ao suprimento material da escola, especialmente no que se refere às carteiras.

As pesquisas de bases desenvolvidas por outros autores acerca da organização administrativa da instrução pública paulista foram fundamentais para esta investigação. Entretanto, muitas delas se valem das leis, decretos e regulamentos que podem dizer de como a legislação criou órgãos e estabeleceu agentes e funcionários, isto é, organizou a máquina administrativa. Mas essa documentação não pode oferecer indícios de como esses órgãos e agentes públicos, cotidianamente, lidavam com os desafios de suprir materialmente uma escola em franca expansão, de por a "máquina" em funcionamento.

É válida a assertiva de Marco Paulo, quando afirma, a partir da legislação, que os primeiros anos após a Proclamação da República foram marcados por um processo de modernização administrativo-burocrático no Estado de São Paulo e, essa modernização também se deu na instrução pública.

Todavia, a modernização que estava no plano legal, não funcionava em todos os termos no cotidiano da administração pública. Se a modernização era marcada pela racionalidade, impessoalidade e burocratização; os ofícios e correspondências dão indícios de que esses elementos não passaram a fazer parte, instantaneamente, da administração pública e escolar.

Duas situações são elucidativas do que se quer aqui demonstrar. A primeira já foi tratada no tópico anterior. Em 1878, o professor da Escola Normal queixa-se com o

\footnotetext{
798 O tema da estrutura administrativa da Instrução Pública paulista, na Primeira República, já foi objeto de estudo de João Lourenço Rodrigues (1930); Moacyr Primitivo (1942); Reis Filho (1974); Degani (1973); Nascimento (1980); Tavares (2004); Souto (2005); Paulo (2007); Paulo; Warde e Parizzolo (2009).
} 
Inspetor da Instrução Pública, pois "foram colocados pelo próprio presidente da

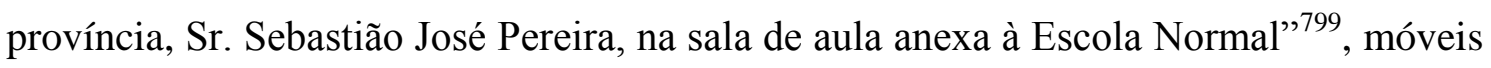
escolares, sem que o professor tivesse conhecimento. Por certo, entre as atribuições do presidente da província, no ano de 1878, não estava a entrega ou distribuição de móveis às escolas. Além disso, em posição de mediação havia um inspetor da instrução pública que parece ter tomado conhecimento do ocorrido por meio da carta do professor reclamante. Isso sinaliza a informalidade na condução dos negócios públicos e a incipiente organização da máquina administrativa a ponto de um agente público executar atribuições que não são de sua competência e, aquele que deveria executar a função, não tem dela conhecimento.

A segunda situação refere-se à ingerência das relações pessoais na administração. Em 21 de fevereiro de 1883, o diretor da Escola Normal de São Paulo, Paulo Bourroul, informa ao Presidente da Província, Conselheiro Francisco do Carvalho Soares Brandão, sobre três caixões de mercadorias destinadas à Escola Normal e embarcados no vapor francês Sully ${ }^{800}$. O que se pontua não é o fato do diretor Paulo Bourroul ter acionado o presidente da província, pois no caso dos materiais escolares importados, era necessária a autorização do presidente para pagamento, pelo tesouro provincial, da despesa. Agora o que chama a atenção é a desconsideração da estrutura hierárquica administrativa, pelo diretor, cujas relações sociais suplantam a hierarquia estabelecida na lei. A mediação deveria ser feita pelo Diretor Geral da Instrução Pública.

No Relatório sobre o estado e necessidade da Instrução Pública da Província de São Paulo apresentado ao presidente da Província, no ano de 1884, pelo inspetor geral Francisco Aurélio de Souza Carvalho, consta a relação dos professores públicos das cadeiras primárias que foram autorizados a comprar móveis e utensílios conforme a verba no corrente ano.

Ao invés da compra dos móveis e objetos escolares ser realizada por órgão ou funcionário público competente, tal autorização é concedida ao professor, como se lê no Relatório sobre o estado e necessidade da Instrução Pública da Província de São Paulo apresentado ao presidente da Província no ano de 1884 pelo inspetor geral Francisco Aurélio de Souza Carvalho.

\footnotetext{
${ }^{799}$ APESP. (Série Manuscrito - Escola Normal de São Paulo; 1849-1855; 1886-1989/Ordem 5131 Grupo Gestão Financeira; Série - Propostas orçamentárias).

${ }^{800}$ APESP. (Série Manuscrito - Escola Normal de São Paulo; 1849-1855; 1886-1989/

Ordem - 5131 Grupo Gestão Financeira; Série - Propostas orçamentárias).
} 
Na página 72 do Relatório registra-se a lista e quantidade dos autorizados: 12 professores de escolas do sexo masculino e 8 professoras de escolas do sexo feminino. A página 71 traz a relação dos professores públicos das cadeiras primárias que foram providas de móveis e utensis no ano de 1884, pela verba do exercício de 1883 e 1884 . Foram 23 escolas do sexo masculino e 12 escolas do sexo feminino. $\mathrm{O}$ documento traz uma relação das escolas públicas de primeiras letras para o sexo masculino (638) e para o sexo feminino (383) permitindo inferir que parte significativa delas sofria com a ausência de uma política mais definida de gestão e de um órgão operacional que efetuasse o controle e a distribuição do mobiliário atendendo de igual modo às escolas.

A concessão de autorização às professores e aos professores para compra dos móveis, registrada nos últimos anos do Império (1883 e 1884), é uma prática corrente descrita no Livro de Moveis e Utensis (Distribuição de 1854 a 1872) ${ }^{801}$.

Em período anterior ao estudado nesta pesquisa, o Livro contém registro do mobiliário de diversas escolas da Província de São Paulo, o valor de cada item e o modo como chegaram aos estabelecimentos de ensino. O livro servia para “n'elle se lançarem os utensis, e as quantias para a compra dos mesmos, e dos moveis que foram fornecidos aos estabelecimentos d'Instrução Pública desta Província" ${ }^{\text {802 }}$. O interesse do Estado na escola se evidencia na ampliação e diversificação do material que pode ser observada nos registros do Livro, feitos a partir de 1870.

No entanto, o mobiliário continua restringindo-se a 1 estrado, 1 cadeira e 1 mesa para professor e bancos e bancas para os alunos. De um lado, essa poderia ser a mobília considerada, pela administração pública, necessária e suficiente às aulas avulsas de primeiras letras, já que "o professor era a escola, ou aula como se dizia, então" outro, os modos de aquisição da mobília demonstram a ausência de uma maior sistematização interna da escola, mas também ausência de uma sistematização externa dos órgãos administrativos na distribuição do material e do mobiliário escolar.

No verso da primeira página do Livro registra-se a importância entregue à professora Maria Francisca da Conceição Barbosa (51\$000) e ao professor Manuel Dias da Silva $(44 \$ 600)$ para compra de móveis. Essa situação pode ser observada até os anos

\footnotetext{
${ }^{801}$ Arquivo Público do Estado de São Paulo. Secretária da Instrução Pública de São Paulo. Ordem 1124 Livro de Móveis e Utensis (Distribuição de 1854 a 1872).

${ }^{802}$ Arquivo Público do Estado de São Paulo. Ordem 1124 - Livro de Móveis e Utensis. Termo de Abertura.

803 REIS FILHO, Casimiro dos. A Educação e a ilusão liberal. São Paulo: Cortez, Autores Associados, 1981. p.114.
} 
de 1868 e 1869, mas também há compras que são feitas pelos Inspetores do Distrito, como se nota nas páginas 2, 3 (verso), 4 (verso), 5, 5 (verso), $7^{804}$.

Nesse momento, o investimento, quando existia, parecia obedecer ao critério do “mínimo necessário". A professora ou o professor se responsabilizavam pela compra do material e mobiliário escolar, quando não com o dinheiro da Província, com o seu próprio.

Em torno do ano de 1870, ou seja, em anos anteriores à aprovação da Lei n. 9 de 22 de março de 1874, o material que chegava à escola, conforme o Livro de Moveis e Utensis, já era mais diversificado e os modos de aquisição, mais formais. Isso significa que o incremento material da escola e uma progressiva complexificação burocrática da instrução pública são anteriores à lei de instrução obrigatória e à Proclamação da República. Embora não se possa negar que ambos os acontecimentos tiveram contribuições importantes tanto para equipar materialmente a escola quanto para maior organização da instrução pública.

No ano de 1869, a escola do Bairro das Almas, como outras, recebeu também utensis: Louzas (27), canetas de latão (27), lápis de pedra (27), traslados cortidos (90), garrafas de tinta (6), tinteiro e areeiro (1), Quadros Históricos (8) e Geográficos (6) da Província. No entanto, não constam mais as importâncias entregues diretamente aos professores, professoras e inspetores. A informação passa a ser: "N'esta data foram entregues ao respectivo professor, n'esta Secretaria os seguintes Utensis" ${ }^{\text {805 }}$. Se o material escolar vai se diversificando, o mobiliário permanece o mesmo, bancos e bancas, mas a forma de adquiri-los torna-se mais complexa.

Quanto à $1^{\mathrm{a}}$ Cadeira de $1^{\mathrm{a}}$ Letras do sexo masculino em Ubatuba registra-se: "Nesta data [1869] officiou-se ao Inspetor do Thezouro solicitando-se expedição de ordem ao Collector d'aquela cidade para pagamento dos móveis abaixo declarados, fornecidos á escola supra” ${ }^{„ 806}$. O mesmo se dá, em 26 de janeiro de 1870, na $1^{\text {a }}$ Cadeira de $1^{\text {as }}$ Letras do sexo feminino de Mogi-Mirim: "Nesta data [26 de janeiro de 1870] officiou-se ao Inspetor do Thezouro solicitando-se expedição de ordem ao Collector da cidade supra para pagar a importancia dos móveis e utensílios fornecidos á esta escola $[\ldots]^{, 807}$.

\footnotetext{
${ }^{804}$ Anexo n.60.

${ }^{805}$ Arquivo Público do Estado de São Paulo. Ordem 1124 - Livro de Móveis e Utensis, p.88.

${ }^{806}$ Idem, p.74.

${ }^{807}$ Idem, p.75.
} 
Quando se refere aos materiais, apenas consta que eles foram "entregues ao professor pela Secretaria", ou seja, a Secretaria da Instrução Pública de São Paulo. Também, não há menção de valor monetário dos objetos. Já quando se trata dos móveis, envia-se um ofício ao Inspetor do Tesouro solicitando expedição de ordem ao Coletor da cidade para pagamento dos móvies ${ }^{808}$. Em quase todas as escolas do Estado os móveis entregues são:

$>6$ bancos de 10 palmos de comprimentos --

$>3$ bancas de 10 palmos de comprimentos e 2 1/2 de largura ----------15\$000

$>1$ meza de 5 palmos em quadra -----------------------------------------20\$000

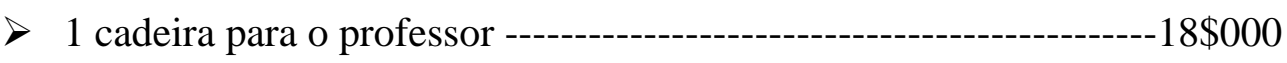

VALOR $=80 \$ 000$

Isso pode indiciar que, enquanto os utensílios já estavam disponíveis na Secretaria, os móveis seriam fabricados de acordo com a demanda. Provavelmente, feitos por um mesmo fabricante na mesma quantidade e mesmo valor para todas as escolas. O pagamento dos móveis era feito pelo Coletor da cidade, depois de autorização dada pelo Inspetor do Tesouro.

Aqui, verifica-se a interação de diferentes órgãos da administração pública para realização de um único serviço - o fornecimento de móveis às escolas. A Secretária de Instrução Pública e o Tesouro Provincial. Sendo o Livro de Móveis e Utensis referente à distribuição de material e mobiliário entre os anos de 1854 a 1872, ele alcança três formas de organização diferentes daquele órgão fazendário. A primeira, da Contadoria Provincial, entre os anos de 1838 e 1859; a segunda, da criação do Tesouro Provincial, em 1859; e a terceira, da reforma do Tesouro em $1868^{809}$.

$\mathrm{Na}$ hierarquia de administração tributária, o Inspetor do Tesouro era o funcionário abaixo do Presidente da Província. Ele deveria dar as ordens para liberação da verba pelo Coletor da cidade. Como uma das Estações Arrecadadoras, a Coletoria era composta por um coletor e um escrivão. "As Coletorias eram as Estações encarregadas da arrecadação da receita comum interna da Província" ${ }^{\Perp 10}$. O pagamento das despesas

\footnotetext{
${ }^{808}$ Idem, p.93.

${ }^{809}$ Acerca da administração tributária e finanças públicas no Império ver Tessitore (1995) e Diniz (2002).

${ }^{810}$ TESSITORE, Viviane. As fontes da riqueza pública: tributos e administração tributária na Província de São Paulo (1832-1892). Faculdade de Filosofia Ciências e Letras. Dissertação de Mestrado, 1995, p.91.
} 
cabia à Tesouraria ${ }^{811}$. Considerando que havia uma única Tesouraria, mas várias Coletorias espalhadas pelo território paulista, é possível supor que, nas regiões mais distantes, a Coletoria acabou assumindo esse papel da Tesouraria.

Na passagem de Província para Estado, São Paulo foi tornando mais complexa e burocrática a organização necessária para dar conta da expansão da Instrução Pública. Durante o regime monárquico, de 1822 a 1889, a Província de São Paulo "era governada por um Presidente e pela Assembleia Provincial" ${ }^{~} 812$ Nesse período, o Livro de Móveis e Utensis e as correspondências da Escola Normal revelam: 1) uma organização pouco especializada do governo para resolver as demandas e problemas do ensino; 2) um envolvimento muito direto do Presidente da Província com as mais diversas questões relativas à Instrução Pública. Reis Filho explicita que era uma "administração extremamente simples e quase sem intermediários" 813 .

Antes da Proclamação da República, na estrutura do Executivo Paulista subordinados ao Presidente da Província, por meio de seus diretores, estavam os vários serviços públicos: Tesouro do Estado, Força Pública, Penitenciária, Hospício de Alienados, Iluminação Pública da capital e de Campinas, Instrução Pública, Escola Normal, Seminário da Glória, Catequese de Índios, Imigração e Serviço Policial. "As dificuldades decorriam da falta de uma linha hierárquica definida, de autoridade, que o patriarcalismo administrativo supria. Em última instância, todos os problemas encontram solução ao nível do chefe supremo do Governo do Estado" ${ }^{\text {„14 }}$.

No caso das escolas de primeiras letras, a informalidade do serviço público se manifesta na autorização e verba concedida aos professores e professoras para compra dos móveis. No caso da Escola Normal, a ausência dos elementos da racionalidade se mostra na relação do diretor da instituição com o Presidente da Província.

As correspondências da Escola Normal da Praça da República indiciam que, mesmo após a Proclamação da República, persistia o hábito das solicitações diretas ao Presidente da Província, sem o recurso aos órgãos intermediários. Em 1892, por exemplo, José Sá Benevides, vice-diretor daquela instituição, pede autorização ao presidente do Estado, José Alves de Cerqueira Cezar, para aquisição de mesas e bancos, necessários à Escola Modelo Anexa.

\footnotetext{
811 TESSITORE, 1995.

${ }^{812}$ REIS FILHO, 1981, p. 16.

${ }^{813}$ REIS FILHO, 1981, p. 19.

${ }^{814}$ Idem, Ibidem.
} 
Isso indica que, mesmo com a complexificação e racionalização decorrentes das mudanças legislativas e administrativas do ano de 1892, o costume (uma lei não escrita) imperava. Mais do que um uso, recorrer diretamente ao chefe maior do executivo constituía um meio obrigatório, um "direito consuetudinário", uma norma que se sobrepõe às normas legais até que estas sejam incorporadas ou não.

$\mathrm{Na}$ administração pública, há práticas que se sedimentam de forma que as alterações legais não significam, pelo menos num primeiro instante, mudanças de procedimentos. Em outras palavras, a força do patriarcalismo se impõe de tal forma que, embora os republicanos tenham assumido a administração pública, imprimindo-lhe uma estrutura racional-legal, a prática de recorrer ao chefe maior do executivo como solução dos problemas, persistia.

É somente a progressiva institucionalização, burocratização e racionalização da administração pública que vai reduzindo o peso da influência, dos pactos políticos e das relações pessoais e afetivas na estrutura e funcionamento do serviço público.

Reis Filho detalha as relações administrativas que afetam a estrutura escolar. No entanto, um estudo das fontes aqui levantadas, indicia que a própria estrutura escolar também vai afetando as relações administrativas já que com a expansão da escola tornase inviável que todas as decisões quanto à aquisição de mobiliário, material escolar, reforma, criação de escolas, contratação, afastamento, demissão e aposentadoria de professor, de todas as escolas de São Paulo passem diretamente pelo chefe maior do executivo. Se, por um lado, a "nova organização governamental correspondia efetivamente ao crescimento socioeconômico desse período, exigindo a sistematização dos órgãos administrativos" ${ }^{\text {815; }}$; por outro, a dinâmica escolar também exigiu mudanças na estrutura administrativa do governo para atender as demandas em prol da expansão e uniformização da escola de massa.

Exemplo disso é o almoxarifado, criado como uma seção da Diretoria Geral da Instrução Pública em 1895 pela Lei n. 374, de 1895, art. $8^{\circ}$. O corpo de funcionários era composto por um chefe de seção, um amanuense e um servente, com as funções de arrecadação, guarda e remessa do material escolar.

A lei é de 3 de setembro, mesmo dia em o Diretor Geral da Instrução Pública, Dr. Arthur César Guimarães, solicita ao Secretário do Interior, Alfredo Pujol, a organização do almoxarifado. Em 10 de setembro, Alfredo Pujol informa que "já se

${ }^{815}$ REIS FILHO, op. cit. p. 21. 
providenciou sobre a nomeação de um funcionário em comissão" ${ }^{816}$ para a Repartição da Instrução Pública ${ }^{817}$.

Antes da criação do Almoxarifado específico da Instrução Pública, os materiais e mobiliário para as escolas públicas paulista poderiam ser guardados no depósito da Escola Normal da Praça da República, no Almoxarifado da Secretária do Interior e até no Tesouro Provincial. Ou seja, não havia um almoxarifado específico voltado somente às necessidades da escola, da Instrução Pública.

Mesmo nos primeiros anos do regime republicano tais espaços pareciam ser suficientes para depositar os objetos pertencentes às escolas. O aumento do número de escolas e as constantes reivindicações de materiais tornou a situação insustentável.

O Decreto n. 144A, de 30 de dezembro de 1892, como já mostrado, criou a Secretária Geral da Instrução Pública com três seções. A Lei n.374, de 1895 alterou a organização da Secretaria com a criação da $4^{\mathrm{a}}$ seção, "incumbida do almoxarifado da própria Secretaria" ${ }^{\text {818 }}$.

Depois de organizado, o almoxarifado tinha, ainda, um funcionário em comissão. Dois meses após a publicação da Lei n.374, em 14 de novembro de 1895, Alfredo Pujol notifica ao Diretor Geral da Instrução Pública o provimento dos lugares da seção criada, a $4^{\mathrm{a}}$ seção $^{819}$.

A Secretaria Geral da Instrução Pública já possuía outros funcionários que poderiam executar o serviço da $4^{\mathrm{a}}$ seção. Atuavam na Secretaria, além do Diretor Geral da Instrução Pública, um chefe de cada uma das três seções, um oficial maior, três primeiros oficiais, três segundos oficiais, seis amanuenses, um arquivista, um ajudante do arquivista, um porteiro, um contínuo e um servente.

O Decreto n.144A não especificou as atribuições dos funcionários da repartição. Segundo Paulo, tais atribuições foram trazidas, de modo geral, pelo Decreto n.58, de 2 de maio de 1892, o qual deu Regulamento para as Secretarias do Interior, da Justiça e da Agricultura, Commercio e Obras Publicas ${ }^{820}$. A leitura das funções do pessoal das secretarias não permite identificar quem seria responsável pela guarda do material. Daí

\footnotetext{
${ }^{816}$ Fonte: Série Manuscritos. Instrução Pública. Ofícios do Governo ao Inspetor Geral. Anos 1894-1896. Caixa 9/ Ordem - 4992. Ofício n. 364.

${ }^{817}$ Anexo n.61.

${ }^{818}$ PAULO, 2007, p.57.

819 Anexo n.62.

${ }^{820}$ Marco Paulo (2007, p.59), em sua tese de doutorado, traz um quadro detalhado das atribuições, número e indicação dos funcionários da Secretaria Geral da Instrução Pública.
} 
a urgência da criação de novos cargos na $4^{\mathrm{a}}$ seção para responsabilizar-se pelos serviços do almoxarifado.

A análise dos elementos formais de um ofício anterior à criação do Almoxarifado, em 3 de setembro de 1895, ajuda a perceber os órgãos da Instrução Pública em funcionamento. Antes, porém, é preciso considerar a ressalva feita por Paulo quando esclarece que "nos documentos do período, é comum denominar a Secretaria Geral de Instrução Pública de Diretoria" ${ }^{\natural 21}$.

Quadro 6 - Ofício do diretor geral em 1895

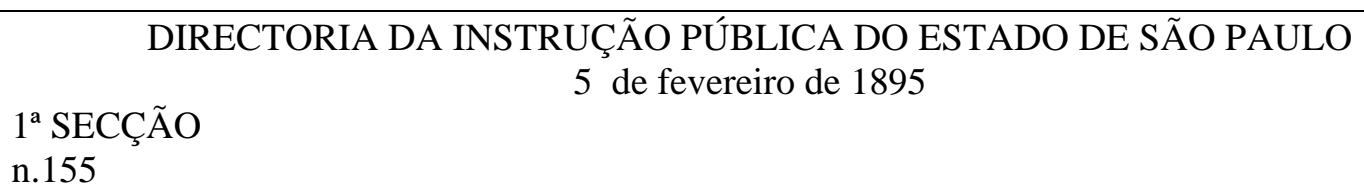

Solicito de vossa parte as providencias necessárias para atender a reclamação que me foi feita pelo inspetor do $2^{\circ}$ distrito escolar, por parte de D. Isabel de Serpa e Souza, professora da escola do $11^{\circ}$ distrito desta capital, no sentido de serem fornecidos para uso dela, os livros e objetos constantes na relação junta.

Acredito que, dentre eles, alguns possa fornecer o almoxarifado que por falta de espaço em seus aposentes ainda não pode definir o conteúdo de 16 caixões remetidos da Escola Normal e em seu depósito.

Ao ilustre cidadão Dr. Cesário Motta Junior M.D. Secretário de Estado dos Negócios do Interior O Diretor Geral - Arthur Guimarães Ordem 4492

Fonte: APESP - Instrução Pública - Ofícios do Governo ao Inspetor Geral. Anos = 1894-1896.

Trata-se de um ofício da Diretoria, ou seja, da Secretaria Geral de Instrução Pública, remetido pelo Diretor Geral da Instrução Pública, Arthur Cesar Guimarães, ao Secretário de Estado dos Negócios do Interior, Cesário Motta Junior. É um ofício de 5 de fevereiro, portanto, anterior à organização do almoxarifado, o que é atestado pelo último parágrafo. O almoxarifado da Secretária do Interior não tinha "espaço em seus aposentos" e, por isso, o material da instrução pública passava, ainda, por uma guarda temporária no depósito da Escola Normal da Praça da República.

$\mathrm{O}$ assunto do ofício interessa à $1^{\mathrm{a}}$ seção, ou seja, às escolas preliminares e complementartes, conforme Decreto n.144A, de 30 de dezembro de 1892 e Lei n.88, de 8 de setembro de 1892. A hierarquia é outro aspecto que chama a atenção. Interessa

${ }^{821}$ PAULO, 2007, p.57. 
saber como os móveis e objetos chegariam aos estabelecimentos de ensino a partir desta estrutura hierárquica.

Uma professora primária passa ao inspetor do distrito uma relação de objetos necessários ao uso da escola. Este transmite o pedido ao Diretor Geral da Instrução Pública que, por sua vez, solicita as providências para satisfação do pedido ao Secretário de Estado dos Negócios do Interior. O objeto da solicitação encontraria solução não mais no presidente do Estado, mas em funcionário a ele subordinado, o Secretário do Interior.

Toda essa burocracia afastava a interposição das relações pessoais nos negócios públicos. Entretanto, quando a morosidade do serviço público exacerbava, reaparecia a “tentação" de recorrer aos antigos métodos. É o que indicia o ofício a seguir.

Quadro 7 - Ofício do inspetor do distrito em 1895

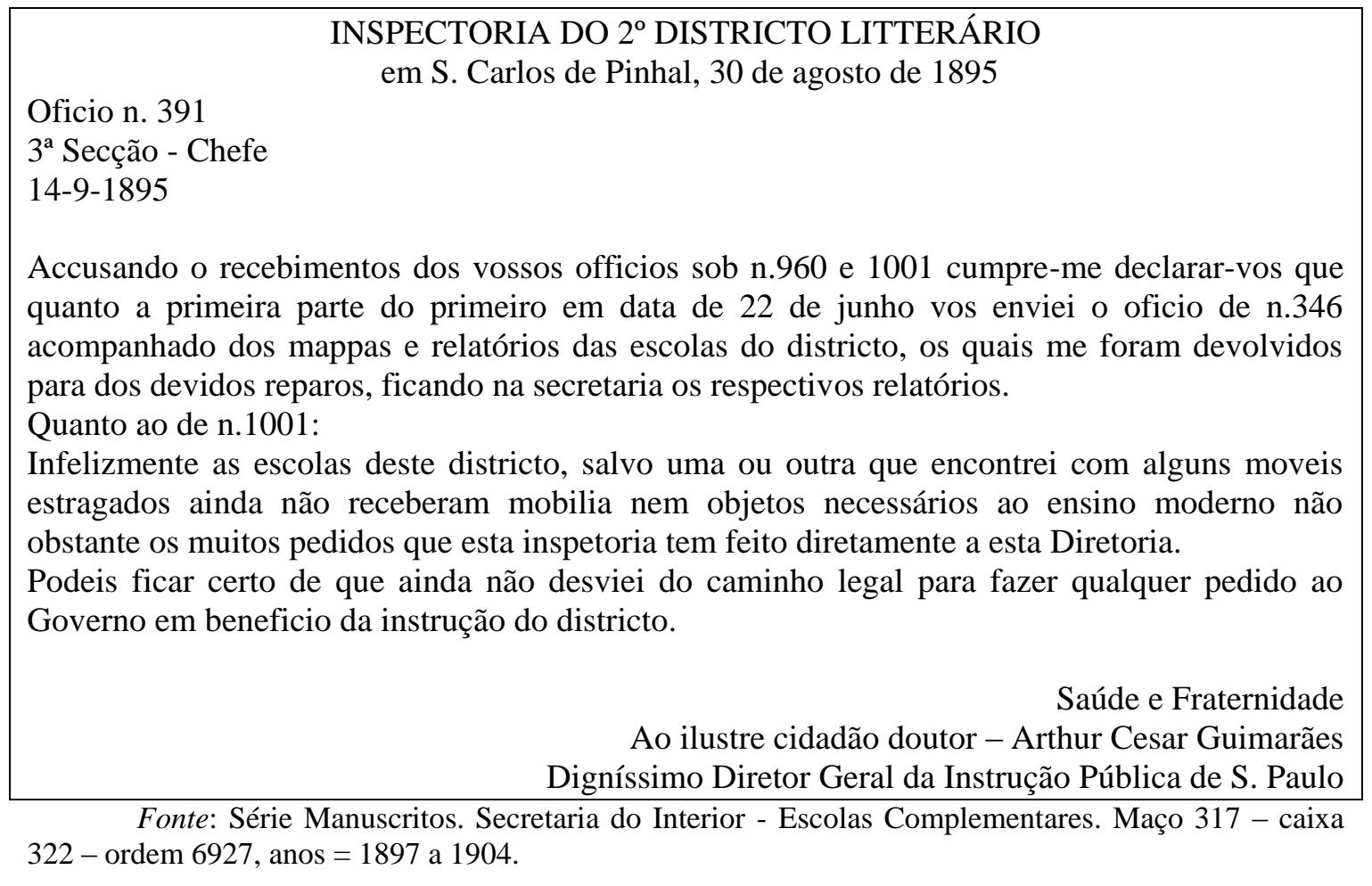

Se o ofício n.155 é endereçado à Diretoria ao Secretário do Interior, o de n.391, é do Inspetor do Distrito à Diretoria. A expressão do último parágrafo, "desviei do caminho legal", tratava-se de uma ameaça do inspetor, pois diante dos "muitos pedidos" feitos “diretamente a esta Diretoria" e não atendidos, ele "ainda" não havia recorrido ao Governo, ou seja, ao Presidente do Estado. Atropelar a estrutura hierárquica e 
burocrática, "importunar" o Presidente com um serviço que não era sua função precípua, atestaria a ineficiência dos funcionários competentes, o Secretário do Interior e o Diretor Geral.

Há um conjunto de ofícios dos inspetores literários entre agosto e setembro de $1895^{822}$, todos tratando de material e móveis escolares ${ }^{823}$. Provavelmente se tratava de uma resposta à consulta feita pelo Diretor Geral da Instrução Pública. O ofício n.391 é uma resposta a outros ofícios endereçados pelo chefe da $3^{\mathrm{a}}$ seção da Secretaria Geral da Instrução Pública, responsável pelo serviço do Conselho Superior, do ensino privado e da estatística escolar.

Foi, possivelmente, no interesse da estatística escolar que se deu a troca destes ofícios. Tanto porque foram endereçados à $3^{\mathrm{a}}$ seção, como por causa dos mapas e relatórios solicitados ao Diretor Geral. Os ofícios indiciam as primeiras tentativas do governo paulista de fazer um levantamento mais sistemático das condições físicas, materiais e mobiliárias das escolas. Não havia um levantamento sistemático de dados para se tomar conhecimento das escolas equipadas ou não com mobiliário. Não era o poder público que ia até a escola. A escola precisava reclamar suas necessidades básicas.

O uso da estatística para administração do ensino público é outro sinal da racionalização e burocratização nos anos iniciais da República. Entretanto, o desvio do "caminho legal” é uma ameaça sempre presente na administração pública.

No âmbito da estrutura administrativa, a organização do almoxarifado é fértil para pensar a expansão do ensino, pois o aumento do número de escolas pressupunha, como corolário, um aumento do material e mobiliário. Portanto, exigiria espaço e pessoal para as operações de guarda, aquisição e distribuição.

A Secretaria dos Negócios do Interior acumulava a responsabilidade por um conjunto de repartições e serviços públicos. Seu almoxarifado deveria comportar os materiais necessários a todos eles. Em 1906, a Lei n. 1.059 estabeleceu:

Artigo 23. - Ficam desannexados da Secretaria dos Negocios do Interior os serviços relativos á acquisição de material para as escholas e grupos escholares do Estado e objectos de expediente da mesma Secretaria e repartições que lhe são subordinadas.

$\S 1 .^{\circ}$ - Para os referidos fins, é creado o Almoxarifado da Secretaria do Interior.

${ }^{822}$ Serie manuscritos. Secretaria do Interior. Escolas complementares. Maço 317 - caixa 322 - Ordem 6927. Anos 1897 a 1904. A documentação da lata é data de 1897 a 1904, todavia, há documentos anteriores a 1897, como os ofícios destacados.

${ }^{823}$ Anexos n.63-65. 
$\S 2 .^{\circ}$ - A nova repartição terá o pessoal composto de um chefe com os vencimentos de 8:400\$000; um ajudante com 3:600\$000; dois auxiliares a 2:400\$000 e dois serventes a 1:080\$000;

$\S 3 .^{\circ}$ - O Governo, no regulamento que expedir, determinará os serviços que passam a ser feitos por esta repartição ${ }^{824}$.

Mesmo tendo sido criado um almoxarifado específico para a Instrução Pública em 1895, a aquisição do material ainda permanecia sobre a responsabilidade do Almoxarifado da Secretária do Interior. A regulamentação veio somente dois anos após com o Decreto n.1.596, de 29 de abril de 1908.

Artigo 1. $0^{\circ}$ - O Almoxarifado da Secretaria do Interior, immediatamente subordinado ao secretario de Estado dos Negocios do Interior, terá a seu cargo os serviços relativos : a) a acquisição, arrecadação e distribuição de todo o material de ensino destinado ás escholas isoladas, grupos escholares e outros estabelecimentos de ensino do Estado, comprehendendo livros didacticos, de escripturação e outros, mappas e mais impressos escholares, moveis e utensílios e quaesquer artigos e objectos destinados ás ditas escholas e estabelecimentos; b) á acquisição, arrecadação e distribuição dos artigos de expediente e de todos e quaesquer objectos necessarios á Secretaria do Interior e a todas as repartições e estabelecimentos a ella subordinados, quer os que devam ser suppridos em virtude de contractos, quer os que devam ser adquiridos em virtude de verbas orçamentarias; c) á fiscalização de todos os fornecimentos feitos, em virtude de contractos, tornando-se imprescindível que as respectivas contas sejam conferidas e visadas pelo chefe do Almoxarifado, previamente, afim de poder ser requisitado o pagamento. Artigo $2{ }^{\circ}$ - A acquisição de material e objectos para abastimento do Almoxarifado, será feita por meio de contractos celebrados mediante concorrencia publica.

$\S 1 .^{\circ}$ - A concorrencia far-se-á pelos moldes estabelecidos pela Secretaria do Interior, e haverá uma commissâo designada pelo secretario do Interior, auxiliada por peritos, tantos quantos sejam necessarios para o exame, verificação e escolha do material.

$\S 2 .^{\circ}$ - Por deliberação do Secretario do Interior, a acquisição de determinados artigos e de certa especialidade de material poderá ser feita por encommenda ou ajuste directo do Almoxarifado.

A longa citação esclarece as funções do almoxarifado da Secretaria do Interior e estabelece os critérios para aquisição de material e objetos. Os dois elementos são indicativos da modernização, racionalização e burocratização do serviço público. $O$ almoxarifado tinha como função primordial adquirir, arrecadar e distribuir os artigos

${ }^{824}$ São Paulo. Lei n. 1.059, de 28 de dezembro de 1906, art. 23. 
necessários à Secretaria do Interior e a todas as suas repartições. A aquisição deveria ser "feita por meio de contractos celebrados mediante concorrência publica",825.

A localização destes contratos, lacuna nesta pesquisa, seria de suma relevância não só para identificar as empresas que comerciavam com a Instrução Pública, mas também os gastos e o investimento do Estado na educação.

Se existe uma diferença entre a lei de obrigatoriedade escolar e sua efetivação pela administração pública é porque houve antes outra diferença - entre o discurso sobre a importância da educação escolar para a sociedade e o investimento nela feito. Se a instrução pública era o meio, por excelência, de redenção da pátria, quanto o governo paulista investiu neste serviço público, no período aqui considerado?

A centralização política e administrativa tão criticada pelos republicanos e liberais durante o Império, apresentou-se como um entrave para a expansão do ensino em São Paulo, sobretudo após os seis primeiros anos de renovação educação que se seguiram à Proclamação da República.

Em alguma medida é possível se dizer da República, no âmbito da educação paulista, o que o historiador Alphonse Sulard escreveu acerca da França da Terceira República: "Quão bela era a República no tempo do Império!"826.

Não pretendo dizer com isso que após a Proclamação da República não houve nenhuma contribuição significativa para a Instrução Pública. O regime republicano trouxe mudanças, sobretudo na legislação, mas para além da legislação, há permanências na condução dos negócios públicos.

Conforme se mostrou anteriormente, durante o Império e, ainda, nos anos iniciais da República, não havia uma política pública de distribuição do mobiliário escolar. A ausência de órgãos que se responsabilizassem, de forma sistemática, pela aquisição e distribuição dos objetos necessários à escola, tornava moroso e desigual o suprimento material das instituições de ensino.

Embora, no plano legal, as reformas da instrução pública nos anos iniciais do regime republicano tornaram mais complexa e burocrática a organização da administração pública e escolar, por vezes as relações pessoais ainda se sobrepunham à hierarquia.

\footnotetext{
${ }^{825}$ Decreto n.1.596, de 29 de abril de 1908 , art.2 ${ }^{\circ}$.

${ }^{826}$ LOVE, Joseph. A locomotiva: São Paulo na federação brasileira (1889-1937). Trad. Vera Alice Cardoso da Silva. Rio de Janeiro: Paz e Terra, 1982, p.174.
} 
Vai desaparecendo, já nos primeiros anos republicanos, a prática de entrega de verbas diretamente aos professores para aquisição de móveis. A criação do almoxarifado da instrução pública, em 1895, é um importante passo na modernização do serviço de aquisição, arrecadação e distribuição do material e mobiliário escolar.

Entretanto, se algumas dificuldades administrativas persistem na passagem do Império para República, não é diferente no que concerne às questões econômicas. O investimento na instrução das massas é, ainda hoje, um desafio para o poder público.

\subsection{O investimento do governo na Instrução Pública}

Tratar do investimento do governo na educação pública exige pensar, simultaneamente, a estruturação da máquina administrativa para ampliação do serviço da instrução pública, e, a partir dos orçamentos (história econômica), o destino da receita, os gastos com a instrução pública.

De acordo com o Ato Adcional de 1834, "a receita e a despesa da Província seria fixada em orçamento apresentado pelo Presidente [da Província], e a dos Municípios em orçamento apresentado pelas respecitvas Câmaras, ambos sujeitos à aprovação pela Assembléia Provincial" ${ }^{\prime 827}$.

O investimento na instrução pública, a divisão de competências entre os poderes locais e nacionais eram e são questões cruciais. Nas palavras de Tavares Bastos, "não há sistema de instrução eficaz sem dispêndio de muito dinheiro" ${ }^{\wedge 28}$. Devido à precariedade dos rendimentos das províncias, ele defende que a "taxa escolar forneceria um valioso contingente ao orçamento da instrução" 829 .

Embora, segundo ele, fosse um assunto impopular, "o imposto que propomos, estreitamente se liga a um novo programa do ensino público, impraticável com os estreitos recursos atuais". O que Tavares Bastos chamou de "novo programa do ensino público" consistia na "construção de casas de escolas próprias [...] fornecimento de mobílias, utensílios, modelos e livros escolares, acomodados aos métodos; a formação de biblioteca populares" ${ }^{\prime 330}$, dentre outros.

\footnotetext{
${ }^{827}$ TESSITORE, Viviane. Fontes da riqueza pública: tributos e administração tributária na província de São Paulo (1832-1892). Dissertação (Mestrado), USP. São Paulo, 1995, p.65.

${ }^{828}$ Tavares Bastos, op. cit., p.151.

${ }^{829}$ Idem, p. 152.

${ }^{830}$ Idem, p.555.
} 
A mesma indagação posta em relação à organização administrativa cabe para pensar as questões econômicas. Uma das mudanças ocorridas com a República foi o aumento da receita do Estado. Segundo Edgar Carone, "o novo sistema constitucional de 1891, dando aos estados o direito de usufruir o valor do imposto de exportação, faz crescer fantasticamente a sua renda [...] permitindo a aplicação de recursos em uma série de atividades públicas" ${ }^{831}$.

A indagação é: na passagem do Império para a República, o aumento da receita paulista redunda em aumento do investimento na instrução pública? Para abordar este tema lançarei mão dos orçamentos e dos Relatórios dos Presidentes da Província e do Estado de São Paulo.

A análise da série de orçamentos coloca em evidência os gastos do governo com a instrução pública nos últimos anos do Império e nos primeiros anos da República. Mostra, também, quanta verba foi destinada para compra de móveis e materiais, ou seja, para criação das condições físicas da escola.

É preciso ressaltar que os valores estabelecidos nos orçamentos serão considerados mais pelo que podem revelar acerca daquilo que o governo compreendia como suficiente para a instrução pública e menos pela exatidão de tais valores.

Serão analisados os orçamentos a partir de 1859, pois nesse ano, pela Lei n. 27, de 11 de maio de 1859, houve uma "separação definitiva entre as Tesourarias geral e provincial $[\ldots]^{p, 832}$. A Contadoria Provincial foi transformada em Thesouro Provincial e "passava a integrar um órgão propriamente provincial, independente da Repartição geral, com estrutura e funcionários próprios ${ }^{" 833}$.

${ }^{831}$ CARONE, Edgar. A evolução industrial de São Paulo (1889-1930). São Paulo: Editora SENAC São Paulo, 2001, p.41.

${ }_{832}^{832}$ TESSITORE, op. cit., p.86.

${ }^{833}$ Idem, ibidem. 
Quadro 8 - Orçamentos para Instrução Pública

\begin{tabular}{|c|c|c|}
\hline ANO & MÓVEIS E UTENSIS & INSTRUÇÃO PÚBLICA \\
\hline $\begin{array}{l}\text { 1. }{ }^{\circ} \text { de Julho de } 1859 \text { a } 30 \text { de } \\
\text { Junho de } 1860\end{array}$ & Não consta & $112.394 \$ 000$ \\
\hline \multicolumn{3}{|l|}{1860 - Não localizada } \\
\hline $\begin{array}{l}\text { 1. }{ }^{\circ} \text { de Julho de } 1861 \text { a } 30 \text { de } \\
\text { Junho de } 1862\end{array}$ & $2.000 \$ 000^{834}$ & $110.997 \$ 010$ \\
\hline $\begin{array}{l}\text { 1. }{ }^{\circ} \text { de Julho de } 1862 \text { a } 30 \text { de } \\
\text { Junho de } 1863\end{array}$ & Não consta & $155.000 \$ 000$ \\
\hline $\begin{array}{l}\text { 1. }{ }^{\circ} \text { de Julho de } 1863 \text { a } 30 \text { de } \\
\text { Junho de } 1864\end{array}$ & $2.000 \$ 000$ & $169.921 \$ 030$ \\
\hline $\begin{array}{l}\text { 1. }{ }^{\circ} \text { de Julho de } 1864 \text { a } 30 \text { de } \\
\text { Junho de } 1865\end{array}$ & $2.000 \$ 000$ & $199.000 \$ 000$ \\
\hline $\begin{array}{l}\text { 1. }{ }^{\circ} \text { de Julho de } 1865 \text { a } 30 \text { de } \\
\text { Junho de } 1866\end{array}$ & $2.000 \$ 000$ & $172.573 \$ 330$ \\
\hline $\begin{array}{l}\text { 1. }{ }^{\circ} \text { de Julho de } 1866 \text { a } 30 \text { de } \\
\text { Junho de } 1867\end{array}$ & $2.000 \$ 000$ & $155.634 \$ 000$ \\
\hline $\begin{array}{l}\text { 1. }{ }^{\circ} \text { de Julho de } 1867 \text { a } 30 \text { de } \\
\text { Junho de } 1868\end{array}$ & $2.000 \$ 000$ & $146.924 \$ 000$ \\
\hline $\begin{array}{l}\text { 1. }{ }^{\circ} \text { de Julho de } 1868 \text { a } 30 \text { de } \\
\text { Junho de } 1869\end{array}$ & $2.000 \$ 000$ & $166.645 \$ 000$ \\
\hline $\begin{array}{l}\text { 1. }{ }^{\circ} \text { de Julho de } 1869 \text { a } 30 \text { de } \\
\text { Junho de } 1870\end{array}$ & $2.000 \$ 000$ & $191.984 \$ 000$ \\
\hline $\begin{array}{l}1^{\circ}{ }^{\circ} \text { de Julho de } 1870 \text { a } 30 \text { do } \\
\text { Junho de } 1871\end{array}$ & 4:000\$000 & $258: 082 \$ 660$ \\
\hline $\begin{array}{l}1^{\circ} \text { de Julho de } 1871 \text { a } 30 \text { de } \\
\text { Junho de } 1872\end{array}$ & 4:000\$000 & $272: 438 \$ 660$ \\
\hline $\begin{array}{l}1^{\circ} \text { de Julho de } 1872 \text { a } 30 \text { de } \\
\text { Junho de } 1873\end{array}$ & $4: 000 \$ 000^{835}$ & $345: 612 \$ 660$ \\
\hline $\begin{array}{l}1^{\circ} \text { de Julho de } 1873 \text { a } 30 \text { de } \\
\text { Junho de } 1874\end{array}$ & 4:000\$000 & $380: 199 \$ 330$ \\
\hline $\begin{array}{l}1^{\circ} \text { de Julho de } 1874 \text { a } 30 \text { de } \\
\text { Junho de } 1875\end{array}$ & 4:000\$000 & $397: 979 \$ 330$ \\
\hline $\begin{array}{l}1^{\circ} \text { de Julho de } 1875 \text { a } 30 \text { de } \\
\text { Junho de } 1876\end{array}$ & 4:000\$000 & $404: 355 \$ 990$ \\
\hline $\begin{array}{l}1^{\circ} \text { de Julho de } 1876 \text { a } 30 \text { do } \\
\text { Junho de } 1877\end{array}$ & 4:000\$000 & Não informado \\
\hline $\begin{array}{l}1^{\circ} \text { de Julho de } 1877 \text { a } 30 \text { de } \\
\text { Junho de } 1878\end{array}$ & 4:000\$000 & Não informado \\
\hline \multicolumn{3}{|l|}{ 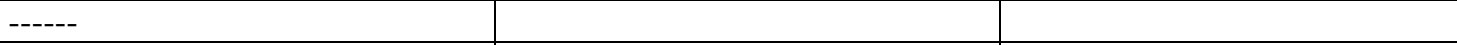 } \\
\hline \multicolumn{3}{|l|}{----- } \\
\hline $\begin{array}{l}\text { 1. }^{\circ} \text { de Julho de } 1880 \text { a } 30 \text { de } \\
\text { Junho de } 1881\end{array}$ & $5: 000 \$ 000$ & $532: 816 \$ 580$ \\
\hline \multicolumn{3}{|l|}{----} \\
\hline $\begin{array}{l}\text { 1. }{ }^{\circ} \text { de Julho de } 1882 \text { a } 30 \text { de } \\
\text { Junho de } 1883\end{array}$ & $\begin{array}{l}\text { 25:000\$000 (Moveis, utensis e } \\
\text { aparelhos } \\
\text { necessarios para o ensino de } \\
\text { chimica e physica na Escóla } \\
\text { Normal) }\end{array}$ & $500: 460 \$ 000$ \\
\hline $\begin{array}{l}1^{\circ} \text { de Julho de } 1883 \text { a } 30 \text { de } \\
\text { Junho de } 1884\end{array}$ & $\begin{array}{l}\text { 20:000 } \$ 000 \text { (Moveis, utensilios e } \\
\text { livros para as escholas) }\end{array}$ & $455: 640 \$ 000$ \\
\hline $\begin{array}{l}1^{\circ} \text { de Julho de } 1884 \text { a } 30 \text { de } \\
\text { Junho de } 1885\end{array}$ & $\begin{array}{l}\text { 20:000\$000 (Moveis, utensis e } \\
\text { livros para as escholas públicas) }\end{array}$ & $600: 000 \$ 000$ \\
\hline
\end{tabular}

\footnotetext{
${ }_{834}^{834}$ Utensis para as aulas.

${ }^{835}$ Primeira vez que aparece "móveis e utensílios" no orçamento provincial.
} 


\begin{tabular}{|c|c|c|}
\hline ANO & MÓVEIS E UTENSIS & INSTRUÇÃO PÚBLICA \\
\hline $\begin{array}{l}\text { 1. }{ }^{\circ} \text { de Julho de } 1885 \text { a } 30 \text { de } \\
\text { Junho de } 1886\end{array}$ & $\begin{array}{l}\text { 20:000 } \$ 000 \text { (Moveis, utensis e } \\
\text { livros para as escholas) }\end{array}$ & $605: 830 \$ 000$ \\
\hline $\begin{array}{l}1^{\circ} \text { de Julho de } 1886 \text { a } 30 \text { de } \\
\text { Junho de } 1887\end{array}$ & $\begin{array}{l}\text { 20:000\$000 (Moveis, utensis e } \\
\text { livros para as escholas) }\end{array}$ & $830: 490 \$ 040$ \\
\hline $\begin{array}{l}1^{\circ} \text { de Julho de } 1887 \text { a } 30 \text { de Ju- } \\
\text { nho de } 1888\end{array}$ & $\begin{array}{l}\text { 10:000 } \$ 000 \text { (Moveis, utensis e } \\
\text { livros para as escholas) }\end{array}$ & $780: 000 \$ 000$ \\
\hline $\begin{array}{l}\text { 1 de Julho de } 1888 \text { a } 30 \text { de Junho } \\
\text { de } 1889\end{array}$ & Não orçado & $918: 420 \$ 000$ \\
\hline $\begin{array}{l}1 \text { de Julho de } 1889 \text { a } 30 \text { de Junho } \\
\text { de } 1890\end{array}$ & $\begin{array}{l}\text { 3:000\$000 (Compra de livros e } \\
\text { objectos necessarios ás aulas ) }\end{array}$ & $918: 420 \$ 000$ \\
\hline $\begin{array}{l}\text { 1. }{ }^{\circ} \text { de Julho de } 1890 \text { a } 30 \text { de } \\
\text { Junho de } 1891\end{array}$ & $\begin{array}{l}\text { 6:000 } \$ 000 \text { (Mobilia, livros e } \\
\text { objectos manuaes ás aulas) }\end{array}$ & $1.343: 844 \$ 800$ \\
\hline $\begin{array}{l}\text { 1. }{ }^{\circ} \text { de Janeiro a } 31 \text { de Dezembro } \\
\text { de } 1892\end{array}$ & Não orçado & $2.265: 680 \$ 000$ \\
\hline $\begin{array}{l}\text { 1. }{ }^{\circ} \text { de Janeiro a } 31 \text { de Dezembro } \\
\text { de } 1893\end{array}$ & Não orçado & $3.924: 340 \$ 000$ \\
\hline $\begin{array}{l}1 .^{\circ} \text { de Janeiro a } 31 \text { de Dezembro } \\
\text { de } 1894^{836}\end{array}$ & $\begin{array}{l}\text { 77:400 } \$ 000 \text { (Expediente, compra } \\
\text { de móveis, aluguel de prédios e } \\
\text { outras despesas). }\end{array}$ & $3.815: 300 \$ 000$ \\
\hline $\begin{array}{l}\text { 1. }{ }^{\circ} \text { do Janeiro a } 31 \text { de Dezembro } \\
\text { de } 1895\end{array}$ & $\begin{array}{l}\text { 10:000 } \$ 000 \text { (Expediente e outras } \\
\text { despesas da E. Normal) + } \\
\text { 150:000 } \$ 000 \text { (Material escolar } \\
\text { das escolas públicas) }\end{array}$ & $4.823: 480 \$ 000$ \\
\hline $\begin{array}{l}\text { 1. }{ }^{\circ} \text { de Janeiro a } 31 \text { de Dezembro } \\
\text { de } 1896\end{array}$ & $\begin{array}{l}\text { 20:000\$000 (Expediente e outras } \\
\text { despesas da E. Normal) + } \\
\text { 200:000 } \$ 000 \text { (Material escolar e } \\
\text { livros das escolas públicas) }\end{array}$ & $5.390: 880 \$ 000$ \\
\hline $\begin{array}{l}\text { 1. }{ }^{\circ} \text { de Janeiro a } 31 \text { de Dezembro } \\
\text { de } 1897\end{array}$ & $\begin{array}{l}\text { 15:000 } \$ 000 \text { (Expediente e outras } \\
\text { despesas da E. Normal) + } \\
\text { 200:000 } \$ 000 \text { (Material escolar e } \\
\text { livros das escolas públicas) }\end{array}$ & $\begin{array}{l}6.599: 820 \$ 000 \\
1^{\text {a }} \text { vez que tem especificação de } \\
\text { despesas para grupos escolares } \\
(25) \text {. }\end{array}$ \\
\hline
\end{tabular}

Fonte: Elaboração da autora a partir das leis orçamentárias da Província e do Estado de São Paulo, de 1859 a 1897

Em 1859 é organizado o Tesouro Provincial. Somente em 1872, aparece na lei orçamentária, a destinação da verba de 2:000\$000 para a aquisição de móveis. Comparando os orçamentos deste período com os registros do já citado Livro de Moveis e Utensis (Distribuição de 1854 a 1872), conclui-se que o valor não correspondia ao mínimo suficiente, ainda mais quando se considera que os 2:000\$000 seria para compra, não só dos móveis, mas de todos os utensílios da escola.

No ano de 1870, o Livro registra somente onze escolas foram providas com móveis, totalizando um gasto de 921\$000. Nesse ano, o Relatório do Inspetor Geral da Instrução Pública, de 1871, informa que "entre publicas e particulares contamos com

\footnotetext{
${ }^{836}$ Neste ano há a criação de diversas escolas e cadeiras de primeiras letras.
} 
pouco mais de 400 escolas para população calculada em 800.000 almas" ${ }^{\text {"837 }}$. Se a disparidade entre o número de escolas e o número da população a ser atendida era grande; não menos gritante era a diferença entre a quantidade de escolas existentes e as que receberam móveis. Ainda que nem todas as escolas necessitassem de móveis em 1870, o valor de 921\$000 por ano, conforme o Livro de Móveis e Utensis, sempre deixaria em déficit o provimento mobiliário das escolas.

Há três documentos que, confrontados, dão informações complementares acerca do tema. O Art. $3^{\circ}$, inciso $7^{\circ}$ do Projeto do Código de Instrução Pública da Província de S. Paulo, do ano de 1857, previa como uma das funções do Diretor Geral da Instrução Pública "proceder ou auctorisar a compra de moveis e utensis para as escholas, aulas e internatos; e, por elles distribuil-os; e determinar o concerto dos edifícios públicos, não excedendo a quota para tais despesas consignada em lei”. Isso significa que, em meados do século XIX, já se admitia a importância de um agente público responsável pela estruturação física e material da escola. No entanto, o Código não entrou em vigor.

No Relatório de 1859, o Presidente da Província, José Joaquim Fernandes Torres informa à Assembleia Provincial que não pode executar o Código de Instrução Pública porque "produziria um accrescimo de despesa muito além da verba consignada para esse ramo do serviço publico" ${ }^{, 838}$. O presidente reconhece que o Código “contem disposições que melhorarão muito a administração da Instrução Publica" ${ }^{839}$, mas não quis "assumir a responsabilidade de aplicar á verba - Instrução Publica - uma quantia superior á orçada" ${ }^{\sharp 40}$. O maior gasto seria com o aumento dos vencimentos dos professores. Nesse caso, não é a ausência da previsão legal o fator limitante da expansão da escola às massas. Alegações de dificuldades financeiras e orçamentárias tem se mostrado, historicamente, como justificativas para o baixo investimento na instrução da população.

Anos mais tarde, além de um agente público, há uma verba destinada para compra de móveis e utensílios. A Lei n. 54 de 15 de abril de 1868, no artigo 22, autorizava o Presidente da Província a "dispender, desde já, até a quantia de seis contos de réis com a compra de livros, moveis e utensílios para as escholas publicas".

\footnotetext{
${ }^{837}$ Secretaria da Inspetoria Geral da Instrução Pública. Relatório apresentado pelo Inspetor Geral da Instrução Pública, Diogo de Mendonça, em 31 de dezembro de 1870, anexo ao Relatorio apresentado á Assembléa Legislativa Provincial de S. Paulo pelo Presidente da Provincia, o Exm. Sr. Dr. Antonio da Costa Pinto Silva, no dia 5 de fevereiro de 1871. S. Paulo, Typ. Americana, 1871, p.6.

${ }^{838}$ SÃO PAULO. Relatório do Presidente da Província Conselheiro José Joaquim Fernandes Torres. Typografia Imparcial de Joaquim Roberto de Azevedo Marrques. São Paulo, 1859, p.9

${ }^{839}$ Idem, ibidem.

${ }^{840}$ Idem, ibidem.
} 
Confrontando o Projeto do Código de Instrução Pública, a lei orçamentária de 1868 e os orçamentos da província, constatamos que a primeira destinação de verba para aquisição de móveis ocorre no exercício financeiro de 1872 a 1873. Ainda assim, não foram orçados seis, mas quatro contos de reis. Esse valor permaneceu inalterado até o ano de 1878, indicando que a criação das cadeiras de primeiras letras e escolas não foi acompanhada de uma ampliação na verba destinada a equipá-las.

Por um lado, a existência de lei estipulando uma quantia para aquisição de móveis e utensis não era garantia de que seria estabelecida, nas leis orçamentárias, a verba devida para aquele fim. Por outro lado, a ausência da lei não significa que não foram adquiridos móveis e utensis para as escolas públicas antes da lei orçamentária de 1872, ou, antes da lei n.54 de 1868. No Livro de Móveis e Utensis, por exemplo, há registro de compra de móveis desde o ano de 1854.

O valor da verba para compra de móveis permaneceria inalterado por anos seguidos. Exceção a essa situação ocorre no exercício financeiro de 1882 a 1883. É notável a elevação da verba destinada a melhora das condições da escola, passando de 5:000\$000 para 25:000\$000. Contudo, esse valor beneficiaria uma única escola - a Escola Normal de São Paulo. No exercício financeiro seguinte (de 1883 a 1884), estipula-se 20:000\$000, desta vez, destinados à aquisição de móveis, utensílios e livros para as escolas públicas.

A escola normal possuía uma verba de expediente, separada da verba das demais escolas públicas, para aquisição de móveis e material escolar. Em alguns orçamentos, somente a escola normal era agraciada com a dotação orçamentária para aquele fim.

O maior valor orçado para aquisição de mobiliário escolar, no período estudado, foi de 20.000\$000, nos anos de 1883 e 1884. De acordo com o Relatório sobre o estado e necessidade da Instrucção Publica da Província de S. Paulo, do ano de 1884, foram 35 escolas (23 do sexo masculino e 12 do sexo feminino) providas com móveis e utensis, pela verba do exercício de 1883 a $1884^{841}$. Diante da quantidade de solicitações, houve critérios para estabelecer a prioridade no atendimento às escolas. Foram "attendidas de preferência as reclamações a favor daquellas escholas que mais o

${ }^{841}$ SÃO PAULO. Relatório sobre o estado e necessidades da Instrucção Publica da Província de S. Paulo, do ano de 1884 apresentado ao Exm. Snr. Presidente da Provínca no ano de 1884, pelo Inspetor Geral. São Paulo, Typ King a Vapor, 1885, p.71. 
mereciam por sua importância, determinada, pela quantidade de alumnos, e já pelo aproveitamento do ensino" 842 .

Em 1885, outras 20 escolas (12 do sexo masculino e 8 do sexo feminino) foram autorizadas a comprar móveis e utensis. Na compra dos materiais "necessários ás suas escholas", os professores deveriam guardar "as regras observadas a respeito daquelles fornecimentos". As regras, provavelmente, diziam respeito a tabelas "pelas quaes deviam ser feitos os fornecimentos de materiaes ás escholas publicas".

Isso ajuda a entender porque, no Livro de Moveis e Utensis, a tabela para a quantidade e valor das mesas e dos bancos é pouco variável. Embora os registros do Livro se estendam somente até o ano de 1872, ele indicia a existência de uma tabela, um valor mais ou menos fixo, para compra de móveis pelos professores. Para a maior parte dos professores e das professoras é liberada, pelo Thesouro Provincial, a verba de 80\$000. Esse valor era suficiente para compra de:

6 bancos de 10 palmos de comprimento $=27 \$ 000$

3 bancos de 10 palmos de comprimento e $2 \frac{1}{2}$ de largura $=15 \$ 000$

1 meza de 5 palmas em quadro $=20 \$ 000$

1 cadeira para o professor $=18 \$ 000$

Além do controle fixado na tabela, há uma coerção sobre os professores a fim de evitar o desvio do patrimônio público. A medida consistia em condicionar a remoção dos professores públicos primárias à comprovação da entrega dos materiais das escolas, por eles adquiridos. Assim, "as remoções, permutas de cadeiras e demissões não sejam concedidas aos Professores-publicos-primarios, sem que pelos Inspetores Literários de districtos, ou os Presidentes das respectivas Câmaras Municipaes, tenha sido informado que, por inventário, fizeram elles entrega dos materiaes das respectivas escholas"843.

Se a definiçãa de um controle sobre os móveis comprados pelos professores tornou-se uma necessidade é porque isso se constituiu um problema a ser sanado. No Livro de Moveis e Utensis consta um registro, feito em 1870, de uma expedição de ordem no valor de $80 \$ 000$ para pagamento dos móveis comprados pela professora da Cadeira de Primeiras Letras do sexo feminino de Brotas, D. Thereza de Arruda Ferraz. Três anos depois, é feita uma retificação neste registro, pois “em ofício de 16 de abril de 1873, o Inspetor do Thesouro declarou não ter sido efetuada a compra destes

\footnotetext{
${ }^{842}$ Idem, p. 13.

${ }^{843}$ Idem, p. 14.
} 
móveis" ${ }^{\text {844 }}$. No caso, não é possível assegurar o motivo da correção do Livro. Contudo, é provável que, três anos após a suposta compra, a professora deixou a escola e não pode prestar conta dos móveis.

A Lei n.6, de 13 de março de 1878 determinou que nenhuma despesa, ainda que autorizada por lei especial, ou ordenada pelo presidente da Província, poderia ser feita pelo Tesouro Provincial, sem que se achasse consignada no respectivo crédito da Lei do Orçamento $^{845}$. A prática proibida na lei, provavelmente, se tratava de uma prática corrente dos presidentes de província: gastar verba além do consignado no crédito da Lei de Orçamento.

Do início ao fim da década de 1880 a verba destinada a Instrução Pública chega a quase dobrar. De 1882 a 1883 é orçado 500:460\$000. De 1888 a 1889, o valor chega a 918:420\$000. Mais significativa é a verba orçada para móveis e utensis. De 5:000\$000, estipulado no início da década de 1880, esse valor sobe para 25:000\$000 e se mantém em 20:000\$000 até quase o fim da década, quando cai novamente para 10:000\$000.

Outro elemento que corrobora com a ideia de que nos últimos anos do regime monárquico houve uma tentativa de incremento do investimento das condições físicas da escola púbica é o Fundo Escolar, criado pela Lei n ${ }^{\circ} 81$, de 06/04/1887, que reforma a instrução pública. O Fundo Escolar é, talvez, a primeira experiência de vinculação de recursos para educação.

De acordo com Romualdo Portela, é “a previsão, no texto, constitucional, de uma alíquota mínima da receita de impostos a ser aplicada em educação" ${ }^{\text {846. A }}$ vinculação ocorre pela primeira vez, "em nível nacional na Constituição de 1934" "847. O sentido da vinculação de recursos para a educação, segundo o mesmo autor, é "garantir um mínimo a ser aplicado em educação e induzir um aumento neste montante em relação à média histórica recente" $" 848$.

No caso de São Paulo, o Fundo Escolar de 1887, pode ser tomado como uma primeira tentativa de elevação do montante aplicado em educação, por meio dos recursos provenientes das seguintes fontes:

$\begin{array}{llrrrr}\text { Donativos } & \text { e } & \text { legados } & \text { para a } & \text { instrucção } & \text { publica. } \\ \text { Producto } & \text { das } & \text { multas } & \text { creadas } & \text { por } & \text { esta } \\ \text { lei. }\end{array}$

\footnotetext{
${ }^{844}$ APESP. Livro de Móveis e Utensis, p.77, verso.

${ }^{845}$ Idem, art. $1^{\circ}$.

846 OLIVEIRA, Romualdo Portela de; ADRIÃO, Theresa (orgs.). Gestão, Financiamento e Direito à Educação: análise da LDB e da Constituição Federal. São Paulo: Xamã, 2001, p.96.

${ }^{847}$ Idem, p.97.

${ }^{848}$ Idem, p. 99.
} 
Producto das multas que por lei não tem destino especial. Producto do imposto de capitação creado por esta lei, e pelas dotações feitas nos orçamentos provincial e municipal ${ }^{849}$.

Em 21 de fevereiro de 1888, o Conselho Municipal de Santa Cruz das Palmeiras, consulta o Diretor Geral da Instrução Pública para saber "se as despezas com a restauração e o fornecimento da mobília das escolas deveriam ser custeadas pelo fundo ultimamente creado em favor da instrucção provincial e quaes as providências a adoptar, desde que a elle não se pudesse recorrer" ${ }^{\prime 850}$.

O director da Instrução Pública, Francisco de Paula Rodrigues Alves, respondeu de acordo com o ofício recebido do presidente da Província, que "ao poder legislativo cumpria deliberar a respeito da breve constituição do fundo escolar, por onde tem de correr as despesas alludidas" $" 851$.

Essa troca de ofícios ratifica o que expõe Viviane Tessitore acerca do Imposto de Capitação para o Fundo Escolar: "As expectativas em torno das reformas de 1887, porém, foram rapidamente frustadas com relação às metas do Fundo Escolar". O objetivo do Fundo era a "construcção de casas, acquisição de moveis, utensis e outros objectos de que precisarem as escolas do mesmo municipio" ${ }^{\text {} 852}$.

Essa "forma de financiamento" da educação foi delegada aos municípios, pois o Fundo não era provincial, mas "creado em cada município" e a aplicação das quantias arrecadadas estava na competência e discricionariedade dos Conselhos Municipais ${ }^{853}$. Porém, "os Conselhos Municipais, que deveriam aplicar sua receita, de acordo com o Presidente Rodrigues Alves, não eram criados, quando criados, não se instalavam, e, quando instalados, não tinham estabilidade e cumpriam deficientemente suas funções" $" 854$.

Outra dificuldade estava relacionada a uma das fontes dos recursos: o imposto de capitação. "A capitação é um imposto cuja incidência ou cobrança sedá 'per capita', ou seja, é exigido de cada pessoa em razão de seu estado ou dos proventos auferidos por sua situação social”855.

\footnotetext{
${ }^{849}$ São Paulo. Lei n ${ }^{\circ} 81$, de 06/04/1887, Art.91, incisos 1, 2, 3, 4.

${ }^{850}$ Decisões da Presidência, anexo ao Relatorio apresentado á Assembléa Legislativa Provincial de São Paulo pelo presidente da provincia, dr. Pedro Vicente de Azevedo, no dia 11 de janeiro de 1889. São Paulo, Typ. a Vapor de Jorge Seckler \& Comp., 1889. p.1

851 Idem, p.2

${ }^{852}$ São Paulo. Lei n ${ }^{\circ} 81$, de 06/04/1887, Art.91.

${ }^{853}$ Idem, art. 91, 95 e 97

${ }^{854}$ TESSITORE, op. cit. p.181.

${ }^{855}$ SILVA, 1994, v.1/2, p.369 apud TESSITORE, 1995, p.181.
} 
Tratava-se de um imposto novo, criado no bojo da reforma do ensino público provincial, pelos artigos 91 a 93 e 95 a 97 da Lei n ${ }^{\circ}$ 81, de 06/04/1887. O órgão arrecadador eram as Coletorias, as Mesas de Rendas e Recebedorias. O agente arrecadador eram os Coletores, Administradores e Lançadores-cobradores nas Mesas de Rendas, e os Lançadores-cobradores nas Recebedorias ${ }^{856}$.

Por isso, o Inspetor do Tesouro Provincial se pronuncia, acerca deste imposto, no relatório que deveria enviar ao Presidente da Província: "formar recursos às Escolas no intuito certamente de levantar o nível moral da Província à altura correspondente ao seu progresso material, cooperando na obra de instrução popular, que é verdadeiro escudo da liberdade ${ }^{\$ 857}$. Mas, qual a dificuldade relacionada ao imposto?

O Inspetor do Tesouro o considerou de difícil regulamentação e de cobrança integral praticamente impossível, porque a lei não isentou ninguém, nem os que normalmente o eram (os paupérrimos e os agentes consulares), nem os colonos, como era do interesse provincial naquele momento; também não forneceu nenhuma base segura para o lançamento - a qual só seria dada pelo registro civil -, obrigando os Exatores a um arrolamento quase iealizável, devido à variação constante da população nas cidades e sua dispersão no cmapo, e, portanto, inexato e arbitrário, que acabaria provocando "clamores não raramente justos" ${ }^{\prime 858}$.

Arrecadado pelas Coletorias, onde permaneceria o Fundo Escolar, o Conselho Municipal deveria requisitar da repartição fiscal o pagamento de qualquer despesa efetuada com a instrução pública ${ }^{859}$, dando aplicação aos recursos.

Pela Lei n.81, os contribuintes eram todos os indivíduos, varões, nacional ou estrangeiro, maior de 21 anos, e também as mulheres, "maior com economia própria, que tivesse pelo menos 1 ano de residência efetiva no distrito fiscal no qual fosse arrolado" $" 860$.

Já que a lei não isentou ninguém, o impasse residia na equidade da cobrança. Acerca da questão, Tessitore afirma que o Contador e Inspetor divergiam.

O primeiro sugeriu que se criasse uma taxa anual de 1 a $3 \$ 000$, cobrada junto com o imposto predial, e a passagem para o Fundo Escolar do próprio imposto predial, cedido às Municipalidades pelo art. 22 da lei n.124, de 28 de maio de 1886. O Inspetor considerava a medida injusta, pois onerava unicamente os proprietários, quando o intuito do legislador havia sido o de distribuir "indistintamente por

\footnotetext{
856 TESSITORES, 1995.

${ }^{857}$ Relatório do Tesouro Provincial, de 20 de dezembro de 1888, p.43 apud TESSITORE, 1995, p.181.

858 TESSITORE, op. cit.,p.181-182.

${ }^{859}$ São Paulo. Lei n ${ }^{\circ} 81$, de 06/04/1887, Art.96 e 97.

${ }^{860}$ Idem, p. 183.
} 
todos os cidadãos o ônus que acarreta o ensino público gratuito $[\ldots]^{\prime 861}$.

O Regulamento de 28 de março de 1888 estabeleceu o rol de isenções. Entretanto, devido à inexatidão do imposto, "sua arrecadação nem chegou a constar dos orçamentos e balanços de receita e despesa" ${ }^{\text {862 }}$.

Todo esse detalhamento do imposto justifica-se pela tentativa de mostrar os contornos dos desafios ligados ao investimento e financiamento da educação no período em estudo: Transferência de parcela da responsabilidade do financiamento da educação da província aos municípios; criação de novos impostos para arcar com os gastos crescentes da instrução pública, onerando a população e não o orçamento provincial; organização da máquina administrativa para captar, distribuir e aplicar os recursos.

O período de vigência do imposto foi de 1887 a 1891. Sua extinção com a Proclamação da República faz entender que esse não era o modo como, naquele momento, os republicanos concebiam o financiamento da educação. No Quadro "Orçamento para a Instrução Pública”, observa-se que a verba destinada a este ramo do serviço público é crescente ao longo da década de 1890. No entanto, os valores orçados para os móveis e utensílios da escola não sofrem elevação signficativa, ficando, no período, abaixo dos valores orçados na década de 1880.

De 1889 a 1890 houve uma drástica redução da verba de 20:000\$000 para 3:000\$000, somente para os objetos da escola, não aparecendo a expressão "móveis". No exercício seguinte, de 1890 a 1891, é orçado 6:000\$000 para objetos e mobília. Por dois anos seguidos, 1892 e 1893 não foi orçada nenhuma verba, seja para utensílios, seja para móveis. Já em 1894, estipula-se o valor de 74:400\$000 para aquisição de móveis e utensis para as escolas públicas paulista. Este é o último valor orçado para essa finalidade, pois nos últimos anos da primeira década republicana, os valores orçados, entre 10:000\$000 e 20:000\$000, para expediente, móveis e utensílios é destinado apenas para a Escola Normal de São Paulo.

Isso não significa que, nenhuma outra escola pública paulista recebeu material ou mobiliário. Mas, pode sinalizar a concentração dos esforços dos republicanos na visibilidade das escolas modelos, sobretudo, na Escola Normal da Praça da República. A leitura e comparação das leis orçamentárias permite cotejar a hipótese de que, na década de 1880, a verba orçada para móveis e utensis seria destinada às escolas públicas

\footnotetext{
${ }^{861}$ Relatório do Tesouro Provincial, de 20 de dezembro de 1888, p.22 apud TESSITORE, 1995, p.182.

${ }^{862}$ TESSITORE, op. cit., p. 182.
} 
espalhadas pelo território paulista. Enquanto a verba de expediente, entre 1895 e 1898 , teve destinação específica para a Escola Normal.

Isso pode ajudar a entender porque a escola da Praça da República e as escolas modelos, como mostrado nesta pesquisa eram equipadas com os mais modernos materiais e mobiliário escolar, eram as destinatárias dos objetos importados, enquanto as demais instituições de ensino espalhados pelo território padeciam por falta de móveis e objetos básicos ao seu funcionamento.

É preciso revisitar a documentação que trata das questões econômicas da escola para interrogar se a profusão material da Escola Normal de São Paulo e a visibilidade do investimento do governo republicano, nesta instituição, não tornaram invisíveis e pouco problemáticas" as condições físicas, de criação e funcionamento, da maior parte das escolas públicas de primeiras letras, nas quais se deu a escolarização da maior parte do povo paulista, no período.

O investimento do Estado na educação das massas está colocado na "tensão entre o centro político e a ordem econômico-social" ${ }^{863}$. O governo decide o modo como se dará o investimento, se serão criados impostos específicos para financiar a instrução pública, se uma parcela da arrecadação total será a esse fim destinada. De qualquer modo, a fiscalidade, chamada por Wilma Peres Costa de "alma do Estado", tem estreita relação não só com a construção do Estado moderno, mas com os serviços públicos por ele prestados.

Não quero com isso afirmar que a cobrança de mais impostos é sinônimo de eficiência da pulsão extrativa ${ }^{864}$ do Estado que, por sua vez, garantiria maior investimento na educação. Pelo contrário, a breve problematização, aqui, dos orçamentos, das finanças públicas e investimento na educação tem a ver com um alerta feito por Costa no sentido de analisar as finanças públicas "em sua relação com as articulações de interesses que permeiam a vida social e a ação política" ${ }^{865}$. Isso corrobora para um tratamento menos técnico e mais politizado das questões entre econômica e educação; entre opções políticas e serviços públicos; entre Estado e investimento na instrução das massas. Daí a importância de se fazer uma História Econômica da escola, perpassada, todavia, por uma história política e cultural.

\footnotetext{
${ }^{863}$ COSTA, Wilma Peres. Finanças e Construção do Estado: fontes para o estudo da história tributária do Brasil no século XIX. America Latina en la Historía Económica, Ciudad de Mexico, v. 15, n.13/14, p. 5167, 2000, p.52.

${ }^{864}$ COSTA, 2000.

${ }^{865}$ Idem, p.65
} 


\section{CONSIDERAÇÕES FINAIS}

Tomar a materialidade da escola, mais especificamente a carteira, como fio condutor para a construção de uma História Econômica da escola, em São Paulo, entre o fim do século XIX e início do século XX, ajudou a problematizar o investimento do Estado na educação, num momento de criação e expansão da escola moderna, pública, obrigatória e de massa.

Este investimento é atravessado por questões internas e externas à escola. Por opções de ordem social; cultural; legal; político-administrativa; econômica, dentre outras.

A escolha do mobiliário escolar ou, até, a não-escolha, teve implicação direta tanto nas condições físicas de funcionamento da escola primária, quanto nas possibilidades de sua expansão pelo território paulista. Diante das condições precárias da receita provincial, deveria o governo paulista continuar deixando sob a responsabilidade dos professores e das famílias dos alunos o ônus do mobiliário escolar? Deveria escolher um mobiliário barato, atendendo mais rapidamente a um maior número de escolas? Deveria considerar as prescrições médico-higiênicas, escolhendo um mobiliário ergonômico que não acarretasse problemas físicos nos alunos, porém mais dispendioso? Deveria importar os melhores e mais modernos tipos de carteira, fabricá-las ou "terceirizar" a produção para fábricas nacionais? Quanto os governos, no fim do regime monárquico e início do republicano, investiram na instrução pública e na compra de móveis e utensis?

Como questão de ordem social, a higiene pública e escolar impunha ao poder público a melhoria do espaço urbano e, como corolário, das condições físicas de funcionamento da escola e da sala de aula. Para tanto, uma medida urgente seria a substituição dos velhos bancos, sem encosto, por um mobiliário ergonômico que evitasse as moléstias decorrentes da má postura dos escolares, comprometendo-lhes o desenvolvimento.

Há um saber médico e higiênico sobre o corpo infantil. Considerá-lo, significava, prover as escolas de um mobiliário que exigiria aumento do investimento na instrução pública. Embora algumas escolas tenham sido providas com as mais modernas carteiras, as reclamações de professores indiciam que, muitas delas, sequer tinham o mínimo necessário ao funcionamento. A ausência de critérios, ou o uso de critérios 
desiguais, no provimento material, estabeleceria uma diferenciação entre as escolas públicas, no interior do mesmo sistema de ensino, que perduraria ao longo do século $\mathrm{XX}$.

A importância conferida à criação dos sistemas de ensino e ao mobiliário escolar, na segunda metade do século XIX, se dá internacionalmente e as Exposições Universais são veículos significativos de propagação de uma modernidade pedagógica que se expressa nos objetos e materiais escolares. As grandes feiras universais fizeram das carteiras objetos de desejo e de necessidade para a escola moderna. Neste caso, além de um valor higiênico e comercial, há um valor cultural associado à aquisição de determinados bens. Esse valor cultural faz crer que mobiliário moderno é igual a escola moderna que é igual a qualidade de educação. Como já assinalou Vidal e Gaspar (2011), há uma retórica hegemônica do campo educacional brasileiro que associa, diretamente, qualidade de ensino e aquisição de tecnologias e modernos materiais escolares. Para essa retórica, contribuíram as Exposições Universais e Nacionais.

A carteira, cuja presença na escola moderna, não pode ser dissociada das prescrições da medicina e da higiene; cuja propaganda e circulação se deram a partir das Exposições Universais, chega as escolas públicas paulista de diferentes modos. Primeiro, via importação, sobretudo, pela ação dos agentes e representantes comerciais. Depois, é fabricada, no país, pela nascente indústria de mobiliário escolar que vê na escola um mercado importante consumidor.

Para fazer a aquisição e distribuição do mobiliário para as escolas espalhadas pelo território paulista, o governo precisou se organizar administrativa e economicamente. A estrutura burocrático-administrativa pode se constituir em um entrave ou elemento facilitador para o conhecimento e suprimento das necessidades materiais das escolas. Nesta pesquisa, é possível apreender como o Estado de São Paulo foi se organizando para atender a escolaridade obrigatória. O que coloca em evidência a distância entre a lei e a sua efetivação pelo poder público.

A distribuição ou não do mobiliário foi um elemento decisivo na concretização da escolaridade obrigatória, pois dele dependia o funcionamento da escola. O investimento na educação pública e o financiamento da educação é, até os dias atuais um desafio para o governo. Não somente por causa da receita, mas porque na decisão do quanto, em quê e como investir, diversas outras questões estão implicadas.

O estudo da carteira, como vetor de relações, pôs em destaque os aspectos sociais, culturais, legais, econômicos e político-administrativo implicados na expansão 
da escola moderna, obrigatória e de massa, assumida pelo Estado. Tal abordagem propicia um olhar menos fragmentado das tensões e desafios quanto ao Estado e a oferta da instrução pública. 


\section{REFERÊNCIAS BIBLIOGRÁFICAS}

ABREU JUNIOR, Laerthe de Moraes. Apontamentos para uma metodologia em cultura material escolar. Campinas, Universidade Estadual de Campinas, Faculdade de Educação. Revista Pro-Posições, v. 16, n. 1 (46), jan.-abr. 2005.

ALCÂNTARA, Wiara Rosa. Uma vida no magistério: fios e meadas da história de uma professora paulista. Dissertação de Mestrado. Faculdade de Educação, Universidade de São Paulo, São Paulo, 2008.

AMATO, Pedro Muñoz. Introdução à Administração Pública. Tradução de Benedicto Silva. Rio de Janeiro, FGV, 1958.

ARIÉS, Phillipe. História social da criança e da família. Rio de Janeiro: Zahar, 1979.

ASSUNÇÃO, Martha Ap. Todeschini de. Real Fábrica de Ferro de São João de Ipanema: um episódio na educação paulista. Dissertação de Mestrado. Faculdade de Educação, Universidade de São Paulo, São Paulo, 2005.

BANDEIRA JUNIOR, Antonio Francisco. A Indústria no Estado de São Paulo em 1901. São Paulo, Diário. Oficial, 1901.

BARBANTI, Maria Lúcia. Escolas Americanas de Confissão Protestante na Província de São Paulo: Um Estudo de suas origens. São Paulo: Dissertação de Mestrado. FEUSP, 1977.

BARBOSA, D.B. A Legislação de Propriedade Intelectual em Vigor. Juiz de Fora: Universo Jurídico, 2007.

BARBOSA, Rui. Obras Completas. V. X. 1883. Tomo IV. Reforma do Ensino Primário.

BARBUY, H. A cidade-exposição: comércio e cosmopolitismo em São Paulo, 18601914. 1. ed. São Paulo: EDUSP, 2006. v. 1. 304p .

BARBUY, H. A Exposição Universal de 1889 em Paris: visão e representação na sociedade industrial. São Paulo: Loyola; História Social USP, 1999.

BARROS, José D'Assunção. História Econômica. Considerações sobre um campo disciplinar. Revista de Economia Política e História Econômia. Ano 4, n.11, jan.2008, p.5-51.

BARROS, Liliane Schrank Lehmann; MOIZO, Rosana Pires Azanha. Formação administrativa da cidade de São Paulo, 1554 - 1954. Revista do Arquivo Municipal, São Paulo, volume 199, 1991. 
BASTOS, Aurelino Cândido Tavares. A província: estudo sobre a descentralização no Brasil. $3^{\text {a }}$ ed. São Paulo: Ed. Nacional; Brasília; INL, 1975.

BASTOS, Maria Helena Camara. Pro Patria Laboremus: Joaquim José de Menezes Vieira (1848-1897). Bragança Paulista: EDUSF, 2002, 350p.

BORGES, Urquiza Maria. Negociantes na cidade de São Paulo (1875-1880). Dissertação de Mestrado. Faculdade de Filosofia, Letras e Ciências Humanas, Universidade de São Paulo, São Paulo, 1979.

BOTO, Carlota. A racionalidade escolar como processo civilizador: moral que captura almas. In: CARVALHO Maria Marta Chagas de; PINTASSILGO, Joaquim (orgs.). Modelos culturais, saberes pedagógicos, Instituições Educacionais: Portugal e Brasil, Histórias Conectadas. São Paulo: Editora da Universidade de São Paulo/FAPESP, 2011. 472p.

BOURDIEU, Pierre. Sur l'État. Cours au Collège de France (1989-1992). Paris, Seuil, 2012.

BUISSON, Ferdinand. Dicionário de Pedagogia e da Instrução Primária. Paris: Librairie Hachette \& Cie., 1887. Parte I, Tomo I.

BUISSON, F. Dictionnaire de Pédagogie et d'instruction primaire. Paris: Librairie Hachette et Cie. 1888. Parte I, Tomo II.

BUISSON, Ferdinand. Rapport sur l'instruction primaire à l'Exposição Universelle de Vienne em 1873. Paris, 1875.

BURKE, Peter. O que é a história cultural? Tradução: Sérgio Goes de Paula. Rio de Janeiro: Jorge Zahar Ed.2005.

CANCLINI, Nestor. Introdução à edição de 2001. As culturas híbridas em tempos de globalização. Culturas híbridas. São Paulo: EDUSP, 2003.

CARONE, Edgar. A evolução industrial de São Paulo (1889-1930). São Paulo: Editora SENAC São Paulo, 2001.

CARVALHO, M. M. C. Por uma história cultural dos saberes pedagógicos. Apud SOUZA, M. \& CATANI, D. Práticas educativas, culturas escolares, profissão docente. In: II CONGRESSO LUSO-BRASILEIRO DE HISTÓRIA DA EDUCAÇÃO. São Paulo: Escrituras, 1998.

CASTRO, Raquel Xavier de Souza. Da cadeira às carteiras escolares individuais: entre mudanças e permanências na materialidade da escola primária catarinense (1836-1914). Florianópolis: Universidade do Estado de Santa Catarina, Dissertação de Mestrado, 2009.

COELHO, Fábio Ulhoa. Manual de Direito Comercial. 17. ed. São Paulo: Saraiva, 2006. 
COLLICHIO, Therezinha A. F. Dois eventos importantes para a História da Educação Brasileira: a Exposição Pedagógica de 1883 e as Conferências Populares da Freguesia da Glória. Revista da Faculdade de Educação/USP. São Paulo, 13:5-14, jul.-dez. 1987.

COSTA RICO, Antón. Mobiliario, dotación y equipamiento escolar en el siglo XIX. Salamanca: Revista interuniversitaria Historia de la Educación. n. 16, 1997.

COSTA, Edilaine Vieira. Nos tempos de Capanema, a saúva e os direitos de monopólio. Cadernos de História da Ciência - Instituto Butantan - Vol. VII, jan/jun 2011.

COSTA, Frederico Lustosa da; ZAMOT, Fuad (orgs.). Brasil - 200 anos de Estado, 200 anos de administração pública. Revista de Administração Pública. Rio de Janeiro 42: 829-74, set./out., 2008.

COSTA, Wilma Peres. A questão fiscal na transformação republicana - continuidade e descontinuidade. Economia e Sociedade, Campinas, (10): 141-73, jun. 1998.

COSTA, Wilma Peres. Finanças e Construção do Estado: fontes para o estudo da história tributária do Brasil no século XIX. America Latina en la Historía Económica, Ciudad de Mexico, v. 15, n.13/14, p. 51-67, 2000.

DEAECTO, Marisa Midori. Comércio e vida urbana na cidade de São Paulo (18891930). São Paulo: Editora Senac São Paulo, 2002.

DEAN, Warren. A industrialização de São Paulo (1880-1945). 3. ed. Tradução de Octávio Mendes Cajado. São Paulo: Difel, 1970.

DEMARTINI, Zeila de Brito (Coord.). Velhos mestres das novas escolas: um estudo das memórias de professores da Primeira República em São Paulo. São Paulo: Centro de Estudos Rurais e Urbanos, 1984.

ESCOLANO, A. La cultura material de la escola. En el centenário de la Junta para La Ampliación de Estudios, 1907-2007. Berlanga de Duero- Soria, 2007.

FELGUEIRAS, Margarida. Materialidade da cultura escolar. A importância da museologia na conservação/comunicação da herança educativa. Campinas, Universidade Estadual de Campinas, Faculdade de Educação. Revista Pro-Posições, v.16, n.1 (46), jan./abr. 2005, p. 67-102.

FERNANDES, Rogério; KUHLMANN JR., Moisés. Sobre a infância. In: FARIA FILHO, Luciano (Org.). A infância e sua educação: materialidades, práticas e representações. Belo Horizonte: Autêntica, 2004.

FRAGOSO, João. Para que serve a história econômica? Notas sobre a história da exclusão no Brasil. Estudos Históricos. Rio de Janeiro, n. 29, 2002, p. 3-28.

FRANCO, Vera Helena de Mello. Contratos: Direito Civil e empresarial. 4ed. São Paulo: Editora Revista dos Tribunais, 2013. 
FREITAS, Marcelo de; MALDONADO, José Manuel. O pregão eletrônico e as contratações de serviços contínuos. Revista Admnistração Pública, Rio de Janeiro 47:1265-281, set.-out. 2013.

GÉLIS, Jacques. A individualização da criança. In: ARIÈS, P.; CHARTIER, R. História da vida privada, v.3. São Paulo: Companhia das Letras, 1992.

GIGLIO, Célia Maria Benedicto. Inspeção e produção de um modelo escolar. A instrução pública na província de São Paulo (Brasil, 1836-1876). In: CARVALHO Maria Marta Chagas de; PINTASSILGO, Joaquim (orgs.). Modelos culturais, saberes pedagógicos, Instituições Educacionais: Portugal e Brasil, Histórias Conectadas. São Paulo: Editora da Universidade de São Paulo/FAPESP, 2011. 472p.

GINZBURG, Carlo. O fio e os rastros: verdadeiro, falso, fictício. Trad. de Rosa Freire d'Aguiar e Eduardo Brandão. São Paulo: Companhia das Letras, 2007.

GOLDMAN, Frank P. Os Pioneiros Americanos no Brasil: Educadores, Sacerdotes, Corvos e Reis. São Paulo: Pioneira, 1972.

GONDRA, J. G. A emergência da Infância. Educação em Revista (impresso). Faculdade de Educação da Universidade Federal de Minas Gerais Belo Horizonte, v. 26, p. 195$214,2010$.

GONDRA, José G. Conformando o discurso pedagógico: a contribuição da Medicina. In: FARIA FILHO, Luciano (et al). Educação, modernidade e civilização: fontes e perspectivas de análises para a história da educação oitocentista. Belo Horizonte: Autêntica, 1998. p. 35-71.

GONDRA, José G.. Educação em Revista, Belo Horizonte, v. 26, n. 1, p.195, abr. 2010.

GROSVENOR, Ian. Pleasing to the Eye and at the Same Time Useful in Purpose: a historical exploração of educational exhibitions. In: LAWN, Martin; GROSVENOR, Ian. Materialities of Schooling: Design, Technology, Objects, Routines. Oxford: Symposium Books, 2005.

GRUZINSKI, Serge.. Les monds mêles de la monarchie catholique et autres connected histories. In: Annales. Histoire, Sciences Sociales, 56 e. Anné, nr. 1, jan. - fev. p. 85 $117,2001$.

HEYWOOD, Colin. Uma história da infância: da Idade Média à época contemporânea no Ocidente. Porto Alegre: Artmed, 2004, 284p.

HILSDORF, Maria Lucia S. A doce violência: notas para a história do ensino obrigatório na província de São Paulo. p.321-341. In: VIDAL, Diana; SÁ, Elizabeth F.; GASPAR, Vera (orgs.). Obrigatoriedade escolar no Brasil. Cuiabá: Edufmt, 2013.

HONORATO, Cezar T. O Estado Imperial e a modernização portuária. In: SZMRECSÁNYI, Tomás; LAPA, José Roberto do Amaral (orgs). História Econômica da Independência e do Império. São Paulo: Hucitec, 1996, v.2. p.161-176. 
KÜHL, Beatriz Mugayar. Arquitetura do ferro e arquitetura ferroviária em São Paulo: reflexões sobre a sua preservação. São Paulo: Ateliê Editorial; Fapesp; Secretaria da Cultura, 1998.

KUHLMANN JUNIOR, Moysés. A educação infantil no século XIX. In: STEPHANOU, Maria; BASTOS, Maria Helena C. (Orgs.). Histórias e memórias da educação no Brasil. V. II: século XIX. Petrópolis: Vozes, 2005.

KUHLMANN JUNIOR, Moysés. As grandes festas didáticas: a educação brasileira e as exposições internacionais (1862-1922). Bragança Paulista: Editora da Universidade São Francisco, 2001. p. 9. (Coleção Estudos CDAPH. Série Historiografia).

KUHLMANN JUNIOR, Moysés. O jardim de infância e a educação das crianças pobres. Final do século XIX, início do século XX. In: MONARCHA, Carlos (Org.). Educação da infância brasileira (1875-1983). Campinas: Autores Associados, 2001.

KULA, Witold. Problemas y métodos de la historia económica. Traducción española. Barcelona: Península, 1977.

LAWN, Martin \& GROSVENOR, Ian (éd.). Materialities of Schooling: design,Technology,Objects, Routines. Oxford: Symposium Books, 2005. - 217 p. (Comparative Histories of Education).

LOVE, Joseph. A locomotiva: São Paulo na federação brasileira (1889-1937). Tradução de Vera Alice Cardoso da Silva. Rio de Janeiro: Paz e Terra, 1982.

MACHADO, Maria Cristina Gomes. A educação como espetáculo. In: STEPHANOU, Maria; BASTOS, Maria Helena C (orgs). Histórias e memórias da educação no Brasil, Vol II: século XIX. Petrópolis, RJ: Vozes, 2005.

MACHADO, Maria de Fátima Costa Monteiro de Sá. Maneiras de Sentar: Contributo para a História das carteiras escolares do ensino primário em Portugal (1835-1970). Dissertação de Mestrado Faculdade de Psicologia e de Ciências da Educação, 2004, Lisboa.

MARTINEZ, Pedro. Presentación. Cuerpo, higiene, educación e historia. Ediciones Universidad Salamanca. Historia de la Educación. Revista interuniversitaria. n.28, 2009, p.23-36.

MASTROMAURO, Giovana Carla. Surtos epidêmicos, teoria miasmática e teoria bacteriológica: instrumentos de intervenção nos comportamentos dos habitantes da cidade do século XIX e início do XX. ANAIS DO XXVI SIMPÓSIO NACIONAL DE HISTÓRIA - ANPUH, São Paulo, jul. 2011.

MEIRELLES, Hely Lopes. Direito Administrativo Brasileiro. 32. Ed. São Paulo: Editora Malheiros, 2006.

MELLO, Balthazar Vieira de. A Hygiene na Escola. São Paulo: Typographia do Diario Official, 1902, p. 20. 
MENEZES, Ulpiano T. Bezerra de. A exposição museológica e o conhecimento histórico. In: Figueiredo, Betênia Gonçalves \& Vidal, Diana Gonçalves. (Org.). Museus. Dos gabinetes de curisoidades à museologia moderna. Belo Horizonte / Brasília: Argumentum / CNPq, 2005.

MENEZES, Ulpiano. Memória e cultura material: documentos pessoais no espaço público. SEMINÁRIO INTERNACIONAL SOBRE ARQUIVOS PESSOAIS, RIO/SÃO PAULO, CPDOC/FGV/USP, 1997.

MOACYR, Primitivo. A instrução pública no estado de São Paulo (1890-1893). 1 vol. São Paulo: Companhia Editora Nacional, 1942.

MONARCHA, Carlos. Arquitetura escolar republicana: a escola normal da praça e a construção de uma imagem de criança. In: FREITAS, Marcos Cesar (Org.). História Social da Infância no Brasil. 3. ed. São Paulo: Editora Cortez, 2001, p.101-140.

MONARCHA, Carlos. Escola Normal da Praça: o lado noturno das luzes. Campinas, Editora da Unicamp, 1999.

MONARCHA, Carlos. Revista do Jardim da Infancia. Uma publicação exemplar. In: MONARCHA, Carlos (org). Educação da infância brasileira (1875-1983). Campinas: Autores Associados, 2001, p. 104-105.

NEVES, Margarida de Souza. As vitrines do progresso: o conceito de trabalho na sociedade brasileira na passagem do século XIX ao século XX; a formação do mercado de trabalho na cidade do Rio de Janeiro. Rio de Janeiro, 1986.

NOGUEIRA, Sonia Martins de Almeida. A descentralização determinada pelo ato adicional de 1834 e suas conseqüências para o desenvolvimento da educação no império: uma abordagem. Ensaio: avaliação e políticas públicas em educação. Rio de Janeiro, v. 07, n. 22, jan. 1999 .

NOGUEIRA, Sonia Martins de Almeida. O surgimento dos Sistemas Nacionais de ensino: a instrução pública no Brasil e na Argentina na segunda metade do século XIX. Tese (Doutorado em Educação). Universidade Federal do Rio de Janeiro, Rio de Janeiro, 1993.

NÓVOA, António. Modeles d'analyse en education comparée: le champ et la carte. In: Education comparée. Montreal/Paris: 1'Harmattan, 1998, p. 9-61.

NÓVOA, António; SCHRIEWER, Jürgen (eds.). A difusão mundial da escola. Lisboa: EDUCA, 2000.

OLIVEIRA, João Gualberto de. Suecos no Brasil. São Paulo: Revista dos Tribunais, 1952.

OLIVEIRA, Romualdo Portela de; ADRIÃO, Theresa (orgs.). Gestão, Financiamento e Direito à Educação: análise da LDB e da Constituição Federal. São Paulo: Xamã, 2001. 
OSSENBACH, Gabriela. Por una Historia Comparada de la Educación en España, Portugal Y América Latina. In: ESCOLANO, A. \& FERNANDES, R. (Eds.). Los caminos hacia la modernidad educativa en España y Portugal (1800-1975). Zamora: SEHE, 1997, p. 227-251.

PASSALACQUA, Padre Camillo. Pedagogia e Methodologia (Theorica e Pratica). São Paulo: Typographia a vapor de Jorge Seckler \& Comp., 1887.

PAULO, Marco A.; WARDE, Mirian. A instalação do serviço de inspeção escolar na Província de São Paulo (1835-1887). Cadernos de História da Educação, v. 12, n. 1, jan.-jun. 2013.

PAULO, Marco Antônio Rodrigues. A organização administrativo-burocrática da Instrução Pública paulista: Estudo sobre o Regulamento da Diretoria Geral de 1910. Tese de doutorado. Faculdade de Educação, Universidade de São Paulo, São Paulo, 2007.

PEDRO, Carina Marcondes Ferreira. Casas importadoras de Santos e seus agentes: comércio e cultura material (1870-1900). São Paulo: Faculdade de Filosofia, Letras e Ciências Humanas. Tese USP, 2010.

PEYRANNE, Josette. Le mobilier scolaire du XIXe siècle a nos jours: contribution a l'étude des pratiques corporelles et de la pédagogie à travers l'évolution du mobilier scolaire. Lille: ANRT, 2001.

PRADO JR., Caio. História Econômica do Brasil. 14 ed. São Paulo: Brasiliense, 1971,

REIS FILHO, Casimiro dos. A Educação e a ilusão liberal. São Paulo: Cortez, Autores

REVEL, Jacques (org). Jogos de Escala. A experiência da microanálise. Tradução Dora Rocha. Rio de Janeiro: FGV, 1998, 262p.

ROCHA, Heloisa Helena Pimenta. Entre a ortopedia e a civilidade: higienismo e educação do corpo no Brasil: Higienismo e educação do corpo no Brasil. Salamanca: Revista interuniversitaria Historia de la Educación. N. 28, 2009, p.109-134.

ROCHA, Heloisa Helena Pimenta; GOUVÊA, Maria Cristina. Infâncias na História. Educação em Revista, Belo Horizonte, v.26, n.1, abr.2010.

ROCHA, Heloísa; GONDRA, José. A escola e a produção de sujeitos higienizados. Perspectiva, n.2. Florianópolis, jul./dez/ 2002, v.20.

RODRIGUES, J. L. Retrospecto histórico. In: Anuário do Ensino do Estado de São Paulo de 1907/1908. S,„o Paulo: Typ. Augusto Siqueira \& C., 1909.

SANTOS, Nilton Pereira. A fábrica de ferro São João do Ipanema: economia e política nas últimas décadas do Segundo Reinado; 1860-1889. São Paulo: Tese de doutorado, 2009. 
SCHELBAUER, Analete Regina. O método intuitivo e lições de coisas no Brasil do século XIX. In: STEPHANOU, Maria; BASTOS, Maria Helena C. (Orgs.). Histórias e memórias da educação no Brasil, Vol II: século XIX. Petrópolis, RJ: Vozes, 2005.

SCHRIEWER, Jürgen. L'internationalisation des discours sur l'éducation : adoption d'une «idéologie mondiale » ou persistence du style de "réflexion systémique » spécifiquement nationale ? Revue Française de Pédagogie, $n^{\circ} 146$, janvier-février-mars 2004, 7-26.

SEGAWA, Hugo, Prelúdio da Metrópole. São Paulo; Ateliê Editorial, 2004.

SILVA, José Claudio Sooma. Teatros da Modernidade: representações de cidade e escola primária no Rio de Janeiro e em Buenos Aires nos anos 1920. 308 f. Tese (Doutorado). Faculdade de Educação da Universidade do Estado do Rio de Janeiro, 2009.

SINGER, Paul. Desenvolvimento econômico e evolução urbana. São Paulo: Editora Nacional/Editora da Universidade de São Paulo, 1968

SOUTO, Rosiley Teixeira. 2005. Recrutamento e qualificação de professores primários na Instrução Pública paulista (1892-1933): um estudo das tecnologias do estadoEstado. São Paulo (Tese de Doutorado). PUC/SP.

SOUZA, Rosa Fátima de. Vestígios da Cultura Material Escolar. Campinas: Editora Autores Associados. Revista Brasileira de História da Educação, n.14, mai/ago. 2007.

SUBRAHMANYAM, Sanjay. Connected histories: notes towards a reconfiguration of early modern Eurasia. In: LIEBERMAN, V. Beyond binary histories. The University of Michigan Press, 1999, p.289-316.

SZMRECSÁNYI, Tomás. História Econômica, Teoria Economica e História Aplicada. Revista de Economia Política, vol.12. n.3 (47), julho-setembro, 1992, p.131.

TESSITORE, Viviane. Fontes da riqueza pública: tributos e administração tributária na provínciaProvíncia de São Paulo (1832-1892). Dissertação (Mestrado), USP. São Paulo, 1995.

TRILlO, Mauricio Tenório. Artilugio de la Nación Moderna: México nas exposições universais 1880-1930. México: Editorial Fondo de Cultura Económica, 1998.

TURAZZI, Maria Inez. A euforia do progresso e a imposição da ordem: a engenharia, a indústria e a organização do trabalho na virada do século XIX ao XX. Rio de Janeiro: COPPE; São Paulo: Marco Zero, 1989.

URICOECHEA, Fernando. O Minotauro Imperial. A burocratização do Estado Patrimonial brasileiro no século XIX. Rio de Janeiro/São Paulo: Difel, 1978.

VIDAL, Diana G. A invenção da modernidade educativa: circulação internacional de modelos pedagógicos, sujeitos e objetos no Oitocentos. In: CURY, Cláudia Engler; 
MARIANO, Serioja (Orgs.). Múltiplas visões: cultura histórica no oitocentos. João Pessoa: Editora Universitária da UFPB, 2009. p. 37-54.

VIDAL, Diana G. O Museu Escolar Brasileiro: Brasil, Portugal e França no âmbito de uma história conctada (final do século XIX). In: FERNANDES, Rogerio, LOPES, Alberto \& FARIA FILHO, Luciano (Org.) Para a compreensão histórica da infância. Porto: Campo das Letras, 2006.

VIDAL, Diana Gonçalves. Faces da obrigatoriedade escolar: lições do passado, desafios do presente. In: Diana Vidal, Elizabeth Sá e Vera Gaspar da Silva. (Orgs.). Obrigatoriedade escolar no Brasil. Cuiabá: EdUFMT, 2013, v. 1, p. 11-20.

VIDAL, Diana Gonçalves; FARIA FILHO, Luciano Mendes de. As lentes da história: estudos de história e historiografia da educação no Brasil. São Paulo: Autores. Associados, 2005, 139 p. (Coleção Memória da Educação).

VIDAL, Diana Gonçalves; GASPAR, V. Por uma história sensorial da escola e da escolarização. In: CASTRO, Cesar Augusto de. (Org.). Cultura material escolar: a escola e seus artefatos (MA, SP, PR, SC e RS, 1870-1925). São Luís: Café \& Lápis, 2011, v. 1.

VIDAL, Diana. Culturas escolares: estudo sobre práticas de leitura e escrita na escola pública primária (Brasil e França, final do século XIX). Campinas, São Paulo: Autores Associados, 2005, p.39 - (Coleção Memória e Educação.

VISCONDE DE URUGUAI (Paulino Soares de Souza). Ensaio sobre o Direito Administrativo. Rio de Janeiro, 1862.

VITOR, Manoel. São Paulo de Antigamente. Grafisyl Editora Gráfica Ltda., 1976.

WEBER, M. Ensaios de Sociologia. Rio de Janeiro: Guanabara, 1982.

\section{Fontes}

GUILLOT, Émile. Édifices Publics pour villes et villages. Paris: H. Dunod et E. Pinat, Editeurs, 1912.

MÉRY, H; GENÈVRIER, J. Traité d'Hygiène. VI - Hygiène Scolaire. Paris: Librairie Baillière et Fils, 1914.

ACERVO HISTÓRICO DA CAETANO DE CAMPOS EM SÃO PAULO. Correspondência da Diretoria (1893-1895).

BRASIL. Lei n.3.129, de 14 de outubro de 1882 - Regula a concessão de patentes aos autores de invenção ou descoberta industrial. Secretaria de Estado dos Negocios da Agricultura, Commercio e Obras Publicas, 1882.

SAO PAULO. Lei n. 3.129, de 14 de outubro de 1882, Art. $3^{\circ}$. 
SAO PAULO. Anuário do Ensino do Estado de Sáo Paulo de 1907/1908.

Secretaria da Inspetoria Geral da Instrução Pública. Relatório apresentado pelo Inspetor Geral da Instrução Pública, Diogo de Mendonça, em 31 de dezembro de 1870, anexo ao Relatorio apresentado á Assembléa Legislativa Provincial de S. Paulo pelo Presidente da Provincia, o Exm. Sr. Dr. Antonio da Costa Pinto Silva, no dia 5 de fevereiro de 1871. S. Paulo, Typ. Americana, 1871.

SÃO PAULO. Relatório do Presidente da Província Conselheiro José Joaquim Fernandes Torres. Typografia Imparcial de Joaquim Roberto de Azevedo Marrques. São Paulo, 1859.

SÃO PAULO. Relatório sobre o estado e necessidades da Instrucção Publica da Província de S. Paulo, do ano de 1884 apresentado ao Exm. Snr. Presidente da Provínca no ano de 1884, pelo Inspetor Geral. São Paulo, Typ King a Vapor, 1885.

SÃO PAULO. Mensagem do Presidente do Estado Fernando Prestes de Albuquerque enviada ao Congresso Legislativo em 07 de abril de 1899. São Paulo: Typografia do Diário Oficial, 1899.

SÃO PAULO. Decisões da Presidência, anexo ao Relatorio apresentado á Assembléa Legislativa Provincial de São Paulo pelo presidente da Provincia, dr. Pedro Vicente de Azevedo, no dia 11 de janeiro de 1889. São Paulo, Typ. a Vapor de Jorge Seckler \& Comp., 1889.

\section{Biblioteca Nationale de France}

DELAGRAVE. Catalogue Spécial de Mobilier Scolaire et Materiel d'enseignement conformes aux Reglements et Programmes Officiels.Paris: Librairie Ch. Delagrave, 1892. Deuxieme Partie.

Disponível em:_gallica.bnf.fr / Bibliothèque Nationale de France

DELAGRAVE. Catalogue Spécial de Mobilier, Materiel Scolaire et accessories de classes.Paris: Librairie Ch. Delagrave, 1890.

Disponível em:_gallica.bnf.fr / Bibliothèque Nationale de France.

LES FILS D’ÉMILE DEYROLLE. Fabrique de Mobilier et de Materiel Scolaire. Paris, 1898.

EXPOSITION DE 1878. Le Mobilier Scolaire à l'Exposition Internationale de 1878. Disponível em:_gallica.bnf.fr / Bibliothèque Nationale de France.

NARJOUX, Félix (1836?-1891). Les écoles publiques en France et en Angleterre: construction et installation, documents officiels, services extérieurs, services intérieurs, salles d'asile, mobilier scolaire, services annexes. Paris: $V^{\mathrm{e}}$. A. Morel et $\mathrm{C}^{\mathrm{ie}}$, LibrairesÉditeurs, 1877.

Disponível em:_gallica.bnf.fr / Bibliothèque Nationale de France.

NARJOUX, Félix. Règlement pour la construction et l'ameublement des maisons d'école... arrêté par le conseil supérieur de l'instruction publique et promulgué par arrêté 
ministériel du 17 Juin 1880. Extrait de la "Revue Pédagogique". Paris: Librairie Ch. Delagrave, 1881.

Disponível em:_gallica.bnf.fr / Bibliothèque Nationale de France.

P. GARCET \& NISIUS. Mobilier Scolaire et Matériel d'Enseignement. Catalogue. Paris, 1882.

BULLETIN OFFICIEL DE L'EXPOSITION UNIVERSELLE DE 1889. V. 1. Disponível em: URL permanente: http://cnum.cnam.fr/redir?FOLXAE16.1

BULLETIN OFFICIEL DE L'EXPOSITION UNIVERSELLE DE 1889. V. 2. Disponível em: URL permanente: http://cnum.cnam.fr/redir?FOLXAE16.2

BULLETIN OFFICIEL DE L'EXPOSITION UNIVERSELLE DE 1889. V. 3. Disponível em: URL permanente: http://cnum.cnam.fr/redir?FOLXAE16.3

CONGRÈS INTERNATIONAL DE LA PROPRIÉTÉ INDUSTRIELLE tenu à Paris du 3 au 10 août 1889. Disponível em: URL permanente:

http://cnum.cnam.fr/redir?8XAE332.8

CONGRÈS INTERNATIONAL DE L'ENSEIGNEMENT PRIMAIRE tenu à Paris du 12 au 16 août 1889.

Disponível em: URL permanente : http://cnum.cnam.fr/redir?8XAE331.2

CONGRÈS INTERNATIONAL D'HYGIÈNE, Paris, 1878. Organisation du congrès. Séances plénières au Palais du Trocadéro.

Disponível em: URL permanente : http://cnum.cnam.fr/redir?8XAE245.1

CONGRÈS INTERNATIONAL D'HYGIÈNE, Paris, 1878. Organisation du congrès. Séances plénières au Palais du Trocadéro.

Disponível em: URL permanente : http://cnum.cnam.fr/redir?8XAE245.2

EXPOSITION INTERNATIONALE DE CHICAGO EN 1893. Rapports. Comité 33. Education et enseignement.

Disponível em: URL permanente : http://cnum.cnam.fr/redir?8XAE388

LIBRAIRIE HACHETTE ET CIE. Exposition universelle de 1889.

Disponível em: gallica.bnf.fr / Bibliothèque Nationale de France

REVUE TECHNIQUE DE L'EXPOSITION UNIVERSELLE DE CHICAGO 1893. Volume 4. La mécanique générale à l'exposition de Chicago. Moteur à vapeur, à gaz, à air hydraulique. Pompes grandes installations mécaniques.

Disponível em: URL permanente : http://cnum.cnam.fr/redir?8XAE399.4

\section{Instituto Histórico e Geográfico Brasileiro}

RIO DE JANEIRO. Primeira Exposição Pedagógica do Rio de Janeiro. Typographia Nacional, 1884. Relatório do Jury. Grupo 3. p. 23-46. 
RIO DE JANEIRO, Exposição Pedagógica, 1883. Conferências effectuadas na exposição pedagógica. Rio de Janeiro: Imprensa Nacional, 1884.

BREWER, Eben. Vienna Universal Exhibition de 1873. Offical catalogue of the American Department. Edited by Eben Brewer for the United States Commision. Printed and Published by J. M. Johnson \& Sons, p.99-114.

\section{Arquivo do Estado de São Paulo}

APESP. Série Manuscritos. Secretaria do Interior. $3^{\text {a }}$. Secção. Escola Normal - Caixa 530 - Ano 1892. Ordem 7135.

APESP - Série Manuscrito - Escola normal de São Paulo; 1849-1855; 1886-1989/ Ordem - 5131. Grupo - Gestão Financeira; Série - Propostas orçamentárias.

APESP. Série Manuscritos. Escola Normal de São Paulo. Ano 1886-1889. Caixa 3 Grupo Gestão - Série Propostas Orçamentárias. Ordem C05131.

APESP. Série Manuscritos. Secretaria do Interior. Escola Normal. Ano 1892. Ordem 7135.

APESP, Secretaria do Interior, $3^{a}$. Secção, Escola Normal - ano 1892 - Ordem - 7135 Série manuscritos.

APESP. Série Instrução Pública, lata 5, n. de Ordem 4917.

APESP. Série Manuscritos, Escola Normal de São Paulo, 1849-1877, caixa 1, ordem 5129.

APESP. Série Correspondência, Escola Normal de São Paulo, 1876-1895, caixa 1.

APESP. Correspondência do Governo com a Instrução Pública - Ordem E01430

APESP. Correspondência do Governo com a Escola Normal (1892) - Ordem E 01170

APESP. Ofícios do Governo para o Inspetor da Instrução Pública (1894-1896) Ordem C04992

APESP. Ofícios do Governo para o Inspetor da Instrução Pública (1898-1902) Ordem C04993

APESP. Ofícios do Ensino Particular (1862 - 1885). Ordem 5010. Caixa 1

APESP. Minutas - Atos Diversos (1876 - 1877) Ordem C 07704

APESP. Livro de Moveis e Utensis (Distribuição de 1854-1872) Ordem 1124

APESP. Livro de "Sahidas" dos Grupos Escolares (1901) Ordem 2287 
APESP. Secretaria do Interior, Escola Normal (1892). Ordem 7135

APESP. Secretaria do Interior, Relatórios Diversos (1897). Ordem 7037

APESP. Secretaria do Interior, Escolas Complementares (1897-1904) Ordem 6927

APESP. Relatório do Presidente da Província de São Paulo - 1884 a 1887

APESP. Relatório sobre o estado de necessidade da Instrução Pública da Província de São Paulo apresentado pelo inspetor geral (1886).

\section{Acervo Histórico Caetano de Campos, em São Paulo}

Livro de Correspondência da Diretoria da Escola Normal da Capital (1893-1895);

Livro de Inventário da Escola Modelo (1894);

Livro de Inventário Geral (1895);

Livro de Oficios da Diretoria (1899-1900);

Livro de Registro de Correspondências do Diretor (1877-1893);

Correspondência Passiva - Ofício do Governo do Estado de São Paulo à Diretoria da Escola Normal (1883-1891).

Catálogos Émile Deyrolle (1910, 1914, outro sem data).

Objetos tridimensionais (carteiras escolares, armários de livros, moedas do Brasil - de 1851 a 1949, balanças, sinetas, canetas de penas, caixa com penas de aço para escrever, mata-borrão, jogos para Jardim da Infância).

Relatórios do Diretor da Escola Normal (1893, 1895, 1896), nos quais se observam plantas arquitetônicas da escola e inventários de bens.

\section{Arquivo Nacional}

Arquivo Nacional. Fundo/Coleção: Privilégios Industriais (PI) - Notação: PI 8471.

Arquivo Nacional. Fundo/Coleção: Privilégios Industriais (PI) - Notação: PI 6519.

Arquivo Nacional. Fundo/Coleção: Privilégios Industriais (PI) - Notação: PI 7155.

Arquivo Nacional. Fundo/Coleção: Privilégios Industriais (PI) - Notação: PI 7194.

Arquivo Nacional. Fundo/Coleção: Privilégios Industriais (PI) - Notação: PI 6377.

Arquivo Nacional. Fundo/Coleção: Privilégios Industriais (PI) - Notação: PI 4969. 
Arquivo Nacional. Fundo/Coleção: Privilégios Industriais (PI) - Notação: PI 1996.

Arquivo Nacional. Fundo/Coleção: Privilégios Industriais (PI) - Notação: PI 2026.

Arquivo Nacional. Fundo/Coleção: Privilégios Industriais (PI) - Notação: PI 426.

Arquivo Nacional. Fundo/Coleção: Privilégios Industriais (PI) - Notação: PI 1596.

Arquivo Nacional. Fundo/Coleção: Privilégios Industriais (PI) - Notação: PI 1343.

Arquivo Nacional. Fundo/Coleção: Privilégios Industriais (PI) - Notação: PI 2438.

Arquivo Nacional. Fundo/Coleção: Privilégios Industriais (PI) - Notação: PI 1624.

Arquivo Nacional. Fundo/Coleção: Privilégios Industriais (PI) - Notação: PI 1700.

Arquivo Nacional. Fundo/Coleção: Privilégios Industriais (PI) - Notação: PI 1770.

Arquivo Nacional. Fundo/Coleção: Privilégios Industriais (PI) - Notação: PI 8749.

Arquivo Nacional. Fundo/Coleção: Privilégios Industriais (PI) - Notação: PI 2925.

Arquivo Nacional. Fundo/Coleção: Privilégios Industriais (PI) - Notação: PI 2831.

Arquivo Nacional. Fundo/Coleção: Privilégios Industriais (PI) - Notação: PI 2832.

Arquivo Nacional. Junta Comercial. Ano - 1897; Livro 342; Registro 45181 - Charles Vautelet \& Cia.

Arquivo Nacional. Série Indústria e Comércio - IC ${ }^{3}$ 101. n.3567, 22 de abril de 1895.

Arquivo Nacional (Brasil). Coordenação de documentos Escritos. Equipe de documentos do Executivo e Legislativo. Coleção: Privilégios Industriais (PI): inventário analítico - conteúdo por notação / Equipe de documentos do Executivo e Legislativo; $2^{\mathrm{a}}$. ed. rev. - Rio de Janeiro : o Arquivo, 2013. 1.692 p.

Arquivo Nacional. Livro de Registro de firmas commerciais, na forma do art. 11 do Dec n. 916 de 24 de outubro de 1890. Junta Comercial da Capital Federal, 15 de janeiro de 1895.

Arquivo Nacional. Junta comercial. Ano - 1897; Livro 342, Registro - 45181 - Charles Vautelet \& Cia.

\section{Documentação do site Archive.org}

SHERWOOD, Geo \& C. W. A descriptive and illustrated catalogue of school furniture. Chicago: Tribune Cmpany's Book and Job Printing Establishment, 1864. 
RIANT, A. Hygiène Scolaire: Influence de 1'École sur la santé des enfants. Paris: Librairie Hachette \& Cie, 1874.

CAMERON, R. M. Catalogue of School Furniture \& Fittings for Board School. Edinburgh, s/d.

UNION SCHOOL FURNITURE COMPANY. Descriptive Catalogue of School Furniture and Supplies. Battle Greek, 1889.

BOBRICK, Gabriel A. Higienic Requirements of School Furniture. New York: Press of Exchange Printing, 1892.

JOSEPH L. ROSS. Illustrated Catalogue of Improved School, Church, and Vestry Furniture. Boston: Hollis \& Gunn, Book and Job Printers, 1872.

THE NATIONAL SCHOOL FURNITURE $\mathrm{C}^{\mathrm{O}}$. Illustrated Catalogue of New and Improved Styles of School and Church Furniture and School Apparatus. New York and Chicago, 1872.

WILLIAM O. HASKELL \& SON. Illustrated Catalogue of the Boston School Furniture. Manufactory. Boston, Mass., 1870.

EDWARD E. BABB E Co. Illustrated Catalogue of School Supplies. Boston, Mass., 1897-1898.

A. G. WHITCOMB. Illustration of Improved School Furniture. $3^{\mathrm{a}}$. Ed. Boston, Mass., 1875. Established in 1844

LES FILS D’ÉMILE DEYROLLE. Mobilier et Materiel Scolaire. Paris, 1925.

STERLING SCHOOL FURNITURE C ${ }^{\circ}$. Price List of School, Churche, Court House, and Office Furniture. Albany, New York, 1875.

G. A. BOBRICK. School Furniture. A traetise on its construction in compliance with higienic requirements. Boston, Mass., 1887.

J. A. BANCROFT \& $\mathrm{C}^{\mathrm{o}}$. Descriptive and Illustrated Catalogue of School Furniture, Apparatus, Globes, Maps \& C. Philadelphia.

SAMUEL WALES, JR. The guide: A description of the modern school furniture. Boston, 1855.

J. GEORGE HODGINS, LL.D. The school house: its architecture, external and internal arrangements. Toronto: Copp, Clark \& $\mathrm{C}^{\mathrm{o}}$., Printers, 1876.

MICHEL LÉVY. Traité d'hygiène publique et privé. $7^{\mathrm{a}}$. Ed. Paris: Librairie J.B. Baillière et Fils, 1879. Tome Second.

UNION SCHOOL FURNISHING C ${ }^{0}$. School Furniture and Supplies. Catalog n. M-29. Chicago, Illinois, 1893. 
CHARLES GINDRIEZ. International Exhibitions. Paris-Philadelphia-Vienna. New York: A. S. Barnes \& $C^{\circ} ., 1878$.

W.P. BLAKE; HENRY PETTIT. Rapports on the Vienna Universal Exhibition 1873. Made to the U.S.Centennial Commission. Philadelphia, 1873.

\section{Biblioteca Nacional Digital Brasil}

Almanak Administrativo, Mercantil e Industrial do Rio de Janeiro, 1891.

Almanak Administrativo, Mercantil e Industrial do Rio de Janeiro, 1893.

Almanak Administrativo, Mercantil e Industrial do Rio de Janeiro, 1894.

Almanak Administrativo, Mercantil e Industrial do Rio de Janeiro, 1895.

Almanak Administrativo, Mercantil e Industrial do Rio de Janeiro, 1896.

Almanak Administrativo, Mercantil e Industrial do Rio de Janeiro, 1897.

Almanak Administrativo, Mercantil e Industrial do Rio de Janeiro, 1898.

Almanak Administrativo, Mercantil e Industrial do Rio de Janeiro, 1899.

Almanak Administrativo, Mercantil e Industrial do Rio de Janeiro, 1902.

Almanak Administrativo, Mercantil e Industrial do Rio de Janeiro, 1903.

Almanak Administrativo, Mercantil e Industrial do Rio de Janeiro, 1908.

Almanak Administrativo, Mercantil e Industrial do Rio de Janeiro, 1909.

Almanak Administrativo, Mercantil e Industrial do Rio de Janeiro, 1910.

Almanak Administrativo, Mercantil e Industrial do Rio de Janeiro, 1917.

Almanak Administrativo, Mercantil e Industrial do Rio de Janeiro, 1923.

JORNAL. O vulgarisador, n.29 - 30 de out. de 1878.

\section{Sites}

Revista A Cigarra, edição de 9 de novembro de 1916. Extraído do site http://martaiansen.blogspot.com.br/2012/09/moveis-escolares-antigos.html.

http://www.crmariocovas.sp.gov.br/txt_html/mem/obj/obj_a/f08_04.html. 
http://tokdehistoria.wordpress.com/tag/carteiras-escolares-da-decada-de-1920/

http://www.portalan.arquivonacional.gov.br/media/Privil\%C3\%A9gios\%20Industriais \%20\%20Conte\%C3\%BAdo\%20abril\%2013.pdf

http://www.arquivoestado.sp.gov.br/guia_ficha.php?fundo=123\&palavra $=$ acessado em $21 / 12 / 2013$

http://uj.novaprolink.com.br/doutrina/2873/A_LEGISLACAO_DE_PROPRIEDADE_ INTELECTUAL_EM_VIGOR 
ANEXOS 


\section{ANEXOS DO CAPÍTULO 2}

\section{Anexo 1}

\section{Secretaria da Escola Normal da Capital}

São Paulo, 21 de Novembro de 1894.

$\mathrm{N}^{\circ} .110$

Cidadão

Sendo necessária a aquisição dos instrumentos constantes da relação junto, na importância de frs. 4.720 segundo os preços extraídos do catálogo da "ancienne Maison Rousseau", para o ensino de mecânica e de astronomia elementar nesta Escola, venho pedir-vos que vos digneis providenciar no sentido de ser feita a referida aquisição ou que me autorizeis a fazer diretamente a encomenda.

Saúde e Fraternidade,

Ao Cidadão Diretor Cesário Motta Junior. D.D. Secretario do Estado dos Negócios do Interior.

O Diretor, Gabriel Prestes

Fonte: Acervo Histórico da Caetano de Campos em São Paulo. Correspondência da Diretoria (18931895) - Ofício n. 110

\section{Anexo 2}

\section{Secretaria da Escola Normal da Capital \\ S. Paulo, 4 de Dezembro de 1894.}

Exmo. Sr. Charles Vautelet.

$\mathrm{N}^{\mathrm{o}} .115$

Acompanha a presente uma lista de instrumentos de mecânica e astronomia necessária para a Escola Normal da Capital de S. Paulo.

Peço-vos que vos encarregueis do fornecimento dos instrumentos constantes da mesma, o mais breve que for possível, nas condições das outras encomendas anteriormente feitas, recomendando porém que o "Theodolito de Gurley" seja americano, que corresponde ao numero 8 do catalogo da casa W.L.E. Gurley (Troy Inglaterra).

Observação: Acompanha a presente carta a lista de instrumentos a que se refere o oficio $\mathrm{n}^{\circ} .110$.

Assinado, O Diretor, G. Prestes

Fonte: Acervo Histórico da Caetano de Campos em São Paulo. Correspondência da Diretoria (1893-1895)

- Ofício n. 115 


\section{ANEXOS DO CAPÍTULO 3}

\section{Anexo n. 3}

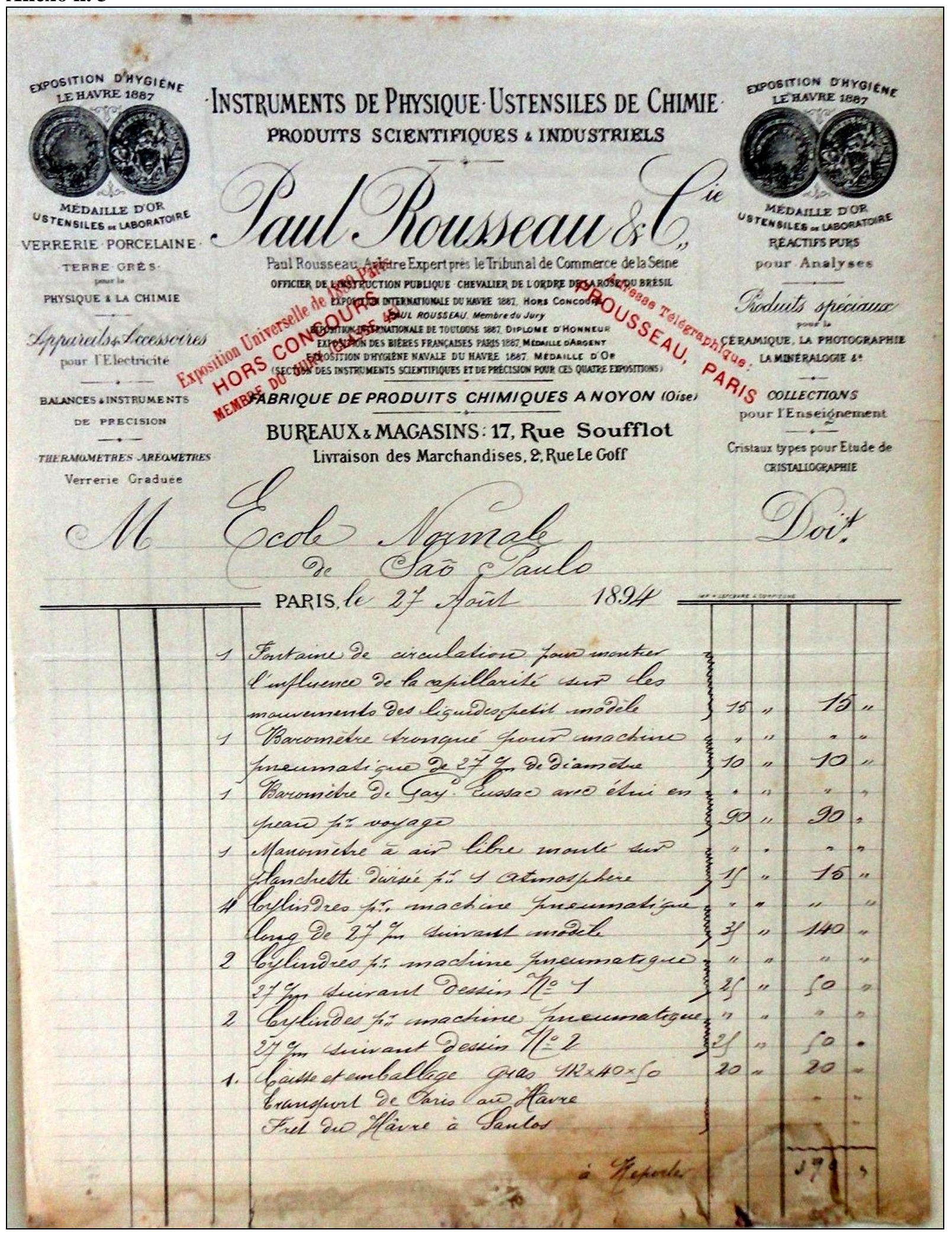

Fonte: APESP. Série Manuscritos. Secretaria do Interior. $3^{\mathrm{a}}$. Secção. Escola Normal - ano 1892. Ordem 7135 
294

Anexo n. 4

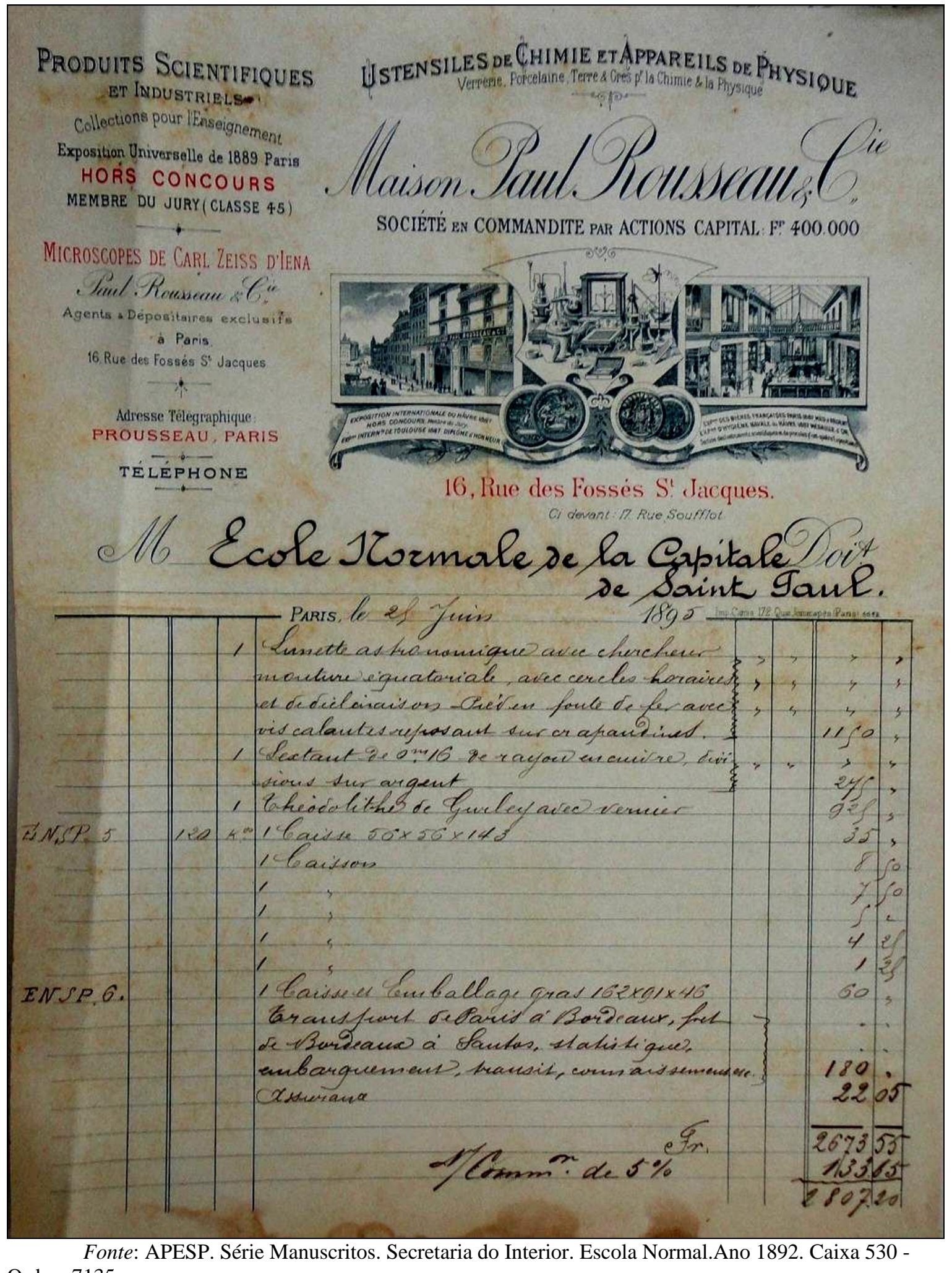

Ordem 7135 


\section{Anexo n.5}

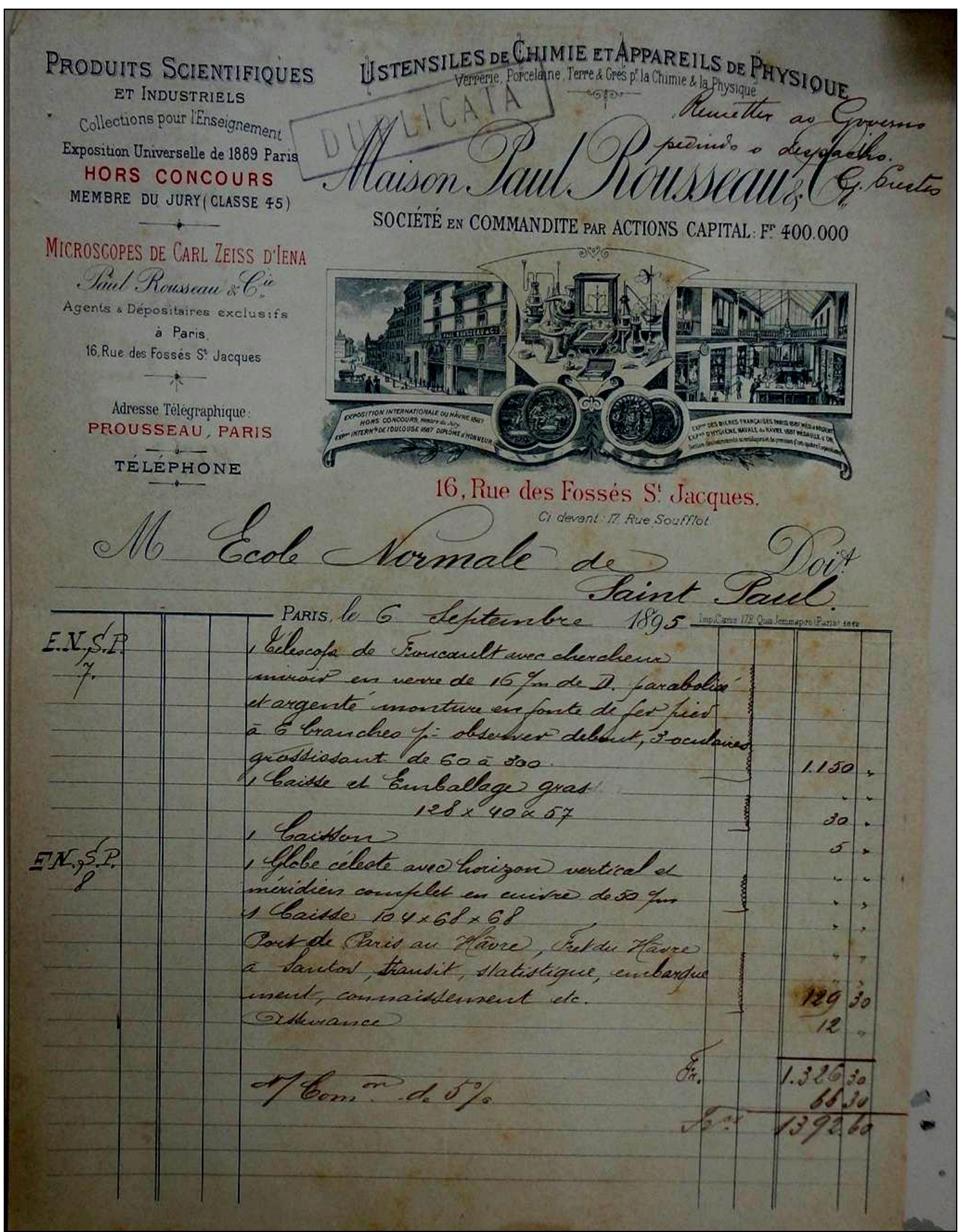

Fonte: APESP. Série Manuscritos. Secretaria do Interior. Escola Normal.Ano 1892. Caixa 530 Ordem 7135 


\section{Anexo n.6}

\section{SECRETARIA DA ESCOLA NORMAL}

São Paulo, 1 de junho de 1895

n.72

Remeto-vos o original da factura dos srs. PAUL ROUSSEAU E COMP. de Paris e conhecimento de um volume contendo material escholar fornecido a esta Eschola por aqueles srs.

Peço-vos a expedição das necessárias ordens a fim de que seja despachado em Santos, com a possível brevidade, o referido volume.

Saúde e fraternidade,

Ao doutor Cesario Motta Junior Secretario dos Negocios Interiores

$\mathrm{O}$ director Gabriel Prestes

Enviou-se o conhecimento á Recebedoria de Rendas em Santos 11-6-1895 Fonte: APESP. Série Manuscritos. Secretaria do Interior. Escola Normal.Ano 1892. Caixa 530 Ordem 7135

\section{Anexo n. 7}

\section{SECRETARIA DA ESCOLA NORMAL DA CAPITAL}

São Paulo, 9 de outubro de 1895

Oficio n. $105-$

Cidadão,

Tenho a honra de vos enviar o conhecimento e a Factura de duas caixas, em duplicata, vindas pelo VAPOR "CALIFORNIA" com material de ensino encomendado para esta escola com autorização do governo. Cumpre-me declarar, para vosso conhecimento, que essas duas caixas vindas pelo "CALIFORNIA" trazem o resto das encomendas feitas em 4 de dezembro de 1894, das quaes já foram recebidas e pagas duas remessas trazidas pelos vapores "MATAPAN" e "BELLANOCK".

Peço-vos que vos digneis providenciar no sentido de ser feito o respectivo despacho na Alfandega e remessa para esta Capital.

Saúde e Fraternidade, Ao cidadão doutor Alfredo Pujol - Secretário de Estado dos Negócios do Interior O director - Gabriel Prestes. 


\section{Anexo n.8}

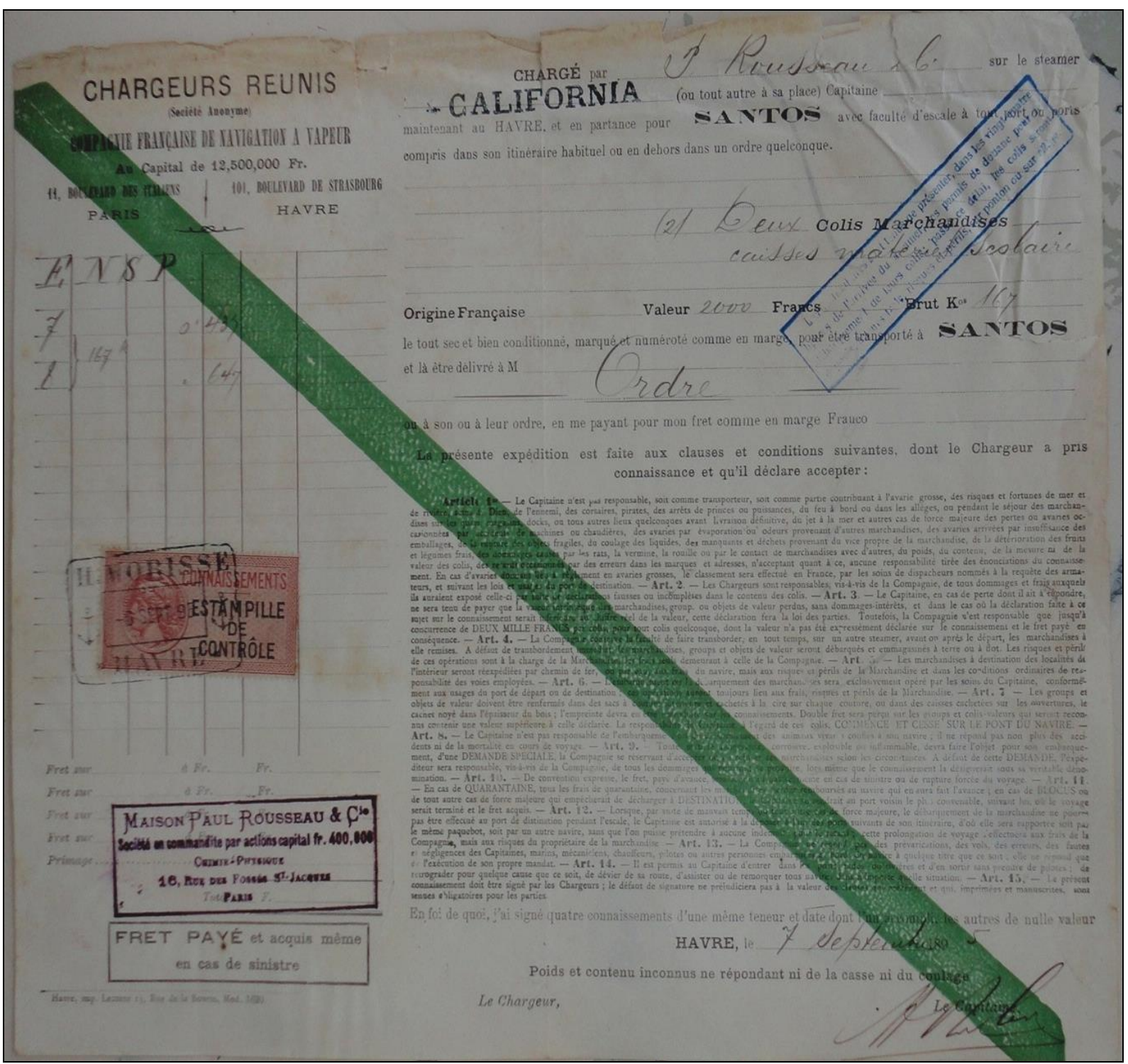

Ordem 7135.

Fonte: APESP. Série Manuscritos. Secretaria do Interior. Escola Normal.Ano 1892. Caixa 530 - 
Anexo n.9

(art. 200:)

Navegação, Grupo $8 .^{\circ}$

Art. 2002

\section{Austro-Fungarian Iloyd Steam Navigation Com- pany de Trieste}

Agentes no Rio de Janeiro.

John Bradshaw \& C., r. Quitanda, 131.

Séde da Companhia em Trieste.

Viagens de Trieste a Santos com escalas por Gibraltar, Bahia, Pernambuco e Rio de Janeiro.

\section{Art. 2003}

Charggours IRéumis, Gociedade Almonyma. COMPANHIA FRANCEZA DE NAVEGaCG̃̃o A VAPOR.

Rua $1^{\circ}$ de Março, 13.

Agente geral F. MAZON.

Serviço regular para o Brazil e Rio da Prata pelos vapores de $1^{*}$ classe:

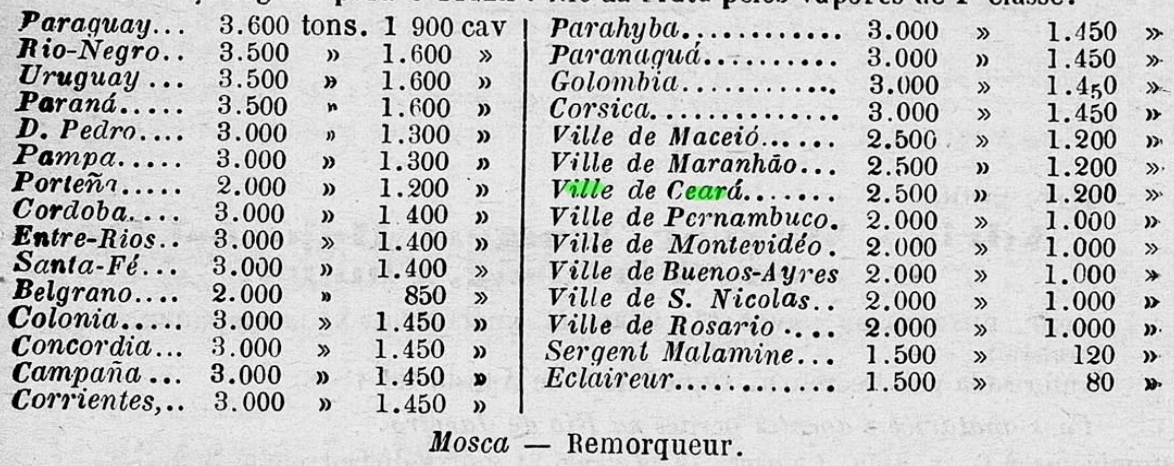

Serviço hebdomadario.

Sahidas aos sabbados do Havre para:

Lisboa, Pernambuco, Maceió, Bahia, Rio de Janeiro e Santos.

O vapor que effectua a quarta sahida mensal do Havre, toca regularmente em Maceió na ida e na volta.

Comp. Brazileira de Navegaç̃o a Vapor
Rina Saude, 14 A.

(Vide neste grupo Lloyd Brazileiro art. 2029).

Art. 2004

Comp. de Cabotagem de S. Joāo da Barra

Séde, em S. João da barra.

Agencia, no Rio de Janeiro, r. Saude, 38.

Tem sempre navios para a conducção de cargas entre o Rio de Janciro, S. João da Barra, Campos, Carangola e vice-versa.

Art. 2005

Comp. Cannl da Lagann a Porto-Aleggro
Garantida pelo Estaclo.

Capital. . . . . . . . . . 4000000\$000

$145:$

Fonte: Almanak Administrativo, Mercantil e Industrial do Rio de Janeiro, 1891, p.1452 
Anexo n. 10

1708

NOTARILIDADES COMMERCIAES DO DISTRICTO FEDERAL

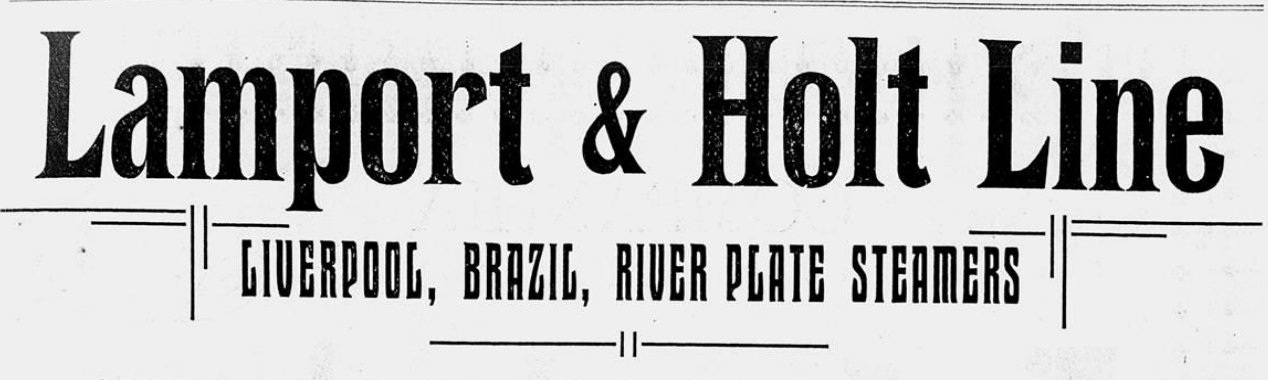

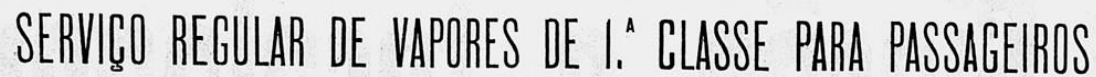
ENTRE

\section{Nova-York, Brazil e Rio da Prata}

Serviço quimzenal de vapores rapidos para carga com excellentes accommodações para um limitado mumero de passageiros de $1 .{ }^{a}$ classe, de GLASGOW, MANCHESTER e LIVERPOOL para os

\section{PORTOS DO BRAZIL}

Serviço separado e quinzenal de carga de ANTUERPIA e LONDRES

Todos estes vapores occeitam carga em transito para PARANAGUá, S. FRANCISCO Do SLL, S. ${ }^{\text {ta }}$ Catharina, rio girande do sil, pelotas e porto alegre

Serviço reģular de carşa para NOVA ORLEANS

FROTA DA GOMPANHIA

\begin{tabular}{|c|c|c|c|c|c|c|c|c|c|c|c|}
\hline & Ton. & & Ton. & & Ton. & & Ton. & & Ton. & & Ton. \\
\hline Varsari.... & 12.000 & Raeburn... & 7.370 & Rembrandt.. & 6.708 & V. de Paris: & 6.300 & Byron.... & 5.192 & Bellaura... & 4.050 \\
\hline Veronese .. & 11.745 & Cavour..... & 7286 & Romney ... & 6.702 & V. du Havre & 6.300 & Tennyson .. & 5.192 & Bellanock.. & 4.000 \\
\hline Voltaire... & 11.000 & Tintoretto .. & 6.978 & Canova..... & 6.680 & Bellagio ... & 6.030 & Virgil..... & 5.182 & Ballena.... & 4.000 \\
\hline Verdi..... & 8.500 & Titian .... & 6987 & Carvantes.. & 6.560 & Bellevue .... & 5.731 & Horace .... & 5.149 & Bellenden.. & 3985 \\
\hline Rossetti... & 8.560 & Thespis ... & 6.760 & Colbert.... & 6.500 & Bellailsa ... & 5.620 & Phidias.... & 4.118 & Newton.... & 3.936 \\
\hline Canning... & 7876 & Raphael ... & 6.721 & Calderon.... & 6.372 & Bellasco ... & 5.620 & Homer..... . & 4.232 & Multon .... & 3:931 \\
\hline Beilgrano.. & 7.400 & Terence ... & 6.710 & Camoens... & 6.372 & Sallust.... & 5.576 & Bellarden .. & 4050 & Chausser.... & 3.880 \\
\hline
\end{tabular}

\section{AGENTES}

Pernambuco. Julius von Sohsten.

Bahia ...... F. Benn \& Son.

Victoria .... Hard Rand \& Co.

Santos .... F. S. Hampshire \&. Co., Lt.

Paranagua. Guimarães \& Co.
S. ta Gatharina .... Estevão Pinto da Luz;: Rio Grande do Sul José da Silva Fresteiro \& Co.

Porto Alegre.... C. Booth.

Monte Video..... A. Real de Azua.

Buenos Ayres.... T. T. Boadle \&. Co.

Rio de Janeiro: Norton Megaw \& Co. Ltd. Rua 1.' de Março, 11a, 1.' andar

Fonte: Almanak Administrativo, Mercantil e Industrial do Rio de Janeiro, 1910, p.1708 
Anexo n.11

Diretoria da Escola Normal de São Paulo,
em 24 de março de 1891

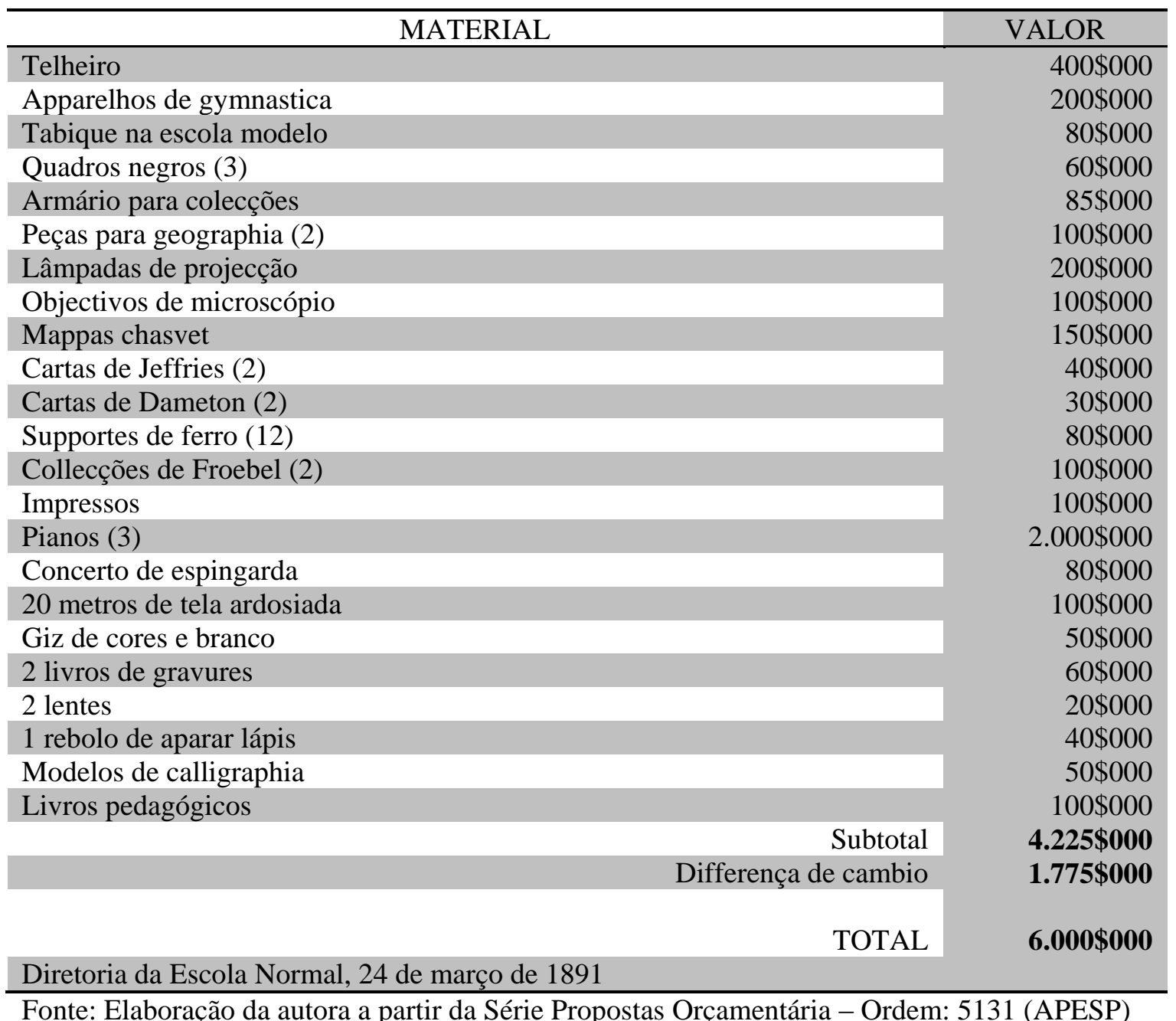


Anexo n.12

\begin{tabular}{|c|c|}
\hline & $\begin{array}{l}\text { Ao Thesouro Provincial para informar } \\
\text { Palacio do Governo de S. Paulo, } 3 \text { de abril de } 1883 \\
\text { Tendo sido autorizado pelo Exmo. Snr. Conselheiro Francisco de Soares Carvalho } \\
\text { Brandão a fazer a compra dos moveis necessários á Escola sob minha direcção, rogo a V. Exa. } \\
\text { que se digne dar as ordens necessárias para que, pelo Thesouro Provincial, seja posta á minha } \\
\text { disposição a quantia de um conto e quinhentos mil reis (1.500\$000) para ser applicada á } \\
\text { compra dos ditos moveis, e também a compra e encadernação de livros portuguezes destinados } \\
\text { á biblioteca da dita Eschola } \\
\text { Deus guarde a V. Exa. } \\
\text { São Paulo, } 4 \text { de abril de } 1883 \\
\text { Ilmo. Exmo. Snr. Visconde de Itu, } \\
\text { Vice-Presidente da Província. } \\
\text { O Diretor da Escola Normal } \\
\text { Dr. Paulo Bourroul }\end{array}$ \\
\hline
\end{tabular}

Fonte: Série Propostas Orçamentária - Ordem: 5131 (APESP)

\section{Anexo n.13}

\section{ESCOLA NORMAL DE SÃO PAULO \\ em 5 de março de 1883}

Acuso o recebimento do officio de V.Exa. datado de 27 de fevereiro em que V.Exa. me declara que pelo Thesouro da Fazenda foram expedidas as necessárias ordens à Alfândega de Santos para que conceda despacho livre a 13 caixotes, contendo apparelhos chimicos, material escolar, cartas e livros destinados á instrução pública desta província.

Resta-me pedir a V.Exa. que se digne dar ao director da meza de rendas da Alfândega de Santos as necessárias ordens para que sejam os referidos caixotes despachados e dirigidos a esta capital.

Conselheiro Francisco de Carvalho Soares Brandão

Presidente da Província de São Paulo

O director da Escola Normal

Paulo Bourroul.

Fonte: (Série Manuscrito - Escola normal de São Paulo; 1849-1855;

1886-1989/ Ordem - 5131 Grupo Gestão Financeira; Série - Propostas orçamentárias). 
Anexo n.14

\section{THESOURO PROVINCIAL}

Em 24 de abril de 1883

O Dr. Paulo Bourroul, diretor da Escola Normal, pede no ofício junto que seja posta á sua disposição a quantia de 1:500\$000 que foi autorisado a dispender com a acquisição de moveis para aquella escola.

Informando o assunto, tenho a honra de declarar a V. Exa. que, sendo determinado, pode realizar-se o pagamento da despesa de que se trata, directamente aos fornecedores, e em vista de contas e recibos.

\section{Deus guarde a V. EXa.}

Exmo Snr. Visconde de Itú Digmo. Vice-presidente da Província

$\mathrm{O}$ inspetor Joaquim Cardozo

Fonte: (Série Manuscrito - Escola normal de São Paulo; 1849-1855; 1886-1989/ Ordem - 5131 Grupo Gestão Financeira; Série - Propostas orçamentárias).

\section{Anexo n.15}

\section{ESCOLA NORMAL DE SÃO PAULO,} em 24 de outubro de 1882

Acuso a recepção do officio de V.Exa. datado de hontem, em que encarrega-me da compra, durante minha estada em Paris, dos apparelhos necessários para o ensino da physica e chimica na escola normal, de obras pedagógicas para a biblioteca da mesma escola, e do estudo da organização de um museu pedagógico que V. Exa. pretende anexar á escola sob minha direção. Em resposta, declaro á V.Exa. que aceito, de muito bom grado e com muito prazer, a incumbência de que digna-se encarregar-me, para cumprimento da qual receberei a quantia designada, assignando, nessa ocasião, a respectiva fiança, como é de direito.

Terminando, cumpre-me agradecer a V.Exa., em nome da Escola Normal, o relevante serviço prestado por V.Exa. a causa da Instrução Publica.

\section{Ilm. E exmo. Sr. Cons. Francisco de Carvalho Soares Brandão Presidente da Provincia O diretor da Escola Normal Paulo Bourroul}

Fonte: APESP - (Série Manuscrito - Escola normal de São Paulo; 1849-1855; 1886-1989. Ordem - 5131/ Grupo - Gestão Financeira; Série - Propostas orçamentárias). 


\section{Anexo n.16}

\section{Paris, em 10 de janeiro de 1883}

Tenho a honra de passar às mãos de V. Exa. a lista do conteúdo de 9 caixas E.N. n. 1-9, e de 4 caixas ENP - n. 1-4. Ficão em meu poder para prestação de contas, as faturas originaes com os respectivos recibos. Os conhecimentos destas 13 caixas e das que ainda restam, serão enviadas directamente a V. Exa. pelos senrs. Pinto \& Braga, comissários desta praça.

Ao presidente da província Conselheiro Francisco do Carvalho Soares Brandão Diretor da Escola Normal Paulo Bourroul

Fonte: APESP. Série Manuscritos. Escola Normal de São Paulo. Ano 1886-1889. Caixa 3 Grupo Gestão - Série Propostas Orçamentárias. Ordem = C05131

\section{Anexo n.17}

Cidadão Dr. Director da Instrução Pública do Estado de São Paulo,

Em resposta ao officio sob n. 3 de 2 do corrente mez, em que me pedis o orçamento dos aparelhos e mais objectos para o ensino de physica e chimica, pedidos pelo Inspector do $9^{\circ}$ districto, remeto-vos junto a este a relação dos referidos objectos com os preços porque se podem obter atualmente $[\ldots]$

Como tenho relação directa com algumas casas na Europa, posso encarregar-me do fornecimento pelos preços cotados.

Saúde e Fraternidade José Eduardo de Macedo Soares.

Fonte: Série Manuscritos. Instrução Pública. Ofícios do Governo ao Inspetor Geral. Anos 1894-1896. Caixa 9/ Ordem - 4992 


\section{Anexo n.18}

\section{Secretaria da Escola Normal da Capital}

S. Paulo, 9 de outubro de 1894

$\mathrm{N}^{\circ} .92$

Cidadão.

Levo ao vosso conhecimento que o professor desta Escola, sr. Macedo Soares fez ao gabinete de física e laboratório de química o donativo dos seguintes objetos:

Um aparelho fotográfico de $1 \frac{1 / 2}{2}$ por $8 \frac{1}{2}$; com todos acessórios, tais como chassis, prensas, porta chapas curta etc.

Um Hydrotimetro de Bandet, completo.

24 vistas para lanterna mágica.

2 tractados de fotografia.

1 lamparina elétrica

1 grande caixa de reativos

Provetas, balões, copos para analises pipetas, porta pipetas diversos reativos quimicamente puros, e tubos para analises.

Este valioso donativo importa em quantia superior a 1:000\$000.

Para que o aparelho fotográfico possa ser convenientemente utilizado já providenciei no sentido de ser aproveitada uma das salas do pavimento subterrâneo para câmara escura, a qual servirá também para o estudo das leis de Ótica.

Saúde e fraternidade,

Ao Cidadão Doutor Cesário Motta Junior. D.D. Secretario do Estado dos Negócios do Interior.

O Diretor Gabriel Prestes

Fonte: Arquivo da Escola Normal Caetano de Campos

Correspondência da Diretoria de 1893 a 1895

\section{Anexo n.19}

\section{SECRETARIA DA ESCOLA NORMAL DA CAPITAL}

27 de outubro de 1894

Oficio n.103

Cidadão

Entre as diversas caixas vindas dos Estados Unidos da America do Norte com material de ensino para a escola modelo, anexa a esta, e que foram depositados em um dos cômodos do pavimento térreo do edifico desta escola, falta a de numero "330" - que, sendo informações do Dr. Lane, diretor da "Escola Americana", foi despachada com diversos objetos.

Peço-vos que vos digneis a providenciar no sentido de ser verificado se teria por equivoco ficado a referida caixa nos armários da Alfândega de Santos.

Ao cidadão Dr. Cesario Motta Junior. Secretário de Estado dos Negócios do Interior

O diretor

Gabriel Prestes

Fonte: APESP. Série Manuscritos. Secretaria do Interior. Escola Normal. Ano 1892. Ordem = 7135 
Anexo n.20

\section{Secretaria da Escola Normal}

S. Paulo, 15 de Dezembro de 1895.

N. ${ }^{\circ} 151$

Cidadão

Tenho a honra de enviar-vos a conta junta, relativo a importância da encomenda de moveis destinados à Escola Complementar Modelo, a que se refere o meu oficio n. ${ }^{\circ} 150$. Por essa nota verifica-se a existência de um saldo de 96 dólares em favor de H. Lane.

Peço-vos as necessárias ordens no sentido de ser posto a disposição do referido cidadão o saldo que existe a seu favor.

Saúde e fraternidade

Ao cidadão Doutor Alfredo Pujol.

D.D. Secretario dos Negócios do Interior.

O Diretor,

Gabriel Prestes

Fonte: Arquivo Histórico Caetano de Campos. Correspondência da diretoria - 1893 a 1895

Anexo n.21

Oficio n. 150

Secretaria da Escola Normal da Capital

16 de dezembro de 1895

Cidadão

Tenho a honra de enviar-vos com este as facturas e os respectivos conhecimento de 128 CAIXAS DE MÓVEIS ESCOLARES e apparelhos de ensino, destinado á escola modelo complementar anexa a esta a eschola, adquiridos nos ESTADOS UNIDOS por intermédio do dr. H. LANE E ORDEM DO GOVERNO.

Como vereis pelos conhecimentos juntos, essa encomenda foi expedida pelo VAPOR "PORT DARWIN" que já deve ter chegado a Santos.

Peço-vos autorizeis que o despacho dessa encomenda seja feito diretamente á escola normal, a fim de evitar que os volumes, que trazem a marca - Secretaria do Interior - se confundam com outros que o Governo tem em deposito para fornecimento das escholas públicas.

Ao cidadão Dr. Alfredo Pujol Secretário dos Negócios do Interior

$\mathrm{O}$ director

Gabriel Prestes

Fonte: APESP. Série Manuscritos. Secretaria do Interior. Escola Normal. Ano 1892. Ordem = 7135 
Anexo n.22

\section{Diretoria da Escola Normal de São Paulo. \\ Em 30 de Outubro de 1890}

$\mathrm{N}^{\circ} .88$

Cidadão.

Em oficio sob n ${ }^{\circ} .13$ deste ano, o ex-diretor desta Escola, Doutor Antonio Caetano de Campos, pediu autorização para fazer aquisição de material escolar e, em consequência de exigência do Tesouro do Estado, apresentou posteriormente com oficio sob $\mathrm{n}^{\circ} .27$ o respectivo orçamento, sendo afinal autorizado a fazer a referia aquisição pelo vosso oficio sob o $\mathrm{n}^{\circ} .7$ de 25 de Março do corrente ano.

Foram-me agora entregues pelo Diretor da Escola Americana e pela Casa Guarany diversos caixões com o referido material escolar e as contas do seu custo. Solicito, pois, que vos digneis ordenar o pagamento de Rs 1:923\$900 à Casa Guarany e Rs 372:600 ao sr. A. Waddul conforme as contas juntas

Saúde e Fraternidade,

Ao Exmo. Cidadão Dr. Americo Brasiliense Almeida de Mello. M.D. Presidente do Estado.

O Vice Diretor,

Doutor José E.C. de Sá e Benevides.

Fonte: Arquivo Histórico Caetano de Campos. Registro de Correspondência. Escola Normal Caetano de Campos

\section{Anexo n.23}

\section{ESCOLA MODELO}

19 de junho de 1893

Cidadão

Três anos de constate trabalho, debaixo de dificuldades quase insuperáveis, enfraqueceram muito as minhas forças physicas, de modo a tornar-se necessária uma mudança por alguns meses, si eu continuar em serviço das escolas publicas de são Paulo.

Alem disso, quero visitar a EXPOSIÇÃO DE CHICAGO, para estudar a exhibição das MOBILIAS, APPARELHOS, LIVROS E TRABALHOS DAS ESCOLAS DA FRANÇA, BELGICA, SUISSA E ALEMANHA E ESTADOS UNIDOS. Si tiver tempo, em meu regresso, desejo visitar as escolas de Portugal e da Alemanha. Preciso passar dous meses no mar, portanto não posso voltar antes de janeiro de 1894. Sendo feriado os meses de dezembro de janeiro, estarei ausente da eschola apenas cinco meses. Esta visita a meu pais natal é motivada por saúde e interesse da eschola, e para ela peço-vos licença de ausência até $1^{\circ}$ de fevereiro de 1894.

Márcia P. Browne

Ao cidadão Dr. Cesario Motta Ministro dos Negócios do Interior.

Fonte: APESP. Série Manuscritos. Secretaria do Interior. Escola Normal. Ano 1892. Ordem = 7135 


\section{Anexo n.24}

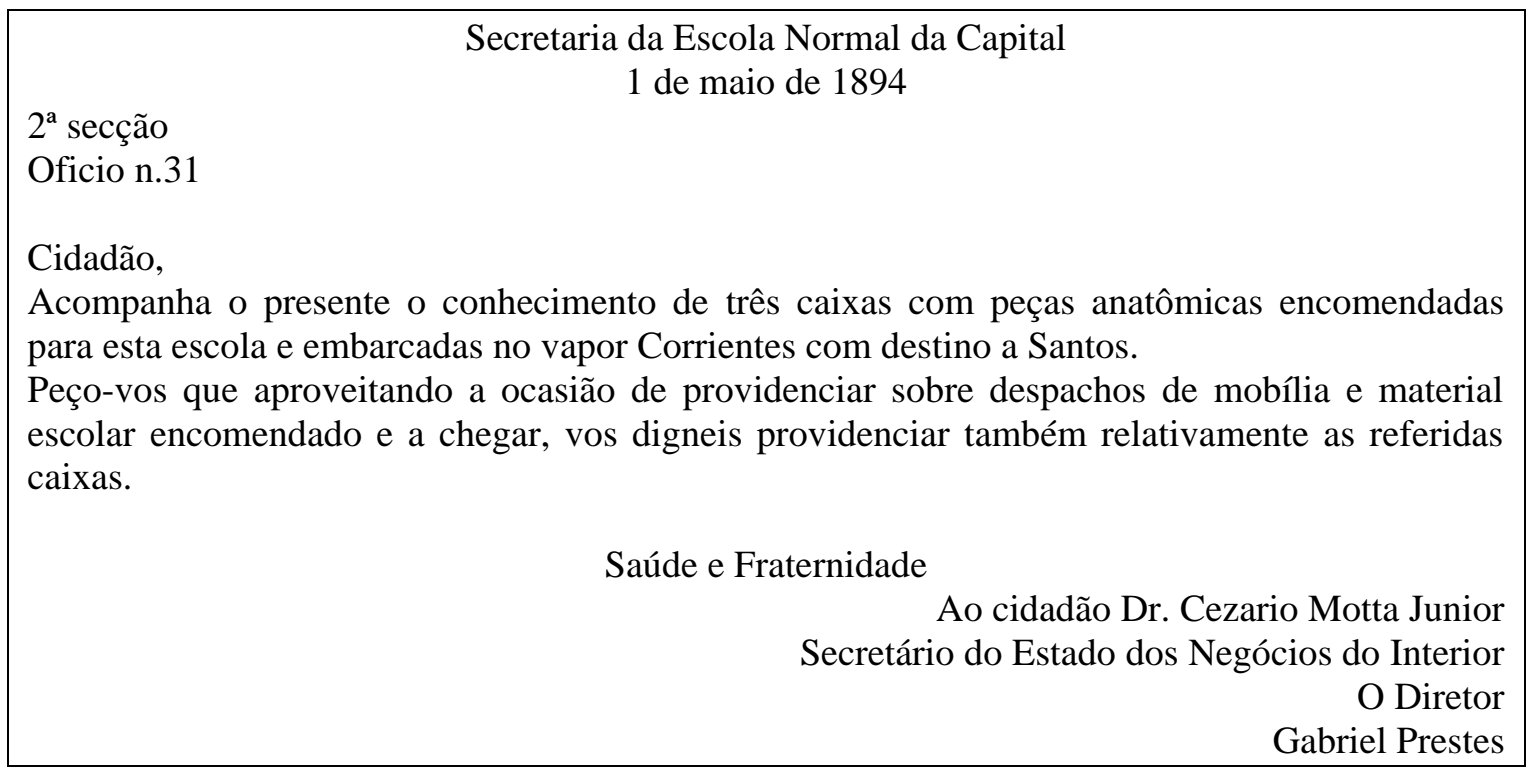

Fonte: APESP. Série Manuscritos. Secretaria do Interior. Escola Normal. Ano 1892. Ordem = 7135

\section{Anexo n.25}

\section{Secretaria da Escola Normal da Capital}

9 de maio de 1894

$2^{\mathrm{a}}$ secção

Oficio n.38

Cidadão.

Acompanha o presente uma copia da relação das peças de anatomia humana e comparada, e de modelos de frutas e flores, encomendadas para esta escola á casa Emile Deyrolle de Paris, e embarcados para Santos no VAPOR CORRIENTES em três caixas conforme consta do conhecimento que vos enviei com o meu officio n. 31 de $1^{\circ}$ do corrente á fim de facilitar a respectiva conferência.

\section{Saúde e Fraternidade}

Ao cidadão Dr. Cesario Motta Junior Secretário do Estado dos Negócios do Interior

O Diretor

Gabriel prestes

Fonte: APESP. Série Manuscritos. Secretaria do Interior. Escola Normal. Ano 1892. Ordem = 7135 
Anexo n.26

\begin{tabular}{|c|c|c|c|c|}
\hline OBJETO & FABRICANTE & $\begin{array}{l}\text { DISTRIBUIDOR/ } \\
\text { REPRESENTANT } \\
\text { E/AGENTE }\end{array}$ & $\begin{array}{c}\text { FONTE/ } \\
\text { REFERÊNCIA }\end{array}$ & OBS: \\
\hline $\begin{array}{l}1 \text { Appareil de } \\
\text { Bohnenberge }\end{array}$ & $\begin{array}{l}\text { Paul Rousseau \& } \\
\text { Comp }{ }^{\mathrm{a}} \text {., de Paris }\end{array}$ & $\begin{array}{l}\text { E. Charles Vautelet } \\
\& \text { Comp }{ }^{\text {a., }} \text { Capital } \\
\text { Federal, } 28 \text { de maio } \\
\text { de } 1895\end{array}$ & $\begin{array}{l}\text { Correspondência, n. } \\
72,1 \text { de jun. } 1898 \text { - } \\
\text { DSCN 3343, pag.109 }\end{array}$ & $\begin{array}{l}\text { Valor=95 francos. } \\
\text { Despacho em } \\
\text { Santos }\end{array}$ \\
\hline 1 Gine a trenil & $\begin{array}{l}\text { Paul Rousseau \& } \\
\text { Compª., de Paris }\end{array}$ & $\begin{array}{l}\text { E. Charles Vautelet } \\
\text { \& Comp }{ }^{\text {a., Capital }} \\
\text { Federal, } 28 \text { de maio } \\
\text { de } 1895\end{array}$ & $\begin{array}{l}\text { Correspondência, n. } \\
72,1 \text { de jun. } 1898 \text { - } \\
\text { DSCN 3343, pag.109 }\end{array}$ & $\begin{array}{l}\text { Valor=157 } \\
\text { francos.Despacho } \\
\text { em Santos }\end{array}$ \\
\hline $\begin{array}{l}\text { Cercle } \\
\text { hydrographiqu } \\
\text { e } 27^{\circ} / \mathrm{m} \mathrm{D.} \\
\text { divisé } \\
\text { ser argent, } \\
\text { double Vernier } \\
\text { domant la } \\
\text { minute, } 2 \\
\text { lunetles de } \\
\text { Galileé, } 7 \\
\text { verres de } \\
\text { couleur et } \\
\text { miroir de } \\
\text { rechunge, Le } \\
\text { tint dans une } \\
\text { boite acajou }\end{array}$ & $\begin{array}{l}\text { Paul Rousseau \& } \\
\text { Comp }{ }^{\mathrm{a}} \text {., de Paris }\end{array}$ & $\begin{array}{l}\text { E. Charles Vautelet } \\
\text { \& Comp }{ }^{\text {a }} \text {, Capital } \\
\text { Federal, } 28 \text { de maio } \\
\text { de } 1895\end{array}$ & $\begin{array}{l}\text { Correspondência, n. } \\
72,1 \text { de jun. } 1898 \text { - } \\
\text { DSCN 3343, pag.109 }\end{array}$ & $\begin{array}{l}\text { Valor }=350 \text { francos. } \\
\text { Despacho em } \\
\text { Santos }\end{array}$ \\
\hline $\begin{array}{l}1 \text { Roue de } \\
\text { carriêre avec } \\
\text { rochet de surité }\end{array}$ & $\begin{array}{l}\text { Paul Rousseau \& } \\
\text { Compª., de Paris }\end{array}$ & $\begin{array}{l}\text { E. Charles Vautelet } \\
\text { \& Comp }{ }^{\text {a }} \text {, Capital } \\
\text { Federal, } 28 \text { de maio } \\
\text { de } 1895\end{array}$ & $\begin{array}{l}\text { Correspondência, n. } \\
72,1 \text { de jun. } 1898 \text { - } \\
\text { DSCN 3344, pag.109 }\end{array}$ & $\begin{array}{l}\text { Valor=125 francos. } \\
\text { Despacho em } \\
\text { Santos }\end{array}$ \\
\hline $\begin{array}{l}1 \text { Sphere } \\
\text { terrestre } \\
\text { móbile sur } \\
\text { pied, diam. } 5 \\
\text { cm }\end{array}$ & $\begin{array}{l}\text { Paul Rousseau \& } \\
\text { Compª., de Paris }\end{array}$ & $\begin{array}{l}\text { E. Charles Vautelet } \\
\& \text { Comp }{ }^{\text {a }} \text {, Capital } \\
\text { Federal, } 28 \text { de maio } \\
\text { de } 1895\end{array}$ & $\begin{array}{l}\text { Correspondência, n. } \\
72,1 \text { de jun. } 1898 \text { - } \\
\text { DSCN 3344, pag.109 }\end{array}$ & $\begin{array}{l}\text { Valor=190 francos. } \\
\text { Despacho em } \\
\text { Santos }\end{array}$ \\
\hline $\begin{array}{l}1 \text { Caisse et } \\
\text { emballage } 115 \\
\text { x } 100 \times 60\end{array}$ & $\begin{array}{l}\text { Paul Rousseau \& } \\
\text { Compª., de Paris }\end{array}$ & $\begin{array}{l}\text { E. Charles Vautelet } \\
\text { \& Comp }{ }^{\text {a., Capital }} \\
\text { Federal, } 28 \text { de maio } \\
\text { de } 1895\end{array}$ & $\begin{array}{l}\text { Correspondência, n. } \\
72,1 \text { de jun. } 1898 \text { - } \\
\text { DSCN 3344, pag.109 }\end{array}$ & $\begin{array}{l}\text { Valor=35 francos. } \\
\text { Despacho em } \\
\text { Santos }\end{array}$ \\
\hline $\begin{array}{l}\text { Transport de } \\
\text { Paris a Anvers, } \\
\text { fret de } \\
\text { Anvers a } \\
\text { Santos, } \\
\text { Statistique, } \\
\text { Embarquement } \\
\text {, transit, } \\
\text { connaissement, } \\
\text { etc. }\end{array}$ & $\begin{array}{l}\text { Paul Rousseau \& } \\
\text { Compª ., de Paris }\end{array}$ & $\begin{array}{l}\text { E. Charles Vautelet } \\
\text { \& Comp }{ }^{\text {a }} \text {, Capital } \\
\text { Federal, } 28 \text { de maio } \\
\text { de } 1895\end{array}$ & $\begin{array}{l}\text { Correspondência, n. } \\
72,1 \text { de jun. } 1898 \text { - } \\
\text { DSCN 3344, pag.109 }\end{array}$ & $\begin{array}{l}\text { Valor=73francos. } \\
\text { Despacho em } \\
\text { Santos }\end{array}$ \\
\hline $\begin{array}{l}\text { Material de } \\
\text { ensino }\end{array}$ & & $\begin{array}{l}\text { E. Charles Vautelet } \\
\& \text { Comp }{ }^{\text {a. }} \text {, Capital } \\
\text { Federal, } 28 \text { de maio } \\
\text { de } 1895 . \text { Nossa } \\
\text { comissão de } 5 \%= \\
51 \text { francos }\end{array}$ & $\begin{array}{l}\text { Correspondência, n. } \\
72,1 \text { de jun. } 1898 \text { - } \\
\text { DSCN 3344, pag.109 }\end{array}$ & $\begin{array}{l}\text { Importa esta fatura } \\
\text { em mil oitenta e } \\
\text { sete francos e dez } \\
\text { centavos }(1087,10) \\
\text { pagáveis no } \\
\text { cambio de vista do } \\
\text { dia do pagamento }\end{array}$ \\
\hline
\end{tabular}




\begin{tabular}{|c|c|c|c|c|}
\hline OBJETO & FABRICANTE & $\begin{array}{l}\text { DISTRIBUIDOR/ } \\
\text { REPRESENTANT } \\
\text { E/AGENTE }\end{array}$ & $\begin{array}{c}\text { FONTE/ } \\
\text { REFERÊNCIA }\end{array}$ & OBS: \\
\hline $\begin{array}{l}1 \text { Lunette } \\
\text { astronomique } \\
\text { avec chercheur } \\
\text { mou- } \\
\text { ture } \\
\text { équatoriale, } \\
\text { avec cercles } \\
\text { horaires et de } \\
\text { declenaison-- } \\
\text { Piedeu fonte de } \\
\text { fer avec } \\
\text { vis colantes } \\
\text { refosans sur } \\
\text { crapaudines. }\end{array}$ & $\begin{array}{l}\text { Paul Rousseau \& } \\
\text { Comp }{ }^{\mathrm{a}} \text {., de Paris }\end{array}$ & & $\begin{array}{l}\text { Correspondência, } 5 \\
\text { de ago. 1895 - } \\
\text { pag.116; DSCN } \\
\text { 3345; DSCN 3346; } \\
\text { DSCN } 3347\end{array}$ & $\begin{array}{l}\text { Valor=1190 } \\
\text { francos } \\
\text { Despacho em } \\
\text { Santos, vapor } \\
\text { "Matapan". }\end{array}$ \\
\hline $\begin{array}{l}1 \text { Lextant de } \\
\mathrm{cm} 16 \text { de rayon } \\
\text { en cuivre, } \\
\text { Divisions sur } \\
\text { argent. }\end{array}$ & $\begin{array}{l}\text { Paul Rousseau \& } \\
\text { Comp }{ }^{\mathrm{a}} \text {., de Paris }\end{array}$ & & $\begin{array}{l}\text { Correspondência, } 5 \\
\text { de ago. 1895 - } \\
\text { pag.116; DSCN } \\
\text { 3345; DSCN 3346; } \\
\text { DSCN } 3347\end{array}$ & $\begin{array}{l}\text { Valor=279 francos } \\
\text { Despacho em } \\
\text { Santos, vapor } \\
\text { "Matapan". }\end{array}$ \\
\hline $\begin{array}{l}1 \text { Theodolito } \\
\text { de Gurley avec } \\
\text { vernier }\end{array}$ & $\begin{array}{l}\text { Paul Rousseau \& } \\
\text { Comp }{ }^{\mathrm{a}} \text {, de Paris }\end{array}$ & & $\begin{array}{l}\text { Correspondência, } 5 \\
\text { de ago. 1895 - } \\
\text { pag.116; DSCN } \\
\text { 3345; DSCN 3346; } \\
\text { DSCN } 3347\end{array}$ & $\begin{array}{l}\text { Valor=929 francos } \\
\text { Despacho em } \\
\text { Santos, vapor } \\
\text { "Matapan". }\end{array}$ \\
\hline $\begin{array}{l}1 \text { Caísse } 56 \text { x } \\
55 \times 143\end{array}$ & $\begin{array}{l}\text { Paul Rousseau \& } \\
\text { Compa ., de Paris }\end{array}$ & & $\begin{array}{l}\text { Correspondência, } 5 \\
\text { de ago. } 1895 \text { - } \\
\text { pag.116; DSCN } \\
\text { 3345; DSCN 3346; } \\
\text { DSCN } 3347\end{array}$ & $\begin{array}{l}\text { Valor=35 francos } \\
\text { Despacho em } \\
\text { Santos, vapor } \\
\text { "Matapan". }\end{array}$ \\
\hline 5 Caisson & $\begin{array}{l}\text { Paul Rousseau \& } \\
\text { Comp }{ }^{a} \text {., de Paris }\end{array}$ & & $\begin{array}{l}\text { Correspondência, } 5 \\
\text { de ago. } 1895 \text { - } \\
\text { pag.116; DSCN } \\
\text { 3345; DSCN 3346; } \\
\text { DSCN } 3347\end{array}$ & $\begin{array}{l}\text { Valor=26 francos } \\
\text { Despacho em } \\
\text { Santos, vapor } \\
\text { "Matapan". }\end{array}$ \\
\hline $\begin{array}{l}1 \text { Caisse } \\
\text { Emballage gras } \\
162 \times 91 \times 46\end{array}$ & $\begin{array}{l}\text { Paul Rousseau \& } \\
\text { Compa ., de Paris }\end{array}$ & & $\begin{array}{l}\text { Correspondência, } 5 \\
\text { de ago. 1895 - } \\
\text { pag.116; DSCN } \\
\text { 3345; DSCN 3346; } \\
\text { DSCN } 3347\end{array}$ & $\begin{array}{l}\text { Valor=60 francos } \\
\text { Despacho em } \\
\text { Santos, vapor } \\
\text { "Matapan". }\end{array}$ \\
\hline $\begin{array}{l}\text { Transport de } \\
\text { Paris á } \\
\text { Bordeau e fret } \\
\text { de Bordeau a } \\
\text { Santos, } \\
\text { statistique, } \\
\text { embarquemens } \\
\text {, transit, } \\
\text { connaissement } \\
\text { etc. }\end{array}$ & $\begin{array}{l}\text { Paul Rousseau \& } \\
\text { Compa ., de Paris }\end{array}$ & & $\begin{array}{l}\text { Correspondência, } 5 \\
\text { de ago. 1895 - } \\
\text { pag.116; DSCN } \\
\text { 3345; DSCN 3346; } \\
\text { DSCN } 3347\end{array}$ & $\begin{array}{l}\text { Valor }=180 \text { francos } \\
\text { Despacho em } \\
\text { Santos, vapor } \\
\text { "Matapan". Total da } \\
\text { fatura }=2807,20 \\
\text { francos }\end{array}$ \\
\hline $\begin{array}{l}\text { Peças de } \\
\text { anatomia } \\
\text { humana e } \\
\text { comparada, e } \\
\text { de modelos de } \\
\text { frutas e flores }\end{array}$ & $\begin{array}{l}\text { Emile Deyrolle } \\
\text { em Paris }\end{array}$ & $\begin{array}{l}\text { "Sr. Etienne Collet } \\
\text { (representante da } \\
\text { casa Emil Deyrolle, } \\
\text { de Paris)" }\end{array}$ & $\begin{array}{l}\text { Correspondência, } \\
\text { n.38, } 9 \text { de mai. } 1894 \\
\text {-DSCN 3353; DSCN } \\
3354 .\end{array}$ & $\begin{array}{l}\text { Embarcadas para } \\
\text { Santos no vapor } \\
\text { "Corrientes" em } 3 \\
\text { caixas no valor de } \\
3.050,20 \text { francos }\end{array}$ \\
\hline
\end{tabular}




\begin{tabular}{|c|c|c|c|c|}
\hline OBJETO & FABRICANTE & $\begin{array}{c}\text { DISTRIBUIDOR/ } \\
\text { REPRESENTANT } \\
\text { E/AGENTE }\end{array}$ & $\begin{array}{c}\text { FONTE/ } \\
\text { REFERÊNCIA }\end{array}$ & OBS: \\
\hline $\begin{array}{l}\text { Cinqüenta (50) } \\
\text { vidros de boca } \\
\text { estreita, com } \\
\text { rolha } \\
\text { esmerilhada } \\
\text { para 120,0; } \\
\text { Duzentos (200) } \\
\text { vidros, de boca } \\
\text { larga, com } \\
\text { rolha } \\
\text { esmerilhada } \\
\text { para 120,0; } \\
\text { Vinte e cinco } \\
\text { (25) vidros de } \\
\text { boca estreita, } \\
\text { com rolha } \\
\text { esmerilhada } \\
\text { para 500,0; } \\
\text { Vinte e cinco } \\
\text { (25) vidros de } \\
\text { boca larga, } \\
\text { com rolha } \\
\text { esmerilhada } \\
\text { para 500,0. }\end{array}$ & & $\begin{array}{l}\text { Depósito da } \\
\text { Farmácia do Estado }\end{array}$ & $\begin{array}{l}\text { Correspondência, } \\
\text { n. } 88,20 \text { de set. } 1894 \\
\text {-DSCN } 3355 .\end{array}$ & $\begin{array}{l}\text { Vasilhames para o } \\
\text { gabinete de } \\
\text { química da Escola, } \\
\text { solicitados ao } \\
\text { Diretor da } \\
\text { Farmácia do } \\
\text { Estado. }\end{array}$ \\
\hline $\begin{array}{l}\text { Aparelhos de } \\
\text { Ginástica }\end{array}$ & & $\begin{array}{l}\text { Sr. E. Charles } \\
\text { Vautelet. }\end{array}$ & $\begin{array}{l}\text { Correspondência, } \\
\text { n.98, } 17 \text { de out. } 1894 \\
\text {-DSCN } 3360 .\end{array}$ & \\
\hline $\begin{array}{l}\text { Material de } \\
\text { ensino para a } \\
\text { escola modelo } \\
\text { anexa }\end{array}$ & $\begin{array}{l}\text { Caixas vindas } \\
\text { dos Estados } \\
\text { Unidos }\end{array}$ & $\begin{array}{l}\text { Dr. Lane, Diretor da } \\
\text { Escola Americana }\end{array}$ & $\begin{array}{l}\text { Correspondência, } \\
\text { n.103, } 27 \text { de out. } \\
1894 \text {-DSCN } 3362 .\end{array}$ & \\
\hline $\begin{array}{l}\text { Instrumentos } \\
\text { para o ensino } \\
\text { de mecânica e } \\
\text { de astronomia } \\
\text { elementar } \\
\text { nesta Escola }\end{array}$ & $\begin{array}{l}\text { Catálogo da } \\
\text { "ancienne } \\
\text { Maison } \\
\text { Rousseau" }\end{array}$ & & $\begin{array}{l}\text { Correspondência, } \\
\text { n.110, } 21 \text { de nov. } \\
1894 \text {-DSCN } 3366 .\end{array}$ & $\begin{array}{l}\text { Valor }=4.720 \\
\text { francos }\end{array}$ \\
\hline $\begin{array}{l}\text { Instrumentos } \\
\text { de mecânica e } \\
\text { astronomia }\end{array}$ & $\begin{array}{l}\text { Casa W.L.E. } \\
\text { Gurley (Troy } \\
\text { Inglaterra) }\end{array}$ & Sr. Charles Vautelet & $\begin{array}{l}\text { Correspondência, } \\
\text { n. } 115,04 \text { de dez. } \\
1894\end{array}$ & $\begin{array}{l}\text { "recomendando } \\
\text { porem que o } \\
\text { "Theodolito de } \\
\text { Gurley" seja } \\
\text { americano, que } \\
\text { corresponde ao } \\
\text { numero } 8 \text { do } \\
\text { catalogo da casa } \\
\text { W.L.E. Gurley } \\
\text { (Troy Inglaterra)" }\end{array}$ \\
\hline $\begin{array}{l}\text { Aparelhos de } \\
\text { ginástica } \\
\text { instalados no } \\
\text { ginásio desta } \\
\text { Escola }\end{array}$ & & $\begin{array}{l}\text { E. Bianchini \& } \\
\text { Chelini }\end{array}$ & $\begin{array}{l}\text { Correspondência, } \\
\text { n.122, } 17 \text { de dez. } \\
1894\end{array}$ & $\begin{array}{l}\text { Valor }=\text { Rs } \\
681 \$ 000\end{array}$ \\
\hline $\begin{array}{l}\text { Quatro pianos } \\
\text { para a Escola } \\
\text { Modelo }\end{array}$ & & $\begin{array}{l}\text { Vendedor Sr. } \\
\text { Henrique Luiz Levy } \\
\text { ou srs. Levy Filhos }\end{array}$ & $\begin{array}{l}\text { Correspondência, } \\
\text { n.12, } 07 \text { de fev. } 1895 \text {; } \\
\text { n.16, } 13 \text { de fev. } 1895 \\
-3371\end{array}$ & piano A. Tahr \\
\hline
\end{tabular}




\begin{tabular}{|c|c|c|c|c|}
\hline OBJETO & FABRICANTE & $\begin{array}{l}\text { DISTRIBUIDOR/ } \\
\text { REPRESENTANT } \\
\text { E/AGENTE }\end{array}$ & $\begin{array}{c}\text { FONTE/ } \\
\text { REFERÊNCIA }\end{array}$ & OBS: \\
\hline $\begin{array}{l}\text { Papel próprio } \\
\text { para trabalhos } \\
\text { manuais, papel } \\
\text { de fantasia. }\end{array}$ & $\begin{array}{l}\text { Casa Garraux - } \\
\text { Europa }\end{array}$ & $\begin{array}{l}\text { Srs. Thiollier \& } \\
\text { Camp }\end{array}$ & $\begin{array}{l}\text { Correspondência, } \\
\text { n.40, } 27 \text { de mar. } 1895 \\
\text {-DSCN } 3375 \text {. }\end{array}$ & $\begin{array}{l}\text { Valor =frs. } 285,75 \text {. } \\
\text { E mais Rs } 402.580 \\
\text { de direitos de } \\
\text { alfândega, } \\
\text { comissão, frete e } \\
\text { carreto }\end{array}$ \\
\hline $\begin{array}{l}\text { Material de } \\
\text { ensino }\end{array}$ & & $\begin{array}{l}\text { Srs. Charles } \\
\text { Vautelet \& Comp }{ }^{\text {. }} \text {, } \\
\text { de Paris } \\
\text { Representantes no } \\
\text { Rio de Janeiro }\end{array}$ & $\begin{array}{l}\text { Correspondência, } \\
\text { n.55, } 09 \text { de mai. } 1895 \\
\text {-DSCN } 3377\end{array}$ & \\
\hline $\begin{array}{l}\text { Objetos de } \\
\text { Ginástica e } \\
\text { aparelhos para } \\
\text { o ensino de } \\
\text { Astronomia }\end{array}$ & $\begin{array}{l}\text { Srs. Charles } \\
\text { Vautelet \& } \\
\text { Comp } . \text {., de Paris }\end{array}$ & & $\begin{array}{l}\text { Correspondência, } \\
\text { n.60, } 13 \text { de mai. } 1895 \\
\text {-DSCN } 3378\end{array}$ & \\
\hline $\begin{array}{l}10 \text { quilos de } \\
\text { ácido sulfúrico } \\
\text { puro para os } \\
\text { serviços do } \\
\text { gabinete de } \\
\text { Química desta } \\
\text { Escola }\end{array}$ & & $\begin{array}{l}\text { Diretor da Farmácia } \\
\text { do Estado }\end{array}$ & $\begin{array}{l}\text { Correspondência, } \\
\text { n.63, } 24 \text { de mai. } 1895 \\
\text {-DSCN } 3379\end{array}$ & \\
\hline $\begin{array}{l}\text { Caixa de } \\
\text { autopsia } \\
\text { fornecida a } \\
\text { esta Escola } \\
\text { para o ensino } \\
\text { da cadeira de } \\
\text { Anatomia } \\
\end{array}$ & & $\begin{array}{l}\text { Ca. de Drogas do } \\
\text { Estado de S. Paulo }\end{array}$ & $\begin{array}{l}\text { Correspondência, } \\
\text { n.66, } 25 \text { de mai. } 1895 \\
\text {-DSCN } 3380\end{array}$ & Valor= Rs 360.000 \\
\hline $\begin{array}{l}\text { Venezianas } \\
\text { colocadas nas } \\
\text { janelas do } \\
\text { edifício da } \\
\text { Escola }\end{array}$ & $\begin{array}{l}\text { J.Jacques } \\
\text { Kessenling \& } \\
\text { Cia }\end{array}$ & & $\begin{array}{l}\text { Correspondência, } \\
\text { n.66, } 25 \text { de mai. } 1895 \\
\text {-DSCN } 3380\end{array}$ & Valor=Rs4:940.000 \\
\hline $\begin{array}{l}\text { Obras } \\
\text { necessárias } \\
\text { para oficina de } \\
\text { trabalhos } \\
\text { manuais e para } \\
\text { arrecadação de } \\
\text { armamento do } \\
\text { batalhão } \\
\text { Escolar }\end{array}$ & $\begin{array}{l}\text { Senhores E. } \\
\text { Catalde \& } \\
\text { Irmãos }\end{array}$ & & $\begin{array}{l}\text { Correspondência, } \\
\text { n.69, } 31 \text { de mai. } 1895 \\
\text {-DSCN } 3381\end{array}$ & Valor $=$ Rs $952 \$ 000$ \\
\hline $\begin{array}{l}\text { Encanamentos } \\
\text { para a } \\
\text { colocação de } \\
\text { lavatórios nas } \\
\text { oficinas de } \\
\text { trabalhos } \\
\text { manuais da } \\
\text { seção } \\
\text { masculina e da } \\
\text { sala de } \\
\text { fotografia }\end{array}$ & Sartorio José & & $\begin{array}{l}\text { Correspondência, } \\
\text { n. } 95,06 \text { de set. } 1895 \\
\text {-DSCN } 3384\end{array}$ & Valor $=$ Rs $358 \$ 000$ \\
\hline
\end{tabular}




\begin{tabular}{|c|c|c|c|c|}
\hline OBJETO & FABRICANTE & $\begin{array}{c}\text { DISTRIBUIDOR/ } \\
\text { REPRESENTANT } \\
\text { E/AGENTE }\end{array}$ & $\begin{array}{c}\text { FONTE/ } \\
\text { REFERÊNCIA }\end{array}$ & OBS: \\
\hline $\begin{array}{l}\text { Novo tapete } \\
\text { nas escadas }\end{array}$ & $\begin{array}{l}\text { Kersserling \& } \\
\text { Sanches }\end{array}$ & & $\begin{array}{l}\text { Correspondência, } \\
\text { n.95, } 06 \text { de set. } 1895 \\
\text {-DSCN } 3384\end{array}$ & Valor $=$ Rs $405 \$ 000$ \\
\hline $\begin{array}{l}\text { Material de } \\
\text { ensino para as } \\
\text { aulas de } \\
\text { trabalhos } \\
\text { manuais e de } \\
\text { economia } \\
\text { domestica da } \\
\text { seção feminina }\end{array}$ & $\begin{array}{l}\text { Libre Mello e } \\
\text { Comp }\end{array}$ & & $\begin{array}{l}\text { Correspondência, } \\
\text { n. } 95,06 \text { de set. } 1895 \\
\text {-DSCN } 3384\end{array}$ & Valor $=$ Rs $682 \$ 220$ \\
\hline $\begin{array}{l}\text { Material de } \\
\text { ensino }\end{array}$ & $\begin{array}{l}\text { Casa Paul } \\
\text { Rousseau, de } \\
\text { Paris }\end{array}$ & $\begin{array}{l}\text { E. Charles Vautelet } \\
\text { e Cia }\end{array}$ & $\begin{array}{l}\text { Correspondência, } \\
\text { n.102, } 16 \text { de set. } \\
1895 \text {-DSCN } 3385\end{array}$ & $\begin{array}{l}\text { Vindas pelos } \\
\text { vapores Bellanock } \\
\text { e Matapan no valor } \\
\text { de frs. } 1.087,10 \mathrm{a} \\
\text { primeira e de frs. } \\
2.087,20 \text { a segunda } \\
\end{array}$ \\
\hline $\begin{array}{l}\text { Espécimes } \\
\text { zoológicos e } \\
\text { botânicos das } \\
\text { costas deste } \\
\text { Estado, assim } \\
\text { como de } \\
\text { coleção de } \\
\text { plantas dos } \\
\text { arredores da } \\
\text { Capital }\end{array}$ & & Alberto Loefgren & $\begin{array}{l}\text { Correspondência, } \\
\text { n.109, pag.130, } 12 \text { de } \\
\text { nov. } 1895 \text {-DSCN } \\
3386\end{array}$ & \\
\hline $\begin{array}{l}\text { Exposição } \\
\text { escolar }\end{array}$ & $\begin{array}{l}\text { Srs. Libre Mello } \\
\text { e } C^{a}\end{array}$ & & $\begin{array}{l}\text { Correspondência, } \\
\text { n.111, pag.131, } 26 \text { de } \\
\text { nov. } 1895 \text {-DSCN } \\
3387 \\
\end{array}$ & Valor $=$ Rs $708 \$ 200$ \\
\hline $\begin{array}{l}\text { Obras de } \\
\text { encanamento } \\
\text { de água e } \\
\text { esgoto da mesa } \\
\text { de Física e } \\
\text { Química }\end{array}$ & José Sortorio & & $\begin{array}{l}\text { Correspondência, } 20 \\
\text { de nov. } 1895 \text {-DSCN } \\
3388\end{array}$ & Valor $=$ Rs $618 \$ 500$ \\
\hline $\begin{array}{l}\text { Aplicação de } \\
\text { um aparelho no } \\
\text { braço de um } \\
\text { aluno }\end{array}$ & $\begin{array}{l}\text { Dr. Galvão } \\
\text { Bueno }\end{array}$ & & $\begin{array}{l}\text { Correspondência, } 20 \\
\text { de nov. } 1895 \text {-DSCN } \\
3388\end{array}$ & Valor $=$ Rs $100 \$ 000$ \\
\hline $\begin{array}{l}\text { Um armário de } \\
\text { canela para a } \\
\text { aula de } \\
\text { trabalhos } \\
\text { manuais }\end{array}$ & Megene Malhaur & & $\begin{array}{l}\text { Correspondência, } 20 \\
\text { de nov. } 1895 \text {-DSCN } \\
3388\end{array}$ & Valor $=$ Rs $250 \$ 000$ \\
\hline $\begin{array}{l}\text { Material de } \\
\text { ensino }\end{array}$ & $\begin{array}{l}\text { Casa Paul } \\
\text { Rousseau, de } \\
\text { Paris }\end{array}$ & $\begin{array}{l}\text { E. Charles Vautelet } \\
\text { e Compa. }\end{array}$ & $\begin{array}{l}\text { Correspondência, } 26 \\
\text { de nov. } 1895 \text {-DSCN } \\
3389\end{array}$ & Valor $=$ frs. 139260 \\
\hline
\end{tabular}




\begin{tabular}{|c|c|c|c|c|}
\hline OBJETO & FABRICANTE & $\begin{array}{c}\text { DISTRIBUIDOR/ } \\
\text { REPRESENTANT } \\
\text { E/AGENTE }\end{array}$ & $\begin{array}{c}\text { FONTE/ } \\
\text { REFERÊNCIA }\end{array}$ & OBS: \\
\hline $\begin{array}{l}\text { Espingarda } \\
\text { para o batalhão } \\
\text { escolar }\end{array}$ & & $\begin{array}{l}\text { Elias Bianchim \& } \\
\text { C }^{a}\end{array}$ & $\begin{array}{l}\text { Correspondência, } \\
\text { n.150, } 16 \text { de dez. } \\
1895 \text {-DSCN 3390, } \\
\text { pag.136 }\end{array}$ & \\
\hline $\begin{array}{l}\text { Móveis } \\
\text { destinados à } \\
\text { Escola } \\
\text { Complementar } \\
\text { Modelo }\end{array}$ & & H. Lane & $\begin{array}{l}\text { Correspondência, } \\
\text { n.151, } 15 \text { de dez. } \\
1895 \text {-DSCN } 3391\end{array}$ & Valor $=96$ dolares \\
\hline $\begin{array}{l}\text { Caixões com } \\
\text { material } \\
\text { escolar }\end{array}$ & & Escola Americana & $\begin{array}{l}\text { Registro de } \\
\text { Correspondência, } \\
\text { n. } 88,30 \text { de out. } 1890\end{array}$ & $\begin{array}{l}\text { Valor= Rs 372:600 } \\
\text { ao sr. A. Waddul }\end{array}$ \\
\hline $\begin{array}{l}\text { Caixões com } \\
\text { material } \\
\text { escolar }\end{array}$ & & Casa Guarany & $\begin{array}{l}\text { Registro de } \\
\text { Correspondência, } \\
\text { n. } 88,30 \text { de out. } 1890 \\
\text { - DSCN } 3396\end{array}$ & $\begin{array}{l}\text { Valor=Rs1:923\$90 } \\
0\end{array}$ \\
\hline $\begin{array}{l}\text { Coleçao da } \\
\text { "Flora } \\
\text { Brasileira" de } \\
\text { Martins }\end{array}$ & & $\begin{array}{l}\text { Negociantes Srs. } \\
\text { Carvalho, Costa \& } \\
\text { Comp }\end{array}$ & $\begin{array}{l}\text { Registro de } \\
\text { Correspondência, } \\
\text { n.120, 04 de ago. } \\
1893 \text { - DSCN } 3402\end{array}$ & \\
\hline $\begin{array}{l}\text { Peças de } \\
\text { anatomia } \\
\text { humana e de } \\
\text { modelo de } \\
\text { flores e frutas }\end{array}$ & $\begin{array}{l}\text { "Emile Deyrolle, } \\
\text { naturaliste } \\
\text { (Paris)" }\end{array}$ & Etienne Collet & $\begin{array}{l}\text { Registro de } \\
\text { Correspondência, } \\
\text { n.134, } 13 \text { de out. } \\
1893 \text { - DSCN } 3403\end{array}$ & $\begin{array}{l}3.050 \text { francos, } \\
\text { conforme catalago } \\
\text { da casa Emile } \\
\text { Deyrolle }\end{array}$ \\
\hline $\begin{array}{l}\text { Peças e } \\
\text { modelos esses } \\
\text { que julgo } \\
\text { necessarios } \\
\text { para o } \\
\text { conveniente } \\
\text { ensino das } \\
\text { materias das } \\
13^{\mathrm{a}} \text { e } 17^{\mathrm{a}} \\
\text { Cadeiras desta } \\
\text { Escola }\end{array}$ & $\begin{array}{l}\text { "Emile Deyrolle, } \\
\text { naturaliste } \\
\text { (Paris)" }\end{array}$ & $\begin{array}{l}\text { Representante } \\
\text { mencionado, mas } \\
\text { não especificado } \\
\text { em DSCN } 3404\end{array}$ & $\begin{array}{l}\text { Registro de } \\
\text { Correspondência, } \\
\text { n.134, } 13 \text { de out. } \\
1893 \text { - DSCN 3403; } \\
\text { DSCN 3404; DSCN } \\
\text { 3405; DSCN 3406; } \\
\text { DSCN } 3407\end{array}$ & $\begin{array}{l}3.050 \text { francos, } \\
\text { conforme catalago } \\
\text { da casa Emile } \\
\text { Deyrolle }\end{array}$ \\
\hline \multirow{2}{*}{$\begin{array}{l}\text { Apparelhos } \\
\text { necessários ao } \\
\text { ensino de } \\
\text { physica, } \\
\text { mechanica e } \\
\text { chimica }\end{array}$} & & \multirow[t]{2}{*}{ Etienne Collet } & \multirow{2}{*}{$\begin{array}{l}\text { Oficio n.260 - } 11 \text { de } \\
\text { março de } 1893 \\
\text { Diretoria da instrução } \\
\text { publica do estado de } \\
\text { São Paulo }\end{array}$} & $\begin{array}{l}\text { Valor }=4.486 \$ 760 \\
+\quad \text { despesas com } \\
\text { encaixotamento e } \\
\text { transporte. }\end{array}$ \\
\hline & & & & \\
\hline \multirow{2}{*}{$\begin{array}{l}\text { Papel de } \\
\text { phantasia para } \\
\text { trabalhos } \\
\text { manuais }\end{array}$} & & Casa Garraux & \multirow{2}{*}{$\begin{array}{l}\text { Nota fiscal da casa } \\
\text { garraux e thiollier }\end{array}$} & \\
\hline & & & & $\begin{array}{l}\text { Ordem de } \\
\text { pagamento em } \\
\text { nome do Sr. } \\
\text { THIOLLIER \& } \\
\text { Cia. }\end{array}$ \\
\hline $\begin{array}{l}\text { Objetos de } \\
\text { gymnastica e } \\
\text { apparelhos } \\
\text { para o ensino } \\
\text { de astronomia }\end{array}$ & & $\begin{array}{l}\text { Charles Vautelet e } \\
\text { Cia }\end{array}$ & $\begin{array}{l}\text { Oficio n. } 60-23 \text { de } \\
\text { maio de } 1895\end{array}$ & $\begin{array}{l}\text { Solicitação de } \\
\text { pagamento }\end{array}$ \\
\hline
\end{tabular}




\begin{tabular}{|c|c|c|c|c|}
\hline OBJETO & FABRICANTE & $\begin{array}{l}\text { DISTRIBUIDOR/ } \\
\text { REPRESENTANT } \\
\text { E/AGENTE }\end{array}$ & $\begin{array}{c}\text { FONTE/ } \\
\text { REFERÊNCIA }\end{array}$ & OBS: \\
\hline \multirow{2}{*}{$\begin{array}{l}\text { Material de } \\
\text { ensino }\end{array}$} & \multirow{2}{*}{$\begin{array}{l}\text { Importado da } \\
\text { Casa Paul } \\
\text { Rousseau e Cia, } \\
\text { de Paris }\end{array}$} & \multirow{2}{*}{$\begin{array}{l}\text { E. Charles Vautelet } \\
\text { e Cia }\end{array}$} & 22 de março de 1895 & \multirow[b]{2}{*}{$\begin{array}{l}\text { valor de fr. } 5856,60 \\
\text { NOSSA } \\
\text { COMISSAO } \\
\text { (Charles vautelet e } \\
\text { cia) de } 5 \%= \\
292.80 \\
\text { TOTAL = FR. } \\
6149,40\end{array}$} \\
\hline & & & & \\
\hline $\begin{array}{l}\text { Material de } \\
\text { ensino }\end{array}$ & $\begin{array}{l}\text { Casa Paul } \\
\text { Rousseau e Cia, } \\
\text { de Paris }\end{array}$ & $\begin{array}{l}\text { E. Charles Vautelet } \\
\text { e Cia }\end{array}$ & $\begin{array}{l}\text { Oficio n. } 123-26 \text { de } \\
\text { novembro de } 1895\end{array}$ & $\begin{array}{l}\text { VALOR = } \\
\text { fr. } 1.392,60 .\end{array}$ \\
\hline $\begin{array}{l}\text { Material de } \\
\text { ensino }\end{array}$ & $\begin{array}{l}\text { Casa Paul } \\
\text { Rousseau e Cia, } \\
\text { de Paris }\end{array}$ & $\begin{array}{l}\text { E. Charles Vautelet } \\
\text { e Cia }\end{array}$ & $\begin{array}{l}\text { Oficio n.102-16 de } \\
\text { outubro de } 1895\end{array}$ & $\begin{array}{l}\text { valor de fr. } \\
1.087,10 \mathrm{a} \\
\text { primeira, e de fr. } \\
2.807,20 \text {, a segunda }\end{array}$ \\
\hline \multirow[t]{2}{*}{$\begin{array}{l}\text { Resto das } \\
\text { encomenda }\end{array}$} & & & $\begin{array}{l}\text { Oficio n. } 105-9 \text { de } \\
\text { outubro de } 1895\end{array}$ & \multirow{2}{*}{$\begin{array}{l}\text { Facturas de duas } \\
\text { caixas, em } \\
\text { duplicata }\end{array}$} \\
\hline & & & & \\
\hline \multirow{2}{*}{$\begin{array}{l}\text { Peças de } \\
\text { anatomia e } \\
\text { modelos de } \\
\text { flores e fructos }\end{array}$} & \multirow{2}{*}{$\begin{array}{l}\text { Casa Emile } \\
\text { Deyrolle, de } \\
\text { Paris }\end{array}$} & \multirow[t]{2}{*}{ Sr. Etienne Collet } & $\begin{array}{l}\text { Oficio n. } 42-22 \text { de } \\
\text { maio de } 1894\end{array}$ & \multirow[t]{2}{*}{ fr. 585,20} \\
\hline & & & & \\
\hline \multirow{3}{*}{$\begin{array}{l}\text { Coleção da } \\
\text { flora } \\
\text { brasiliense } \\
\text { para a } \\
\text { biblioteca }\end{array}$} & & \multirow[t]{3}{*}{ Lebre, Mello e Cia } & Oficio n. $127-27$ de & \multirow{3}{*}{$\begin{array}{l}\text { PROCEDENTES } \\
\text { DA CAPITAL } \\
\text { FEDERAL } \\
\end{array}$} \\
\hline & & & setembro de 1893 & \\
\hline & & & & \\
\hline \multirow{3}{*}{$\begin{array}{l}\text { Caixa para } \\
\text { autopsia (aula } \\
\text { de anatomia }\end{array}$} & \multirow{3}{*}{$\begin{array}{l}\text { Companhia de } \\
\text { drogas do estado } \\
\text { de S. Paulo }\end{array}$} & & \multirow{3}{*}{$\begin{array}{l}\text { Oficio n.65-25 de } \\
\text { maio de } 1895\end{array}$} & \multirow{3}{*}{$\begin{array}{l}\text { valor de } 360 \$ 000 \\
\text { IMPORTACAO } \\
\text { DIRETA DE } \\
\text { TODOS OS } \\
\text { PAIZES. Despesa } \\
\text { do rio de janeiro a } \\
\text { são Paulo = } 10.000\end{array}$} \\
\hline & & & & \\
\hline & & & & \\
\hline 76 venezianas & $\begin{array}{l}\text { Jacques } \\
\text { Kesselring \& Cia }\end{array}$ & & $\begin{array}{l}\text { Oficio n. } 65-25 \text { de } \\
\text { maio de } 1895\end{array}$ & $\begin{array}{l}\text { valor de 4:940\$000 } \\
\text { reis }\end{array}$ \\
\hline $\begin{array}{l}\text { Fazer uns } \\
\text { assentos de } \\
\text { taboas no } \\
\text { quintal; tirar } \\
\text { uma parede da } \\
\text { dita casa, } \\
\text { consertar o } \\
\text { forro e o } \\
\text { assoalho, } \\
\text { segurar o } \\
\text { madeiramento }\end{array}$ & $\begin{array}{l}\text { Constructor } \\
\text { Joaquim da Silva } \\
\text { Santos }\end{array}$ & & $\begin{array}{l}\text { SECRETARIA DO } \\
\text { INTERIOR } \\
3^{\mathrm{a}} \text {. SECÇÃO } \\
\text { ESCOLA NORMAL } \\
\text { - ANO } 1892 \\
\text { ORDEM - } 7135 \text { - } \\
\text { SERIE } \\
\text { MANUSCRITOS }\end{array}$ & $\begin{array}{l}\text { Valor }=\text { duzentos e } \\
\text { quarenta e cinco } \\
\text { mil reis }(245 \$ 000)\end{array}$ \\
\hline
\end{tabular}




\begin{tabular}{|c|c|c|c|c|}
\hline OBJETO & FABRICANTE & $\begin{array}{c}\text { DISTRIBUIDOR/ } \\
\text { REPRESENTANT } \\
\text { E/AGENTE }\end{array}$ & $\begin{array}{c}\text { FONTE/ } \\
\text { REFERÊNCIA }\end{array}$ & OBS: \\
\hline $\begin{array}{l}\text { Obras na } \\
\text { escola normal } \\
\text { sito a rua da } \\
\text { boa morte }\end{array}$ & $\begin{array}{l}\text { Companhia } \\
\text { Cantareira e } \\
\text { Esgotos }\end{array}$ & & & Valor $=164 \$ 980$ \\
\hline $\begin{array}{l}\text { Material de } \\
\text { ensino }\end{array}$ & Emile deyrolle & $\begin{array}{l}\text { Agencia do } \\
\text { syndicato de } \\
\text { material escolar }\end{array}$ & & \\
\hline $\begin{array}{c}\text { Material para } \\
\text { Escola Modelo }\end{array}$ & & Escola Americana & & $248 \$ 000$ \\
\hline $\begin{array}{l}\text { Apparelhos de } \\
\text { gymnastica }\end{array}$ & $\begin{array}{l}\text { E. Bianchini \& } \\
\text { Chelini }\end{array}$ & & $\begin{array}{l}\text { Oficio n. } 122-17 \text { de } \\
\text { dezembro de } 1894\end{array}$ & $681 \$ 000$ \\
\hline $\begin{array}{c}\text { 128 CAIXAS } \\
\text { DE MÓVEIS } \\
\text { ESCOALRES } \\
\text { e apparelhos de } \\
\text { ensino }\end{array}$ & & H. Lane & $\begin{array}{l}\text { Oficio n. } 150-16 \text { de } \\
\text { dezembro de } 1895\end{array}$ & $\begin{array}{l}\text { Adquiridos nos } \\
\text { ESTADOS } \\
\text { UNIDOS }\end{array}$ \\
\hline $\begin{array}{l}\text { Espingarda } \\
\text { para batalhão } \\
\text { escolar }\end{array}$ & $\begin{array}{c}\text { Elias Bianchini } \\
\text { \& Cia }\end{array}$ & & & \\
\hline Pianos & & Levy Filhos & & \\
\hline $\begin{array}{c}10 \text { armários de } \\
\text { Olio }\end{array}$ & $\begin{array}{l}\text { Miguel Malhano } \\
\text { - grande } \\
\text { marcenaria e } \\
\text { carpintaria } \\
\text { paulista }\end{array}$ & & $\begin{array}{l}\text { Oficio n. } 18-19 \text { de } \\
\text { fevereiro de } 1895\end{array}$ & valor de $1.000 \$ 000$ \\
\hline $\begin{array}{l}\text { Papel de } \\
\text { phantasia }\end{array}$ & & $\begin{array}{l}\text { Casa Garraux. } \\
\text { Thiollier \& Cia }\end{array}$ & 27 de março de 1894 & \\
\hline $\begin{array}{l}\text { Obras } \\
\text { necessárias } \\
\text { para oficina de } \\
\text { trablahos } \\
\text { manuais e para } \\
\text { o batalhão } \\
\text { escolar. }\end{array}$ & $\begin{array}{l}\text { E. Cataldi e } \\
\text { Irmaos (grande } \\
\text { oficina - } \\
\text { marcenaria e } \\
\text { carpintaria }\end{array}$ & & & \\
\hline $\begin{array}{l}\text { Despesa } \\
\text { extraordinária } \\
\text { feita com a } \\
\text { exposição } \\
\text { escolar }\end{array}$ & $\begin{array}{l}\text { Lebre, Mello \& } \\
\text { Comp }\end{array}$ & & $\begin{array}{l}\text { Oficio n. } 111-26 \text { de } \\
\text { novembro de } 1895\end{array}$ & $708 \$ 200$ \\
\hline $\begin{array}{l}\text { Aparelhos para } \\
\text { água, gaz e } \\
\text { exgotto }\end{array}$ & $\begin{array}{l}\text { Oficina "A } \\
\text { Santaria" }\end{array}$ & & & \\
\hline $\begin{array}{l}\text { Material } \\
\text { escolar }\end{array}$ & & $\begin{array}{l}\text { Espindola, Siqueira } \\
\& \text { Co. }\end{array}$ & 27 de junho de 1895 & $\begin{array}{l}\text { Importação direta } \\
\text { das fábricas mais } \\
\text { importantes da } \\
\text { Europa e da } \\
\text { América do Norte. }\end{array}$ \\
\hline
\end{tabular}

Fonte: Elaboração da autora a partir das Correspondências da Diretoria do Acervo Histórico da Caetano de Campos em São Paulo. 
Anexo n.27

\section{Secretaria da Escola Normal da Capital \\ São Paulo, 17 de outubro de 1894.}

$\mathrm{N}^{\circ} .98$

Exmo. Sr. E. Charles Vautelet.

Acompanha a presente uma pequena lista de aparelhos de Ginástica necessária para a Escola Normal da Capital de S. Paulo.

Peço-vos que vos encarregueis do fornecimento dos aparelhos constantes da mesma, o mais breve que for possível, nas condições das outras encomendas anteriormente feitas.

(Assinado) G. Prestes, -

Fonte: Acervo Histórico da Caetano de Campos em São Paulo - Correspondências da Diretoria.

Anexo n.28

\section{Secretaria da Escola Normal da Capital \\ S. Paulo, 4 de Dezembro de 1894}

$\mathrm{N}^{\circ} .115$

Exmo. Sr. Charles Vautelet.

Acompanha a presente uma lista de instrumentos de mecânica e astronomia necessária para a Escola Normal da Capital de S. Paulo.

Peço-vos que vos encarregueis do fornecimento dos instrumentos constantes da mesma, o mais breve que for possível, nas condições das outras encomendas anteriormente feitas, recomendando porem que o "Theodolito de Gurley" seja americano, que corresponde ao numero 8 do catalogo da casa W.L.E. Gurley (Troy Inglaterra).

Observação: Acompanha a presente carta a lista de instrumentos a que se refere o oficio $\mathrm{n}^{\mathrm{o}} .110$.

Assinado, O Diretor, G. Prestes

Fonte: Acervo Histórico da Caetano de Campos em São Paulo. Correspondência da Diretoria (18931895) - Ofício n. 115. 


\section{Anexo n.29}

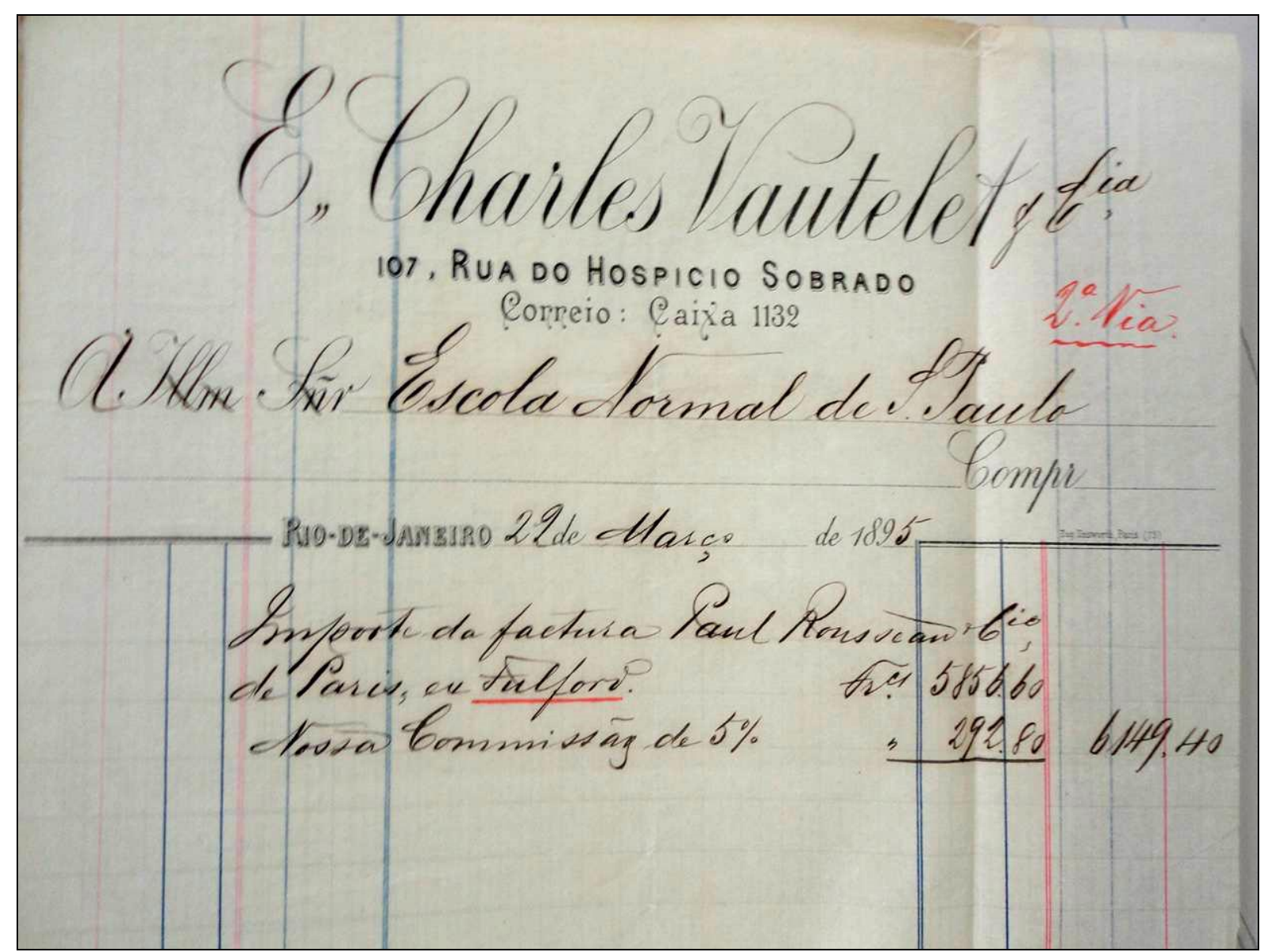

Fonte: APESP. Série Manuscritos. Secretaria do Interior. Escola Normal.Ano 1892. Caixa 530 Ordem 7135 


\section{Anexo n.30}

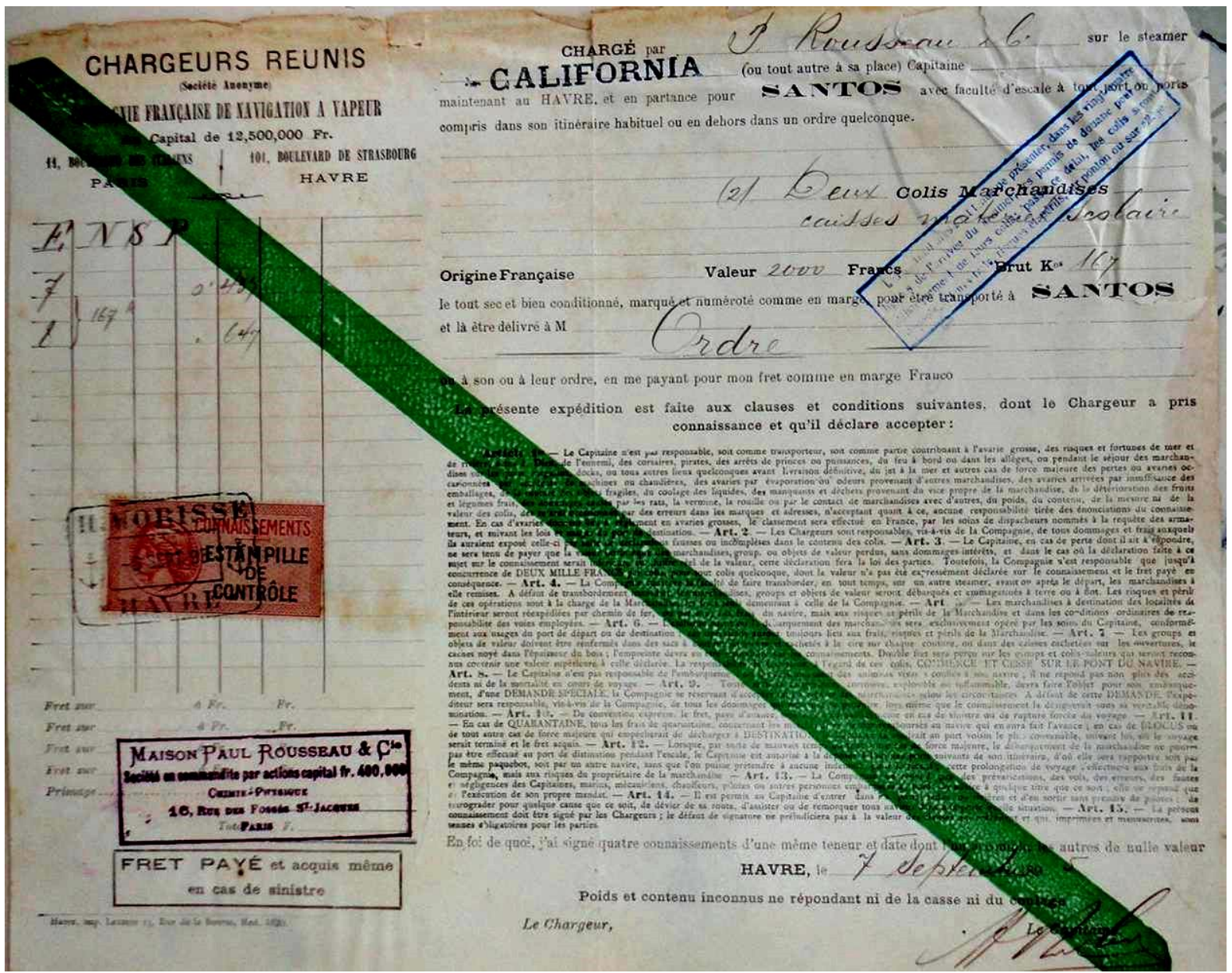

Fonte: Fonte: APESP. Série Manuscritos. Secretaria do Interior. Escola Normal.Ano 1892. Caixa 530 - Ordem 7135 


\section{MATERIILL E MOBLLA ESCOLLR}

Fornecimento para Escolas superiores. Musêos, elc.

\section{7 rua Soufflot. Pariz.}

Representante no Rio de Janeiro

E. Charles Vautelet, r. Hospicio, 107, C. do Correio 1132.

Exposição permanente no edificio do Pedagogium.

Fonte: Almanak Administrativo, Mercantil e Industrial do Rio de Janeiro, p.1323

Anexo n.32

\section{Material e Mobilia Escolar}

Fornecimento para Escolas superiores, Musêos, etc.

Maison Paul Rousseau \& G., E. Stock, successor, Emile Deyrolle, Pariz.

Representantes no Rio de Janeiro

E. Charles Vautelet \& G., I. Hospicio, 107, G. do Correio, 1132 .

Socios :

E. Charles Vautelet, residente em Pariz.

Paulo Moreira da Silva, 22, r. Buarque de Macedo, Ca.

pital Federal.

Exposição permanente no edificio do Pedagogium.

Fonte: Almanak Administrativo, Mercantil e Industrial do Rio de Janeiro, 1899, p.748 
Anexo n.33

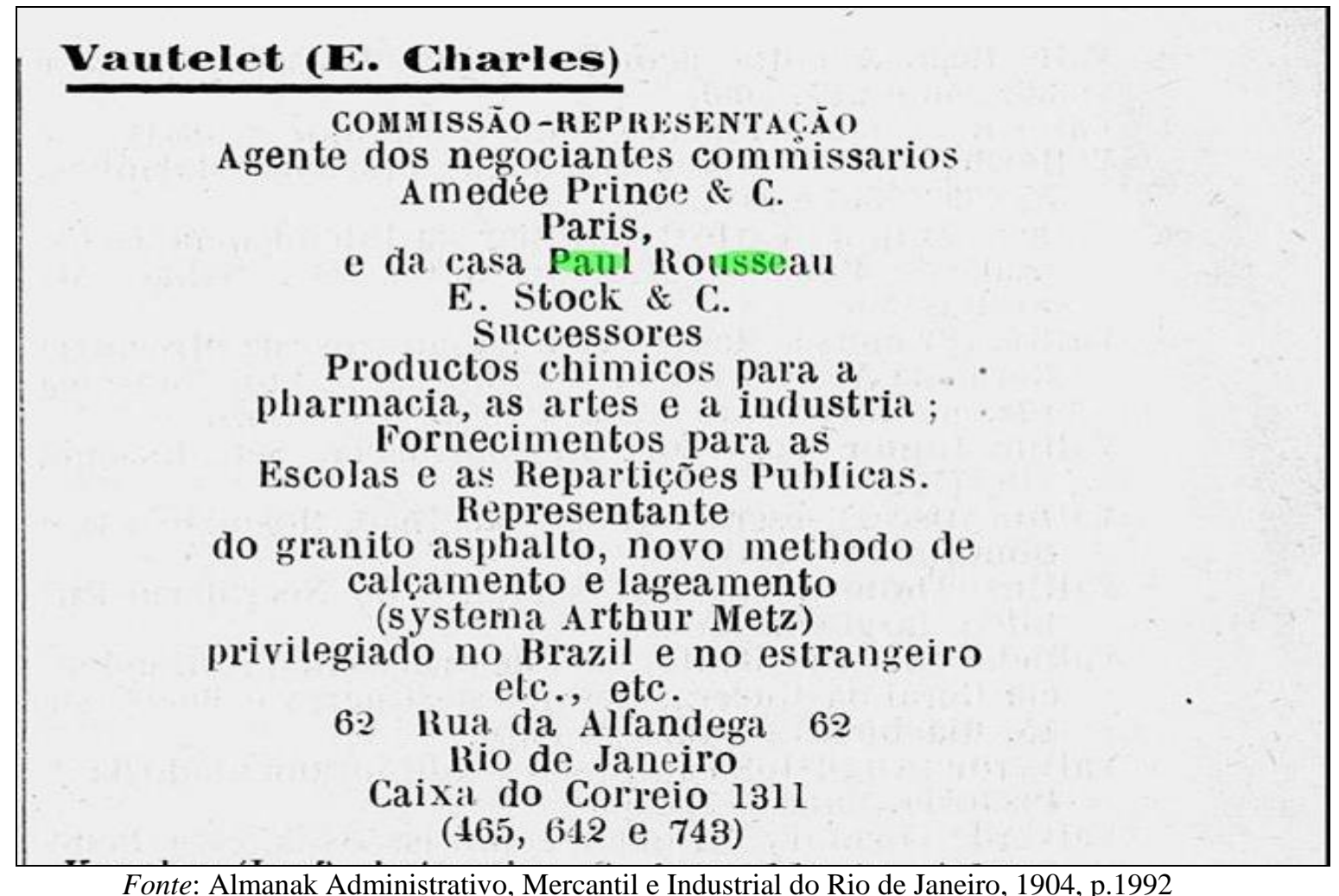

\section{Anexo n.34}

\section{SECRETARIA DA ESCOLA NORMAL DA CAPITAL}

São Paulo, 26 de novembro de 1895

n.113

Cidadão,

Acampanha o presente uma conta de E. CHARLES VAUTELET e Cia de importância de material de ensino fornecido pela casa PAUL ROUSSEAU e Cia, de Paris na importância de frs $1.392,60$, conforme autorização do governo. Peço que vos digneis providenciar a fim de que seja paga a importância da referida conta visto que já se acha esta escola de posse do material de ensino a que ella se refere.

Ao cidadão doutor Alfredo Pujol Secretário de Estado dos Negócios do Interior

$\mathrm{O}$ director

Gabriel Prestes.

Off. a Fazenda (497) em 3-12-1895

Fonte: APESP. Série Manuscritos. Secretaria do Interior. Escola Normal.Ano 1892. Caixa 530 -

Ordem 7135 


\section{Anexo n.35}

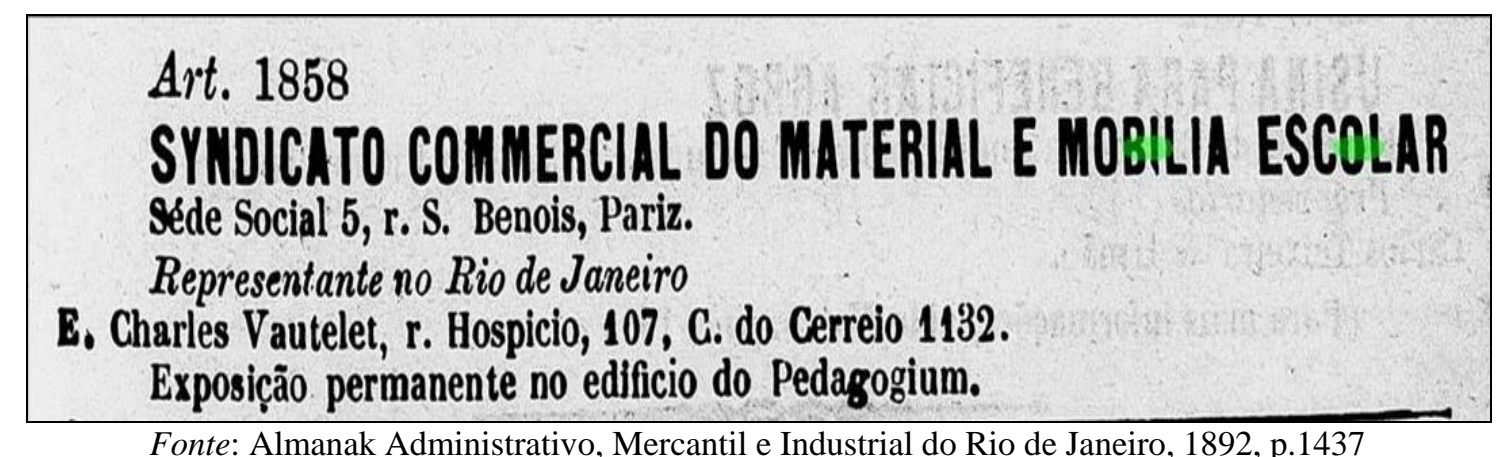

Fonte: Almanak Administrativo, Mercantil e Industrial do Rio de Janeiro, 1892, p.1437

\section{Anexo n.36}

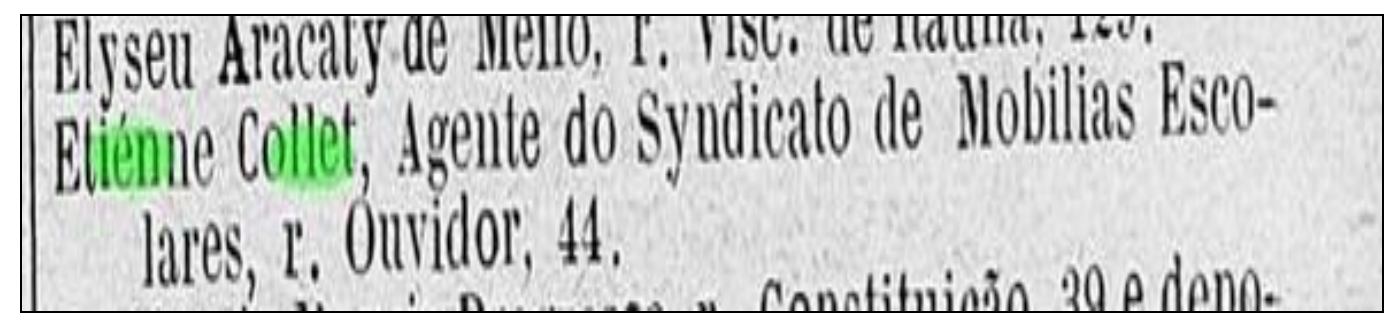

Fonte: Almanak Administrativo, Mercantil e Industrial do Rio de Janeiro, 1897, p. 557

\section{Anexo n.37}

\section{Directoria da Instrução Publica do Estado de São Paulo}

11 de março de 1893

$2^{\mathrm{a}}$ secção

Oficio n.260

Tendo o cidadão ETIENNE COLLET, encarregado da compra dos apparelhos necessários ao ensino de physica, mechanica e chimica da Escola Normal, comunica a esta Directoria que correrão por conta do Estado as despesas de encaixotamento e transporte dos mesmos apparelhos e serão incluídas nas respectivas facturas, rogo-vos a necessária autorisação para a satisfação de taes despesas, além da quantia de 4.486\$760, já autorisada para o pagamento da encomenda feita.

\section{Saúde e Fraternidade}

Ao ilustre cidadão Dr. Cesario Motta Junior Secretário de Estado dos Negócios do Interior

O Director

Fonte: APESP. Série Manuscritos. Secretaria do Interior. Escola Normal.Ano 1892. Caixa 530 Ordem 7135 
Anexo n.38

\section{Secretaria da Escola Normal da Capital \\ 22 de maio de 1894}

Oficio n. 42

Cidadão

Acompanhão o presente as facturas das peças de anatomia e modelos de flores e fructos, encomendados para esta escola, e que se acham na alfândega de santos em descarga no VAPOR CORRIENTES.

Como vereis pelos referidos documentos a importância total devida aos fornecedores é de fr.3.635,20 - devendo, porém, ser deduzida a quantia de fr.3.050 que já foi paga e entregue ao Sr. Etienne Collet (representante da casa Emile Deyrolle, de Paris), nos termos do aviso n. 225 de 16 de outubro de 1893 da Secretaria do Estado dos Negócios do Interior. Resta, pois, á paga a quantia de fr.585,20. Solicito a expedição de ordem vossa a fim de ser pelo Thesouro do Estado effectuado o pagamento da referida quantia de fr.585,20.

O diretor - Gabriel Prestes

Ordem 7135

Fonte: APESP. Série Manuscritos. Secretaria do Interior. Escola Normal.Ano 1892. Caixa 530 -

Anexo n.39

Secretaria da Escola Normal da Capital

São Paulo, 25 de agosto de 1893

$2^{\mathrm{a}}$ Secção

Oficio n. 113 -

Requisita-se o orçamento

Cidadão,

Tenho a honra de vos transmitir a inclusa relação de instrumentos e apparelhos de gymnastica, necessários para a instalação de um gymnasio n'esta escola a fim de que o respectivo ensino seja convenientemente ministrado aos seus alumnos e aos da escola modelo anexa, requisitados pelos professor Manoel Baraziola.

Peço-vos caso seja aprovada pelo governo a referida instalação e a indicação dos mencionados instrumentos e apparelhos, a necessária autorização para por encomenda e por intermédio de alguma casa comercial importadora fazer na Europa a acquisição dos mesmos.

Saúde e Fraternidade

Ao cidadão Dr. Cezário Motta Junior Secretário do Estado dos Negócios do Interior

$\mathrm{O}$ director interino José Sá Benevides Ordem 7135

Fonte: APESP. Série Manuscritos. Secretaria do Interior. Escola Normal.Ano 1892. Caixa 530 - 


\section{Anexo n.40}

\section{Diretoria da Escola Normal de São Paulo \\ 15 de março de 1892}

Offício n. 10

Cidadão,

Em consequência da requisição de Miss Browne, professora-diretora da Escola Modelo anexa a esta, venho pedir-vos autorização para fazer acquisicao de MESAS E BANCOS necessários para as aulas da referida escola. Essa MOBILIA ESCOLAR, conforme o PREÇO pedido pelos FORNECEDORES (COMPANHIA MECHANICA E IMPORTADORA DE SÃO PAULO) deverá importar em $300 \$ 000$.

Autorizado em 16/03/1982 Ao Cidadão Dr. José Alves de Cerqueira Cezar M. D. Presidente do Estado

$\mathrm{O}$ vice-diretor José Sá Benevides.

Fonte: APESP. Série Manuscritos. Secretaria do Interior. Escola Normal.Ano 1892. Caixa 530 Ordem 7135 


\section{ANEXOS DO CAPÍTULO 4}

\section{Anexo n.41}

\section{Secretaria do Estado dos Negócios do Interior}

São Paulo, 19 de dezembro de 1894

Autorização ao inspetor do $18^{\circ}$ distrito literário para adquirir os moveis constantes da inclusa relação, mesmo as carteiras que irão depois.

4651

Relação da mobília necessária para as escolas de Itu

Para o primeiro grupo escolar (sexo masculino)

\section{- 60 carteiras americanas}

- 6 poltronas

- 1 armário

- 6 cadeiras ordinárias

Para o $2^{\circ}$ grupo escolar dr. Cesário Motta (sexo feminino)

\section{- 45 carteiras americanas}

- 6 mesas pequenas

-6 poltronas

- 6 cadeiras ordinárias

- 1 armário

- 2 quadros-negro

-3 relogios de parede

Fonte: Série Manuscritos. Instrução Pública. Ofícios do Governo ao Inspetor Geral. Anos 18941896. Caixa 9/ Ordem - 4992

\section{Anexo n.42}

Resumo da relação dos moveis e utensílios indispensáveis para o Grupo Escolar Luiz Leite de Amparo

- 2 coleções completas de mapa de historia natural

- cadernos americanos para o exercício de calculo

- 30 CARTEIRAS AMERICANAS

16 de julho de 1896

O Director

José Antonio de Paula Santos

Fonte: Série Manuscritos. Instrução Pública. Ofícios do Governo ao Inspetor Geral. Anos 18941896. Caixa 9/ Ordem - 4992. 


\section{Anexo n.43}

\section{SECRETARIA D’ESTADO DOS NEGÓCIOS DO INTERIOR}

São Paulo, 9 de abril de 1896

$3^{\mathrm{a}}$. secção

n.58

Cidadão, Diretor Geral Interino da Instrução Pública.

"Recomendo-vos que providencieis no sentido de ser fornecidas 200 CARTEIRAS AMERICANAS e respectivos assentos para as duas secções do grupo escolar de S. José dos Campos".

Saúde e Fraternidade

Alfredo Pujol

Nota: ao chefe do almoxarifado para providenciar

Fonte: Série Manuscritos. Instrução Pública. Ofícios do Governo ao Inspetor Geral. Anos 18941896. Caixa 9/ Ordem - 4992

\section{Anexo n.44}

\section{SECRETARIA D’ESTADO DOS NEGÓCIOS DO INTERIOR} São Paulo, 8 de maio de 1896

n. 90

$3^{\mathrm{a}}$ secção

Cidadão, Diretor Geral Interino da Instrução Pública

"Em resposta a vosso oficio de 7 do corrente, declaro-vos ficardes autorisado a fornecer a cada uma das 4 escolas da cidade de Bragança, 200 CARTEIRAS AMERICANAS para dous alumnos ou 40 ditas para um só alumno”.

Assinatura não legível

Fonte: Série Manuscritos. Instrução Pública. Ofícios do Governo ao Inspetor Geral. Anos 18941896. Caixa 9/ Ordem - 4992 


\section{Anexo n.45}

4462 a 4465

$2^{\mathrm{a}}$. sub-diretoria

$3^{\mathrm{a}}$. secção

n. 407

ao insetor do $19^{\circ}$. Districto

Em 1897

Lista de material para o grupo escolar de amparo em 4465

- 80 espingardas para o batalhão escolar

- 40 (CARTEiRAS “CHANDLER”

Dentre outros.

Fonte: APESP, Secretaria do Interior, Relatórios Diversos (1897). Ordem 7037. Caixa 432

\section{Anexo n.46}

\section{Secretaria do Estado dos Negócios do Interior}

São Paulo, 21 de setembro de 1895

$3^{\mathrm{a}}$. secção

n. 169

Ao cidadão Dr. Director Geral da Instrução Pública

"Em resposta ao vosso oficio n.862 de 11 do corrente, ao qual acompanha um do inspetor do $22^{\circ}$ distrito, em que aquele funcionário representa sobre a necessidade de MOBILIA $\mathrm{E}$ MATERIAL ESCOLAR para as duas escolas da vila de Bebedouro, e reclama em favor das de Jaboticabal a substituição da antiga por NOVA MOBILIA avaliando em 60 CARTEIRAS DO TIPO PAULISTA, todas aquelas necessidades e, como fizeste sentir em vosso oficio, o contrato de 1.200 CARTEIRAS tem despertado reclamações superiores á sua capacidade, comunico-vos que, a 19 deste mez, foi o cidadão José Maragliano encarregado de construir 1.500 CARTEIRAS, devendo ser lavrado contrato nos termos do primitivo".

Saúde e Fraternidade

Alfredo Pujol

Fonte: APESP, Série Manuscritos. Instrução Pública. Ofícios do Governo ao Inspetor Geral. Anos 1894-1896. Caixa 9/ Ordem - 4992. 


\section{Anexo n.47}

\section{SECRETARIA D’ESTADO DOS NEGÓCIOS DO INTERIOR \\ São Paulo, 15 de maio de 1896}

$3^{\mathrm{a}}$. secção,

n.95

Cidadão, Diretor Geral Interino da Instrução Pública

"Em resposta ao vosso oficio n. 456 de 8 do corrente autoriso-vos a satisfazer o pedido do inspetor do ??? distrito remetendo para a escola intermédia do bairro do Rio Abaixo e para do Mato Dentro, em Atibaia, os seguintes objetos escolares:

Os livros didáticos necessários para ambas mais vinte e tres carteiras tipo Paulista, sendo quinze para a primeira e oito para a segunda, e um quadro para cada uma delas".

A. D. Bueno

Nota: Ao chefe do almoxarifado para satisfazer

Fonte: APESP, Série Manuscritos. Instrução Pública. Ofícios do Governo ao Inspetor Geral. Anos 1894-1896. Caixa 9/ Ordem - 4992.

\section{Anexo n.48}

\section{Ilm. Sr. Director}

Cumprido o despacho retro, quanto aos MOVEIS de que trata a $1^{\mathrm{a}}$, digo, a conta inclusa. Quanto á outra parte já providencie dando ordens ao fornecedor José Maragliano que está prestes a cumpri-la como me avisa. Em 26 de maio de 1896

Francisco Botelho

Fonte: APESP, Série Manuscritos. Instrução Pública. Ofícios do Governo ao Inspetor Geral. Anos 1894-1896. Caixa 9/ Ordem - 4992

\section{Anexo n.49}

\section{Ilm. Sr. Diretor}

O almoxarifado tem as cartilhas das mães que substituem, no entender d'esta diretoria, as Cartilhas da Infancia; como o Barrilote de tinta do pedido retro, quadros-negros não existem, mas deve tel-os o FORNECEDOR MARAGLIANO aguardo ordens.

Secção, 26 de março de 1896

Francisco Botelho Cumprido, exceção dos quadros negro que o almoxarifado não tem. Em 11-4-1896. Fonte: APESP, Série Manuscritos. Instrução Pública. Ofícios do Governo ao Inspetor Geral. Anos 1894-1896. Caixa 9/ Ordem - 4992 
Anexo n.50

SECRETARIA D’ESTADO DOS NEGÓCIOS DO INTERIOR
São Paulo, 29 de abril de 1896
n.74
Cidadão, Diretor Geral da Instrução Publica
“Em resposta ao vosso oficio n. 331 de 5 do corrente devolvo-vos a inclusa conta do cidadão
MAJOR JOSÉ MARAGLIANO, na importância de 12:140\$000, provenientes de MOBILIAS
ESCOLARES fornecidas as escolas do Estado afim de que informeis se os TINTEIROS não
estão incluídos nos preçOs das CARTEIRAS e se houve ACORDO quanto ao preço do
ENCAIXOTAMENTO”.
NOTA: Informe-se de acordo com a minuta junta, devolvendo-se a conta apresentada ao
FORNECEDOR.
FORNECEDOR.

Fonte: APESP, Série Manuscritos. Instrução Pública. Ofícios do Governo ao Inspetor Geral. Anos 1894-1896. Caixa 9/ Ordem - 4992.

\section{Anexo n.51}

A Directoria Geral da Instrução Pública.

Grupo Caçapava e Santa Branca.

$2^{\mathrm{a}} \mathrm{Via}$

Deve a

José Refinete, importância dos objetos seguintes:

Para o Grupo Escolar de Caçapava

- 6 mezas escrivaninha a $50 \$$-------300\$000

- 6 cadeiras austríacas a $12 \$$-------- 72\$000

Para o Grupo Santa Branca

- 3 mezas escrivaninha a 50\$ ------- $150 \$ 000$

- 3 cadeiras austríacas a $12 \$$-------- $36 \$ 000$

Engradamento e carreto -----------------48\$500

Total $=606 \$ 500$

São Paulo, 24 de maio de 1896

José Refinete

Informei na $1^{\mathrm{a}}$ via

Secção do almoxarifado aos 26 de maio de 1896

Francisco Botelho - chefe da secção.

Fonte: APESP, Série Manuscritos. Instrução Pública. Ofícios do Governo ao Inspetor Geral. Anos 1894-1896. Caixa 9/ Ordem - 4992 


\section{Anexo n.52}

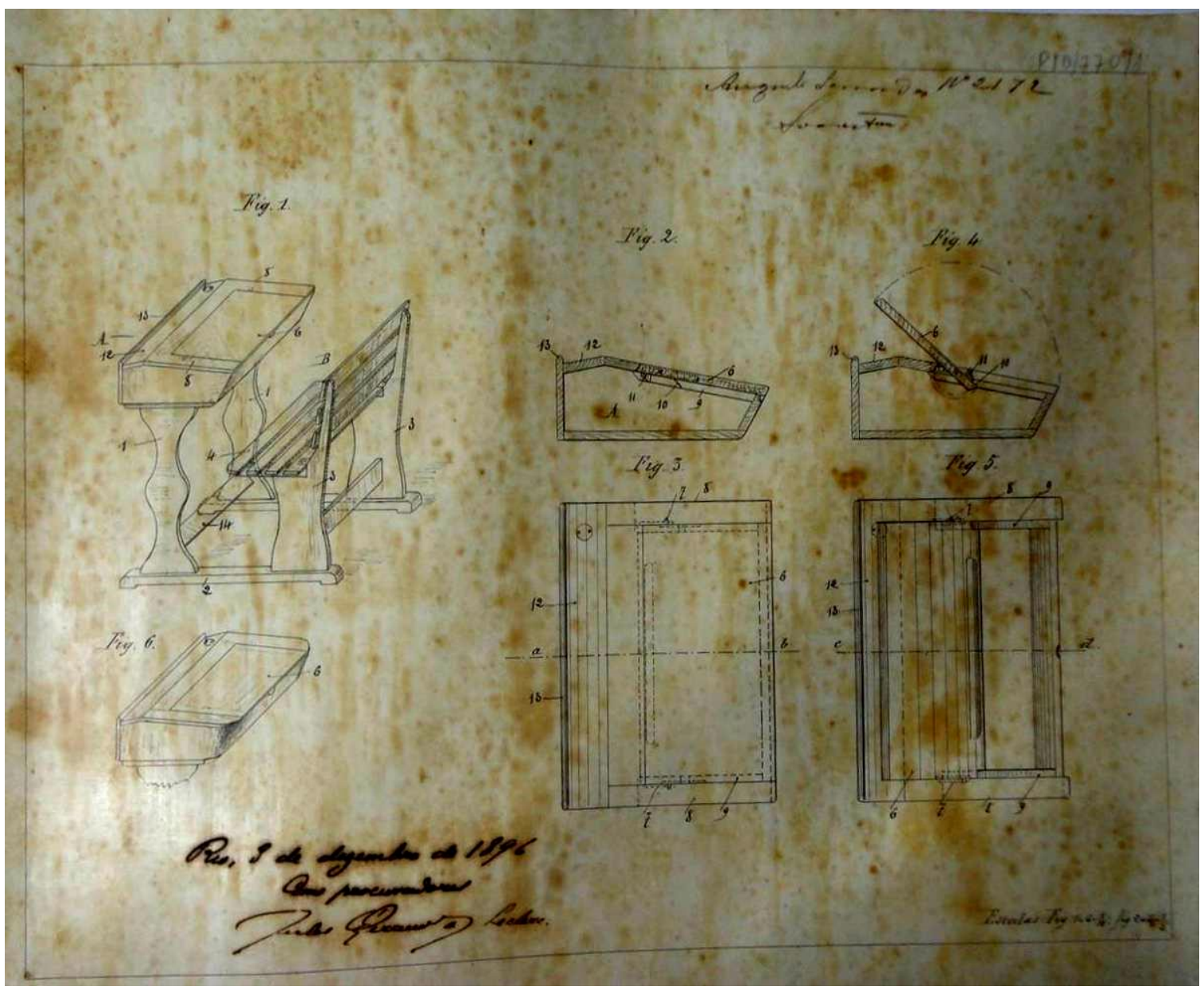

Fonte: Arquivo Nacional do Rio de Janeiro. Fundo/Coleção Privilégios Industriais. Notação do Documento - 1770 


\section{Anexo n.53}

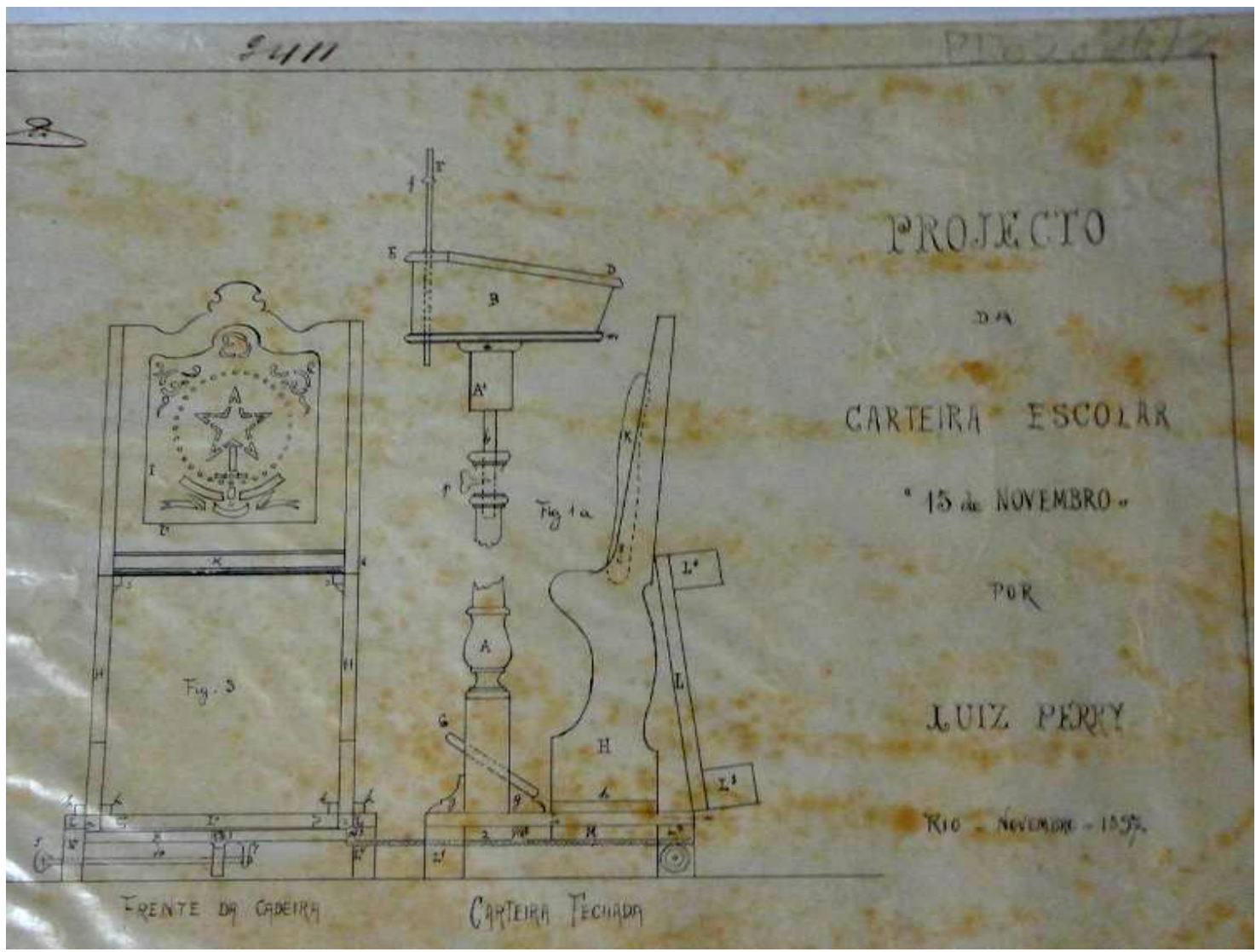

Fonte: Arquivo Nacional do Rio de Janeiro. Fundo/Coleção Privilégios Industriais.

Notação do Documento - 2026

\section{Anexo n.54}

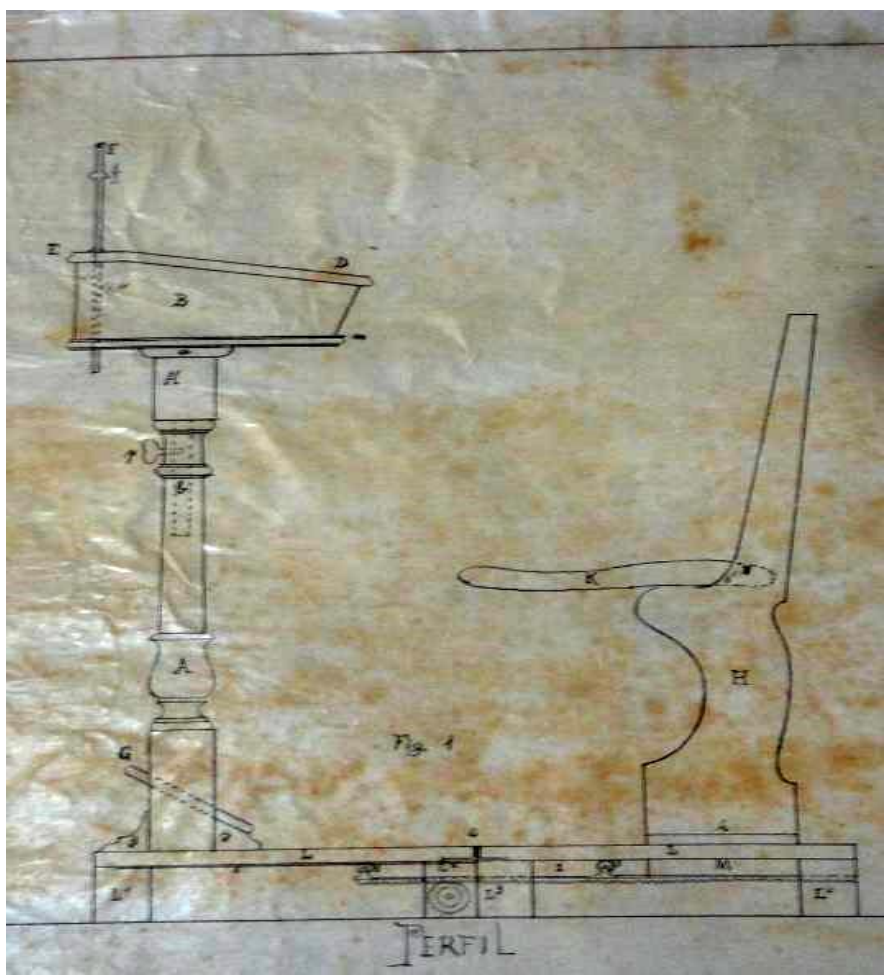




\section{Anexo n. 55}

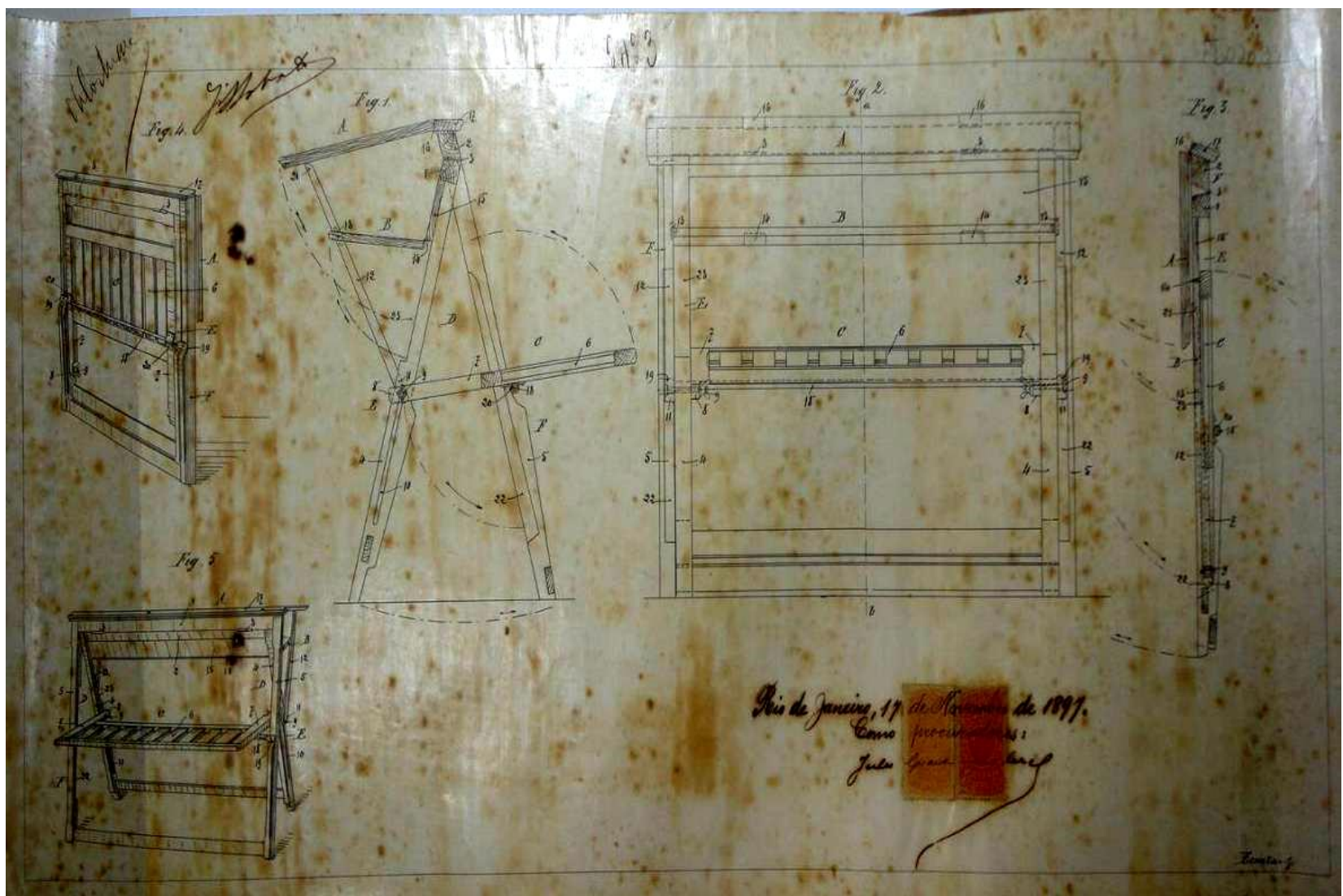

Fonte: Arquivo Nacional do Rio de Janeiro. Fundo/Coleção Privilégios Industriais.

Notação do Documento - 2038 


\section{Anexo n.56}

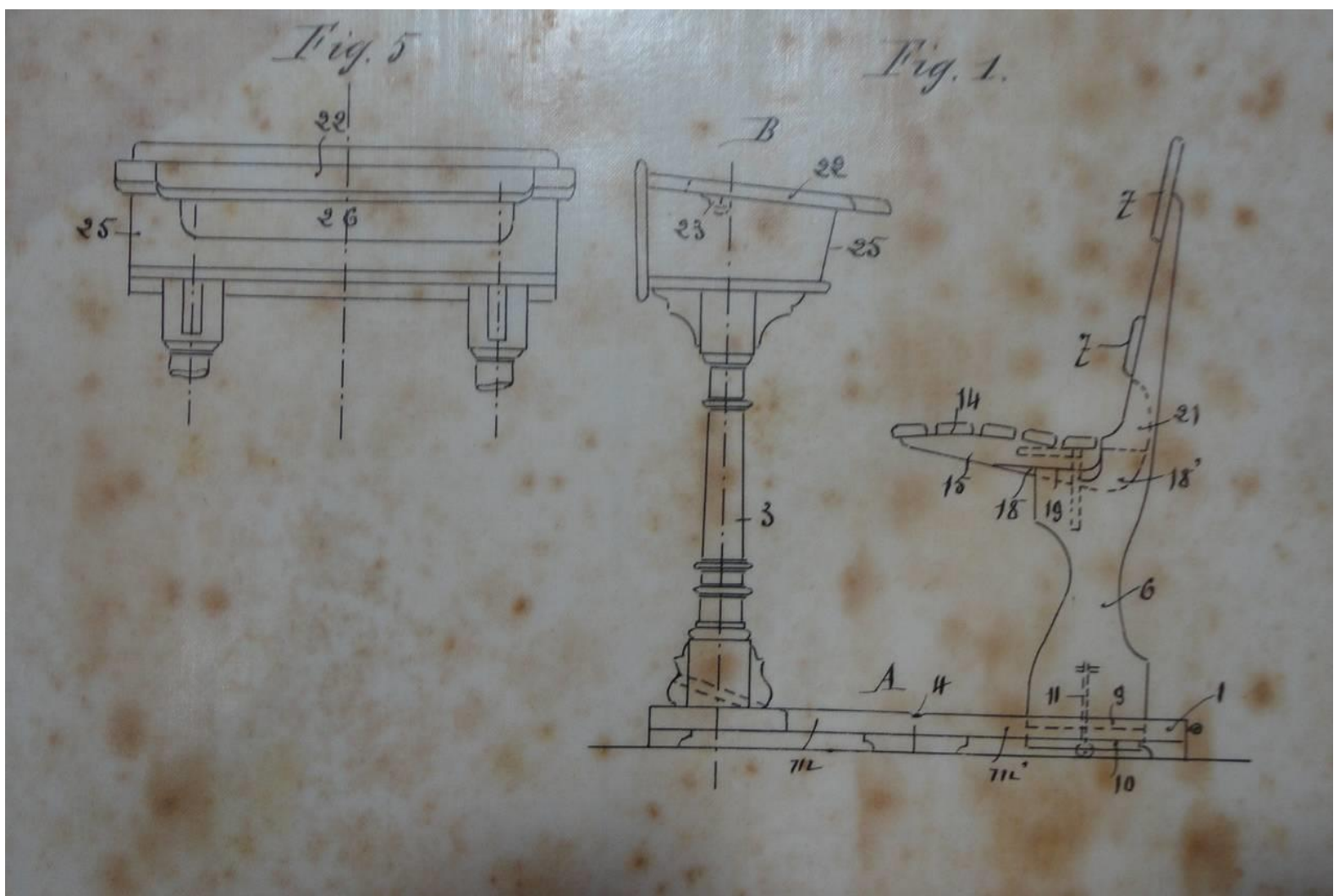

Fonte: Arquivo Nacional do Rio de Janeiro. Fundo/Coleção Privilégios Industriais. Notação do Documento - 1996 


\section{Anexo n.57}

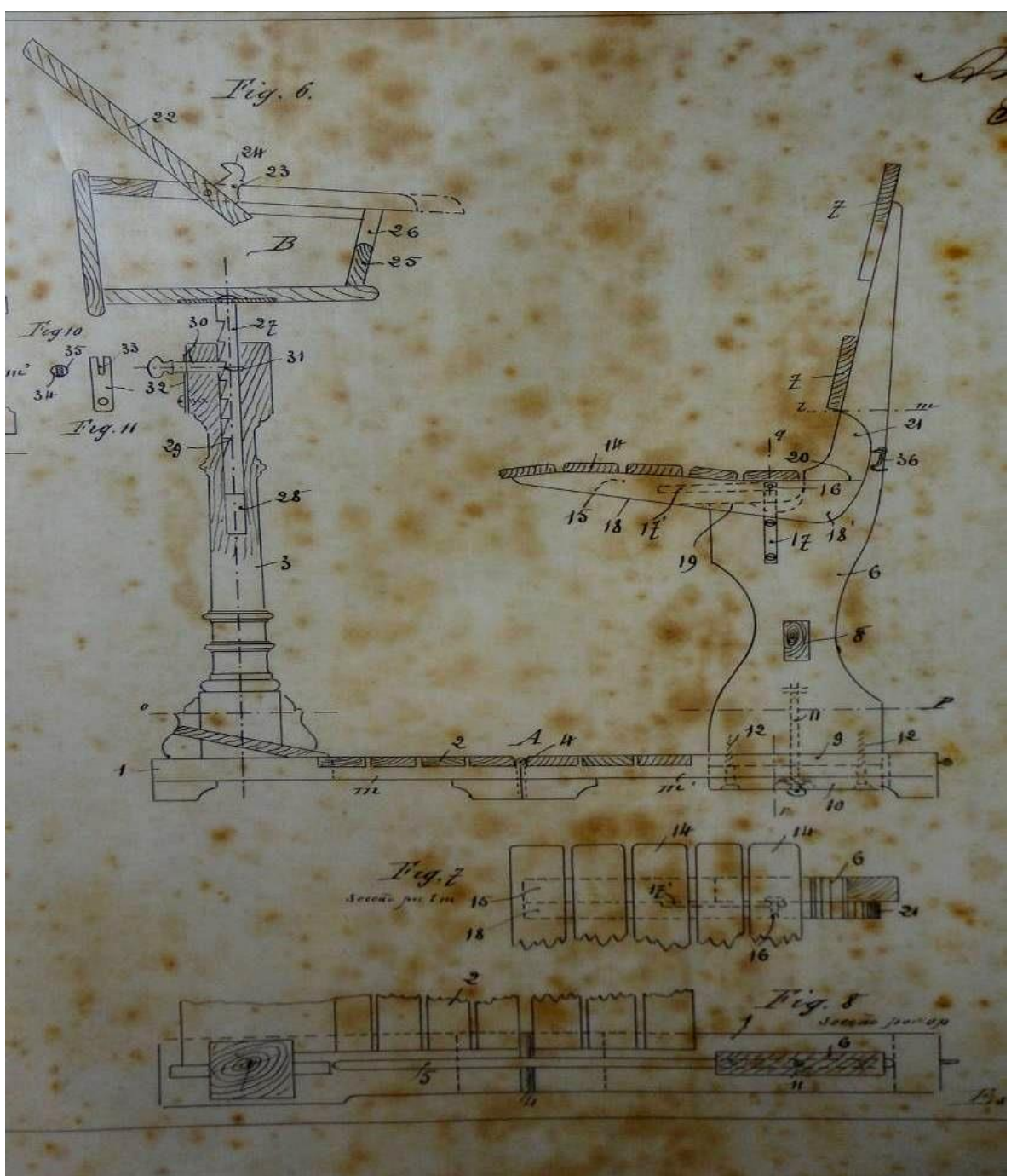

Fonte: Arquivo Nacional do Rio de Janeiro. Fundo/Coleção Privilégios Industriais. Notação do Documento - 1996 - Figuras 6, 7 e 8 


\section{Anexo n.58}

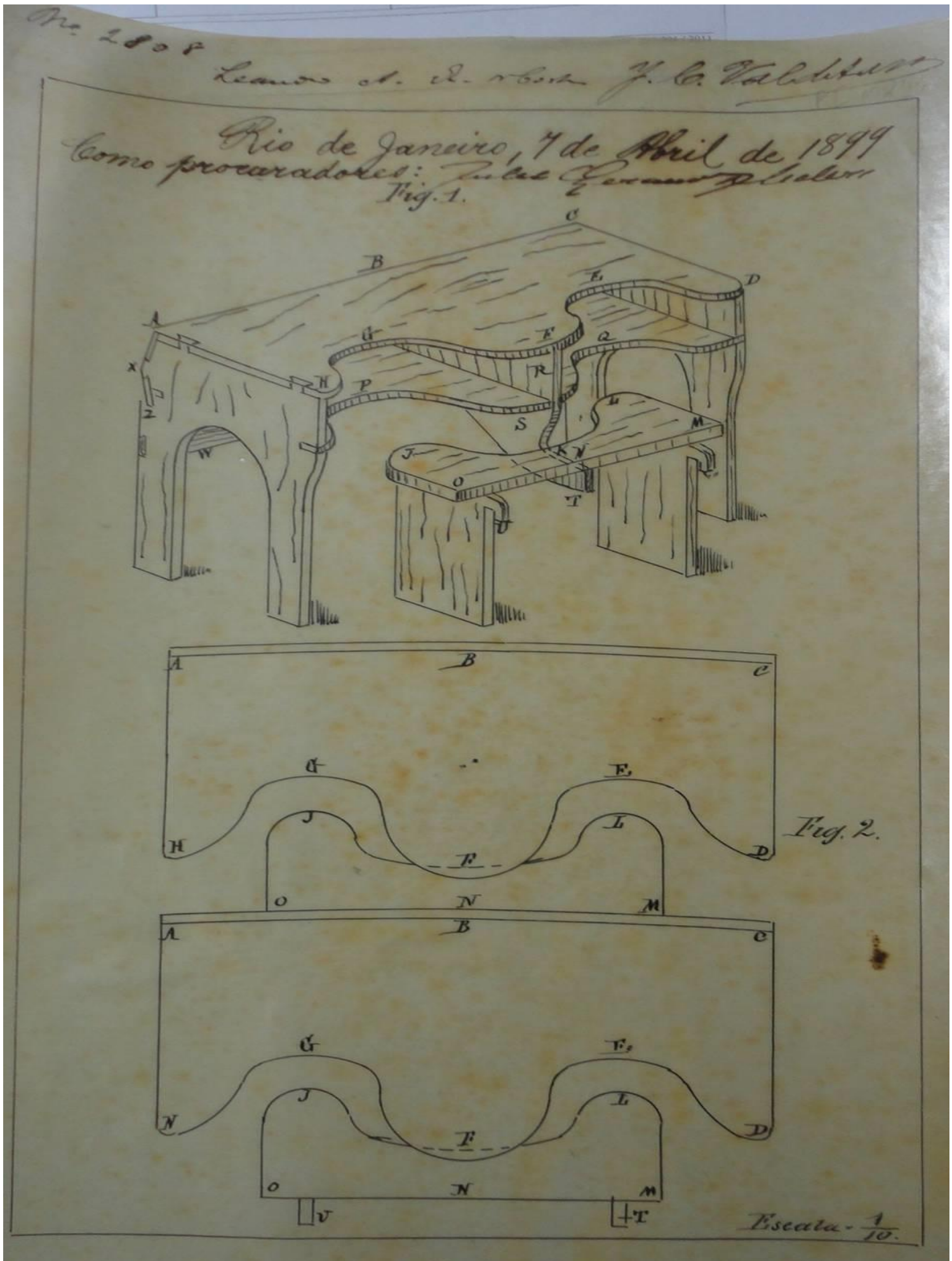

Fonte: Arquivo Nacional do Rio de Janeiro. Fundo/Coleção Privilégios Industriais.

Notação do Documento - 2438 


\section{Anexo n.59}

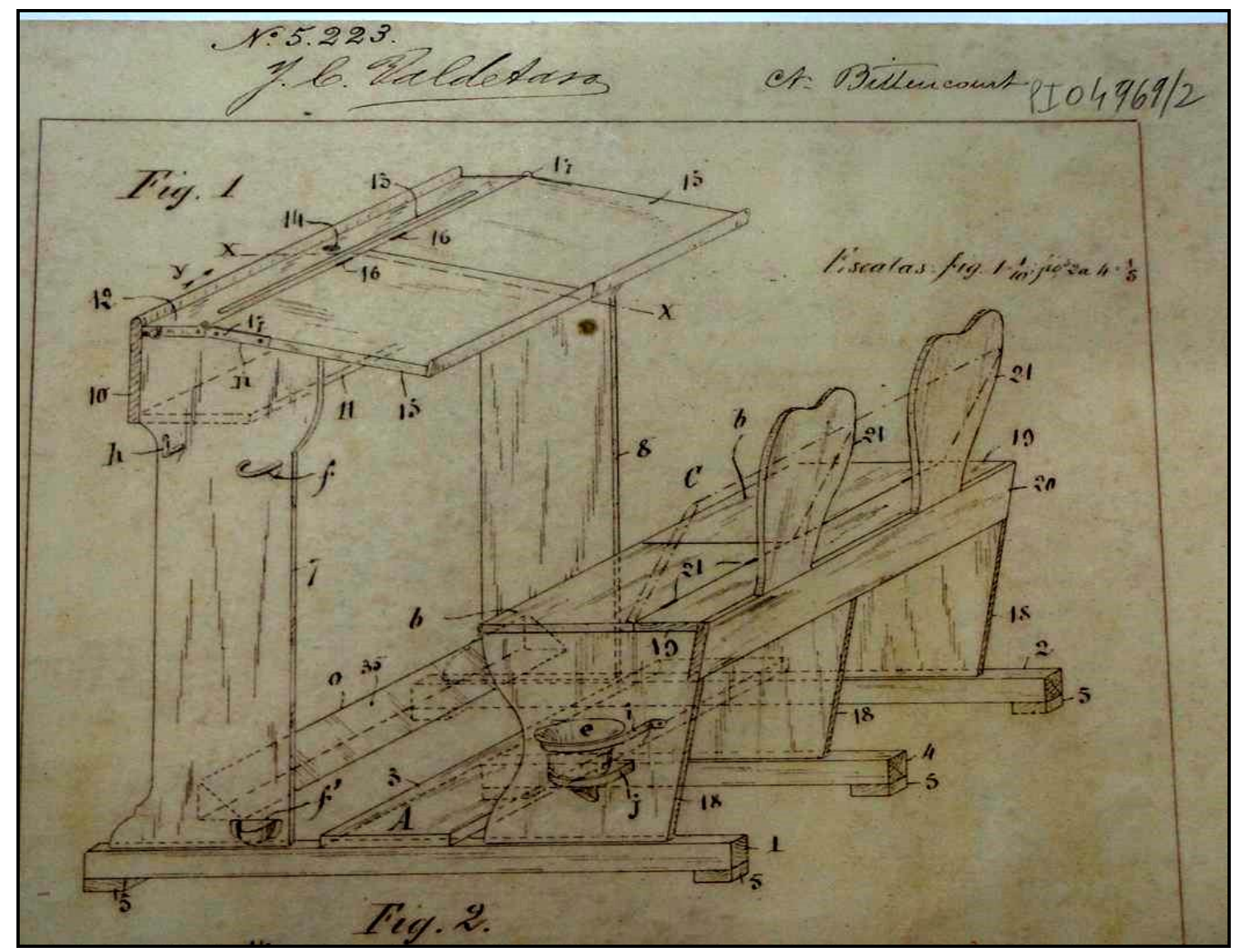

Fonte: Arquivo Nacional do Rio de Janeiro. Fundo/Coleção Privilégios Industriais. Notação do Documento - 4969 


\section{ANEXOS DO CAPÍTULO 5}

\section{Anexo n.60}

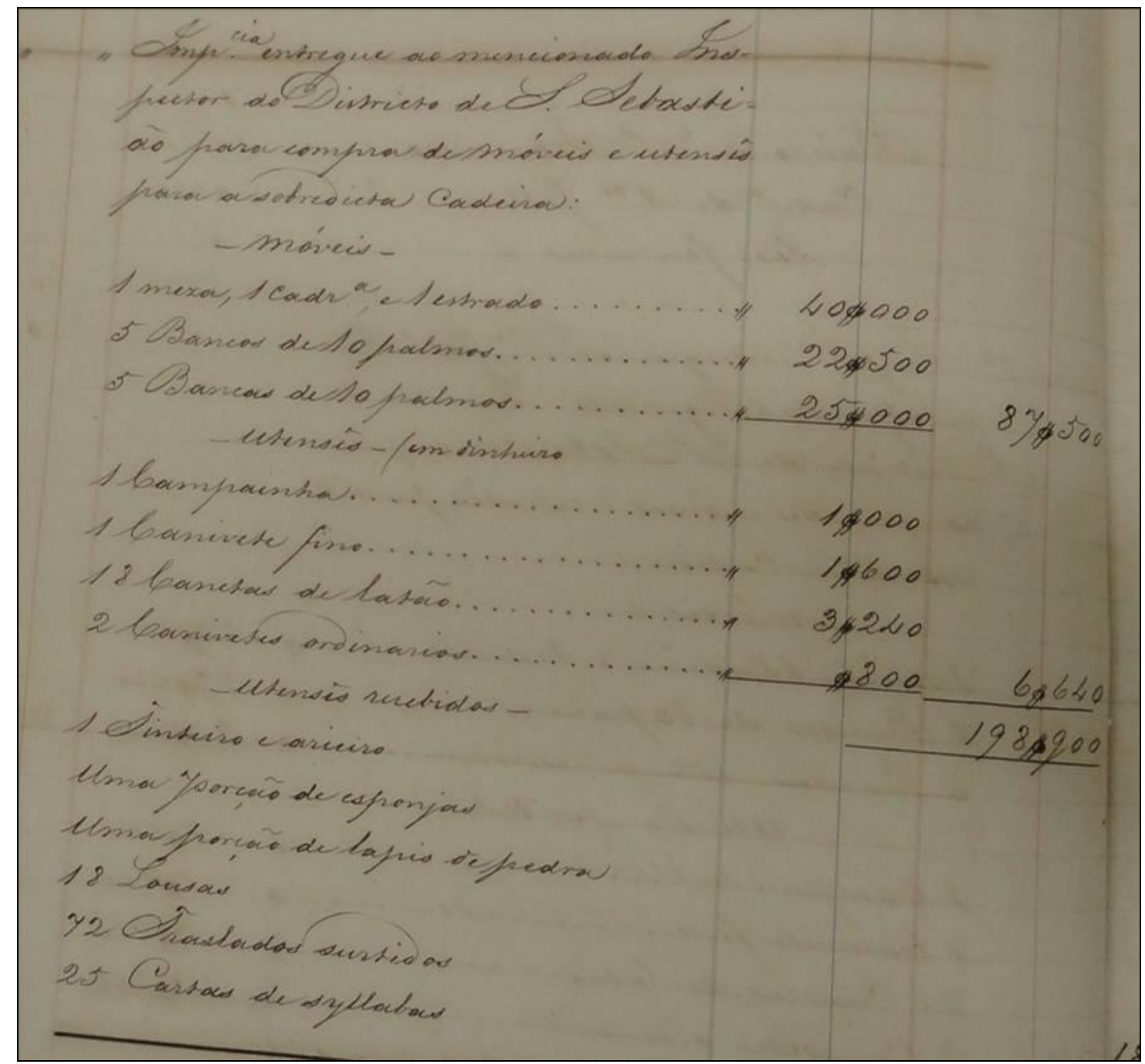

Fonte: Livro de "Moveis e Utensis (Distribuição de 1854 a 1872), p.5 (verso) 


\section{Anexo n.61}

\section{A SECRETARIA DO ESTADO DOS NEGÓCIOS DO INTERIOR}

São Paulo, 10 de setembro de 1895

$3^{\mathrm{a}}$. secção

n. 364

Ao cidadão Dr. Diretor Geral da Instrução Publica

Respondendo a vosso oficio n. 843, de 3 do corrente, em que pedistes providencias no sentido de ser organizado o almoxarifado dessa Repartição, tenho a declarar-vos que já se providenciou sobre a nomeação de um funcionário em comissão.

Alfredo Pujol

Fonte: APESP, Série Manuscritos. Instrução Pública. Ofícios do Governo ao Inspetor Geral. Anos 1894-1896. Caixa 9/ Ordem - 4992

\section{Anexo n.62}

\section{SECRETARIA D'ESTADO DOS NEGÓCIOS DO INTERIOR}

São Paulo, 14 de novembro de 1895

$3^{\mathrm{a}}$. secção

n. 201

Cidadão Dr. Diretor Geral da Instrução Publica

Em resposta a vosso officio n.1076, de 11 do corrente, declaro-vos que, estando providos os logares, da secção do almoxarifado, creados pela recente Lei n. 374, de 3 de setembro ultimo, devem ser dispensados os funccionários, que haviam sido nomeados em commissão, de modo a regularisar-se a dita secção, de acordo com a Lei citada.

\section{Saúde e Fraternidade}

Alfredo Pujol

Fonte: Série Manuscritos. Instrução Pública. Ofícios do Governo ao Inspetor Geral. Anos 18941896. Caixa 9/ Ordem - 4992. 
Anexo n.63

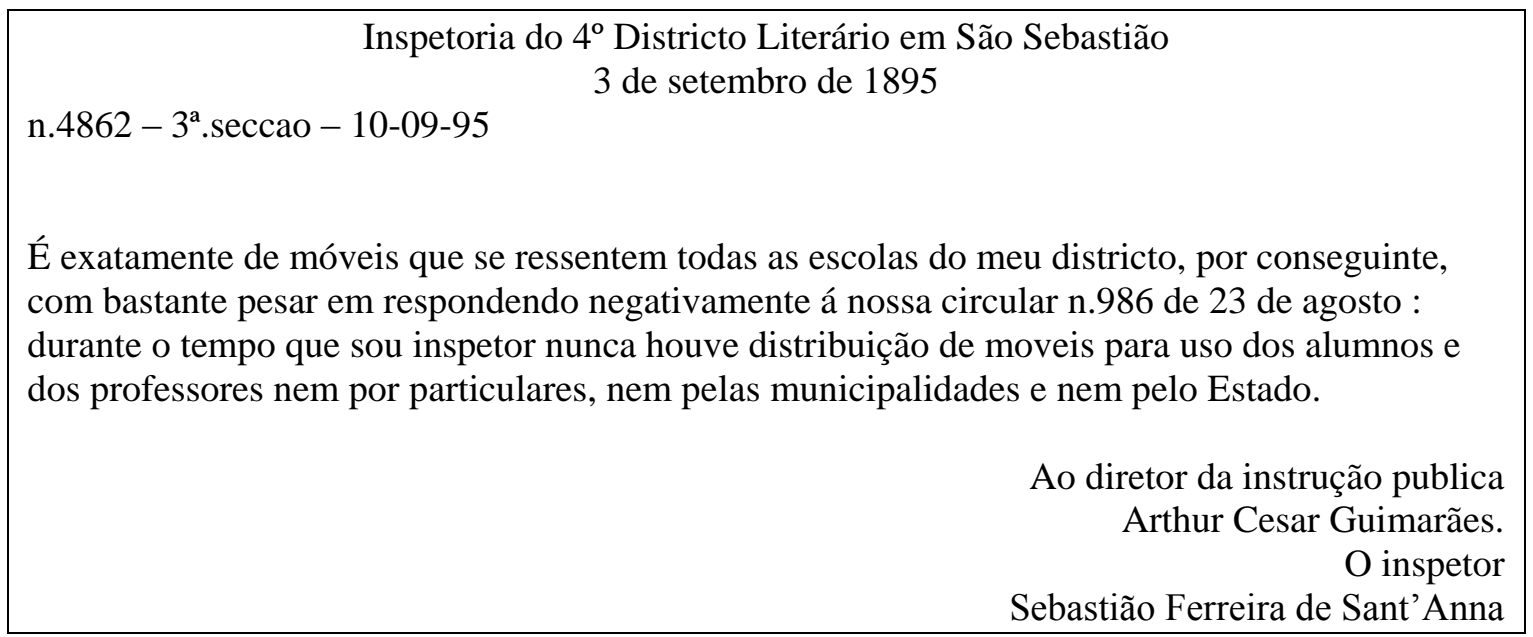

Fonte: Série Manuscritos. Instrução Pública. Ofícios do Governo ao Inspetor Geral. Anos 18941896. Caixa 9/ Ordem - 4992.

\title{
Anexo n.64
}

\author{
Inspectoria do $4^{\circ}$ Districto Literário \\ 6 de setembro de 1895
}

n. $4863-3^{\mathrm{a}}$. seccao $-10-09-95$

Cumprindo a ordem dessa Diretoria acusada em circular n. 1.005, tenho a honra de informar que, no districto sob minha jurisdição, não houve distribuição de moveis sem autorização dessa Diretoria. Cumpre-me declarar que para este districto só vieram 120 bancos carteiras destinadas ao Grupo Escolar Dr. Bernardino de Campos e isto em virtude da ordem dessa repartição. Trato de organizar um mappa demonstrando uma relação dos moveis e livros distribuídos pelas escolas deste districto, julgando ser este o único meio de conhecer-se o material existente e mesmo collocar essa Diretoria no caso de julgar da necessidade real de cada escola".

Ao diretor da instrução publica Arthur Cesar Guimarães

$\mathrm{O}$ inspetor Julio Cesar d'Oliveira

Fonte: APESP, Secretaria do Interior, Relatórios Diversos (1897). Ordem 7037. Caixa 432 


\section{Anexo n.65}

\section{Inspectoria do $3^{\circ}$ Districto Literário}

$3^{\text {a }}$. secção

chefe

3-9-1895

Respondendo a circular n. 985

As escolas do $3^{\circ}$. Districto, desde que sou inspetor, não receberam moveis nem do estado, nem de particulares.

Aproveito o ensejo para vos comunicar que taes escolas, principalmente as de S. Vicente e as do município de conceição de Itanhaem, estão desprovidas de moveis.

Cidadão dr. Arthur Cesar Guimarães

Diretor Geral da Instrução Pública.

Santos, 29 de agosto de 1895

O Inspetor Literário Carlos Escobar

Fonte: Série Manuscritos. Instrução Pública. Ofícios do Governo ao Inspetor Geral. Anos 18941896. Caixa 9/ Ordem - 4992. 